Portland State University

PDXScholar

$1-1-2012$

\title{
Apatite Crystal Populations of the 1991 Mount Pinatubo Eruption, Philippines: Implications for the Generation of High Sulfur Apatite in Silicic Melts
}

Ashley Elizabeth Van Hoose

Portland State University

Follow this and additional works at: https://pdxscholar.library.pdx.edu/open_access_etds Let us know how access to this document benefits you.

\section{Recommended Citation}

Van Hoose, Ashley Elizabeth, "Apatite Crystal Populations of the 1991 Mount Pinatubo Eruption, Philippines: Implications for the Generation of High Sulfur Apatite in Silicic Melts" (2012). Dissertations and Theses. Paper 123.

https://doi.org/10.15760/etd.123

This Thesis is brought to you for free and open access. It has been accepted for inclusion in Dissertations and Theses by an authorized administrator of PDXScholar. Please contact us if we can make this document more accessible: pdxscholar@pdx.edu. 
Apatite Crystal Populations of the 1991 Mount Pinatubo eruption, Philippines:

Implications for the Generation of High Sulfur Apatite in Silicic Melts

\author{
by
}

Ashley Elizabeth Van Hoose

A thesis submitted in partial fulfillment of the requirements for the degree of

\author{
Master of Science \\ in \\ Geology
}

\author{
Thesis Committee: \\ Martin J. Streck, Chair \\ John S. Pallister \\ Robert B. Perkins
}

Portland State University

(C)2012 


\begin{abstract}
On June 15, 1991, Mount Pinatubo, Philippines, ejected 20 million tonnes of sulfur dioxide into the atmosphere, significantly impacting global climate and stratospheric ozone. Recharging basaltic magma mixed into the $50 \mathrm{~km}^{3}$ dacitic magma reservoir 6 to $11 \mathrm{~km}$ beneath Mount Pinatubo, and triggered the 1991 eruption. The result of the magma mixing was a hybrid andesite with quenched basalt inclusions that erupted as a dome between June 7 and June 12 . On June 15, approximately $5 \mathrm{~km}^{3}$ of anhydrite-bearing magma was erupted from the main phenocryst-rich, dacitic reservoir. This study will utilize this extraordinary framework of the 1991 Pinatubo eruption to investigate the systematics of sulfur uptake by apatite in order to further develop apatite as a monitor for magmatic sulfur.

In the dacite and hybrid andesite, apatite occurs as individual phenocrysts (up to $\sim 200 \mu \mathrm{m}$ diameter) or included within anhydrite, hornblende, and plagioclase phenocrysts. In the basaltic magmatic inclusions, apatite is found as acicular microphenocrysts. Electron microprobe data collected on apatite yield low- $(<0.3$ wt. \% $\left.\mathrm{SO}_{3}\right)$, medium- (0.3-0.7 wt.\% $\left.\mathrm{SO}_{3}\right)$, and high-sulfur $\left(>0.7\right.$ wt. $\left.\% \mathrm{SO}_{3}\right)$ apatites in all juvenile products, and show that two distinct populations of apatites exist: "silicic" apatites (hosted in dacite and andesite) and basalt apatites. Apatites crystallizing from silicic melt have predominantly low- to medium-sulfur contents, but high-sulfur apatites with as much as $1.2-1.7 \mathrm{wt} . \% \mathrm{SO}_{3}$ occur sporadically as inclusions in plagioclase, hornblende, Fe-Ti oxide, and anhydrite. These concentrations are much
\end{abstract}


higher than what could be achieved through equilibrium crystal-melt partitioning at pre-eruption conditions $\left(760 \pm 20^{\circ} \mathrm{C}, 220 \mathrm{MPa}, \mathrm{NNO}+1.7,77 \mathrm{ppm} \mathrm{S}\right.$ in melt inclusions) and a partition coefficient of 13. Apatite in the basalt is always sulfur-rich with compositions forming a continuous array between 0.7 to $2.6 \mathrm{wt} . \% \mathrm{SO}_{3}$. The population of apatite that crystallized from silicic melt has elevated cerium, fluorine, and chlorine and lower magnesium concentrations (average dacite values in wt.\%: $0.21 \mathrm{Ce}_{2} \mathrm{O}_{3}, 1.4 \mathrm{~F}, 1.1 \mathrm{Cl}, \& 0.14 \mathrm{MgO}$ ) relative to the population of apatite from the basalt (average basalt values in wt.\%: $0.05 \mathrm{Ce}_{2} \mathrm{O}_{3}, 1.0 \mathrm{~F}, 0.78 \mathrm{Cl}$, \& $0.22 \mathrm{MgO}$ ).

LA-ICP-MS trace element data also show distinct apatite populations between silicic and basalt apatites. Silicic apatites have elevated REE concentrations (La avg. $=$ $750 \mathrm{ppm}$ ), lower $\mathrm{Sr}$ (avg.=594 ppm), and a pronounced negative Eu anomaly (avg. $\mathrm{Eu} / \mathrm{Eu}^{*}=0.57$ ) relative to basalt apatites (avg. values: $217 \mathrm{ppm} \mathrm{La,} 975 \mathrm{ppm} \mathrm{Sr}$, and $\left.\mathrm{Eu} / \mathrm{Eu}^{*}=1.16\right)$. The correlation of EMP sulfur data and LA-ICP-MS trace element data show no difference between high-S and low-S silicic apatites. These compositional systematics rule out the possibility that sulfur-rich apatite from dacite are inherited from mafic magma.

Sulfur element maps of apatites show no evidence of S-diffusion from anhydrite hosts. Areas of high-S concentrations show complicated patterns that suggest multiple periods of sulfur enrichment.

High-S silicic apatites are likely the product of "fluid-enhanced crystallization" from early enrichment of a $\mathrm{SO}_{2}$-rich fluid phase from the underplating basalt, which occurred prior to or at anhydrite saturation. This fluid phase is the only possible 
sufficient source of sulfur for generating high-S apatites in a cool, "wet", dacitic melt. The dynamics of apatite sulfur enrichment via "fluid-enhanced crystallization" is yet unclear and requires further experimental laboratory investigation. 


\section{DEDICATION}

For Arron Steiner, your passion for hard rock geology continues to inspire me. 


\section{ACKNOWLEDGEMENTS}

First and foremost, I must thank my advisor, Dr. Martin J. Streck for first inspiring me to become a hard rock geologist, and then providing me with this intriguing project, and his expertise and insight throughout the whole process. This thesis project was funded by the National Science Foundation (NSF) grant EAR0838611 awarded to Dr. Streck. I must also thank my thesis committee, Drs. John S. Pallister and Robert B. Perkins, for their guidance in polishing the final product. Special thanks goes to Dr. Pallister for supplying the samples used in this thesis project. I would like to recognize and thank the people at Oregon State University, Dr. Frank J. Tepley III and Dale Burns, for their assistance with electron microprobe analyses. Many thanks also to the people at ETH Zürich, Switzerland, Drs. Chris Heinrich and Markus Wälle, for providing access to and training on the LA-ICP-MS. To the PSU Geology faculty and staff, you collectively molded me into the geologist that I am today. I cannot satisfactorily express my gratitude for the knowledge and skills that you have imparted on me. I will put them to good use. Thanks to all of the good friends who have come and gone at PSU for the necessary distractions and keeping me anchored to reality. To my loving family and my first, brand-new nephew, Eli, I could never have finished without all of your love and support to pull me through the rough times. Finally, special thanks goes to Arron Steiner, to whom this thesis is dedicated. You believed in me and never let me give up on myself. I am so grateful for your love every day. 


\section{TABLE OF CONTENTS}

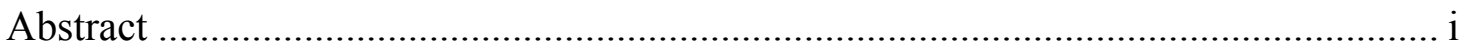

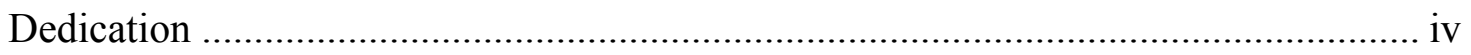

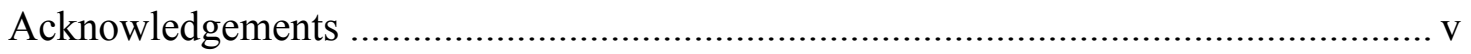

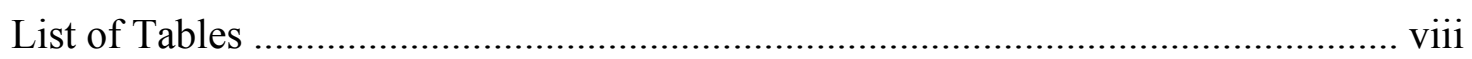

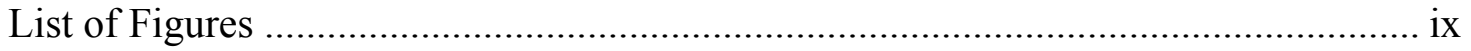

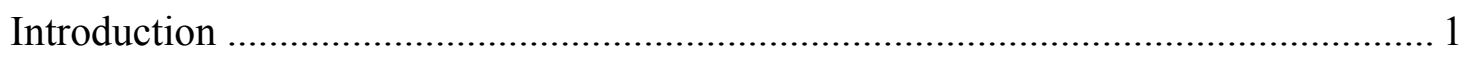

Geologic Setting and Description of Units ............................................................. 5

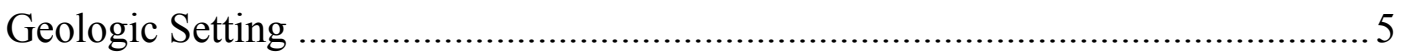

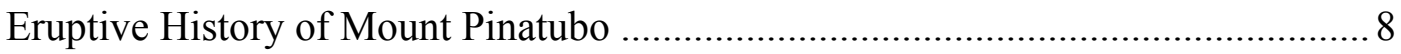

1991 Eruptions of Mount Pinatubo ……………………................................... 12

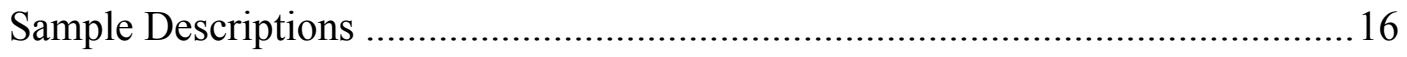

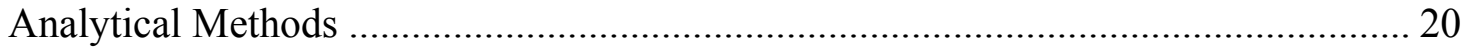

Electron Microprobe (EMP) Analysis .............................................................. 20

Laser-Ablation Inductively Coupled Plasma Mass Spectrometry (LA-ICP-MS) . 21

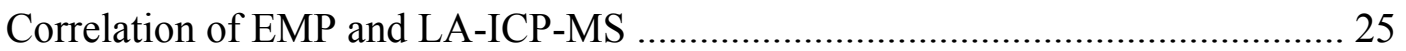

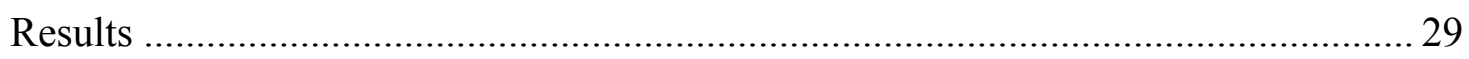

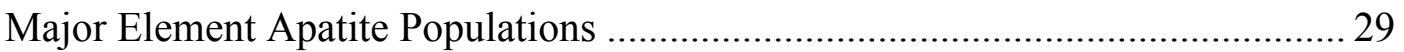

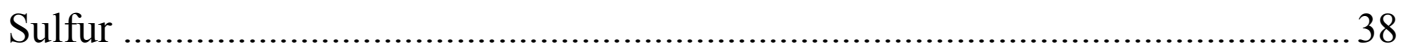

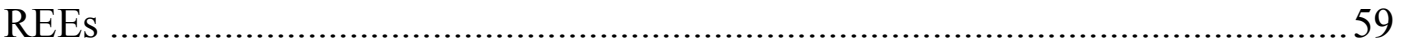

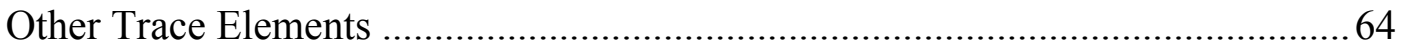

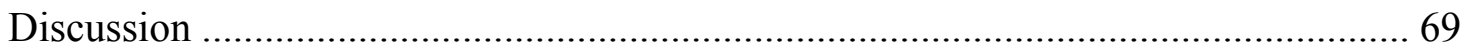


Sulfur Concentrations in Apatite ……………………….....................................69

Trace Element Concentrations in Apatite ………………….............................. 81

Melt Environment of High-S vs. Low-S Apatites ………………........................... 86

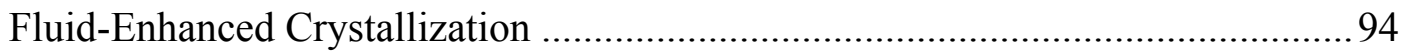

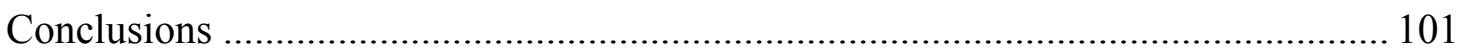

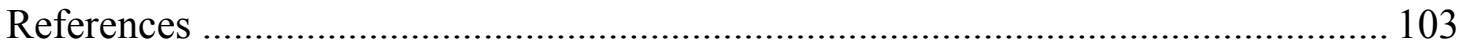

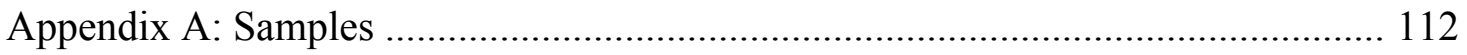

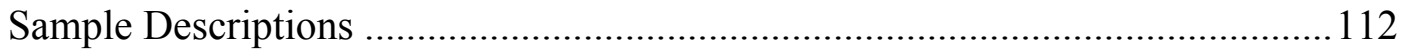

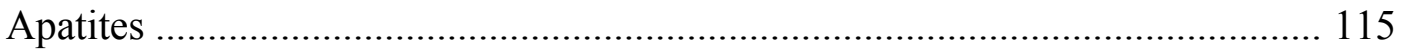

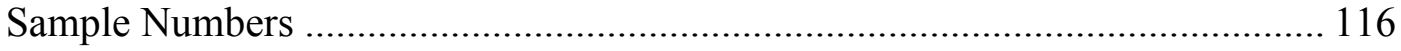

Appendix B: Electron Microprobe (Additional CD in Back) ................................... 117

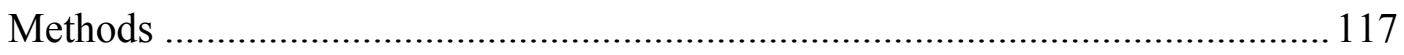

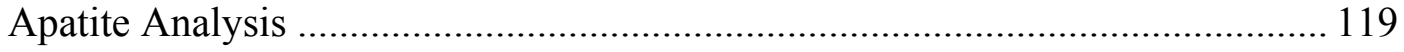

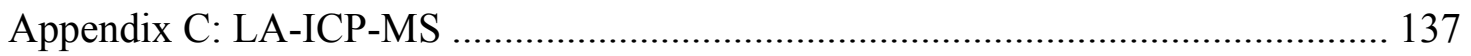

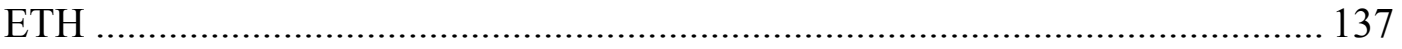

Appendix D: Correlation of EMP and LA-ICP-MS ............................................. 155

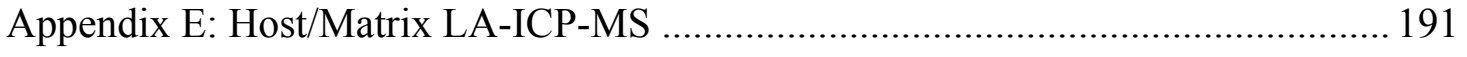

Appendix F: Element Maps .......................................................................... 218

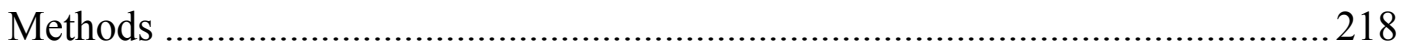

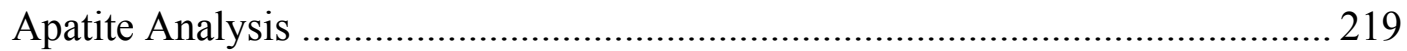




\section{LIST OF TABLES}

Table 1: Descriptive statistics of the EMP data collected from Pinatubo apatites........ 32

Table 2: Results of the t-test comparing the means of apatites from the three juvenile components.

Table 3: Representative EMP results for low-S apatites from 1991 Pinatubo eruption 40

Table 4: Representative EMP results for medium-S apatites from 1991 Pinatubo eruption.

Table 5: Representative EMP results for high-S apatites from 1991 Pinatubo eruption.

Table 6: Representative EMP results for 1991 Pinatubo "silicic" apatites with variable $\mathrm{SO}_{3}$ concentrations... 43

Table 7: Representative LA-ICP-MS results for "silicic" apatites from 1991 Pinatubo eruption 


\section{LIST OF FIGURES}

Figure 1: Location map of Mount Pinatubo study area...................................................

Figure 2: Geologic map of Ancestral and Modern Pinatubo volcanic deposits............. 11

Figure 3: Magma mixing model for the trigger of the 1991 Mount Pinatubo

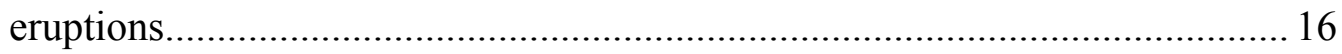

Figure 4: Mount Pinatubo sample location map....................................................... 18

Figure 5: Samples and thin sections from the 1991 Mount Pinatubo eruption used in

this study

Figure 6: Illustration of the method used to correlate major element data collected with

EMP and trace element data collected with LA-ICP-MS................................. 21

Figure 7: Durango apatite REE data collected from LA-ICP-MS in this study

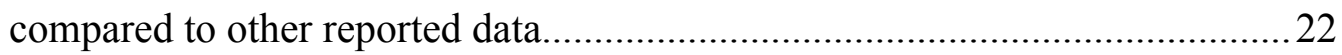

Figure 8: SILLS user interface window with selected integration intervals for background levels and signal (apatite)........................................................... 24

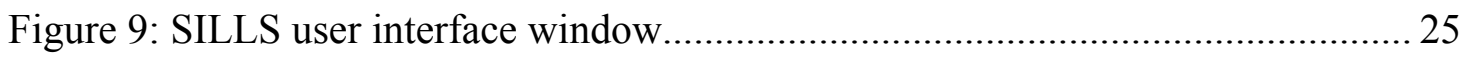

Figure 10: Cerium concentrations of apatites measured by EMP and LA-ICP-MS..... 26

Figure 11: Sulfur concentrations of apatites measured by EMP and LA-ICP-MS....... 27

Figure 12: Sodium concentrations of apatites measured by EMP and LA-ICP-MS.....28

Figure 13: Descriptive statistics of the EMP data collected from Pinatubo apatites.... 34

Figure 14: Descriptive statistics of the EMP data collected from Pinatubo apatites.... 35

Figure 15: EMP apatite data distinguishing populations of apatites................................36 
Figure 16: EMP apatite data. Apatite populations are distinguished by $\mathrm{Ce}_{2} \mathrm{O}_{3}$ wt.\%, $\mathrm{Cl}$ wt.\%, and $\mathrm{F}$ wt.\%.

Figure 17: EMP apatite data. Apatite populations are distinguished by $\mathrm{MgO}$ wt.\%

concentrations. 38

Figure 18: Apatite crystal structure and unit cell. 45

Figure 19: EMP apatite data. The strong positive correlation between $\mathrm{Na}_{2} \mathrm{O}$ wt.\% and $\mathrm{SO}_{3}$ wt. $\%$ suggests that $\mathrm{S}^{6+}+\mathrm{Na}^{+} \Leftrightarrow \mathrm{P}^{5+}+\mathrm{Ca}^{2+}$ could be a significant coupled substitution 46

Figure 20: EMP apatite data. The lack of a strong positive correlation between $\mathrm{SiO}_{2}$ wt. $\%$ and $\mathrm{SO}_{3}$ wt. $\%$ in dacite apatites suggests that $\mathrm{S}^{6+}+\mathrm{Si}^{4+} \Leftrightarrow 2 \mathrm{P}^{5+}$ is not a significant coupled substitution. 47

Figure 21: EMP apatite data. $\mathrm{S}^{6+}+\mathrm{Na}^{+} \Leftrightarrow \mathrm{P}^{5+}+\mathrm{Ca}^{2+}$ coupled substitution................ 48

Figure 22: EMP apatite data. $\mathrm{S}^{6+}+\mathrm{Si}^{4+} \Leftrightarrow 2 \mathrm{P}^{5+}$ coupled substitution

Figure 23: EMP apatite data. $\mathrm{S}^{6+}+\mathrm{Na}^{+}+\mathrm{Si}^{4+}+\mathrm{REE}^{3+} \Leftrightarrow 2 \mathrm{P}^{5+}+2 \mathrm{Ca}^{2+}$ coupled substitution 50

Figure 24: EMP apatite data. $\mathrm{S}^{6+}+\mathrm{Na}^{+}+\mathrm{Si}^{4+}+2 \mathrm{Ce}^{3+} \Leftrightarrow 3 \mathrm{P}^{5+}+\mathrm{Ca}^{2+}$ coupled substitution

Figure 25: EMP apatite data. $\mathrm{Si}^{4+}+2 \mathrm{Na}^{+}+2 \mathrm{~S}^{6+}+4 \mathrm{REE}^{3+} \Leftrightarrow 4 \mathrm{P}^{5+}+5 \mathrm{Ca}^{2+}$ coupled substitution

Figure 26: Sulfur profiles found in Pinatubo apatites.

Figure 27: Backscatter image and element maps of P, S, Na, and F for PH12C-1 Ap2 in contact with anhydrite and glass 
Figure 28: Backscatter image and element maps of P, S, Na, and F for PH12C-6 Ap5 hosted in anhydrite. 56

Figure 29: Backscatter image and element maps of $\mathrm{P}, \mathrm{S}, \mathrm{Na}, \mathrm{F}$, and $\mathrm{Cl}$ for PH12C-3b Ap11 hosted in anhydrite 57

Figure 30: Backscatter image and element maps of $\mathrm{P}, \mathrm{S}, \mathrm{Na}, \mathrm{F}$, and $\mathrm{Cl}$ for $\mathrm{PH} 12 \mathrm{C}-7$ Ap6. 58

Figure 31: REE patterns for all apatites analyzed using LA-ICP-MS.......................... 60

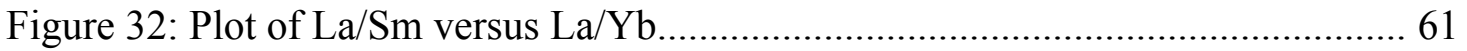

Figure 33: Shaded regions represent the range of REE concentrations in a) dacite apatites, b) andesite apatites, and c) basalt apatites. 63

Figure 34: Distinct populations of apatites based upon Th, U, and Sr concentrations. 66 Figure 35: Sulfur solubility curve of a dacitic melt at $900 \mathrm{C}^{\circ}$ is strongly dependent upon the oxidation state of the melt. 71

Figure 36: Sulfur solubility is also dependent upon pressure and temperature............. 73

Figure 37: Pre-eruption $f \mathrm{O}_{2}$ and temperature for Buag period and 1991 Pinatubo

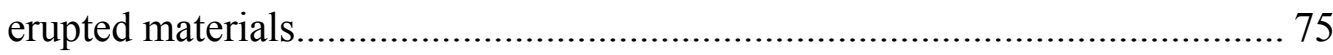

Figure 38: Profiles of high-S silicic apatites................................................................ 77

Figure 39: Sulfur distributions in apatites fully or partially hosted by anhydrite do not show diffusion profiles from the contact between apatite and anhydrite. 80

Figure 40: The average REE patterns for silicic and basalt apatites are very

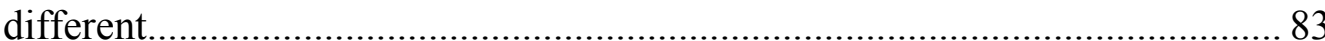

Figure 41: Silicic apatites plot nowhere near the Sr vs. La field of basalt apatites...... 85 
Figure 42: Reflected light petrographic images of a) skeletal basalt apatite and b)

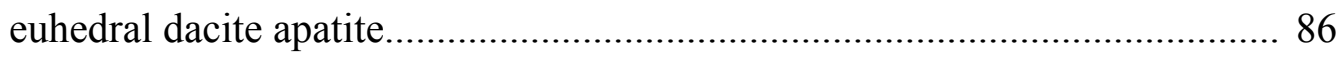

Figure 43: The xenocrystic apatite, P-22892-2a Ap1, is located as an inclusion in a xenocrystic hornblende with strong disequilibria textures................................. 89

Figure 44: REE patterns from multiple laser spots in an apatite with $\mathrm{SO}_{3}$ concentrations ranging from $\sim 0.1$ to $\sim 0.9$ wt. $\%$ show no significant difference

Figure 45: Comparison of REE patterns between high-S apatites and low-S apatites for apatites from each juvenile component........................................................... 91

Figure 46: Silicic apatites do not plot with basalt apatites based upon $\mathrm{Sm}$ and $\mathrm{Eu} / \mathrm{Eu}$ *,

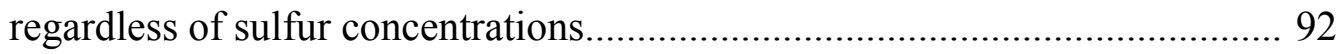

Figure 47: Sr concentrations represent the level of differentiation of the melt hosting

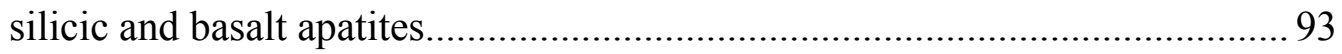

Figure 48: Basalt apatites have $\mathrm{Sr}$ concentrations and $\mathrm{Eu} / \mathrm{Eu}^{*}$ that reflect a less differentiated melt 94

Figure 49: Temperature and oxygen fugacity field for anhydrite-bearing eruptions, including the 1991 Pinatubo eruption................................................................ 96

Figure 50: Curves of equal concentrations of $\mathrm{SO}_{2}$ and $\mathrm{H}_{2} \mathrm{~S}$ under "dry" and "wet" conditions.

Figure 51: Temperature and oxygen fugacity fields of stability for sulfides and sulfates in rhyolitic magmas at $\sim 780^{\circ} \mathrm{C}, \sim 930^{\circ} \mathrm{C}$, and $\sim 1,000^{\circ} \mathrm{C}$. 100 


\section{INTRODUCTION}

On June 15, 1991, Mount Pinatubo, Philippines, erupted $5 \mathrm{~km}^{3}$ dense rock equivalent (DRE) of volcanic material, and, along with it, 20 million tonnes (Mt) of $\mathrm{SO}_{2}$ into the stratosphere. At the time, it was the highest recorded amount of $\mathrm{SO}_{2}$ released from a single eruption event recorded by the Total Ozone Mapping Spectrometer (TOMS) on NASA satellite, Nimbus 7 since it began monitoring global $\mathrm{SO}_{2}$ and ozone in 1978 (Bluth, 1992). The 1991 Pinatubo eruption exceeded the $\mathrm{SO}_{2}$ erupted from El Chichón in 1982 ( 8 Mt) by nearly threefold (Luhr et al., 1984; Bluth, 1992). As a result, global warming trends were reversed for a few years after the eruption with some regional decreases in average temperature of 0.5 degrees Celsius as predicted by Hansen et al., (1992). The eruption was triggered by an injection of basaltic magma into the base of the dacitic magma chamber, which led to magma mixing and a hybrid andesitic scoria and lava. The hybridized material erupted days before the climactic plinian eruption of June $15^{\text {th }}$ (Pallister et al., 1992, 1996; Wolfe and Hobblit, 1996).

High-sulfur eruptions such as the 1991 Pinatubo eruption are being recognized as more common than previously thought. The recognition of magmatic anhydrite crystallizing from these eruptions as a primary phase was first observed in the $1982 \mathrm{El}$ Chichón trachyandesite, and has since been found in the 1991 Pinatubo dacite, Lascár Volcano, Chile (1993 and 26.5 ka), Redoubt Volcano, Alaska (USA) (1989-1990), Nevado del Ruiz, Columbia (1985), Mount Lamington, Papua New Guinea (1951), Sutter Buttes, California (USA) (Pleistocene 1.36-1.59 Ma), El Teniente "Porphyry 
A", Central Chile (Late Miocene 5.7 Ma), Julcani, Peru (10.2 to 9.7 Ma), Yanacocha, Peru (14.5 to 8.4 Ma), Eagle Mountain (Oligocene), Santa Rita, New Mexico (USA) (63Ma) Cajon Pass Deep Scientific Drillhole, USA, California (Late Cretaceous (?)), and Cerro Lanza, Mexico, (Williams and Curtis, 1977; Arculus et al., 1983; Luhr et al., 1984; Rye et al., 1984; Drexler and Munoz, 1988; Fournelle, 1990; Luhr, 1990, 2008; Matthews et al., 1994; Bernard et al., 1996; Hattori, 1996; Pallister et al., 1996; Peng et al., 1997; Barth and Dorais, 2000; Parat et al., 2002; Audétat et al., 2004; Stern et al., 2007; Chambefort et al., 2008; Swanson and Kearney, 2008). Subduction zone-related, calc-alkaline, hydrous, highly oxidized volcanism with an excess of sulfur is the perfect environment for magmatic anhydrite to crystallize (Carroll and Rutherford, 1987). In addition to anhydrite, these conditions promote the growth of high-S apatite ( $>0.7 \mathrm{wt} . \% \mathrm{SO}_{3}$ ) by exchanging oxidized $\mathrm{S}^{6+}$ for $\mathrm{P}^{5+}$ via chargebalancing coupled substitutions with $\mathrm{Na}^{+}, \mathrm{Si}^{4+}$, and $\mathrm{REE}^{3+}$. It is because of this and apatite's resistance to weathering and ubiquitous nature, that apatite is being developed as a monitor for the changes of magmatic sulfur within a given melt (Peng et al; 1997; Streck and Dilles, 1998; Parat et al., 2002; Broderick, 2008).

The problem lies in the genesis of apatites with such enriched $\mathrm{S}$ contents in dacitic to rhyolitic melts (64 to 78 wt. $\% \mathrm{SiO}_{2}$ ). Sulfur concentrations in a melt are controlled by many interacting intensive parameters that may be in flux, such as temperature, pressure, oxygen fugacity $\left(f \mathrm{O}_{2}\right)$, and melt composition (i.e. silica content). Generally speaking, a relatively $\operatorname{cool}\left(800^{\circ} \mathrm{C}\right)$, oxidized, rhyolitic melt within a few kilometers of the surface cannot dissolve as much sulfur as a hot $\left(1100^{\circ} \mathrm{C}\right)$, 
oxidized, basaltic melt generated at depth. Furthermore, temperature, $f \mathrm{O}_{2}$, and $\mathrm{S}, \mathrm{P}$, and $\mathrm{Ca}$ concentrations of the surrounding melt also affect sulfur partitioning into apatite, complicating the relationship with sulfur further (Peng et al., 1997; Parat and Holtz, 2004, 2005). However, apatites with nearly 2 wt. $\% \mathrm{SO}_{3}$ have been observed in this and other studies (Streck and Dilles, 1998; Parat et al., 2002; Broderick, 2008). These high-S apatites were hosted in magmas that could not have the required sulfur concentration of $1,000 \mathrm{ppm}$ or $615 \mathrm{ppm}$ assuming equilibrium partitioning of sulfur between apatite and melt and a partition coefficient of 8 or 13, respectively (Baker and Rutherford, 1996b; Parat and Holtz, 2004, 2005). This means that such apatites either 1) grew in a melt different from the one they are currently hosted, i.e. they are inherited from a more mafic melt, 2) apatite is gaining sulfur from neighboring anhydrite, or 3) a transient and heterogeneous sulfur-rich fluid was present at times in the silicic melts, providing the required sulfur concentrations for high-S apatite crystallization. The object of this study is to determine which of these three mechanisms is generating high-S apatites in the 1991 Pinatubo system.

To do this, apatites from the three juvenile components of the 1991 Pinatubo eruption (dacitic pumice, hybrid andesite, and basalt inclusions within the andesite) were analyzed for major elements, including $\mathrm{SO}_{3}$, using electron microprobe (EMP) analyses, and trace elements, including rare earth elements (REE), using laser-ablation inductively coupled plasma mass spectrometry (LA-ICP-MS). Apatites have long been recognized for controlling the REE budget in whole rock, and as such, used to monitor changes within a melt, such as magma mixing. Evidence for this would be expressed 
as distinct apatite populations or chemical zonation, which has been shown with backscattered electron (BSE) and cathodoluminescence (CL) imaging with a scanning electron microscope (SEM) in other studies. REE patterns and zonation in apatites give us many clues about a changing melt environment and are excellent tools for determining inheritance from another melt. 


\section{GEOLOGIC SETTING AND DESCRIPTION OF UNITS}

\section{Geologic Setting}

Mount Pinatubo (1,745 meters above mean sea level; pre-eruption) (Newhall et al., 1996) is the northern-most volcano within a chain of mostly inactive volcanoes that comprise the Bataan segment of the Luzon Arc, which extends from the Philippines to Taiwan (Fig. 1). The 1,200 km arc consists of a chain of late Tertiary and Quaternary stratovolcanoes and volcanic necks of mostly andesitic composition (Defant et al., 1988, 1989, 1991). Mount Pinatubo is located on Luzon Island at latitude $15^{\circ} 08^{\prime} \mathrm{N}$, longitude $120^{\circ} 22^{\prime} \mathrm{E}, 90 \mathrm{~km}$ northwest of Manila and $120 \mathrm{~km}$ east of the Manila Trench (Wolfe and Hoblitt, 1996). The Manila Trench and Luzon Arc are the result of the subduction of the South China Sea oceanic crust beneath the Philippine Sea plate that began 15 Ma in the Middle Miocene (Defant et al., 1988, 1989, 1991).

The Central Luzon Arc is divided into three segments. From north to south, these segments are the Bataan arc (BA), the Macolod Corridor (MC), and the Mindoro arc (MA) (Defant et al., 1988, 1989, 1991). The BA has two semi-parallel lineaments: the Western Bataan Lineament (WBL) and the Eastern Bataan Lineament (EBL). The MA is similar to the BA, and has two parallel lineaments: the West Mindoro Lineament (WML) and the East Mindoro Lineament (EML). These arcs are separated by the NE-SW "cross-arc" zone of volcanism, the Macolod Corridor, and may represent rifting (Defant et al., 1988, 1989, 1991). Mount Pinatubo lies north in the

tightly spaced, arcuate volcanism of the WBL. The WBL is more depleted in alkalis, 
large ion lithophile elements (LILE), and light rare earth elements (LREE) when compared to the MC, EBL, and MA (Defant et al., 1988, 1989, 1991). This is due to different levels of crustal and sediment contamination and degrees of partial melting (Defant et al., 1988, 1989, 1991).

Exposed west and northwest of Mount Pinatubo, the east-dipping Zambales Ophiolite Complex (ZOC) consists of gabbros, pyroxenites, peridotites, and related felsic intrusions. Directly north, the ZOC exposure is primarily basalt (Abranjano et al., 1989; Delfin et al., 1996; Newhall et al., 1996). Subsurface investigations for geothermal resources between August 1988 and November 1989 revealed the plutonic nature of the ZOC as "a chaotic mixture of hornfels and moderately to completely altered microdiorite, micro-quartz monzodiorite, diabase, and gabbroic dikes" (Delfin et al., 1996). The complex is intersected orthogonally by the Iba fracture zone; splitting it into three sections. Mount Pinatubo lies at the intersection of the two significant geologic features (Defant et al., 1988, 1989, 1991; Newhall et al., 1996). The WBL developed on the ZOC beginning about 4 Ma.

The Tarlac Formation consists of marine, non-marine, and volcanoclastic sediments of Miocene to Pliocene age that lie unconformably above the ZOC (Newhall et al., 1996). Exposures of this formation can be found northeast and southeast of Mount Pinatubo (Newhall et al., 1996). 


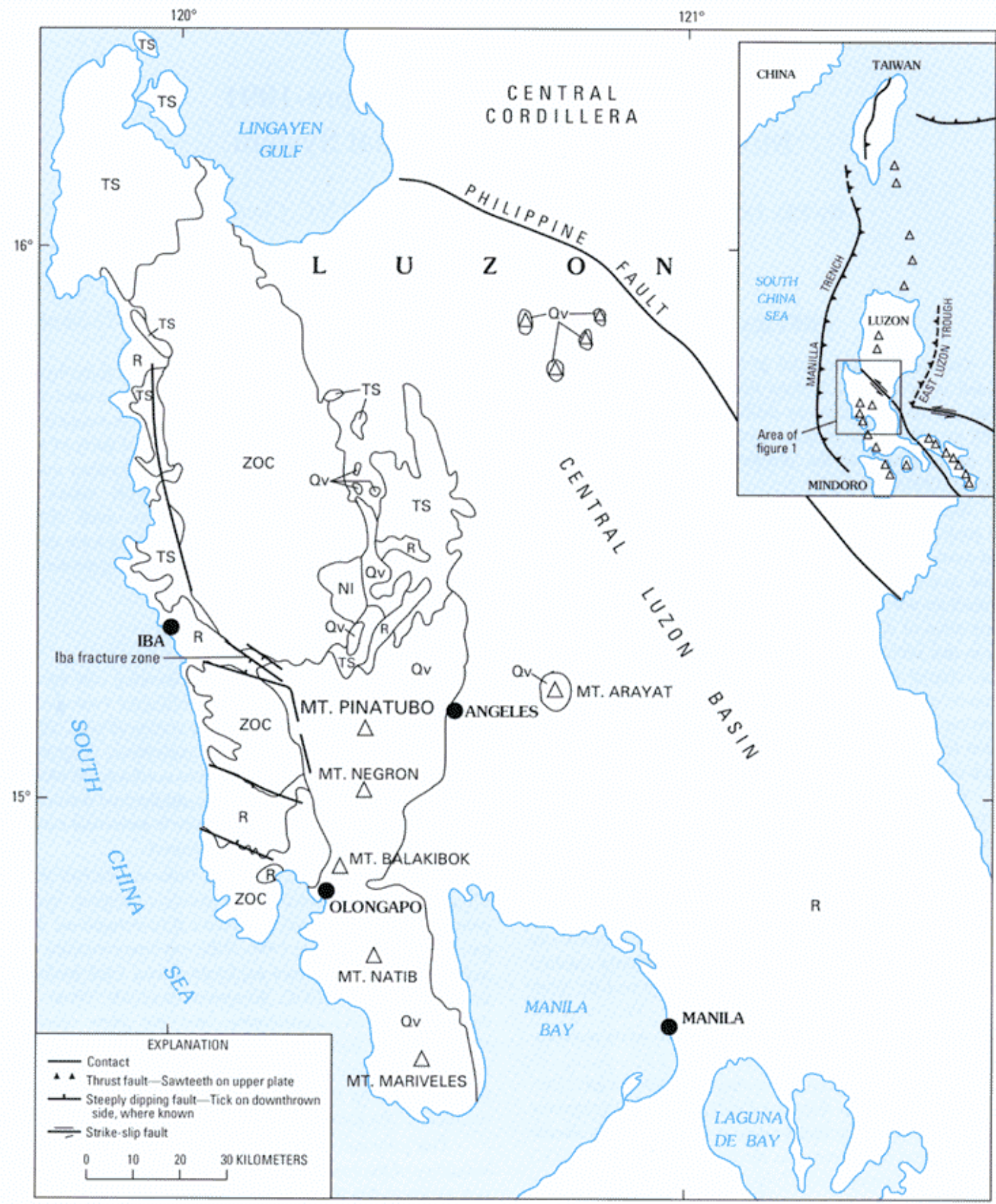

Figure 1: Location map of Mount Pinatubo study area (after Delfin et al., 1996). 


\section{Eruptive History of Mount Pinatubo}

The eruptive history of Mount Pinatubo can be divided into two main time periods: Ancestral Pinatubo (1Ma to some time prior to $35 \mathrm{ka}$ ) and Modern Pinatubo (35 ka to present) (Fig. 2). Relicts of the walls of the caldera of ancestral Pinatubo are embodied as rugged terrain surrounding Modern Pinatubo. Ancestral Pinatubo was an andesite-dacite stratovolcano that was roughly in the same location as Modern Pinatubo. Eruptive materials from ancestral Pinatubo include a two-pyroxene, hornblende andesite interbedded with pyroclastic flows and near-vent fall breccias. No evidence exists in support of large eruptions in ancestral Pinatubo's history, and all activity ceased tens to thousands of years prior to the initial growth and caldera forming eruptions of Modern Pinatubo (Newhall et al., 1996).

Modern Pinatubo's history can be divided into six or as many as a dozen eruptive periods. Due to the indistinct nature between the rock units from each period, classification of stratigraphy of Modern Pinatubo primarily relies upon radiogenic ${ }^{14} \mathrm{C}$ dating techniques performed on charcoal remnants from trees. Uncertainty of the sources of some of the charcoal samples and the potential of a tree fixing the amount of ${ }^{14} \mathrm{C}$ prior to its death from any given eruption prevents good certainty of the exact number of eruptive periods. The eruptive periods are significantly shorter than the periods of respite that can last hundreds to thousands of years (Newhall et al., 1996; Wolfe and Hoblitt, 1996) The main six eruptive periods of Modern Pinatubo are: Inararo period (>35 ka), Sacobia period (17 ka), Pasbul period (9 ka), Maraunot period $(3.9-2.3 \mathrm{ka})$, and Buag period (500 a). 
Products and eruptive phenomena of past eruptions of Modern Pinatubo are very similar to that of the 1991 eruptions (Newhall et al., 1996; Di Muro et al., 2008). The magma reservoir becomes enriched with volatiles from periodic influxes of basaltic magmas during long periods of respite. Evidence for this is observed in inclusions within products of historic eruptions (Daag et al., 1996b; Newhall et al., 1996; Wolfe and Hobblit, 1996; Di Muro et al, 2008). Andesitic to dacitic lavas erupt and form vent-filling domes, which then erupt explosively, destroying the initial dome. Over time, this has produced a stratigraphy rich in pumiceous pyroclastic flow and pumiceous lahar deposits. Late-stage domes of andesitic to dacitic lavas rebuild Pinatubo to pre-eruptive elevations. The repetitive phenomena, in addition to the unwelded, easily erodible pyroclastic flow materials, prevent Modern Pinatubo from ever growing very large (Newhall et al, 1996).

The main eruptive material from each of the Modern Pinatubo eruptive periods consists of a cummingtonite-hornblende dacite $\left(\sim 64\right.$ wt. $\left.\% \mathrm{SiO}_{2}\right)$ that almost always exists in two distinct phases: a white, crystal-rich phase ( $\sim 7 \%$ phenocrysts), and a tan-grey crystal-poor phase ( $\sim 15 \%$ phenocrysts) (Newhall et al., 1996; Pallister et al., 1996; Di Muro et al., 2008). The source of this material is believed to have existed consistently throughout Modern Pinatubo's history as a large, shallow, cool body of magma, and has been repeatedly replenished with volatiles from an underplating basaltic magma source. This is supported by the consistent material and nature of Modern Pinatubo eruptions (Daag et al., 1996b; Newhall et al., 1996). The source for this dacite reservoir is believed to be the fractionation of basalt that is generated by 
direct partial melting of primitive mantle wedge material. The basalt melt ponds at the lower-crust/upper-mantle interface, briefly allowing the crystallization of garnet. This material begins fractional crystallization, and the more buoyant dacitic residue rises to shallow crustal levels, where it collects into a large magma reservoir beneath Modern Pinatubo (Prouteau and Scaillet, 2003). Eruptions only occur when there is sufficient saturation of volatiles in the dacite magma reservoir. Repose periods are growing shorter and eruptive volumes appear to be diminishing with time. The 1991 eruption was the smallest in Modern Pinatubo history with the shortest repose period ( $\sim 500$ years) (Newhall et al., 1996). 


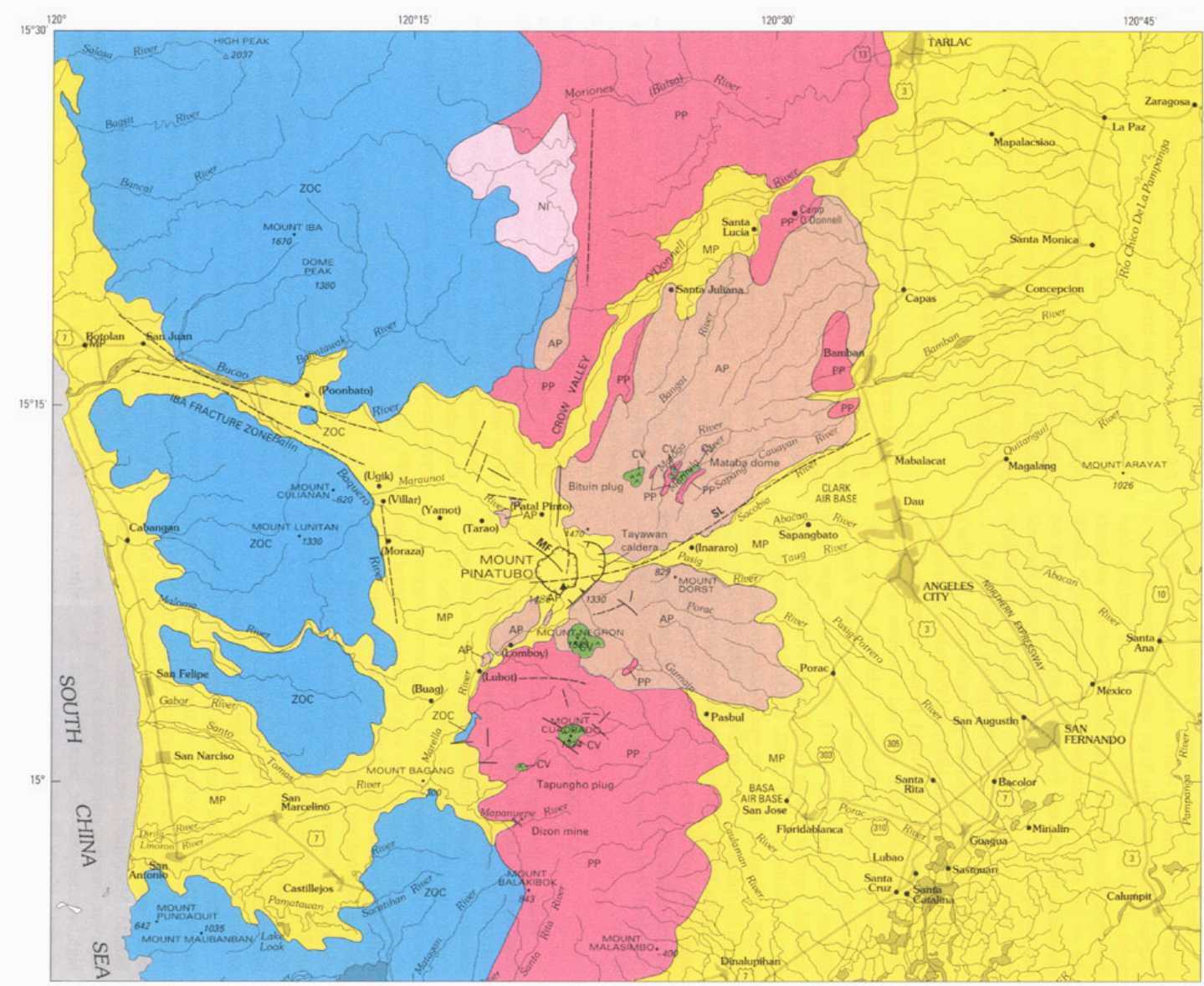

Figure 2: Geologic map of Ancestral and Modern Pinatubo volcanic deposits (after Newhall et al., 1996). Explanation of units is on the following page. 
MP Volcanic rocks of modern Pinatubo (Holocene and late Pleistocene, 40 ka to present)-Mainly dacitic pyroclastic-flow and lahar deposits

AP Deposits of ancestral Pinatubo (Pleistocene)-Andesitic and dacitic pyroclastic-flow and lahar deposits, and lava flows

CV Ancestral satellite vent deposits (Pleistocene)-Andesite and dacite dofnes and plugs, contemporaneous with deposits of ancestral Pinatubo

NI Neogene intrusives (Pliocene? and Miocene)-Granodiorite and diorite porphyry

PP Pre-Pinatubo sedimentary and volcanic rocks, mostly Tarlac Formation (Early Pliocene and late Miocene)

ZOC Zambales Ophiolite complex (Eocene)-Mainly peridotite, gabbro, and basalt

\section{EXPLANATION OF MAP SYMBOLS}

Contact-Dashed where inferred

Fault-Dashed where inferred; MF, Maraunot Fault; SL, Sacobia

Lineament

TI T Rim of Tayawan Caldera

Boundary of caldera formed on June 15,1991

\section{Eruptions of Mount Pinatubo}

The 1991 eruptions ended a 500 year hiatus from activity (Newhall et al., 1996) and produced four distinct juvenile magmatic components: a primary ( $~ 85 \%$ volumetric proportion), white, phenocryst-rich dacitic pumice, a secondary $(\sim 15 \%)$ tan, phenocryst-poor dacitic pumice, a hybrid-andesite, and an olivine-clinopyroxene quenched basalt that occurs as inclusions of variable size in the hybrid andesite (Bernard et al., 1996; David et al., 1996; Pallister et al., 1996). 
Beginning in March 1991, two and a half weeks of local earthquakes announced the re-awakening of Mount Pinatubo. On April 2, the native Aeta people observed several steam eruptions, and numerous volcano-tectonic earthquakes occurred persistently, indicating the injection of a volatile-rich basalt into the dacitic magma reservoir (Pallister et al., 1992, 1996; Wolfe and Hoblitt, 1996). Pallister et al. $(1992,1996)$ have documented significant petrographic and geochemical evidence of magma mixing between the basaltic and dacitic endmembers to produce the hybrid andesite (Fig. 3). There is no evidence of assimilations of the ZOC (Fournelle et al., 1996; Pallister et al., 1996).

Correlation Spectrometer (COSPEC) measurements of $\mathrm{SO}_{2}$ emissions from Pinatubo first taken in mid-May showed a rate of 500 tonnes of $\mathrm{SO}_{2} /$ day. This number increased tenfold by late May indicating either 1) magma was rising, or 2) the hydrothermal system beneath Pinatubo that had absorbed a good portion of the $\mathrm{SO}_{2}$ released was being boiled, allowing more $\mathrm{SO}_{2}$ to reach the surface (Daag et al., 1996a). From June $1^{\text {st }}$ to $7^{\text {th }}$, localized, shallow earthquakes resolved a narrow pipelike zone near the summit. The COSPEC measurement taken on June $5^{\text {th }}$ was only 260 tonnes of $\mathrm{SO}_{2} /$ day, indicating that the conduit for the escaping gas was being plugged (Daag et al., 1996a). Shortly thereafter, a hybrid andesite dome with basaltic inclusions was formed between June $7^{\text {th }}$ and $12^{\text {th }}$ at the head of the Maraunot River canyon, northwest of the pre-eruption summit. A final pre-climactic eruption COSPEC measurement was made on June $10^{\text {th }}$ and gave and $\mathrm{SO}_{2}$ emission rate of 13,000 tonnes/day (Daag et al., 1996a). Four brief vertical eruptions began at 0851 (local 
time) on June 12, destroying part of the andesitic dome, and continued until June 14. Eruptions during this time produced ash and andesitic scoria (Pallister et al., 1996; Wolfe and Hoblitt, 1996). A sequence of 13 surge-producing eruptions began June 14, leading to the final climatic eruption at 1342 on June 15 (Wolfe and Hoblitt, 1996). Peak eruptive conditions lasted for three hours and sent 2 to $10 \mathrm{~km}^{3}$ of eruptive material into the stratosphere at a discharge rate of $4 \times 10^{8}$ to $2 \times 10^{9} \mathrm{~kg}$ per second (Koyaguchi, 1996; Paladio-Melosantos et al., 1996). By 1440, the eruption cloud was $60,000 \mathrm{~km}^{2}$ (Koyaguchi, 1996). The climactic plinian eruption covered $2,000 \mathrm{~km}^{2}$ with normally graded ash and pumice 10 to $25 \mathrm{~cm}$ thick. The eruption spread material over most of Luzon plus 4 million $\mathrm{km}^{2}$ of the South China Sea and Southeast Asia and ejected 17 million tons of $\mathrm{SO}^{2}$ into the stratosphere (Bluth et al., 1992; Lynn et al., 1996).

To make matters worse for the people of Luzon, Typhoon Yunya passed within $75 \mathrm{~km}$ of Pinatubo on June 15 at 1100 . The copious rainfall mixed with the tephra of the eruption, producing a heavy, sodden mess that caused a great deal of damage. Strong winds from the typhoon spread ash further than it would have traveled without the tropical storm. Post-paroxysmal eruptions and the residual heat near Mount Pinatubo generated moisture condensation and atmospheric instability. The result was increased rainfall, devastating lahars, and secondary phreatic eruptions (Oswalt et al., 1996).

Two pumice-types were produced during the June 12-14 and June 15 climactic eruptions. Each exhibit identical mineralogies and chemical compositions, including 
both major and trace elements. It has been suggested that the difference in types is strictly due to a change from a sudden and violent eruptive episode early in the climactic June 15 eruption, to a less violent, more sustained eruption. The violent nature in the early eruption physically shattered any crystals that had grown in the magma reservoir, as evidenced in the abundant and small $(<10$ micrometers $(\mu \mathrm{m})$ to $<1 \mu \mathrm{m}$ ) crystal fragments observed in the phenocryst-poor type (Bernard et al., 1996; David et al., 1996; Pallister et al., 1996).

Rutherford and Devine (1996) report pre-eruption conditions of $780^{\circ} \pm 10^{\circ} \mathrm{C}$, $f \mathrm{O}_{2}$ of $3 \log$ units above the nickel-nickel oxygen buffer $(\mathrm{NNO}+3)$. However, there is work by Evans and Scalliet (1997) and Scalliet and Evans (1999) that suggests that this is an overestimate due to improper use of the Fe-Ti oxide geothermometer at such high oxygen fugacities and that pre-eruption $f \mathrm{O}_{2}$ is likely closer to $\mathrm{NNO}+1.7$. Total pressure was $220 \pm 50$ megapascals (MPa). This pressure is the equivalent of depths of $7.7 \pm 1.75$ kilometers $(\mathrm{km})$ beneath Mount Pinatubo, and correlates well with the low seismic velocity zone measured at depths of 6 to $11 \mathrm{~km}$ (Mori, et al., 1996; Rutherford and Devine, 1996). The dacitic magma reservoir was hydrous and volatile-rich with 5.1 to 6.4 wt. $\% \mathrm{H}_{2} \mathrm{O}$. Sulfur concentrations varied between melt inclusions ( 55 to $77 \pm 28 \mathrm{ppm}$ ) and matrix glass (36 ppm) (Rutherford and Devine, 1996). Fe-Mg exchange equilibria suggest a basalt magma temperature of $1200^{\circ} \mathrm{C}$ (Pallister et al., 1996).

Between July and November 1992, a freshly mixed andesite dome grew in the floor of the caldera before it was filled with rainwater. Geochemical evidence showed 
that a new batch of basalt had injected into the dacitic reservoir to produce the 1992 andesite dome (Daag et al., 1996b). COSPEC measurements during this period revealed an $\mathrm{SO}_{2}$ emission rate of only 200 - 600 tonnes/day (Daag et al., 1996a). The dacitic chamber was still degassed or gas-poor and only able to produce effusive lava dome eruptions (Daag et al., 1996a, 1996b).

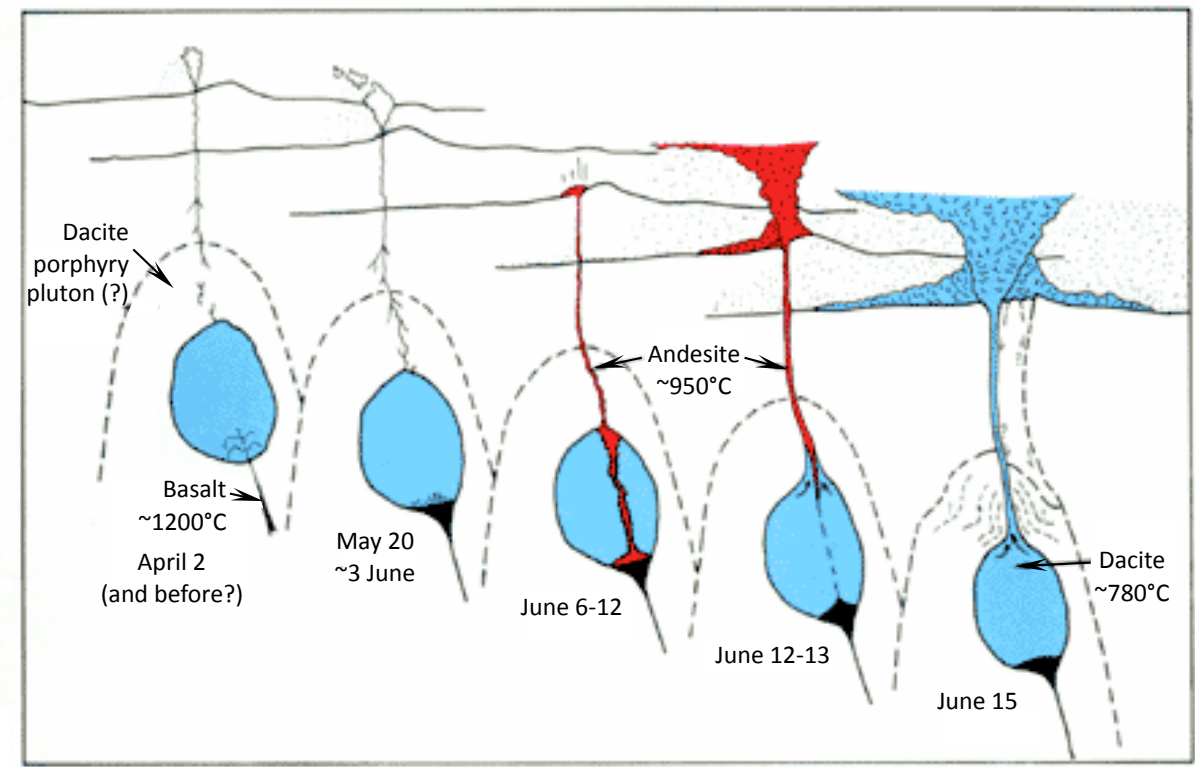

Figure 3: Magma mixing model for the trigger of the 1991 Mount Pinatubo eruptions. Basalt recharge into the dacitic magma reservoir generated a hybrid andesite that buoyantly rose to the surface, generating a path for the volatile-saturated dacite magma to follow and erupt explosively (after Pallister et al., 1996).

\section{Sample Descriptions}

Dr. John S. Pallister graciously donated samples for this study from the collection at the Cascades Volcano Observatory (CVO) United States Geologic Survey (USGS) in Vancouver, WA. The samples are generic representatives of three of the four juvenile magmatic components from the 1991 Pinatubo eruption and were 
collected shortly after the climactic eruption. The samples are the phenocryst-rich dacitic pumice, $\mathrm{PH} 12 \mathrm{C}\left(64 \mathrm{wt} . \% \mathrm{SiO}_{2}\right.$ ) collected from the Bucao drainage on the northwest flank of Pinatubo, the hybrid andesite lava, CN6791-d (59 wt.\% $\mathrm{SiO}_{2}$ ), and the basalt inclusion, $\mathrm{P}-22892-2 \mathrm{a}\left(51 \mathrm{wt} . \% \mathrm{SiO}_{2}\right)$. Both the andesite and basalt samples were collected from the Maraunot River drainage northwest of the current caldera (Fig. 4 and Fig. 5) The phenocryst-poor dacitic pumice has been selectively excluded from the scope of this study due to a lack of sufficiently sized and preserved crystals. Detailed sample descriptions can be found in Appendix A.

Apatite is present in all of the samples. Dacite- and andesite-hosted apatites (silicic apatites) are euhedral to subhedral, range in size from $10 \mu \mathrm{m}$ to $180 \mu \mathrm{m}$, and are found as inclusions in anhydrite, plagioclase, hornblende, and Fe-Ti oxides, or as individual groundmass phenocrysts. Basalt-hosted apatites (mafic apatites) have a strikingly different morphological expression, and are often acicular and skeletal, suggesting rapid growth due to quenching. These apatites are typically much smaller than silicic apatites $(\sim 5 \mu \mathrm{m}$ to $60 \mu \mathrm{m})$ and do not occur as inclusions in other host phenocrysts. Due to this morphological difference, apatites in the hybrid andesite were likely inherited solely from the dacite endmember. The objective of this study was to constrain the conditions of the formation of high-S silicic apatites using the welldocumented 1991 Pinatubo system as a framework. 


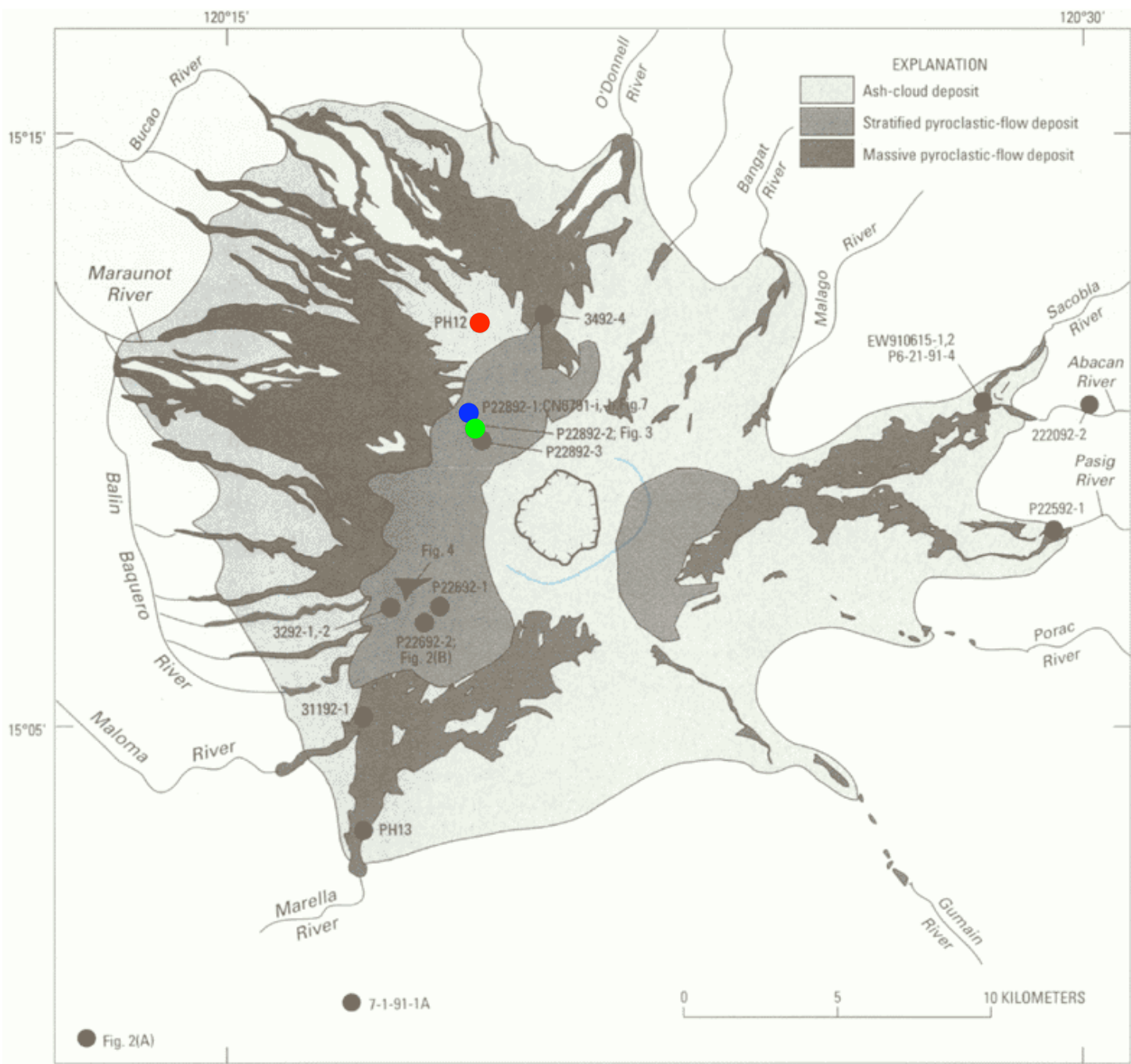

Figure 4: Mount Pinatubo sample location map. Basalt (green) and andesite (blue) samples were taken from stratified pyroclastic flow deposits at the top of the Maraunot River drainage. Dacite (red) samples were collected from ash fall deposits in the Bucao drainage (after Pallister et al., 1996). 


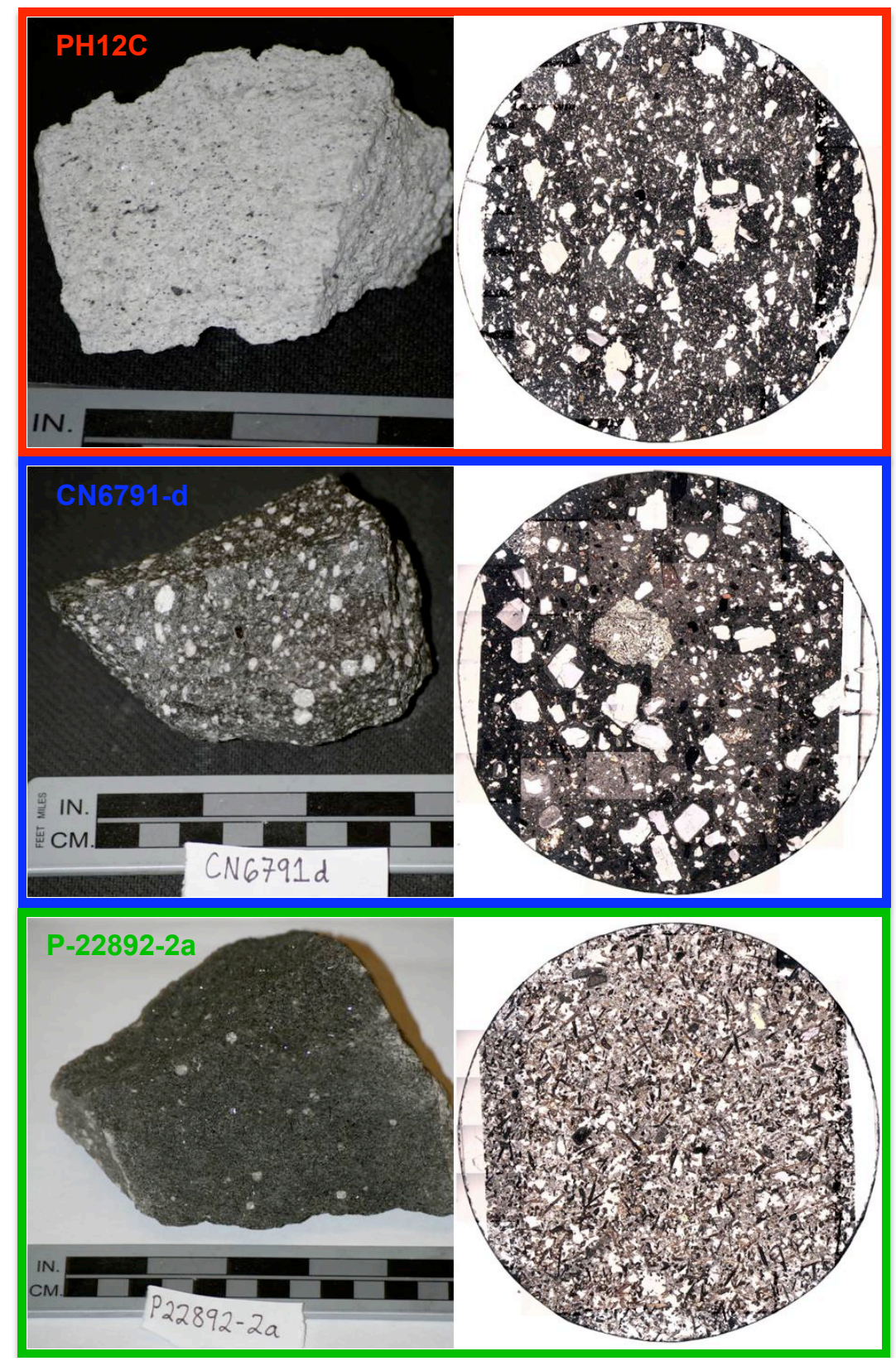

Figure 5: Samples and thin sections from the 1991 Mount Pinatubo eruption used in this study. PH12C (red) is a sample of the crystal-rich dacitic pumice from the climactic June 15 plinian eruption. CN6791-d (blue) is a sample of the hybrid andesite lava from the June 7-12 dome. P22892-2a (green) is a sample of a large, quenched basaltic inclusion from the June 7-12 dome. 


\begin{abstract}
ANALYTICAL METHODS
Electron Microprobe (EMP) Analysis

Apatites from thin sections were analyzed for major elements using a fivespectrometer CAMECA SX100 electron microprobe housed at Oregon State University. Analyses were controlled via remote access at Portland State University. Apatite analysis operating conditions were an accelerating voltage of $15 \mathrm{kV}$, a beam current of $20 \mathrm{nA}$, and a beam size of $2 \mu \mathrm{m}$ diameter. Apatite analyses and EMP procedures can be found in Appendix B. The main purpose of the EMP analyses was to determine the sulfur content and intra-grain variability across apatite grains using traverse analyses (Fig. 6).

Additionally, several of the smaller apatites that were unsuitable for LA-ICPMS were selected for element mapping of $\mathrm{S}, \mathrm{Na}, \mathrm{F}, \mathrm{Cl}$, and $\mathrm{P}$ to produce a more complete picture of sulfur distribution within a given grain. Apatites selected for element mapping were hosted within primarily anhydrite, but also hornblende and FeTi oxides. Apatite element mapping operating conditions were an accelerating voltage of $15 \mathrm{kV}$, a beam current of $30 \mathrm{nA}$, and a beam size of $0 \mu \mathrm{m}$ diameter. All element maps generated in this study can be found in Appendix F.
\end{abstract}


b.

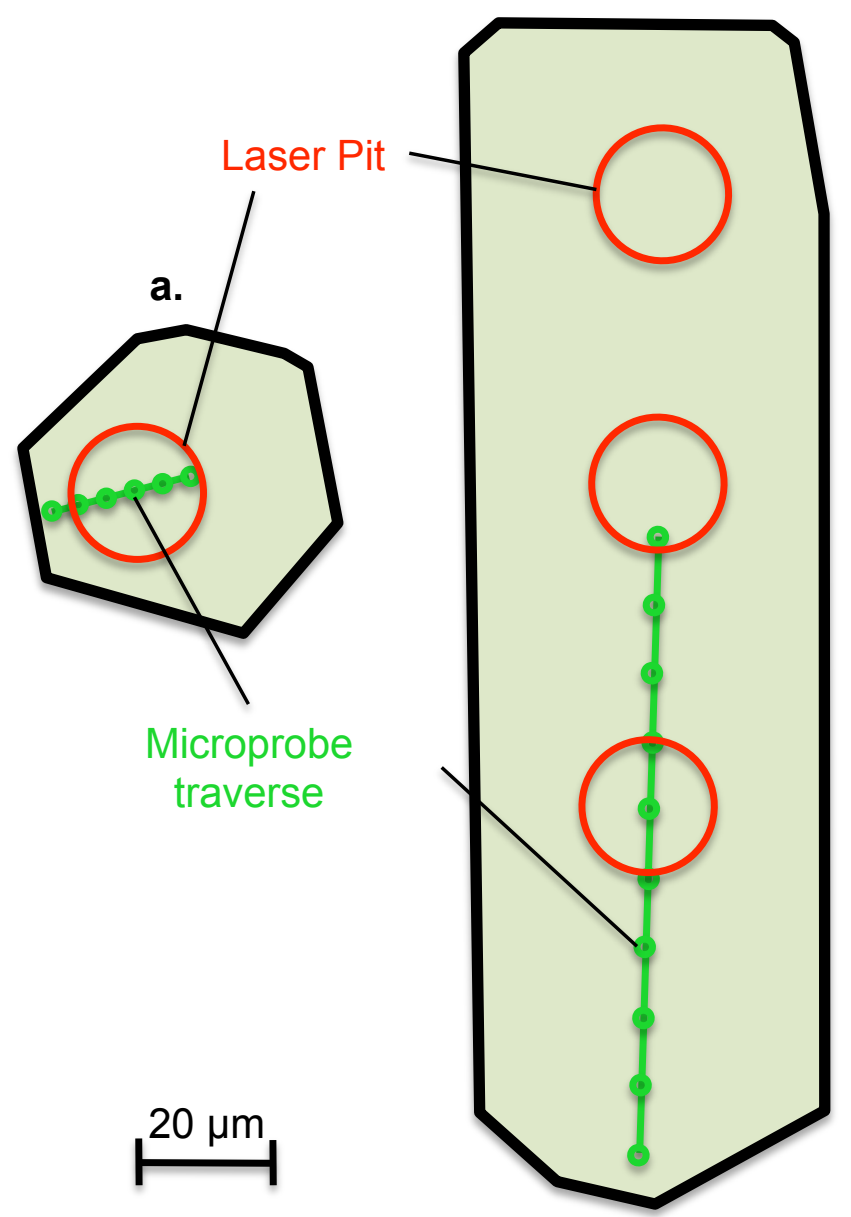

Figure 6: Illustration of the method used to correlate major element data collected with EMP (green traverse) and trace element data collected with LA-ICP-MS (red circles). Laser spots were selected to overlap the microprobe traverse. Major element values used with trace element data are the average of the EMP spots overlapped by the laser spot. Two examples of apatites: a) apatite cut perpendicular to the c-axis with a single laser spot; b) apatite cut parallel to the c-axis with multiple laser spots.

\section{Laser-Ablation Inductively Coupled Plasma Mass Spectrometry (LA-ICP-MS)}

Trace elements, including REE, were acquired on apatites, anhydrites, plagioclase, hornblendes, and glass from thin sections using LA-ICP-MS analyses. To ensure data consistency, a large crystal of Durango apatite was also analyzed. These analyses agreed well with published values (Fig. 7). LA-ICP-MS data were acquired 
using the $193 \mathrm{~nm}$ ArF Excimer Laser coupled with an ELAN 6100 ICP quadrupole mass spectrometer at Eidgenössische Technische Hochschule (ETH) Zürich, Switzerland. Laser settings were $23,24,28$, and $30 \mathrm{kV}$ and a $10 \mathrm{~Hz}$ repetition rate, yielding a fluence of about $12 \mathrm{~J} / \mathrm{cm}^{2}$ on the ablation site. For apatites, beam sizes of 15,20 , and $40 \mu \mathrm{m}$ were used.

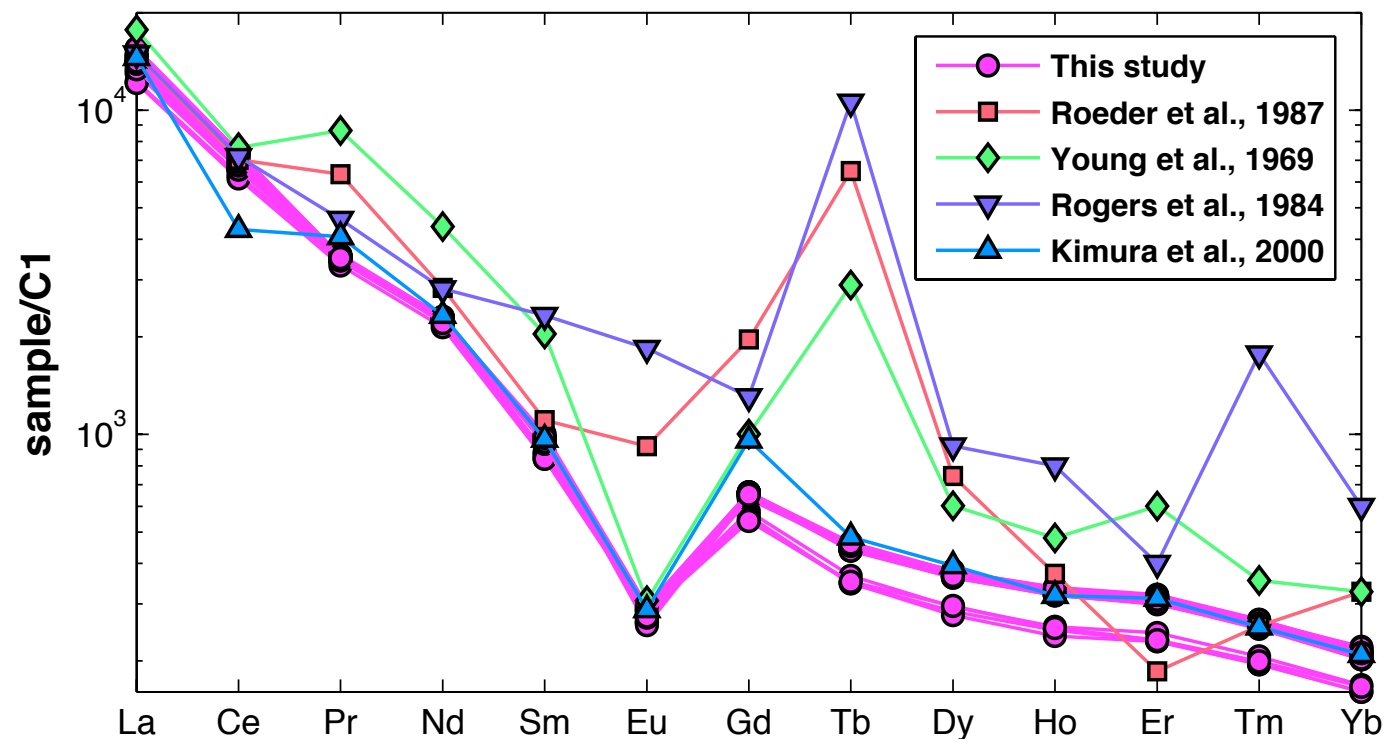

Figure 7: Durango apatite REE data collected from LA-ICP-MS in this study compared to other reported data. Data collected by Roeder et al., 1987, Young et al., 1969, and Rogers et al, 1984 was converted to ppm from oxide EMP results. Data from Kimura et al., 2000 was collected by LA-ICP-MS and compares well with the data collected during this study.

Apatites selected for LA-ICP-MS analyses had to be large enough for the sizeable laser spots. Dacite-, andesite-, and basalt-hosted apatites were selected with a variable range of $\mathrm{SO}_{3}$ including low $(<0.3 \mathrm{wt} . \%)$, medium (0.3-0.7 wt.\%), and high ( $>0.7$ wt.\%). Locations of EMP traverses were recorded on petrographic microscope images taken of the apatites. Using these images, laser spot positions were selected to overlap the pre-existing traverses (Fig. 6). Some apatites were large enough for up to 
four laser spots, but the majority was only large enough for one. Host minerals were analyzed in order to identify and reduce sources of potential contamination (Figs. 8 and 9) during ablation using 15, 20, and $40 \mu \mathrm{m}$ beam sizes appropriate for individual crystals (See Appendix E for host and glass LA-ICP-MS results).

The MATLAB-based program, SILLS, was used to process all LA-ICP-MS data. SILLS requires both an internal and external standard to quantify element concentrations. NIST 610 was the external standard used at ETH, and the internal standard for apatites was $\mathrm{CaO}$ concentration set to 54 wt.\%. For further details on the calculation settings used in SILLS for apatites, Durango apatites, host minerals, and glass, refer to Appendix C. Figures 8 and 9 are examples of the user interface window used to select integration intervals for background levels, signal (apatite concentrations), and matrix (host mineral/glass concentrations). Apatite intervals were selected in order to minimize contamination from any surrounding matrix by maximizing $\mathrm{P}, \mathrm{Ca}$, and $\mathrm{Ce}$ signals, and minimizing signals belonging to matrix, such as $\mathrm{Al}, \mathrm{K}, \mathrm{S}, \mathrm{Ba}$, and $\mathrm{Mg}$. Comparison of measured REE values from this study to previously published Durango apatite REE data normalized to $\mathrm{C} 1$ chondrite (Fig. 7) provides confidence in the accuracy of the LA-ICP-MS results from this study. 


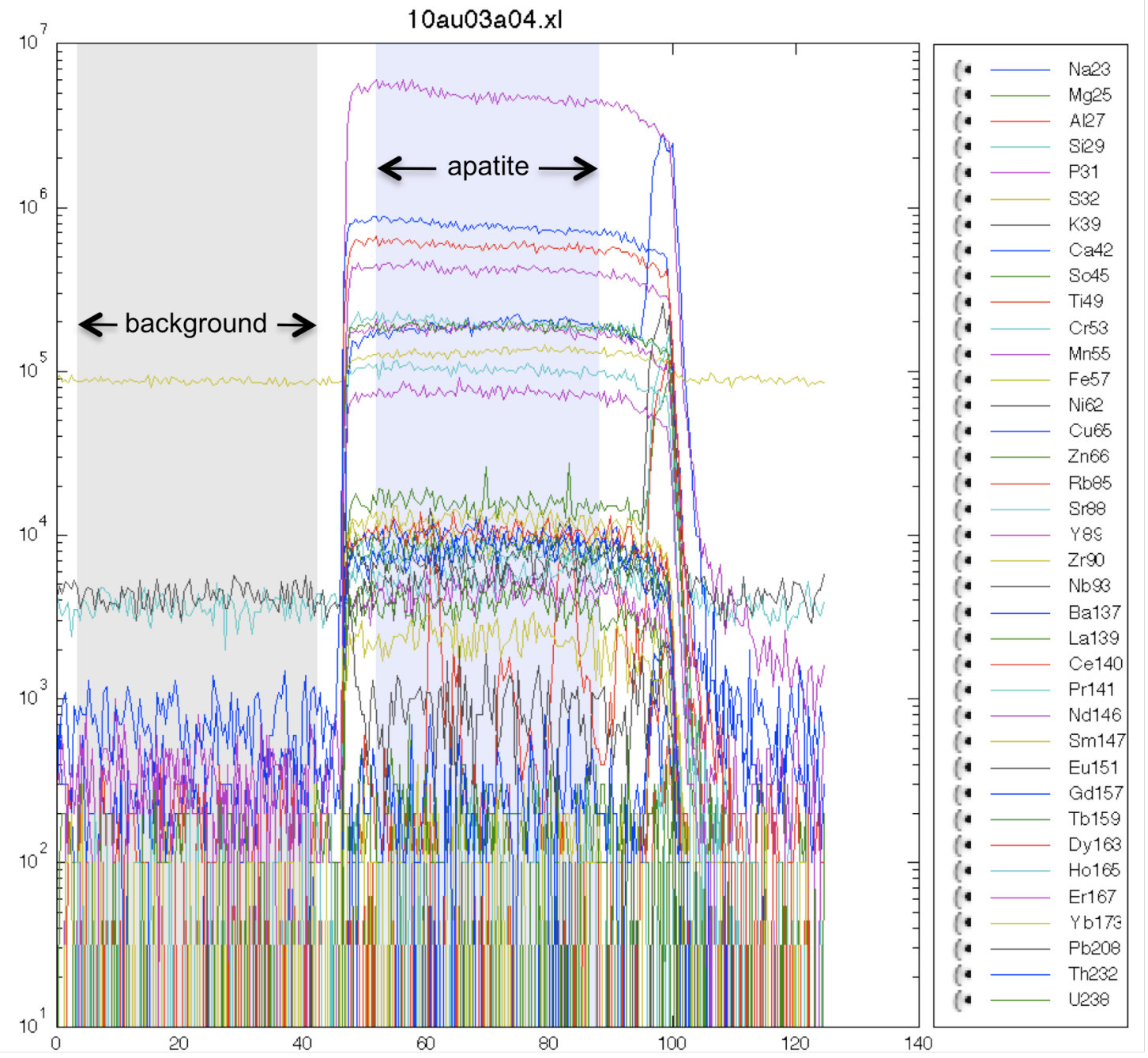

Figure 8: SILLS user interface window with selected integration intervals for background levels and signal (apatite). 


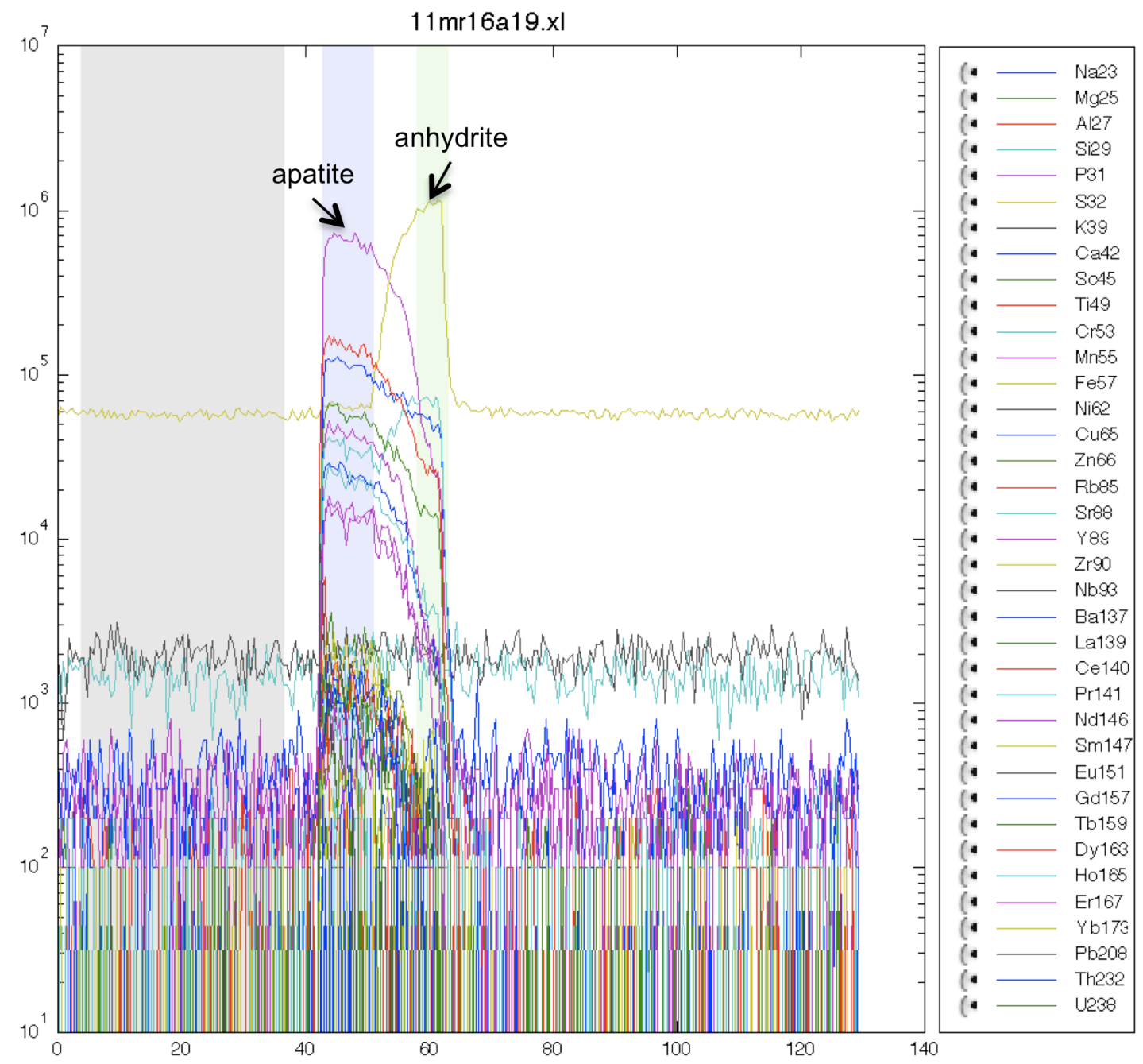

Figure 9: SILLS user interface window. Selected interval for apatite signal was carefully chosen to reduce the effects of matrix contamination from host anhydrite.

\section{Correlation of EMP and LA-ICP-MS}

$\mathrm{SO}_{3}$ and other major element concentrations determined by EMP analyses were correlated with the trace and REE concentrations, such as $\mathrm{Sr}$ and $\mathrm{La}$, acquired with LA-ICP-MS by taking the average of the EMP spot values overlapped by the LA- 
ICP-MS laser spot (Fig. 6). Concentric growth was assumed for apatites when laser spots did not directly overlap a microprobe traverse, i.e. major element concentrations were assumed to have the same profile from the center to any point along the rim. By overlapping EMP sulfur concentrations and LA-ICP-MS trace element data, we can observe if changing sulfur concentrations correlates with changing trace element and REE concentrations. $\mathrm{Ce}, \mathrm{S}$, and $\mathrm{Na}_{2} \mathrm{O}$ were collected with both analytical methods, and the comparison of results is provided in Figures 10, 11, and 12. A general trend with some scatter along the 1:1 line provides confidence in the quality of both data sets.

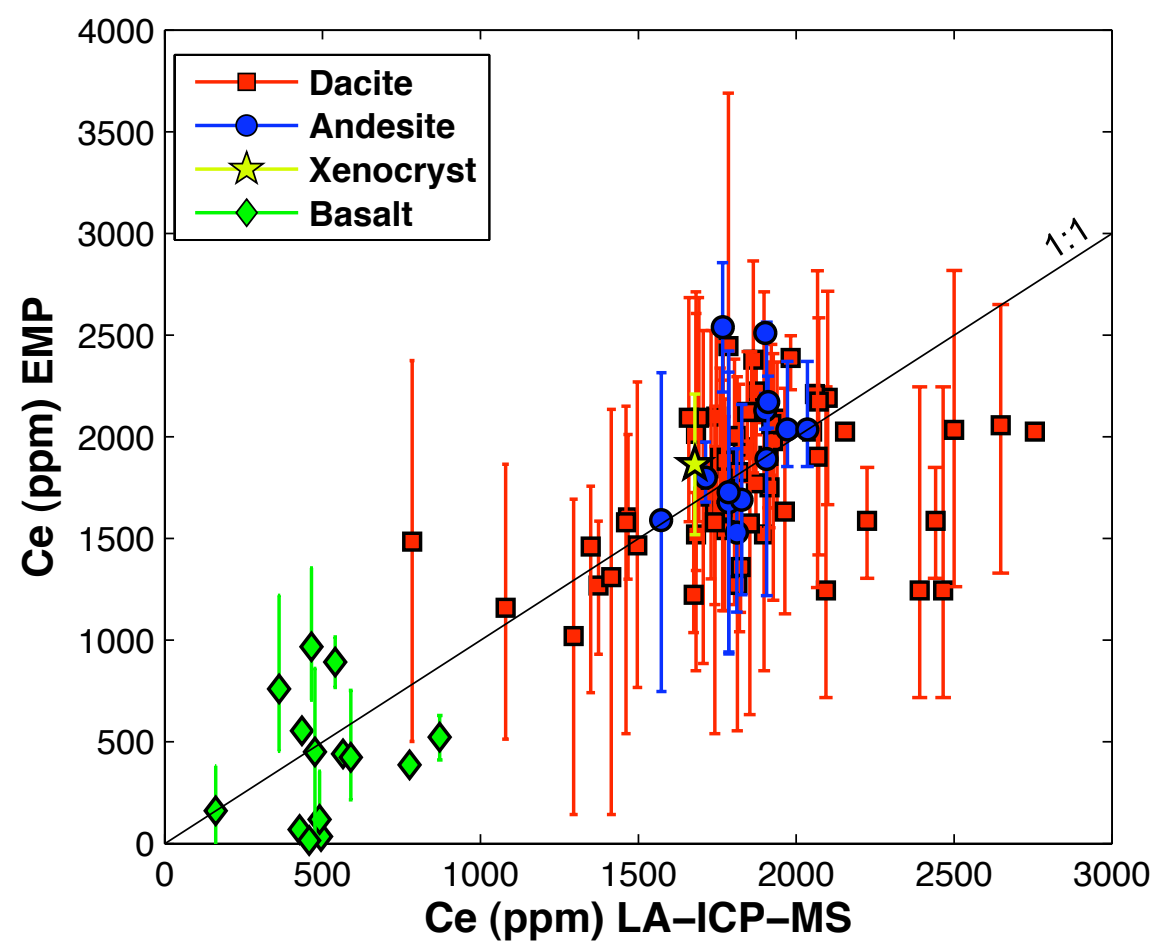

Figure 10: Cerium concentrations of apatites measured by EMP and LA-ICP-MS. Positive trend along the 1:1 line gives confidence in the accuracy of the LA-ICP-MS data. The bars that correspond with the EMP axis represent the range of EMP Ce values overlapped by the laser spot. 


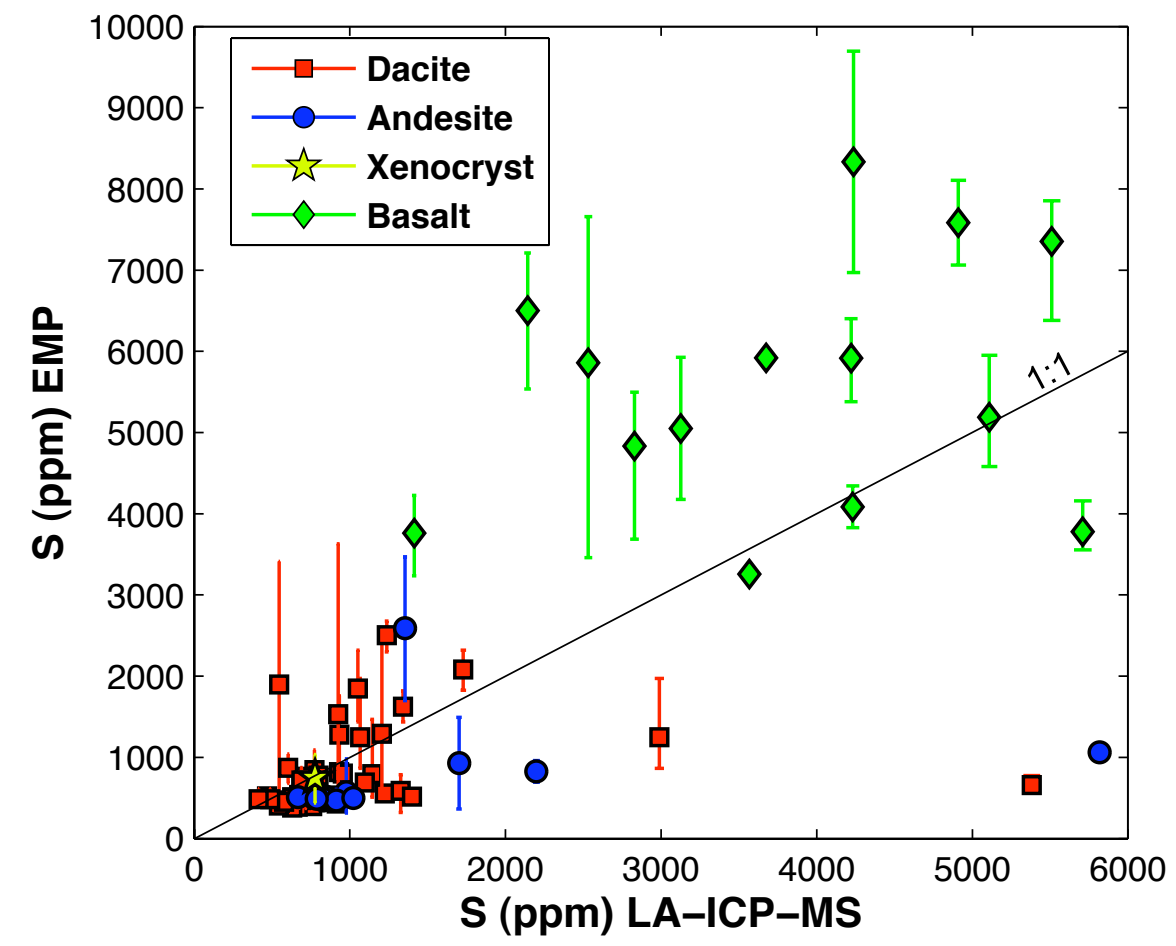

Figure 11: Sulfur concentrations of apatites measured by EMP and LA-ICP-MS. Positive trend along the 1:1 line gives confidence in the accuracy of the LA-ICP-MS data. Measuring sulfur concentrations with LA-ICP-MS is a difficult process and some deviation from the 1:1 line is expected. Additionally, laser spots may not correspond perfectly with the area measured by EMP. The bars that correspond with the EMP axis represent the range of EMP S values overlapped by the laser spot. 


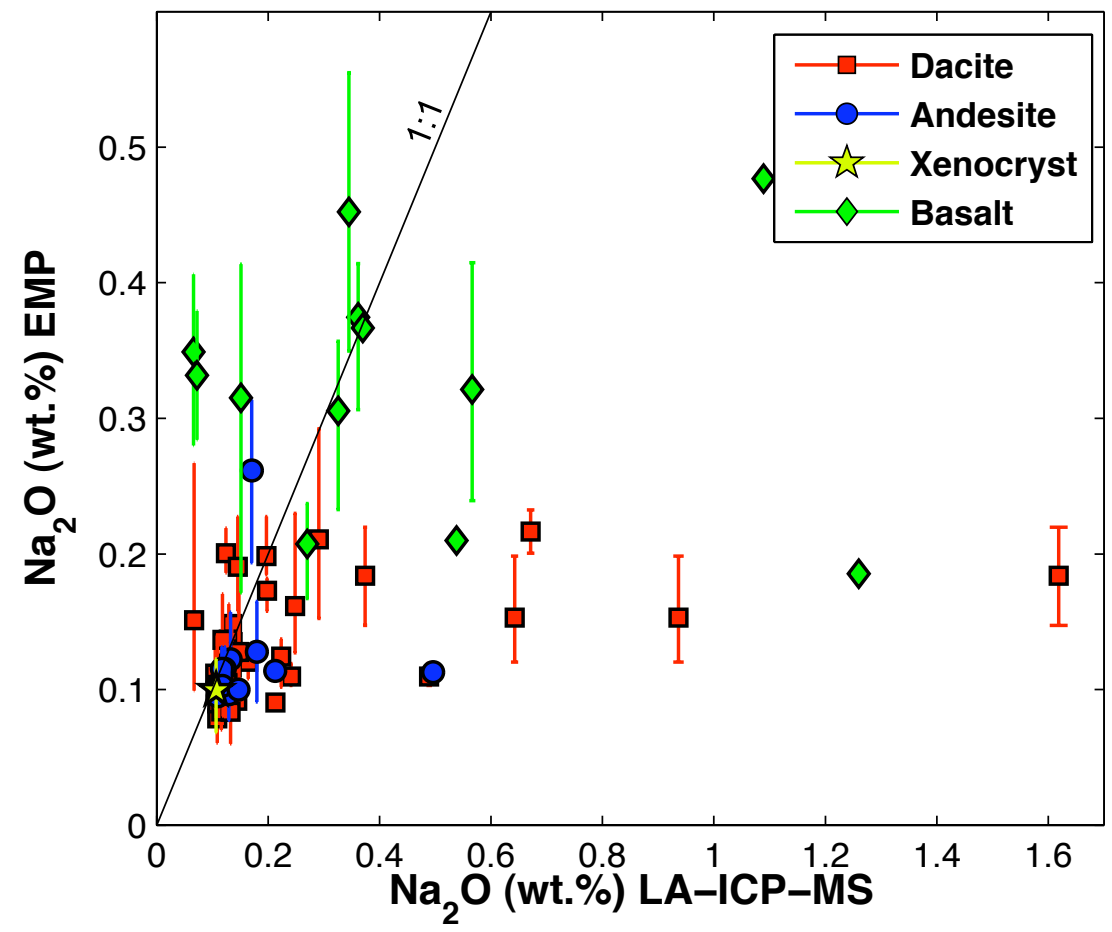

Figure 12: Sodium concentrations of apatites measured by EMP and LA-ICP-MS. Positive trend along the 1:1 line gives confidence in the accuracy of the LA-ICP-MS data. High $\mathrm{Na}_{2} \mathrm{O}$ values measured by LA-ICP-MS reflect some contamination from the matrix. However, these data points showed acceptable trace element concentrations and were kept in the data set. The bars that correspond with the EMP axis represent the range of EMP S values overlapped by the laser spot. 


\section{RESULTS}

\section{Major Element Apatite Populations}

One of the theories behind the generation of high-S apatites in dacitic to rhyolitic melts tested in this study is inheritance of apatites from more mafic melts. To address this and determine if significant populations of apatite exist among those hosted in the dacite, andesite, and basalt based on major element data alone, F- and tstatistical tests were performed using descriptive statistics of the EMP data (Table 1 and Table 2). Confidence levels were set to $\alpha=0.05$ for all statistical analyses.

The F-test is a comparison of the variances (i.e. the width of the normal distribution curve) between two populations under the assumed null hypothesis $\left(\mathrm{H}_{\mathrm{o}}\right)$ that the variances are equal (Davis, 2002). The results of the F-test (Table 1, Fig. 13) between the dacite- hosted apatites and the andesite-hosted apatites show that $\mathrm{H}_{\mathrm{o}}$ is rejected for $\mathrm{Cl}, \mathrm{SO}_{3}, \mathrm{Ce}_{2} \mathrm{O}_{3}, \mathrm{FeO}, \mathrm{SiO}_{2}, \mathrm{Na}_{2} \mathrm{O}$, and $\mathrm{MgO}$, meaning that there is a statistically significant difference between the variances of each of these oxides between dacite- and andesite-hosted apatites. No significant difference could be detected in the variances of $\mathrm{CaO}, \mathrm{P}_{2} \mathrm{O}_{5}, \mathrm{~F}$, and $\mathrm{MnO}$. Comparing dacite- and basalthosted apatites, there were significant differences in variances of all elements of Table 1 except $\mathrm{Cl}$, and $\mathrm{Ce}_{2} \mathrm{O}_{3}$. The andesite- vs. basalt-hosted apatite F-test resulted in differences in variances of all elements except $\mathrm{F}, \mathrm{Ce}_{2} \mathrm{O}_{3}$, and $\mathrm{FeO}$. In short, the results

of the F-tests indicate that the variance of the most abundant oxides within an apatite $\left(\mathrm{CaO}\right.$ and $\left.\mathrm{P}_{2} \mathrm{O}_{5}\right)$ cannot be distinguished between the dacite- and andesite-hosted 
apatites, but can be distinguished when either the dacite- or andesite-hosted apatites are tested against the basalt-hosted apatites. These data support the position of andesite-hosted apatites coming solely from the dacite during magma mixing.

The t-test is a comparison of the means of two populations where $\mathrm{H}_{\mathrm{o}}=$ means of the two populations are the same (Davis, 2002). When comparing the means of the major elements and oxides of the basalt-hosted apatite with the dacite- and andesitehosted apatites, all of the elements and oxides measured in the EMP analyses reject $\mathrm{H}_{0}$. There is a significant difference in the means of all the oxides of dacite-hosted vs. basalt-hosted apatites and andesite-hosted vs. basalt-hosted apatites (Table 2, Fig. 14). The results of the t-test between the dacite- and andesite-hosted apatites show that only $\mathrm{CaO}$ and $\mathrm{SiO}_{2}$ cannot be distinguished at $\alpha=0.05$. Overall, the results of the statistical tests show that there are at least two (dacite/andesite and basalt), maybe three (dacite, andesite, and basalt) statistically significant apatite populations based solely on major element concentrations. Plots of $\mathrm{Ce}_{2} \mathrm{O}_{3}$ vs. $\mathrm{MgO}$ and major elements against $\mathrm{SO}_{3}$ further confirm these results (Figs. 15, 16, and 17). For purposes of simplicity and clarity, dacite and andesite apatites will be a single group collectively referred to as "silicic apatites". This term in no way suggests any significantly large amount of $\mathrm{SiO}_{2}$ within these apatites, such that they should be classified as Ellestadite (Pasero et al., 2010).

One additional statistical test was performed on a particular basalt-hosted apatite (P-22892-2a Ap1). This apatite, unlike all of the other analyzed basalt apatites, is an inclusion hosted in a hornblende that has experienced significant disequilibria 
conditions and does not display the typical acicular and skeletal morphologies. Furthermore, EMP analysis of this apatite shows major element concentrations that more closely resemble that found in dacite and andesite apatites. To determine statistically if this apatite is a xenocryst originally from the dacite, a Z-test was performed to compare the mean values of the single microprobe traverse across P22892-2a Ap1 with the means and standard deviations of dacite, andesite, and basalt apatites. For this test, $\mathrm{H}_{\mathrm{o}}=$ xenocryst is the same as the major group. Rejection of $\mathrm{H}_{\mathrm{o}}$ occurred only when P-22892-2a Ap1 was tested against the basalt apatites $\left(\mathrm{P}_{2} \mathrm{O}_{5}, \mathrm{Cl}\right.$, $\mathrm{SO}_{3}, \mathrm{Ce}_{2} \mathrm{O}_{3}$, and $\mathrm{MgO}$ ). This confirms that P-22892-2a Ap1 is a xenocryst and likely originated from the dacite. This special case will be re-visited in the discussion. 
Table 1: Descriptive statistics of the EMP data collected from Pinatubo apatites. Listed are the results of the F-test comparing the means of apatites from the three juvenile components. There are three statistically significant groups between the dacite, andesite and basalt apatites.

\begin{tabular}{|c|c|c|c|c|c|c|c|c|c|c|c|c|}
\hline & & $\mathrm{CaO}$ & $\mathrm{P}_{2} \mathrm{O}_{5}$ & $\mathrm{~F}$ & $\mathrm{Cl}$ & $\mathrm{SO}_{3}$ & $\mathrm{Ce}_{2} \mathrm{O}_{3}$ & $\mathrm{FeO}$ & $\mathrm{SiO}_{2}$ & $\mathrm{Na}_{2} \mathrm{O}$ & $\mathrm{MnO}$ & $\mathrm{MgO}$ \\
\hline Mean & $\mathbf{N}$ & & & & & & & & & & & \\
\hline Dacite & 401 & 53.72 & 41.16 & 1.40 & 1.13 & 0.30 & 0.21 & 0.37 & 0.27 & 0.13 & 0.18 & 0.14 \\
\hline Andesite & 70 & 53.90 & 41.68 & 1.20 & 1.16 & 0.19 & 0.21 & 0.47 & 0.21 & 0.12 & 0.20 & 0.16 \\
\hline Basalt & 145 & 53.33 & 39.35 & 1.00 & 0.78 & 1.52 & 0.05 & 0.49 & 1.17 & 0.34 & 0.13 & 0.22 \\
\hline \multicolumn{13}{|l|}{ Std Dev } \\
\hline Dacite & & 0.97 & 0.80 & 0.25 & 0.18 & 0.26 & 0.07 & 0.18 & 1.25 & 0.07 & 0.06 & 0.02 \\
\hline Andesite & & 0.91 & 0.81 & 0.22 & 0.14 & 0.20 & 0.06 & 0.15 & 0.46 & 0.06 & 0.05 & 0.03 \\
\hline Basalt & & 1.48 & 1.22 & 0.20 & 0.20 & 0.53 & 0.06 & 0.15 & 1.71 & 0.16 & 0.07 & 0.03 \\
\hline Xenocryst & & 53.86 & 41.79 & 1.10 & 1.19 & 0.16 & 0.20 & 0.52 & 0.12 & 0.11 & 0.22 & 0.13 \\
\hline \multicolumn{13}{|c|}{ F-Test } \\
\hline $\begin{array}{r}\mathrm{H}_{\mathrm{o}}=\text { The varianc } \\
\boldsymbol{\alpha}=\end{array}$ & $\begin{array}{l}\text { es of } \mathrm{tl} \\
0.05 \\
\text { Dacit }\end{array}$ & $\begin{array}{l}2 \text { grou } \\
\text { vs. Ans }\end{array}$ & are the & ame & & & & & & & & \\
\hline F-Stat & & 1.14 & 1.03 & 1.36 & 1.78 & 1.81 & 1.60 & 1.39 & 7.45 & 1.67 & 1.30 & 1.47 \\
\hline F-Table Value & & 1.38 & 1.33 & 1.38 & 1.38 & 1.38 & 1.38 & 1.38 & 1.38 & 1.38 & 1.38 & 1.33 \\
\hline \multicolumn{13}{|c|}{ Dacite vs. Basalt } \\
\hline F-Stat & & 2.32 & 2.36 & 1.58 & 1.22 & 4.05 & 1.20 & 1.49 & 1.90 & 4.54 & 1.79 & 2.37 \\
\hline F-Table Value & & 1.25 & 1.25 & 1.26 & 1.25 & 1.25 & 1.26 & 1.26 & 1.25 & 1.25 & 1.25 & 1.25 \\
\hline \multicolumn{13}{|c|}{ Andesite vs. Basalt } \\
\hline F-Stat & & 2.63 & 2.30 & 1.16 & 2.17 & 7.32 & 1.33 & 1.07 & 14.1 & 7.61 & 2.33 & 1.62 \\
\hline F-Table Value & & 1.43 & 1.43 & 1.39 & 1.43 & 1.43 & 1.43 & 1.39 & 1.43 & 1.43 & 1.43 & 1.43 \\
\hline Reject $\mathrm{H}_{\mathrm{o}}$ ? & & Reject & Reject & Fail & Reject & Reject & Fail & Fail & Reject & Reject & Reject & Reject \\
\hline
\end{tabular}


Table 2: Results of the t-test comparing the means of apatites from the three juvenile components. Z-test results comparing the average EMP values of the xenocryst apatite hosted in basalt to each of the groups confirms it did not grow in the basalt.

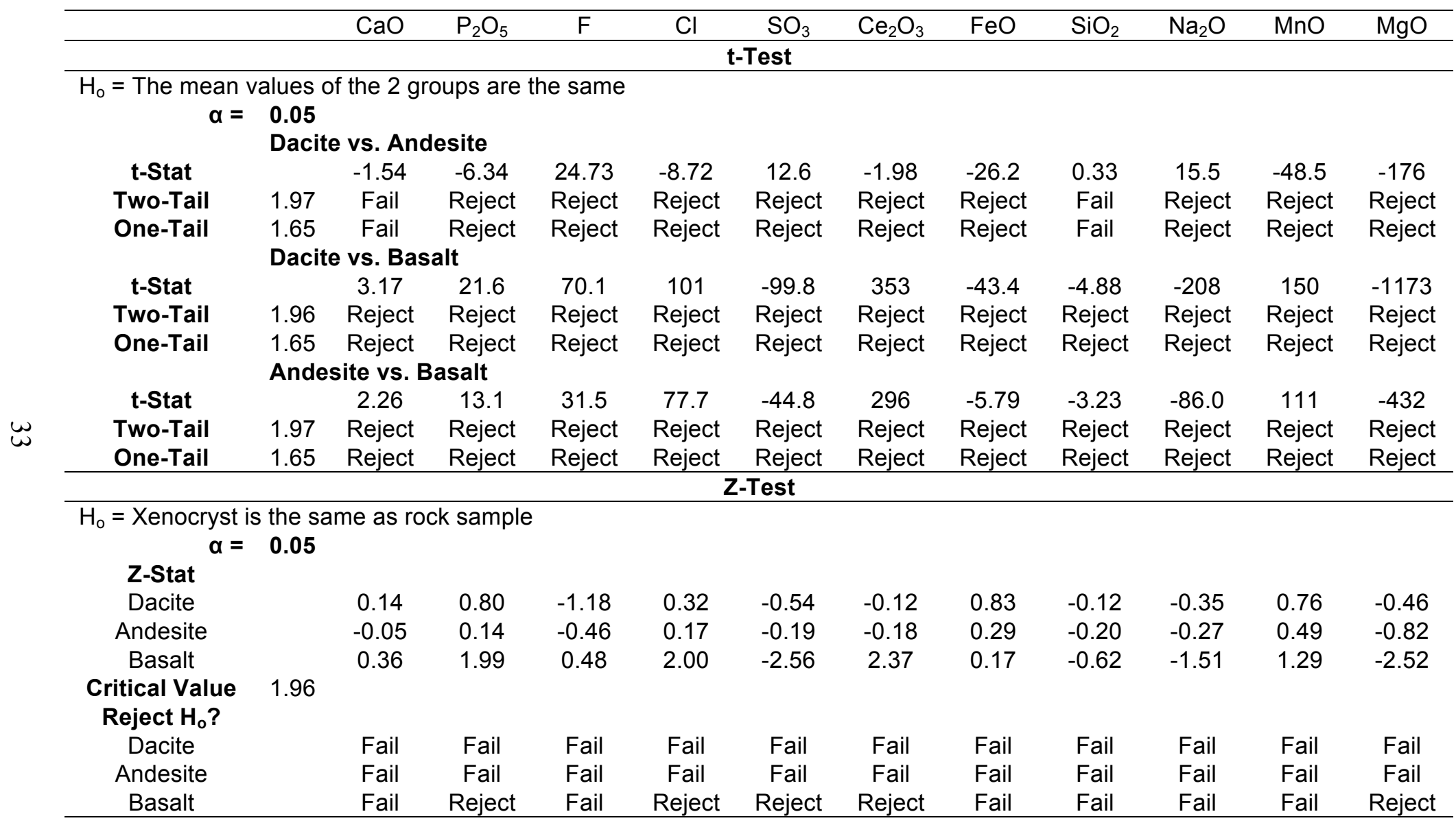




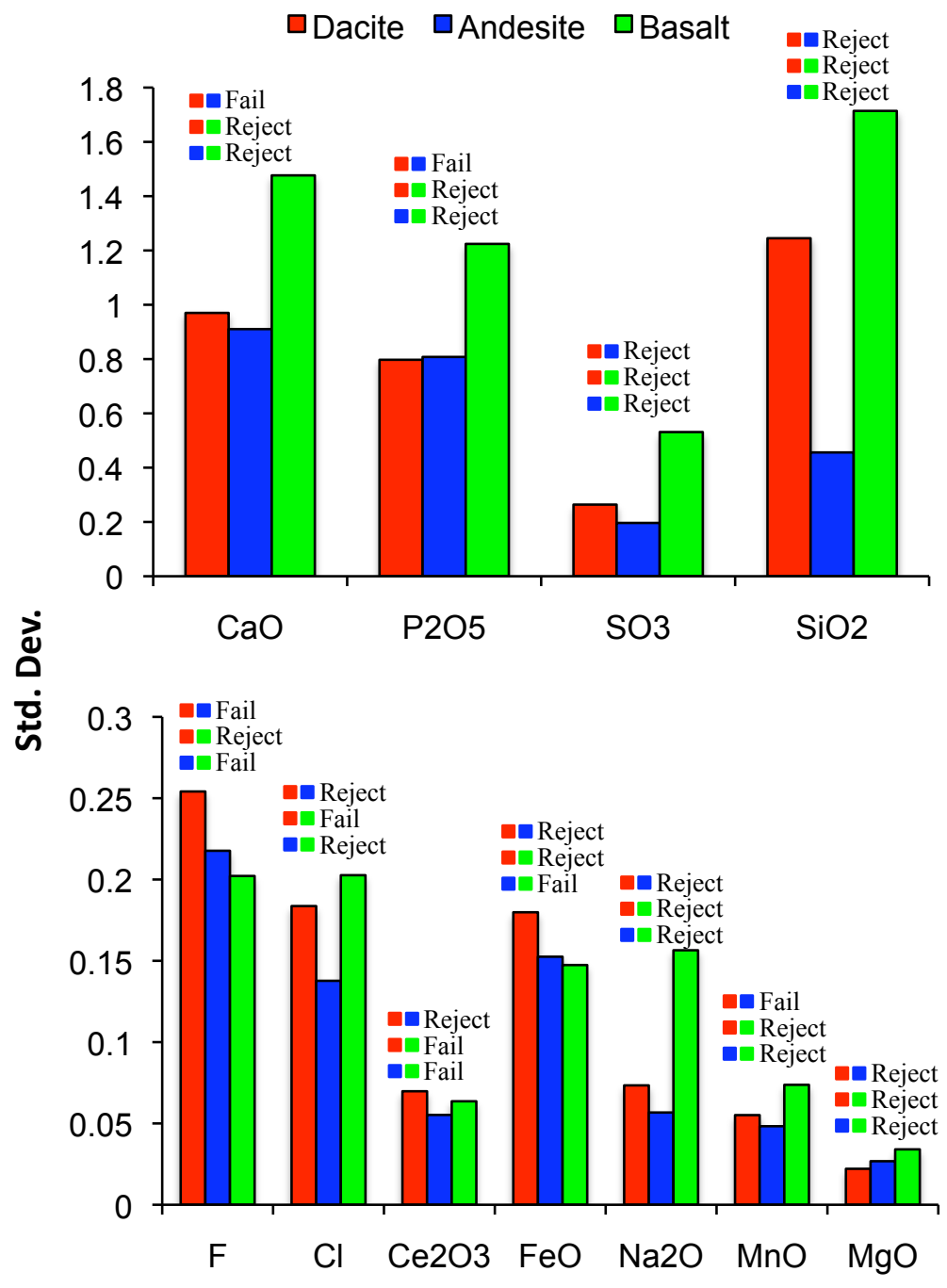

Figure 13: Descriptive statistics of the EMP data collected from Pinatubo apatites. Results of the F-test comparing the means of the three groups are shown above each oxide/element. Null hypothesis states that the variances of the groups are the same: Reject - reject the null, Fail - fail to reject the null. There are three statistically significant groups between the dacite, andesite and basalt apatites. 

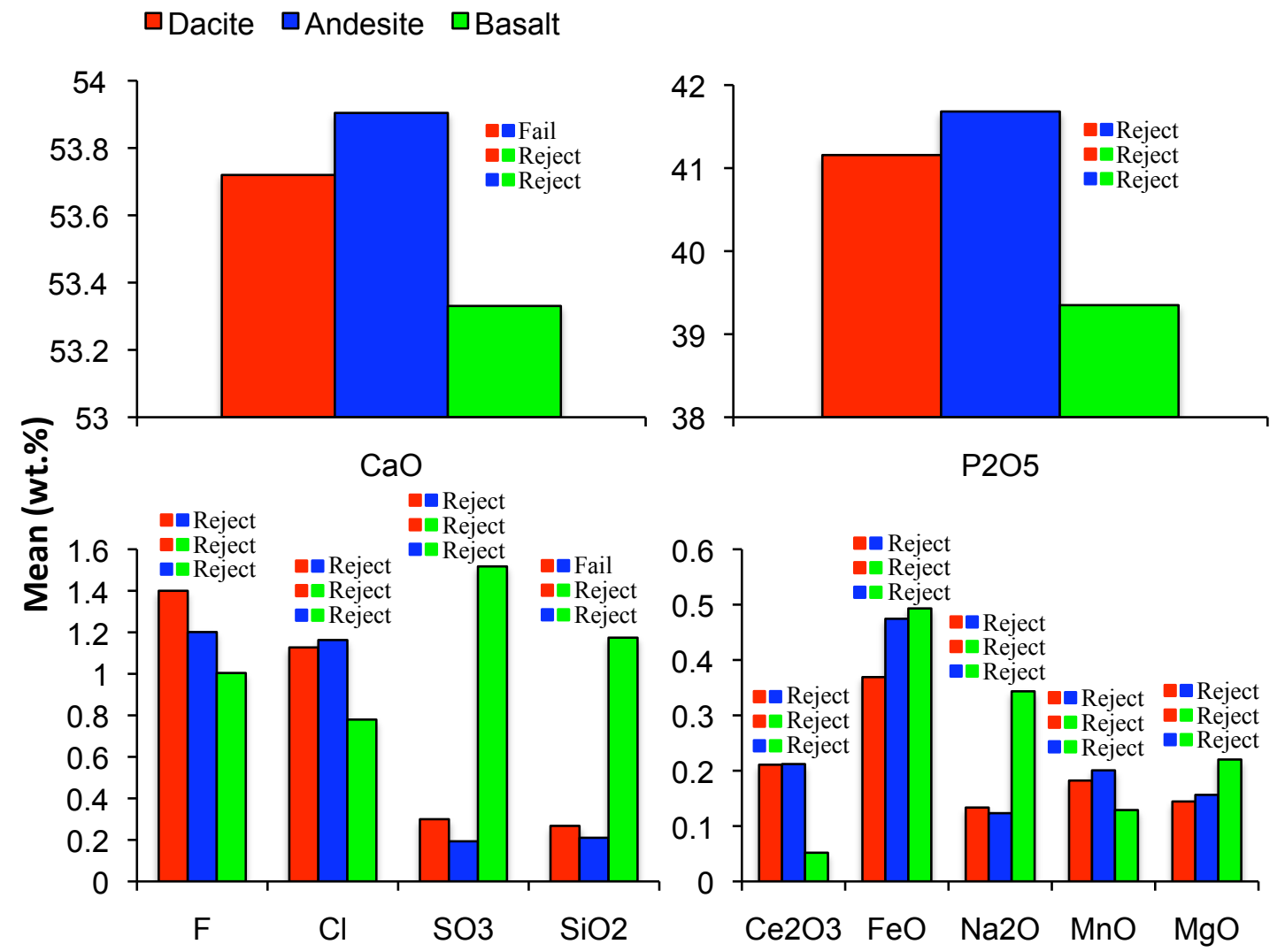

Figure 14: Descriptive statistics of the EMP data collected from Pinatubo apatites. Results of the t-test comparing the means of the three groups are shown above each oxide/element. Null hypothesis states that the means of the groups are the same: Reject - reject the null, Fail - fail to reject the null. There are three statistically significant groups between the dacite, andesite and basalt apatites. 


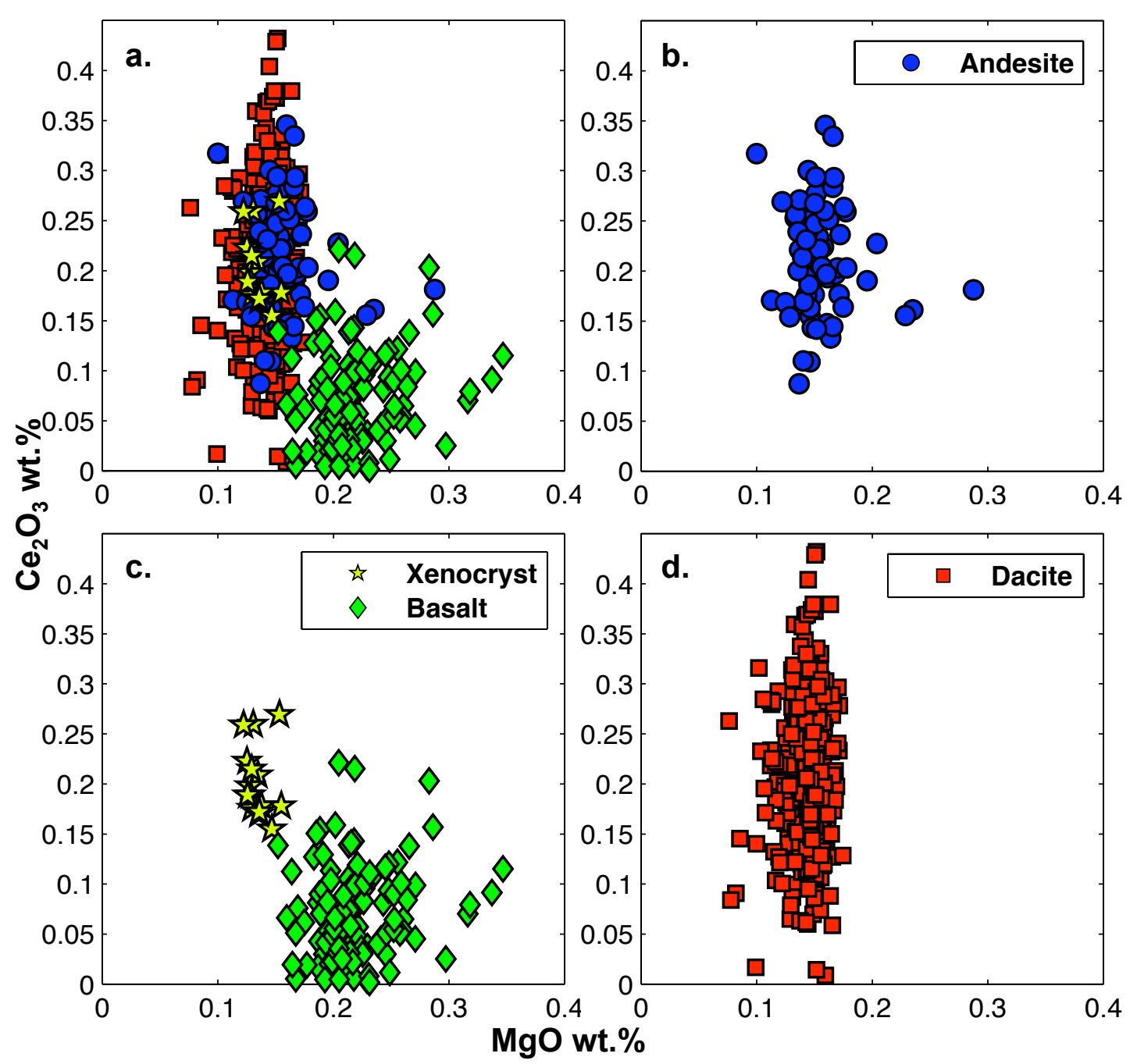

Figure 15: EMP apatite data distinguishing populations of apatites. The dacite and andesitehosted apatites form a population with higher $\mathrm{Ce}_{2} \mathrm{O}_{3}$ wt.\% concentrations and lower $\mathrm{MgO}$ wt.\% concentrations. Basalt-hosted apatites have lower $\mathrm{Ce}_{2} \mathrm{O}_{3}$ wt. \% concentrations and higher $\mathrm{MgO}$ wt. $\%$ concentrations. 

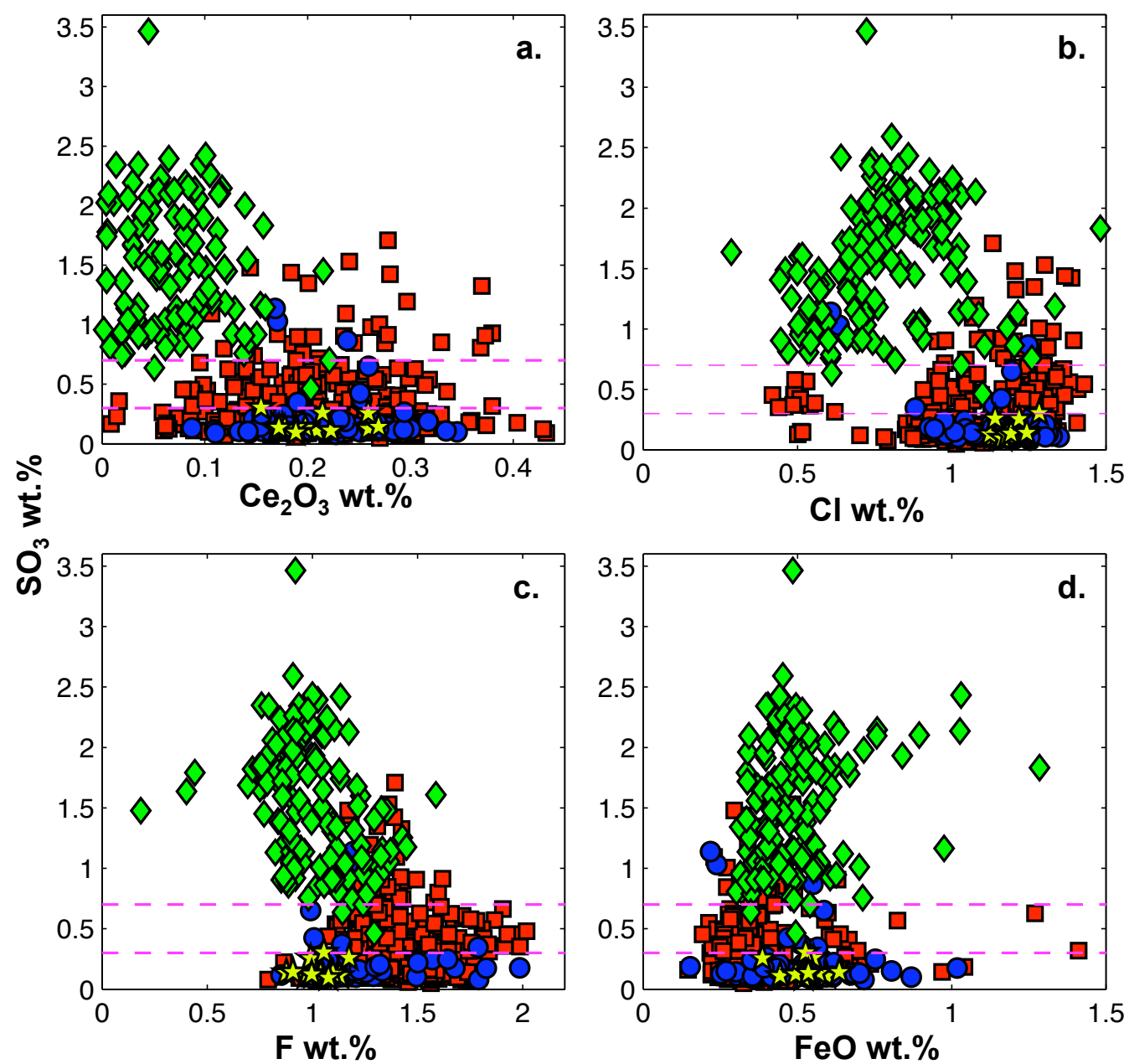

Figure 16: EMP apatite data. Apatite populations are distinguished by $\mathrm{Ce}_{2} \mathrm{O}_{3}$ wt.\%, $\mathrm{Cl}$ wt.\%, and $\mathrm{F}$ wt.\%. FeO wt.\% concentrations are comparable between populations. Colors and symbols are as previously defined. Purple dashed lines delineate the boundaries between low- and medium-S apatites $\left(0.3 \mathrm{wt} . \% \mathrm{SO}_{3}\right)$ and medium- and high-S apatites $\left(0.7 \mathrm{wt. \%} \mathrm{SO}_{3}\right)$. 

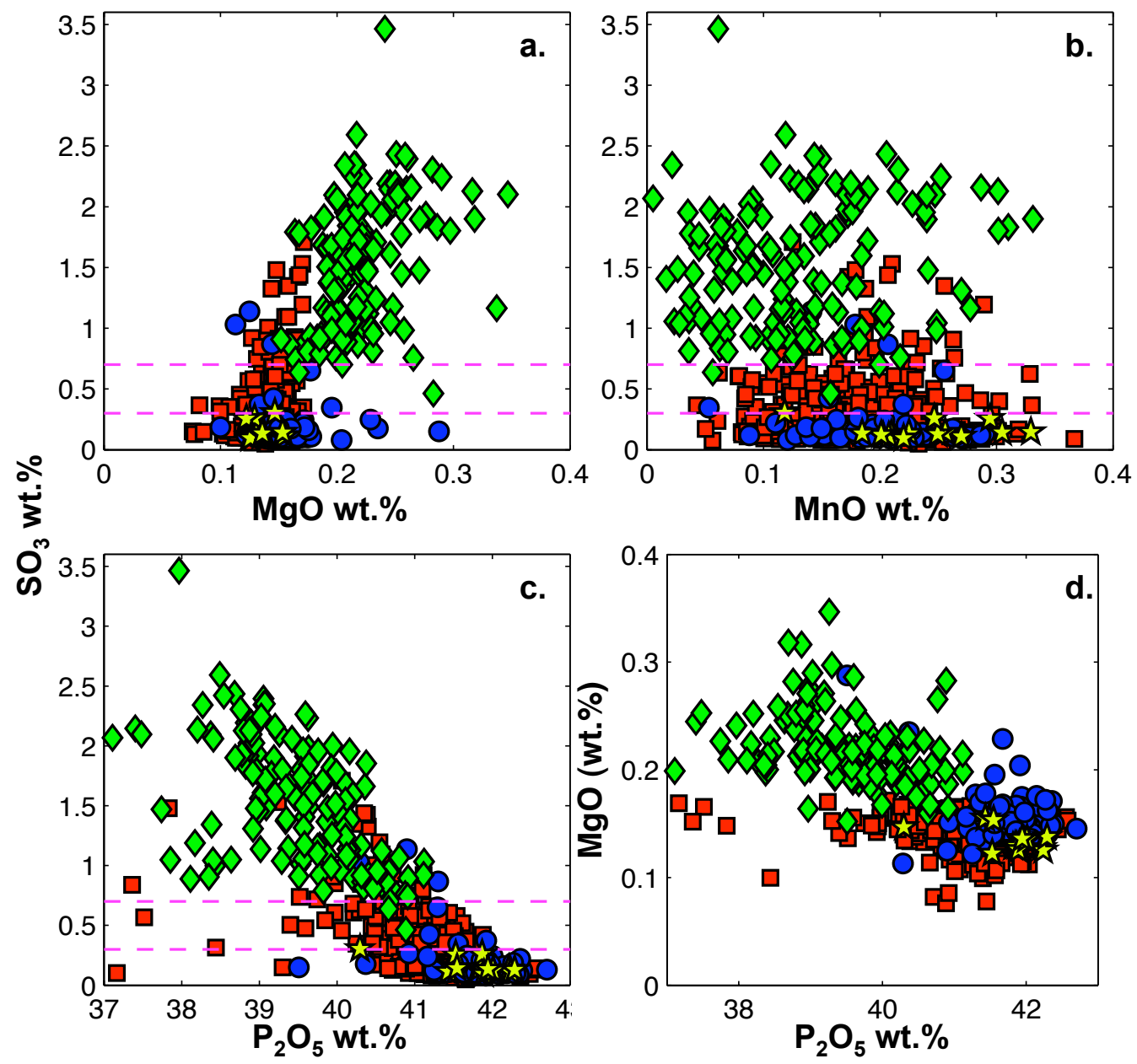

Figure 17: EMP apatite data. Apatite populations are distinguished by MgO wt.\% concentrations. MnO wt.\% concentrations are comparable between populations. Negative correlation between $\mathrm{P}_{2} \mathrm{O}_{5}$ wt. \% and $\mathrm{SO}_{3}$ wt.\% (c.) shows the replacement of $\mathrm{P}^{5+}$ for $\mathrm{S}^{6+}$. Colors and symbols are as previously defined.

\section{Sulfur}

EMP results revealed $\mathrm{SO}_{3}$ concentrations ranging from 0.1 to $2.6 \mathrm{wt} . \%$, with a single basalt apatite analysis reaching as high as $3.5 \mathrm{wt} . \%$. Apatites were divided by their $\mathrm{SO}_{3}$ concentrations as defined by Broderick (2008): low-S apatites $(<0.3 \mathrm{wt} . \%)$, medium-S apatites (0.3-0.7 wt.\%), and high-S apatites ( $>0.7$ wt.\%). Silicic apatites 
ranged from 0.1 to $1.7 \mathrm{wt} . \% \mathrm{SO}_{3}$, and $29 \%$ of these apatites analyzed had a least one EMP analysis with a high-S value. All basalt apatites analyzed were found to be highS apatites with only two analysis points falling below $0.7 \mathrm{wt} . \%$. Tables 3 through 6 present representative EMP data of low, medium, high, and variable-S apatites. Refer to Appendix B for complete EMP analyses.

$\mathrm{S}^{6+}$ was readily available in all three juvenile components due to the high oxidative conditions of the 1991 Pinatubo eruption. This is consistent with the data indicating that most sulfur exists as $\mathrm{S}^{6+}$ species at or above $\mathrm{NNO}+1$ (Carroll and Rutherford, 1985, 1987, 1988; Nilsson and Peach, 1993; Metrich and Clocchiatti, 1996; Paris et al., 2001; Jugo et al., 2005a, 2005b). Sulfur can only enter the T-site in apatite (Fig. 18) by replacing $\mathrm{P}^{5+}$ via coupled substitutions as sulfate, $\mathrm{S}^{6+}$. Sulfide, $\mathrm{S}^{2-}$, generated under reducing conditions, is unsuitable as a replacement for $\mathrm{P}^{5+}$. Several exchange reactions governing the concentration of sulfur in apatite have been proposed:

$$
\begin{array}{lr}
\mathrm{S}^{6+}+\mathrm{Na}^{+} \Leftrightarrow \mathrm{P}^{5+}+\mathrm{Ca}^{2+} \text { (Liu and Comodi, 1993) } & \text { Eq } 1 \\
\mathrm{~S}^{6+}+\mathrm{Si}^{4+} \Leftrightarrow 2 \mathrm{P}^{5+}(\text { Rouse and Dunn, 1982) } & \text { Eq } 2 \\
\mathrm{~S}^{6+}+\mathrm{Na}^{+}+\mathrm{Si}^{4+}+\mathrm{REE}^{3+} \Leftrightarrow 2 \mathrm{P}^{5+}+2 \mathrm{Ca}^{2+}(\text { Tepper and Kuehner, } 1999) & \text { Eq } 3 \\
\mathrm{~S}^{6+}+\mathrm{Na}^{+}+\mathrm{Si}^{4+}+2 \mathrm{Ce}^{3+} \Leftrightarrow 3 \mathrm{P}^{5+}+\mathrm{Ca}^{2+}(\text { Parat et al., subm. }) & \text { Eq } 4 \\
\mathrm{Si}^{4+}+2 \mathrm{Na}^{+}+2 \mathrm{~S}^{6+}+4 \mathrm{REE}^{3+} \Leftrightarrow 4 \mathrm{P}^{5+}+5 \mathrm{Ca}^{2+} \text { (Parat et al., 2002) } & \text { Eq } 5
\end{array}
$$


Table 3: Representative EMP results for low-S (<0.3 wt.\% $\left.\mathrm{SO}_{3}\right)$ apatites from 1991 Pinatubo eruption. Position of analysis on crystal is approximate.

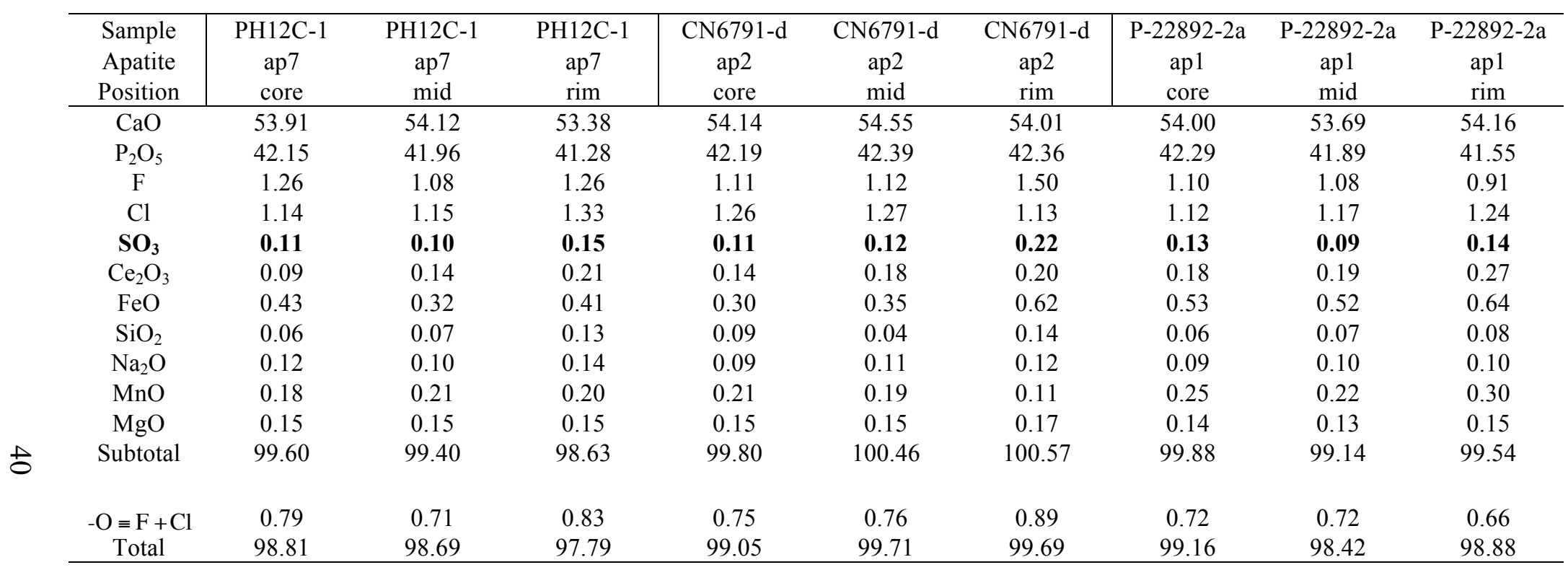


Table 4: Representative EMP results for medium-S (0.3-0.7 wt.\% $\left.\mathrm{SO}_{3}\right)$ apatites from 1991 Pinatubo eruption. Position of analysis on crystal is approximate.

\begin{tabular}{|c|c|c|c|c|c|c|}
\hline $\begin{array}{l}\text { Sample } \\
\text { Apatite } \\
\text { Position }\end{array}$ & $\begin{array}{c}\text { PH12C-7 } \\
\text { ap18 } \\
\text { core }\end{array}$ & $\begin{array}{c}\text { PH12C-7 } \\
\text { ap18 } \\
\text { mid }\end{array}$ & $\begin{array}{c}\text { PH12C-7 } \\
\text { ap18 } \\
\text { mid }\end{array}$ & $\begin{array}{c}\text { PH12C-7 } \\
\text { ap18 } \\
\text { rim }\end{array}$ & $\begin{array}{l}\text { CN6791-d } \\
\text { ap1 } \\
\text { core } \\
\end{array}$ & $\begin{array}{c}\text { CN6791-d } \\
\text { ap1 } \\
\text { rim }\end{array}$ \\
\hline $\mathrm{CaO}$ & 54.05 & 54.04 & 54.26 & 53.90 & 54.26 & 54.06 \\
\hline $\mathrm{P}_{2} \mathrm{O}_{5}$ & 41.22 & 40.95 & 41.01 & 41.08 & 42.01 & 41.56 \\
\hline $\mathrm{F}$ & 1.95 & 1.75 & 1.82 & 1.99 & 1.57 & 1.79 \\
\hline $\mathrm{Cl}$ & 0.49 & 0.49 & 0.51 & 0.44 & 1.04 & 0.88 \\
\hline $\mathrm{SO}_{3}$ & 0.46 & 0.58 & 0.42 & 0.35 & 0.24 & 0.35 \\
\hline $\mathrm{Ce}_{2} \mathrm{O}_{3}$ & 0.09 & 0.20 & 0.16 & 0.17 & 0.18 & 0.19 \\
\hline $\mathrm{FeO}$ & 0.28 & 0.28 & 0.26 & 0.25 & 0.58 & 0.57 \\
\hline $\mathrm{SiO}_{2}$ & 0.15 & 0.19 & 0.16 & 0.12 & 0.12 & 0.56 \\
\hline $\mathrm{Na}_{2} \mathrm{O}$ & 0.20 & 0.23 & 0.17 & 0.17 & 0.16 & 0.19 \\
\hline $\mathrm{MnO}$ & 0.08 & 0.23 & 0.21 & 0.16 & 0.21 & 0.05 \\
\hline $\mathrm{MgO}$ & 0.13 & 0.13 & 0.12 & 0.11 & 0.17 & 0.20 \\
\hline Subtotal & 99.11 & 99.07 & 99.11 & 98.73 & 100.54 & 100.39 \\
\hline$-\mathrm{O} \equiv \mathrm{F}+\mathrm{Cl}$ & 0.93 & 0.85 & 0.88 & 0.94 & 0.90 & 0.95 \\
\hline Total & 98.17 & 98.22 & 98.23 & 97.79 & 99.64 & 99.44 \\
\hline
\end{tabular}


Table 5: Representative EMP results for high-S ( $\left.>0.7 \mathrm{wt} \% \mathrm{SO}_{3}\right)$ apatites from 1991 Pinatubo eruption. Position of analysis on crystal is approximate.

\begin{tabular}{|c|c|c|c|c|c|c|c|c|}
\hline $\begin{array}{l}\text { Sample } \\
\text { Apatite } \\
\text { Position }\end{array}$ & $\begin{array}{c}\text { PH12C-7 } \\
\text { ap7 } \\
\text { core }\end{array}$ & $\begin{array}{c}\text { PH12C-7 } \\
\text { ap7 } \\
\text { mid }\end{array}$ & $\begin{array}{c}\text { PH12C-7 } \\
\text { ap7 } \\
\text { rim }\end{array}$ & $\begin{array}{l}\text { CN6791-d } \\
\text { ap4 } \\
\text { core }\end{array}$ & $\begin{array}{l}\text { CN6791-d } \\
\text { ap4 } \\
\text { rim }\end{array}$ & $\begin{array}{c}\text { P-22892-2a } \\
\text { ap26 } \\
\text { core }\end{array}$ & $\begin{array}{c}\text { P-22892-2a } \\
\text { ap26 } \\
\text { mid }\end{array}$ & $\begin{array}{c}\text { P-22892-2a } \\
\text { ap26 } \\
\text { rim }\end{array}$ \\
\hline $\mathrm{CaO}$ & 53.57 & 54.01 & 54.29 & 52.45 & 54.30 & 53.07 & 54.32 & 55.86 \\
\hline $\mathrm{P}_{2} \mathrm{O}_{5}$ & 40.40 & 40.69 & 41.12 & 40.29 & 40.90 & 39.37 & 39.09 & 37.74 \\
\hline $\mathrm{F}$ & 1.42 & 1.41 & 1.33 & 1.17 & 1.20 & 1.37 & 1.33 & 0.92 \\
\hline $\mathrm{Cl}$ & 1.21 & 1.17 & 1.16 & 0.64 & 0.61 & 0.58 & 0.46 & 0.50 \\
\hline $\mathrm{SO}_{3}$ & 1.33 & 0.76 & 0.92 & 1.03 & 1.14 & 1.14 & 1.49 & 1.47 \\
\hline $\mathrm{Ce}_{2} \mathrm{O}_{3}$ & 0.37 & 0.20 & 0.17 & 0.17 & 0.17 & 0.16 & 0.08 & 0.10 \\
\hline $\mathrm{FeO}$ & 0.33 & 0.38 & 0.31 & 0.24 & 0.22 & 0.39 & 0.49 & 0.43 \\
\hline $\mathrm{SiO}_{2}$ & 0.32 & 0.13 & 0.10 & 0.62 & 0.64 & 0.67 & 0.80 & 0.68 \\
\hline $\mathrm{Na}_{2} \mathrm{O}$ & 0.23 & 0.15 & 0.16 & 0.32 & 0.36 & 0.24 & 0.41 & 0.34 \\
\hline $\mathrm{MnO}$ & 0.19 & 0.26 & 0.13 & 0.18 & 0.14 & 0.12 & 0.03 & 0.07 \\
\hline $\mathrm{MgO}$ & 0.14 & 0.15 & 0.13 & 0.11 & 0.12 & 0.20 & 0.23 & 0.23 \\
\hline Subtotal & 99.51 & 99.31 & 99.83 & 97.21 & 99.79 & 97.31 & 98.73 & 98.34 \\
\hline$-\mathrm{O} \equiv \mathrm{F}+\mathrm{Cl}$ & 0.87 & 0.86 & 0.82 & 0.64 & 0.64 & 0.71 & 0.66 & 0.50 \\
\hline Total & 98.64 & 98.45 & 99.01 & 96.58 & 99.15 & 96.60 & 98.07 & 97.84 \\
\hline
\end{tabular}


Table 6: Representative EMP results for 1991 Pinatubo "silicic" apatites with variable $\mathrm{SO}_{3}$ concentrations. Position of analysis on crystal is approximate.

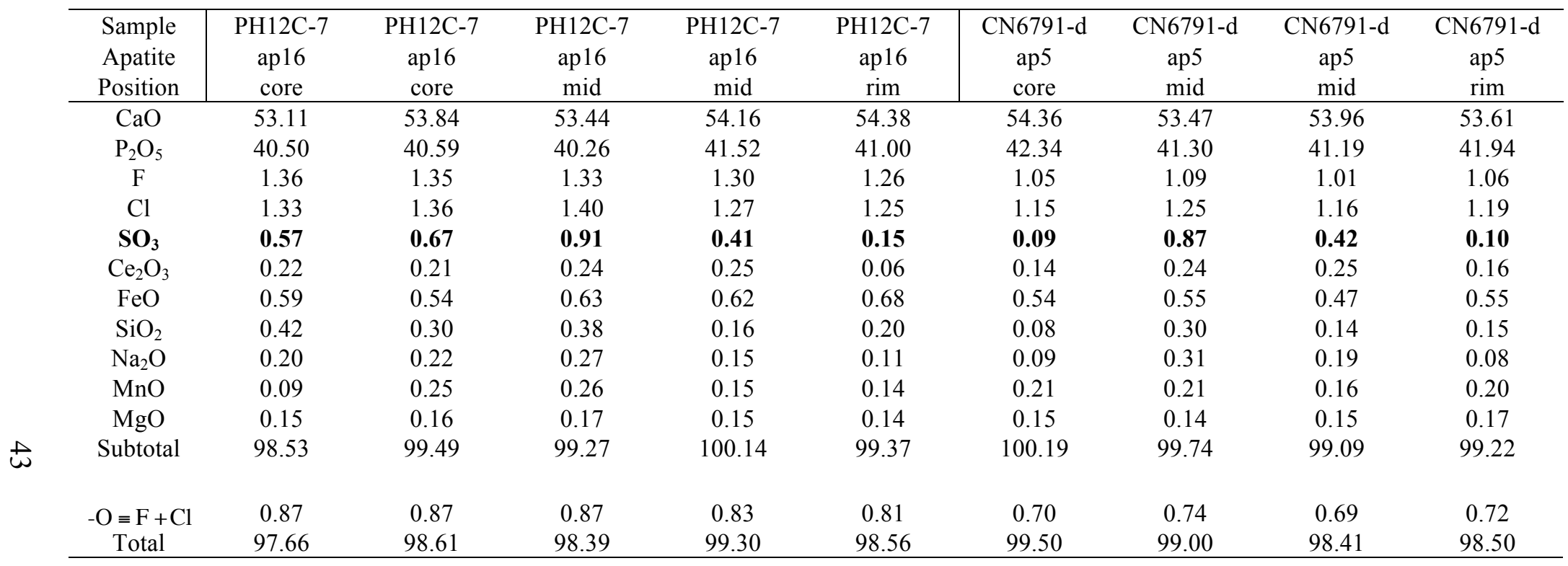


Table 6: Continued. Basalt apatite.

\begin{tabular}{|c|c|c|c|}
\hline $\begin{array}{l}\text { Sample } \\
\text { Apatite } \\
\text { Position }\end{array}$ & $\begin{array}{c}\text { P-22892-2a } \\
\text { ap33 } \\
\text { core }\end{array}$ & $\begin{array}{c}\text { P-22892-2a } \\
\text { ap33 } \\
\text { mid }\end{array}$ & $\begin{array}{c}\text { P-22892-2a } \\
\text { ap33 } \\
\text { rim }\end{array}$ \\
\hline $\mathrm{CaO}$ & 54.21 & 53.75 & 54.58 \\
\hline $\mathrm{P}_{2} \mathrm{O}_{5}$ & 38.11 & 38.92 & 40.66 \\
\hline $\mathrm{F}$ & 1.30 & 0.89 & 1.14 \\
\hline $\mathrm{Cl}$ & 0.54 & 0.66 & 0.61 \\
\hline $\mathrm{SO}_{3}$ & 0.89 & 1.31 & 0.64 \\
\hline $\mathrm{Ce}_{2} \mathrm{O}_{3}$ & 0.09 & 0.10 & 0.05 \\
\hline $\mathrm{FeO}$ & 0.33 & 0.41 & 0.35 \\
\hline $\mathrm{SiO}_{2}$ & 0.64 & 0.68 & 0.44 \\
\hline $\mathrm{Na}_{2} \mathrm{O}$ & 0.19 & 0.29 & 0.16 \\
\hline $\mathrm{MnO}$ & 0.14 & 0.12 & 0.06 \\
\hline $\mathrm{MgO}$ & 0.21 & 0.20 & 0.17 \\
\hline Subtotal & 96.65 & 97.33 & 98.86 \\
\hline $\begin{array}{c}-\mathrm{O} \equiv \mathrm{F}+\mathrm{Cl} \\
\text { Total }\end{array}$ & $\begin{array}{c}0.67 \\
95.98\end{array}$ & $\begin{array}{c}0.53 \\
9680\end{array}$ & $\begin{array}{c}0.62 \\
9824\end{array}$ \\
\hline
\end{tabular}




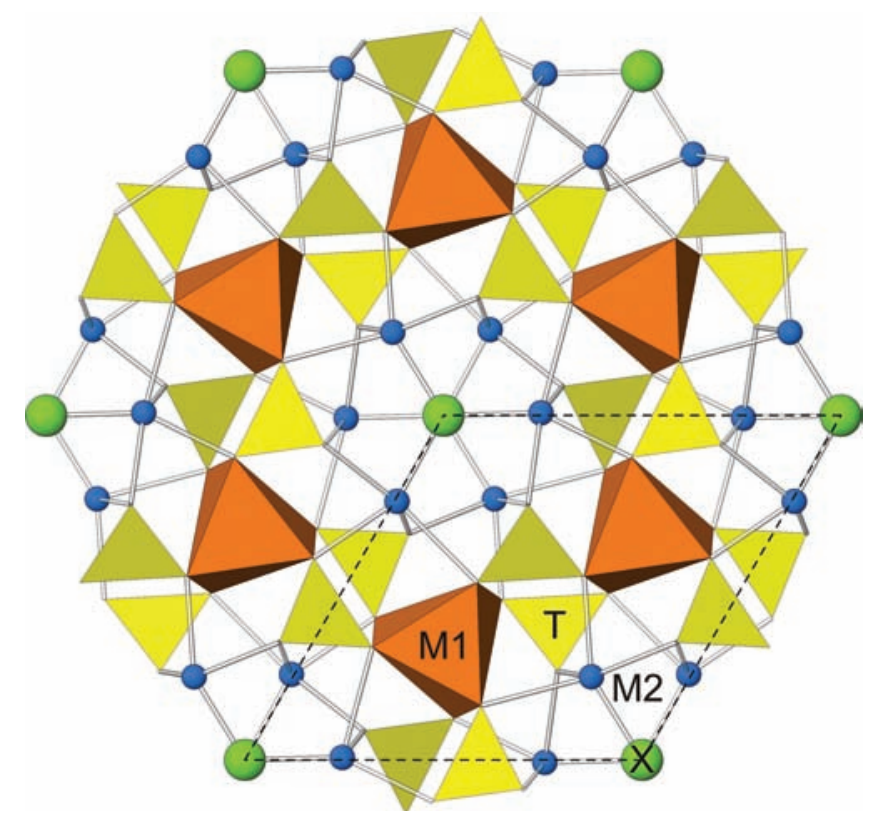

Figure 18: Apatite crystal structure and unit cell. $\mathrm{S}^{6+}$ replaces $\mathrm{P}^{5+}$ in the $\mathrm{T}$ site through various coupled substitutions (after Pasero et al., 2010).

The positive linear trend between $\mathrm{Na}_{2} \mathrm{O}$ and $\mathrm{SO}_{3}$ (Fig. 19) suggests that $\mathrm{Na}^{+}$is a more significant cation in coupled substitutions when compared to the scatter seen between $\mathrm{SiO}_{2}$ and $\mathrm{SO}_{3}$ (Fig. 20). Figures 21 through 25 show the exchange reactions listed above for Pinatubo apatite EMP data. Figure 21 and Figure 22 confirm that $\mathrm{Na}^{+}$ is preferred over $\mathrm{Si}^{4+}$ for coupled substitutions in both silicic and basalt apatites. In fact, the highest correlation coefficients (i.e. the strongest linear trend between two cations or cation pairings) for andesite and basalt apatites are associated with the exchange reaction in Eq 1. However, the basalt apatite data falls poorly on the 1:1 trend line. Exchange reactions that involve $\mathrm{Na}^{+}, \mathrm{Si}^{4+}$, and $\mathrm{REE}^{3+}\left(\mathrm{Ce}^{3+}\right)(\mathrm{Eq} \mathrm{3}, 4$, and 5) produce good correlation coefficients for all apatites and the data fall nicely on the 1:1 trend line. The highest correlation coefficient for dacite apatites is associated with Eq 3 (Fig. 23), but the data do not pass as well through the origin as it does in Figure 
24 (Eq 4). Therefore, the exchange reaction that best matches the data is

$$
\mathrm{S}^{6+}+\mathrm{Na}^{+}+\mathrm{Si}^{4+}+2 \mathrm{Ce}^{3+} \Leftrightarrow 3 \mathrm{P}^{5+}+\mathrm{Ca}^{2+}
$$
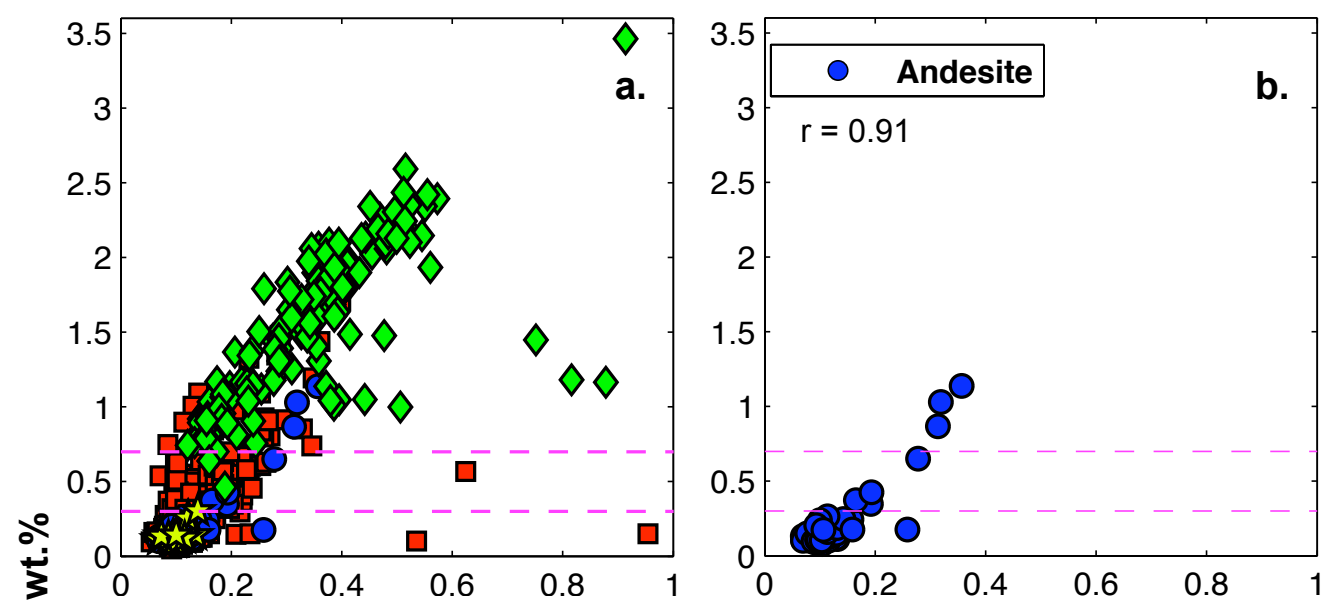

$$
\text { คे } 3 \text {. }
$$

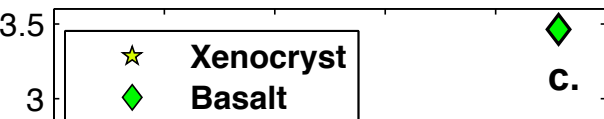

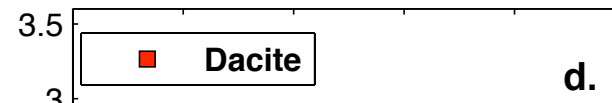

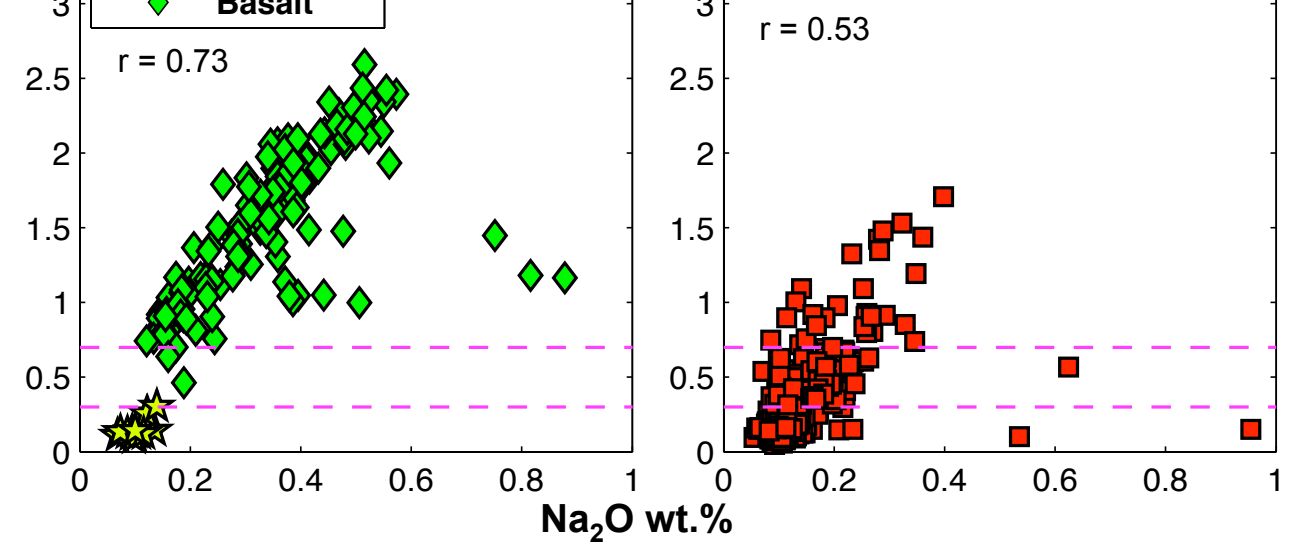

Figure 19: EMP apatite data. The strong positive correlation between $\mathrm{Na}_{2} \mathrm{O}$ wt.\% and $\mathrm{SO}_{3}$ wt.\% suggests that $\mathrm{S}^{6+}+\mathrm{Na}^{+} \Leftrightarrow \mathrm{P}^{5+}+\mathrm{Ca}^{2+}$ could be a significant coupled substitution for incorporating $\mathrm{S}$ into apatites in all three juvenile products from Pinatubo. Purple dashed lines delineate the boundaries between low- and medium-S apatites $\left(0.3 \mathrm{wt} . \% \mathrm{SO}_{3}\right)$ and medium- and high-S apatites $\left(0.7 \mathrm{wt} . \% \mathrm{SO}_{3}\right) . \mathrm{r}=$ correlation coefficient. 

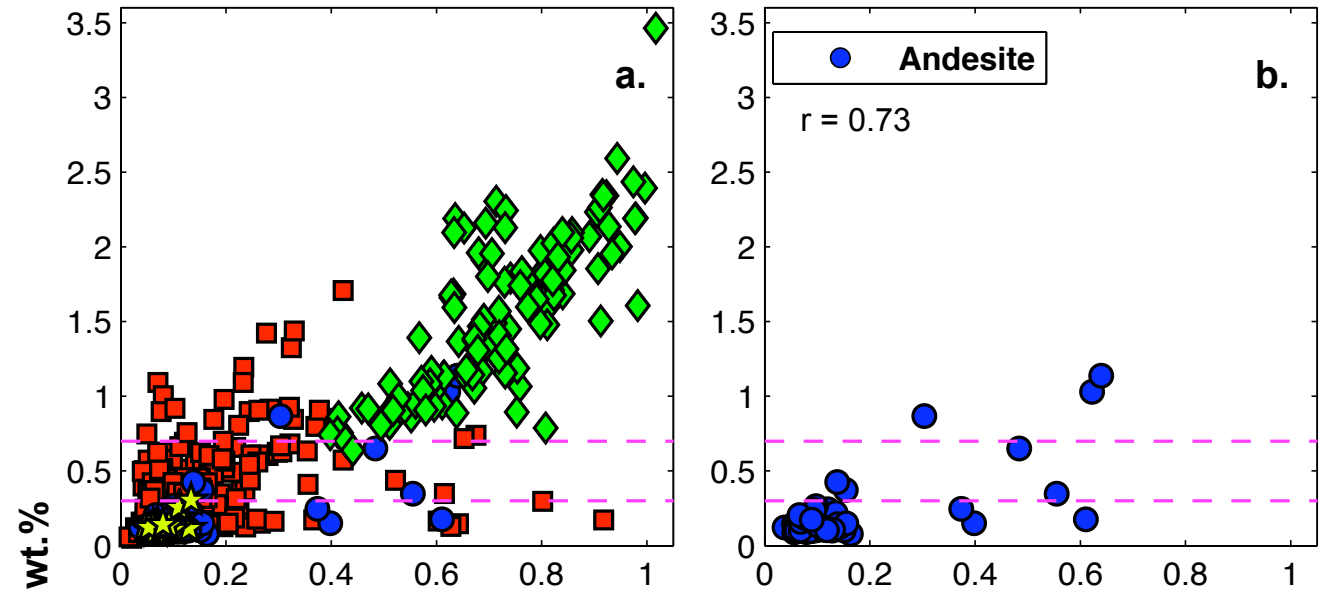

\section{\&}
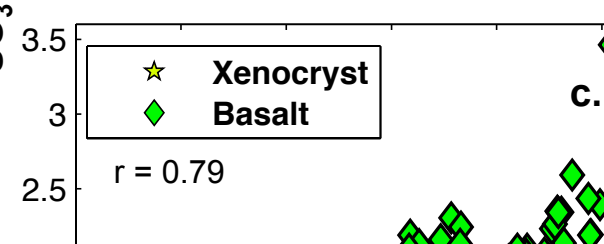

c.

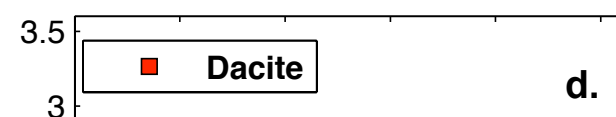

Figure 20: EMP apatite data. The lack of a strong positive correlation between $\mathrm{SiO}_{2}$ wt.\% and $\mathrm{SO}_{3}$ wt.\% in dacite apatites suggests that $\mathrm{S}^{6+}+\mathrm{Si}^{4+} \Leftrightarrow 2 \mathrm{P}^{5+}$ is not a significant coupled substitution. However, there is a strong correlation in andesite- and basalt-hosted apatites. The $\mathrm{Si}-\mathrm{S}$ coupled substitution has more significance in more primitive magmas. $r=$ correlation coefficient. 

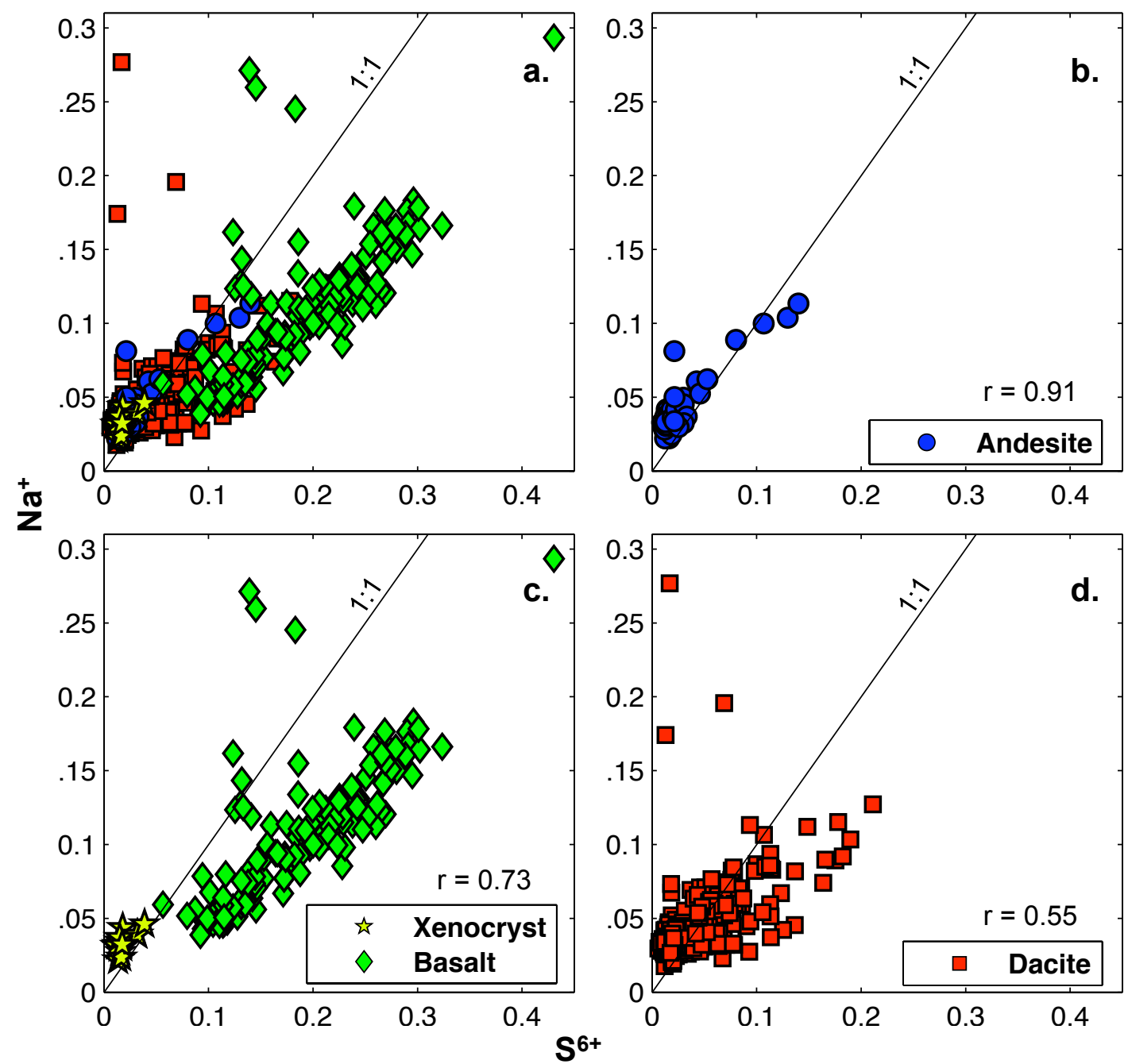

Figure 21: EMP apatite data. $\mathrm{S}^{6+}+\mathrm{Na}^{+} \Leftrightarrow \mathrm{P}^{5+}+\mathrm{Ca}^{2+}$ coupled substitution. This exchange reaction is associated with the highest correlation coefficients $(r)$ for andesite (b.) and basalt (c.) apatites. However, the basalt data does not fall well on the 1:1 line. 

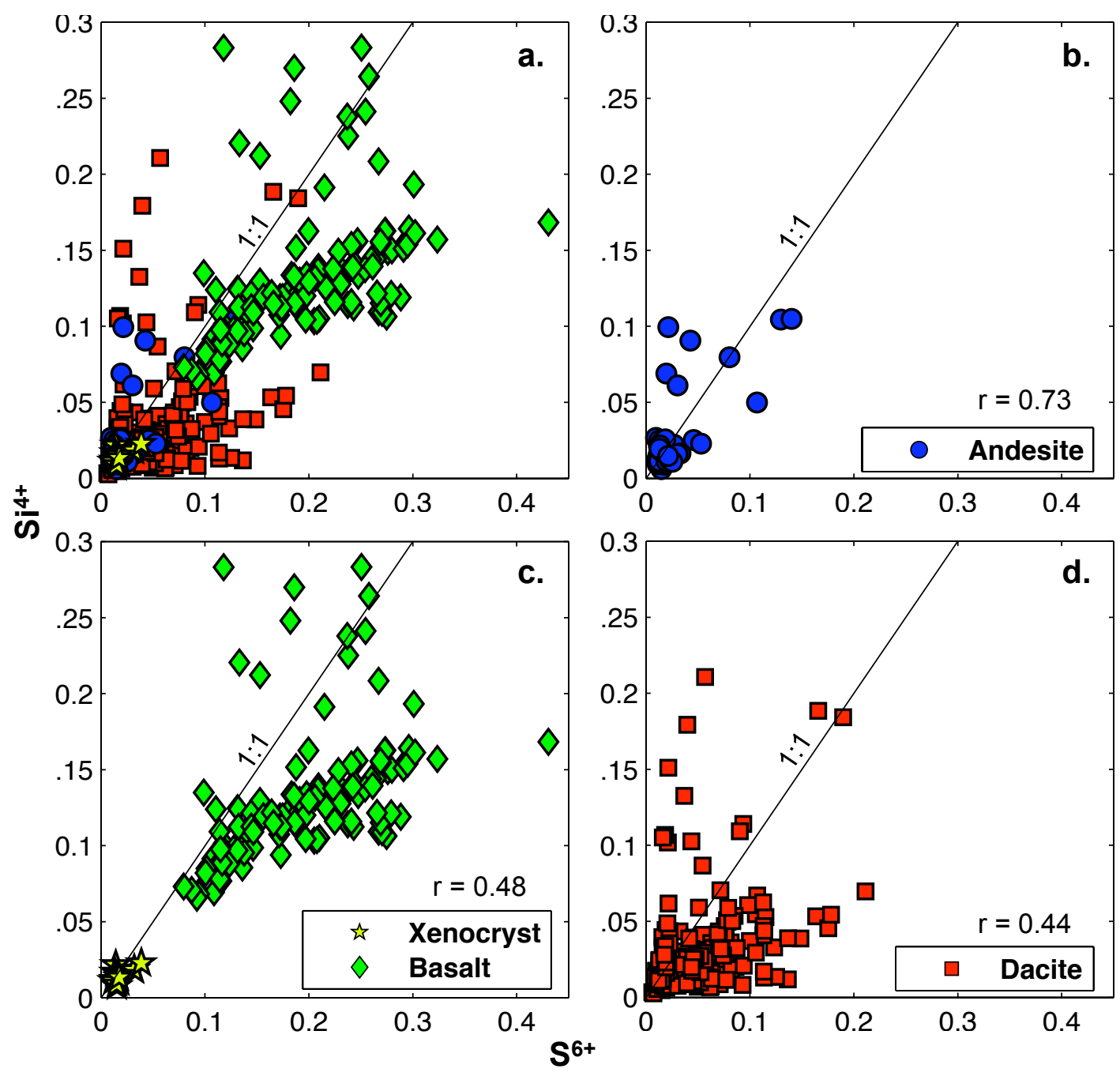

Figure 22: EMP apatite data. $\mathrm{S}^{6+}+\mathrm{Si}^{4+} \Leftrightarrow 2 \mathrm{P}^{5+}$ coupled substitution. This exchange reaction is associated with the lowest correlation coefficients ( $r)$ for dacite (d.) and basalt (c.) apatites. The scatter produced around the $1: 1$ line shows that $\mathrm{Si}^{4+}$ alone is not the cation used during coupled substitution. 


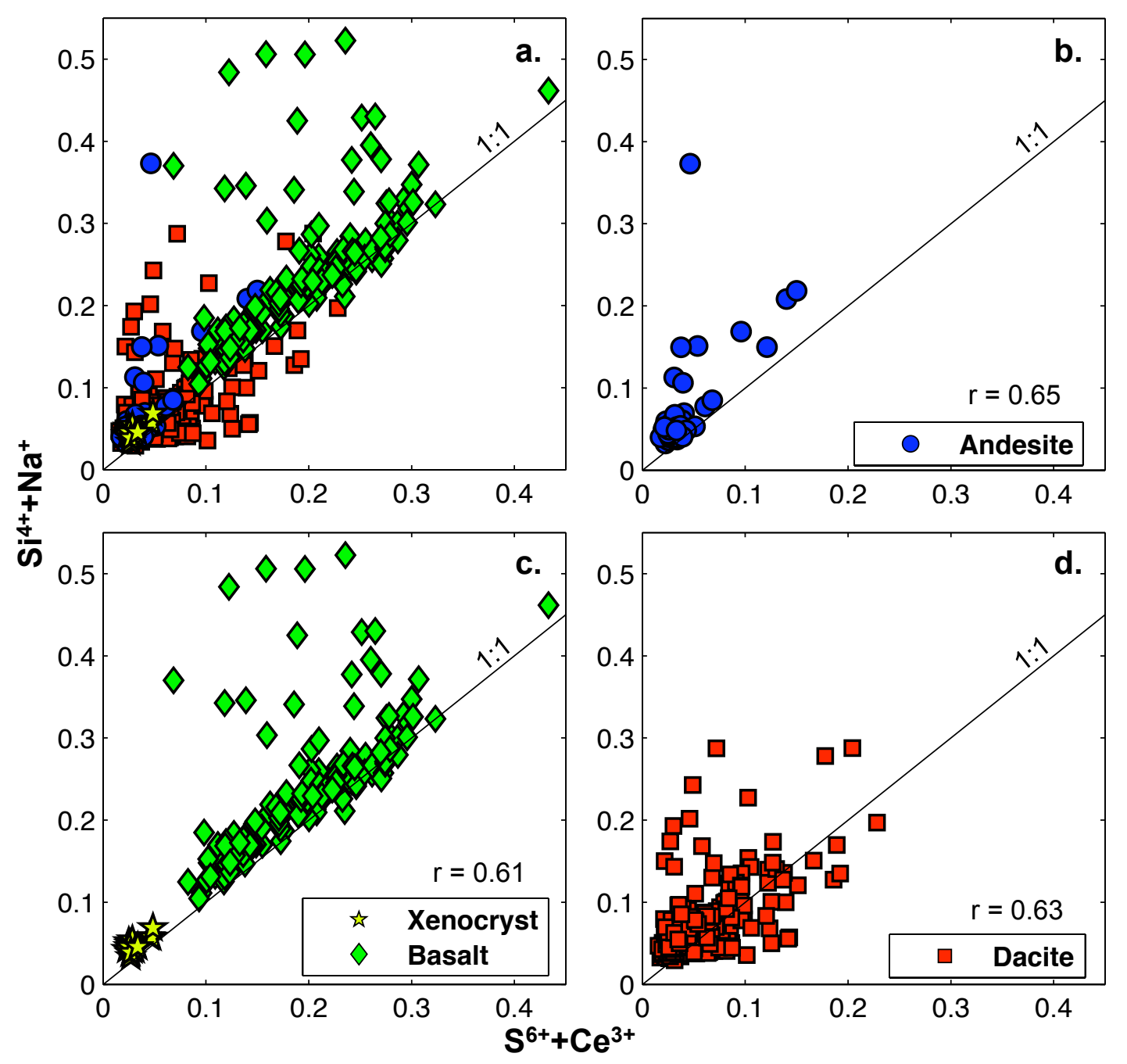

Figure 23: EMP apatite data. $\mathrm{S}^{6+}+\mathrm{Na}^{+}+\mathrm{Si}^{4+}+\mathrm{REE}^{3+} \Leftrightarrow 2 \mathrm{P}^{5+}+2 \mathrm{Ca}^{2+}$ coupled substitution. There is good correlation along the 1:1 line for all three juvenile component apatites, yet the data pass just above the origin. 


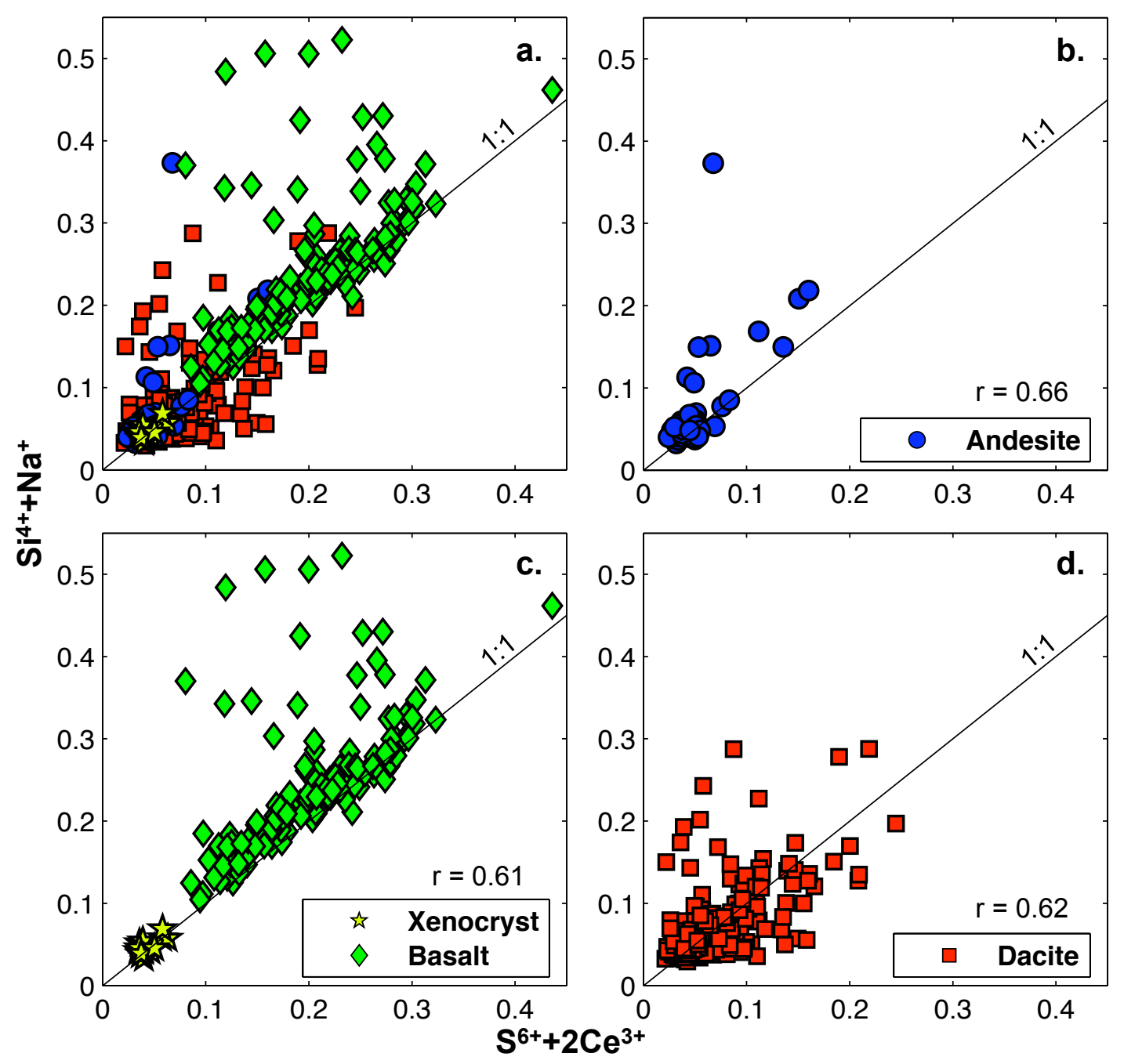

Figure 24: EMP apatite data. $\mathrm{S}^{6+}+\mathrm{Na}^{+}+\mathrm{Si}^{4+}+2 \mathrm{Ce}^{3+} \Leftrightarrow 3 \mathrm{P}^{5+}+\mathrm{Ca}^{2+}$ coupled substitution. There is good correlation along the 1:1 line for all three juvenile component apatites, and the data pass through the origin. This exchange reaction is the best fit for Pinatubo apatites. 


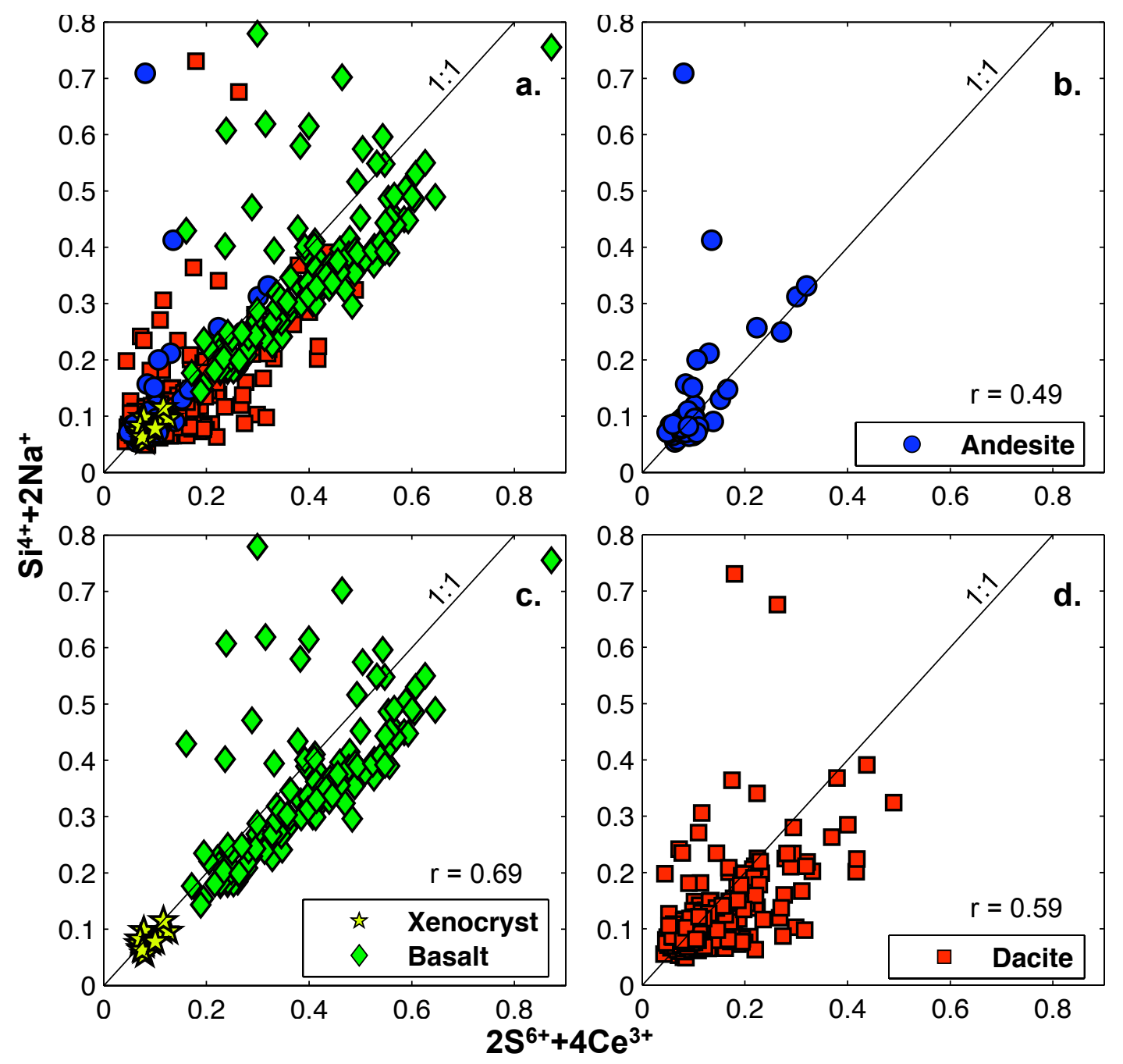

Figure 25: EMP apatite data. $\mathrm{Si}^{4+}+2 \mathrm{Na}^{+}+2 \mathrm{~S}^{6+}+4 \mathrm{REE}^{3+} \Leftrightarrow 4 \mathrm{P}^{5+}+5 \mathrm{Ca}^{2+}$ coupled substitution. Basalt apatites (c.) have the best correlation coefficient in this exchange reaction and fall well along the 1:1 line.

Core to rim sulfur profiles of apatites come in four varieties: 1) homogenous $\mathrm{SO}_{3}, 2$ ) rimward increasing $\mathrm{SO}_{3}, 3$ ) rimward decreasing $\mathrm{SO}_{3}$, and 4) oscillatory $\mathrm{SO}_{3}$

(Fig. 26). All four profiles were found in each apatite population. Intra-grain variations in $\mathrm{SO}_{3}$ concentrations can range from low to high with very abrupt transitions over short distances $(\sim 2-5 \mu \mathrm{m})$. High-S silicic apatites occur primarily as inclusions in 
anhydrite. However, they also occur as inclusions in plagioclase, hornblende, and FeTi oxides. Large apatites that occur as microphenocrysts in the groundmass never show high-S concentrations. These apatites range in $\mathrm{SO}_{3}$ from $0.05 \mathrm{wt} . \%$ to $0.30 \mathrm{wt} . \%$ with an average of 0.13 wt.\%. This is consistent with previous studies on Pinatubo apatites (Imai et al., 1993, 1996) and Eagle Mountain Andesite apatites (Parat et al., 2002).

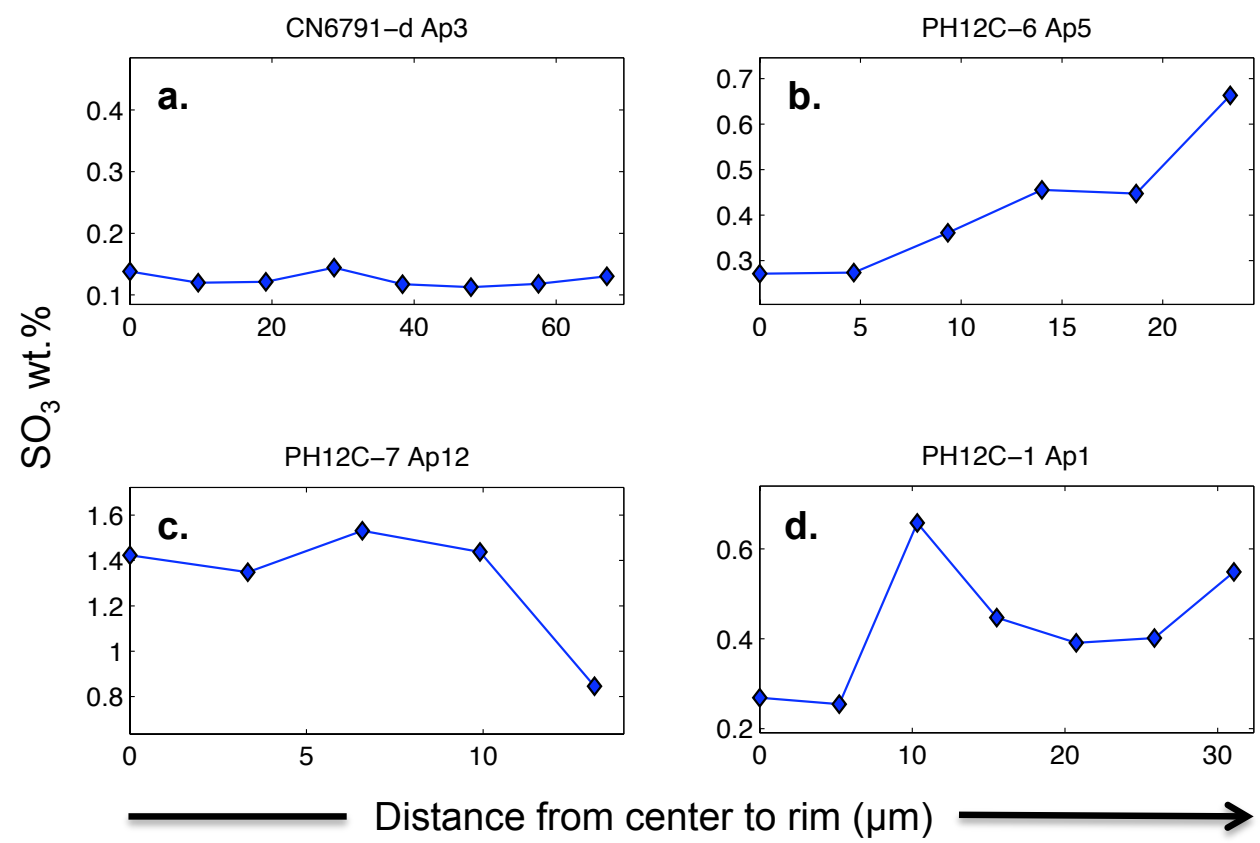

Figure 26: Sulfur profiles found in Pinatubo apatites: a) homogenous sulfur, b) rimward increase in sulfur, c) rimward decrease in sulfur, and d) oscillatory sulfur.

S-element maps (Figs. 27 and 28) of small apatites show that S distributions within a single crystal can be very irregular and correspond with $\mathrm{Na}$ distributions. High-S concentrations most commonly appear as globular blobs near to off-center of the grain, sometimes surrounded by a high-S halo that follows the shape of the crystal. 
Even more irregular shapes were observed, such as horseshoe shapes or slightly curved lines (Figs. 29 and 30). EMP analyses showed that 29\% of silicic apatites analyzed had a high-S concentration. However, this percentage could be grossly underestimated if the selected traverses missed pockets of high-S observed in the element maps, like in Figure 28. It is speculated that high-S silicic apatites are closer to $50 \%$. Refer to Appendix F for all apatite element maps. 

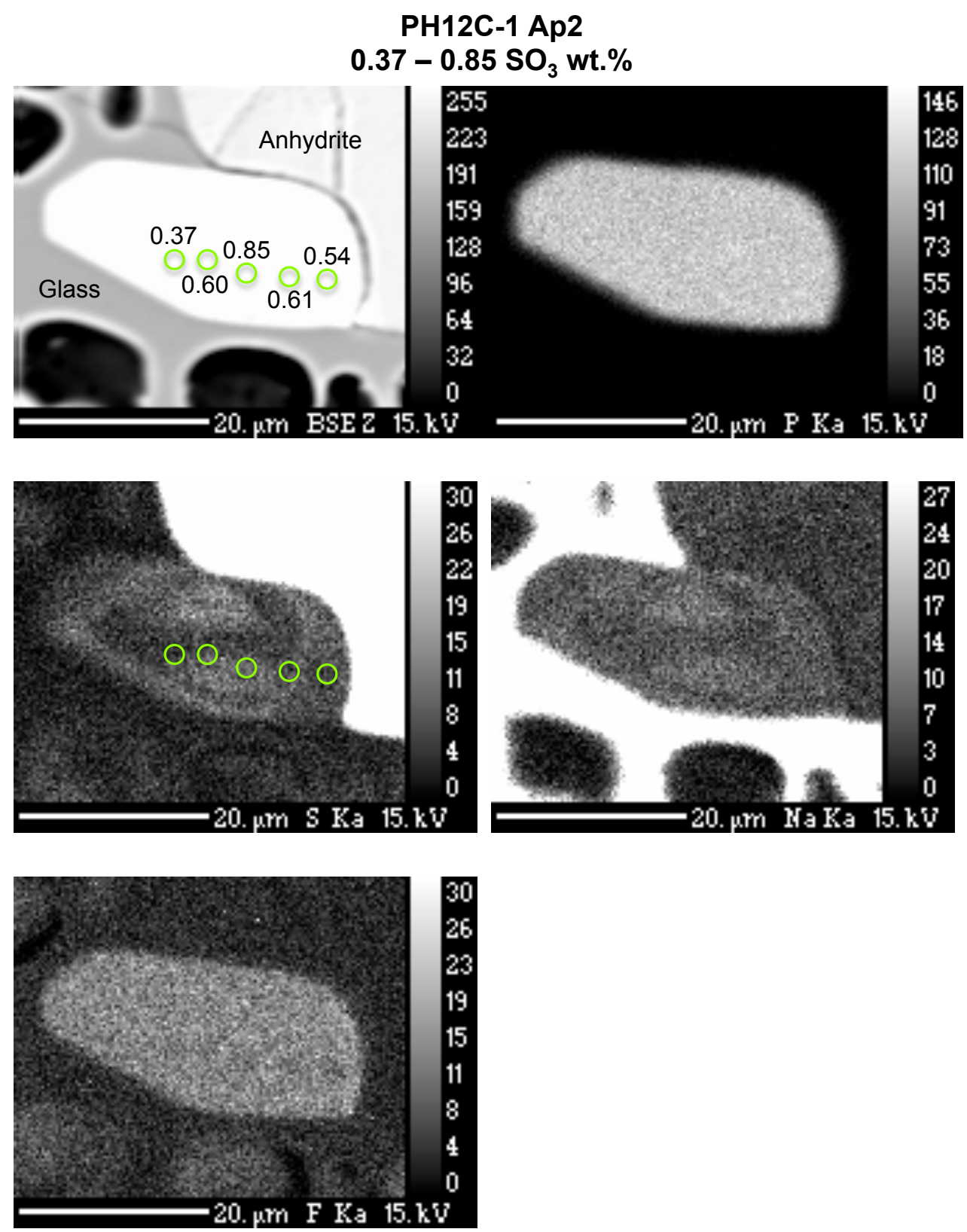

Figure 27: Backscatter image and element maps of $\mathrm{P}, \mathrm{S}, \mathrm{Na}$, and $\mathrm{F}$ for PH12C-1 Ap2 in contact with anhydrite and glass. The lack of sulfur enrichment at the apatite/anhydrite contact shows that apatite is not leaching sulfur from nearby anhydrite. Sulfur concentrations in this apatite are very complex with two globular concentrations near the center surrounded by a halo of sulfur enrichment. The matching patches of Na-enrichment with $\mathrm{S}$ confirm that $\mathrm{Na}^{+}$is an important cation in coupled substitutions with $\mathbf{S}^{6+}$. 

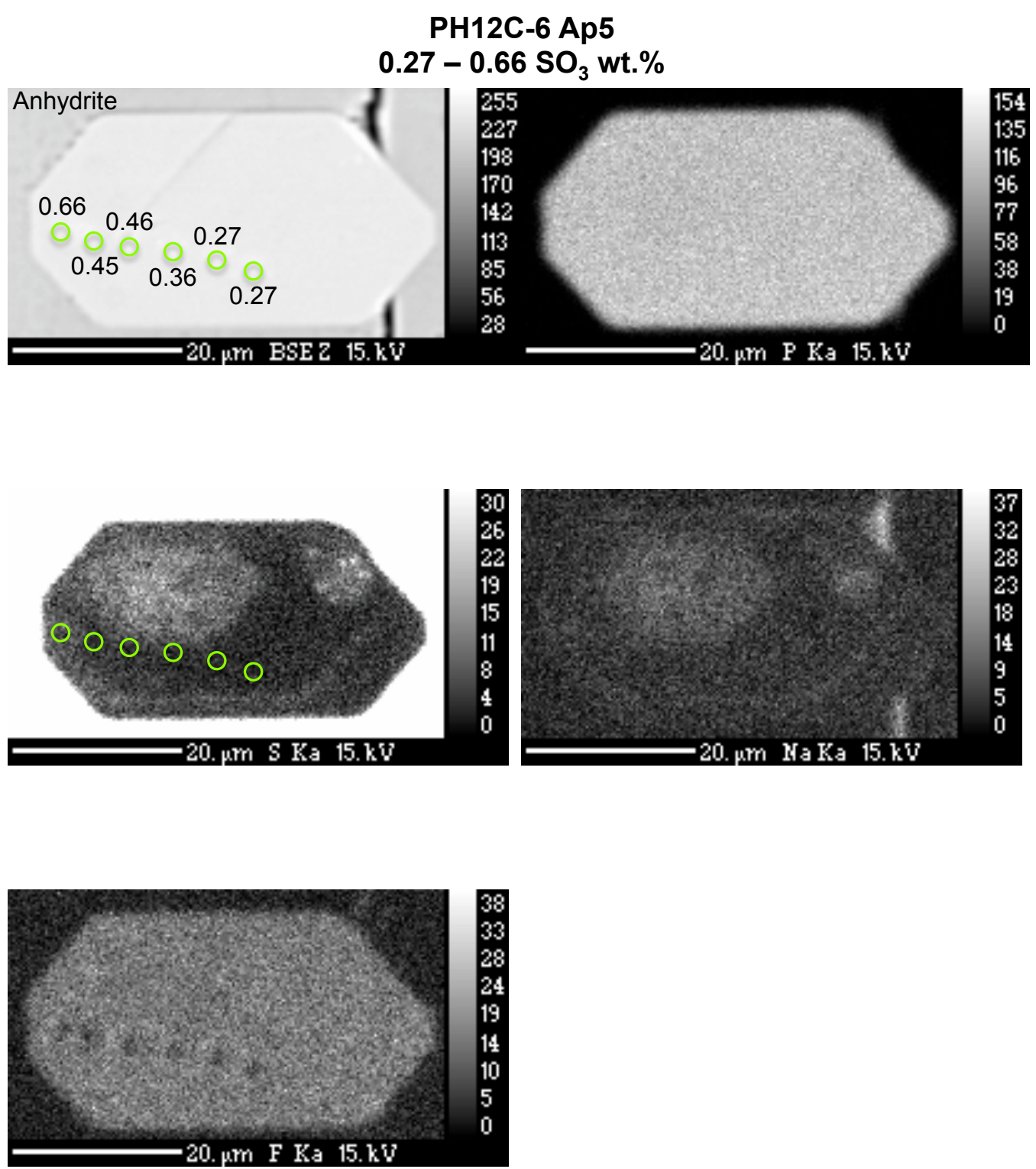

Figure 28: Backscatter image and element maps of P, S, Na, and F for PH12C-6 Ap5 hosted in anhydrite. The lack of sulfur enrichment around the rim of the crystal at the apatite/anhydrite contact shows that apatite is not leaching sulfur from nearby anhydrite. Sulfur concentrations in this apatite are very complex with two globular concentrations near the center surrounded by a halo of sulfur enrichment. 

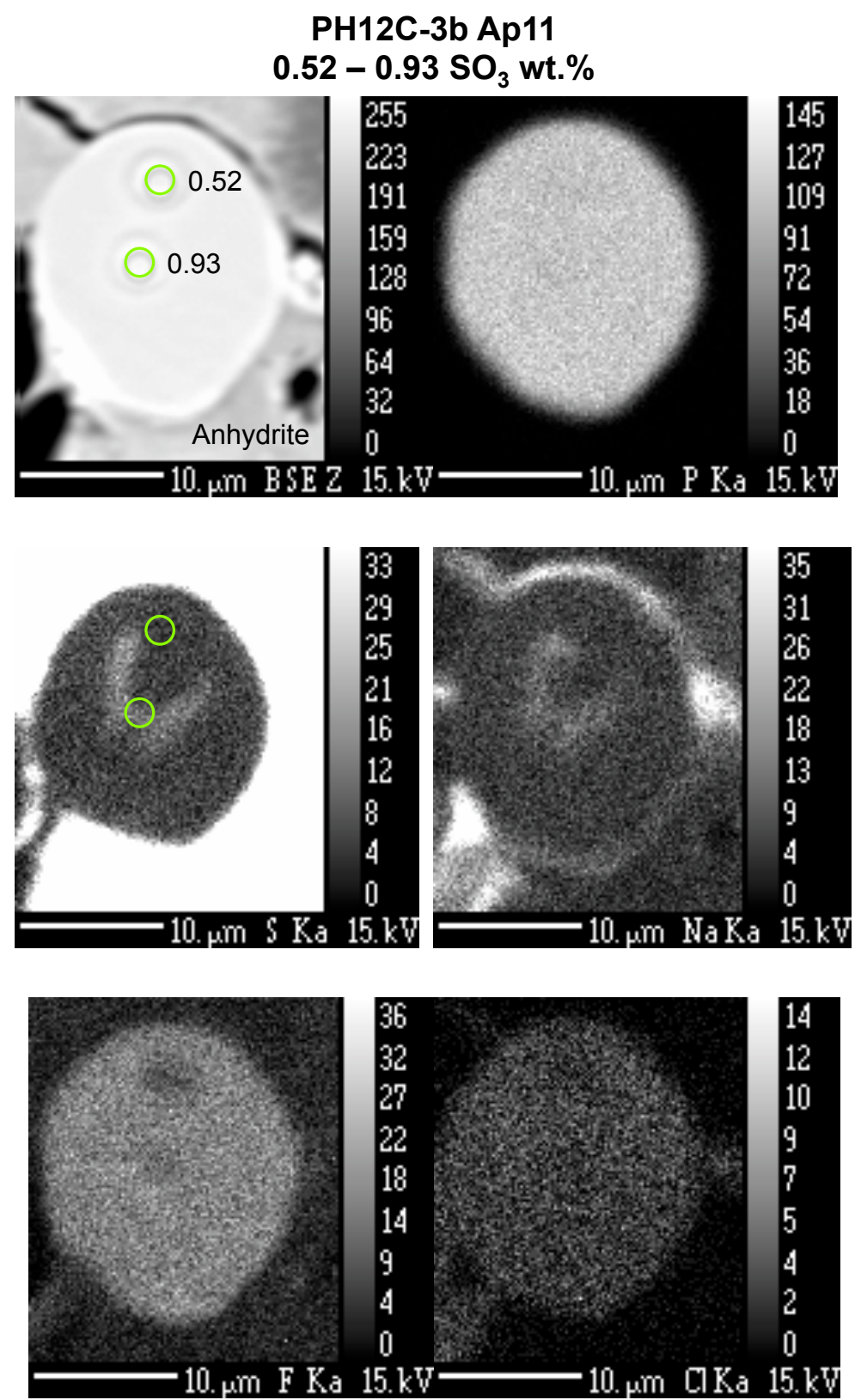

Figure 29: Backscatter image and element maps of P, S, Na, F, and Cl for PH12C-3b Ap11 hosted in anhydrite. Sulfur enrichment is in the form of a horseshoe shape. 

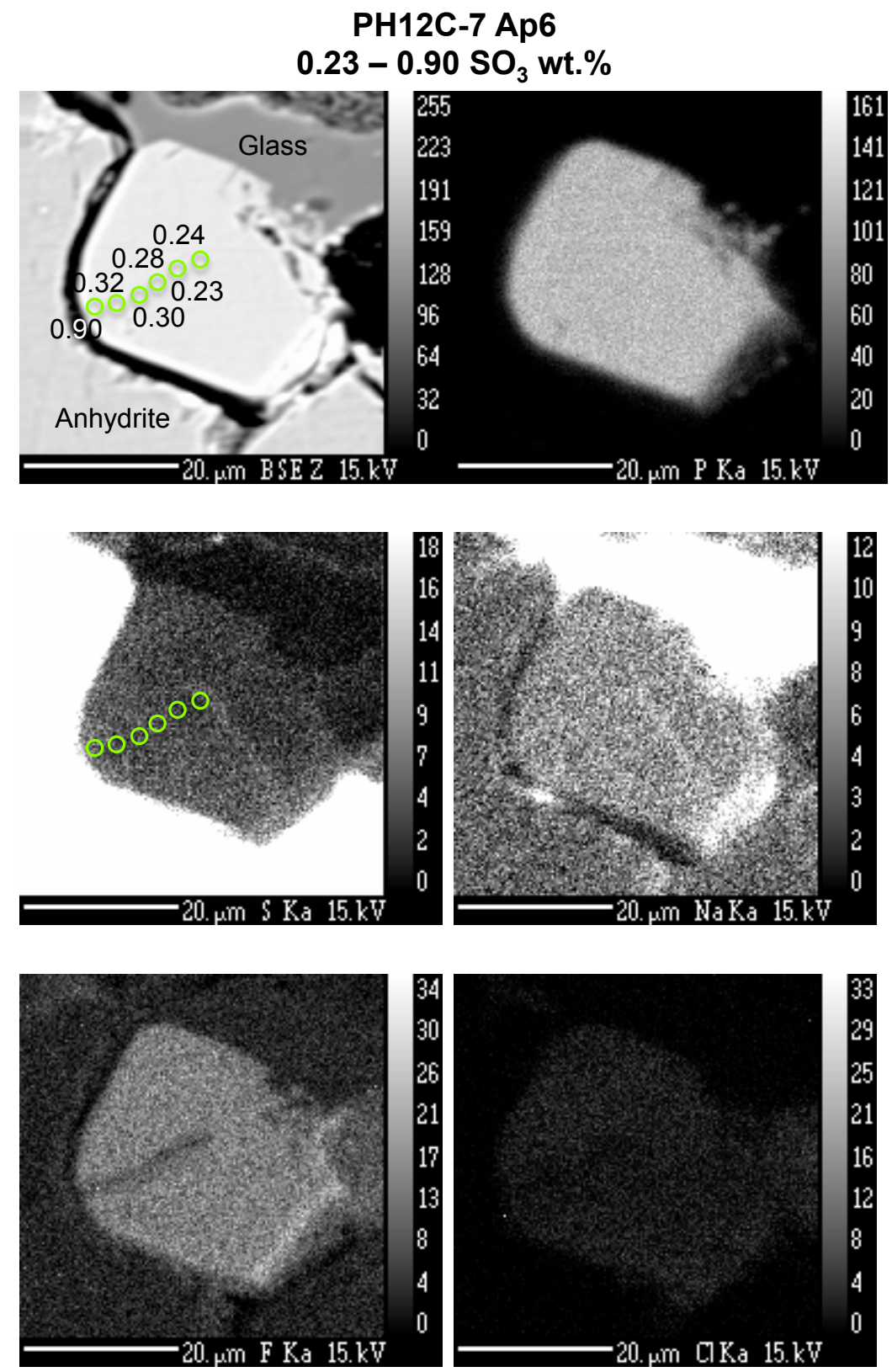

Figure 30: Backscatter image and element maps of $\mathrm{P}, \mathrm{S}, \mathrm{Na}, \mathrm{F}$, and $\mathrm{Cl}$ for PH12C-7 Ap6. Sulfur enrichment is in the form of an irregular line running from the center of the crystal to the rim. High-S measured at the rim of the crystal is likely due to the interaction volume of the electron beam including anhydrite. 


\section{REEs}

Apatites have been much studied for their ability to control whole rock REE concentrations and retain REE concentrations representative of the melt from which they grew. Apatite plus sphene have been shown to contain approximately $30 \%$ of the total whole rock REE budget. Because of the incompatible nature of REEs, more evolved, silicic melts have higher concentrations of REEs than more primitive, mafic melts. REEs enter apatite through the coupled substitutions listed in the previous section in addition to the following exchange reactions:

$$
\begin{array}{lr}
\mathrm{REE}^{3+}+\mathrm{Si}^{4+} \Leftrightarrow \mathrm{Ca}^{2+}+\mathrm{P}^{5+}(\text { Rønsbo, 1989, 2008) } & \text { Eq } 6 \\
\mathrm{REE}^{3+}+\mathrm{Na}^{+} \Leftrightarrow 2 \mathrm{Ca}^{2+} \text { (Rønsbo, 1989; Rakovan and Reeder, 1996) } & \text { Eq } 7
\end{array}
$$

We can use this relationship to track the melt environment of apatites. Representative trace element and REE LA-ICP-MS data are presented in Table 7.

Figure 31 shows REE patterns normalized to $\mathrm{C} 1$ chondrite of all LA-ICP-MS analyses and the average REE patterns of dacite, andesite, and basalt apatites, respectively. Silicic apatites have overall higher concentrations of REEs than basalt apatites, and display the typical enrichment in LREEs relative to middle and HREEs. For example, La concentrations in dacite apatites range from 320 to $1110 \mathrm{ppm}$, andesite apatites range from 690 to 890 ppm, and basalt apatites range from 79 to 326 ppm. Average La concentrations for dacite, andesite, and basalt apatites are 750 ppm, 785 ppm, and 217 ppm, respectively.

Europium concentrations create very different patterns between silicic and basalt apatites. When the Eu concentration in a REE pattern is much lower than the 
trend developed by the Sm and Gd concentrations on either side, then a negative Eu anomaly $\left(\mathrm{Eu} / \mathrm{Eu}^{*}<1\right)$ is generated. Felsic magmas will generally grow apatites with larger negative Eu anomalies than basaltic magmas (Watson and Green, 1981).

$\mathrm{Eu} / \mathrm{Eu}^{*}$ in dacite apatites range from 0.47 to 0.79 , andesite apatites range from 0.56 to 0.67, and basalt apatites range from 0.81 to 1.50 . Average $\mathrm{Eu} / \mathrm{Eu}^{*}$ for dacite, andesite and basalt apatites are $0.57,0.60$, and 1.16 , respectively. These results are consistent with the general trend of silicic melts having more negative $(<1) \mathrm{Eu} / \mathrm{Eu}^{*}$ than mafic melts with no or positive $\mathrm{Eu} / \mathrm{Eu}^{*}(\geq 1)$, and add further evidence to the hypothesis that the andesite apatites were inherited solely from the dacite.

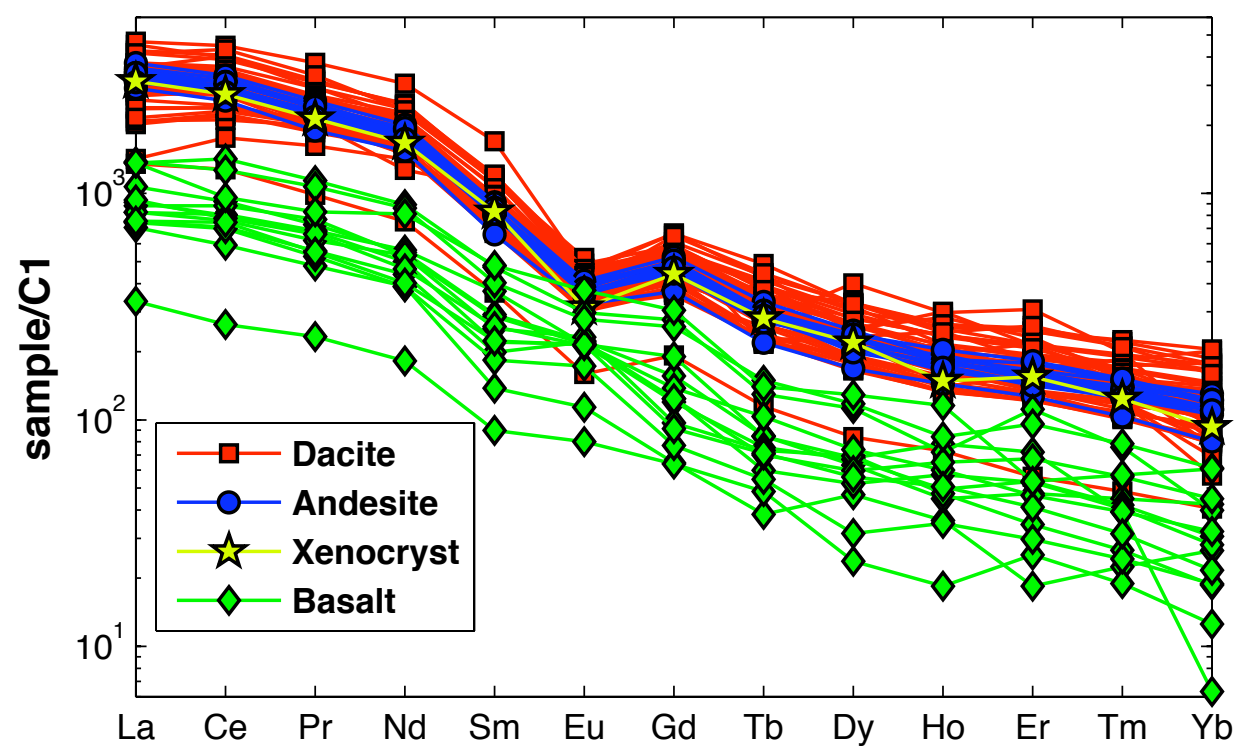

Figure 31: REE patterns for all apatites analyzed using LA-ICP-MS. All apatites have LREE enrichment over HREE. Dacite and andesite apatites make a distinct population when compared to basalt apatite REE patterns. Basalt apatites have significantly lower total REE, and are lacking the negative Europium anomaly $\left(\mathrm{Eu} / \mathrm{Eu}^{*}<1\right)$ that is seen in dacite and andesite apatites. One apatite hosted in the basalt has a pattern like the more silicic apatites and is likely a xenocryst. 
$(\mathrm{La} / \mathrm{Sm})_{\mathrm{N}}$ and $(\mathrm{La} / \mathrm{Yb})_{\mathrm{N}}$ normalized ratios can be used to express the steepness of the LREE pattern and whole REE pattern, respectively. Any differences in these ratios could suggest separate apatite populations. Figure 32 does not show any groupings when comparing these ratios among the silicic and basalt apatites. The average $\mathrm{La} / \mathrm{Yb}$ for dacite (28.9), andesite (29.5), and basalt (29.4) apatites are almost identical. Regardless of the similarity in REE pattern steepness between populations of apatites, the overall difference in REE concentrations and $\mathrm{Eu} / \mathrm{Eu}^{*}$ distinguish silicic and basalt apatites.

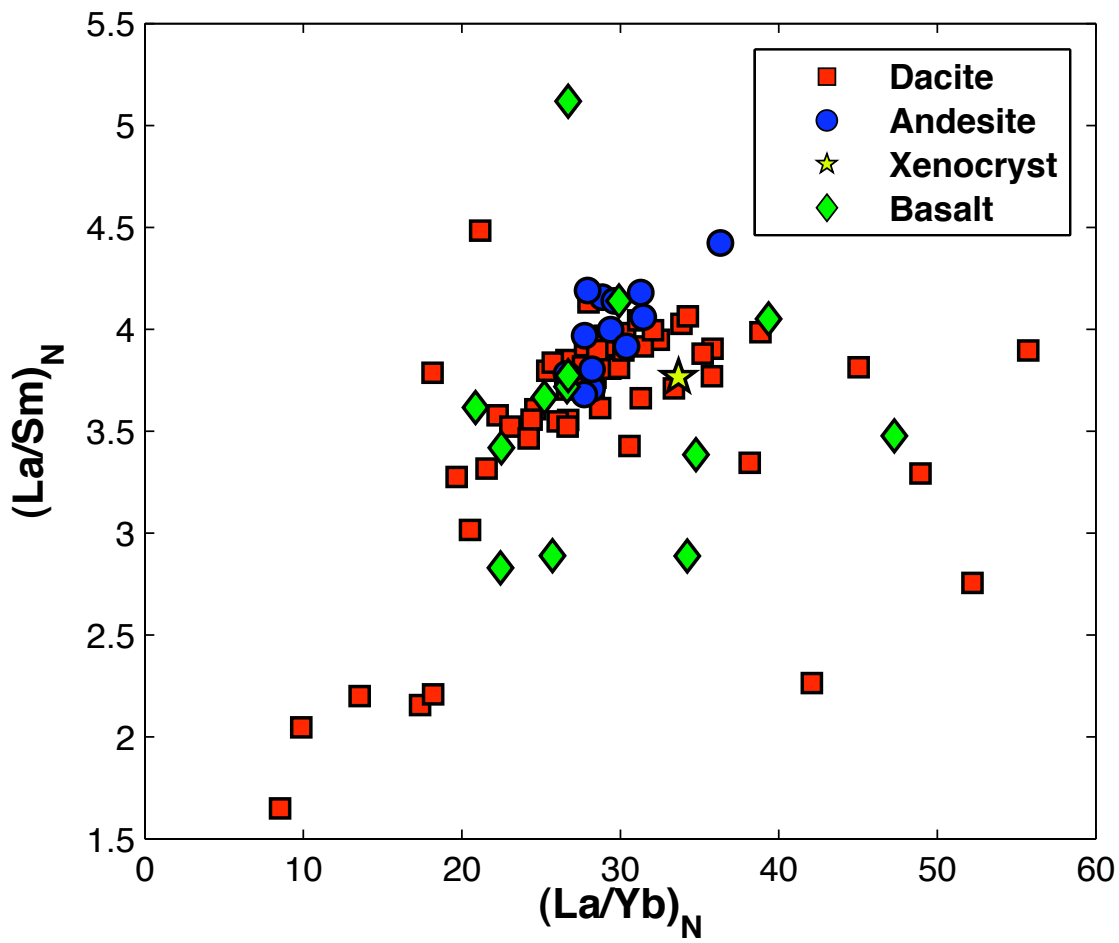

Figure 32: Plot of La/Sm (steepness of the LREE) versus La/Yb (steepness of all REE). There are no significant groupings between silicic apatites and basalt apatites, which suggests that the slope of the REE patterns do not vary much. 
Figure 33 is a simplified version of Figure 31 to better show the variability of REE concentrations among apatite populations represented by the filled regions. In each population, there is one apatite (PH12C-6, CN6791-d Ap6, and P-22892-2a Ap13) that falls below the range of its population enough that it was not included in the main shading. Although the concentrations of the apatites are lower than the general population, the patterns of each represent the population in which they belong, and should not be considered separate populations of $n=1$. Reason for these depleted concentrations could simply reflect heterogeneities of REE concentrations in the melt. Each of these apatites is rather small, $\sim 20 \mu \mathrm{m}$ in the longest dimension, and the low concentrations of REE could be a consequence of a lower volume of ablated material available for analysis in the mass spectrometer. The low concentrations could also be due to dilution of REE by analyzing low REE of the surrounding material. 


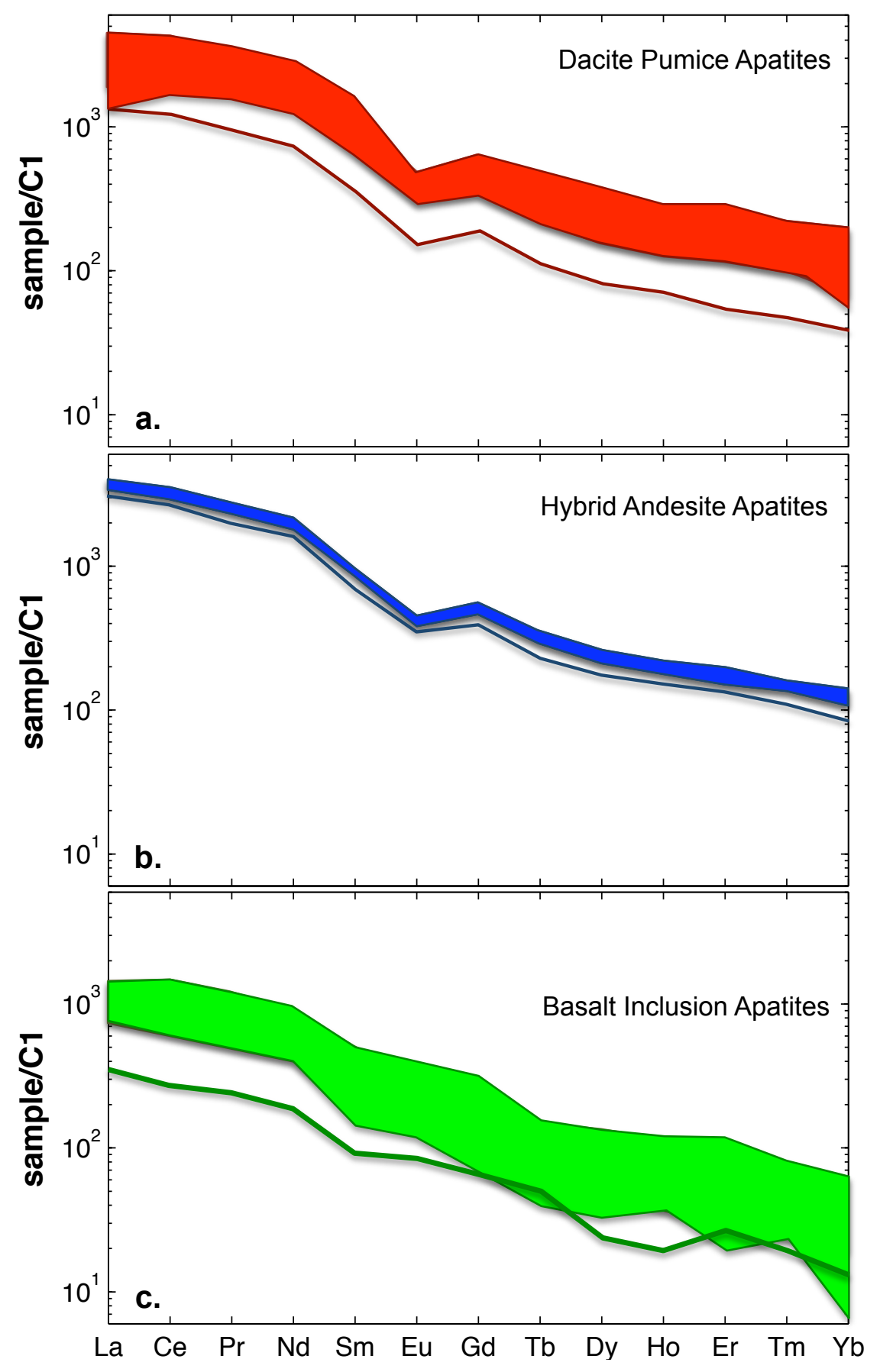

Figure 33: Shaded regions represent the range of REE concentrations in a) dacite apatites, b) andesite apatites, and c) basalt apatites. Silicic apatites have a narrower range and a pronounced negative Eu anomaly. Basalt apatites have a broader range of REE concentrations. Each group has one apatite that falls below the range of the group. 


\section{Other Trace Elements}

In addition to the distinctions made between apatite population based on REE concentrations and patterns, apatites from the 1991 Pinatubo eruptive products also show populations through trace element chemistry, particularly $\mathrm{Th}, \mathrm{U}$, and $\mathrm{Sr}$ (Fig. 34). Th and $U$ concentrations, on average, are higher in silicic apatites than basalt apatites. These concentrations are a reflection of the levels of differentiation experienced by the dacite and basalt magmas. The more differentiated dacite magma has higher concentrations of the more incompatible elements (Th and U) when compared to the less differentiated basalt magma. Th and $U$ show a negative correlation with $\mathrm{Eu} / \mathrm{Eu}^{*}$. Average $\mathrm{U}$ concentrations are $7.7 \mathrm{ppm}, 7.6 \mathrm{ppm}$, and $4.4 \mathrm{ppm}$ in dacite, andesite, and basalt apatites, respectively. Average Th concentrations are $20.0 \mathrm{ppm}, 19.7 \mathrm{ppm}$, and $15.7 \mathrm{ppm}$ in dacite, andesite, and basalt apatites, respectively. Apatites have been shown in many studies to be good proxies for determining the level of differentiation and oxidation state of the melt from which they grew (Puchelt and Emmermann, 1976; Watson and Capobianco, 1981; Sha and Chappell, 1999; Tepper and Kuehner, 1999; Belousova et al., 2002; Dempster el al., 2003; Humphreys et al., 2006; Macdonald et al., 2008; Boyce and Hervig, 2009).

Sr concentrations in apatites also reflect the level of differentiation and silica content of the host melt. Basalt apatites have the highest Sr concentrations (average = $975 \mathrm{ppm}$ ), and dacite apatites have the lowest (average $=594 \mathrm{ppm})$. Andesite apatites show slightly higher Sr concentrations (average $=625$ ) than dacite apatites. This may reflect the effects of magma mixing between dacite and basalt. Sr has a positive 
correlation with Eu/Eu*. Two basalt apatites (P-22892-2a Ap12 and P-22892-2a Ap13) have low $\mathrm{Sr}$ concentrations ( $\sim 620$ and $\sim 450 \mathrm{ppm}$, respectively). P-22892-2a Ap13 is much smaller than other basalt apatites analyzed with LA-ICP-MS, and the low $\mathrm{Sr}$ concentration likely reflects dilution from analysis of the low $\mathrm{Sr}$ surrounding material. A second analysis of P-22892-2a Ap12 gave a Sr concentration of $\sim 1,030$ $\mathrm{ppm}$. The other analysis of $\sim 620 \mathrm{ppm}$ Sr may also be a result of dilution.

In summary, silicic apatites and basalt apatites fall into distinct populations based upon major element chemistry, REE concentrations and patterns, and other trace element concentrations. Strong morphological differences also exist between silicic apatites and basalt apatites (Fig. 42). 

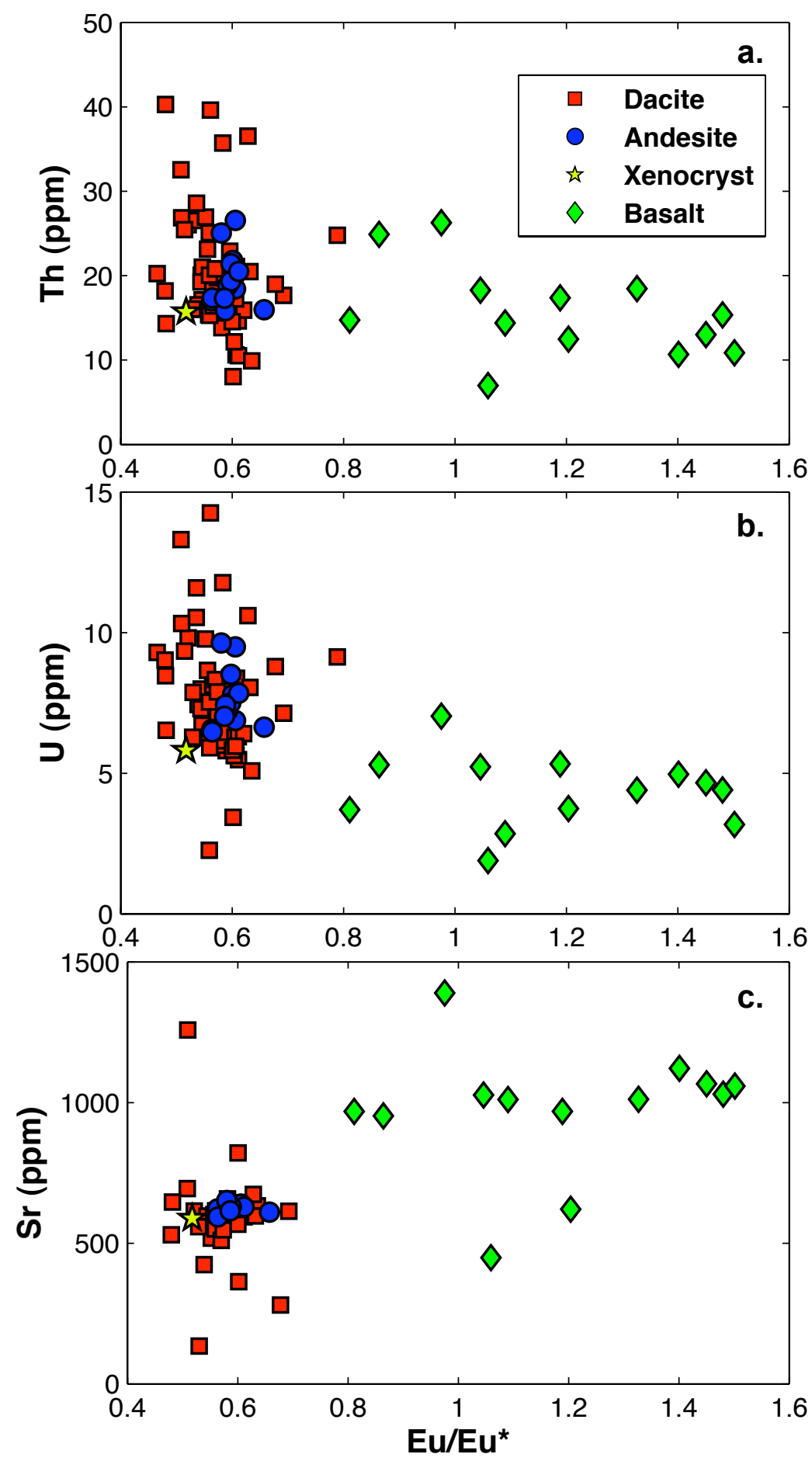

Figure 34: Distinct populations of apatites based upon Th, $\mathrm{U}$, and $\mathrm{Sr}$ concentrations. The more differentiated melts produce apatites with higher concentrations of incompatible elements. 
Table 7: Representative LA-ICP-MS results for "silicic" apatites from 1991 Pinatubo eruption. $\mathrm{SO}_{3}$ are averages of EMP data.

\begin{tabular}{|c|c|c|c|c|c|c|c|c|c|}
\hline \multirow[b]{2}{*}{$\begin{array}{l}\text { Sample } \\
\text { Apatite }\end{array}$} & \multicolumn{5}{|c|}{ "Silicic" Apatites of Dacite } & \multicolumn{4}{|c|}{ "Silicic" Apatites of Hybrid Andesite } \\
\hline & $\begin{array}{l}\text { PH12C-2 } \\
\text { ap6 }\end{array}$ & $\begin{array}{l}\text { PH12C-7 } \\
\text { ap4 pt1 }\end{array}$ & $\begin{array}{c}\text { PH12C-7 } \\
\text { ap4 pt2 }\end{array}$ & $\begin{array}{l}\text { PH12C-7 } \\
\text { ap16 pt1 }\end{array}$ & $\begin{array}{l}\text { PH12C-7 } \\
\text { ap16 pt3 }\end{array}$ & $\begin{array}{l}\text { CN6791-d } \\
\text { ap5 pt1 }\end{array}$ & $\begin{array}{l}\text { CN6791-d } \\
\text { ap5 pt2 }\end{array}$ & $\begin{array}{l}\text { CN6791-d } \\
\text { ap6 }\end{array}$ & $\begin{array}{c}\text { CN6791-d } \\
\text { ap7 }\end{array}$ \\
\hline $\mathrm{SO}_{3}$ & 0.32 & 0.13 & 0.18 & 0.63 & 0.38 & 0.23 & 0.65 & 0.13 & 0.12 \\
\hline $\mathrm{S}$ & 932 & 675 & 689 & 1237 & 926 & 1701 & 1355 & 666 & 912 \\
\hline Sc & n.d. & n.d. & n.d. & n.d. & n.d. & n.d. & n.d. & n.d. & 0.30 \\
\hline $\mathrm{Cr}$ & n.d. & n.d. & n.d. & n.d. & n.d. & n.d. & n.d. & n.d. & n.d. \\
\hline $\mathrm{Ni}$ & n.d. & n.d. & n.d. & n.d. & 12.3 & n.d. & n.d. & n.d. & n.d. \\
\hline $\mathrm{Cu}$ & n.d. & n.d. & n.d. & n.d. & n.d. & 4.6 & 4.2 & n.d. & 5.8 \\
\hline $\mathrm{Zn}$ & 2.9 & n.d. & n.d. & 11 & 5.3 & 2.1 & 2.9 & 2.5 & 1.7 \\
\hline $\mathrm{Rb}$ & 0.10 & n.d. & n.d. & n.d. & n.d. & n.d. & n.d. & n.d. & n.d. \\
\hline $\mathrm{Sr}$ & 518 & 644 & 632 & 673 & 597 & 639 & 629 & 611 & 621 \\
\hline $\mathrm{Y}$ & 293 & 269 & 262 & 325 & 245 & 268 & 263 & 216 & 283 \\
\hline $\mathrm{Zr}$ & 1.4 & 0.69 & 0.48 & 1.6 & n.d. & 0.68 & 0.40 & 0.57 & 0.60 \\
\hline $\mathrm{Nb}$ & n.d. & n.d. & n.d. & n.d. & n.d. & n.d. & n.d. & n.d. & n.d. \\
\hline $\mathrm{Ba}$ & 3.9 & 4.1 & 5.6 & 8.52 & 4.50 & 4.0 & 2.8 & 2.5 & 4.0 \\
\hline $\mathrm{La}$ & 795 & 733 & 733 & 830 & 737 & 780 & 805 & 691 & 746 \\
\hline $\mathrm{Ce}$ & 1864 & 1821 & 1853 & 1921 & 1743 & 1828 & 1902 & 1573 & 1786 \\
\hline $\operatorname{Pr}$ & 222 & 219 & 218 & 227 & 204 & 211 & 223 & 176 & 214 \\
\hline $\mathrm{Nd}$ & 888 & 783 & 809 & 894 & 809 & 815 & 833 & 706 & 826 \\
\hline $\mathrm{Sm}$ & 141 & 119 & 118 & 138 & 115 & 118 & 120 & 98 & 126 \\
\hline $\mathrm{Eu}$ & 22 & 21 & 20 & 25 & 20 & 21 & 21 & 18 & 20 \\
\hline $\mathrm{Gd}$ & 108 & 93 & 88 & 108 & 82 & 92 & 91 & 73 & 97 \\
\hline $\mathrm{Tb}$ & 13 & 9 & 10 & 12 & 11 & 10 & 10 & 8 & 11 \\
\hline Dy & 65 & 51 & 52 & 60 & 46 & 53 & 52 & 41 & 57 \\
\hline Ho & 11 & 9 & 10 & 10 & 8 & 9 & 11 & 8 & 10 \\
\hline $\mathrm{Er}$ & 30 & 26 & 22 & 27 & 25 & 23 & 26 & 20 & 25 \\
\hline $\mathrm{Yb}$ & 23 & 19 & 14 & 16 & 13 & 18 & 20 & 13 & 18 \\
\hline $\mathrm{Pb}$ & 32 & 17 & 3.6 & 127 & 259 & 3.2 & 14 & 4.2 & 3.9 \\
\hline $\mathrm{Th}$ & 27 & 17 & 15 & 37 & 20 & 27 & 21 & 16 & 17 \\
\hline $\mathrm{U}$ & 9.8 & 6.3 & 6.3 & 11 & 8.1 & 9.5 & 7.8 & 6.6 & 6.6 \\
\hline
\end{tabular}


Table 7: Continued. Basalt apatites.

\begin{tabular}{|c|c|c|c|c|}
\hline \multirow[b]{2}{*}{$\begin{array}{l}\text { Sample } \\
\text { Apatite }\end{array}$} & \multicolumn{4}{|c|}{ Basalt Apatites } \\
\hline & $\begin{array}{c}\text { P-22892-2a } \\
\text { ap12 pt1 }\end{array}$ & $\begin{array}{c}\text { P-22892-2a } \\
\text { ap12 pt2 }\end{array}$ & $\begin{array}{c}\text { P-22892-2a } \\
\text { ap20 }\end{array}$ & $\begin{array}{c}\text { P-22892-2a } \\
\text { ap23 }\end{array}$ \\
\hline $\mathrm{SO}_{3}$ & 1.46 & 1.84 & 1.21 & 0.81 \\
\hline $\mathrm{S}$ & 2532 & 5510 & 2829 & 3566 \\
\hline $\mathrm{Sc}$ & n.d. & n.d. & n.d. & n.d. \\
\hline $\mathrm{Cr}$ & n.d. & n.d. & n.d. & n.d. \\
\hline $\mathrm{Ni}$ & n.d. & n.d. & n.d. & n.d. \\
\hline $\mathrm{Cu}$ & 8.7 & 12 & 7.4 & 4.7 \\
\hline $\mathrm{Zn}$ & 4.0 & 1.7 & 4.4 & 12 \\
\hline $\mathrm{Rb}$ & n.d. & n.d. & 5.0 & 15 \\
\hline $\mathrm{Sr}$ & 621 & 1027 & 1011 & 1066 \\
\hline $\mathrm{Y}$ & 53 & 83 & 76 & 54 \\
\hline $\mathrm{Zr}$ & 0.44 & 5.0 & 9.5 & 12 \\
\hline $\mathrm{Nb}$ & n.d. & 0.15 & 0.31 & 0.48 \\
\hline $\mathrm{Ba}$ & n.d. & 8.2 & 23 & 61 \\
\hline $\mathrm{La}$ & 168 & 254 & 217 & 176 \\
\hline $\mathrm{Ce}$ & 363 & 565 & 491 & 428 \\
\hline $\mathrm{Pr}$ & 44 & 68 & 63 & 49 \\
\hline $\mathrm{Nd}$ & 178 & 250 & 228 & 177 \\
\hline $\mathrm{Sm}$ & 20 & 43 & 33 & 27 \\
\hline $\mathrm{Eu}$ & 6 & 13 & 12 & 10 \\
\hline $\mathrm{Gd}$ & 13 & 31 & 24 & 15 \\
\hline $\mathrm{Tb}$ & 1 & 3 & 3 & 2 \\
\hline Dy & 11 & 16 & 16 & 8 \\
\hline Ho & 2 & 2 & 3 & 2 \\
\hline $\mathrm{Er}$ & 3 & 8 & 9 & 5 \\
\hline $\mathrm{Yb}$ & 4 & 7 & 5 & 3 \\
\hline $\mathrm{Pb}$ & 30 & 2.4 & 12 & 4.8 \\
\hline Th & 12 & 18 & 18 & 13 \\
\hline $\mathrm{U}$ & 3.7 & 5.2 & 4.4 & 4.7 \\
\hline
\end{tabular}




\section{DISCUSSION}

\section{Sulfur Concentrations in Apatite}

Sulfur (S) is a major volatile component of magmatic systems the solubility of which is highly dependent upon pressure, temperature, oxygen fugacity $\left(\mathrm{O}_{2}\right)$, sulfur fugacity $\left(\mathrm{S}_{2}\right)$, and bulk composition of the melt (Carroll and Rutherford, 1985, 1987, 1988; Wallace and Carmichael, 1992, Jugo et al., 2005a). Sulfur exists as $\mathrm{S}^{2-}$ in

sulfides (FeS-rich melt) under reducing conditions and as $\mathrm{S}^{6+}$ in sulfates (e.g. Anhydrite - $\mathrm{CaSO}_{4}$ ) under oxidizing conditions (Carroll and Rutherford, 1985, 1987, 1988; Nilsson and Peach, 1993; Metrich and Clocchiatti, 1996; Paris et al., 2001; Jugo et al., 2005a, 2005b). S solubility is most significantly affected by $\mathrm{fO}_{2}$ in both basaltic and silicic magmas (Carroll and Rutherford, 1985, 1988; Clemente et al., 2004; Jugo et al., 2005a, 2005b).

Experiments performed by Buchanan and Nolan (1979) at $1200^{\circ} \mathrm{C}$ and $1 \mathrm{~atm}$ with synthetic tholeiitic melts showed that the amount of dissolved sulfur in these melts increased with increasing sulfur fugacity and decreasing oxygen fugacity. Sulfur saturation was achieved at oxygen fugacity isobars of - $\log 10.50$ and - $\log 11.50$ with corresponding sulfur fugacity values of $-\log 1.75$ and $-\log 3.75$, respectively. In other words, there is a positive correlation between sulfur fugacity and oxygen fugacity at sulfur saturation. Immiscible sulfide phases will only form in sulfur-saturated tholeiitic melts at lower oxygen fugacities. In rhyolitic melts at a given $f \mathrm{O}_{2}$, sulfur solubility will increase with increasing $f \mathrm{~S}_{2}$ (Clemente et al., 2004). 
Figure 35 from Hattori (1996) shows the behavior of sulfur solubility with increasing oxygen fugacity in a dacitic melt at $900^{\circ} \mathrm{C}$. At $\sim$ QFM-1.7 the concentration of sulfur as the $\mathrm{S}^{2-}$ species dissolved in the melt is about $330 \mathrm{ppm}$. This value decreases to a minimum of $\sim 130 \mathrm{ppm}$ at $\sim \mathrm{QFM}+0.6$. At this point, the main dissolved sulfur species begins to transition from $\mathrm{S}^{2-}$ to $\mathrm{SO}_{4}{ }^{2-}\left(\mathrm{S}^{6+}\right)$, and $\mathrm{S}$ dissolved in melt as a function of oxygen fugacity changes from a negative correlation to a positive correlation. At QFM+4, approximately $850 \mathrm{ppm}$ of sulfur as sulfate can be dissolved in a melt (Carroll and Rutherford, 1987, 1988; Hattori, 1996). Rhyolitic melts at $933^{\circ} \mathrm{C}, 2 \mathrm{kbar}$, and $\mathrm{NNO}+2.4$ can achieve sulfur concentrations of nearly $1,000 \mathrm{ppm}$ (Clemente et al., 2004). This quick transition of sulfur speciation is common in calcalkaline, dacitic-rhyolitic magmas (Carroll and Rutherford, 1988). Experiments on basaltic melts have shown that changes in $\mathrm{fO}_{2}$ from sulfide-saturation to sulfatesaturation produced a ten-fold increase in dissolved sulfur (Jugo et al., 2005a). Trachyandesitic melts supersaturated in sulfur at $<\mathrm{NNO}+1$ will begin to precipitate sulfides (i.e. pyrrhotite: Fe-S), and anhydrite will begin to precipitate at $\mathrm{NNO}+1-1.5$ (Carroll and Rutherford, 1987; Luhr, 1990). 


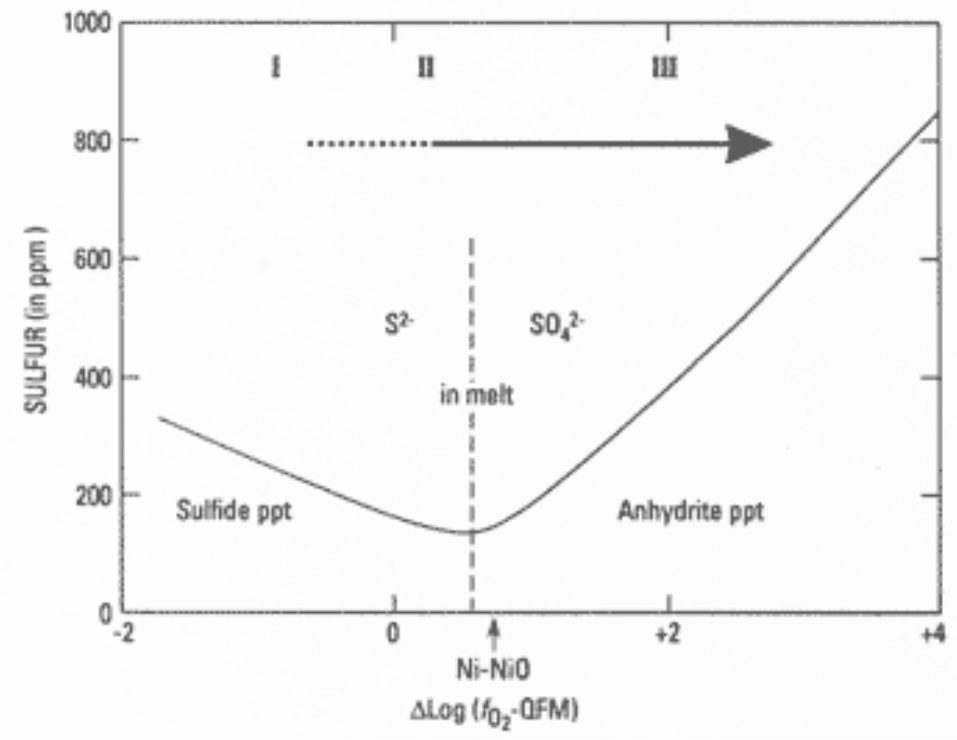

Figure 35: Sulfur solubility curve of a dacitic melt at $900 \mathrm{C}^{\circ}$ is strongly dependent upon the oxidation state of the melt. Under reducing conditions (I) S2- is the dominant sulfur species dissolved in the melt and sulfides will precipitate if the sulfur concentrations fall above the curve. Between I and II, the solubility decreases with increasing $f \mathrm{O}_{2}$. At II, a solubility minimum is reached and the dominant species shifts from $S^{2-}$ to $S^{6+}$, and anhydrite may precipitate with sufficient sulfur present. From there, solubility increases dramatically with increased $\mathrm{fO}_{2}$ (after Hattori et al., 1996).

Higher temperatures allow more $\mathrm{S}$ to be dissolved in the melt (Liu et al., 2007). $\mathrm{MnO}-\mathrm{Mn}_{3} \mathrm{O}_{4}$ (MNO) buffered experiments utilizing El Chichón trachyandesite have shown glass $\mathrm{S}$ concentrations of $\sim 2,000 \mathrm{ppm}$ and $\sim 500 \mathrm{ppm}$ at $985^{\circ} \mathrm{C}$ and $870^{\circ} \mathrm{C}$, respectively at anhydrite saturation (Carroll and Rutherford, 1987). The effect of temperature increase on increasing sulfur solubility is magnified under oxidizing conditions. Sulfide saturated melts only hold $150 \mathrm{ppm}$ less than anhydrite-saturated melts at a temperature of $850^{\circ} \mathrm{C}$. In contrast, melts at $1025^{\circ} \mathrm{C}$ differ by $1750 \mathrm{ppm}$ between MNO (2,200 ppm) and NNO (450 ppm) (Carroll and Rutherford, 1987). 
The concentration of $\mathrm{FeO}$ in the melt also has a large effect on sulfur solubility for reducing conditions. At $2 \mathrm{~kb}$ pressure, sulfide saturated melts have $100 \mathrm{ppm} \mathrm{S}$ at 2 wt.\% FeO and 700 ppm S at 8.5 wt.\% FeO (Carroll and Rutherford, 1987; Wallace and Carmichael, 1992; Carroll and Webster, 1994; Moretti and Ottonello, 2005). This is due to Fe-S complexes (Clemente et al., 2004). Lower sulfur solubilities are associated with $\mathrm{SiO}_{2}$-rich melts due to higher polymerization (Katsura and Nagashima, 1974; Carroll and Webster, 1994; Moretti and Ottonello, 2005; Liu et al., 2007). Water content does not seem to have a significant effect on sulfur solubility (Luhr, 1990; Wallace and Carmichael, 1994; Liu et al., 2007).

Sulfur solubility has been shown in experimental studies to increase with pressure under fluid-saturated conditions (Fig. 36). Dacitic melts at manganitehausmanite (MNO) and hematite-magnetite (HM) oxidizing buffer conditions and $1,025^{\circ} \mathrm{C}$ showed an increase in $\mathrm{S}$ concentrations from $\sim 1,400 \mathrm{ppm}$ at $100 \mathrm{MPa}$ to $\sim 3,000 \mathrm{ppm}$ at $300 \mathrm{MPa}$. Comparatively, quartz-fayalite-magnetite (QFM) reducing buffer conditions at $1,025^{\circ} \mathrm{C}$ only showed an increase in $\mathrm{S}$ concentrations from $\sim 600$ ppm at $100 \mathrm{MPa}$ to $1,000 \mathrm{ppm}$ at $200 \mathrm{MPa}$ (Carroll and Rutherford, 1985). Sulfur contents at sulfide saturation (SCSS) in basaltic melts show an opposite trend and decrease with increasing pressure with temperature held constant (Mavrogenes and O’Neill, 1999).

In summary, oxidized, high-temperature, basaltic magmas can dissolve a greater amount of sulfur than their low-temperature, silicic counterparts. This will affect the expected sulfur contents of apatites. 

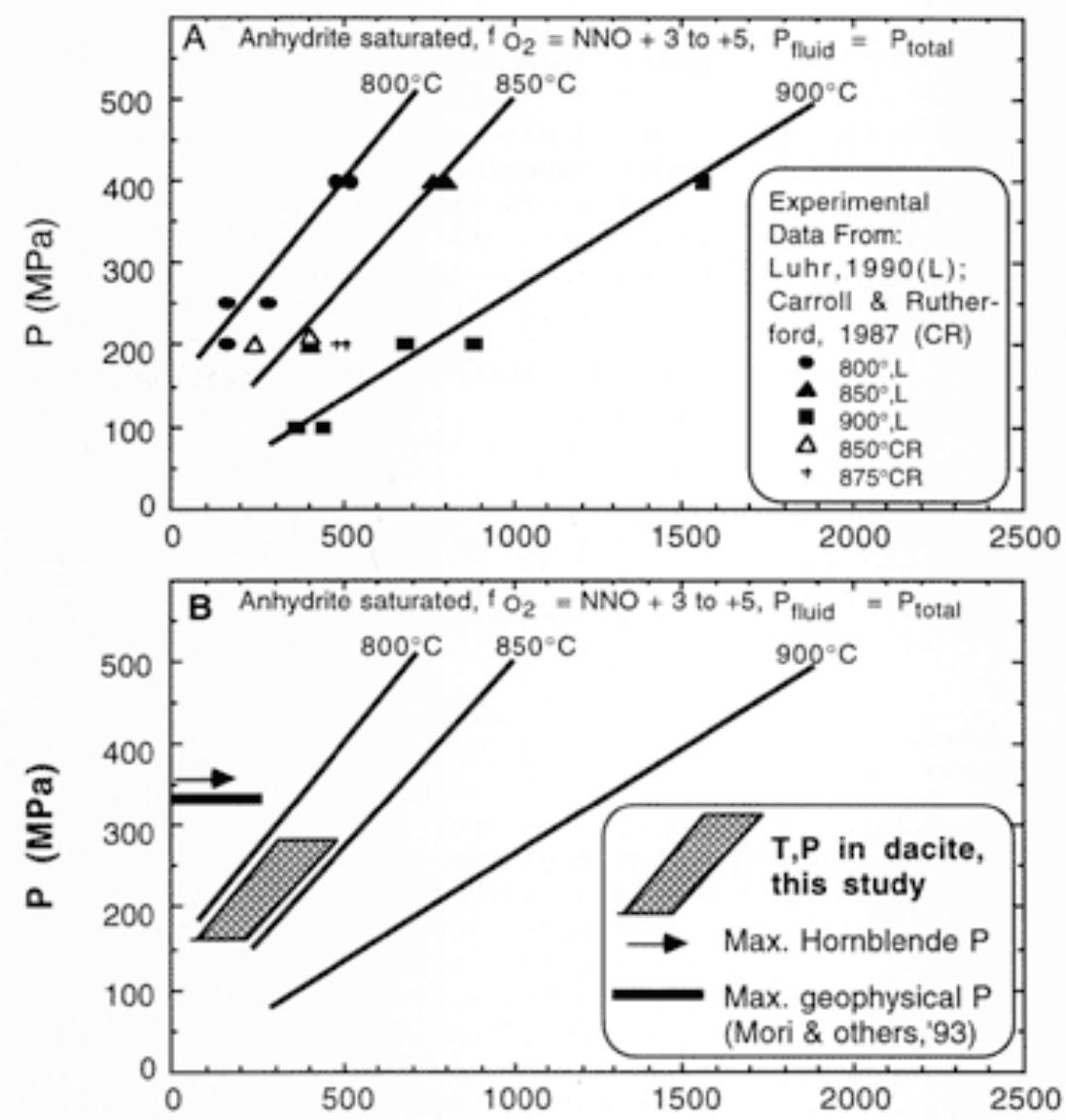

Sulfur solubility (ppm S) in dacitic to rhyolitic melt

Figure 36: Sulfur solubility is also dependent upon pressure and temperature. Increasing temperature and pressure allows for more sulfur to be dissolved in melts. The shaded region in $B$ represents Pinatubo dacite pre-eruption pressure and temperature conditions (after Fournelle et al., 1996).

Sulfur concentrations in apatite are determined by the concentration of sulfate in the melt and the partition coefficient of sulfur between crystallizing apatite and melt $\left(D_{S}^{\text {apatite/melt }}\right)$. Experimental results on anhydrite-undersaturated and anhydrite-saturated haplogranitic melts have shown $\mathrm{D}_{\mathrm{S}}^{\text {apatite/melt }}$ to depend strongly upon the sulfate concentration of the melt, and to a lesser extent temperature (T). The partition 
coefficient decreases with increasing $\mathrm{wt}^{\circ} \% \mathrm{SO}_{3}$ in the melt $\left(\mathrm{D}_{\mathrm{S}}^{\text {apatite/melt }}: 14.2\right.$ to 2.7 , at $\mathrm{SO}_{3} \mathrm{wt} \%$ in melt: 0.03 to 0.19 , respectively), and increases with decreasing temperature ( ${ }_{\mathrm{S}}^{\text {apatite/melt }}: 4.5$ to 14.2 , at $\mathrm{T}=1,100$ to $900^{\circ} \mathrm{C}$, respectively) (Parat and

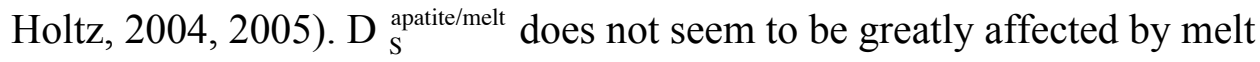
composition and is very similar for dacitic and trachyandesitic compositions at similar temperatures and oxygen fugacities (Baker and Rutherford, 1996b; Peng et al., 1997; Parat and Holtz, 2005). Cool, oxidized, sulfate-rich melts should produce a sulfur-rich apatite. However, the correlation between sulfate in melt and sulfur in apatite is not that simple. Both an anhydrite-undersaturated melt $\left(0.04\right.$ wt. $\left.\% \mathrm{SO}_{3}\right)$ and an anhydritesaturated melt $\left(0.2\right.$ wt. $\left.\% \mathrm{SO}_{3}\right)$ at $1,000^{\circ} \mathrm{C}$ can produce an apatite with 0.5 wt. $\% \mathrm{SO}_{3}$ (Parat and Holtz, 2005).

At anhydrite-saturated conditions, Parat and Holtz (2005) showed sulfur concentrations in apatite decreased with increasing $\mathrm{P}_{2} \mathrm{O}_{5}$ concentrations in the melt, regardless of concomitant increasing sulfur concentrations in melt. Sulfur exchange reactions in Eqs. 1 through 5 are influenced by the activities of $\mathrm{P}$ in the melt probably more so than $f \mathrm{~S}_{2}$ (Parat and Holtz, 2005).

Mount Pinatubo dacites show very high bulk sulfur concentrations ranging from 1,470 ppm to 2,210 ppm (Bernard et al., 1996), and melt inclusions with average sulfur concentrations of 55 to $77 \pm 29$ ppm (Rutherford and Devine, 1996). The majority of the bulk sulfur is in the phase of anhydrite phenocrysts (Gerlach et al., 1996; Pallister et al., 1996; Bernard et al., 1996). Estimated conditions of the $\sim 50 \mathrm{~km}^{3}$ dacitic magma chamber $\left(760 \pm 20^{\circ} \mathrm{C}, 220 \mathrm{MPa}, \mathrm{NNO}+1.7,77 \mathrm{ppm} \mathrm{S}\right.$ in melt inclusions) 
(Scaillet and Evans, 1999) (Fig. 36b and Fig. 37) could produce apatite with 1,000 ppm S or $0.25 \mathrm{wt} \% \mathrm{SO}_{3}$, using a partition coefficient of 13 . This $\mathrm{D}_{\mathrm{S}}^{\text {apatite/melt }}$ was determined with Pinatubo dacite crystallization experiments performed by Baker and Rutherford at pre-eruption conditions (1996a).

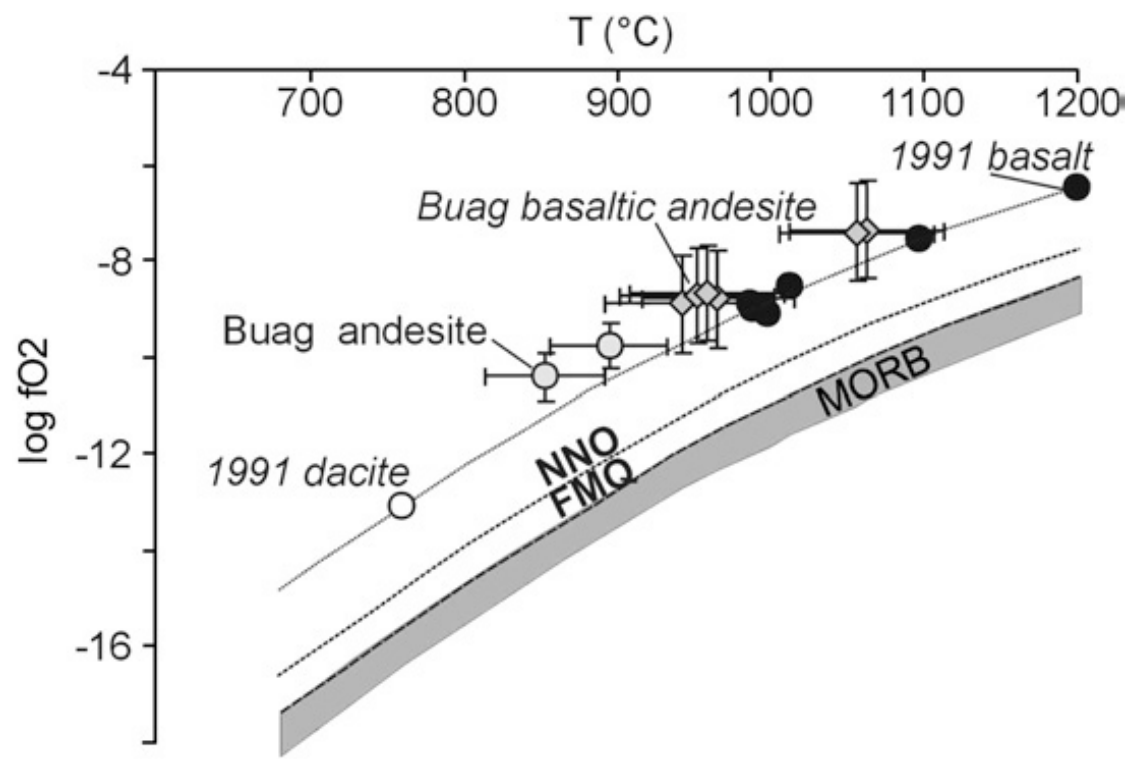

Figure 37: Pre-eruption $\mathrm{fO}_{2}$ and temperature for Buag period and 1991 Pinatubo erupted materials. $\mathrm{fO}_{2}$ of Pinatubo juvenile components during the past 500 years fall consistently 1.7 $\log _{10}$ units above the NNO oxygen buffer (after Di Muro et al., 2008).

In this study, high-sulfur apatites $\left(>0.7 \mathrm{wt} \% \mathrm{SO}_{3}\right)$ in Mount Pinatubo dacites with $\mathrm{SO}_{3}$ values up to $1.7 \mathrm{wt} \%$ were found. Producing an apatite with $1.7 \mathrm{wt} \% \mathrm{SO}_{3}$ via equilibrium partitioning with the surrounding melt would require a concentration of $523 \mathrm{ppm}$ dissolved sulfur assuming a $\mathrm{D}_{\mathrm{S}}^{\text {apatite/melt }}$ of 13 . This is nearly an order of magnitude higher than the sulfur concentrations measured in Pinatubo dacite glass inclusions. Parat and Holtz (2005) showed that, at $\mathrm{NNO}+3.6,200 \mathrm{MPa}$, and $900^{\circ} \mathrm{C}$, producing an apatite with $0.67 \mathrm{wt} \% \mathrm{SO}_{3}$ from a hydrous rhyolite melt would require a 
sulfur concentration of $413 \mathrm{ppm}$ in the surrounding melt and a partition coefficient of 6.5. At higher oxygen fugacities and temperatures, more sulfur should dissolve in any given melt. Therefore, it is more likely to produce high-S apatites under the conditions of the experiment of Parat and Holtz (2005) than at Pinatubo dacite pre-eruption conditions, which were cooler and less oxidized. This is not the case. Even the extreme conditions of the Parat and Holtz (2005) experiment could not produce high-S apatites through equilibrium apatite/melt partitioning. It must be the case that high-S apatites are grown under different conditions.

Low-S, groundmass apatites have an average of $0.13 \mathrm{wt} . \% \mathrm{SO}_{3}$ that corresponds to a melt concentration of $40 \mathrm{ppm}$ using a partition coefficient of 13. This corresponds well to the measured values of sulfur in melt inclusions and gives confidence in the value of the partition coefficient for Pinatubo dacite melt and apatites.

In Figure 38, high-S silicic apatites show three sulfur profiles: 1) rimward decrease in $\mathrm{SO}_{3}, 2$ ) rimward increase in $\mathrm{SO}_{3}$, and 3) oscillatory $\mathrm{SO}_{3}$. Apatites with type 1 profiles may be recording the transition from a sulfur-undersaturated environment to a sulfur-saturated environment with the onset of anhydrite crystallization. Greater partitioning of sulfur into anhydrite would prevent sulfur from entering apatite (Streck and Dilles, 1998; Parat et al., 2002). Also, decreased $\mathrm{SO}_{3}$ in apatite may be due to a decreasing $\mathrm{D}_{\mathrm{S}}^{\text {apatite/melt }}$, or apatite inheritance from a more mafic melt. An inherited apatite should have a high-S core and a low-S rim that reflect the transition in melt composition during magma mixing from a mafic to felsic. 
PH12C-1 Ap3
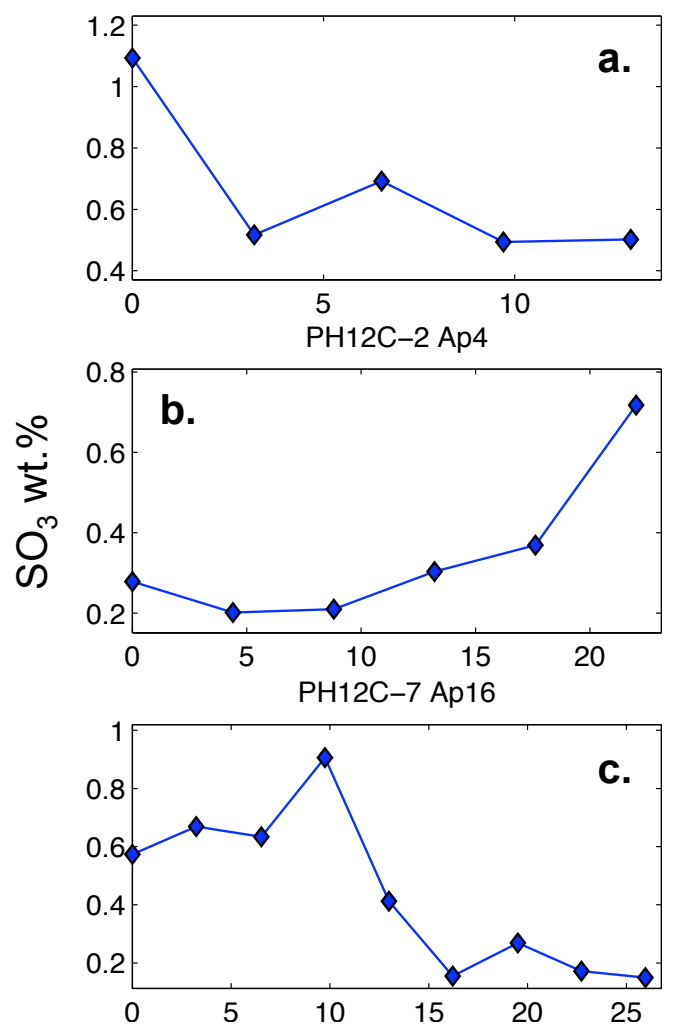

Distance from center to rim $(\mu \mathrm{m})$

Figure 38: Profiles of high-S silicic apatites. a) rimward decrease, b) rimward increase, and c) oscillatory. Such abrupt transitions between high- and low-S concentrations suggest that interactions of apatites between silicic and mafic magmas are not responsible for generating high$\mathrm{S}$ apatites.

Type 2 sulfur profiles suggest a possible decrease in temperature during ascent that raised the $\mathrm{D}_{\mathrm{S}}^{\text {apatie/melt }}$, but would also lower the sulfur solubility in the melt and thus the sulfur content. This scenario seems unlikely due to the rapid ascent of the dacite magma during the climactic eruption. There exists plenty of petrological evidence for the dacite reservoir being in equilibrium at $760 \pm 20^{\circ} \mathrm{C}$ prior to eruption, and having likely been at a similar temperature throughout Modern Pinatubo history (Newhall et al., 1996; Pallister et al., 1996; Scaillet and Evans, 1999). Another 
possible explanation for profile 2 is an increase in the oxygen fugacity of the melt would allow more $\mathrm{SO}_{3}$ to be dissolved in the melt and increase the sulfur content of the apatite, but it is difficult to say if the concomitant drop in $\mathrm{D}_{\mathrm{S}}^{\text {apatitemelt }}$ will affect the apatite $\mathrm{SO}_{3}$ concentration more or less (Parat and Holtz, 2004, 2005). It is also uncertain if increases in $f \mathrm{O}_{2}$ above $\sim \mathrm{NNO}+1$ will significantly affect the sulfur solubility in dacitic melts. Data from Clemente et al. (2004) show that at $2 \mathrm{kbar}$ and $800^{\circ} \mathrm{C}$, the concentration of sulfur in a rhyolitic melt decreases slightly from $373 \mathrm{ppm}$ to $281 \mathrm{ppm}$ when $f \mathrm{O}_{2}$ increases from $\mathrm{NNO}+1$ to $\mathrm{NNO}+1.8$. Other experimental runs under these conditions showed no significant increase in sulfur content in the melt with increasing $f \mathrm{O}_{2}$. It has been argued by Imai et al. (1993) that the dacitic reservoir beneath Pinatubo was already oxidized and volatile-rich prior to phenocryst crystallization.

Rimward increase in sulfur was often observed in apatites hosted in anhydrite. It is quite possible that increasing sulfur concentrations could simply reflect sulfur from anhydrite. The electron beam near the rim of the crystal could have generated an excitation volume that included some of the host anhydrite, thereby increasing the observed sulfur content. Assuming no contamination from anhydrite, the increase in sulfur could also mean that a diffusion profile exists between anhydrite and apatite. Sulfur element maps of apatites hosted in or near anhydrite (Figs. 39a, b, d, and e) show that this is not the case. Sulfur distribution is very complex and not isolated to the rims of apatite grains. Higher sulfur contents are generally localized in discrete globular blobs near-center of the grain, sometimes surrounded by sulfur-rich halos 
(Fig. 39b and e). Even sulfur-rich apatites not hosted in anhydrite display similar sulfur distributions (Fig. 39c).

Type 3 sulfur profiles display rapid changes in the $\mathrm{SO}_{3}$ concentration. To achieve such a profile, sulfur as $\mathrm{S}^{6+}$ would have to diffuse quickly in the melt to reach an apatite in order for the change in surrounding sulfur to be recorded in the apatite. Such rapid diffusion of sulfur in a dacitic melt is kinetically impossible. The most mobile sulfur species is $\mathrm{S}^{2-}$, which does not partition into apatite (Baker and Rutherford, 1996b; Freda et al., 2005). Such strongly oscillating sulfur profiles suggest that the interaction between apatite, melt, and sulfur is complicated and not restricted to simple melt/apatite equilibrium partitioning. Kinetic effects during growth or heterogeneities in the melt could possibly generate oscillatory profile (Baker and Rutherford, 1996a). The oscillation may represent multiple regions and periods of sulfur enrichment prior to or during anhydrite saturation in the dacite. The apatites in Figure $39 \mathrm{~b}$ and e have two high-S cores that may have originally been two separate apatites that grew together. The two spots could represent one period of sulfur enrichment and the halo surrounding them could represent a second enrichment period. 

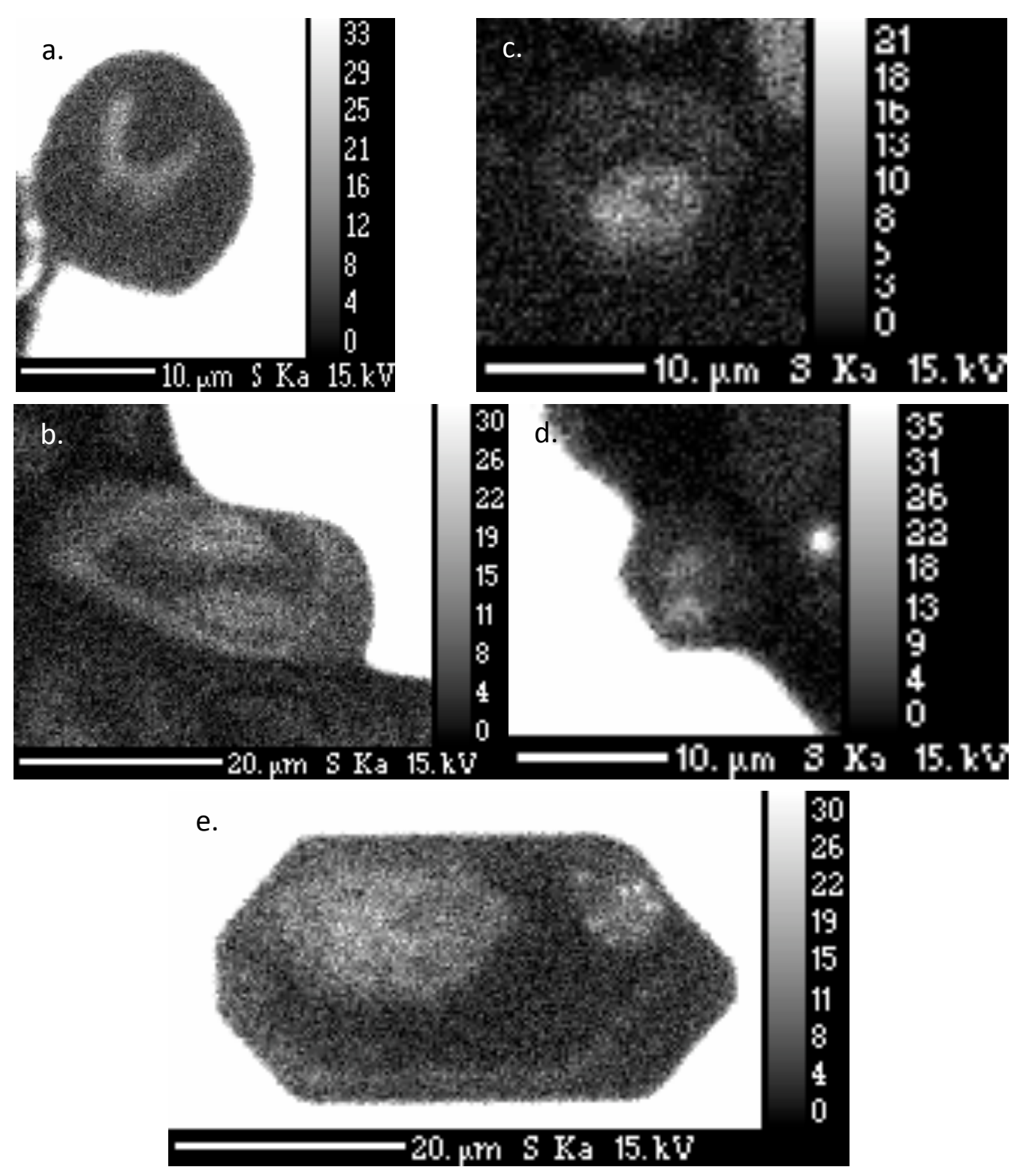

Figure 39: Sulfur distributions in apatites fully or partially hosted by anhydrite (a, b, d, e) do not show diffusion profiles from the contact between apatite and anhydrite. The distribution of sulfur is very complex and suggests multiple periods of sulfur-enrichment during apatite growth prior to anhydrite saturation. Apatites with multiple high-S cores may have originally been multiple crystals that grew together. Apatites hosted in Fe-Ti oxides (c.) show similar sulfur distributions. 


\section{Trace Element Concentrations in Apatite}

Apatites have long been recognized for the ability to control the majority of the whole-rock REE budget (Watson and Capobianco, 1981). REE and trace element fractionation into apatite is generally governed by Henry's Law behavior (with some exceptions, e.g. Gd), such that the activity and concentration of an infinitely dilute species are linearly related to the concentration of the species multiplied by Henry's Law constant (Pan et al., 2003). REE concentrations of apatite reflect the degree of fractionation and oxidation state of the magma from which they grew (Belousova et al., 2002). As such, the slope of REE patterns when normalized to $\mathrm{C} 1$ chondrite varies systematically from ultramafic to mafic/intermediate and to fractionated granitoids (Belousova et al., 2002). Apatites from different rock groups can be distinguished by Sr, Y, Mn, total REE, degree of LREE enrichment, and size of Eu/Eu* (Puchelt and Emmermann, 1976; Sha and Chappell, 1999; Belousova et al., 2002). The $\Sigma$ REE in apatite from metamorphic rocks were shown to be much lower than that in apatite from igneous rocks (Puchelt and Emmermann, 1976). They are also an excellent indicator of granite petrogenesis (Sha and Chappell, 1999).

Magma mixing and differentiation are also recorded in apatite REE concentrations, and show that these dynamic processes must occur within very short timescales (days to years) to be reflected in very strongly zoned apatites (e.g. intracrystalline La concentrations ranging from $100 \mathrm{ppm}$ to $300 \mathrm{ppm}$ ) (Tepper and Kuehner, 1999; Dempster et al., 2003; Humphreys et al., 2006; Macdonald et al., 2008; Boyce and Hervig, 2009). This zonation is observed via back-scattered electron 
and cathodluminescence images (Tepper and Kuehner, 1999; Dempster et al., 2003). Dempster et al. (2003) presented data on the Shap Granite apatites, many of which show evidence of inheritance from other magmas. Cores of these apatites have drastically different chemistries, and were brought into the chamber early while there was still vigorous mixing. For example, one apatite had La concentrations of $\sim 1000$ ppm at the core and $\sim 750 \mathrm{ppm}$ at the rim.

Apatites can tell many things about the melt from which they grew. Therefore, we can use this information to determine if high-S apatites found in the dacitic pumice are inherited from the basalt intrusion. Examining the results of REE concentrations of Pinatubo apatites, it was determined that two distinct populations exist: silicic apatites and basalt apatites (Fig. 40). REE profiles from both silicic and basalt apatites have the typical enrichment in LREE over HREE (Puchelt and Emmermann, 1979; Roeder et al., 1987; Hughes et al., 1991) and similar REE slopes, which means that both came from melts that were LREE enriched (Watson and Green, 1981). However, there are two fundamental differences between silicic and basalt apatite REE profiles: 1) silicic apatites have higher concentrations of REE, and 2) silicic apatites have a strong negative Europium anomaly (Fig. 40). These results are consistent with previous studies (Puchelt and Emmermann, 1976; Watson and Green, 1981; Sha and Chappell, 1999; Tepper and Kuehner, 1999; Belousova et al., 2002; Broderick, 2008).

Apatites from more fractionated, enriched melts have higher REE concentrations. Increased REE concentrations may also be explained by larger REE partition coefficients in more felsic melts (Watson and Green, 1981). A Eu/Eu*<1 in 
apatite can be generated when the surrounding melt in which it grows is more differentiated and has experienced significant feldspar crystallization, or when the ratio of $\mathrm{Eu}^{2+} / \mathrm{Eu}^{3+}$ is high in the melt. Eu behaves compatibly in feldspars, but $\mathrm{Eu}^{2+}$ is preferred as a substitute for $\mathrm{Ca}^{2+}, \mathrm{Sr}^{2+}$, and $\mathrm{Na}^{+}$. Apatites prefer $\mathrm{Eu}^{3+}$ as a substitute for $\mathrm{Ca}^{2+}$ in both $\mathrm{M}$ sites (Fig. 18). Pinatubo apatites obtain $\mathrm{Eu} / \mathrm{Eu}^{*}$ directly from the surrounding melt, which is why basalt and silicic apatites have $\mathrm{Eu} / \mathrm{Eu} * \geq 1$ and $\mathrm{Eu} / \mathrm{Eu}^{*}<1$, respectively. Sha and Chappell (1999) showed that S-type and felsic I-type (S-sedimentary, I-igneous) granitic magmas are more reduced and peraluminous than mafic I-type magmas, and therefore, have higher $\mathrm{Eu}^{2+} / \mathrm{Eu}^{3+}$ ratios and more negative Eu anomalies. This may only have a minor effect on Pinatubo apatites.

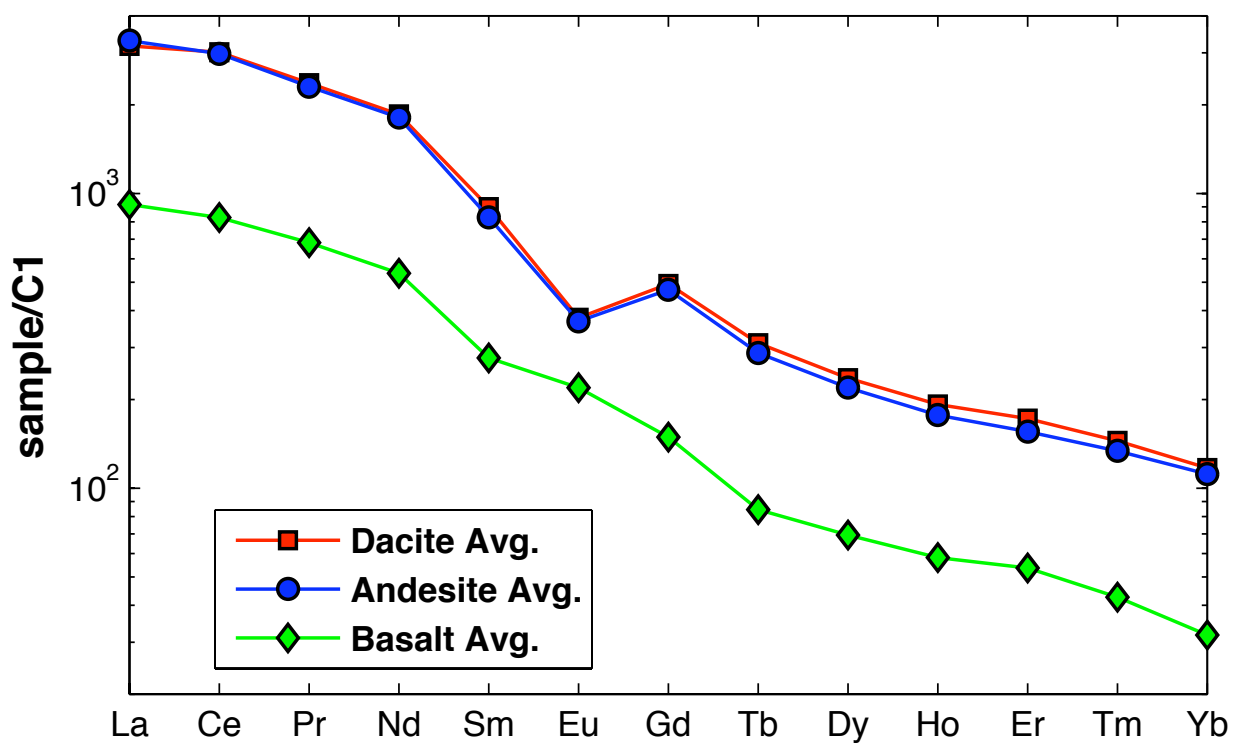

Figure 40: The average REE patterns for silicic and basalt apatites are very different. If high-S apatites were inherited from the basalt, then they should exhibit REE patterns closer to basalt apatites. Instead, the REE patterns for silicic apatites reflect a more differentiated melt environment. 
$\mathrm{Sr}$ is also a good indicator of melt environment for apatites. The partitioning of Sr follows Henry's Law behavior (Pan et al., 2003) and is not dependent upon melt composition or temperature (Watson and Green, 1981; Pan et al., 2003). Therefore, Sr concentration in an apatite is a direct reflection of the Sr concentration of the surrounding melt. More mafic melts will have higher Sr concentrations, and more felsic melts will have lower Sr concentrations due to the compatible nature of Sr. If high-S apatites are inherited from the basalt, the Sr concentrations of these apatites should be elevated compared to other silicic apatites. In Figure 41, silicic apatites display much lower Sr concentrations than basaltic apatites and much higher La concentrations. There is no group of silicic apatites with high-S that plot with basalt apatites. There is one dacite apatite with a $\mathrm{Sr}$ concentration of $\sim 1250 \mathrm{ppm}$. This apatite is low-S and hosted in anhydrite. It is likely that this elevated Sr concentration may be a result of contamination.

Previous studies showed intracrystalline diffusion of elements that do not require coupled substitutions (e.g. Sr, $\mathrm{Mn}, \mathrm{Fe}$ ) proceed much faster than others that do (e.g. REE), and LREE diffusion will proceed more rapidly than $\Sigma$ REE (Tepper and Kuehner, 1999). Homogenous intracrystalline Sr concentrations and chondrite normalized La/Sm ratios may indicate diffusion of these elements and not the original concentration at crystallization. Assuming that high-S dacite apatites have cores inherited from the basalt and rims that are in equilibrium with the dacite, if intracrystalline diffusion of Sr had taken place in these crystals, then these apatites would have an intermediate Sr concentration between basalt apatites and low-S, 
homogenous silicic apatites. There is no such group in Figure 41. Basalt apatites and silicic apatites are grouped fairly tight with respect to $\mathrm{Sr}$ and La with some scatter. This means either 1) intracrystalline diffusion is not occurring, or 2) there are no silicic apatites with cores inherited from the basalt. Since there are no high-S, silicic apatites with high $\mathrm{Sr}$ concentrations, scenario 2) is more likely the case.

Overall, the evidence from the REE patterns and $\mathrm{Sr}$ concentrations suggest that apatites found in the dacite grew in a dacite melt, regardless of sulfur concentration. The same can be said of basalt apatites.

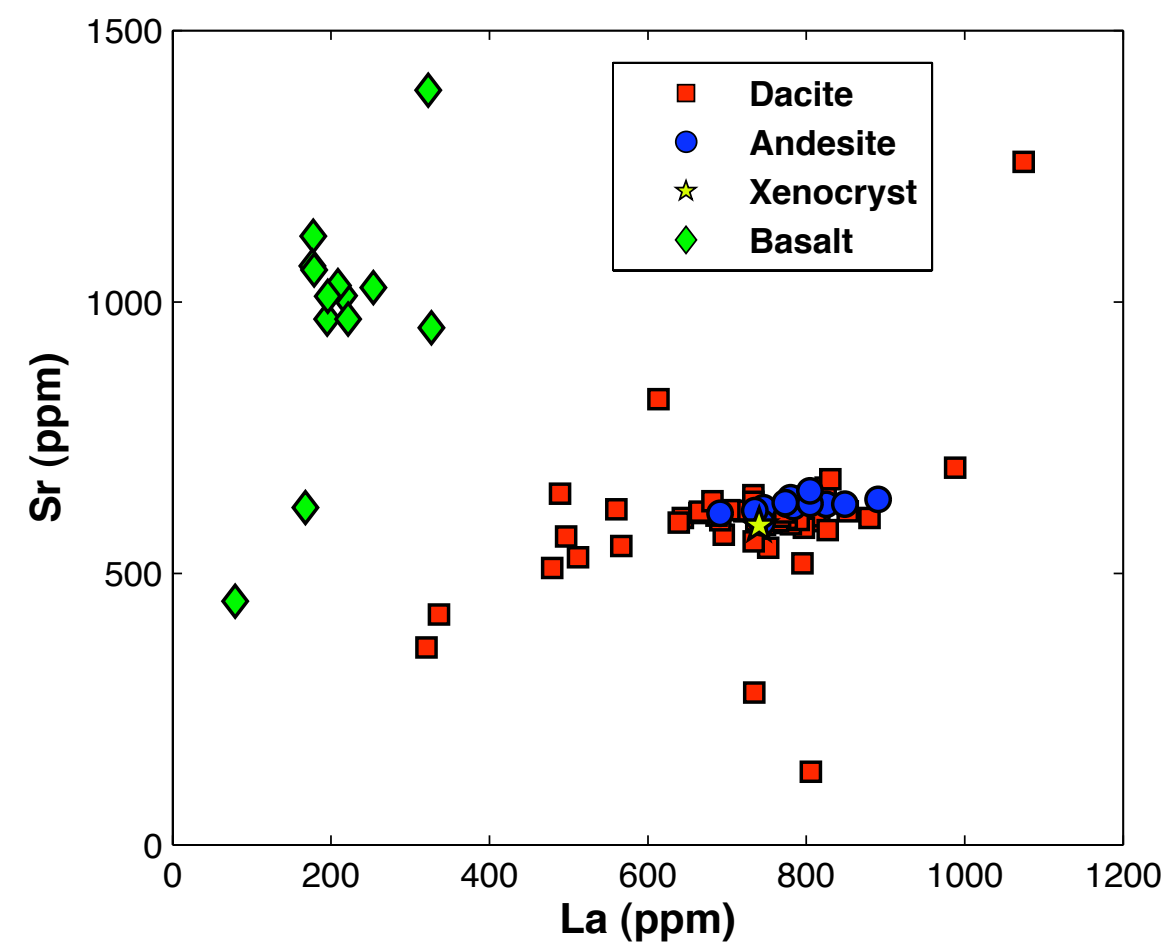

Figure 41: Silicic apatites plot nowhere near the Sr vs. La field of basalt apatites. These data suggest that silicic apatites, regardless of sulfur concentration, did not grow in the basalt. One dacite apatite has a $\mathrm{Sr}$ concentration of $\sim 1250 \mathrm{ppm}$. This is a low-S apatite and the high $\mathrm{Sr}$ concentration is likely due to contamination from the host. 


\section{Melt Environment of High-S vs. Low-S Apatites}

Major and trace element concentrations of apatites have shown that silicic apatites and basalt apatites are distinct populations and come from different melt environments. High-S, silicic apatites show no difference in chemistry from other silicic apatites except sulfur. Additionally, silicic apatites and basalt apatites have very different morphologies. Basalt apatites are skeletal and often acicular, indicating: 1) rapid growth from quenching (Gardner et al., 1972), and 2) that apatite saturation in the basalt is only achieved at high degrees of crystallinity during quenching. Silicic apatites are euhedral to subhedral with no textural evidence of quenching (Fig. 42). These results are consistent with the findings of high-S apatites from the San Juan Central Caldera Complex (Broderick, 2008; Parat et al., 2002). The origin of these high-S apatites must be of means other than inheritance or S-diffusion from anhydrite.
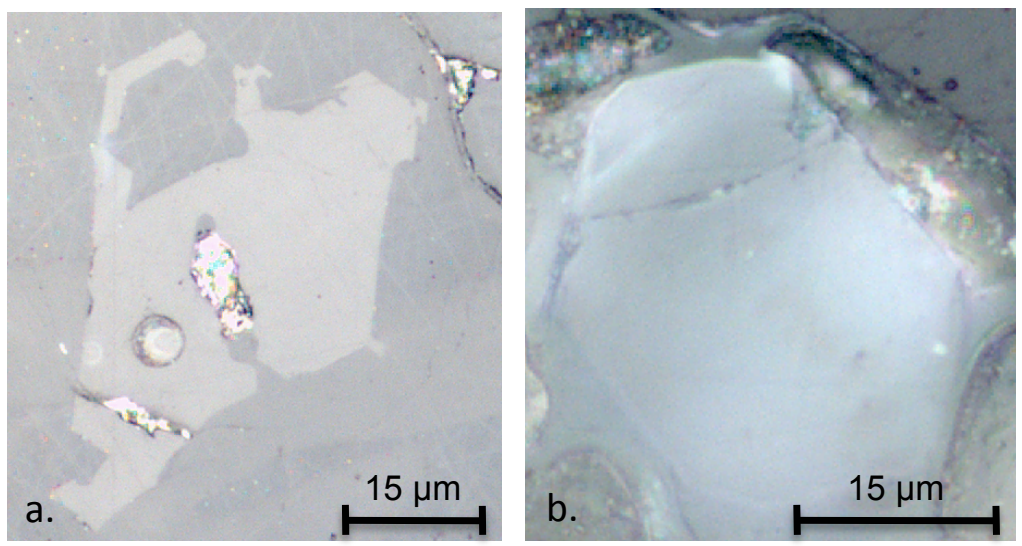

Figure 42: Reflected light petrographic images of a) skeletal basalt apatite and b) euhedral dacite apatite. These apatites exhibit very different morphologies. 
Inheritance of high-S apatite cores from the basalt was not shown to have occurred in this study of 1991 Pinatubo apatites. However, that doesn't mean that inheritance of dacite apatites in the basalt didn't occur. Figure 43 further examines the scenario of the xenocrystic apatite hosted in a xenocrystic hornblende found in the basalt. $\mathrm{SO}_{3}$ in this apatite ranges from $\sim 0.1$ to $\sim 0.3 \mathrm{wt}$. $\%$, values much lower than the high-S content of basalt apatites, which are generally greater than $1 \mathrm{wt} . \%$. The REE pattern of the xenocrystic apatite also matches patterns of silicic apatites by having elevated REE concentrations relative to basalt apatites and a distinct negative $\mathrm{Eu} / \mathrm{Eu}$ * The REE pattern of the hosting xenocrystic hornblende also matches the pattern of hornblendes from a more silicic source. Furthermore, there are clear disequilibria textures, including a resorption rim on the hornblende host and a reaction rim around a nearby quartz xenocryst. This example shows that our approach to tracking original apatite melt using major and trace element chemistry is valid.

If we examine an apatite (PH12C-7 Ap16) that has strong changes in $\mathrm{SO}_{3}$ more closely by comparing the $\mathrm{SO}_{3}$ content with corresponding REE patterns (Fig. 44), we see that there is no significant difference in the REE patterns between laser spots that overlap high-S zones, and laser spots that overlap low-S zones. There is no evidence for an inherited high-S core. Such abrupt changes in $\mathrm{SO}_{3}$ within this and many other apatites do not suggest interaction with silicic and basaltic melts. PH12C-7 Ap16 is hosted in an Fe-Ti oxide, so there is no possibility that the high-S concentration near the center $\left(\sim 0.9\right.$ wt. $\left.\% \mathrm{SO}_{3}\right)$ is an artifact of interaction volume including anhydrite. 
Furthermore, low-S apatites and high-S apatites from the dacite and andesite melts do not show any significant difference in REE patterns, Sm, or Eu/Eu* (Figs. 45 and 46), and there is no correlation between $\mathrm{Sr}$ and sulfur concentration (Fig. 47). As discussed, $\mathrm{Sr}$ and $\mathrm{Eu} / \mathrm{Eu}$ * are indicators of degrees of magma differentiation, and any correlation of these with $\mathrm{SO}_{3}$ would suggest that the sulfur content of the apatite is controlled by the degree of differentiation of the surrounding melt. Figure 48 shows no correlation among the silicic apatites between $\mathrm{SO}_{3}, \mathrm{Sr}, \mathrm{Eu} / \mathrm{Eu}^{*}$. These apatites are clustered very tightly with respect to $\mathrm{Sr}$ and $\mathrm{Eu} / \mathrm{Eu}^{*}$, away from the distinct region of basalt apatites, regardless of $\mathrm{SO}_{3}$ being high or low. 

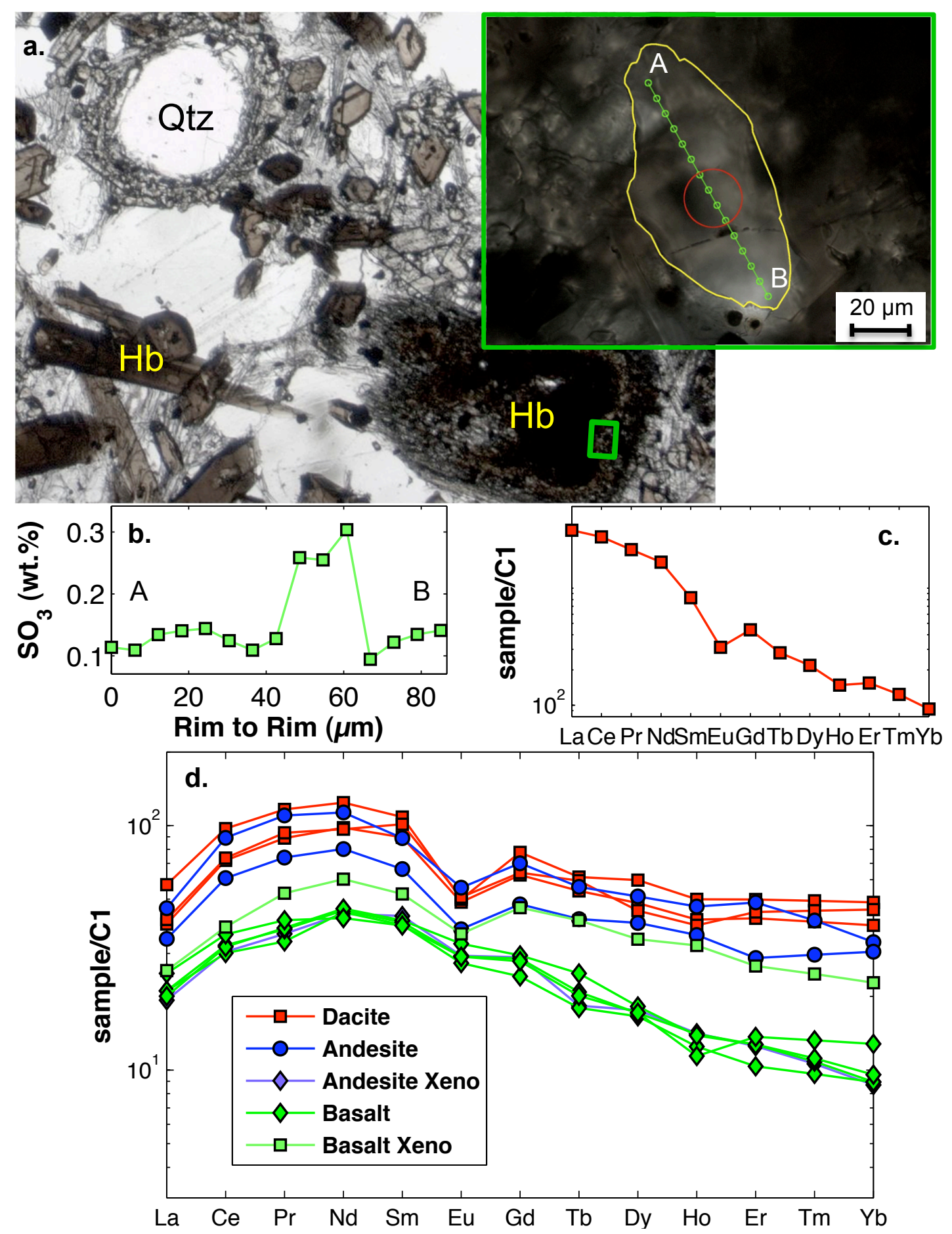

Figure 43: The xenocrystic apatite, P-22892-2a Ap1, is located as an inclusion in a xenocrystic hornblende with strong disequilibria textures (a). Sulfur concentrations (b) and REE pattern (c) of this apatite match more closely to silicic apatite. REE patterns of hornblende from each juvenile component show that the xenocrystic hornblende also originated from the dacite (d). 

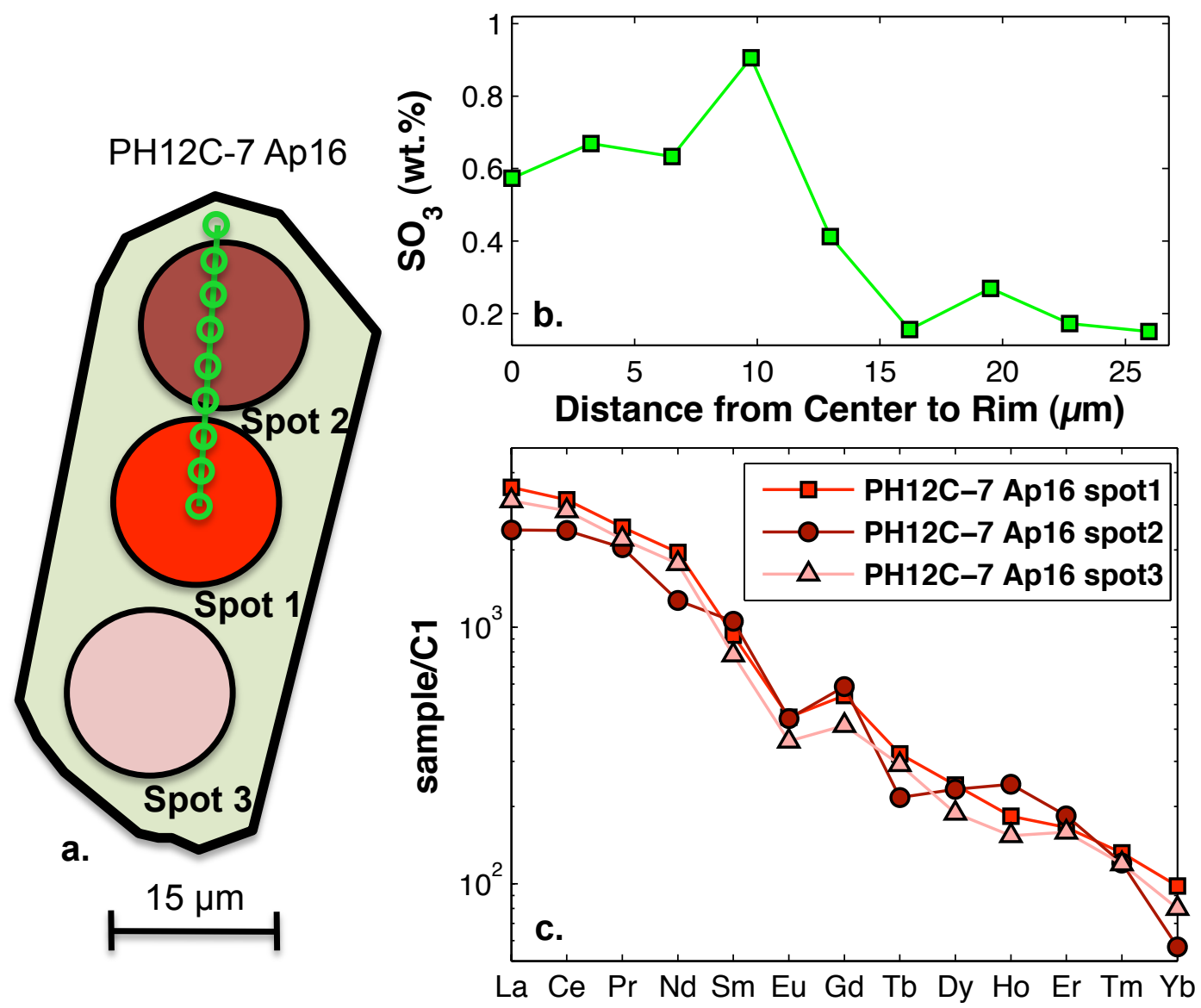

Figure 44: REE patterns from multiple laser spots in an apatite (PH12C-7 Ap16) with $\mathrm{SO}_{3}$ concentrations ranging from $\sim 0.1$ to $\sim 0.9 \mathrm{wt} \% \%$ show no significant difference. The high-S core does not show an REE pattern that would suggest inheritance from the basalt. The melt environment of this apatite did not change during growth other than the amount sulfate available for exchange. 


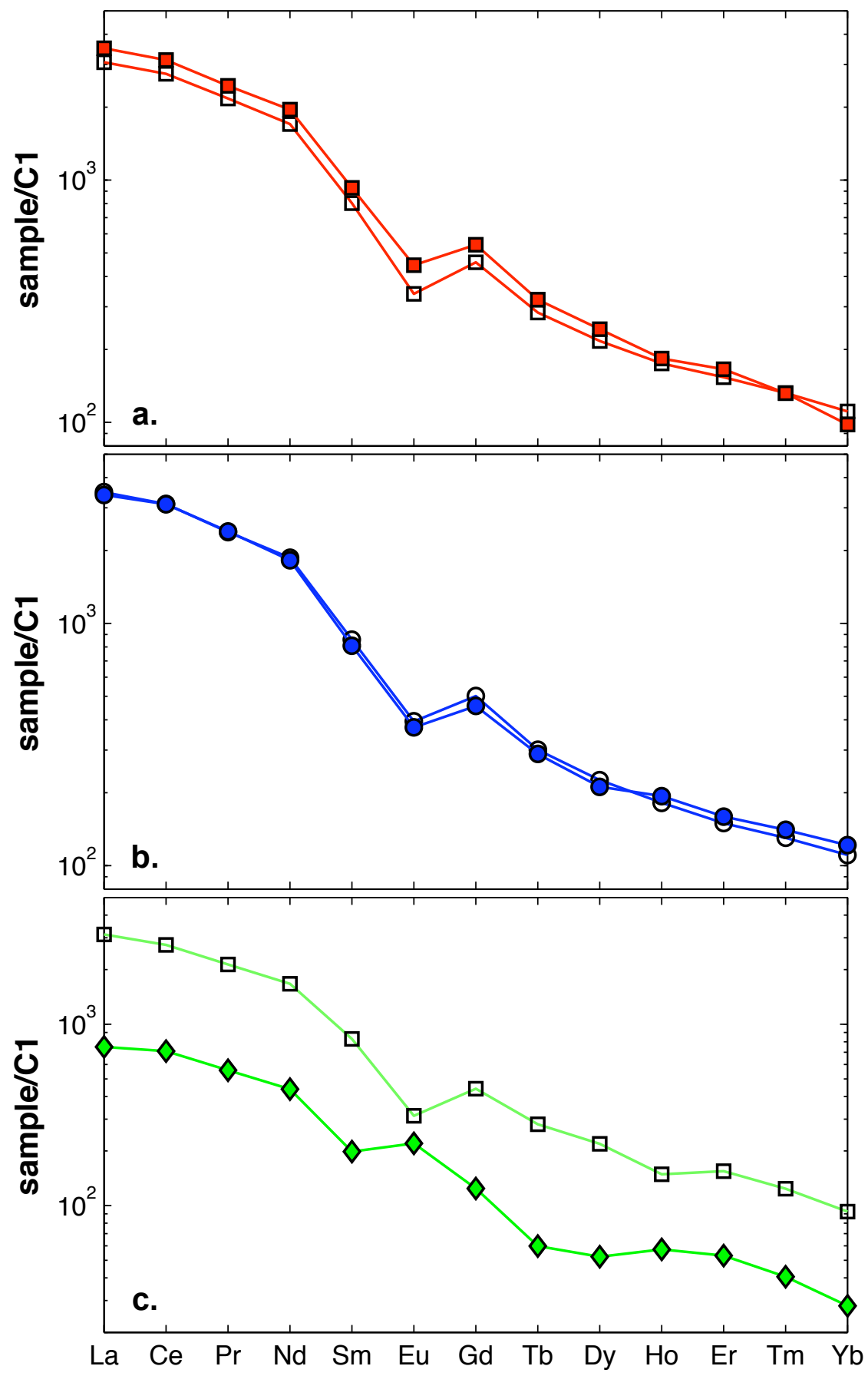

Figure 45: Comparison of REE patterns between high-S apatites (filled symbols) and low-S apatites (empty symbols) for apatites from each juvenile component. REE patterns do not vary significantly for dacite (a) and andesite (b) apatites and suggest that they grew in the same melt. The difference in REE patterns for the basalt apatites reflects that the only low-S apatite in the basalt was xenocrystic (Fig. 43). 

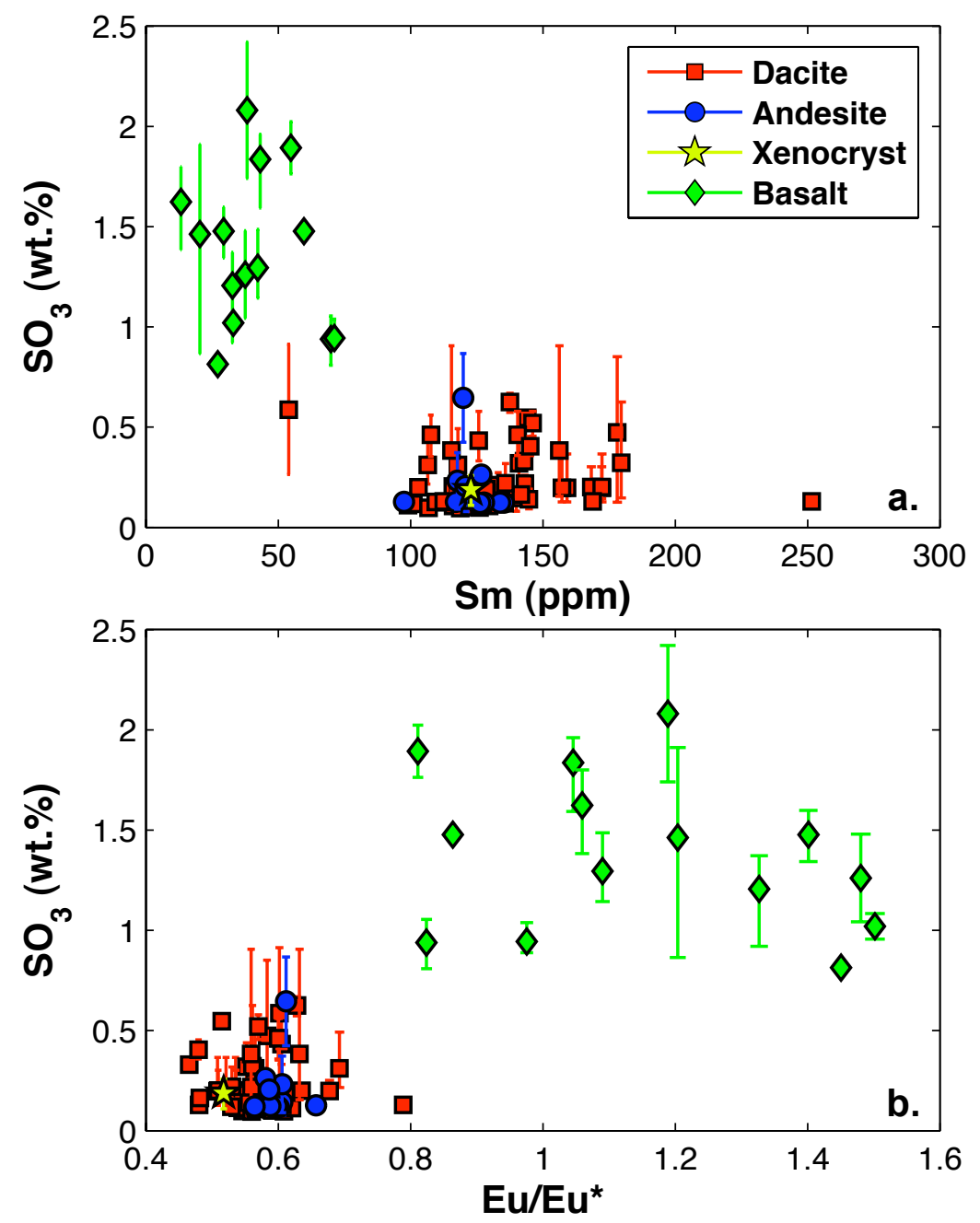

Figure 46: Silicic apatites do not plot with basalt apatites based upon $\mathrm{Sm}(\mathrm{a})$ and $\mathbf{E u} / \mathbf{E u}$ (b), regardless of sulfur concentrations. This shows that high-S silicic apatites grew in a more differentiated melt. The "error bars" represent the minimum and maximum $\mathrm{SO}_{3}$ concentrations measured by EMP that was overlapped by the laser spot. 

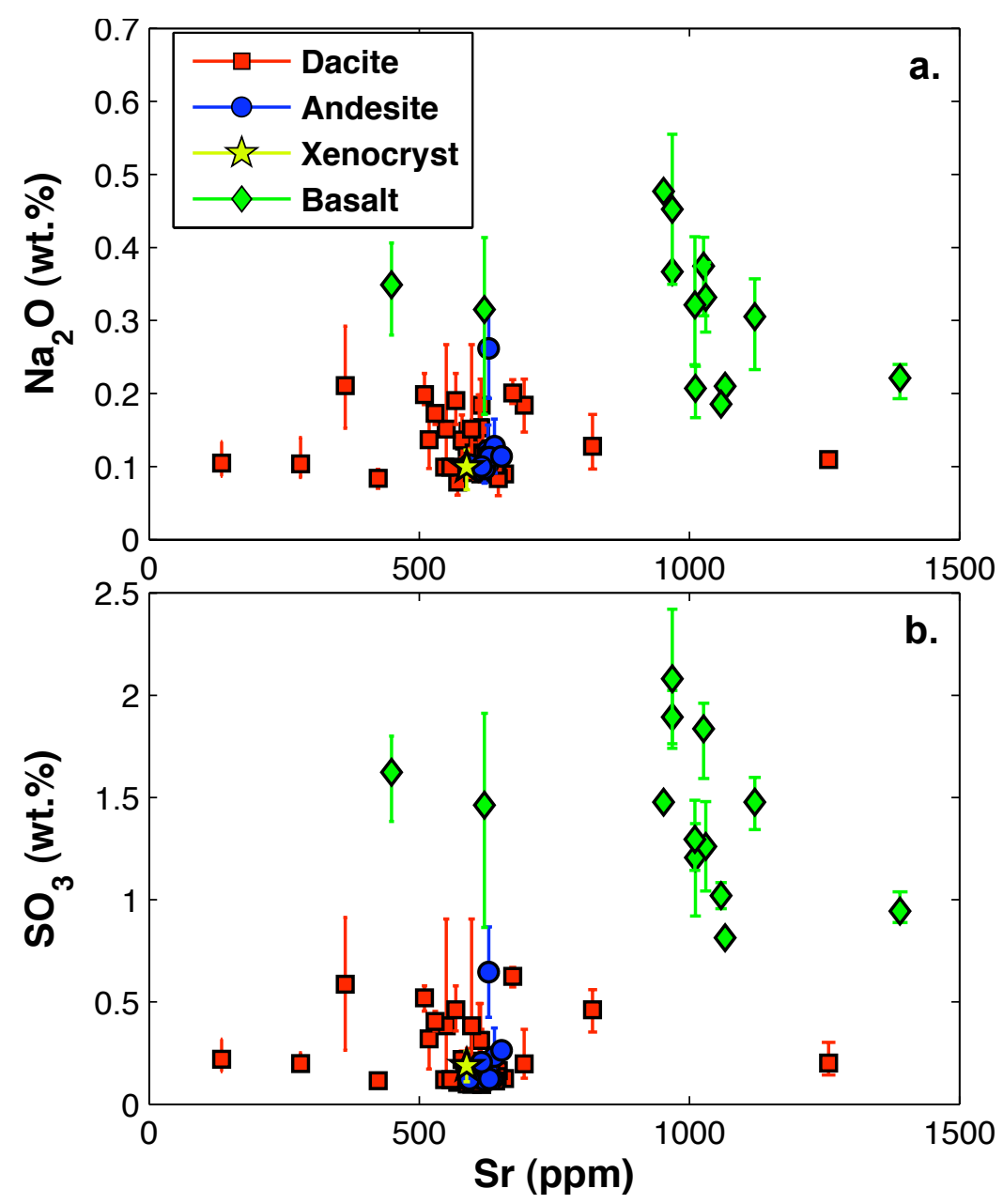

Figure 47: Sr concentrations represent the level of differentiation of the melt hosting silicic and basalt apatites. $\mathrm{Sr}$ concentrations vary among groups without correlation to $\mathrm{SO}_{3}$ or $\mathrm{Na}_{2} \mathrm{O}$. In fact, some of the most sulfur-rich silicic apatites have the lowest $\mathrm{Sr}$ concentrations. The "error bars" represent the minimum and maximum $\mathrm{SO}_{3}$ and $\mathrm{Na}_{2} \mathrm{O}$ concentrations measured by EMP that was overlapped by the laser spot. 


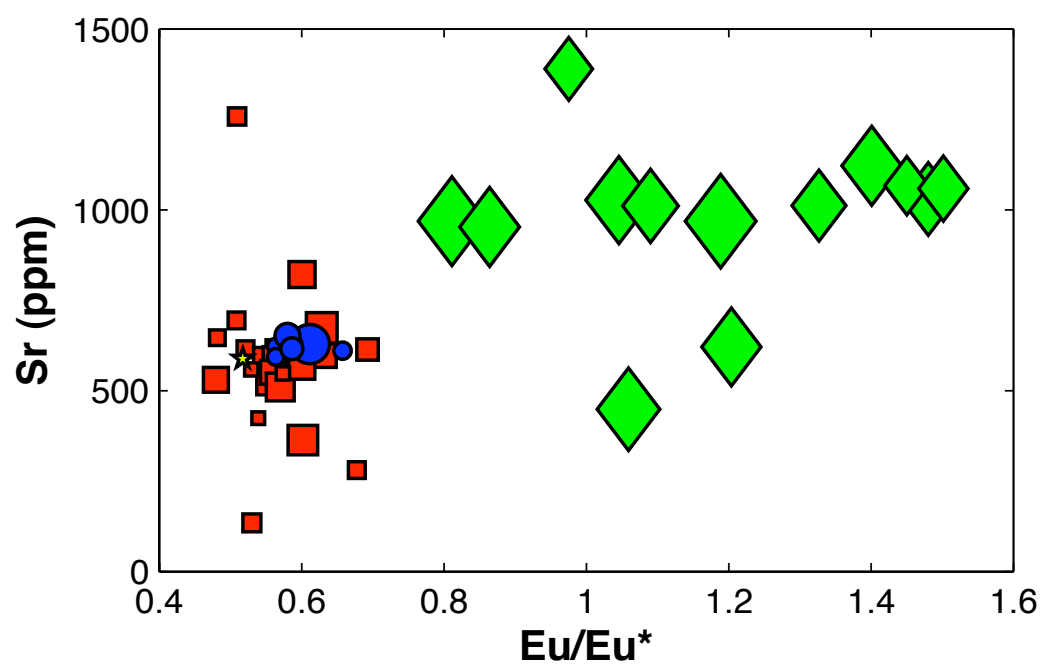

Figure 48: Basalt apatites have $\mathrm{Sr}$ concentrations and $\mathrm{Eu} / \mathrm{Eu}$ * that reflect a less differentiated melt. If high-S silicic apatites were inherited from the basalt, they would plot closer to this field. However, silicic apatites are tightly grouped in a field indicating a more differentiated melt. The size of the data markers is directly correlated to the average $\mathrm{SO}_{3}$ of the apatites. Low-, medium-, and high-S silicic apatites plot in the same field, and therefore, grew in the same melt.

\section{Fluid-Enhanced Crystallization}

Thus far, we have examined three scenarios for generating high-S silicic apatites: equilibrium partitioning, S-diffusion from anhydrite, and mafic inheritance. Each of these mechanisms has failed to explain how these apatites are obtaining such high sulfur concentrations. One remaining scenario to consider is the presence of a sulfur-rich fluid phase as a source for the excess sulfur needed to grow high-S apatites.

Gerlach et al. (1996) studied the S and $\mathrm{Cl}$ content of melt inclusions and matrix glass using EMP and found that there was no significant difference in $\mathrm{S}$ and $\mathrm{Cl}$ concentrations between the two types of glass. From this, they concluded that there was no significant degassing of $\mathrm{S}$ or $\mathrm{Cl}$ from the melt during ascent and eruption. 20 million tons of $\mathrm{SO}_{2}$ was injected into the stratosphere during the 1991 Pinatubo 
eruption, 17 million tons during the climactic event. This amount of $\mathrm{SO}_{2}$ is one order of magnitude higher than the amount of sulfur that could have been dissolved in the 5 $\mathrm{km}^{3}$ DRE of melt erupted at the pre-eruption conditions. In order to account for the "excess" sulfur ejected into the atmosphere, an additional source of sulfur is required. Many previous studies, including ones about Pinatubo, have concluded that the likely source of sulfur is a sulfur-rich fluid phase that has significantly accumulated over time within the magma reservoir from injections of underplating basaltic magmas (Luhr et al., 1984; Matthews et al., 1992; Pallister et al., 1992; Westrich and Gerlach, 1992; Wallace and Gerlach, 1994; Gerlach et al., 1996; Pasteris et al., 1996; Kress, 1997; Scaillet et al., 1998; Keppler, 1999; Parat et al., 2002; Broderick, 2008; Chambefort et al., 2008).

Volcanic eruptions that have recorded "excess" sulfur input into the stratosphere commonly have anhydrite as a primary igneous phase, such as the 1982 El Chichón and 1991 Mount Pinatubo eruptions (Luhr et al., 1984; Bernard et al., 1991, 1996; Pallister et al., 1992, 1995, 1996; Hattori, 1993, 1996; Gerlach et al., 1996; Fournelle et al., 1996; Pasteris et al., 1996). Conditions for generating anhydrite-saturated eruptions (Fig. 49) include: high water content (5-6 wt.\%), waterbearing phenocryst phases (e.g., hornblende and biotite), high $f \mathrm{O}_{2}$, and fluid-saturated at 7-9 $\mathrm{km}$ depth (Luhr, 2008). The timing of anhydrite saturation and its close association with apatite is important when considering the melt conditions for crystallizing high-S silicic apatite because anhydrite will become the dominate sulfur phase at sulfur saturation. 


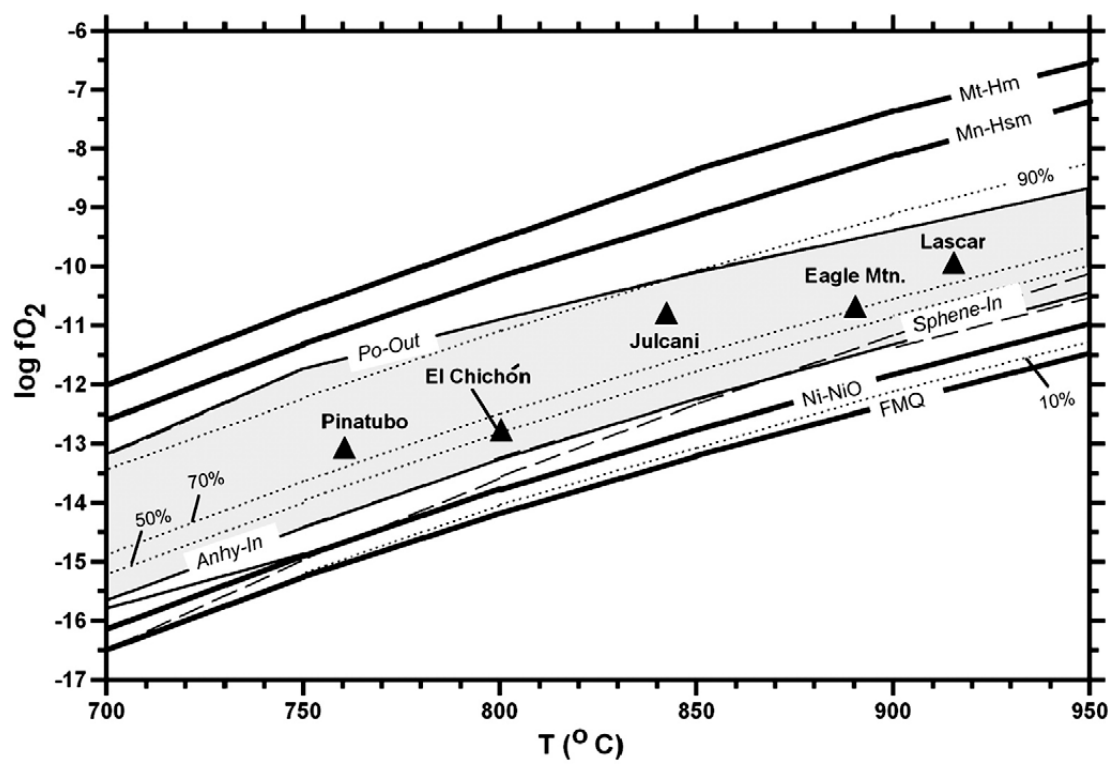

Figure 49: Temperature and oxygen fugacity field for anhydrite-bearing eruptions, including the 1991 Pinatubo eruption. The presence of anhydrite can have a significant effect on the sulfur partitioning between apatite, melt, and sulfur-rich fluid. The dotted lines at $10 \%, 50 \%, 70 \%$, and $90 \%$ represent the amount of sulfur dissolved as $S^{6+}$ (after Luhr, 2008).

I propose the following model for the generation of high-S apatites in the 1991 Pinatubo dacite:

1) $\mathrm{SO}_{2}$ from the hot $\left(\sim 1200^{\circ} \mathrm{C}\right)$ basaltic intrusion was reduced when it came into contact with the cool $\left(\sim 780^{\circ} \mathrm{C}\right)$, water-rich dacite magma reservoir approximately $8-9 \mathrm{~km}$ below the surface (Matthews et al., 1992; Hattori, 1993, 1996; Pallister et al., 1996). The $\mathrm{SO}_{2}$ was reduced to $\mathrm{H}_{2} \mathrm{~S}$ and oxidized the dacite and added more sulfur to the melt (Fig. 50) (Hattori, 1993, 1996).

2) Minor amounts of sulfides, including pyrrhotite, were deposited from a separate fluid phase, as indicated by globular inclusions in oxides, plagioclase, and hornblende (Fig. 51) (Hattori, 1993, 1996). 
This likely happened when the sulfur saturation curve reached the minimum at $\sim \mathrm{NNO}+0.6$ (Hattori, 1996).

3) Prior to or concurrent with anhydrite crystallization, earlycrystallizing apatites hosted in other phenocryst phases (e.g., plagioclase, hornblende, and Fe-Ti oxide) acquired medium- and high-S concentrations from the surrounding melt and sulfur-rich fluid phase. It has been speculated that apatite could have precipitated directly from the fluid phase via "magmatic vapor deposition" (Jakubowski et al., 2002), which could account for the high-S and abrupt intracrystalline transitions from high- to low-S. Lack of anhydrite inclusions in plagioclase and quartz phenocrysts suggests that anhydrite saturation occurred later in the crystallization of the dacite magma after fluid saturation, which allowed sulfur to be partitioned into apatite (Pasteris et al., 1996).

4) Anhydrite saturation was reached in the dacite at $\mathrm{NNO}+1-1.5$ (Carroll and Rutherford, 1987; Luhr, 1990), and at depth based upon evidence of anhydrite inclusions in deep-forming phenocrysts of hornblende (Fournelle et al., 1996; this study). The relatively constant sulfur concentration among different glass inclusions from Rutherford and Devine (1996) suggests that the melt was at anhydrite saturation prior to eruption (Pasteris et al., 1996). 
5) Pyrrhotite and other sulfide phases became unstable but were still present at $\mathrm{NNO}+1.7$, the pre-eruption oxygen fugacity of the dacite magma (Scaillet and Evans, 1999). Vapor deposition of small pyramids of anhydrite on pre-existing anhydrite phenocryst faces occurred during this time, pulling sulfur away from late-forming apatite microphenocrysts (Jakubowski et al., 2002). Sulfur concentration for these groundmass apatites achieved equilibrium with the surrounding melt prior to eruption. 


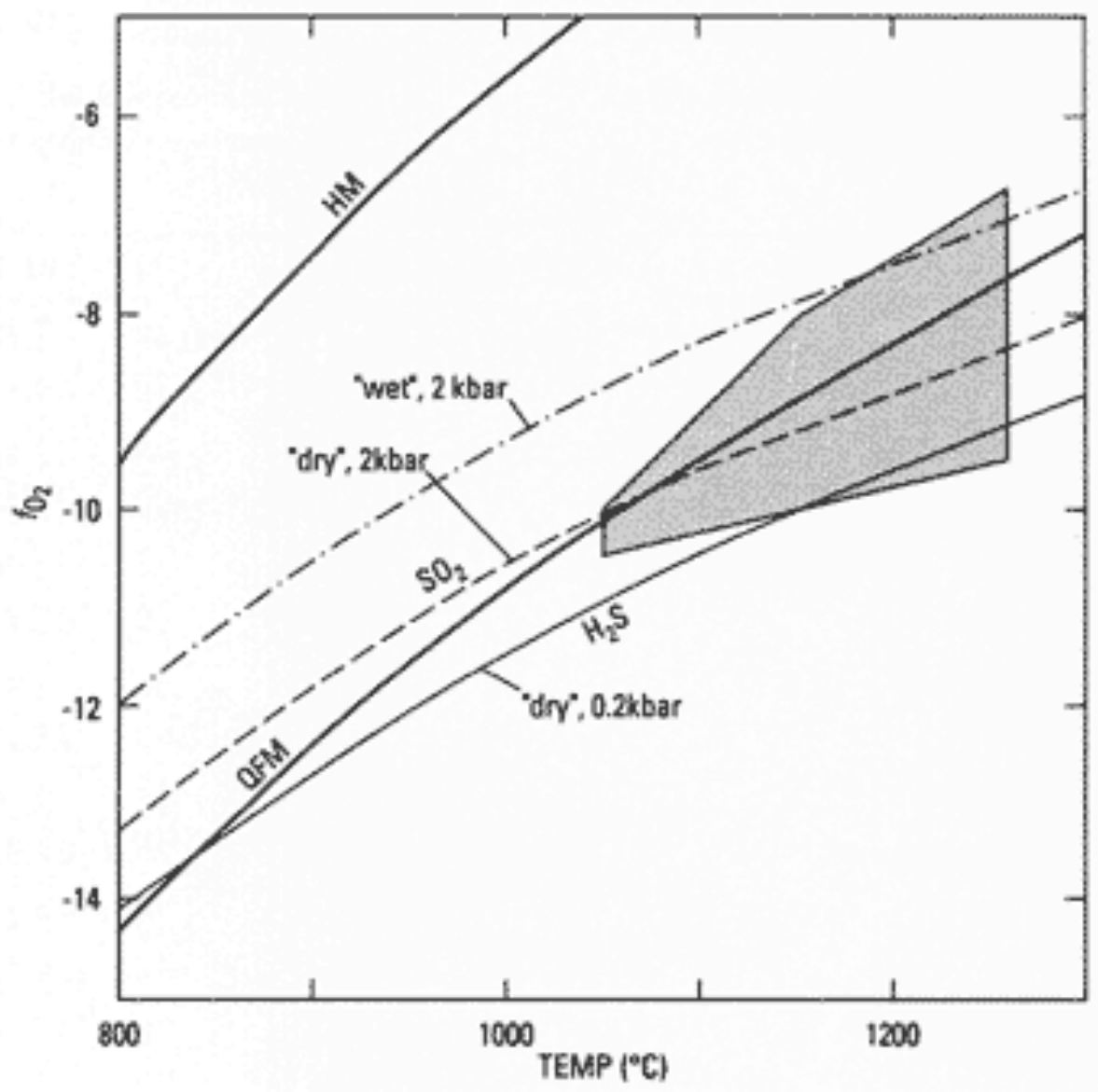

Figure 50: Curves of equal concentrations of $\mathrm{SO}_{2}$ and $\mathrm{H}_{2} \mathrm{~S}$ under "dry" $\left(\mathrm{XH}_{2} \mathrm{O}=0.001, \mathrm{X}=\right.$ volume ratio) and "wet" $\left(\mathrm{XH}_{2} \mathrm{O}=1\right)$ conditions. Shaded region is the field of fluids from basalt melts. When water is introduced and temperature and $\mathrm{fO}_{2}$ is held constant, the ratio of $\mathrm{SO}_{2} / \mathrm{H}_{2} \mathrm{~S}$ in the fluid drops. To reach a ratio of $\mathrm{SO}_{2} / \mathrm{H}_{2} \mathrm{~S}=1, \mathrm{fO}_{2}$ must increase. When S-rich fluids from a hot, "dry" basalt are introduced into a "wet", cool dacite the $\mathrm{SO}_{2} / \mathrm{H}_{2} \mathrm{~S}$ ratio must consequently drop (after Hattori, 1996). 


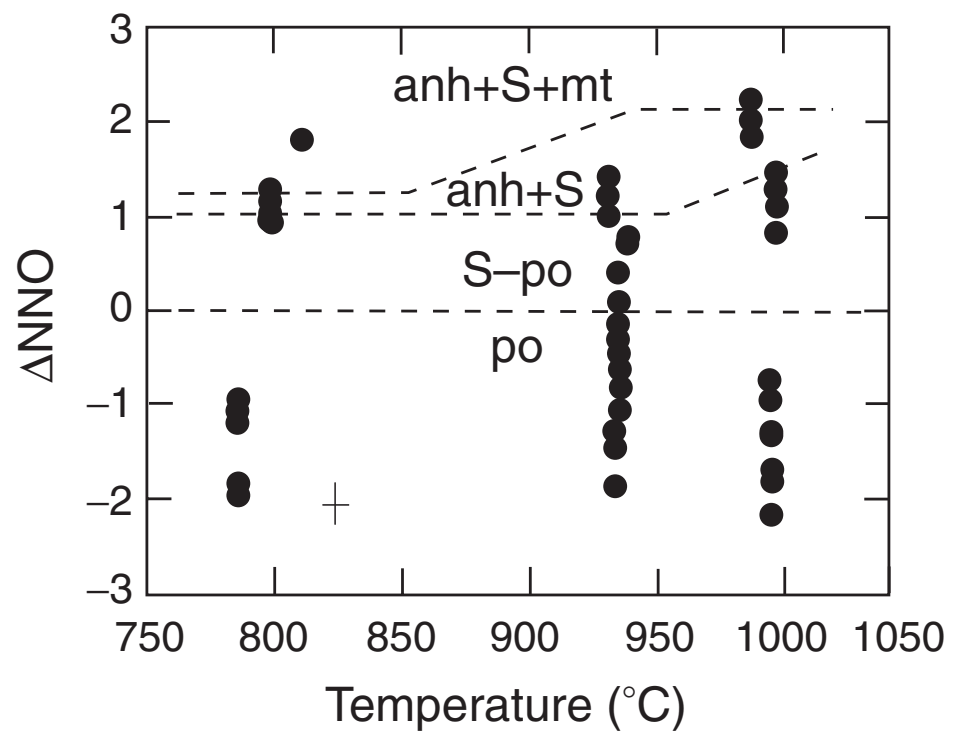

Figure 51: Temperature and oxygen fugacity fields of stability for sulfides and sulfates in rhyolitic magmas at $\sim 780^{\circ} \mathrm{C}, \sim 930^{\circ} \mathrm{C}$, and $\sim 1,000^{\circ} \mathrm{C}$ (after Clemente et al, 2004). 


\section{CONCLUSIONS}

In this study, apatites from the three juvenile components of the 1991 Mount Pinatubo eruptions were investigated in order to constrain the timing and melt conditions for crystallizing high-S $(>0.7 \mathrm{wt} . \%)$ apatites hosted in the dacitic pumice. Concentrations of $\mathrm{SO}_{3}$ in nearly $30 \%$ of the apatites analyzed exceeded $0.7 \mathrm{wt} . \%$, which is a much higher concentration than can be achieved through direct apatite/melt equilibrium partitioning. At $\sim 780^{\circ} \mathrm{C}, 220 \mathrm{MPa}, \mathrm{NNO}+1.7$, and $77 \mathrm{ppm} \mathrm{S}$ (Scaillet and Evans, 1999), the pre-eruption conditions of the 1991 Pinatubo dacite magma reservoir, a partition coefficient of 13 (Baker and Rutherford, 1996b) would yield apatite with only 0.25 wt. $\% \mathrm{SO}_{3}$.

Direct diffusion from neighboring or hosting anhydrite was also eliminated as a source of high-S apatites. No diffusion profiles were observed in S element maps of apatites hosted in anhydrite. Sulfur concentrated regions were globular or irregularly shaped, near- to off-center of the apatite grain, sometimes surrounded by a sulfur-rich halo. This may suggest multiple events of apatite sulfur enrichment.

All apatites analyzed from the basalt were high-S, which is consistent with sulfur solubility and apatite/melt sulfur partitioning. Major and trace element analysis was used to rule-out the possibility of inheritance of high-S apatite from the basalt into the dacite during magma mixing/mingling. Direct comparison of $\mathrm{MgO}, \mathrm{Ce}_{2} \mathrm{O}_{3}, \mathrm{Cl}, \mathrm{F}$, $\mathrm{Sr}, \mathrm{Eu} / \mathrm{Eu}^{*}$, and REE profiles in silicic and basalt apatites show that there are two statistically distinct apatite populations. High-S silicic apatites did not grow under the same melt conditions as the high-S basalt apatites. Melt environments inferred from 
trace elements and REE signatures of both low-S and high-S silicic apatites were indistinguishable, meaning there was little change in the dacite melt during apatite growth other than sulfur.

Fluid-enhanced crystallization is proposed to be the mechanism for generating high-S apatites in cool, fluid-saturated, calc-alkaline melts, like the 1991 Pinatubo dacite with the following model. Numerous injections of underplating basalt provided excess sulfur and increased the oxygen fugacity of the dacite reservoir. There is evidence that this has occurred throughout Modern Pinatubo's history (Newhall et al., 1996; Di Muro et al., 2008). Pyrrhotite globules formed early before the dacite reached an oxygen fugacity of $\sim \mathrm{NNO}+1-1.5$ (Carroll and Rutherford, 1987; Luhr 1990; Hattori, 1993, 1996). After the major sulfur species in the fluid phase and melt shifted from $\mathrm{S}^{2-}$ to $\mathrm{S}^{6+}$ with oxidation of the dacite melt, early medium- and high-S apatite inclusions either 1) directly crystallized from the vapor via vapor phase crystallization or 2) partitioned sulfur from the fluid phase and the surrounding melt via fluid-enhanced crystallization. When anhydrite saturation was achieved later in the crystallization of the dacite reservoir, sulfur was partitioned into crystallizing anhydrite from both the melt and fluid phase (Jakubowski et al., 2002) and was no longer available for late-crystallizing apatite microphenocrysts. Future investigations of apatite crystallization experiments under sulfur-rich fluid saturated conditions at and below anhydrite saturation could be performed to validate this model. 


\section{REFERENCES}

Abranjano, T.A., Pasteris, J.D., and Bacuta, G.C., 1989, Zambales ophiolite, Philippines, I. Geology and petrology of the critical zone of the Acoje massif: Tectonophysics, v. 168, p. 65-100.

Arculus, R.J., Johnson, R.W., Chappell, B.W., McKee, C.O., and Sakai, H., 1983, Ophiolite-contaminated andesites, trachybasalts, and cognate inclusions of Mount Lamington, Papua New Guinea: anhydrite-amphibole-bearing lavas and the 1951 cumulodome: Journal of Volcanology and Geothermal Research, v. 18 , p. 215-247.

Audétat, A., Pettke, T., and Dolejš, D., 2004, Magmatic anhydrite and calcite in the ore-forming quartz-monzodiorite magma at Santa Rita, New Mexico (USA): genetic constraints on porphyry-Cu mineralization: Lithos, v. 72, p. 147-161.

Baker, L.L., and Rutherford, M.J., 1996a, Sulfur diffusion in rhyolite melts: Contributions to Mineralogy and Petrology, v. 123, p. 335-344.

Baker, L.L., and Rutherford, M.J., 1996b, Crystallization of anhydrite-bearing magmas, in Brown, M., Candela, P.A., Peck, D.L., Stephens, W.E., Walker, R.J., and Zen, E-an, eds., Origin of granites and related rocks: Geological Society of America Special Paper 315, p. 243-250.

Barth, A.P., and Dorais, M.J., 2000, Magmatic anhydrite in granitic rocks: first occurrence and potential petrologic consequences: American Mineralogist, v. 85 , p. 430-435.

Belousova, E.A., Griffin, W.L., O’Reilly, S.Y., and Fisher, N.I., 2002, Apatite as an indicator mineral for mineral exploration: trace-element compositions and their relationship to host rock type: Journal of Geochemical Exploration, v. 76, p. 45-69.

Bernard, A., Knittel, U., Weber, B., Weis, D., Albrecht, A., Hattori, K., Klein, J., Oles, D., 1996, Petrology and geochemistry of the 1991 eruption products of Mount Pinatubo, in Newhall, C.G., and Punongbayan, R.S., (Eds.), Fire and Mud: Eruptions and Lahars of Mount Pinatubo, Philippines. Philippine Inst. Volcanol. Seismol., Quezon City, and Univ. Washington Press, Seattle, WA, p. 767-797.

Bernard, A., Demaiffe, D., Mattielli, N., and Punongbayan, R.S, 1991, Anhydritebearing pumices from Mount Pinatubo: further evidence for the existence of sulphur-rich silicic magmas: Nature, v. 354, p. 139-140.

Bluth, G.J.S., Doiron, S.D., Schnetzler, C.C., Krueger, A.J., and Walter, L.S., 1992, Global tracking of the $\mathrm{SO}_{2}$ clouds from the June, 1991 Mount Pinatubo eruptions: Geophysical Research Letters, v. 19, p. 151-154.

Boyce, J.W., and Hervig, R.L., 2009, Apatite as a monitor of late-stage magmatic processes at Volcán Irazú, Costa Rica: Contributions to Mineralogy and Petrology, v. 157, p. 135-145. 
Broderick, C.A., 2008, The origin of sulfur-rich apatites in silicic magmas [Master's thesis]: Portland State University, $183 \mathrm{p}$.

Buchanan, D.L., and Nolan, J., 1979, Solubility of sulfur and sulfide immiscibility in synthetic tholeiitic melts and their relevance to Bushveld-Complex rocks: Canadian Mineralogist, v. 17, p. 483-494.

Carroll, M.R., and Rutherford, M.J., 1985, Sulfide and sulfate saturation in hydrous silicate melts: Journal of Geophysical Research, v. 90, p. C601-C612.

Carroll, M.R., and Rutherford, M.J., 1987, The stability of igneous anhydrite: experimental results and implications for sulfur behavior in the $1982 \mathrm{El}$ Chichón trachyandesite and other evolved magmas: Journal of Petrology, v. 28, p. 781-801.

Carroll, M.R., and Rutherford, M.J., 1988, Sulfur speciation in hydrous experimental glasses of varying oxidation state: results from measured wavelength shifts of sulfur X-rays: American Mineralogist, v. 73, p. 845-849.

Carroll, M.R. and Webster, J.D., 1994, Solubilities of sulfur, noble gases, nitrogen, chlorine, and fluorine in magmas: Reviews in Mineralogy and Geochemistry, v. 30, p. 231-279.

Chambefort, I., Dilles, J.H., and Kent, A.J.R., 2008, Anhydrite-bearing andesite and dacite as a source for sulfur in magmatic-hydrothermal mineral deposits: Geology, v. 36, no. 9, p. 719-722.

Clemente, B., Scaillet, B., and Pichavant, M., 2004, The solubility of sulphur in hydrous rhyolitic melts: Journal of Petrology, v. 45, no. 11, p. 2171-2196.

Daag, A.S., Tubianosa, B.S., Newhall, C.G., Tuñgol, N.M., Javier, D., Dolan, M.T., Reyes, P.J.D., Arboleda, R.A., Martinez, M.M.L., and Regalado, M.T.M., 1996a, Monitoring sulfur dioxide emission at Mount Pinatubo, in Newhall, C.G., and Punongbayan, R.S., (Eds.), Fire and Mud: Eruptions and Lahars of Mount Pinatubo, Philippines. Philippine Inst. Volcanol. Seismol., Quezon City, and Univ. Washington Press, Seattle, WA, p. 409-414.

Daag, A.S., Dolan, M.T., Laguerta, E.P., Meeker, G.P., Newhall, C.G., Pallister, J.S., and Solidum, R.U., 1996b, Growth of a postclimactic lava dome at Mount Pinatubo, July-October 1992, in Newhall, C.G., and Punongbayan, R.S., (Eds.), Fire and Mud: Eruptions and Lahars of Mount Pinatubo, Philippines. Philippine Inst. Volcanol. Seismol., Quezon City, and Univ. Washington Press, Seattle, WA, p. 647-664.

David, C.P.C, Dulce, R.G., Nolasco-Javier, D.D., Zamoras, L.R., Jumawan, F.T., and Newhall, C.G., 1996, Changing proportions of two pumice types from the June 15, 1991, eruption of Mount Pinatubo, in Newhall, C.G., and Punongbayan, R.S., (Eds.), Fire and Mud: Eruptions and Lahars of Mount Pinatubo, Philippines. Philippine Inst. Volcanol. Seismol., Quezon City, and Univ. Washington Press, Seattle, WA, p. 681-685.

Davis, J.C., 2002, Statistics and data analysis in geology $-3^{\text {rd }}$ ed.: New York, John Wiley \& Sons, $638 \mathrm{p}$. 
Defant, M.J., De Boer, J.Z., and Oles, D., 1988, The western Central Luzon volcanic arc, the Philippines: two arcs divided by rifting?: Tectonophysics, v. 145 p. 305-317.

Defant, M.J., Jacques, D., Maury, R.C., De Boer, J., and Joron, J.-L., 1989, Geochemistry and tectonic setting of the Luzon arc, Philippines: Geological Society of America Bulletin, v. 101, p. 663-672.

Defant, M.J., Maury, R.C., Ripley, E.M., Feigenson, M.D., Jacques, D., 1991, An example of island-are petrogenesis: geochemistry and petrology of the Southern Luzon Arc, Philippines: Journal of Petrology, v. 32, p. 455-500.

Delfin, F.G., Jr., Villarosa, H.G., Clemente, V.C., Candelaria, M.R., and Ruaya, J.R., 1996, Geothermal exploration of the pre-1991 Mount Pinatubo hydrothermal system, in Newhall, C.G., and Punongbayan, R.S., (Eds.), Fire and Mud: Eruptions and Lahars of Mount Pinatubo, Philippines. Philippine Inst. Volcanol. Seismol., Quezon City, and Univ. Washington Press, Seattle, WA, p. 197-212.

Dempster, T.J., Jolivet, M., Tubrett, M.N., and Braithwaite, C.J.R., 2003, Magmatic zoning in apatite: a monitor of porosity and permeability change in granites: Contributions to Mineralogy and Petrology, v. 145, p. 568-577.

Di Muro, A., Pallister, J., Villemant, B., Newhall, C., Semet, M., Martinez, M., and Mariet, C., 2008, Pre-1991 sulfur transfer between mafic injections and dacite magma in the Mt. Pinatubo reservoir: Journal of Volcanology and Geothermal Research, v. 175, p. 517-540.

Drexler, J.W., and Munoz, J.L., 1988, Highly oxidized, pyrrhotite-anhydrite-bearing silicic magmas from the Julcani Ag- $\mathrm{Cu}-\mathrm{Bi}-\mathrm{Pb}-\mathrm{Au}-\mathrm{W}$ district, Peru; physicochemical conditions of a productive magma. CIM conference on Granite-related mineral deposits, v. 39, 72-79.

Evans, B.W., and Scaillet, B., 1997, The redox state of Pinatubo dacite and the ilmenite-hematite solvus: American Mineralogist, v. 82, p. 625-629.

Fournelle, J., 1990, Anhydrite in Nevado del Ruiz November 1985 pumice: relevance to the sulfur problem: Journal of Volcanology and Geothermal Research, v. 42, p. 189-201.

Fournelle, J., Carmody, R., and Daag, A.S, 1996, Anhydrite-bearing pumices from the June 15, 1991, eruption of Mount Pinatubo: Geochemistry, mineralogy, and petrology, in Newhall, C.G., and Punongbayan, R.S., (Eds.), Fire and Mud: Eruptions and Lahars of Mount Pinatubo, Philippines. Philippine Inst. Volcanol. Seismol., Quezon City, and Univ. Washington Press, Seattle, WA, p. 845-863.

Freda, C., Baker, D.R., and Scarlato, P., 2005, Sulfur diffusion in basaltic melts: Geochimica et Cosmochimica Acta., v. 69, no. 21, p. 5061-5069.

Gardner, P.M., 1972, Hollow apatites in a layered basic intrusion, Norway: Geological Magazine, v. 109, no. 5, p. 385-464.

Gerlach, T.M., Westrich, H.R., and Symonds, R.B., 1996, Preeruption vapor in magma of the climactic Mount Pinatubo eruption: Source of the giant 
stratosphere sulfur dioxide cloud, in Newhall, C.G., and Punongbayan, R.S., (Eds.), Fire and Mud: Eruptions and Lahars of Mount Pinatubo, Philippines. Philippine Inst. Volcanol. Seismol., Quezon City, and Univ. Washington Press, Seattle, WA, p. 415-433.

Hansen, J., Lacis, A., Ruedy, R., and Sato, M., 1992, Potential climate impact of Mount Pinatubo eruption: Geophysical Research Letters, v. 19, no. 2, p. 215218.

Hattori, K., 1993, High-sulfur magma, a product of fluid discharge from underlying mafic magma: evidence from Mount Pinatubo, Philippines: Geology, v. 21, p. 1083-1086.

Hattori, K., 1996, Occurrence and origin of sulfide and sulfate in the 1991 Mount Pinatubo eruption products, in Newhall, C.G., and Punongbayan, R.S., (Eds.), Fire and Mud: Eruptions and Lahars of Mount Pinatubo, Philippines. Philippine Inst. Volcanol. Seismol., Quezon City, and Univ. Washington Press, Seattle, WA, p. 807-824.

Humphreys, M.C.S., Blundy, J.D., and Sparks, S.J., 2006, Magma evolution and opensystem processes at Shiveluch Volcano: insights from phenocryst zoning: Journal of Petrology, v. 47, no. 12, p. 2303-2334.

Imai, A., Listanco, E.L., and Fujii, T., 1993, Petrologic and sulfur isotopic significance of highly oxidized and sulfur-rich magma of Mt. Pinatubo, Philippines: Geology, v. 21, p. 699-702.

Imai, A., Listanco, E.L., and Fujii, T., 1996, Highly oxidized and sulfur-rich dacitic magma of Mount Pinatubo: Implication for metallogenesis of porphyry copper mineralization in the Western Luzon Arc, in Newhall, C.G., and Punongbayan, R.S., (Eds.), Fire and Mud: Eruptions and Lahars of Mount Pinatubo, Philippines. Philippine Inst. Volcanol. Seismol., Quezon City, and Univ. Washington Press, Seattle, WA, p. 865-874.

Jakubowski, R.T., Fournelle, J., Welch, S., Swope, R.J., and Camus, P., 2002, Evidence for magmatic vapor deposition of anhydrite prior to the 1991 climactic eruption of Mount Pinatubo, Philippines: American Mineralogist, v. 87, p. 1029-1045.

Jugo, P.J., Luth, R.W., and Richards, J.P., 2005a, An experimental study of the sulfur content in basaltic melts saturated with immiscible sulfide or sulfate liquids at $1300^{\circ} \mathrm{C}$ and $1.0 \mathrm{GPa}$ : Journal of Petrology, v. 46, p. 783-798.

Jugo, P.J., Luth, R.W., and Richards, J.P., 2005b, Experimental data on the speciation of sulfur as a function of oxygen fugacity in basaltic melts: Geochimica et Cosmochimica Acta, v. 69, no. 2, p. 497-503.

Katsura,T., and Nagashima, S., 1974, Solubility of sulfur in some magmas at $1 \mathrm{~atm}$ pressure: Geochimica et Cosmochimica Acta, v. 38. p. 517-531.

Keppler, H., 1999, Experimental evidence for the source of excess sulfur in explosive volcanic eruptions: Science, v. 284, no. 5420, p. 1652-1654.

Kimura, J.-I., Danhara, T., and Iwano, H., 2000, A preliminary report on trace element determinations in zircon and apatite crystals using Excimer laser ablation- 
inductively coupled plasma mass spectrometry (ExLa-ICPMS): Fission Track News Letter, v. 103. p. 11-20.

Koyaguchi, T., 1996, Volume estimation of tephra-fall deposits from the June 15, 1991, eruption of Mount Pinatubo by theoretical and geological methods, in Newhall, C.G., and Punongbayan, R.S., (Eds.), Fire and Mud: Eruptions and Lahars of Mount Pinatubo, Philippines. Philippine Inst. Volcanol. Seismol., Quezon City, and Univ. Washington Press, Seattle, WA, p.583-600.

Kress, V., 1997, Magma mixing as a source for Pinatubo sulphur: Nature, v. 389, p. 591-593.

Liu, Y., and Comodi, P., 1993, Some aspects of the crystal-chemistry of apatites: Mineralogical Magazine, v. 57, p. 709-719.

Liu, Y, Samaha, N.T., and Baker, D.R., 2007, Sulfur concentration at sulfide saturation (SCSS) in magmatic silicate melts: Geochimica et Cosmochimica Acta, v. 71, p. 1783-1799.

Luhr, J.F., Carmichael, I.S.E., and Varekamp, J.C., 1984, The 1982 eruptions of El Chichón volcano, Chiapas, Mexico: Mineralogy and petrology of the anhydrite-bearing pumices: Journal of Volcanology and Geothermal Research, v. 23, p. 69-108.

Luhr, J.F., 1990, Experimental phase relations of water- and sulfur- saturated arc magmas and the 1982 eruptions of El Chichón volcano: Journal of Petrology, v. 31, p. 1071-1114.

Luhr, J.F., 2008, Primary igneous anhydrite: Progress since its recognition in the 1982 El Chichón trachyandesite: Journal of Volcanology and Geothermal Research, v. 175, p. 394-407.

Macdonald, R., Bagiński, B., Belkin, H.E., Kzierżanowski, P., and Jeżak, L., 2008, REE partitioning between apatite and melt in a peralkaline volcanic suite, Kenya Rift Valley: Mineralogical Magazine, v. 76, no. 6, p. 1147-1161.

Matthews, S.J., Jones, A.P., and Bristow, C.S., 1992, A simple magma-mixing model for sulphur behavior in calc-alkaline volcanic rocks: mineralogical evidence from Mount Pinatubo 1991 eruption: Journal of the Geological Society, v. 149, p. 863-866.

Matthews, S.J., Jones, A.P., and Gardeweg, M.C., 1994, Lascar Volcano, Northern Chile; Evidence for steady-state disequilibrium: Journal of Petrology, v. 35, no. 2, p. 401-432.

Mavrogenes, J.A., and O'Neill, H.St.C., 1999, The relative effects of pressure, temperature and oxygen fugacity on the solubility of sulfide in mafic magmas: Geochimica et Cosmochimica Acta, v. 63, no. 7/8, p. 1173-1180.

Metrich, N., and Clocchiatti, R., 1996, Sulfur abundance and its speciation in oxidized alkaline melts: Geochimica et Cosmochimica Acta, v. 60, no. 21, p. 41514160.

Mori, J., Eberhart-Phillips, D., and Harlow, D.H., 1996, Three-dimensional velocity structure at Mount Pinatubo: Resolving magma bodies and earthquake hypocenter, in Newhall, C.G., and Punongbayan, R.S., (Eds.), Fire and Mud: 
Eruptions and Lahars of Mount Pinatubo, Philippines. Philippine Inst.

Volcanol. Seismol., Quezon City, and Univ. Washington Press, Seattle, WA, p. 317-382.

Moretti, R. and Ottonello, G., 2005, Solubility and speciation of sulfur in silicate melts: The Conjugated Toop-Samis-Flood-Grjotheim (CTSFG) model: Geochimica et Cosmochimica Acta, v. 69, no. 4, p. 801-823.

Newhall, C. G., Daag, A.S., Delfin, F.G., Jr., Hoblitt, R.P., McGeehin, J., Pallister, J.S., Regalado, M.T.M., Rubin, M., Tubianosa, B.S., Tamayo, Jr., and R.A., Umbal, J.V., 1996, Eruptive history of Mount Pinatubo, in Newhall, C.G., and Punongbayan, R.S., (Eds.), Fire and Mud: Eruptions and Lahars of Mount Pinatubo, Philippines. Philippine Inst. Volcanol. Seismol., Quezon City, and Univ. Washington Press, Seattle, WA, p. 165-195.

Nilsson, K, and Peach, C.L., 1993, Sulfur speciation, oxidation state, and sulfur concentration in backarc magmas: Geochimica et Cosmochimica Acta, v. 57, p. 3807-3813.

Oswalt, J.S., Nichols, W., and O'Hara, F., 1996, Meteorological observations of the 1991 Mount Pinatubo eruption, in Newhall, C.G., and Punongbayan, R.S., (Eds.), Fire and Mud: Eruptions and Lahars of Mount Pinatubo, Philippines. Philippine Inst. Volcanol. Seismol., Quezon City, and Univ. Washington Press, Seattle, WA, p. 625-636.

Paladio-Melosantos, L.O., Solidum, R.U., Scott, W.E., Quiambao, R.B., Umbal, J.V., Rodolfo, K.S., Tubianosa, B.S., Delos Reyes, P.J., Alonso, R.A., and Ruelo, H.B, 1996, Tephra Falls of the 1991 Eruptions of Mount Pinatubo, in Newhall, C.G., and Punongbayan, R.S., (Eds.), Fire and Mud: Eruptions and Lahars of Mount Pinatubo, Philippines. Philippine Inst. Volcanol. Seismol., Quezon City, and Univ. Washington Press, Seattle, WA, p. 513-535.

Pallister, J.S., Hoblitt, R.P., and Reyes, A.G., 1992, A basalt trigger for the 1991 eruptions of Pinatubo volcano?: Nature, v. 356, p. 426-428.

Pallister, J.S., Meeker, G.P., and Luhr, J.F., 1995, Recognizing ancient sulfur-rich eruptions: Lessons from Pinatubo El Chichón and Mount St. Helens: International Union of Geodesy and Geophysics General Assembly, $21^{\text {st }}$, Abstracts, p. A279.

Pallister, J.S., Hoblitt, R.P., Meeker, G.P., Knight, R.J., and Siems, D.F., 1996, Magma mixing at Mount Pinatubo: Petrographic and chemical evidence from the 1991 deposits, in Newhall, C.G., and Punongbayan, R.S., (Eds.), Fire and Mud: Eruptions and Lahars of Mount Pinatubo, Philippines. Philippine Inst. Volcanol. Seismol., Quezon City, and Univ. Washington Press, Seattle, WA, p. 687-731.

Pan, Y., Dong, P., and Chen, N., 2003, Non-Henry's Law behavior of REE partitioning between fluorapatite and $\mathrm{CaF}_{2}$-rich melts: controls of intrinsic vacancies and implications for natural apatites: Geochimica et Cosmochimica Acta, v. 67, no. 10, p. 1889-1900. 
Parat, F., Dungan, M.A., and Streck, M.J., 2002, Anhydrite, pyrrhotite, and sulfur-rich apatite: tracing the sulfur evolution of an Oligocene andesite (Eagle Mountain, CO, USA): Lithos, v. 64, p. 63-75.

Parat, F., and Holtz, F., 2004, Sulfur partitioning between apatite and melt and effect of sulfur on apatite solubility at oxidizing conditions: Contributions to Mineralogy and Petrology, v. 147, p. 201-212.

Parat, F., and Holtz, F., 2005, Sulfur partition coefficient between apatite and rhyolite: the role of bulk S content: Contributions to Mineralogy and Petrology, v. 150, p. 643-651.

Paris, E., Giuli, G., and Carroll, M.R., 2001, The valence and speciation of sulfur in glasses by X-ray absorption spectroscopy: The Canadian Mineralogist, v. 39, p. 331-339.

Pasero, M., Kampf, A.R., Ferraris, C., Pekov, I.V., Rakovan, J., and White, T.J., 2010, Nomenclature of the apatite supergroup minerals: European Journal of Mineralogy, v. 22, p. 163-179.

Pasteris, J.D., Wopenka, B., Wang, A., and Harris, T.N., 1996, Relative timing of fluid and anhydrite saturation: Another consideration in the sulfur budget of the Mount Pinatubo eruption, in Newhall, C.G., and Punongbayan, R.S., (Eds.), Fire and Mud: Eruptions and Lahars of Mount Pinatubo, Philippines.

Philippine Inst. Volcanol. Seismol., Quezon City, and Univ. Washington Press, Seattle, WA, p. 875-891.

Peng, G., Luhr, J.F., and McGee, J.J., 1997, Factors controlling sulfur concentrations in volcanic apatite: American Mineralogist, v. 82, p. 1210-1224.

Prouteau, G., and Scaillet, B., 2003, Experimental constraints on the origin of the 1991 Pinatubo dacite: Journal of Petrology, v. 44, p. 2203-2241.

Puchelt, H., and Emmermann, R., 1976, Bearing of rare earth patterns of apatites from igneous and metamorphic rocks: Earth and Planetary Science Letters, v. 31, p. 279-286.

Rakovan, J., and Reeder, R.J., 1996, Intracrystalline rare earth element distributions in apatite: Surface structural influences on incorporation during growth: Geochimica et Cosmochimica Acta, v. 60, no. 22, p. 4435-4445.

Roeder, P.L., MacArthur, D., Ma, X.-P., Palmer, G.R., and Mariano, A.N., 1987, Cathodoluminescence and microprobe study of rare-earth elements in apatite: American Mineralogist, v. 72, p. 801-811.

Rogers, P.S.Z., Duffy, C.J., Benjamin, T.M., and Maggiore, C.J., 1984, Geochemical applications of nuclear microprobes: Nuclear Instruments and Methods in Physics Research, v. B3, p. 671-676.

Rønsbo, J.G., 1989, Coupled substitutions involving REEs and $\mathrm{Na}$ and $\mathrm{Si}$ in apatites in alkaline rocks from the Ilimaussaq intrusion, South Greenland, and the Petrological implications: American Mineralogist, v. 74, p. 869-901.

Rønsbo, J.G., 2008, Apatite in the Ilimaussaq alkaline complex: occurrence, zonation and compositional variation: Lithos, v. 106, p. 71-82. 
Rouse, R.C., Dunn, P.J., 1982, A contribution to the crystal chemistry of ellestadite and silicate sulfate apatites: American Mineralogist, v. 67, p. 90-96.

Rutherford, M.J. and Devine, J.D., 1996, Preeruption pressure-temperature conditions and volatiles in the 1991 dacitic magma of Mount Pinatubo, in Newhall, C.G., and Punongbayan, R.S., (Eds.), Fire and Mud: Eruptions and Lahars of Mount Pinatubo, Philippines. Philippine Inst. Volcanol. Seismol., Quezon City, and Univ. Washington Press, Seattle, WA, p. 751-766.

Rye, R.O., Luhr, J.F., and Wasserman, M.D., 1984, Sulfur and oxygen isotopic systematics of the 1982 eruptions of El Chichón volcano, Chiapas, Mexico: Journal of Volcanology and Geothermal Research, v. 23, p. 109-123.

Scaillet, B., Clemente, B., Evans, B.W., and Pichavant, M., 1998, Redox control of sulfur degassing in silicic magmas: Journal of Geophysical Research, v. 103, no. B10, p. 23,937-23,949.

Scaillet, B., and Evans, B.W., 1999, The 15 June 1991 eruption of Mount Pinatubo. I. Phase equilibria and pre-eruption $\mathrm{P}-\mathrm{T}-\mathrm{fO}_{2}-\mathrm{fH}_{2} \mathrm{O}$ conditions of the dacite magma: Journal of Petrology, v. 40, no. 3, p. 381-411.

Scott, W.E., Hoblitt, R.P., Torres, R.C., Self, S., Martinez, M. L., and Nillos T. Jr., 1996, Pyroclastic flows of the June 15, 1991, Climactic Eruption of Mount Pinatubo, in Newhall, C.G., and Punongbayan, R.S., (Eds.), Fire and Mud: Eruptions and Lahars of Mount Pinatubo, Philippines. Philippine Inst. Volcanol. Seismol., Quezon City, and Univ. Washington Press, Seattle, WA, p.545-570.

Sha, L.-K., and Chappell, B.W., 1999, Apatite chemical composition, determined by electron microprobe and laser-ablation inductively coupled plasma mass spectrometry, as a probe into granite petrogenesis: Geochimica et Cosmochimica Acta, v. 63, no. 22., p. 3861-3881.

Stern, C.R., Funk, J.A., Skewes, M.A., and Arévalo, A., 2007, Magmatic anhydrite in plutonic rocks at the El Teniente $\mathrm{Cu}-\mathrm{Mo}$ deposit, Chile, and the role of sulfurand copper-rich magmas in its formation: Economic Geology, v. 102, p. 13351344.

Streck, M.J., and Dilles, J.H., 1998, Sulfur evolution of oxidized arc magmas as recorded in apatite from a porphyry copper batholith: Geology, v. 26, no. 6, p. 523-526.

Swanson, S.E., and Kearney, C.S., 2008, Anhydrite in the 1989-1990 lavas and xenoliths from Redoubt Volcano, Alaska: Journal of Volcanology and Geothermal Research, v. 175, p. 509-516.

Tepper, J.H., and Kuehner, S.M., 1999, Complex zoning in apatite from the Idaho batholith: a record of magma mixing and intracrystalline trace element diffusion: American Mineralogist, v. 84, p. 581-595.

Wallace, P. and Carmichael, I.S.E, 1992, Sulfur in basaltic magmas: Geochemica et Cosmochimica, v. 56, p. 1863-1874. 
Wallace, P. and Carmichael, I.S.E, 1994, S speciation in submarine basaltic glasses as determined by measurements of $\mathrm{S} K \alpha \mathrm{X}$-ray wavelength shifts: American Mineralogist, v. 79, p. 161-167.

Wallace, P.J., and Gerlach, T.M., 1994, Magmatic vapor source for sulfur dioxide released during volcanic eruptions: evidence from Mount Pinatubo: Science, v. 265, p. 497-499.

Watson, E.B., and Capobianco, C.J., 1981, Phosphorus and rare earth elements in felsic magmas: an assessment of the role of apatite: Geochimica et Cosmochimica Acta, v. 45, p. 2349-2358.

Watson, E.B., and Green, T.H., 1981, Apatite/liquid partition coefficients for the rare earth elements and strontium: Earth and Planetary Science letters, v. 56, p. 405-421.

Westrich, H.R., and Gerlach, T.M., 1992, Magmatic gas source for the stratospheric SO2 cloud from the June 15, 1991 eruption of Mount Pinatubo: Geology, v. 20, p. 867-870.

Williams, H., and Curtis, G.H., 1977, The Sutter Buttes of California: A study of PlioPliestocene volcanism: Univ. Calif. Publ. Geol. Sci. v. 116, p. 1-56, 6 plates.

Wolfe, E.W. and Hoblitt, R.P., 1996, Overview of the eruptions, in Newhall, C.G., and Punongbayan, R.S., (Eds.), Fire and Mud: Eruptions and Lahars of Mount Pinatubo, Philippines. Philippine Inst. Volcanol. Seismol., Quezon City, and Univ. Washington Press, Seattle, WA, p. 3-20.

Young, E.J., Myers, A.T., Munson, E.L., and Conklin, N.M., 1969, Mineralogy and geochemistry of fluorapatite from Cerro de Mercado, Durango, Mexico: U.S. Geological Survey Professional Paper, 650-D, p. D84-D93. 


\section{APPENDIX A: SAMPLES}

\section{Sample descriptions}

\section{Hybrid Andesite Lava}

On June 7, 1991, a small lava dome of approximately 50 to 100 meters in diameter, appeared northwest of the summit in the upper part of the Maraunot River canyon (Wolfe and Hobblit, 1996). The dome continued to grow through June 11. The growth was interrupted June 12-14 when several lateral blasts destroyed the southeastern section of the dome. Lateral expansion of the dome continued despite the destruction, and the dome was reported to be flat topped when it was last seen on June 14. The climatic eruption of June 15 destroyed the remaining dome (Wolfe and Hobblit, 1996).

Samples of the andesitic lava dome were collected from prismatically jointed and scoracious blocks deposited by a series of pyroclastic flows at the base of the Maraunot River on the northwest side of the $2.5 \mathrm{~km}$ caldera (Pallister et al., 1996; Wolfe and Hobblit, 1996). The andesite is homogenous. $\mathrm{SiO}_{2}$ ranges from 59.0 wt.\% to 62.4 wt.\% with an average of 59.7 wt.\% (Pallister et al., 1996). The andesite is phenocryst-rich (52 vol.\%) with 3-7 vol.\% vesicles, and has the following mineral assemblage (in order of decreasing abundance): plagioclase (31\%), hornblende (12\%), augite $(5 \%)$, olivine $(2 \%)$, Fe-Ti oxides $(2 \%)$, biotite $(1 \%)$, quartz xenocrysts $(<1 \%)$, and trace amounts of: apatite, anhydrite, and sulfides (Pallister et al., 1996; Bernard et 
al., 1996). Phenocrysts are set in a pilotaxitic groundmass composed of clinopyroxene, plagioclase, and Fe-Ti microphenocrysts with matrix glass (Pallister et al., 1996; Bernard et al., 1996).

Disequilibria textures are abundant in the form of reaction rims on large plagioclase phenocrysts, and opaque hornblende. Basaltic xenoliths with mineral assemblages of olivine, hornblende, and augite are abundant and can be small (a few $\mathrm{mm}$ in diameter) to fairly large (up to $\sim 40 \mathrm{~cm}$ ) (Pallister et al., 1996). These and other data and have led to the conclusion that the andesite is a result of magma mixing of the dacitic reservoir beneath Pinatubo with a fresh surge of underplating basaltic magma (Pallister et al., 1996; Bernard et al., 1996; Hattori, 1996).

\section{Basalt Inclusion}

Basalt inclusions of various sizes ( $\mathrm{mm}$ to $\mathrm{cm}$ ) are found in andesite as referenced above. Samples were collected in the same location as the hybrid andesite. $\mathrm{SiO}_{2}$ ranges from $50.5 \mathrm{wt.} \%$ to $52.0 \mathrm{wt} . \%$ with an average of $51.2 \mathrm{wt. \%}$ (Pallister et al., 1996). The basalt has a quenched, diktytaxitic groundmass texture with abundant elongated hornblende phenocrysts (Pallister et al., 1996; Bernard et al., 1996). The basalt phenocryst assemblage is as follows (in order of decreasing abundance): hornblende (31\%), plagioclase (22\%), augite (12\%), olivine (3\%), Fe-Ti oxides, hornblende xenocrysts $(1 \%)$, quartz xenocrysts $(1 \%)$, apatite $(<1 \%)$, and trace amounts of sulfides (Pallister et al., 1996). 
A two-stage crystallization event took place. Crystallization began with the anhydrous phases, olivine and augite. As water fugacity and undercooling of the basalt increased as it intruded into the dacite magma reservoir, elongate hornblende, plagioclase, and magnetite began to crystallize, creating the diktytaxitic texture (Pallister et al., 1996).

\section{Phenocryst-rich Dacite Pumice}

June 15, 1991 bore witness to the climactic plinian eruption of Mount Pinatubo. Tephra falls from this event are the most voluminous of all of the vertical eruptions that occurred prior to and following this eruption. The climatic eruption produced $3.4-4.4 \mathrm{~km}^{3}$ (DRE) dacite pumice from tephra falls (Paladio-Melosantos et al., 1996) and $\sim 5.5 \mathrm{~km}^{3}$ (DRE) of pyroclastic flow deposits (Scott et al., 1996). The dacite pumice comes in two varieties with an $80 \%-20 \%$ distribution: a phenocrystrich (47 vol.\%), white pumice, and a phenocryst-poor (15 vol.\%), tan pumice (David et al., 1996). Chemically, there is no difference between the two pumice types (Pallister et al., 1996). Because of this, no samples of the phenocryst-poor pumice were included in this study. Any further reference to "dacite" or "dacite pumice" infers the phenocryst-rich type.

Vesicles are abundant (61 vol.\%) and elongated (Pallister et al., 1996). $\mathrm{SiO}_{2}$ in the dacite is homogenous and ranges from $64.3 \mathrm{wt} . \%$ to $65.0 \mathrm{wt} . \%$ with an average of $64.6 \mathrm{wt.} \%$. The phenocryst assemblage is as follows (in order of decreasing abundance): plagioclase (31\%), hornblende (12\%), 1\% each cummingtonite, Fe-Ti 
oxides, quartz, anhydrite $(<1 \%)$, and trace amounts of apatite, biotite, olivine, and bronzite (Pallister et al., 1996). Samples for this study were collected from a pyroclastic flow deposit in the Bucao drainage on the northwest flank of Pinatubo.

\section{Apatites}

\section{Dacite and Andesite Hosts}

Apatites were found primarily as inclusions in anhydrite and to lesser degrees in plagioclase, hornblende, and Fe-Ti oxides. These apatites range in size from very small $(\sim 10 \mu \mathrm{m})$ to large $(\sim 250 \mu \mathrm{m})$ and are euhedral to amorphously anhedral (primarily in anhydrite). Microphenocrysts of euhedral apatite are also found in the groundmass with an average diameter of $\sim 130 \mu \mathrm{m}$. Apatite samples were prepared insitu on polished $80 \mu \mathrm{m}$ thick sections ( 8 sections of dacite, 1 section of andesite) for EMP and LA-ICP-MS analyses.

\section{Basalt Host}

The shapes of apatite in the basalt is significantly different than those found in either the dacite or andesite. All apatites occur as skeletal, acicular microphenocrysts with sizes ranging from $\sim 10 \mu \mathrm{m}$ to $\sim 90 \mu \mathrm{m}$. One polished $80 \mu \mathrm{m}$ thick section was prepared from the basalt for EMP and LA-ICP-MS analyses. 
Sample numbers
Dacite
- PH12C-1
- $\mathrm{PH} 12 \mathrm{C}-2$
- $\mathrm{PH} 12 \mathrm{C}-3 \mathrm{a}$
- $\mathrm{PH} 12 \mathrm{C}-3 \mathrm{~b}$
- $\mathrm{PH} 12 \mathrm{C}-4$
- $\mathrm{PH} 12 \mathrm{C}-5$
- $\mathrm{PH} 12 \mathrm{C}-6$
- $\mathrm{PH} 12 \mathrm{C}-7$

Andesite

- CN6791-d

Basalt

- $\quad \mathrm{P}-22892-2 \mathrm{a}$ 


\section{APPENDIX B: ELECTRON MICROPROBE}

\section{EMP data on additional $C D$}

\section{Methods}

Major elements of apatites were measured with a CAMECA SX100 electron microprobe (EMP) housed at Oregon State University in Corvallis, OR via remote access at Portland State University in Portland, OR. The EMP operating conditions during apatite analyses were $15 \mathrm{kV}, 20 \mathrm{nA}$, and $2 \mu \mathrm{m}$ diameter electron beam. Elements selected for analysis were: $\mathrm{Ca}, \mathrm{P}, \mathrm{F}, \mathrm{Cl}, \mathrm{S}, \mathrm{Ce}, \mathrm{Fe}, \mathrm{Si}, \mathrm{Na}, \mathrm{Mn}$, and Mg. Apatite crystals were analyzed using variable point traverses dependant upon crystal length.

Natural mineral standards were analyzed to test the accuracy and precision of the EMP results. Means and standard deviations of standard analyses as unknowns were compared to published data (Tables B-1 through B-3). Three standards were tested prior to apatite analyses: fluorapatite (FLAP; USNM 104021), anhydrite (ANHY), and tugtupite (TUGT). 
Table B-1. EMP analysis information for fluorapatite (FLAP) standard USNM 104021 from Durango, Mexico. " $n$ " indicates the number of times this standard was analyzed throughout this study.

Fluorapatite (FLAP) Standard, USNM 104021, Durango, Mexico

\begin{tabular}{ccccc|cc}
\hline (wt.\%) & $\begin{array}{c}\text { Mean } \\
\mathrm{n}=19\end{array}$ & $\begin{array}{c}\text { Standard } \\
\text { Deviation }\end{array}$ & $\begin{array}{c}\text { Relative } \\
\text { Standard Dev. }\end{array}$ & $\begin{array}{c}\text { Detection Limit } \\
\text { Published }\end{array}$ & \multicolumn{2}{c}{ (ppm) } \\
\hline $\mathrm{SiO}_{2}$ & 0.37 & 0.01 & 2.08 & 0.34 & $\mathrm{Si}$ & 99 \\
$\mathrm{FeO}^{*}$ & 0.05 & 0.02 & 48.4 & 0.06 & $\mathrm{Fe}$ & 977 \\
$\mathrm{MgO}$ & 0.00 & 0.01 & 484 & 0.01 & $\mathrm{Mg}$ & 144 \\
$\mathrm{CaO}$ & 53.95 & 0.23 & 0.43 & 54.02 & $\mathrm{Ca}$ & 541 \\
$\mathrm{Ce}_{2} \mathrm{O}_{3}$ & 0.62 & 0.06 & 9.54 & 0.55 & $\mathrm{Ce}$ & 1590 \\
$\mathrm{Na}_{2} \mathrm{O}$ & 0.27 & 0.02 & 7.41 & 0.23 & $\mathrm{Na}$ & 307 \\
$\mathrm{P}_{2} \mathrm{O}_{5}$ & 40.79 & 0.27 & 0.66 & 40.78 & $\mathrm{P}$ & 370 \\
$\mathrm{MnO}$ & 0.01 & 0.05 & 454 & 0.01 & $\mathrm{Mn}$ & 1171 \\
$\mathrm{SO}_{3}$ & 0.41 & 0.04 & 9.92 & 0.37 & $\mathrm{~S}$ & 103 \\
$\mathrm{~F}$ & 3.54 & 0.48 & 13.7 & 3.53 & $\mathrm{~F}$ & 1473 \\
$\mathrm{Cl}$ & 0.41 & 0.04 & 10.3 & 0.41 & $\mathrm{Cl}$ & 277 \\
$\mathrm{Total}$ & 100.45 & 0.41 & 0.40 & 99.92 & & \\
\hline
\end{tabular}

Table B-2. EMP analysis information for anhydrite (ANHY) standard from Cropwell Bishop. "n" indicates the number of times this standard was analyzed throughout this study.

\begin{tabular}{|c|c|c|c|c|c|c|}
\hline (wt. \%) & $\begin{array}{l}\text { Mean } \\
\mathrm{n}=5\end{array}$ & $\begin{array}{c}\text { Standard } \\
\text { Deviation }\end{array}$ & $\begin{array}{c}\text { Relative } \\
\text { Standard Dev. }\end{array}$ & $(\mathrm{ppm})$ & Published & $\begin{array}{c}\text { Detection } \\
\text { Limit } \\
\end{array}$ \\
\hline $\mathrm{SiO}_{2}$ & 0.00 & 0.01 & 284 & $\mathrm{Si}$ & -- & 88 \\
\hline $\mathrm{FeO}^{*}$ & 0.02 & 0.05 & 205 & $\mathrm{Fe}$ & -- & 958 \\
\hline $\mathrm{MgO}$ & -0.01 & 0.01 & -115 & $\mathrm{Mg}$ & -- & 131 \\
\hline $\mathrm{CaO}$ & 42.61 & 0.65 & 1.53 & $\mathrm{Ca}$ & 29.38 & 522 \\
\hline $\mathrm{Ce}_{2} \mathrm{O}_{3}$ & 0.02 & 0.02 & 96.7 & $\mathrm{Ce}$ & -- & 1485 \\
\hline $\mathrm{Na}_{2} \mathrm{O}$ & 0.00 & 0.01 & 120 & $\mathrm{Na}$ & -- & 281 \\
\hline $\mathrm{P}_{2} \mathrm{O}_{5}$ & 0.02 & 0.01 & 37.4 & $\mathrm{P}$ & -- & 268 \\
\hline $\mathrm{MnO}$ & 0.01 & 0.06 & 651 & $\mathrm{Mn}$ & -- & 1079 \\
\hline $\mathrm{SO}_{3}$ & 56.58 & 1.94 & 3.43 & $\mathrm{~S}$ & 23.55 & 270 \\
\hline $\mathrm{F}$ & 0.03 & 0.03 & 114 & $\mathrm{~F}$ & -- & 1101 \\
\hline $\mathrm{Cl}$ & 0.00 & 0.01 & -671 & $\mathrm{Cl}$ & -- & 282 \\
\hline Total & 99.34 & 1.42 & 1.43 & & & \\
\hline
\end{tabular}


Table B-3. EMP analysis information for tugtupite (TUGT) standard from SW Greenland. " $n$ " indicates the number of times this standard was analyzed throughout this study.

\begin{tabular}{|c|c|c|c|c|}
\hline (wt.\%) & $\begin{array}{c}\text { Analyzed } \\
n=1\end{array}$ & $(\mathrm{ppm})$ & $\begin{array}{l}\text { Detection } \\
\text { Limit }\end{array}$ & Published \\
\hline $\mathrm{SiO}_{2}$ & 53.17 & $\mathrm{Si}$ & 164 & 24.02 \\
\hline $\mathrm{FeO}^{*}$ & -0.05 & $\mathrm{Fe}$ & 854 & -- \\
\hline $\mathrm{MgO}$ & -0.01 & $\mathrm{Mg}$ & 131 & -- \\
\hline $\mathrm{CaO}$ & 0.02 & $\mathrm{Ca}$ & 323 & -- \\
\hline $\mathrm{Ce}_{2} \mathrm{O}_{3}$ & 0.09 & $\mathrm{Ce}$ & 1310 & -- \\
\hline $\mathrm{Na}_{2} \mathrm{O}$ & 26.54 & $\mathrm{Na}$ & 661 & 19.66 \\
\hline $\mathrm{P}_{2} \mathrm{O}_{5}$ & 0.03 & $\mathrm{P}$ & 234 & -- \\
\hline $\mathrm{MnO}$ & -0.06 & $\mathrm{Mn}$ & 1162 & -- \\
\hline $\mathrm{SO}_{3}$ & 0.02 & $\mathrm{~S}$ & 93 & -- \\
\hline $\mathrm{F}$ & -0.01 & $\mathrm{~F}$ & 917 & -- \\
\hline $\mathrm{Cl}$ & 7.70 & $\mathrm{Cl}$ & 291 & 7.58 \\
\hline Total & 87.57 & & & \\
\hline
\end{tabular}

\section{Apatite Analysis}

Apatites were analyzed in situ from ten polished thick sections $(80 \mu \mathrm{m}$ thickness): eight dacite pumice sections (PH12C-1, PH12C-2, PH12C-3a, PH12C-3b, PH12C-4, PH12C-5, PH12C-6, and PH12C-7), one hybrid andesite section (CN6791d), and one basalt inclusion section (P-22892-2a). Thick sections were prepared in Germany. The $80 \mu \mathrm{m}$ thickness was chosen over the standard $30 \mu \mathrm{m}$ thickness to allow adequate volume for LA-ICP-MS analysis. EMP analyses were performed to constrain the major element chemistry and sulfur content of the apatites. Table B-4 is a summary of apatite analyses and $\mathrm{SO}_{3}$ wt.\% content.

Variable point traverses were used for apatites analysis. The number of points in each traverse was dependent upon the length of the crystal and selected to achieve a point spacing of 3 to $6 \mu \mathrm{m}$. Ideally, the selected traverse began at the center of the crystal and ended at the rim. In some smaller crystals, traverses spanned the entire 
length of the crystal from rim to rim. Traverses were chosen to avoid any cracks or impurities on the apatite surface.

Table B- 4. Apatite analyses from dacite pumice, hybrid andesite, and basalt inclusion.

\begin{tabular}{ccc|cc}
\hline Sample & $\begin{array}{c}\text { \# of crystals } \\
\text { analyzed }\end{array}$ & $\begin{array}{c}\text { \# of point } \\
\text { analyses }\end{array}$ & \multicolumn{2}{|c}{ (wt.\%) } \\
$\mathrm{Min} \mathrm{SO}_{3}$ & $\mathrm{Max} \mathrm{SO}_{3}$ \\
\hline PH12C-1 & 13 & 88 & 0.08 & 1.09 \\
PH12C-2 & 9 & 46 & 0.13 & 1.71 \\
PH12C-3a & 2 & 7 & 0.14 & 0.81 \\
PH12C-3b & 13 & 58 & 0.05 & 0.93 \\
PH12C-4 & 4 & 13 & 0.10 & 0.49 \\
PH12C-5 & 3 & 8 & 0.15 & 1.00 \\
PH12C-6 & 6 & 24 & 0.16 & 0.91 \\
PH12C-7 & 19 & 157 & 0.09 & 1.53 \\
CN6791-d & 10 & 70 & 0.08 & 1.14 \\
P-22892-2a & 33 & 159 & $0.11(0.46)^{*}$ & 3.46 \\
\hline * Minimum & &
\end{tabular}
from dacite.

EMP results from this study showed that sulfur content of the apatites ranged from low $\left(<0.3\right.$ wt. $\left.\% \mathrm{SO}_{3}\right)$ to high $\left(>0.7 \mathrm{wt} . \% \mathrm{SO}_{3}\right)$ in each of the sections analyzed, regardless of host rock type (Fig. B-1). Intra-grain variation of sulfur fell into one of four profiles: 1) rimward increase $\mathrm{SO}_{3}, 2$ ) rimward decrease $\mathrm{SO}_{3}, 3$ ) oscillatory $\mathrm{SO}_{3}$, or 4) homogenous $\mathrm{SO}_{3}$ (Fig. B-2). Each of these sulfur profiles were found within each the dacite, andesite, and basalt samples. 

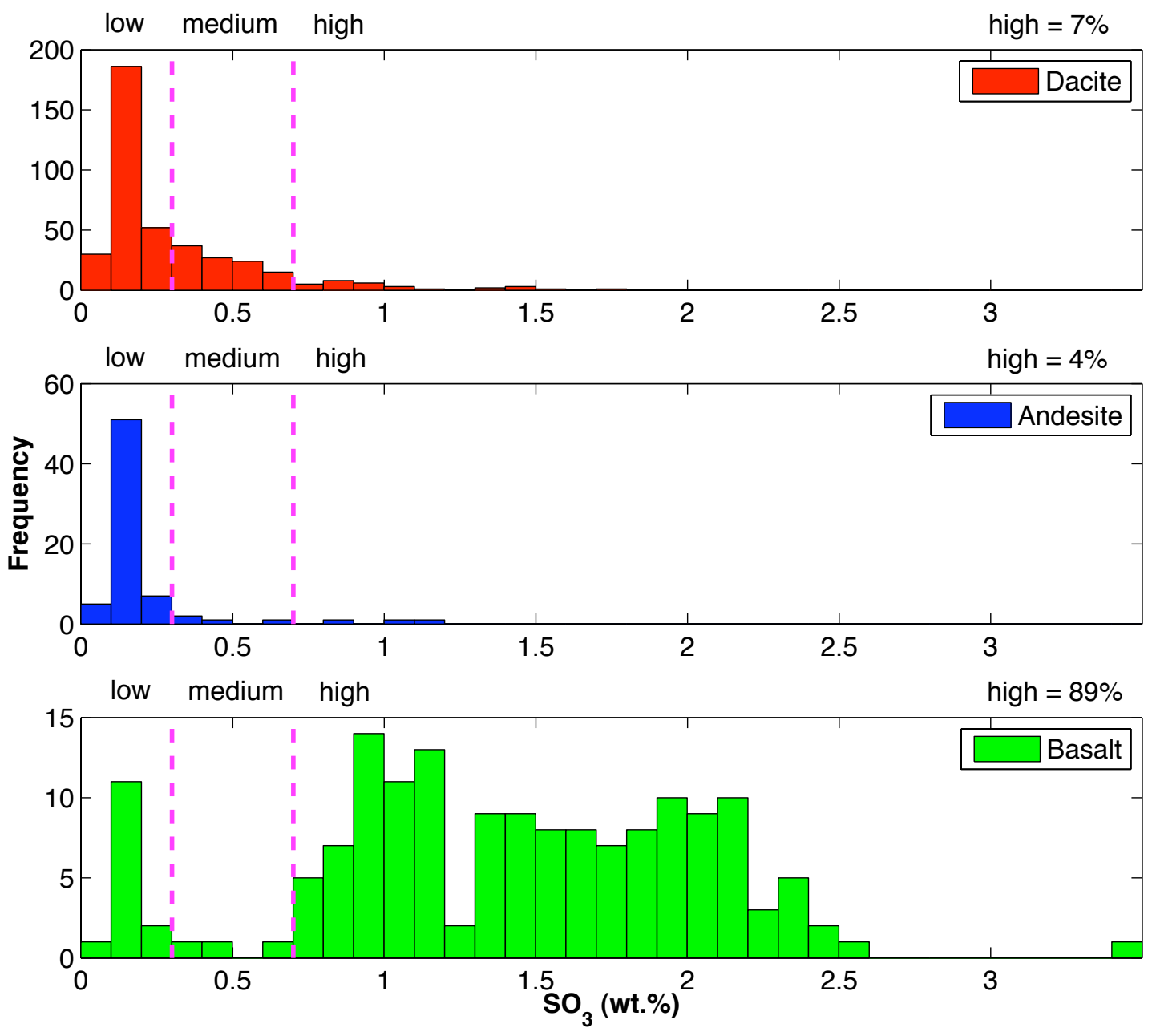

Figure B-1. Histograms showing the distribution of $\mathrm{SO}_{3} \mathrm{wt} . \%$ for each rock type. Number of analyses for each unit, " $n$ ", are as follows: dacite $n=401$, andesite $n=70$, basalt $n=159$. The percentage of high-S apatite ( $\left.>0.7 \mathrm{wt} . \% \mathrm{SO}_{3}\right)$ analyses are reported for each unit: dacite $7 \%$, andesite $4 \%$, and basalt $89 \%$. Purple dashed lines represent the division between low-S and med$\mathrm{S}$ apatites $\left(\mathrm{x}=0.3 \mathrm{wt} . \% \mathrm{SO}_{3}\right)$, and med-S and high-S apatites $\left(\mathrm{x}=0.7 \mathrm{wt.} \% \mathrm{SO}_{3}\right)$. 

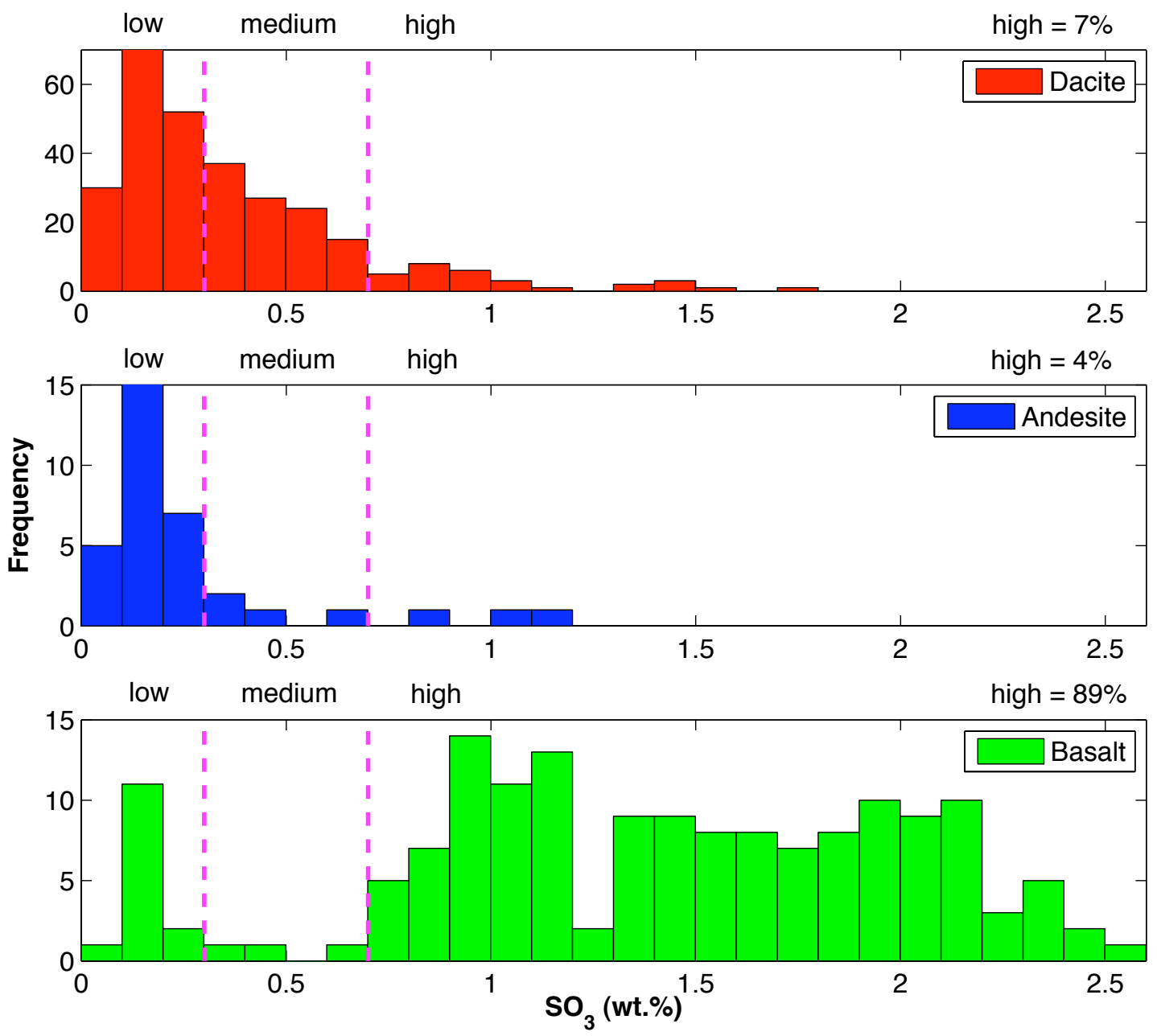

Figure B-1. Continued, histograms showing the distribution of $\mathrm{SO}_{3} \mathrm{wt}$ \% for each rock type. The Frequency $y$-axis has been reduced in the dacite and andesite histograms to zoom-in on the distribution of high-S $\left(>0.7\right.$ wt.\% $\left.\mathrm{SO}_{3}\right)$ apatites. $\mathrm{The}^{\mathrm{SO}_{3}} \mathrm{wt} . \% \mathrm{x}$-axis domain has also been reduced to $[0,2.6]$. 

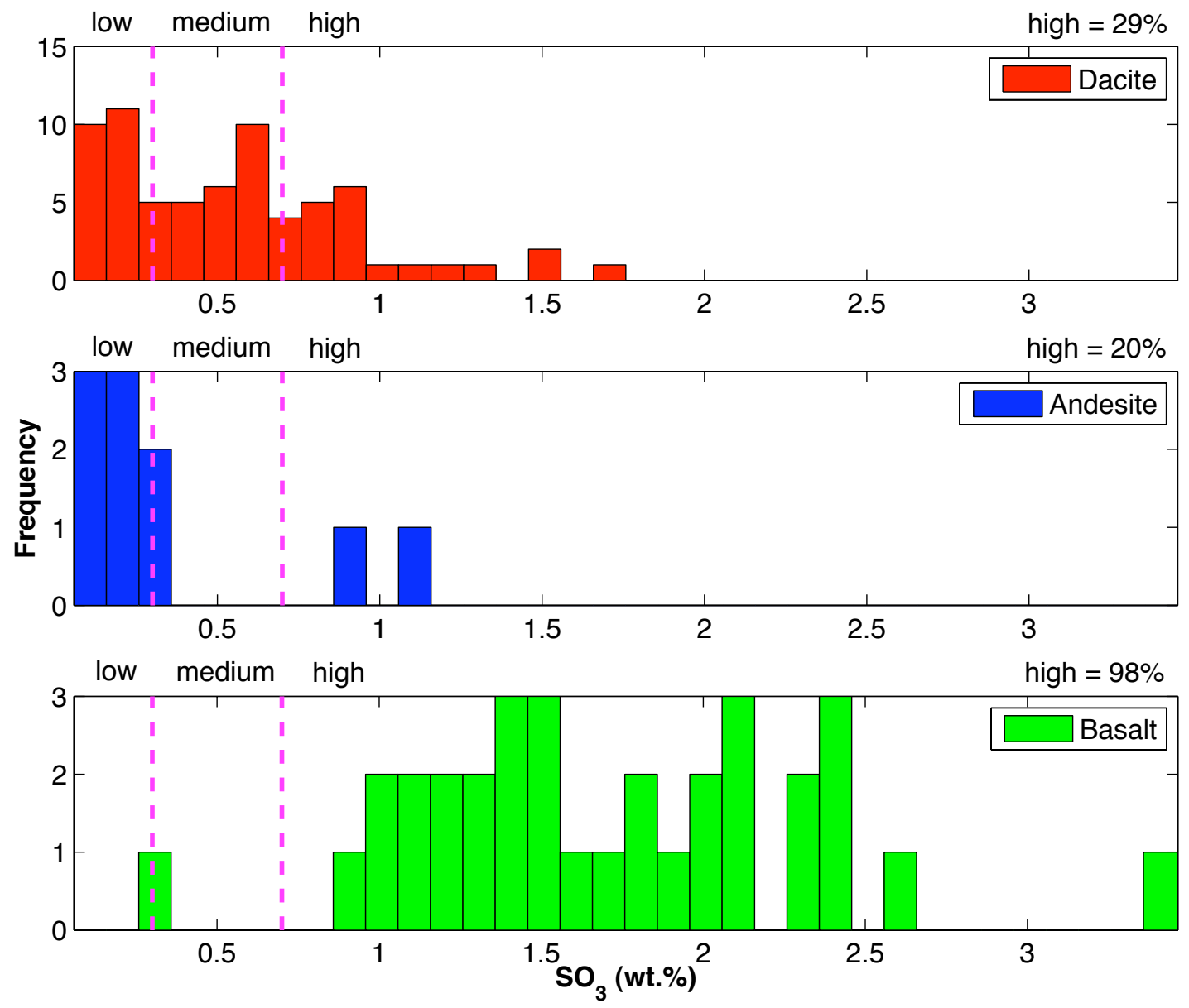

Figure B-1. Continued. Histograms showing the distribution of the highest $\mathrm{SO}_{3} \mathrm{wt} . \%$ value measured in a single apatite grain for each rock type. Number of apatites analyzed for each unit, " $n$ ", are as follows: dacite $n=69$, andesite $n=10$, basalt $n=33$. The percentage of high-S apatite $\left(>0.7\right.$ wt. $\% \mathrm{SO}_{3}$ ) analyses are reported for each unit: dacite $29 \%$, andesite $20 \%$, and basalt $98 \%$. 

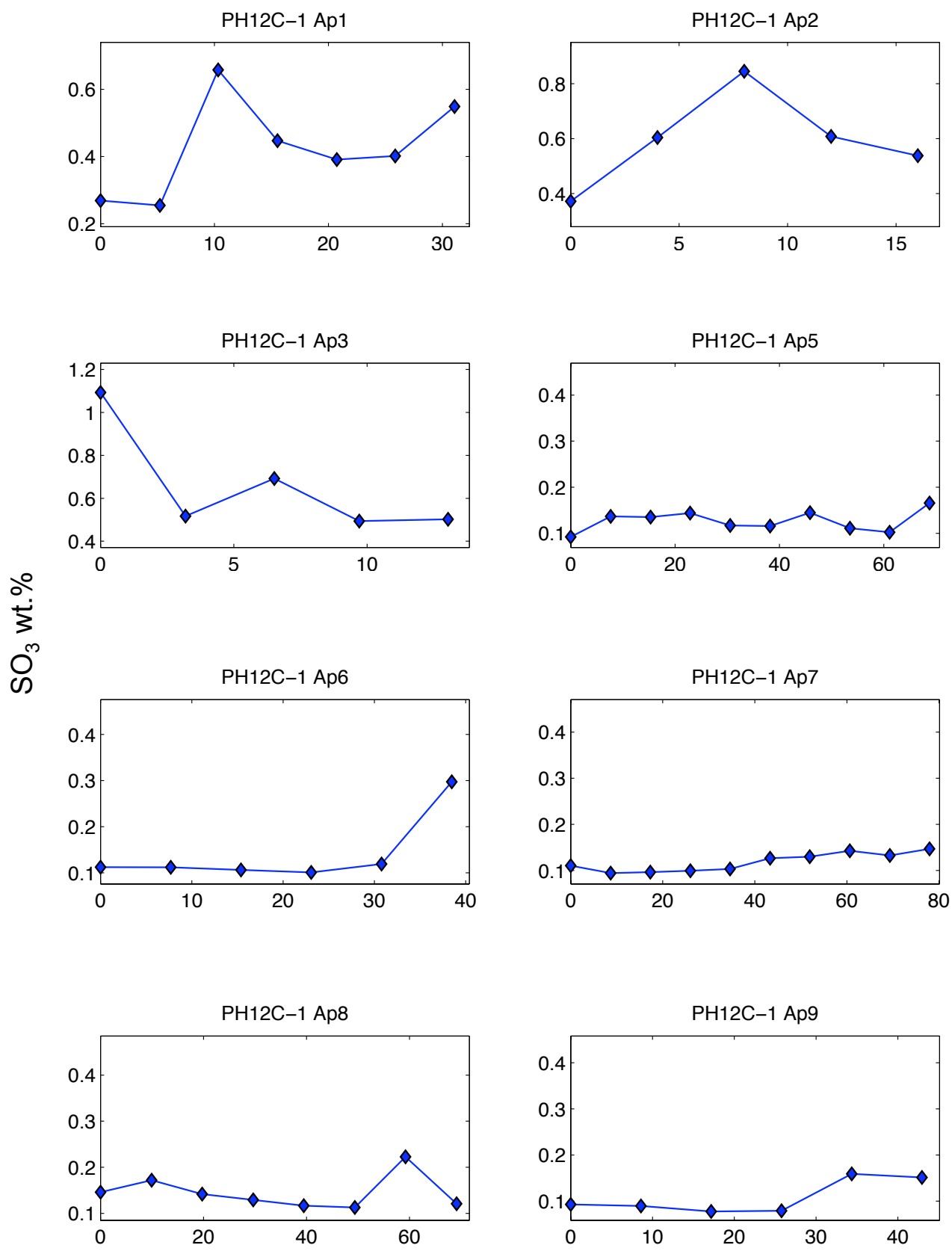

Distance from center to rim $(\mu \mathrm{m})$

Figure B-2: EMP $\mathrm{SO}_{3}$ wt.\% center to rim traverses. 

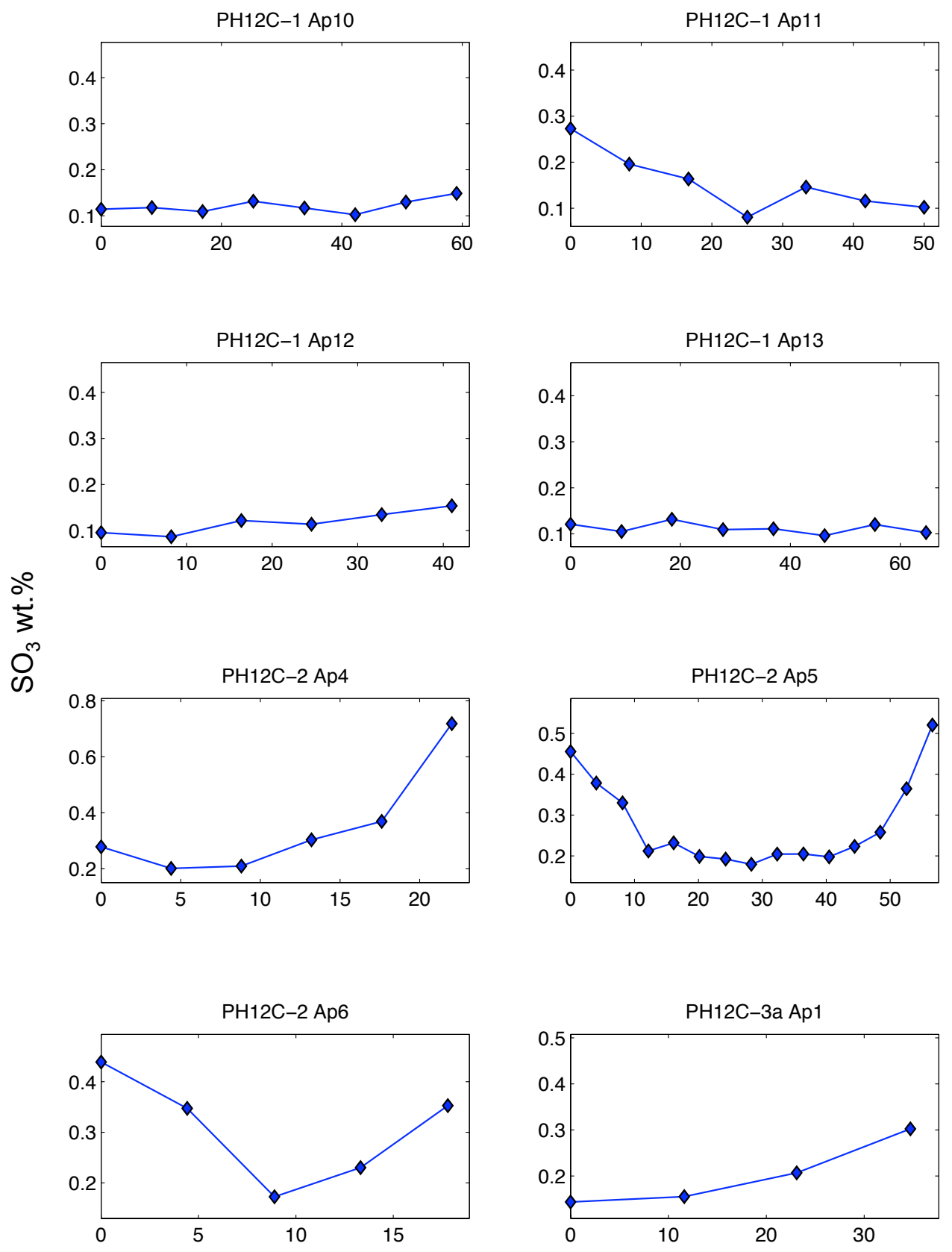

Distance from center to rim $(\mu \mathrm{m})$

Figure B-2: $\mathrm{EMP} \mathrm{SO}_{3}$ wt.\% center to rim traverses. 

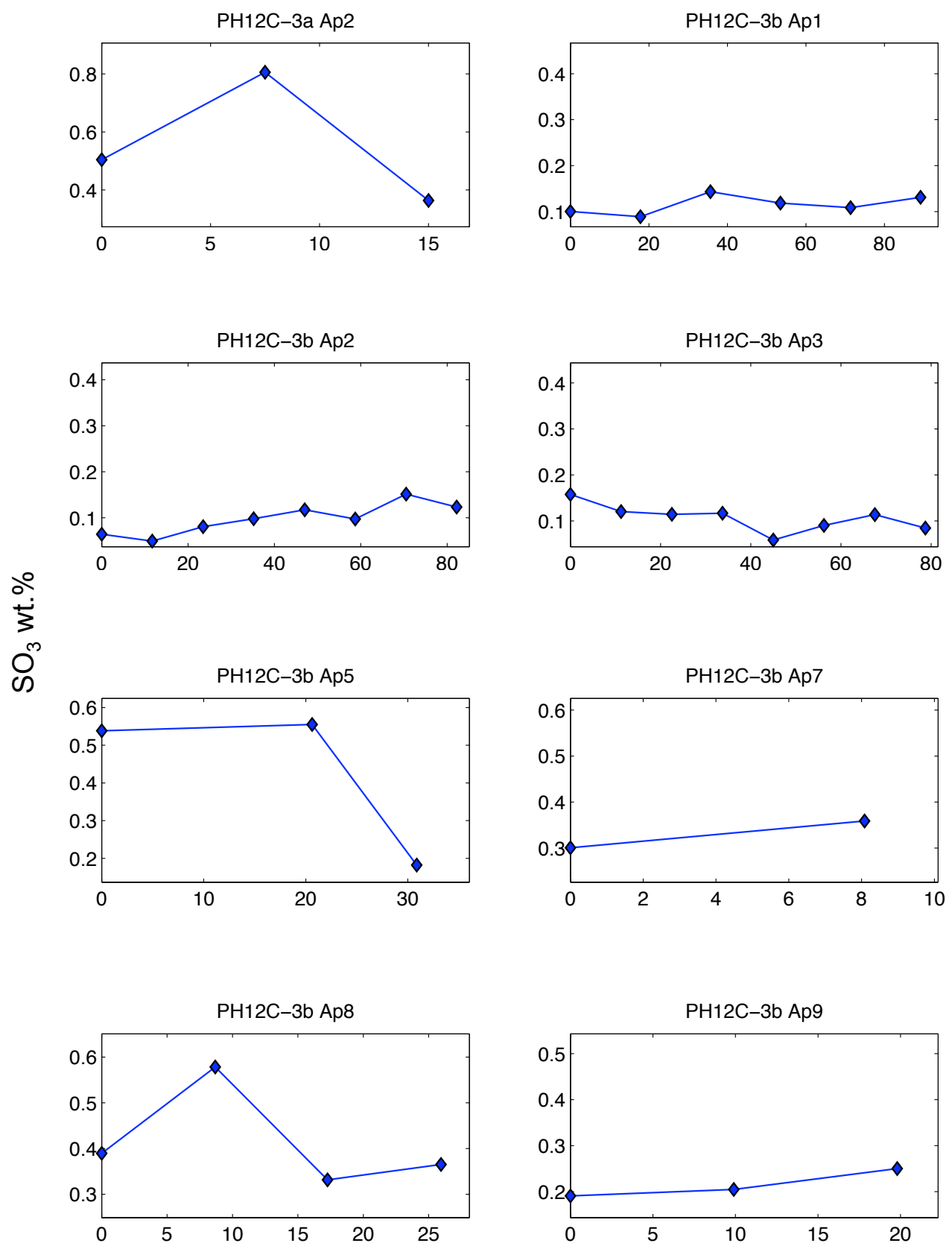

Distance from center to rim $(\mu \mathrm{m})$

Figure B-2: $\mathrm{EMP} \mathrm{SO}_{3}$ wt.\% center to rim traverses. 

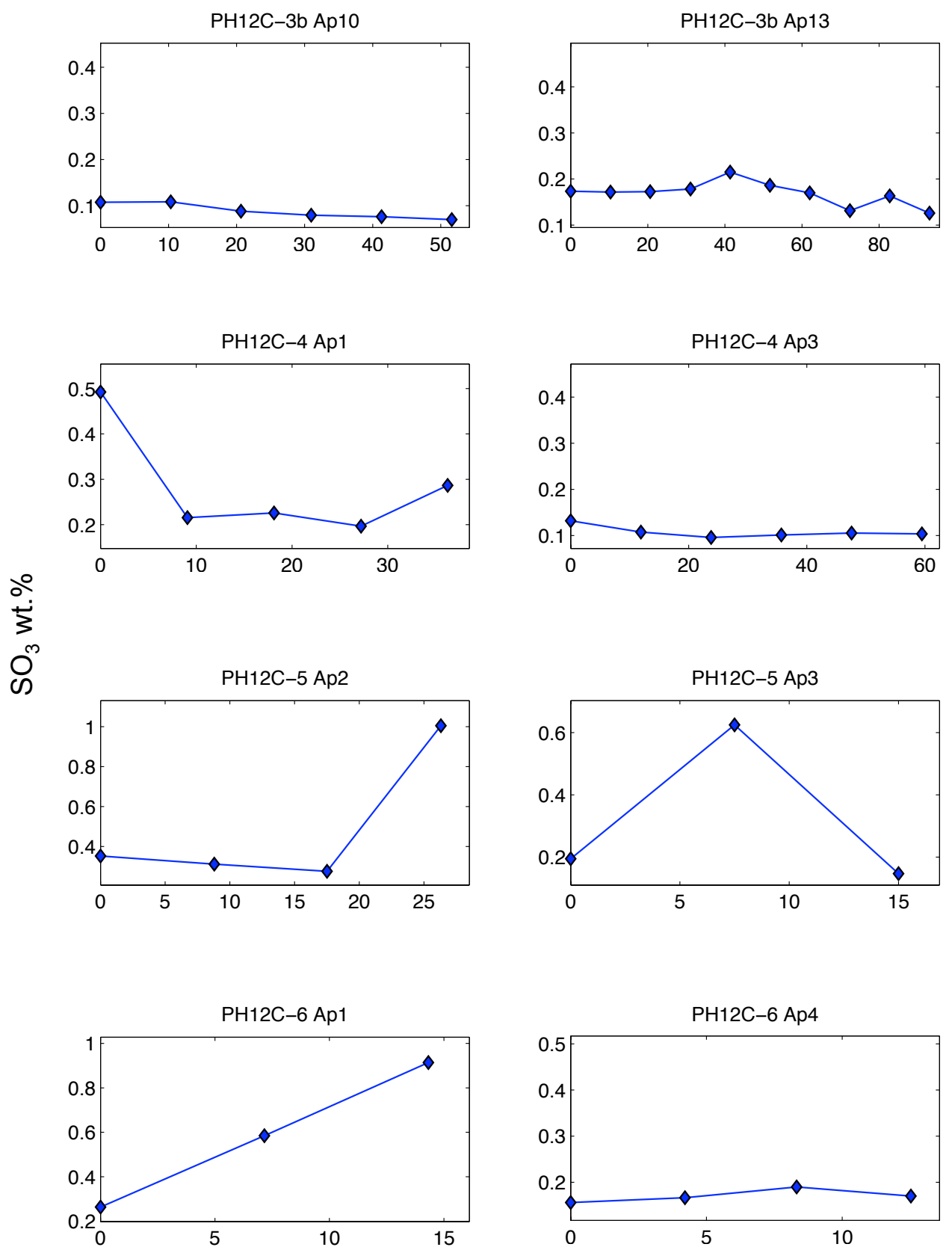

Distance from center to rim $(\mu \mathrm{m})$

Figure B-2: EMP $\mathrm{SO}_{3}$ wt.\% center to rim traverses. 

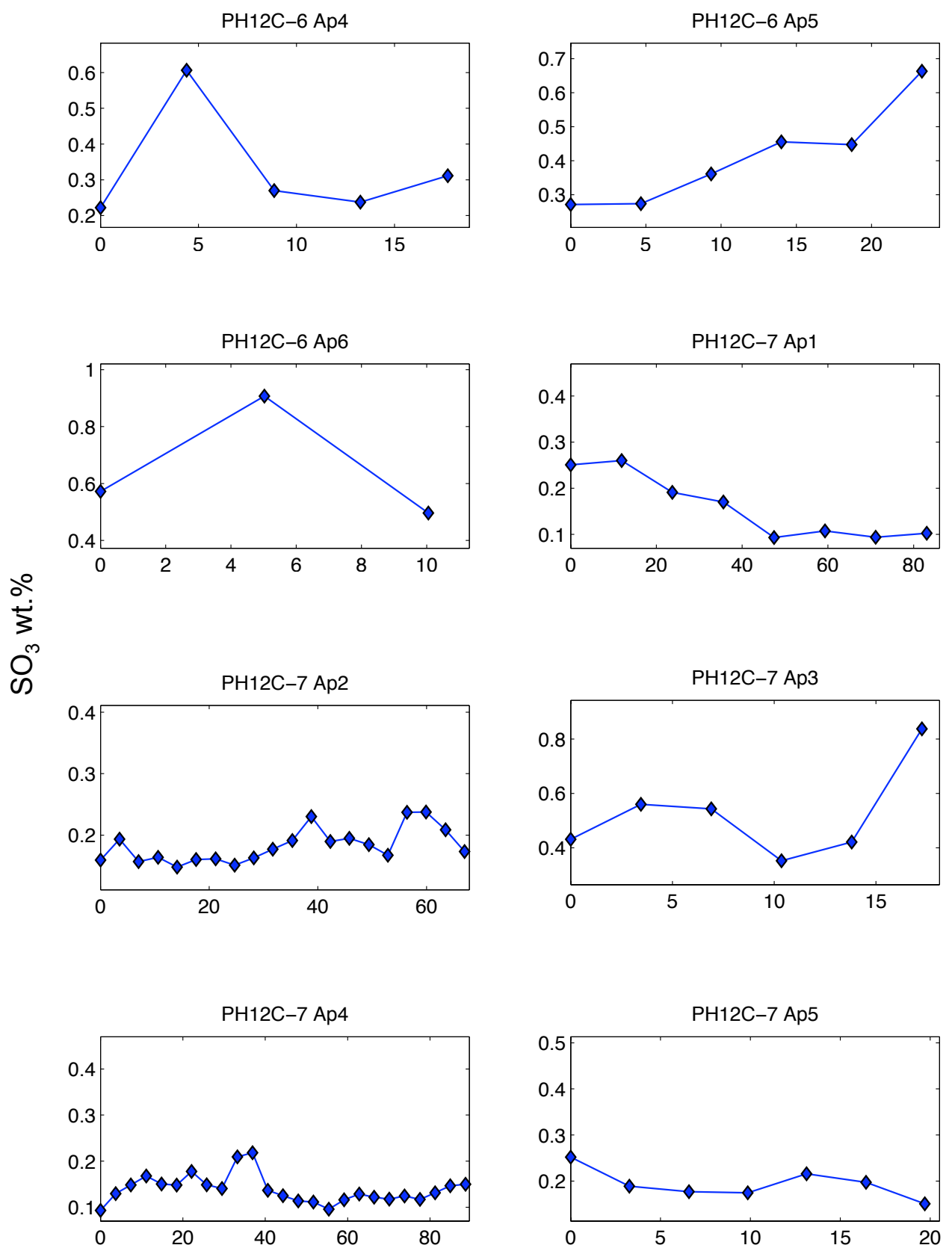

Distance from center to rim $(\mu \mathrm{m})$

Figure B-2: EMP $\mathrm{SO}_{3}$ wt.\% center to rim traverses. 

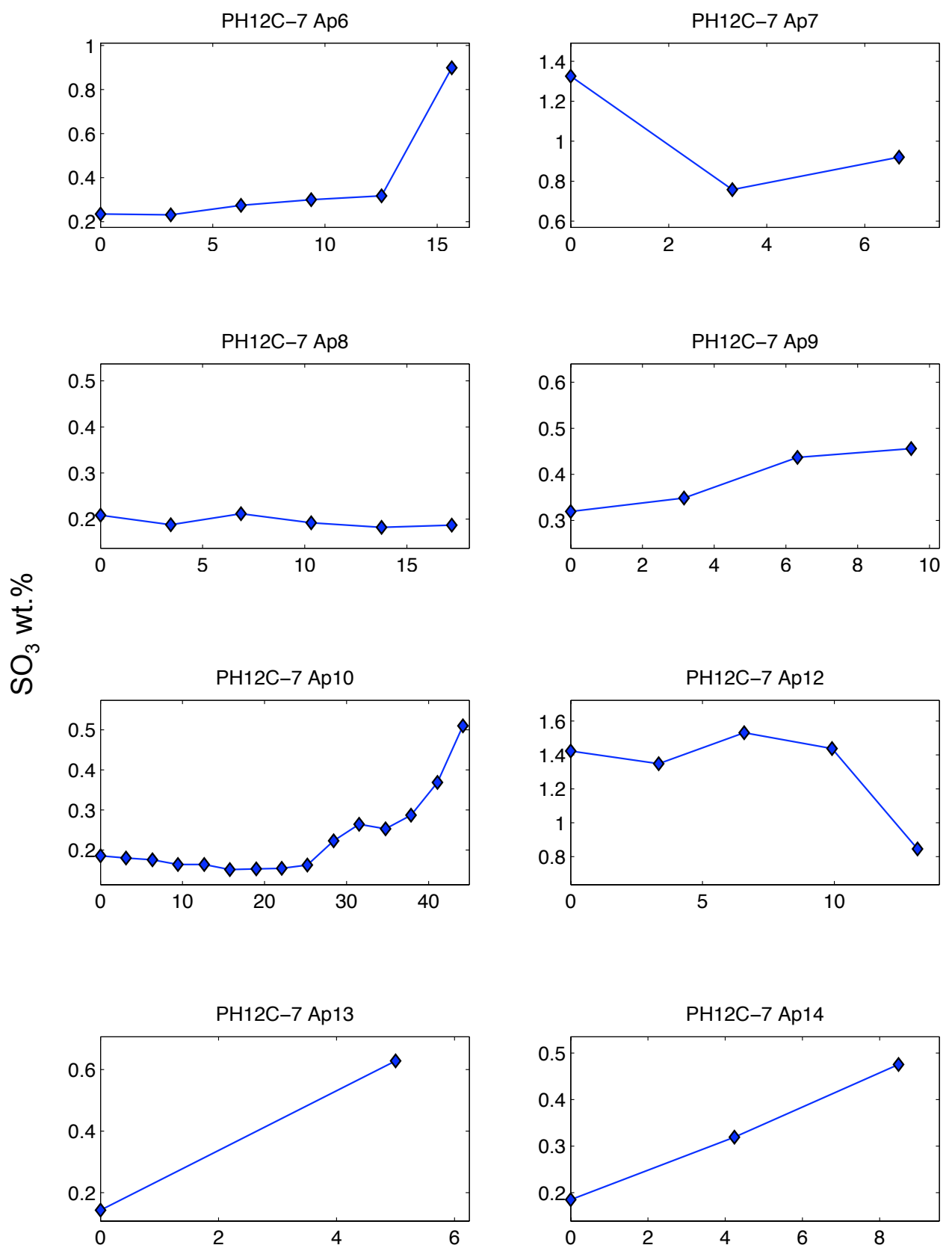

Distance from center to rim $(\mu \mathrm{m})$

Figure B-2: EMP $\mathrm{SO}_{3}$ wt.\% center to rim traverses. 

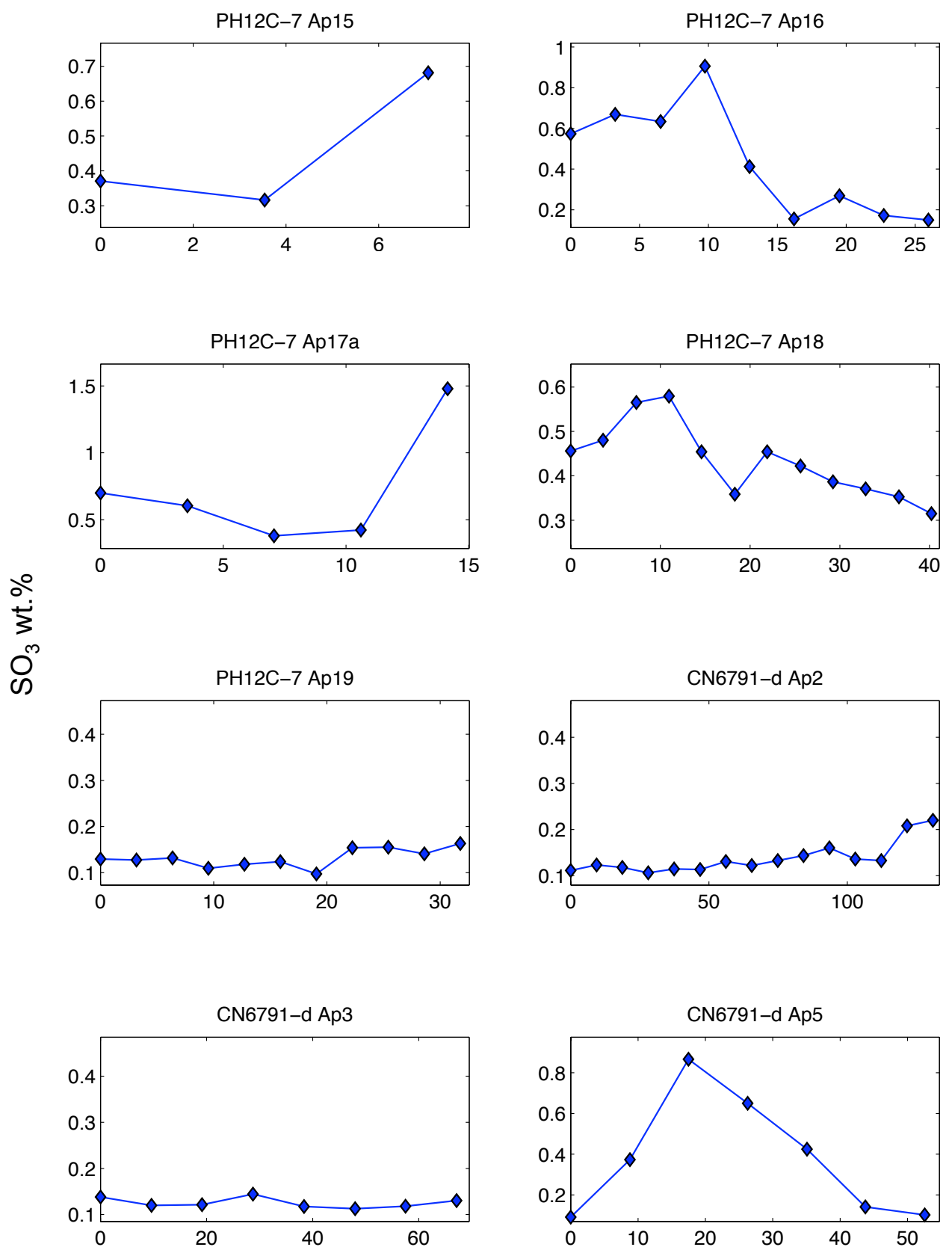

Distance from center to rim $(\mu \mathrm{m})$

Figure B-2: $\mathrm{EMP} \mathrm{SO}_{3}$ wt.\% center to rim traverses. 

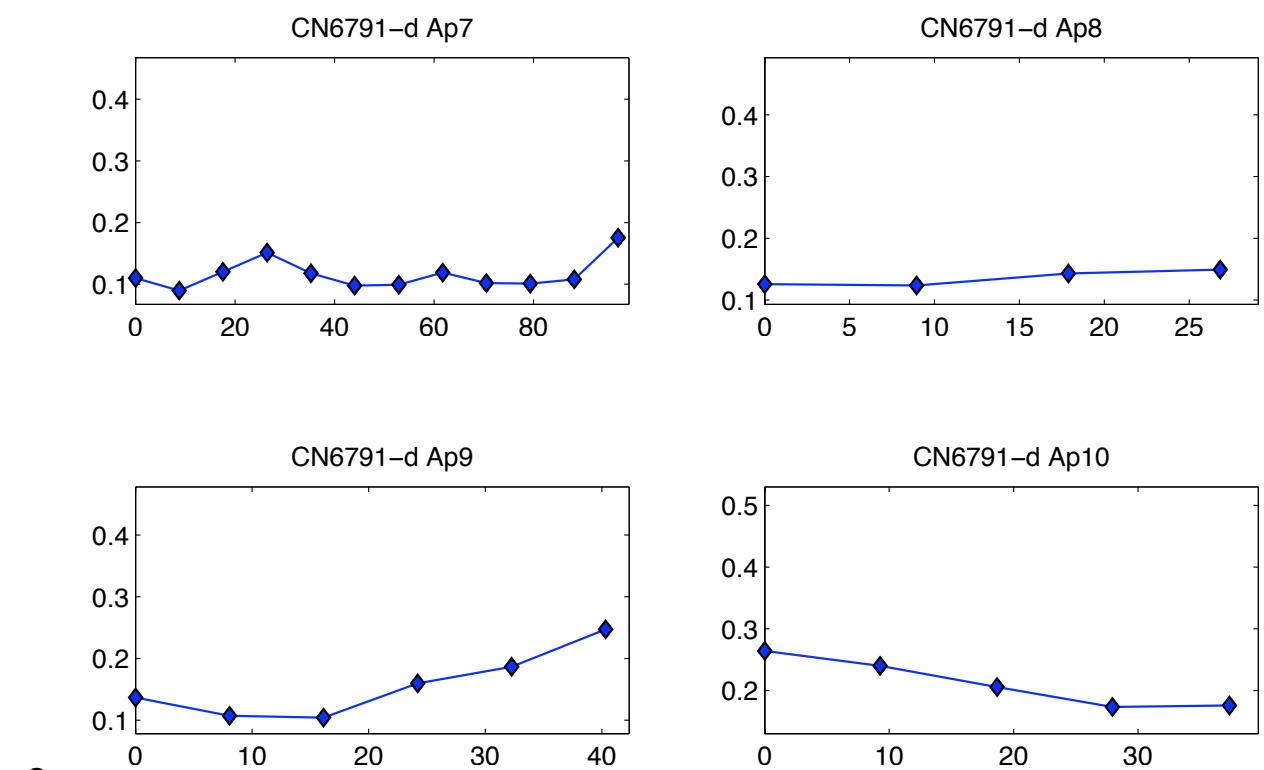

¿̊
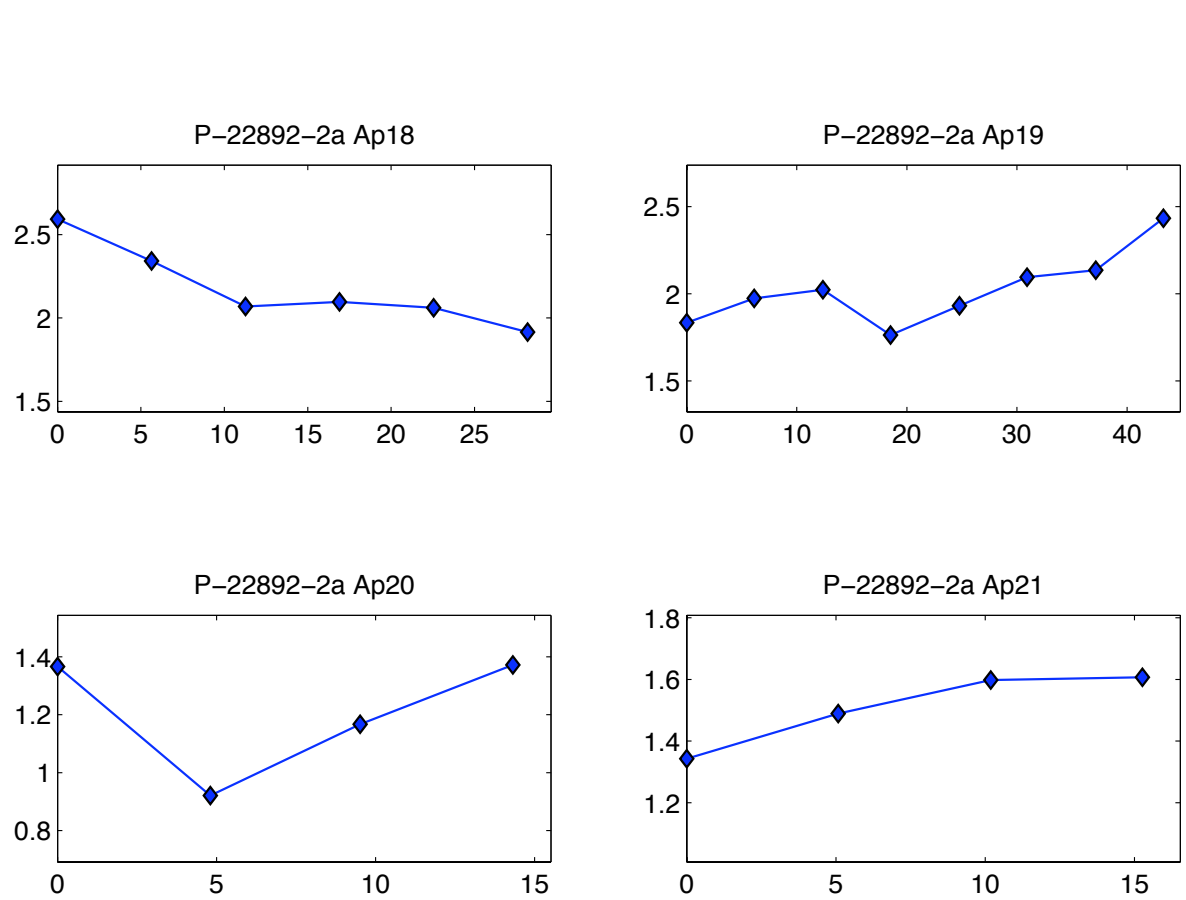

Distance from center to rim $(\mu \mathrm{m})$

Figure B-2: $\mathrm{EMP} \mathrm{SO}_{3}$ wt.\% center to rim traverses. 

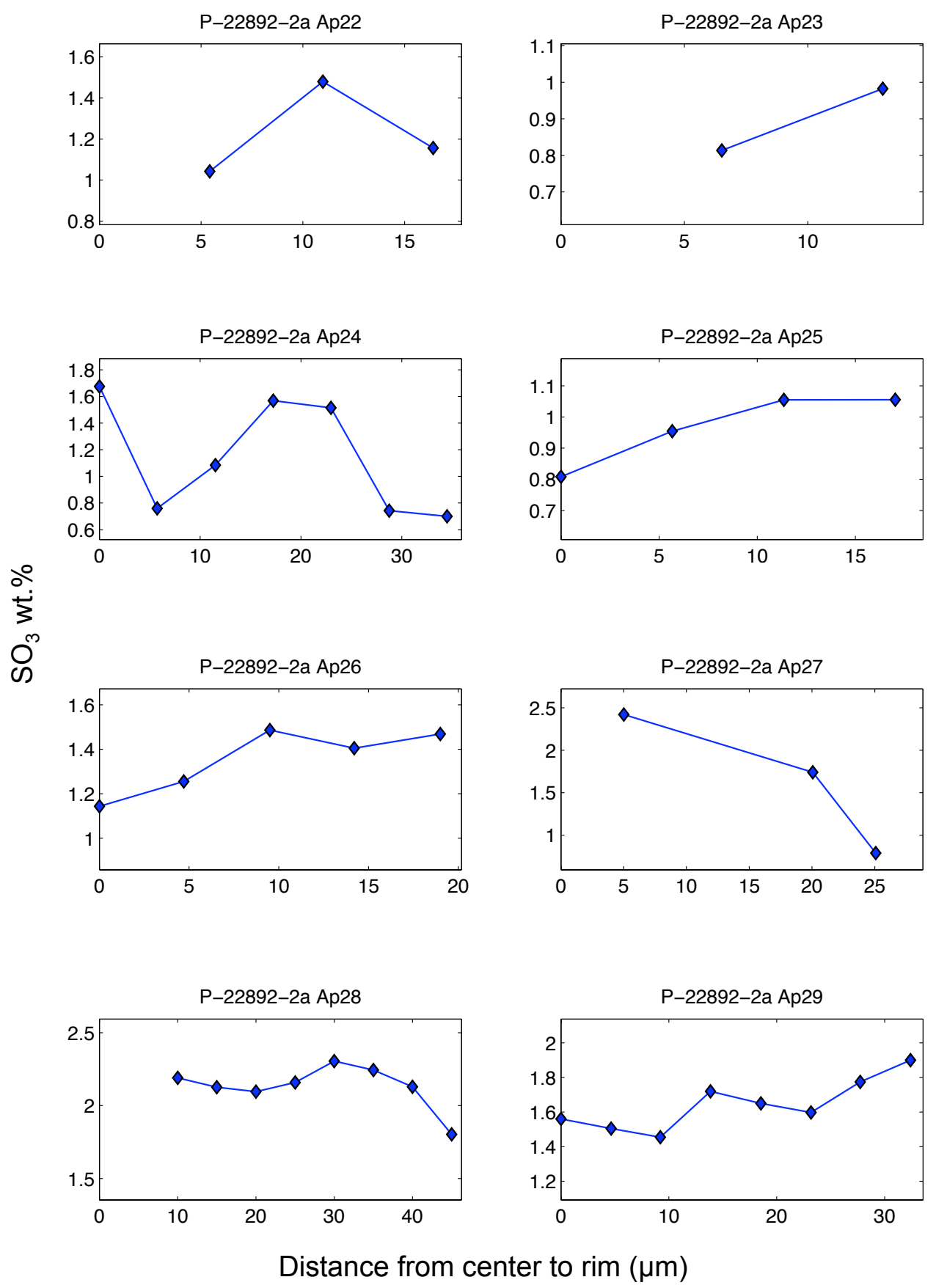

Figure B-2: $\mathrm{EMP} \mathrm{SO}_{3}$ wt.\% center to rim traverses. 


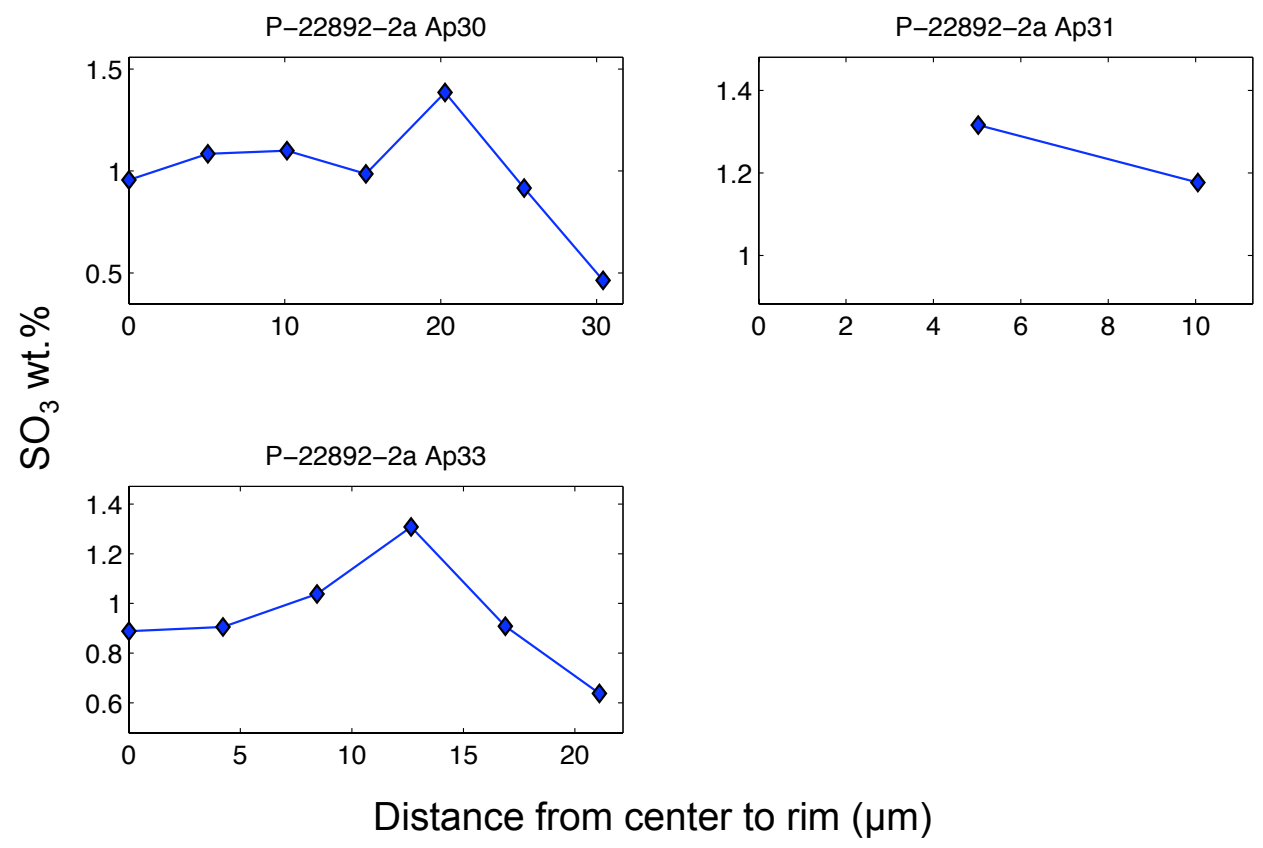

Figure B-2: EMP $\mathrm{SO}_{3}$ wt.\% center to rim traverses. 

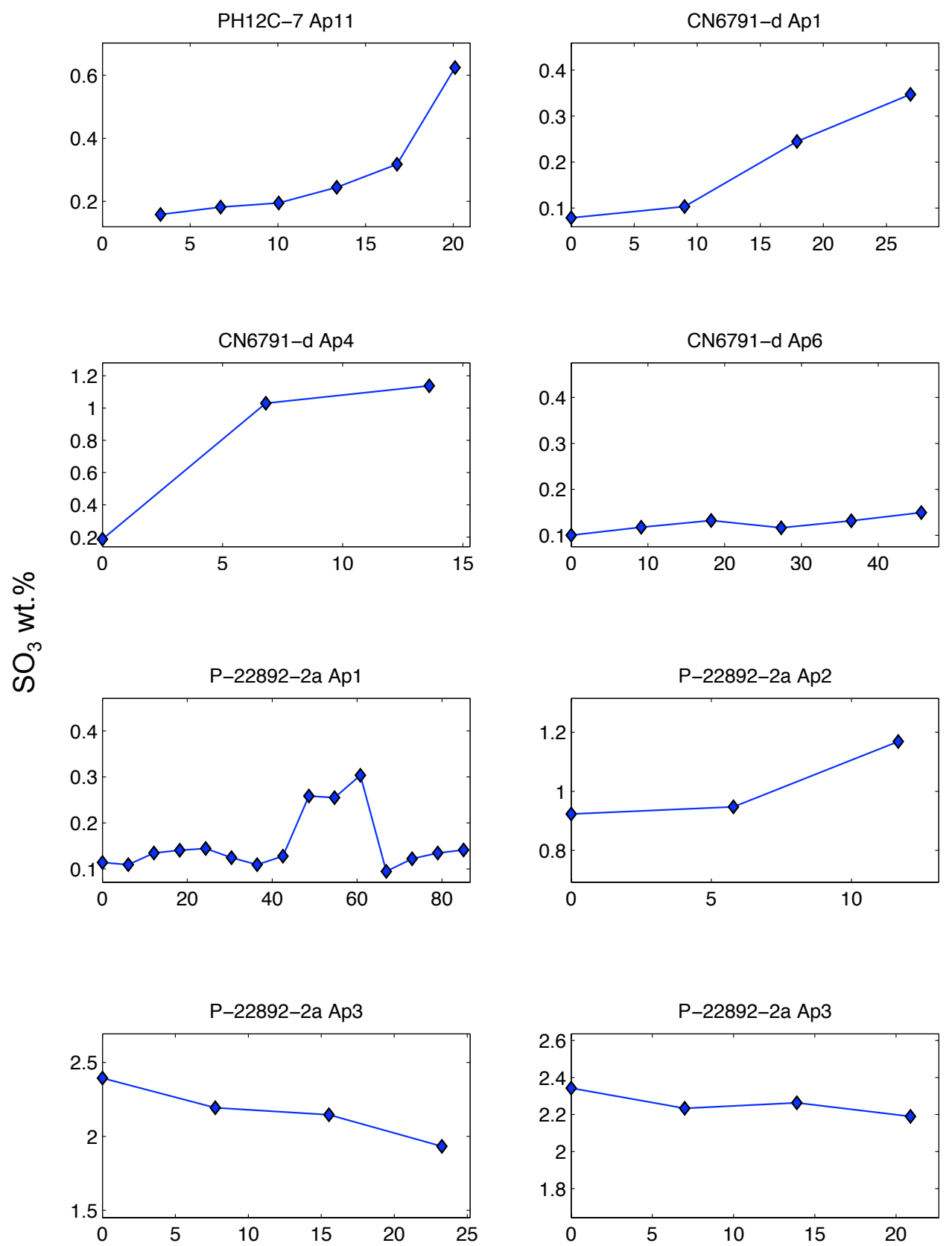

Distance from rim to rim $(\mu \mathrm{m})$

Figure B-2: $\mathrm{EMP} \mathrm{SO}_{3}$ wt.\% rim to rim traverses. 

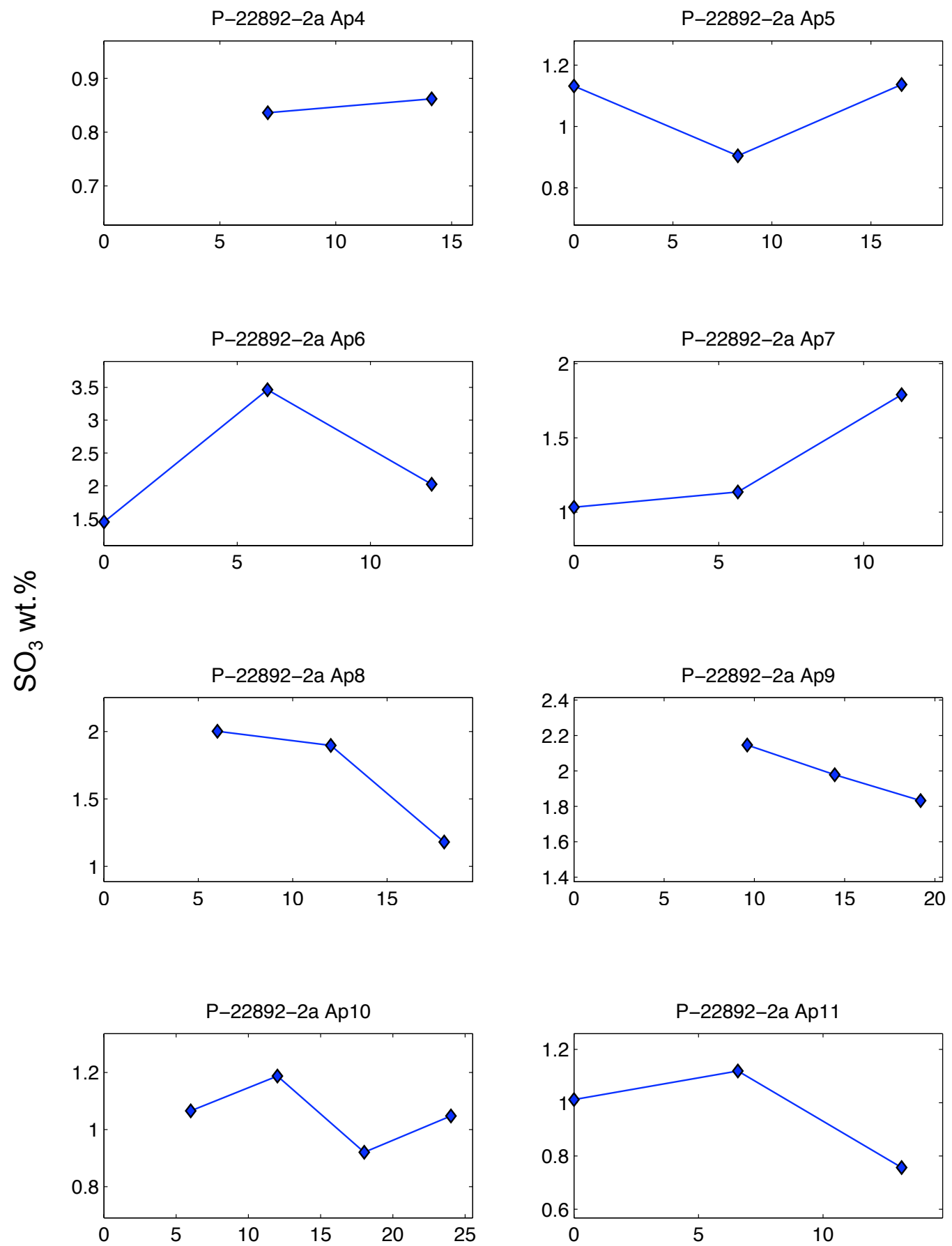

Distance from rim to rim $(\mu \mathrm{m})$

Figure B-2: $\mathrm{EMP} \mathrm{SO}_{3}$ wt.\% rim to rim traverses. 

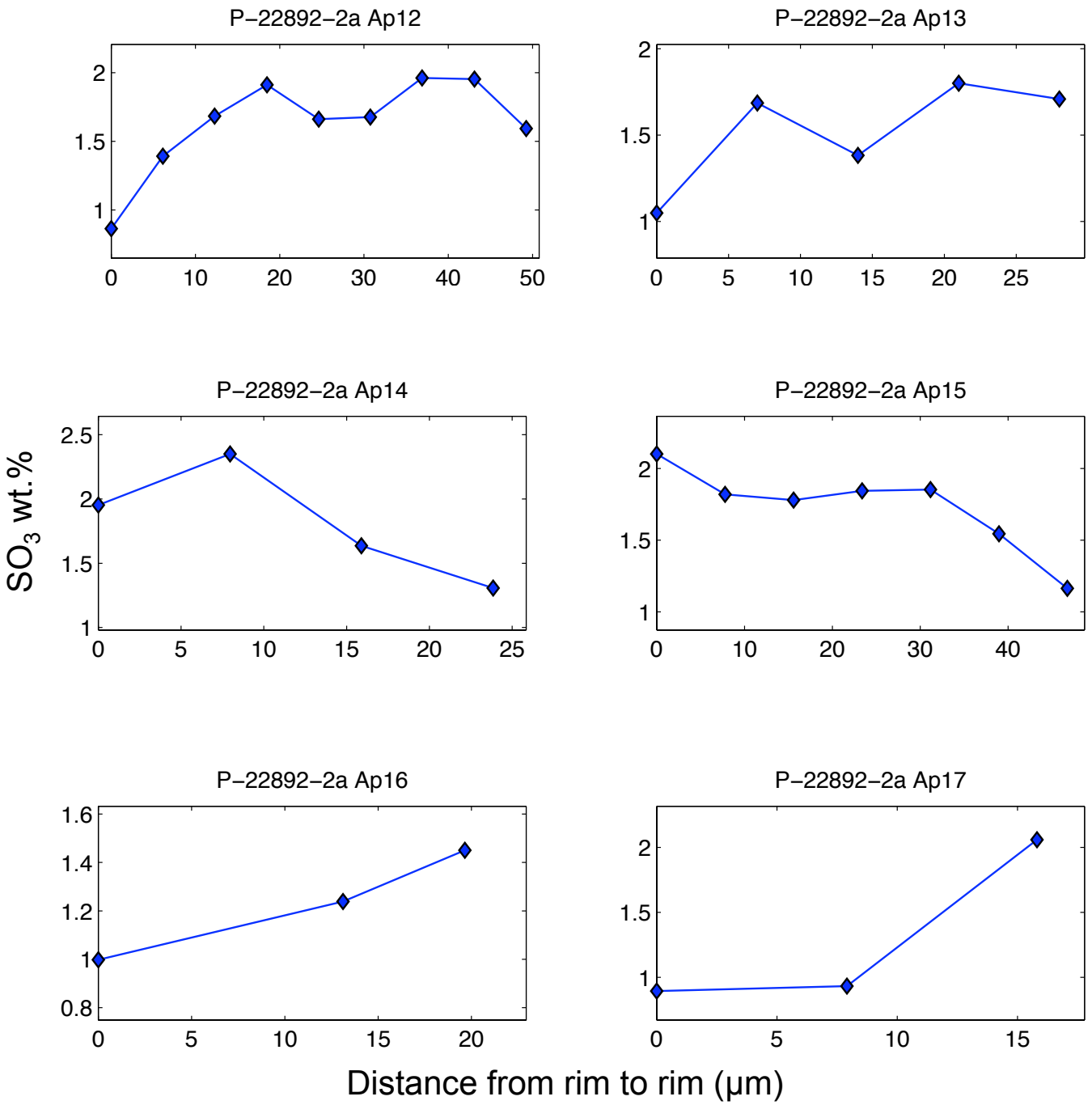

Figure B-2: $\mathrm{EMP} \mathrm{SO}_{3}$ wt.\% rim to rim traverses. 


\section{APPENDIX C: LA-ICP-MS}

\section{ETH}

LA-ICP-MS data were acquired at ETH Zurich, Switzerland using a 193nm ArF Excimer laser coupled with an ELAN 6100 ICP quadrupole mass spectrometer. Laser settings were $23,24,28$, and $30 \mathrm{kV}$ and a $10 \mathrm{~Hz}$ repetition rate, yielding a fluence of about $12 \mathrm{~J} / \mathrm{cm}^{2}$ on the ablation site. Beam size was determined based upon grain size: 15,20 , and $40 \mu \mathrm{m}$ for apatites, $15-20 \mu \mathrm{m}$ for anhydrite hosts and matrix glass, and 20 and $40 \mu \mathrm{m}$ for plagioclase and hornblende hosts.

The MATLAB-based program, SILLS, was used to process all LA-ICP-MS data. SILLS uses a user interface window to select integration intervals of background levels, signal, and matrix. Signal intervals for apatite were chosen to minimize contamination from host minerals, such as anhydrite, hornblende, and plagioclase, or matrix glass. To calibrate these data, both an internal and external standard is used. The internal standard for apatites was $\mathrm{CaO}=54$ wt.\% (derived from EMP data), and the external standard used in this study was NIST 610. If the apatite signal was low, further calibration parameters were entered to further filter the apatite signal from the surrounding matrix. These parameters included a matrix internal standard, and a second apatite parameter. $\mathrm{CaO}=42 \mathrm{wt} . \%$ was used as the matrix internal standard for anhydrite hosts, and $\mathrm{EMP}^{\mathrm{SiO}}{ }_{2}$ wt.\% values presented in Pallister et al., 1996 were used for hornblende and plagioclase hosts. Total oxides were set to $100 \%$ for matrix glass. The second calibration parameter for apatite in an anhydrite host was an 
equation that defined the ratio of $\mathrm{Ca} / \mathrm{P}=2$. This equation was also used for matrix glass contamination. Apatites in a hornblende or plagioclase host used a matrix-only tracer, such as $\mathrm{K}$ or Al, as a second calibration parameter. LA-ICP-MS results are listed in Table C-1. Error summaries and detection limits are listed in Table C-2. 
Table C- 1. ETH LA-ICP-MS data reduced using SILLS (major elements in wt.\%, trace elements in $\mathrm{ppm})$. $\mathrm{CaO}=54 \mathrm{wt} . \%$ was used as an internal standard.

\begin{tabular}{|c|c|c|c|c|c|c|c|}
\hline & $\begin{array}{l}\text { PH12C-1 } \\
\text { ap5 pt1 }\end{array}$ & $\begin{array}{l}\text { PH12C-1 } \\
\text { ap5 pt2 }\end{array}$ & $\begin{array}{c}\text { PH12C-1 } \\
\text { ap6 }\end{array}$ & $\begin{array}{c}\text { PH12C-1 } \\
\text { ap7 }\end{array}$ & $\begin{array}{l}\text { PH12C-1 } \\
\text { ap8 pt1 }\end{array}$ & $\begin{array}{c}\text { PH12C-1 } \\
\text { ap8 pt2 }\end{array}$ & $\begin{array}{c}\text { PH12C-1 } \\
\text { ap9 }\end{array}$ \\
\hline $\mathrm{SiO}_{2}$ & 0.17 & 0.18 & 0.14 & 0.12 & 0.12 & 0.09 & 0.13 \\
\hline $\mathrm{TiO}_{2}$ & n.d. & n.d. & n.d. & 0.00 & 0.00 & n.d. & 0.00 \\
\hline $\mathrm{Al}_{2} \mathrm{O}_{3}$ & n.d. & n.d. & n.d. & n.d. & n.d. & n.d. & n.d. \\
\hline $\mathrm{FeO}^{*}$ & 0.29 & 0.30 & 0.30 & 0.30 & 0.27 & 0.28 & 0.29 \\
\hline $\mathrm{MnO}$ & 0.18 & 0.19 & 0.18 & 0.19 & 0.19 & 0.18 & 0.21 \\
\hline $\mathrm{MgO}$ & 0.17 & 0.16 & 0.17 & 0.17 & 0.16 & 0.17 & 0.17 \\
\hline $\mathrm{CaO}$ & 54 & 54 & 54 & 54 & 54 & 54 & 54 \\
\hline $\mathrm{Na}_{2} \mathrm{O}$ & 0.13 & 0.14 & 0.11 & 0.11 & 0.11 & 0.12 & 0.12 \\
\hline $\mathrm{K}_{2} \mathrm{O}$ & n.d. & n.d. & n.d. & n.d. & n.d. & n.d. & n.d. \\
\hline $\mathrm{P}_{2} \mathrm{O}_{5}$ & 38.0 & 38.7 & 35.4 & 33.9 & 33.4 & 33.1 & 34.8 \\
\hline $\mathrm{S}$ & 908 & 1224 & 694 & 640 & 684 & 705 & 758 \\
\hline $\mathrm{Sc}$ & n.d. & n.d. & n.d. & 0.26 & 0.20 & 0.25 & 0.24 \\
\hline $\mathrm{Cr}$ & n.d. & n.d. & n.d. & n.d. & n.d. & n.d. & n.d. \\
\hline $\mathrm{Ni}$ & n.d. & n.d. & n.d. & n.d. & n.d. & n.d. & 1.88 \\
\hline $\mathrm{Cu}$ & n.d. & n.d. & n.d. & 0.22 & n.d. & n.d. & n.d. \\
\hline $\mathrm{Zn}$ & 3.42 & n.d. & 2.96 & 2.14 & 2.25 & 2.13 & 2.33 \\
\hline $\mathrm{Rb}$ & n.d. & n.d. & 0.06 & n.d. & 0.03 & 0.03 & n.d. \\
\hline $\mathrm{Sr}$ & 605 & 596 & 571 & 593 & 658 & 614 & 589 \\
\hline Y & 291 & 296 & 245 & 258 & 274 & 237 & 261 \\
\hline $\mathrm{Zr}$ & 0.57 & 0.86 & 0.53 & 0.50 & 0.82 & 0.65 & 0.73 \\
\hline $\mathrm{Nb}$ & n.d. & n.d. & n.d. & n.d. & n.d. & n.d. & n.d. \\
\hline $\mathrm{Ba}$ & 3.51 & 4.31 & 4.46 & 4.09 & 4.53 & 4.34 & 3.80 \\
\hline $\mathrm{Pb}$ & 2.94 & 3.41 & 3.52 & 3.00 & 2.71 & 2.82 & 3.81 \\
\hline Th & 20.8 & 20.0 & 16.9 & 15.4 & 18.0 & 15.5 & 17.1 \\
\hline $\mathrm{U}$ & 6.89 & 7.99 & 7.02 & 6.29 & 7.13 & 5.81 & 6.71 \\
\hline $\mathrm{La}$ & 812 & 816 & 696 & 754 & 824 & 722 & 748 \\
\hline $\mathrm{Ce}$ & 1912 & 1939 & 1747 & 1743 & 1898 & 1683 & 1785 \\
\hline $\operatorname{Pr}$ & 221 & 225 & 206 & 205 & 221 & 196 & 215 \\
\hline $\mathrm{Nd}$ & 868 & 871 & 787 & 813 & 855 & 767 & 845 \\
\hline $\mathrm{Sm}$ & 128 & 135 & 116 & 123 & 128 & 113 & 126 \\
\hline $\mathrm{Eu}$ & 21 & 22 & 20 & 20 & 21 & 19 & 20 \\
\hline $\mathrm{Gd}$ & 102 & 107 & 91 & 93 & 94 & 87 & 100 \\
\hline $\mathrm{Tb}$ & 11 & 12 & 10 & 11 & 11 & 10 & 11 \\
\hline Dy & 60 & 60 & 53 & 53 & 53 & 47 & 53 \\
\hline Но & 10 & 10 & 9 & 9 & 9 & 8 & 10 \\
\hline Er & 25 & 26 & 22 & 25 & 25 & 24 & 24 \\
\hline $\mathrm{Yb}$ & 19 & 20 & 18 & 18 & 17 & 16 & 18 \\
\hline
\end{tabular}

n.d. $=$ not detected 
Table C- 1. Continued.

\begin{tabular}{|c|c|c|c|c|c|c|c|}
\hline & $\begin{array}{c}\text { PH12C-1 } \\
\text { ap10 } \\
\end{array}$ & $\begin{array}{l}\text { PH12C-1 } \\
\text { ap11 pt1 }\end{array}$ & $\begin{array}{l}\text { PH12C-1 } \\
\text { ap11 pt2 }\end{array}$ & $\begin{array}{c}\text { PH12C-1 } \\
\text { ap12 } \\
\end{array}$ & $\begin{array}{c}\text { PH12C-1 } \\
\text { ap13 } \\
\end{array}$ & $\begin{array}{l}\text { PH12C-2 } \\
\text { ap1 pt1 }\end{array}$ & $\begin{array}{l}\text { PH12C-2 } \\
\text { ap1 pt2 }\end{array}$ \\
\hline $\mathrm{SiO}_{2}$ & 0.13 & 0.12 & 0.09 & 0.12 & 0.15 & n.d. & n.d. \\
\hline $\mathrm{TiO}_{2}$ & n.d. & n.d. & 0.00 & n.d. & n.d. & n.d. & n.d. \\
\hline $\mathrm{Al}_{2} \mathrm{O}_{3}$ & n.d. & n.d. & n.d. & n.d. & 0.00 & 0.48 & 2.46 \\
\hline $\mathrm{FeO}^{*}$ & 0.28 & 0.28 & 0.28 & 0.28 & 0.24 & 0.05 & 0.03 \\
\hline $\mathrm{MnO}$ & 0.18 & 0.19 & 0.19 & 0.18 & 0.18 & 0.16 & 0.20 \\
\hline $\mathrm{MgO}$ & 0.17 & 0.17 & 0.17 & 0.16 & 0.15 & 0.11 & 0.14 \\
\hline $\mathrm{CaO}$ & 54 & 54 & 54 & 54 & 54 & 54 & 54 \\
\hline $\mathrm{Na}_{2} \mathrm{O}$ & 0.12 & 0.14 & 0.14 & 0.14 & 0.12 & 0.37 & 1.62 \\
\hline $\mathrm{K}_{2} \mathrm{O}$ & 0.00 & n.d. & n.d. & n.d. & 0.00 & n.d. & n.d. \\
\hline $\mathrm{P}_{2} \mathrm{O}_{5}$ & 33.8 & 39.6 & 39.1 & 37.9 & 38.1 & 44.2 & 44.2 \\
\hline $\mathrm{S}$ & 686 & 1326 & 773 & 915 & 913 & n.d. & n.d. \\
\hline $\mathrm{Sc}$ & 0.22 & n.d. & n.d. & 0.57 & 0.33 & n.d. & n.d. \\
\hline $\mathrm{Cr}$ & n.d. & n.d. & n.d. & n.d. & n.d. & n.d. & n.d. \\
\hline $\mathrm{Ni}$ & n.d. & n.d. & n.d. & n.d. & n.d. & n.d. & n.d. \\
\hline $\mathrm{Cu}$ & 0.22 & n.d. & n.d. & n.d. & 0.22 & n.d. & 246 \\
\hline $\mathrm{Zn}$ & 2.09 & 2.69 & 2.52 & 1.37 & 1.68 & n.d. & n.d. \\
\hline $\mathrm{Rb}$ & n.d. & n.d. & n.d. & 0.12 & 0.05 & 0.27 & n.d. \\
\hline $\mathrm{Sr}$ & 593 & 584 & 590 & 598 & 424 & 614 & 695 \\
\hline Y & 262 & 294 & 285 & 274 & 364 & 330 & 392 \\
\hline $\mathrm{Zr}$ & 0.63 & 0.67 & 0.52 & 1.06 & 0.45 & 0.27 & 0.57 \\
\hline $\mathrm{Nb}$ & n.d. & n.d. & n.d. & n.d. & n.d. & 0.05 & n.d. \\
\hline $\mathrm{Ba}$ & 4.05 & 3.38 & 3.49 & 4.08 & 3.68 & 5.23 & 28.83 \\
\hline $\mathrm{Pb}$ & 3.56 & 3.63 & 2.95 & 2.98 & 3.06 & 14.03 & 2.05 \\
\hline Th & 15.4 & 21.0 & 19.7 & 21.1 & 16.5 & 26.0 & 32.6 \\
\hline $\mathrm{U}$ & 6.00 & 7.48 & 7.41 & 8.38 & 7.44 & 9.81 & 13.3 \\
\hline $\mathrm{La}$ & 776 & 797 & 780 & 790 & 336 & 852 & 988 \\
\hline $\mathrm{Ce}$ & 1805 & 1915 & 1873 & 1873 & 1079 & 2465 & 2391 \\
\hline $\operatorname{Pr}$ & 215 & 226 & 222 & 219 & 150 & 273 & 287 \\
\hline $\mathrm{Nd}$ & 829 & 873 & 867 & 854 & 648 & 978 & 1139 \\
\hline $\mathrm{Sm}$ & 124 & 140 & 133 & 130 & 127 & 159 & 172 \\
\hline $\mathrm{Eu}$ & 21 & 22 & 22 & 22 & 21 & 23 & 25 \\
\hline $\mathrm{Gd}$ & 96 & 104 & 103 & 95 & 107 & 115 & 132 \\
\hline $\mathrm{Tb}$ & 11 & 12 & 11 & 11 & 13 & 14 & 18 \\
\hline Dy & 55 & 59 & 58 & 60 & 69 & 69 & 80 \\
\hline Ho & 9 & 10 & 10 & 10 & 13 & 13 & 14 \\
\hline Er & 25 & 28 & 27 & 27 & 34 & 34 & 41 \\
\hline $\mathrm{Yb}$ & 18 & 20 & 17 & 18 & 27 & 15 & 30 \\
\hline
\end{tabular}


Table C- 1. Continued.

\begin{tabular}{|c|c|c|c|c|c|c|c|}
\hline & $\begin{array}{l}\text { PH12C-2 } \\
\text { ap1 pt3 }\end{array}$ & $\begin{array}{c}\text { PH12C-2 } \\
\text { ap2 }\end{array}$ & $\begin{array}{c}\text { PH12C-2 } \\
\text { ap6 }\end{array}$ & $\begin{array}{c}\text { PH12C-3a } \\
\text { ap1 pt1 }\end{array}$ & $\begin{array}{l}\text { PH12C-3a } \\
\text { ap1 pt2 }\end{array}$ & $\begin{array}{l}\text { PH12C-3b } \\
\text { ap1 pt2 }\end{array}$ & $\begin{array}{c}\text { PH12C-3b } \\
\text { ap1 pt1 }\end{array}$ \\
\hline $\mathrm{SiO}_{2}$ & n.d. & n.d. & 0.19 & 6.41 & n.d. & 0.10 & 0.09 \\
\hline $\mathrm{TiO}_{2}$ & n.d. & n.d. & n.d. & 0.01 & n.d. & n.d. & n.d. \\
\hline $\mathrm{Al}_{2} \mathrm{O}_{3}$ & n.d. & n.d. & 0.00 & 1.01 & 0.80 & 0.00 & 0.00 \\
\hline $\mathrm{FeO}^{*}$ & 0.12 & n.d. & 0.28 & 0.55 & n.d. & 0.29 & 0.29 \\
\hline $\mathrm{MnO}$ & 0.20 & 0.23 & 0.17 & 0.25 & 0.16 & 0.23 & 0.22 \\
\hline $\mathrm{MgO}$ & 0.10 & 0.22 & 0.16 & 0.39 & 0.27 & 0.15 & 0.16 \\
\hline $\mathrm{CaO}$ & 54 & 54 & 54 & 55 & 54 & 54 & 54 \\
\hline $\mathrm{Na}_{2} \mathrm{O}$ & n.d. & n.d. & 0.13 & 0.49 & 0.24 & 0.11 & 0.11 \\
\hline $\mathrm{K}_{2} \mathrm{O}$ & n.d. & n.d. & 0.00 & 0.24 & n.d. & 0.00 & 0.00 \\
\hline $\mathrm{P}_{2} \mathrm{O}_{5}$ & 44.2 & 44.2 & 35.1 & 45.0 & 44.2 & 39.0 & 39.8 \\
\hline $\mathrm{S}$ & 1143 & 547 & 932 & n.d. & n.d. & 655 & 592 \\
\hline $\mathrm{Sc}$ & n.d. & n.d. & n.d. & 0.83 & n.d. & 0.19 & 0.24 \\
\hline $\mathrm{Cr}$ & n.d. & n.d. & n.d. & 13.0 & n.d. & 3.61 & n.d. \\
\hline $\mathrm{Ni}$ & n.d. & n.d. & n.d. & n.d. & n.d. & n.d. & n.d. \\
\hline $\mathrm{Cu}$ & 2.63 & 9.52 & n.d. & 34.9 & n.d. & 0.99 & 0.19 \\
\hline $\mathrm{Zn}$ & n.d. & n.d. & 2.90 & 38.5 & n.d. & 1.64 & 2.18 \\
\hline $\mathrm{Rb}$ & 2.24 & 4.56 & 0.10 & 6.29 & 6.24 & n.d. & 0.04 \\
\hline $\mathrm{Sr}$ & n.d. & n.d. & 518 & n.d. & 1258 & 602 & 593 \\
\hline Y & 326 & 327 & 293 & 370 & 379 & 215 & 200 \\
\hline $\mathrm{Zr}$ & 0.79 & 4.79 & 1.39 & 5.73 & 25.6 & 0.33 & 0.34 \\
\hline $\mathrm{Nb}$ & n.d. & 0.29 & n.d. & 0.38 & n.d. & n.d. & n.d. \\
\hline $\mathrm{Ba}$ & n.d. & n.d. & 3.87 & 45.7 & 73.9 & 3.66 & 3.48 \\
\hline $\mathrm{Pb}$ & n.d. & n.d. & 32.4 & 5576 & 619 & 2.98 & 3.75 \\
\hline Th & 26.5 & 35.7 & 26.9 & 28.6 & 26.9 & 10.6 & 10.5 \\
\hline $\mathrm{U}$ & 10.5 & 11.8 & 9.77 & 11.6 & 10.3 & 5.63 & 5.48 \\
\hline $\mathrm{La}$ & 824 & 1012 & 795 & 894 & 1074 & 644 & 639 \\
\hline $\mathrm{Ce}$ & 2094 & 2500 & 1864 & 2225 & 2441 & 1706 & 1730 \\
\hline $\operatorname{Pr}$ & 244 & 294 & 222 & 271 & 290 & 190 & 194 \\
\hline $\mathrm{Nd}$ & 985 & 1116 & 888 & 1078 & 1130 & 680 & 683 \\
\hline $\mathrm{Sm}$ & 157 & 178 & 141 & 168 & 172 & 99 & 101 \\
\hline $\mathrm{Eu}$ & 23 & 28 & 22 & 26 & 24 & 17 & 18 \\
\hline $\mathrm{Gd}$ & 112 & 117 & 108 & 132 & 121 & 73 & 76 \\
\hline $\mathrm{Tb}$ & 15 & 14 & 13 & 15 & 16 & 8 & 8 \\
\hline Dy & 74 & 78 & 65 & 81 & 63 & 41 & 41 \\
\hline Но & 14 & 12 & 11 & 14 & 15 & 7 & 7 \\
\hline Er & 39 & 31 & 30 & 34 & 37 & 20 & 19 \\
\hline $\mathrm{Yb}$ & 28 & 26 & 23 & 28 & 13 & 13 & 13 \\
\hline
\end{tabular}


Table C- 1. Continued.

\begin{tabular}{|c|c|c|c|c|c|c|c|}
\hline & $\begin{array}{c}\text { PH12C-3b } \\
\text { ap2 }\end{array}$ & $\begin{array}{c}\text { PH12C-3b } \\
\text { ap3 }\end{array}$ & $\begin{array}{c}\text { PH12C-3b } \\
\text { ap5 pt1 }\end{array}$ & $\begin{array}{c}\text { PH12C-3b } \\
\text { ap7 }\end{array}$ & $\begin{array}{c}\text { PH12C-3b } \\
\text { ap8 }\end{array}$ & $\begin{array}{c}\text { PH12C-3b } \\
\text { ap10 }\end{array}$ & $\begin{array}{c}\text { PH12C-3b } \\
\text { ap13 pt1 }\end{array}$ \\
\hline $\mathrm{SiO}_{2}$ & 0.10 & 0.14 & 7.78 & 0.12 & 0.60 & 0.14 & 0.13 \\
\hline $\mathrm{TiO}_{2}$ & n.d. & n.d. & 0.01 & n.d. & n.d. & n.d. & n.d. \\
\hline $\mathrm{Al}_{2} \mathrm{O}_{3}$ & n.d. & n.d. & 1.12 & 0.00 & 0.03 & 0.00 & n.d. \\
\hline $\mathrm{FeO}^{*}$ & 0.29 & 0.29 & 0.49 & 0.35 & 0.33 & 0.29 & 0.29 \\
\hline $\mathrm{MnO}$ & 0.23 & 0.23 & 0.25 & 0.24 & 0.25 & 0.18 & 0.20 \\
\hline $\mathrm{MgO}$ & 0.16 & 0.16 & 0.23 & 0.20 & 0.20 & 0.17 & 0.17 \\
\hline $\mathrm{CaO}$ & 54 & 54 & 54 & 54 & 54 & 54 & 54 \\
\hline $\mathrm{Na}_{2} \mathrm{O}$ & 0.11 & 0.11 & 0.67 & 0.21 & 0.25 & 0.12 & 0.13 \\
\hline $\mathrm{K}_{2} \mathrm{O}$ & n.d. & 0.00 & 0.33 & n.d. & 0.01 & 0.00 & n.d. \\
\hline $\mathrm{P}_{2} \mathrm{O}_{5}$ & 39.5 & 38.1 & 44.2 & 44.2 & 44.2 & 35.9 & 41.4 \\
\hline $\mathrm{S}$ & 665 & 629 & n.d. & n.d. & n.d. & 630 & 798 \\
\hline $\mathrm{Sc}$ & 0.24 & 0.20 & 0.39 & 0.64 & 0.18 & 0.23 & n.d. \\
\hline $\mathrm{Cr}$ & n.d. & n.d. & 4.80 & n.d. & n.d. & n.d. & n.d. \\
\hline $\mathrm{Ni}$ & n.d. & n.d. & n.d. & n.d. & n.d. & n.d. & n.d. \\
\hline $\mathrm{Cu}$ & 1.52 & n.d. & 11.0 & 8.46 & n.d. & 0.46 & 0.53 \\
\hline $\mathrm{Zn}$ & 1.83 & 1.64 & 7.16 & 0.63 & 1.35 & 2.53 & 2.80 \\
\hline $\mathrm{Rb}$ & 0.05 & 0.03 & 9.33 & 0.13 & 0.52 & 0.03 & n.d. \\
\hline $\mathrm{Sr}$ & 597 & 606 & n.d. & n.d. & n.d. & 615 & 589 \\
\hline $\mathrm{Y}$ & 236 & 233 & 308 & 319 & 272 & 269 & 284 \\
\hline $\mathrm{Zr}$ & 0.63 & 0.65 & 6.34 & 0.99 & 0.35 & 0.61 & 0.61 \\
\hline $\mathrm{Nb}$ & n.d. & n.d. & 0.39 & n.d. & 0.11 & n.d. & n.d. \\
\hline $\mathrm{Ba}$ & 3.86 & 3.35 & 67.4 & n.d. & n.d. & 4.29 & 3.46 \\
\hline $\mathrm{Pb}$ & 2.83 & 3.42 & 542 & 443 & 17.3 & 5.23 & 3.45 \\
\hline Th & 15.5 & 13.8 & 25.5 & 20.3 & 19.4 & 15.3 & 19.4 \\
\hline $\mathrm{U}$ & 6.42 & 6.15 & 9.35 & 9.29 & 7.86 & 5.90 & 7.34 \\
\hline $\mathrm{La}$ & 692 & 687 & 888 & 866 & 805 & 726 & 741 \\
\hline $\mathrm{Ce}$ & 1759 & 1769 & 2100 & 2059 & 1928 & 1683 & 1775 \\
\hline $\operatorname{Pr}$ & 201 & 200 & 244 & 233 & 222 & 202 & 207 \\
\hline $\mathrm{Nd}$ & 729 & 723 & 933 & 955 & 863 & 779 & 812 \\
\hline $\mathrm{Sm}$ & 107 & 110 & 144 & 143 & 126 & 119 & 121 \\
\hline $\mathrm{Eu}$ & 18 & 18 & 22 & 18 & 23 & 19 & 20 \\
\hline $\mathrm{Gd}$ & 79 & 83 & 115 & 96 & 105 & 91 & 101 \\
\hline $\mathrm{Tb}$ & 9 & 9 & 12 & 11 & 10 & 10 & 11 \\
\hline Dy & 44 & 45 & 64 & 56 & 53 & 53 & 57 \\
\hline Ho & 8 & 8 & 11 & 10 & 11 & 10 & 10 \\
\hline Er & 19 & 20 & 26 & 27 & 27 & 25 & 26 \\
\hline $\mathrm{Yb}$ & 15 & 15 & 23 & 32 & 17 & 18 & 17 \\
\hline
\end{tabular}


Table C- 1. Continued.

\begin{tabular}{|c|c|c|c|c|c|c|c|}
\hline & $\begin{array}{l}\text { PH12C-3b } \\
\text { ap13 pt2 }\end{array}$ & $\begin{array}{l}\text { PH12C-3b } \\
\text { ap13 pt3 }\end{array}$ & $\begin{array}{c}\text { PH12C-4 } \\
\text { ap1 pt1 }\end{array}$ & $\begin{array}{c}\text { PH12C-4 } \\
\text { ap1 pt2 }\end{array}$ & $\begin{array}{c}\text { PH12C-4 } \\
\text { ap2 pt1 }\end{array}$ & $\begin{array}{c}\text { PH12C-4 } \\
\text { ap2 pt2 }\end{array}$ & $\begin{array}{c}\text { PH12C-4 } \\
\text { ap2 pt3 }\end{array}$ \\
\hline $\mathrm{SiO}_{2}$ & 0.17 & 0.14 & 10.2 & 14.3 & n.d. & n.d. & n.d. \\
\hline $\mathrm{TiO}_{2}$ & n.d. & n.d. & 0.01 & 0.02 & n.d. & n.d. & n.d. \\
\hline $\mathrm{Al}_{2} \mathrm{O}_{3}$ & 0.00 & n.d. & 1.43 & 2.23 & n.d. & n.d. & n.d. \\
\hline $\mathrm{FeO}^{*}$ & 0.32 & 0.29 & 0.37 & 0.44 & 0.14 & 0.04 & 0.21 \\
\hline $\mathrm{MnO}$ & 0.20 & 0.19 & 0.17 & 0.18 & 0.27 & 0.27 & 0.26 \\
\hline $\mathrm{MgO}$ & 0.17 & 0.18 & 0.18 & 0.19 & 0.15 & 0.17 & 0.18 \\
\hline $\mathrm{CaO}$ & 54 & 54 & 54 & 54 & 54 & 54 & 54 \\
\hline $\mathrm{Na}_{2} \mathrm{O}$ & 0.16 & 0.13 & 0.64 & 0.94 & n.d. & n.d. & n.d. \\
\hline $\mathrm{K}_{2} \mathrm{O}$ & 0.00 & n.d. & 0.38 & 0.66 & n.d. & n.d. & n.d. \\
\hline $\mathrm{P}_{2} \mathrm{O}_{5}$ & 40.0 & 39.9 & 31.6 & 31.9 & 44.2 & 44.2 & 44.2 \\
\hline S & 1096 & 689 & 2989 & 1066 & 910 & n.d. & 1398 \\
\hline $\mathrm{Sc}$ & 0.29 & 0.26 & n.d. & 0.63 & n.d. & n.d. & n.d. \\
\hline $\mathrm{Cr}$ & n.d. & n.d. & n.d. & n.d. & n.d. & n.d. & n.d. \\
\hline $\mathrm{Ni}$ & n.d. & n.d. & n.d. & n.d. & n.d. & n.d. & n.d. \\
\hline $\mathrm{Cu}$ & 0.71 & n.d. & 2.23 & 2.95 & n.d. & 24.6 & 10.2 \\
\hline $\mathrm{Zn}$ & 2.13 & 2.06 & 6.56 & 14.9 & n.d. & n.d. & 1.49 \\
\hline $\mathrm{Rb}$ & n.d. & n.d. & 11.5 & 20.5 & 0.20 & n.d. & n.d. \\
\hline $\mathrm{Sr}$ & 600 & 596 & 611 & 613 & n.d. & n.d. & n.d. \\
\hline $\mathrm{Y}$ & 288 & 275 & 215 & 223 & 313 & 456 & 345 \\
\hline $\mathrm{Zr}$ & 0.63 & 0.68 & 8.71 & 8.53 & 0.70 & n.d. & 0.62 \\
\hline $\mathrm{Nb}$ & n.d. & n.d. & 0.47 & 0.44 & n.d. & n.d. & n.d. \\
\hline $\mathrm{Ba}$ & 5.05 & 5.04 & 94.4 & 148 & n.d. & n.d. & n.d. \\
\hline $\mathrm{Pb}$ & 3.82 & 6.12 & 192 & 869 & 15.7 & 135 & 41.3 \\
\hline Th & 22.9 & 19.3 & 18.3 & 17.7 & 19.8 & 40.3 & 24.8 \\
\hline $\mathrm{U}$ & 8.40 & 7.29 & 8.13 & 7.13 & 7.13 & 8.47 & 9.13 \\
\hline $\mathrm{La}$ & 775 & 765 & 665 & 666 & 894 & 1110 & 890 \\
\hline $\mathrm{Ce}$ & 1832 & 1813 & 1692 & 1660 & 2050 & 2755 & 2154 \\
\hline $\operatorname{Pr}$ & 219 & 210 & 189 & 179 & 238 & 351 & 252 \\
\hline $\mathrm{Nd}$ & 847 & 820 & 694 & 707 & 1012 & 1393 & 1038 \\
\hline $\mathrm{Sm}$ & 129 & 129 & 118 & 106 & 124 & 252 & 169 \\
\hline $\mathrm{Eu}$ & 22 & 20 & 19 & 20 & 23 & 26 & 29 \\
\hline $\mathrm{Gd}$ & 97 & 98 & 86 & 72 & 118 & 106 & 76 \\
\hline $\mathrm{Tb}$ & 12 & 11 & 8 & 9 & 10 & 10 & 14 \\
\hline Dy & 58 & 56 & 48 & 46 & 58 & 98 & 61 \\
\hline Но & 11 & 10 & 8 & 8 & 10 & 16 & 16 \\
\hline $\mathrm{Er}$ & 26 & 27 & 25 & 21 & 27 & 49 & 34 \\
\hline $\mathrm{Yb}$ & 20 & 19 & 17 & 13 & 29 & 14 & 12 \\
\hline
\end{tabular}


Table C- 1. Continued.

\begin{tabular}{|c|c|c|c|c|c|c|c|}
\hline & $\begin{array}{c}\text { PH12C-4 } \\
\text { ap3 pt1 }\end{array}$ & $\begin{array}{c}\text { PH12C-4 } \\
\text { ap3 pt2 }\end{array}$ & $\begin{array}{c}\text { PH12C-5 } \\
\text { ap3 } \\
\end{array}$ & $\begin{array}{c}\text { PH12C-6 } \\
\text { ap1 } \\
\end{array}$ & $\begin{array}{c}\text { PH12C-7 } \\
\text { ap1 pt1 }\end{array}$ & $\begin{array}{l}\text { PH12C-7 } \\
\text { ap1 pt2 }\end{array}$ & $\begin{array}{c}\text { PH12C-7 } \\
\text { ap2 pt1 }\end{array}$ \\
\hline $\mathrm{SiO}_{2}$ & 0.11 & 0.11 & n.d. & 3.74 & 0.12 & 0.14 & n.d. \\
\hline $\mathrm{TiO}_{2}$ & 0.00 & n.d. & n.d. & 0.00 & n.d. & n.d. & n.d. \\
\hline $\mathrm{Al}_{2} \mathrm{O}_{3}$ & n.d. & 0.00 & n.d. & 0.47 & 0.00 & 0.00 & n.d. \\
\hline $\mathrm{FeO}^{*}$ & 0.29 & 0.29 & n.d. & 0.20 & 0.30 & 0.30 & 0.29 \\
\hline $\mathrm{MnO}$ & 0.23 & 0.23 & 0.28 & 0.08 & 0.24 & 0.22 & 0.18 \\
\hline $\mathrm{MgO}$ & 0.15 & 0.16 & 0.18 & 0.13 & 0.17 & 0.17 & 0.18 \\
\hline $\mathrm{CaO}$ & 54 & 54 & 54 & 25.0 & 54 & 54 & 54 \\
\hline $\mathrm{Na}_{2} \mathrm{O}$ & 0.11 & 0.12 & n.d. & 0.29 & 0.12 & 0.13 & 0.13 \\
\hline $\mathrm{K}_{2} \mathrm{O}$ & 0.00 & 0.00 & n.d. & 0.16 & 0.00 & 0.00 & n.d. \\
\hline $\mathrm{P}_{2} \mathrm{O}_{5}$ & 32.9 & 33.2 & 44.2 & 14.3 & 33.2 & 33.0 & 40.6 \\
\hline $\mathrm{S}$ & 549 & 544 & 1205 & 16506 & 604 & 717 & 5381 \\
\hline $\mathrm{Sc}$ & 0.23 & 0.29 & n.d. & 0.32 & 0.26 & 0.25 & n.d. \\
\hline $\mathrm{Cr}$ & n.d. & n.d. & n.d. & n.d. & n.d. & 2.27 & n.d. \\
\hline $\mathrm{Ni}$ & 1.18 & n.d. & n.d. & n.d. & n.d. & n.d. & n.d. \\
\hline $\mathrm{Cu}$ & n.d. & n.d. & n.d. & 4.00 & 0.86 & 0.22 & n.d. \\
\hline $\mathrm{Zn}$ & 2.45 & 2.34 & n.d. & 5.13 & 2.36 & 2.18 & n.d. \\
\hline $\mathrm{Rb}$ & 0.05 & 0.03 & n.d. & 4.71 & 0.03 & 0.02 & n.d. \\
\hline $\mathrm{Sr}$ & 604 & 612 & n.d. & 363 & 579 & 602 & 646 \\
\hline Y & 272 & 273 & 305 & 106 & 333 & 333 & 287 \\
\hline $\mathrm{Zr}$ & 0.64 & 0.62 & 1.82 & 2.77 & 0.50 & 0.82 & n.d. \\
\hline $\mathrm{Nb}$ & n.d. & n.d. & n.d. & 0.17 & n.d. & n.d. & n.d. \\
\hline $\mathrm{Ba}$ & 3.97 & 3.59 & n.d. & 39.5 & 4.00 & 3.82 & 6.84 \\
\hline $\mathrm{Pb}$ & 3.89 & 3.57 & n.d. & 7.78 & 3.82 & 3.87 & 2.50 \\
\hline Th & 16.4 & 16.9 & 39.6 & 8.04 & 20.0 & 23.1 & 14.3 \\
\hline $\mathrm{U}$ & 6.55 & 6.45 & 14.25 & 3.43 & 7.53 & 8.66 & 6.52 \\
\hline $\mathrm{La}$ & 767 & 773 & 986 & 321 & 827 & 880 & 489 \\
\hline $\mathrm{Ce}$ & 1773 & 1767 & 2647 & 784 & 1983 & 2072 & 1374 \\
\hline $\operatorname{Pr}$ & 208 & 212 & 309 & 91 & 241 & 247 & 173 \\
\hline $\mathrm{Nd}$ & 809 & 812 & 1065 & 344 & 942 & 966 & 723 \\
\hline $\mathrm{Sm}$ & 122 & 124 & 180 & 54 & 143 & 145 & 142 \\
\hline $\mathrm{Eu}$ & 20 & 21 & 26 & 9 & 23 & 23 & 19 \\
\hline $\mathrm{Gd}$ & 98 & 95 & 113 & 38 & 107 & 112 & 97 \\
\hline $\mathrm{Tb}$ & 11 & 11 & 14 & 4 & 12 & 13 & 11 \\
\hline Dy & 54 & 54 & 52 & 21 & 65 & 66 & 55 \\
\hline Ho & 10 & 10 & 12 & 4 & 12 & 12 & 11 \\
\hline Er & 25 & 25 & 26 & 9 & 30 & 31 & 35 \\
\hline $\mathrm{Yb}$ & 18 & 17 & 22 & 7 & 23 & 24 & 19 \\
\hline
\end{tabular}


Table C- 1. Continued.

\begin{tabular}{|c|c|c|c|c|c|c|c|}
\hline & $\begin{array}{l}\text { PH12C-7 } \\
\text { ap2 pt2 }\end{array}$ & $\begin{array}{c}\mathrm{PH} 12 \mathrm{C}-7 \\
\text { ap3 } \\
\end{array}$ & $\begin{array}{c}\text { PH12C-7 } \\
\text { ap4 pt1 }\end{array}$ & $\begin{array}{c}\text { PH12C-7 } \\
\text { ap4 pt2 }\end{array}$ & $\begin{array}{l}\text { PH12C-7 } \\
\text { ap4 pt3 }\end{array}$ & $\begin{array}{l}\text { PH12C-7 } \\
\text { ap4 pt4 }\end{array}$ & $\begin{array}{c}\text { PH12C-7 } \\
\text { ap5 } \\
\end{array}$ \\
\hline $\mathrm{SiO}_{2}$ & n.d. & n.d. & n.d. & n.d. & n.d. & n.d. & n.d. \\
\hline $\mathrm{TiO}_{2}$ & n.d. & n.d. & n.d. & n.d. & n.d. & n.d. & n.d. \\
\hline $\mathrm{Al}_{2} \mathrm{O}_{3}$ & n.d. & 0.05 & 0.00 & n.d. & n.d. & 0.00 & n.d. \\
\hline $\mathrm{FeO}^{*}$ & 0.30 & 0.25 & 0.29 & 0.30 & 0.28 & 0.24 & 0.26 \\
\hline $\mathrm{MnO}$ & 0.19 & 0.19 & 0.20 & 0.20 & 0.21 & 0.19 & 0.23 \\
\hline $\mathrm{MgO}$ & 0.19 & 0.19 & 0.17 & 0.16 & 0.17 & 0.17 & 0.20 \\
\hline $\mathrm{CaO}$ & 54 & 54 & 54 & 54 & 54 & 54 & 54 \\
\hline $\mathrm{Na}_{2} \mathrm{O}$ & 0.13 & 0.15 & 0.12 & 0.12 & 0.12 & 0.11 & 0.11 \\
\hline $\mathrm{K}_{2} \mathrm{O}$ & n.d. & 0.01 & n.d. & n.d. & n.d. & 0.00 & n.d. \\
\hline $\mathrm{P}_{2} \mathrm{O}_{5}$ & 41.6 & 44.2 & 39.4 & 39.4 & 39.9 & 38.2 & 44.2 \\
\hline $\mathrm{S}$ & 930 & n.d. & 675 & 689 & 577 & 468 & n.d. \\
\hline $\mathrm{Sc}$ & n.d. & n.d. & n.d. & n.d. & n.d. & n.d. & n.d. \\
\hline $\mathrm{Cr}$ & n.d. & n.d. & n.d. & n.d. & n.d. & n.d. & n.d. \\
\hline $\mathrm{Ni}$ & n.d. & n.d. & n.d. & n.d. & n.d. & n.d. & n.d. \\
\hline $\mathrm{Cu}$ & 3.71 & 10.5 & n.d. & n.d. & n.d. & 1.59 & n.d. \\
\hline $\mathrm{Zn}$ & n.d. & 26.8 & n.d. & n.d. & n.d. & n.d. & 5.78 \\
\hline $\mathrm{Rb}$ & n.d. & n.d. & n.d. & n.d. & 0.22 & n.d. & n.d. \\
\hline $\mathrm{Sr}$ & 618 & 821 & 644 & 632 & 641 & 616 & 280 \\
\hline Y & 272 & 233 & 269 & 262 & 268 & 258 & 271 \\
\hline $\mathrm{Zr}$ & n.d. & n.d. & 0.69 & 0.48 & 0.59 & 0.42 & 1.48 \\
\hline $\mathrm{Nb}$ & n.d. & n.d. & n.d. & n.d. & n.d. & n.d. & n.d. \\
\hline $\mathrm{Ba}$ & 5.85 & n.d. & 4.09 & 5.59 & 4.27 & 4.57 & n.d. \\
\hline $\mathrm{Pb}$ & 15.6 & 348 & 17.5 & 3.55 & 6.20 & 224 & 28.6 \\
\hline Th & 12.2 & 15.1 & 17.0 & 14.6 & 15.9 & 17.2 & 19.0 \\
\hline $\mathrm{U}$ & 5.63 & 5.82 & 6.28 & 6.30 & 6.41 & 5.96 & 8.79 \\
\hline $\mathrm{La}$ & 560 & 613 & 733 & 733 & 790 & 703 & 734 \\
\hline $\mathrm{Ce}$ & 1468 & 1497 & 1821 & 1853 & 1964 & 1814 & 1824 \\
\hline $\operatorname{Pr}$ & 186 & 195 & 219 & 218 & 234 & 215 & 228 \\
\hline $\mathrm{Nd}$ & 690 & 731 & 783 & 809 & 833 & 771 & 843 \\
\hline $\mathrm{Sm}$ & 116 & 108 & 119 & 118 & 126 & 113 & 120 \\
\hline $\mathrm{Eu}$ & 19 & 18 & 21 & 20 & 23 & 19 & 23 \\
\hline $\mathrm{Gd}$ & 81 & 77 & 93 & 88 & 98 & 84 & 90 \\
\hline $\mathrm{Tb}$ & 11 & 8 & 9 & 10 & 10 & 11 & 10 \\
\hline Dy & 56 & 57 & 51 & 52 & 57 & 54 & 52 \\
\hline Ho & 11 & 11 & 9 & 10 & 9 & 8 & 10 \\
\hline Er & 26 & 21 & 26 & 22 & 26 & 21 & 27 \\
\hline $\mathrm{Yb}$ & 19 & 17 & 19 & 14 & 19 & 17 & 11 \\
\hline
\end{tabular}


Table C- 1. Continued.

\begin{tabular}{|c|c|c|c|c|c|c|c|}
\hline & $\begin{array}{c}\text { PH12C-7 } \\
\text { ap8 } \\
\end{array}$ & $\begin{array}{c}\text { PH12C-7 } \\
\text { ap11 } \\
\end{array}$ & $\begin{array}{l}\text { PH12C-7 } \\
\text { ap16 pt1 }\end{array}$ & $\begin{array}{l}\text { PH12C-7 } \\
\text { ap16 pt2 }\end{array}$ & $\begin{array}{l}\text { PH12C-7 } \\
\text { ap16 pt3 }\end{array}$ & $\begin{array}{l}\text { PH12C-7 } \\
\text { ap18 pt1 }\end{array}$ & $\begin{array}{l}\text { PH12C-7 } \\
\text { ap18 pt2 }\end{array}$ \\
\hline $\mathrm{SiO}_{2}$ & 1.58 & 0.16 & n.d. & n.d. & n.d. & 0.23 & n.d. \\
\hline $\mathrm{TiO}_{2}$ & 0.00 & n.d. & 0.00 & n.d. & n.d. & n.d. & n.d. \\
\hline $\mathrm{Al}_{2} \mathrm{O}_{3}$ & 0.13 & 0.01 & n.d. & n.d. & n.d. & 0.01 & 0.00 \\
\hline $\mathrm{FeO}^{*}$ & 0.39 & 0.31 & 0.32 & n.d. & 0.23 & 0.32 & 0.24 \\
\hline $\mathrm{MnO}$ & 0.24 & 0.22 & 0.18 & 0.15 & 0.18 & 0.20 & 0.21 \\
\hline $\mathrm{MgO}$ & 0.24 & 0.21 & 0.18 & 0.09 & 0.18 & 0.14 & 0.14 \\
\hline $\mathrm{CaO}$ & 54 & 54 & 54 & 54 & 54 & 54 & 54 \\
\hline $\mathrm{Na}_{2} \mathrm{O}$ & 0.22 & 0.13 & 0.12 & n.d. & 0.07 & 0.20 & 0.20 \\
\hline $\mathrm{K}_{2} \mathrm{O}$ & 0.05 & n.d. & n.d. & n.d. & n.d. & 0.00 & 0.00 \\
\hline $\mathrm{P}_{2} \mathrm{O}_{5}$ & 38.8 & 44.2 & 32.7 & 23.6 & 31.6 & 36.9 & 36.3 \\
\hline S & 956 & n.d. & 1237 & n.d. & 926 & 1729 & 1342 \\
\hline $\mathrm{Sc}$ & n.d. & n.d. & n.d. & n.d. & n.d. & n.d. & n.d. \\
\hline $\mathrm{Cr}$ & n.d. & n.d. & n.d. & n.d. & n.d. & n.d. & n.d. \\
\hline $\mathrm{Ni}$ & n.d. & n.d. & n.d. & n.d. & 12.26 & n.d. & n.d. \\
\hline $\mathrm{Cu}$ & 2.19 & 1.39 & n.d. & 38.5 & n.d. & 458 & 21.5 \\
\hline $\mathrm{Zn}$ & 7.67 & 4.60 & 10.9 & 56.1 & 5.28 & 7.21 & n.d. \\
\hline $\mathrm{Rb}$ & 1.40 & n.d. & n.d. & n.d. & n.d. & 0.22 & n.d. \\
\hline $\mathrm{Sr}$ & 633 & 134 & 673 & 550 & 597 & 510 & 530 \\
\hline $\mathrm{Y}$ & 216 & 293 & 325 & 248 & 245 & 395 & 397 \\
\hline $\mathrm{Zr}$ & 0.58 & 1.08 & 1.64 & 9.93 & n.d. & 1.02 & 1.27 \\
\hline $\mathrm{Nb}$ & n.d. & n.d. & n.d. & n.d. & n.d. & n.d. & n.d. \\
\hline $\mathrm{Ba}$ & 9.29 & n.d. & 8.52 & 204 & 4.50 & 5.34 & 1.80 \\
\hline $\mathrm{Pb}$ & 12.8 & 16.8 & 127 & 1186 & 259 & 6.31 & 3.36 \\
\hline Th & 9.89 & 16.0 & 36.5 & 25.1 & 20.5 & 20.8 & 18.2 \\
\hline $\mathrm{U}$ & 5.09 & 7.88 & 10.6 & 2.26 & 8.05 & 8.33 & 9.02 \\
\hline $\mathrm{La}$ & 681 & 806 & 830 & 566 & 737 & 479 & 512 \\
\hline $\mathrm{Ce}$ & 1675 & 2067 & 1921 & 1461 & 1743 & 1349 & 1415 \\
\hline $\operatorname{Pr}$ & 193 & 243 & 227 & 189 & 204 & 179 & 186 \\
\hline $\mathrm{Nd}$ & 703 & 911 & 894 & 580 & 809 & 801 & 801 \\
\hline $\mathrm{Sm}$ & 103 & 136 & 138 & 156 & 115 & 146 & 145 \\
\hline $\mathrm{Eu}$ & 18 & 21 & 25 & 25 & 20 & 25 & 22 \\
\hline $\mathrm{Gd}$ & 71 & 106 & 108 & 117 & 82 & 118 & 129 \\
\hline $\mathrm{Tb}$ & 8 & 12 & 12 & 8 & 11 & 14 & 16 \\
\hline Dy & 43 & 52 & 60 & 57 & 46 & 81 & 80 \\
\hline Но & 7 & 10 & 10 & 13 & 8 & 14 & 13 \\
\hline $\mathrm{Er}$ & 21 & 28 & 27 & 29 & 25 & 39 & 42 \\
\hline $\mathrm{Yb}$ & 17 & 21 & 16 & 9 & 13 & 33 & 26 \\
\hline
\end{tabular}


Table C- 1. Continued.

\begin{tabular}{|c|c|c|c|c|c|c|c|}
\hline & $\begin{array}{l}\text { PH12C-7 } \\
\text { ap18 pt3 }\end{array}$ & $\begin{array}{l}\text { PH12C-7 } \\
\text { ap19 pt1 }\end{array}$ & $\begin{array}{l}\text { PH12C-7 } \\
\text { ap19 pt2 }\end{array}$ & $\begin{array}{c}\text { CN6791-d } \\
\text { ap1 }\end{array}$ & $\begin{array}{l}\text { CN6791-d } \\
\text { ap2 pt1 }\end{array}$ & $\begin{array}{c}\text { CN6791-d } \\
\text { ap2 pt2 }\end{array}$ & $\begin{array}{c}\text { CN6791-d } \\
\text { ap3 pt1 }\end{array}$ \\
\hline $\mathrm{SiO}_{2}$ & 0.61 & n.d. & n.d. & 0.12 & 0.14 & 0.13 & 0.08 \\
\hline $\mathrm{TiO}_{2}$ & n.d. & n.d. & n.d. & n.d. & n.d. & n.d. & n.d. \\
\hline $\mathrm{Al}_{2} \mathrm{O}_{3}$ & n.d. & n.d. & 0.00 & 0.00 & 0.00 & n.d. & n.d. \\
\hline $\mathrm{FeO}^{*}$ & 0.26 & 0.28 & 0.23 & 0.31 & 0.28 & 0.30 & 0.28 \\
\hline $\mathrm{MnO}$ & 0.21 & 0.27 & 0.27 & 0.20 & 0.18 & 0.19 & 0.19 \\
\hline $\mathrm{MgO}$ & 0.15 & 0.14 & 0.13 & 0.18 & 0.17 & 0.17 & 0.16 \\
\hline $\mathrm{CaO}$ & 54 & 54 & 54 & 54 & 54 & 54 & 54 \\
\hline $\mathrm{Na}_{2} \mathrm{O}$ & 0.15 & 0.11 & 0.11 & 0.13 & 0.11 & 0.12 & 0.12 \\
\hline $\mathrm{K}_{2} \mathrm{O}$ & 0.00 & n.d. & n.d. & 0.00 & 0.00 & 0.00 & n.d. \\
\hline $\mathrm{P}_{2} \mathrm{O}_{5}$ & 37.5 & 34.3 & 33.6 & 39.5 & 34.9 & 35.1 & 37.9 \\
\hline $\mathrm{S}$ & 1052 & 488 & 414 & 978 & 831 & 847 & 769 \\
\hline $\mathrm{Sc}$ & n.d. & n.d. & n.d. & 0.43 & 0.33 & 0.27 & n.d. \\
\hline $\mathrm{Cr}$ & n.d. & n.d. & n.d. & n.d. & 3.16 & n.d. & n.d. \\
\hline $\mathrm{Ni}$ & n.d. & n.d. & n.d. & n.d. & n.d. & n.d. & n.d. \\
\hline $\mathrm{Cu}$ & 3.00 & n.d. & n.d. & 9.12 & 0.73 & 0.50 & 0.45 \\
\hline $\mathrm{Zn}$ & 12.7 & n.d. & n.d. & 2.60 & 2.10 & 1.76 & 1.72 \\
\hline $\mathrm{Rb}$ & n.d. & n.d. & n.d. & 0.15 & n.d. & 0.04 & n.d. \\
\hline $\mathrm{Sr}$ & 568 & 547 & 559 & 627 & 627 & 623 & 627 \\
\hline Y & 357 & 300 & 303 & 281 & 273 & 251 & 288 \\
\hline $\mathrm{Zr}$ & 0.79 & 1.31 & 0.30 & 0.63 & 0.88 & 0.72 & 0.66 \\
\hline $\mathrm{Nb}$ & n.d. & n.d. & n.d. & n.d. & n.d. & n.d. & n.d. \\
\hline $\mathrm{Ba}$ & 3.08 & 2.23 & 3.81 & 3.60 & 4.99 & 4.14 & 4.96 \\
\hline $\mathrm{Pb}$ & 9.31 & 5.05 & 5.48 & 3.01 & 2.98 & 2.94 & 3.86 \\
\hline Th & 14.6 & 17.3 & 16.1 & 18.4 & 21.8 & 18.8 & 19.4 \\
\hline $\mathrm{U}$ & 7.94 & 7.89 & 6.28 & 6.87 & 7.79 & 7.23 & 7.51 \\
\hline $\mathrm{La}$ & 497 & 752 & 734 & 775 & 825 & 784 & 849 \\
\hline $\mathrm{Ce}$ & 1295 & 1859 & 1845 & 1812 & 1907 & 1787 & 1972 \\
\hline $\operatorname{Pr}$ & 184 & 223 & 217 & 213 & 221 & 208 & 227 \\
\hline $\mathrm{Nd}$ & 784 & 869 & 846 & 819 & 852 & 801 & 885 \\
\hline $\mathrm{Sm}$ & 140 & 136 & 127 & 121 & 127 & 117 & 135 \\
\hline $\mathrm{Eu}$ & 24 & 22 & 19 & 22 & 22 & 20 & 23 \\
\hline $\mathrm{Gd}$ & 108 & 102 & 91 & 98 & 100 & 91 & 99 \\
\hline $\mathrm{Tb}$ & 14 & 10 & 11 & 11 & 11 & 10 & 11 \\
\hline Dy & 72 & 60 & 59 & 56 & 56 & 51 & 56 \\
\hline Ho & 13 & 10 & 10 & 10 & 10 & 9 & 10 \\
\hline Er & 33 & 29 & 29 & 25 & 24 & 23 & 28 \\
\hline $\mathrm{Yb}$ & 19 & 21 & 17 & 18 & 18 & 17 & 19 \\
\hline
\end{tabular}


Table C- 1. Continued.

\begin{tabular}{|c|c|c|c|c|c|c|c|}
\hline & $\begin{array}{c}\text { CN6791-d } \\
\text { ap3 pt2 }\end{array}$ & $\begin{array}{l}\text { CN6791-d } \\
\text { ap5 pt1 }\end{array}$ & $\begin{array}{l}\text { CN6791-d } \\
\text { ap5 pt2 }\end{array}$ & $\begin{array}{c}\text { CN6791-d } \\
\text { ap6 }\end{array}$ & $\begin{array}{c}\text { CN6791-d } \\
\text { ap7 }\end{array}$ & $\begin{array}{c}\text { CN6791-d } \\
\text { ap8 }\end{array}$ & $\begin{array}{c}\text { CN6791-d } \\
\text { ap9 }\end{array}$ \\
\hline $\mathrm{SiO}_{2}$ & 0.12 & 0.17 & 0.17 & 0.16 & 0.12 & 3.07 & 0.15 \\
\hline $\mathrm{TiO}_{2}$ & n.d. & n.d. & n.d. & 0.00 & n.d. & n.d. & n.d. \\
\hline $\mathrm{Al}_{2} \mathrm{O}_{3}$ & n.d. & 0.00 & 0.00 & 0.01 & 0.00 & 0.76 & n.d. \\
\hline $\mathrm{FeO}^{*}$ & 0.27 & 0.31 & 0.33 & 0.28 & 0.32 & 0.26 & 0.31 \\
\hline $\mathrm{MnO}$ & 0.19 & 0.23 & 0.24 & 0.21 & 0.22 & 0.22 & 0.20 \\
\hline $\mathrm{MgO}$ & 0.16 & 0.17 & 0.18 & 0.16 & 0.18 & 0.14 & 0.17 \\
\hline $\mathrm{CaO}$ & 54 & 54 & 54 & 54 & 54 & 54 & 54 \\
\hline $\mathrm{Na}_{2} \mathrm{O}$ & 0.12 & 0.18 & 0.17 & 0.11 & 0.13 & 0.50 & 0.12 \\
\hline $\mathrm{K}_{2} \mathrm{O}$ & n.d. & n.d. & 0.00 & 0.00 & 0.00 & 0.02 & n.d. \\
\hline $\mathrm{P}_{2} \mathrm{O}_{5}$ & 37.7 & 36.8 & 40.3 & 35.6 & 35.2 & 37.2 & 36.7 \\
\hline S & 823 & 1701 & 1355 & 666 & 912 & 1024 & 788 \\
\hline $\mathrm{Sc}$ & 0.29 & n.d. & n.d. & n.d. & 0.30 & n.d. & n.d. \\
\hline $\mathrm{Cr}$ & n.d. & n.d. & n.d. & n.d. & n.d. & n.d. & n.d. \\
\hline $\mathrm{Ni}$ & n.d. & n.d. & n.d. & n.d. & n.d. & n.d. & n.d. \\
\hline $\mathrm{Cu}$ & 0.48 & 4.61 & 4.17 & n.d. & 5.82 & 10.2 & 1.79 \\
\hline $\mathrm{Zn}$ & 1.48 & 2.07 & 2.94 & 2.51 & 1.75 & 3.50 & 1.74 \\
\hline $\mathrm{Rb}$ & n.d. & n.d. & n.d. & n.d. & n.d. & n.d. & n.d. \\
\hline $\mathrm{Sr}$ & 636 & 639 & 629 & 611 & 621 & 630 & 593 \\
\hline $\mathrm{Y}$ & 300 & 268 & 263 & 216 & 283 & 275 & 267 \\
\hline $\mathrm{Zr}$ & 0.70 & 0.68 & 0.40 & 0.57 & 0.60 & 0.55 & 1.02 \\
\hline $\mathrm{Nb}$ & n.d. & n.d. & n.d. & n.d. & n.d. & n.d. & n.d. \\
\hline $\mathrm{Ba}$ & 4.82 & 4.00 & 2.85 & 2.52 & 4.02 & 12.7 & 3.11 \\
\hline $\mathrm{Pb}$ & 3.56 & 3.15 & 13.5 & 4.22 & 3.86 & 5.23 & 2.82 \\
\hline Th & 21.4 & 26.5 & 20.5 & 16.0 & 17.0 & 15.8 & 17.4 \\
\hline $\mathrm{U}$ & 8.51 & 9.49 & 7.84 & 6.63 & 6.56 & 7.43 & 6.48 \\
\hline $\mathrm{La}$ & 891 & 780 & 805 & 691 & 746 & 773 & 744 \\
\hline $\mathrm{Ce}$ & 2035 & 1828 & 1902 & 1573 & 1786 & 1911 & 1767 \\
\hline $\operatorname{Pr}$ & 238 & 211 & 223 & 176 & 214 & 231 & 208 \\
\hline $\mathrm{Nd}$ & 919 & 815 & 833 & 706 & 826 & 870 & 808 \\
\hline $\mathrm{Sm}$ & 134 & 118 & 120 & 98 & 126 & 128 & 126 \\
\hline $\mathrm{Eu}$ & 23 & 21 & 21 & 18 & 20 & 20 & 20 \\
\hline $\mathrm{Gd}$ & 104 & 92 & 91 & 73 & 97 & 88 & 96 \\
\hline $\mathrm{Tb}$ & 12 & 10 & 10 & 8 & 11 & 10 & 10 \\
\hline Dy & 61 & 53 & 52 & 41 & 57 & 57 & 52 \\
\hline Но & 10 & 9 & 11 & 8 & 10 & 10 & 10 \\
\hline $\mathrm{Er}$ & 27 & 23 & 26 & 20 & 25 & 25 & 26 \\
\hline $\mathrm{Yb}$ & 21 & 18 & 20 & 13 & 18 & 20 & 18 \\
\hline
\end{tabular}


Table C- 1. Continued.

\begin{tabular}{|c|c|c|c|c|c|c|c|}
\hline & $\begin{array}{l}\text { CN6791-d } \\
\text { ap10 pt1 }\end{array}$ & $\begin{array}{c}\text { CN6791-d } \\
\text { ap10 pt2 }\end{array}$ & $\begin{array}{c}\text { P-22892- } \\
\text { 2a } \\
\text { ap1 }\end{array}$ & $\begin{array}{c}\text { P-22892- } \\
\text { 2a } \\
\text { ap12 pt1 }\end{array}$ & $\begin{array}{c}\mathrm{P}-22892- \\
2 \mathrm{a} \\
\text { ap12 pt2 }\end{array}$ & $\begin{array}{c}\text { P-22892- } \\
\text { 2a } \\
\text { ap13 }\end{array}$ & $\begin{array}{c}\mathrm{P}-22892- \\
2 \mathrm{a} \\
\text { ap19 pt3 }\end{array}$ \\
\hline $\mathrm{SiO}_{2}$ & 0.15 & n.d. & 0.12 & n.d. & 0.70 & 0.55 & 0.30 \\
\hline $\mathrm{TiO}_{2}$ & 0.00 & n.d. & n.d. & n.d. & 0.00 & 0.00 & 0.00 \\
\hline $\mathrm{Al}_{2} \mathrm{O}_{3}$ & 0.00 & 0.00 & 0.00 & 0.02 & 0.02 & 0.14 & n.d. \\
\hline $\mathrm{FeO} *$ & 0.26 & 0.29 & 0.28 & 0.16 & 0.34 & 0.15 & 0.26 \\
\hline $\mathrm{MnO}$ & 0.18 & 0.20 & 0.23 & 0.09 & 0.16 & 0.04 & 0.12 \\
\hline $\mathrm{MgO}$ & 0.17 & 0.17 & 0.14 & 0.13 & 0.24 & 0.06 & 0.24 \\
\hline $\mathrm{CaO}$ & 54 & 54 & 54 & 24.4 & 54 & 24.4 & 54 \\
\hline $\mathrm{Na}_{2} \mathrm{O}$ & 0.15 & 0.21 & 0.11 & 0.15 & 0.36 & 0.07 & 0.37 \\
\hline $\mathrm{K}_{2} \mathrm{O}$ & n.d. & 0.00 & n.d. & n.d. & 0.00 & n.d. & n.d. \\
\hline $\mathrm{P}_{2} \mathrm{O}_{5}$ & 35.6 & 36.2 & 36.1 & 11.0 & 27.1 & 13.0 & 33.9 \\
\hline $\mathrm{S}$ & 2199 & 5818 & 777 & 2532 & 5510 & 2142 & 4910 \\
\hline $\mathrm{Sc}$ & n.d. & n.d. & n.d. & n.d. & n.d. & n.d. & n.d. \\
\hline $\mathrm{Cr}$ & n.d. & n.d. & n.d. & n.d. & n.d. & n.d. & 36.7 \\
\hline $\mathrm{Ni}$ & n.d. & n.d. & n.d. & n.d. & n.d. & n.d. & 20.1 \\
\hline $\mathrm{Cu}$ & 22.8 & 53.2 & 1.92 & 8.66 & 11.7 & 42.6 & n.d. \\
\hline $\mathrm{Zn}$ & 3.27 & 3.32 & 1.35 & 4.01 & 1.69 & 5.07 & 8.58 \\
\hline $\mathrm{Rb}$ & 0.08 & n.d. & n.d. & n.d. & n.d. & n.d. & 0.80 \\
\hline $\mathrm{Sr}$ & 615 & 652 & 588 & 621 & 1027 & 449 & 968 \\
\hline $\mathrm{Y}$ & 262 & 298 & 267 & 53 & 83 & 32 & 91 \\
\hline $\mathrm{Zr}$ & 1.06 & 1.72 & 0.43 & 0.44 & 5.01 & 1.82 & n.d. \\
\hline $\mathrm{Nb}$ & n.d. & n.d. & n.d. & n.d. & 0.15 & n.d. & 0.97 \\
\hline $\mathrm{Ba}$ & 3.53 & 5.44 & 3.47 & n.d. & 8.21 & n.d. & n.d. \\
\hline $\mathrm{Pb}$ & 5.61 & 21.1 & 4.06 & 30.2 & 2.41 & 5.41 & 11.6 \\
\hline Th & 17.3 & 25.0 & 15.7 & 12.5 & 18.3 & 6.98 & 14.7 \\
\hline $\mathrm{U}$ & 7.02 & 9.63 & 5.81 & 3.74 & 5.23 & 1.89 & 3.71 \\
\hline $\mathrm{La}$ & 735 & 805 & 741 & 168 & 254 & 79 & 195 \\
\hline $\mathrm{Ce}$ & 1713 & 1902 & 1679 & 363 & 565 & 162 & 495 \\
\hline $\operatorname{Pr}$ & 203 & 224 & 198 & 44 & 68 & 22 & 64 \\
\hline $\mathrm{Nd}$ & 795 & 887 & 764 & 178 & 250 & 83 & 257 \\
\hline $\mathrm{Sm}$ & 121 & 127 & 123 & 20 & 43 & 13 & 55 \\
\hline $\mathrm{Eu}$ & 20 & 21 & 18 & 6 & 13 & 5 & 12 \\
\hline $\mathrm{Gd}$ & 93 & 100 & 88 & 13 & 31 & 13 & 38 \\
\hline $\mathrm{Tb}$ & 10 & 11 & 10 & 1 & 3 & 2 & 3 \\
\hline Dy & 49 & 59 & 54 & 11 & 16 & 6 & 17 \\
\hline Но & 9 & 11 & 8 & 2 & 2 & 1 & 4 \\
\hline Er & 23 & 29 & 25 & 3 & 8 & 4 & 12 \\
\hline $\mathrm{Yb}$ & 18 & 20 & 15 & 4 & 7 & 2 & 1 \\
\hline
\end{tabular}

n.d. $=$ not detected 
Table C- 1. Continued.

\begin{tabular}{|c|c|c|c|c|c|c|c|}
\hline & $\begin{array}{c}\text { P-22892- } \\
2 \mathrm{a} \\
\text { ap20 }\end{array}$ & $\begin{array}{c}\text { P-22892- } \\
2 \mathrm{a} \\
\text { ap21 }\end{array}$ & $\begin{array}{c}\text { P-22892- } \\
2 \mathrm{a} \\
\text { ap22 }\end{array}$ & $\begin{array}{c}\text { P-22892- } \\
2 \mathrm{a} \\
\text { ap23 }\end{array}$ & $\begin{array}{c}\text { P-22892- } \\
2 \mathrm{a} \\
\text { ap25 }\end{array}$ & $\begin{array}{c}\text { P-22892- } \\
2 \mathrm{a} \\
\text { ap26 }\end{array}$ & $\begin{array}{c}\mathrm{P}-22892- \\
2 \mathrm{a} \\
\text { ap27 }\end{array}$ \\
\hline $\mathrm{SiO}_{2}$ & 2.16 & 0.77 & n.d. & 4.90 & n.d. & 3.79 & 0.38 \\
\hline $\mathrm{TiO}_{2}$ & 0.01 & 0.00 & n.d. & 0.01 & n.d. & 0.01 & 0.01 \\
\hline $\mathrm{Al}_{2} \mathrm{O}_{3}$ & 0.27 & 0.00 & n.d. & 0.79 & n.d. & 0.52 & 0.09 \\
\hline $\mathrm{FeO}^{*}$ & 0.29 & 0.23 & 0.14 & 0.35 & n.d. & 0.36 & 0.24 \\
\hline $\mathrm{MnO}$ & 0.10 & 0.11 & 0.10 & 0.13 & n.d. & 0.13 & 0.15 \\
\hline $\mathrm{MgO}$ & 0.24 & 0.23 & 0.17 & 0.26 & n.d. & 0.25 & 0.25 \\
\hline $\mathrm{CaO}$ & 54 & 54 & 54 & 54 & 54 & 54 & 54 \\
\hline $\mathrm{Na}_{2} \mathrm{O}$ & 0.27 & 0.33 & 0.07 & 0.54 & n.d. & 0.57 & 0.35 \\
\hline $\mathrm{K}_{2} \mathrm{O}$ & 0.11 & n.d. & n.d. & 0.38 & n.d. & 0.24 & n.d. \\
\hline $\mathrm{P}_{2} \mathrm{O}_{5}$ & 33.2 & 37.3 & 36.0 & 38.2 & 44.2 & 32.9 & 29.4 \\
\hline S & 2829 & 4221 & 3126 & 3566 & 1413 & 5109 & 4236 \\
\hline $\mathrm{Sc}$ & n.d. & n.d. & 0.76 & n.d. & 6.33 & n.d. & 1.89 \\
\hline $\mathrm{Cr}$ & n.d. & n.d. & 20.5 & n.d. & 205 & n.d. & 21.8 \\
\hline $\mathrm{Ni}$ & n.d. & 11.4 & n.d. & n.d. & 93.0 & n.d. & n.d. \\
\hline $\mathrm{Cu}$ & 7.43 & n.d. & 150 & 4.70 & n.d. & 10.4 & 9.26 \\
\hline $\mathrm{Zn}$ & 4.43 & 5.15 & 18.1 & 11.9 & n.d. & 7.88 & 9.97 \\
\hline $\mathrm{Rb}$ & 4.96 & 0.29 & 2.45 & 15.2 & n.d. & 10.6 & 4.28 \\
\hline $\mathrm{Sr}$ & 1011 & 1121 & 1030 & 1066 & n.d. & 1010 & 969 \\
\hline Y & 76.1 & 66.0 & 84.9 & 53.7 & 110 & 81.3 & 74.7 \\
\hline $\mathrm{Zr}$ & 9.50 & 4.32 & n.d. & 12.2 & n.d. & 9.24 & 3.85 \\
\hline $\mathrm{Nb}$ & 0.31 & 0.12 & n.d. & 0.48 & n.d. & n.d. & n.d. \\
\hline $\mathrm{Ba}$ & 23.1 & 3.15 & 6.68 & 61.3 & n.d. & 37.7 & 7.20 \\
\hline $\mathrm{Pb}$ & 11.6 & 2.55 & 8.71 & 4.77 & n.d. & 27.5 & 44.6 \\
\hline Th & 18.5 & 10.7 & 15.4 & 13.0 & n.d. & 14.4 & 17.4 \\
\hline $\mathrm{U}$ & 4.40 & 4.96 & 4.41 & 4.66 & n.d. & 2.85 & 5.33 \\
\hline $\mathrm{La}$ & 217 & 178 & 209 & 176 & 323 & 196 & 221 \\
\hline $\mathrm{Ce}$ & 491 & 435 & 540 & 428 & 871 & 465 & 476 \\
\hline $\operatorname{Pr}$ & 63 & 52 & 71 & 49 & 106 & 58 & 61 \\
\hline $\mathrm{Nd}$ & 228 & 201 & 243 & 177 & 407 & 244 & 212 \\
\hline $\mathrm{Sm}$ & 33 & 29 & 38 & 27 & 70 & 42 & 38 \\
\hline $\mathrm{Eu}$ & 12 & 12 & 13 & 10 & 17 & 12 & 12 \\
\hline $\mathrm{Gd}$ & 24 & 25 & 19 & 15 & 55 & 28 & 25 \\
\hline $\mathrm{Tb}$ & 3 & 2 & 3 & 2 & 5 & 4 & 3 \\
\hline Dy & 16 & 13 & 17 & 8 & 28 & 18 & 15 \\
\hline Ho & 3 & 3 & 3 & 2 & 4 & 3 & 4 \\
\hline Er & 9 & 8 & 6 & 5 & 18 & 7 & 11 \\
\hline $\mathrm{Yb}$ & 5 & 5 & 3 & 3 & 6 & 5 & 7 \\
\hline
\end{tabular}


Table C- 1. Continued.

\begin{tabular}{|c|c|c|c|}
\hline & $\begin{array}{c}\text { P-22892- } \\
2 \mathrm{a} \\
\text { ap30 }\end{array}$ & $\begin{array}{c}\text { P-22892- } \\
2 \mathrm{a} \\
\text { ap32 }\end{array}$ & $\begin{array}{c}\mathrm{P}-22892- \\
2 \mathrm{a} \\
\text { ap33 }\end{array}$ \\
\hline $\mathrm{SiO}_{2}$ & 15.2 & 14.0 & n.d. \\
\hline $\mathrm{TiO}_{2}$ & 0.03 & 0.03 & 0.00 \\
\hline $\mathrm{Al}_{2} \mathrm{O}_{3}$ & 3.20 & 2.63 & n.d. \\
\hline $\mathrm{FeO}^{*}$ & 0.57 & 0.59 & 0.41 \\
\hline $\mathrm{MnO}$ & 0.16 & 0.21 & 0.20 \\
\hline $\mathrm{MgO}$ & 0.30 & 0.33 & 0.46 \\
\hline $\mathrm{CaO}$ & 54 & 54 & 54 \\
\hline $\mathrm{Na}_{2} \mathrm{O}$ & 1.26 & 1.09 & n.d. \\
\hline $\mathrm{K}_{2} \mathrm{O}$ & 1.12 & 1.04 & n.d. \\
\hline $\mathrm{P}_{2} \mathrm{O}_{5}$ & 34.7 & 27.1 & 52.6 \\
\hline $\mathrm{S}$ & 4232 & 3674 & 5710 \\
\hline $\mathrm{Sc}$ & n.d. & n.d. & n.d. \\
\hline $\mathrm{Cr}$ & n.d. & n.d. & 58.7 \\
\hline $\mathrm{Ni}$ & n.d. & n.d. & n.d. \\
\hline $\mathrm{Cu}$ & n.d. & 29.5 & 28.7 \\
\hline $\mathrm{Zn}$ & n.d. & 11.2 & 36.6 \\
\hline $\mathrm{Rb}$ & 41.3 & 42.1 & n.d. \\
\hline $\mathrm{Sr}$ & 1059 & 953 & 1390 \\
\hline $\mathrm{Y}$ & 54.7 & 124 & 161 \\
\hline $\mathrm{Zr}$ & 37.3 & 40.5 & 17.4 \\
\hline $\mathrm{Nb}$ & 2.04 & 0.87 & n.d. \\
\hline $\mathrm{Ba}$ & 192 & 158 & n.d. \\
\hline $\mathrm{Pb}$ & 193 & 10.4 & 3450 \\
\hline $\mathrm{Th}$ & 10.8 & 24.9 & 26.3 \\
\hline $\mathrm{U}$ & 3.18 & 5.30 & 7.03 \\
\hline $\mathrm{La}$ & 179 & 327 & 323 \\
\hline $\mathrm{Ce}$ & 457 & 776 & 589 \\
\hline $\operatorname{Pr}$ & 51 & 100 & 77 \\
\hline $\mathrm{Nd}$ & 184 & 394 & 371 \\
\hline $\mathrm{Sm}$ & 33 & 60 & 71 \\
\hline $\mathrm{Eu}$ & 12 & 16 & 21 \\
\hline $\mathrm{Gd}$ & 18 & 51 & 61 \\
\hline $\mathrm{Tb}$ & 3 & 5 & 5 \\
\hline Dy & 14 & 29 & 32 \\
\hline Ho & 3 & 5 & 6 \\
\hline $\mathrm{Er}$ & 7 & 15 & 9 \\
\hline $\mathrm{Yb}$ & 3 & 10 & 10 \\
\hline
\end{tabular}


Table C- 2. ETH LA-ICP-MS error summary (1б) and detection limits (ppm).

\begin{tabular}{|c|c|c|c|c|c|c|}
\hline & \multicolumn{6}{|c|}{ ETH - August 3, 2010} \\
\hline & \multicolumn{3}{|c|}{ Error Summary $(1 \sigma)$} & \multicolumn{3}{|c|}{ Detection Limits (ppm) } \\
\hline & high & low & average & high & low & average \\
\hline $\mathrm{SiO}_{2}$ & 3.07 & 0.01 & 0.19 & 1451 & 41.9 & 356 \\
\hline $\mathrm{TiO}_{2}$ & 0.003 & 0.00003 & 0.001 & 8.43 & 0.26 & 2.19 \\
\hline $\mathrm{Al}_{2} \mathrm{O}_{3}$ & 0.76 & 0.00002 & 0.06 & 143 & 0.16 & 11.4 \\
\hline $\mathrm{FeO}^{*}$ & 0.33 & 0.003 & 0.11 & 100 & 4.05 & 39.3 \\
\hline $\mathrm{MnO}$ & 0.24 & 0.0003 & 0.07 & 11.6 & 0.21 & 3.32 \\
\hline $\mathrm{MgO}$ & 0.18 & 0.001 & 0.06 & 35.0 & 0.29 & 9.06 \\
\hline $\mathrm{CaO}$ & 54 & 0.06 & 18.7 & 2081 & 39.6 & 635 \\
\hline $\mathrm{Na}_{2} \mathrm{O}$ & 0.50 & 0.0003 & 0.07 & 67.1 & 0.36 & 7.13 \\
\hline $\mathrm{K}_{2} \mathrm{O}$ & 0.02 & 0.00005 & 0.002 & 21.2 & 0.54 & 5.44 \\
\hline $\mathrm{P}_{2} \mathrm{O}_{5}$ & 40.3 & 0.02 & 12.7 & 358 & 2.56 & 92.8 \\
\hline $\mathrm{S}$ & 5818 & 7.18 & 542 & 364 & 12.9 & 88.7 \\
\hline $\mathrm{Sc}$ & 0.43 & 0.03 & 0.16 & 1.25 & 0.05 & 0.32 \\
\hline $\mathrm{Cr}$ & 3.16 & 0.65 & 1.90 & 33.5 & 0.86 & 8.75 \\
\hline $\mathrm{Ni}$ & 1.11 & 0.54 & 0.83 & 16.2 & 0.84 & 5.21 \\
\hline $\mathrm{Cu}$ & 53.2 & 0.08 & 6.05 & 3.61 & 0.10 & 0.79 \\
\hline $\mathrm{Zn}$ & 7.61 & 0.22 & 1.67 & 2.69 & 0.14 & 0.88 \\
\hline $\mathrm{Rb}$ & 1.53 & 0.01 & 0.23 & 0.32 & 0.01 & 0.09 \\
\hline $\mathrm{Sr}$ & 652 & 1.10 & 235 & 5.56 & 0.01 & 1.46 \\
\hline $\mathrm{Y}$ & 300 & 0.75 & 95.5 & 3.55 & 0.01 & 0.84 \\
\hline $\mathrm{Zr}$ & 2.27 & 0.05 & 0.51 & 0.38 & 0.02 & 0.14 \\
\hline $\mathrm{Nb}$ & 0.23 & 0.09 & 0.18 & 0.23 & 0.01 & 0.07 \\
\hline $\mathrm{Ba}$ & 12.7 & 0.23 & 2.61 & 4.52 & 0.07 & 0.70 \\
\hline $\mathrm{Pb}$ & 42.9 & 0.12 & 4.20 & 3.35 & 0.02 & 0.31 \\
\hline Th & 26.5 & 0.19 & 7.40 & 0.88 & 0.01 & 0.25 \\
\hline $\mathrm{U}$ & 9.63 & 0.11 & 3.00 & 0.58 & 0.01 & 0.16 \\
\hline $\mathrm{La}$ & 891 & 0.89 & 273 & 5.64 & 0.01 & 1.35 \\
\hline $\mathrm{Ce}$ & 2035 & 1.62 & 637 & 8.96 & 0.01 & 2.08 \\
\hline $\mathrm{Pr}$ & 238 & 0.54 & 75.5 & 2.75 & 0.01 & 0.64 \\
\hline n.d. & 919 & 2.66 & 294 & 13.0 & 0.04 & 3.07 \\
\hline $\mathrm{Sm}$ & 135 & 1.12 & 45.7 & 5.36 & 0.05 & 1.38 \\
\hline $\mathrm{Eu}$ & 23.2 & 0.25 & 8.00 & 1.16 & 0.02 & 0.32 \\
\hline $\mathrm{Gd}$ & 104 & 1.03 & 35.4 & 4.62 & 0.05 & 1.26 \\
\hline $\mathrm{Tb}$ & 12.0 & 0.13 & 3.96 & 0.58 & 0.01 & 0.16 \\
\hline Dy & 61.1 & 0.59 & 20.3 & 2.85 & 0.03 & 0.74 \\
\hline Но & 11.1 & 0.13 & 3.76 & 0.60 & 0.01 & 0.16 \\
\hline $\mathrm{Er}$ & 29.1 & 0.43 & 9.88 & 2.01 & 0.04 & 0.58 \\
\hline $\mathrm{Yb}$ & 21.0 & 0.44 & 7.59 & 2.17 & 0.05 & 0.64 \\
\hline
\end{tabular}


Table C-2. Continued.

\begin{tabular}{|c|c|c|c|c|c|c|}
\hline & \multicolumn{6}{|c|}{ ETH - August 4, 2010} \\
\hline & \multicolumn{3}{|c|}{ Error Summary $(1 \sigma)$} & \multicolumn{3}{|c|}{ Detection Limits (ppm) } \\
\hline & high & low & average & high & low & average \\
\hline $\mathrm{SiO}_{2}$ & 0.74 & 0.01 & 0.11 & 1051 & 86 & 324 \\
\hline $\mathrm{TiO}_{2}$ & 0.002 & 0.0004 & 0.001 & 5.46 & 0.34 & 1.80 \\
\hline $\mathrm{Al}_{2} \mathrm{O}_{3}$ & 0.11 & 0.00002 & 0.03 & 185 & 0.24 & 22.8 \\
\hline $\mathrm{FeO}^{*}$ & 0.05 & 0.003 & 0.02 & 53.5 & 5.03 & 18.1 \\
\hline $\mathrm{MnO}$ & 0.04 & 0.0004 & 0.01 & 1.91 & 0.24 & 0.79 \\
\hline $\mathrm{MgO}$ & 0.04 & 0.001 & 0.01 & 4.52 & 0.31 & 1.37 \\
\hline $\mathrm{CaO}$ & 5.47 & 0.07 & 0.97 & 596 & 48.0 & 220 \\
\hline $\mathrm{Na}_{2} \mathrm{O}$ & 0.06 & 0.0003 & 0.01 & 77.5 & 0.38 & 10.6 \\
\hline $\mathrm{K}_{2} \mathrm{O}$ & 0.03 & 0.0001 & 0.005 & 14.4 & 1.23 & 4.86 \\
\hline $\mathrm{P}_{2} \mathrm{O}_{5}$ & 6.64 & 0.02 & 1.76 & 25.8 & 3.05 & 9.33 \\
\hline $\mathrm{S}$ & 294 & 8.97 & 79.5 & 377 & 24.9 & 102 \\
\hline $\mathrm{Sc}$ & 0.38 & 0.04 & 0.13 & 0.84 & 0.04 & 0.24 \\
\hline $\mathrm{Cr}$ & 4.84 & 0.98 & 3.47 & 12.8 & 1.88 & 5.46 \\
\hline $\mathrm{Ni}$ & 0 & 0 & 0 & 7.64 & 1.37 & 3.58 \\
\hline $\mathrm{Cu}$ & 14.0 & 0.08 & 2.69 & 1.52 & 0.11 & 0.46 \\
\hline $\mathrm{Zn}$ & 4.50 & 0.28 & 0.98 & 2.28 & 0.26 & 0.76 \\
\hline $\mathrm{Rb}$ & 2.25 & 0.01 & 0.53 & 0.22 & 0.01 & 0.06 \\
\hline $\mathrm{Sr}$ & 193 & 1.32 & 18.8 & 3.87 & 0.01 & 0.69 \\
\hline $\mathrm{Y}$ & 58.0 & 0.74 & 13.9 & 0.13 & 0.01 & 0.05 \\
\hline $\mathrm{Zr}$ & 5.02 & 0.04 & 0.69 & 0.16 & 0.02 & 0.07 \\
\hline $\mathrm{Nb}$ & 0.47 & 0.04 & 0.20 & 0.10 & 0.01 & 0.04 \\
\hline $\mathrm{Ba}$ & 15.4 & 0.26 & 2.79 & 3.94 & 0.08 & 0.71 \\
\hline $\mathrm{Pb}$ & 349 & 0.13 & 33.5 & 0.41 & 0.03 & 0.11 \\
\hline Th & 4.26 & 0.17 & 1.61 & 0.08 & 0.01 & 0.04 \\
\hline $\mathrm{U}$ & 2.16 & 0.12 & 0.85 & 0.08 & 0.01 & 0.03 \\
\hline $\mathrm{La}$ & 165 & 1.24 & 33.6 & 0.35 & 0.01 & 0.10 \\
\hline $\mathrm{Ce}$ & 376 & 2.08 & 81.8 & 0.47 & 0.01 & 0.13 \\
\hline $\operatorname{Pr}$ & 44.6 & 0.61 & 10.4 & 0.14 & 0.01 & 0.05 \\
\hline n.d. & 173 & 2.80 & 42.4 & 0.62 & 0.05 & 0.24 \\
\hline $\mathrm{Sm}$ & 26.6 & 1.16 & 9.07 & 0.43 & 0.06 & 0.20 \\
\hline $\mathrm{Eu}$ & 4.16 & 0.26 & 1.68 & 0.16 & 0.02 & 0.06 \\
\hline $\mathrm{Gd}$ & 20.7 & 1.04 & 7.41 & 0.46 & 0.06 & 0.20 \\
\hline $\mathrm{Tb}$ & 2.56 & 0.13 & 0.93 & 0.07 & 0.01 & 0.03 \\
\hline Dy & 11.2 & 0.58 & 4.32 & 0.29 & 0.03 & 0.12 \\
\hline Ho & 2.57 & 0.13 & 0.91 & 0.07 & 0.01 & 0.03 \\
\hline $\mathrm{Er}$ & 7.84 & 0.43 & 2.86 & 0.34 & 0.04 & 0.13 \\
\hline $\mathrm{Yb}$ & 13.2 & 0.43 & 3.29 & 0.71 & 0.06 & 0.22 \\
\hline
\end{tabular}


Table C-2. Continued.

\begin{tabular}{|c|c|c|c|c|c|c|}
\hline & \multicolumn{6}{|c|}{ ETH - March 16, 2011} \\
\hline & \multicolumn{3}{|c|}{ Error Summary $(1 \sigma)$} & \multicolumn{3}{|c|}{ Detection Limits (ppm) } \\
\hline & high & low & average & high & low & average \\
\hline $\mathrm{SiO}_{2}$ & 0.73 & 0.06 & 0.31 & 2547 & 368 & 976 \\
\hline $\mathrm{TiO}_{2}$ & 0.01 & 0.001 & 0.003 & 23.7 & 1.80 & 7.21 \\
\hline $\mathrm{Al}_{2} \mathrm{O}_{3}$ & 0.14 & 0.0003 & 0.02 & 172 & 3.13 & 15.7 \\
\hline $\mathrm{FeO}^{*}$ & 0.11 & 0.01 & 0.03 & 182 & 21.9 & 57.9 \\
\hline $\mathrm{MnO}$ & 0.08 & 0.001 & 0.01 & 9.78 & 1.59 & 3.89 \\
\hline $\mathrm{MgO}$ & 0.09 & 0.01 & 0.02 & 32.1 & 1.94 & 6.56 \\
\hline $\mathrm{CaO}$ & 5.31 & 0.25 & 0.77 & 1321 & 201 & 533 \\
\hline $\mathrm{Na}_{2} \mathrm{O}$ & 0.09 & 0.001 & 0.02 & 71.3 & 1.64 & 6.88 \\
\hline $\mathrm{K}_{2} \mathrm{O}$ & 0.01 & 0.0004 & 0.003 & 40.0 & 4.54 & 12.1 \\
\hline $\mathrm{P}_{2} \mathrm{O}_{5}$ & 19.0 & 0.07 & 1.09 & 138 & 14.9 & 38.3 \\
\hline $\mathrm{S}$ & 982 & 43.3 & 117 & 479 & 64.1 & 178 \\
\hline $\mathrm{Sc}$ & 3.80 & 0.76 & 1.87 & 4.41 & 0.38 & 1.36 \\
\hline $\mathrm{Cr}$ & 235 & 21.9 & 69.6 & 96.4 & 17.9 & 38.2 \\
\hline $\mathrm{Ni}$ & 195 & 11.6 & 63.6 & 49.6 & 6.09 & 17.6 \\
\hline $\mathrm{Cu}$ & 32.9 & 1.09 & 7.39 & 6.67 & 0.99 & 2.54 \\
\hline $\mathrm{Zn}$ & 35.0 & 2.00 & 6.71 & 13.1 & 0.97 & 4.20 \\
\hline $\mathrm{Rb}$ & 3.33 & 0.13 & 1.49 & 1.49 & 0.08 & 0.34 \\
\hline $\mathrm{Sr}$ & 515 & 5.13 & 41.3 & 3.80 & 0.12 & 0.74 \\
\hline $\mathrm{Y}$ & 86.0 & 1.52 & 9.60 & 1.22 & 0.10 & 0.26 \\
\hline $\mathrm{Zr}$ & 25.8 & 0.18 & 2.41 & 1.81 & 0.19 & 0.47 \\
\hline $\mathrm{Nb}$ & 0.77 & 0.15 & 0.39 & 0.55 & 0.08 & 0.23 \\
\hline $\mathrm{Ba}$ & 141 & 0.75 & 10.4 & 8.12 & 0.42 & 1.44 \\
\hline $\mathrm{Pb}$ & 139 & 0.54 & 11.6 & 3.73 & 0.11 & 0.47 \\
\hline Th & 10.1 & 0.64 & 1.95 & 0.60 & 0.08 & 0.18 \\
\hline $\mathrm{U}$ & 4.90 & 0.40 & 1.02 & 0.41 & 0.06 & 0.15 \\
\hline $\mathrm{La}$ & 160 & 2.33 & 15.8 & 1.81 & 0.07 & 0.31 \\
\hline $\mathrm{Ce}$ & 465 & 3.59 & 36.8 & 2.78 & 0.08 & 0.41 \\
\hline $\operatorname{Pr}$ & 66.1 & 1.04 & 6.55 & 0.80 & 0.04 & 0.15 \\
\hline n.d. & 241 & 4.76 & 27.3 & 3.85 & 0.24 & 0.80 \\
\hline $\mathrm{Sm}$ & 38.2 & 2.00 & 8.19 & 1.71 & 0.23 & 0.62 \\
\hline $\mathrm{Eu}$ & 6.73 & 0.64 & 1.85 & 0.42 & 0.06 & 0.17 \\
\hline $\mathrm{Gd}$ & 29.5 & 1.63 & 7.31 & 1.68 & 0.25 & 0.67 \\
\hline $\mathrm{Tb}$ & 3.57 & 0.21 & 0.90 & 0.25 & 0.03 & 0.09 \\
\hline Dy & 23.3 & 0.86 & 4.32 & 0.88 & 0.14 & 0.37 \\
\hline Но & 4.54 & 0.22 & 0.94 & 0.23 & 0.04 & 0.10 \\
\hline $\mathrm{Er}$ & 11.3 & 0.74 & 2.98 & 1.01 & 0.16 & 0.43 \\
\hline $\mathrm{Yb}$ & 13.4 & 0.76 & 3.05 & 2.05 & 0.24 & 0.64 \\
\hline
\end{tabular}




\section{APPENDIX D: CORRELATION OF EMP AND LA-ICP-MS}

To correlate the LA-ICP-MS data with the EMP data (e.g. Sr and $\mathrm{SO}_{3}$ wt.\%), laser spots were ideally placed over the previous EMP point traverses (Fig. D-1). The much larger laser spot size overlapped multiple EMP spots, therefore, the average of the overlapped EMP spots were used in conjunction with LA-ICP-MS data. Data from some laser spots illustrated in Figure D-1 were not used in the final data analysis due to significant contamination from the matrix. 

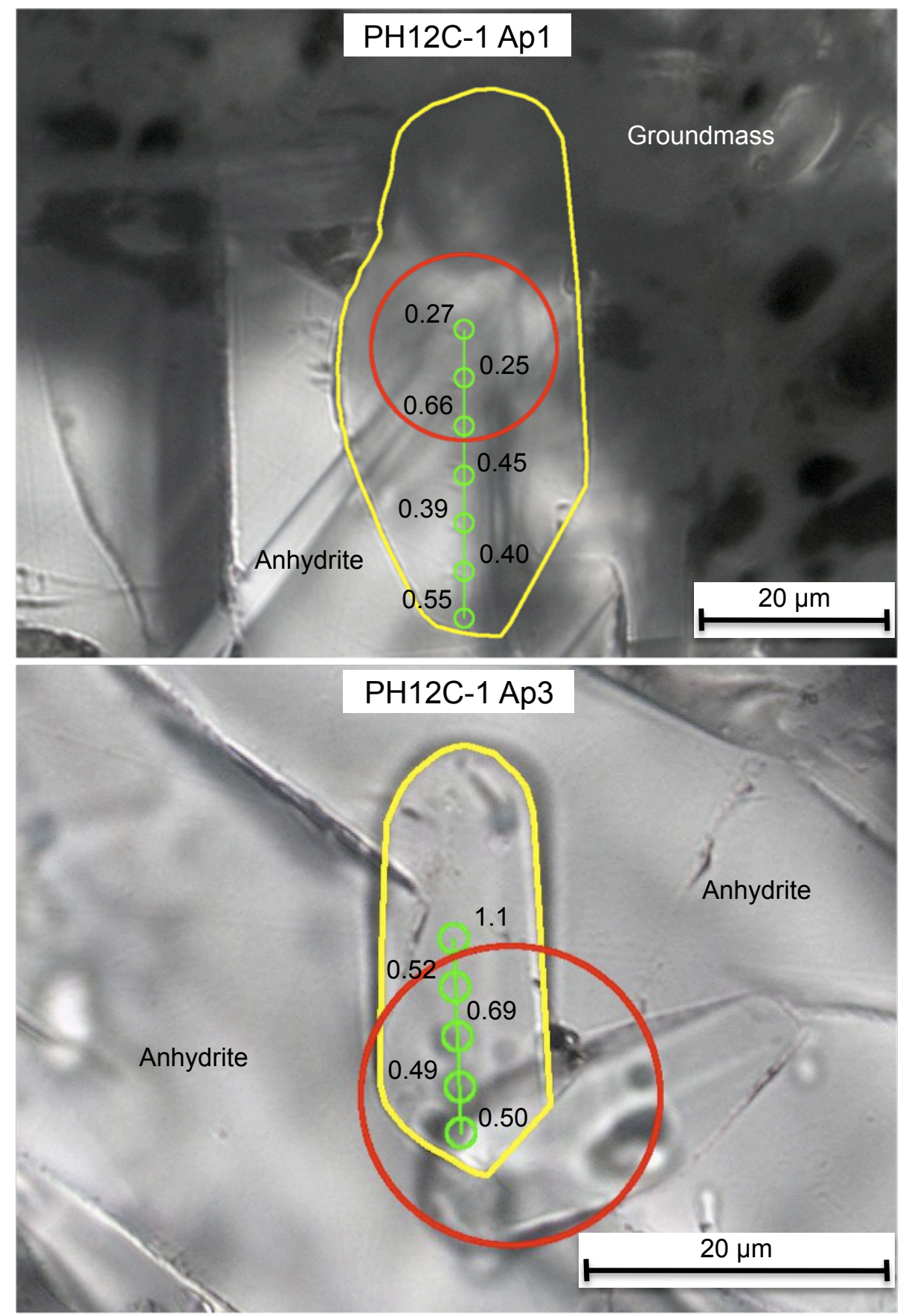

Figure D-1: EMP (green line and circles) and LA-ICP-MS (red circle) data correlation. EMP $\mathrm{SO}_{3}$ wt.\% values are shown beside the EMP spots. Laser spot size is represented by scale bar, EMP spot size is $2 \mu \mathrm{m}$. 

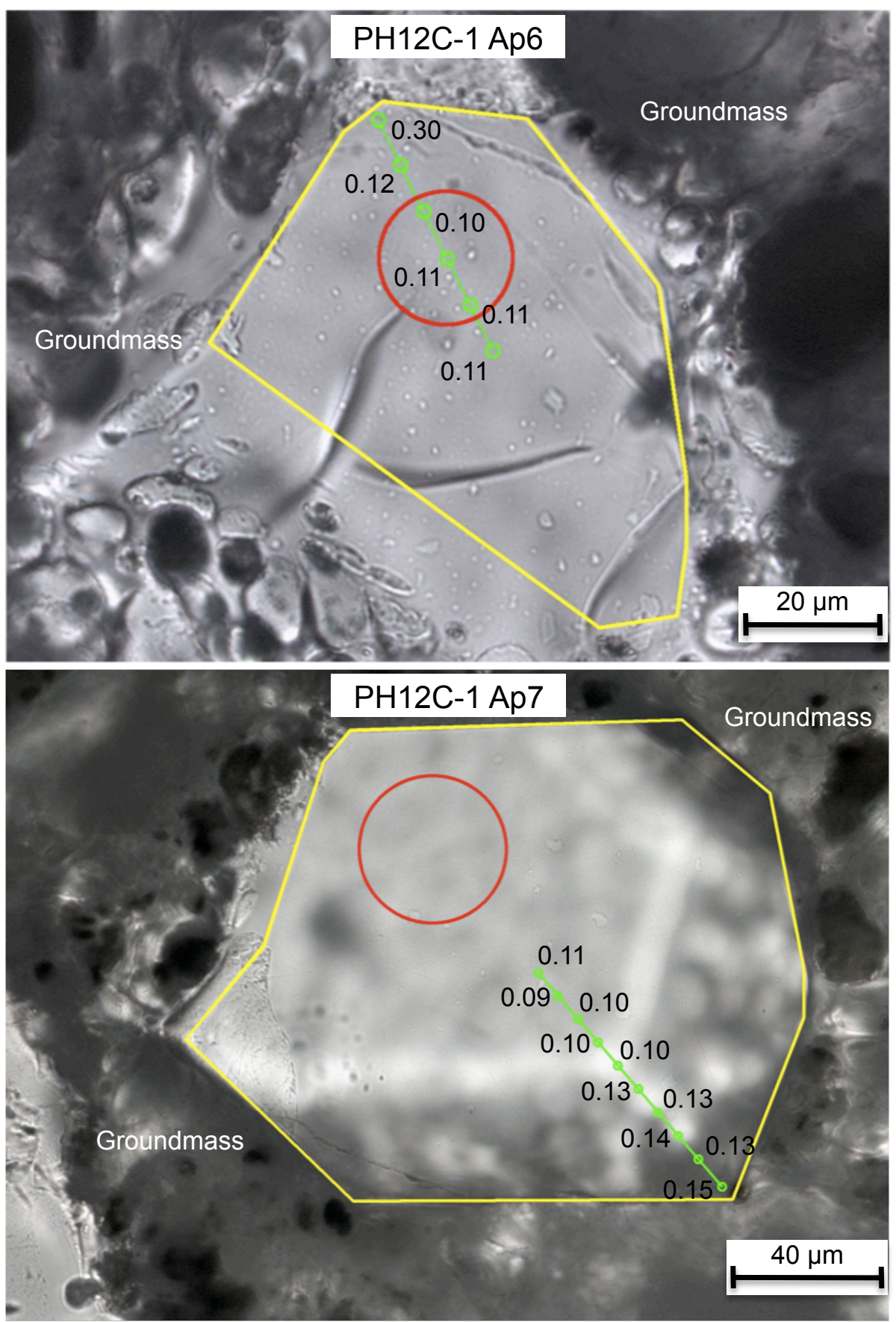

Figure D-1: Continued, EMP (green line and circles) and LA-ICP-MS (red circle) data correlation. EMP $\mathrm{SO}_{3}$ wt.\% values are shown beside the EMP spots. Laser spot size is represented by scale bar, EMP spot size is $2 \mu \mathrm{m}$. 

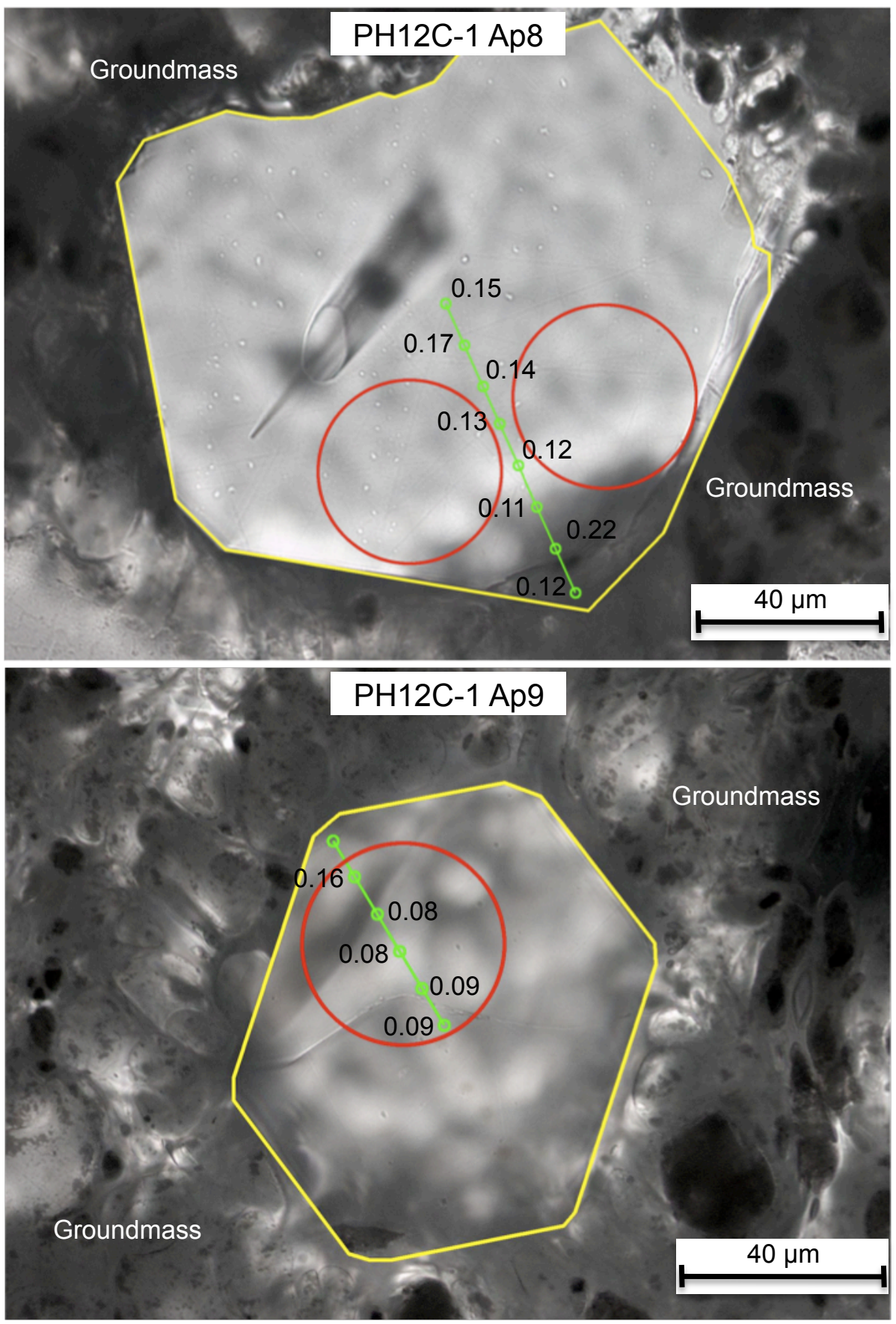

Figure D-1: Continued, EMP (green line and circles) and LA-ICP-MS (red circle) data correlation. EMP $\mathrm{SO}_{3}$ wt.\% values are shown beside the EMP spots. Laser spot size is represented by scale bar, EMP spot size is $2 \mu \mathrm{m}$. 

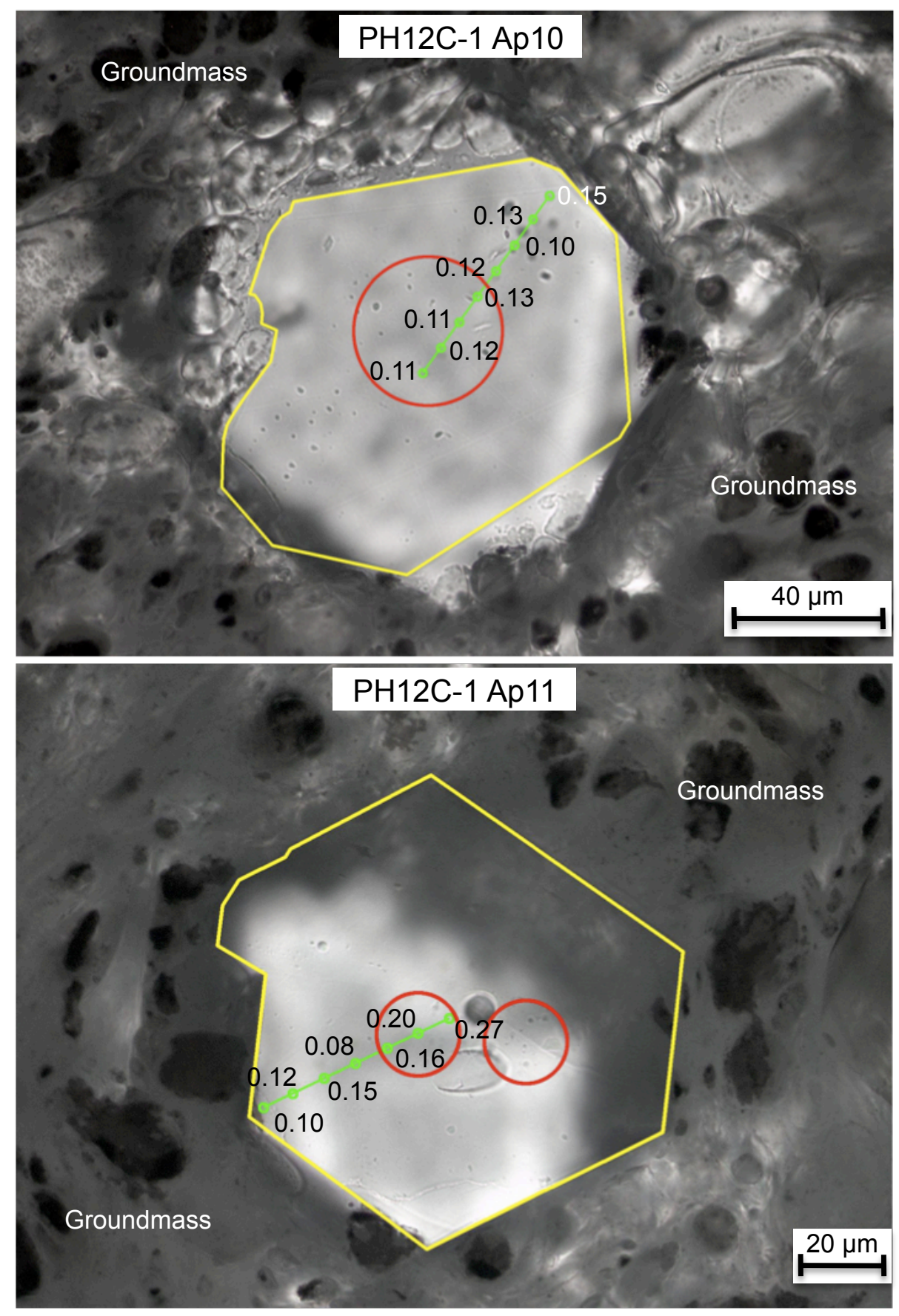

Figure D-1: Continued, EMP (green line and circles) and LA-ICP-MS (red circle) data correlation. EMP $\mathrm{SO}_{3}$ wt.\% values are shown beside the EMP spots. Laser spot size is represented by scale bar, EMP spot size is $2 \mu \mathrm{m}$. 

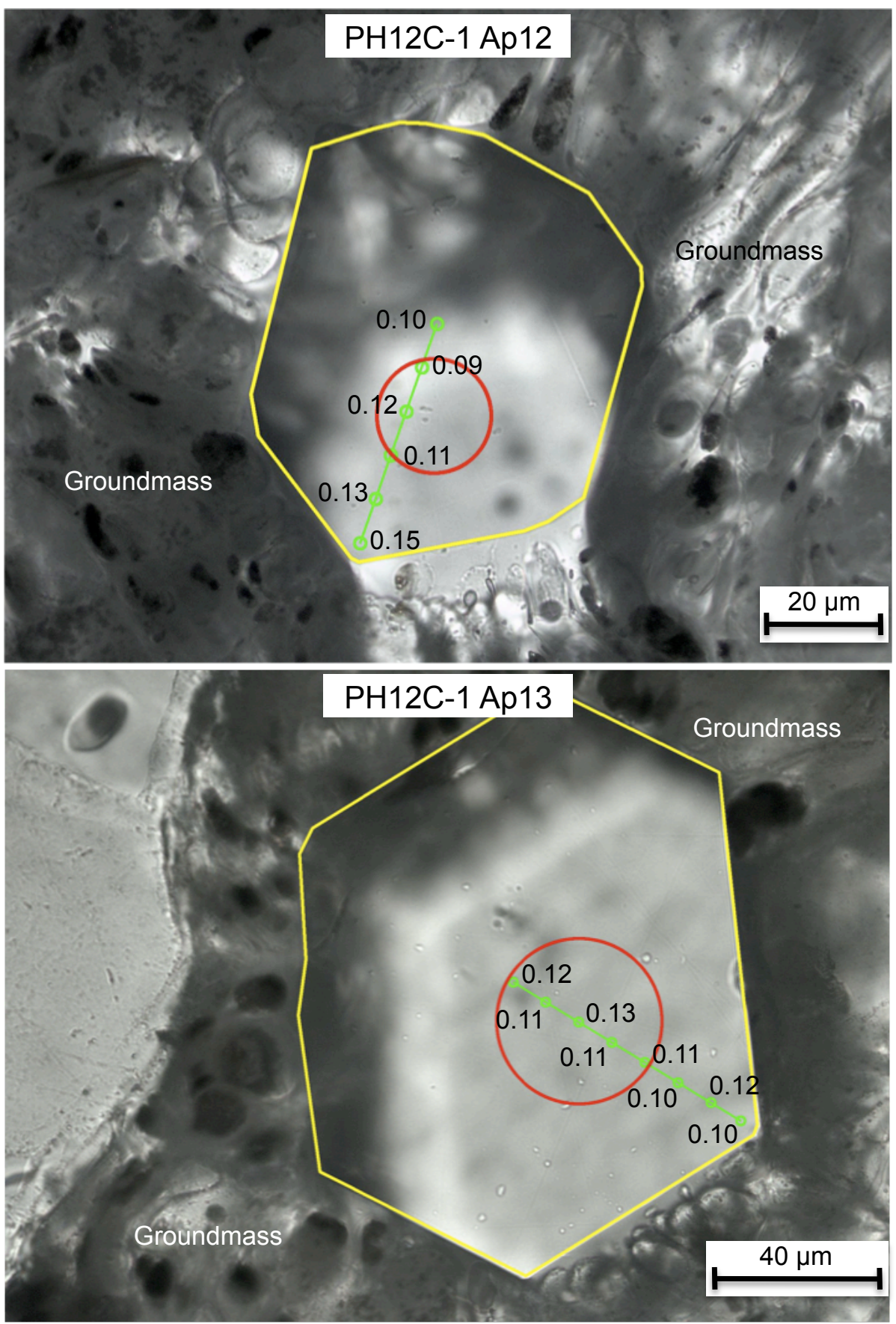

Figure D-1: Continued, EMP (green line and circles) and LA-ICP-MS (red circle) data correlation. EMP $\mathrm{SO}_{3}$ wt.\% values are shown beside the EMP spots. Laser spot size is represented by scale bar, EMP spot size is $2 \mu \mathrm{m}$. 

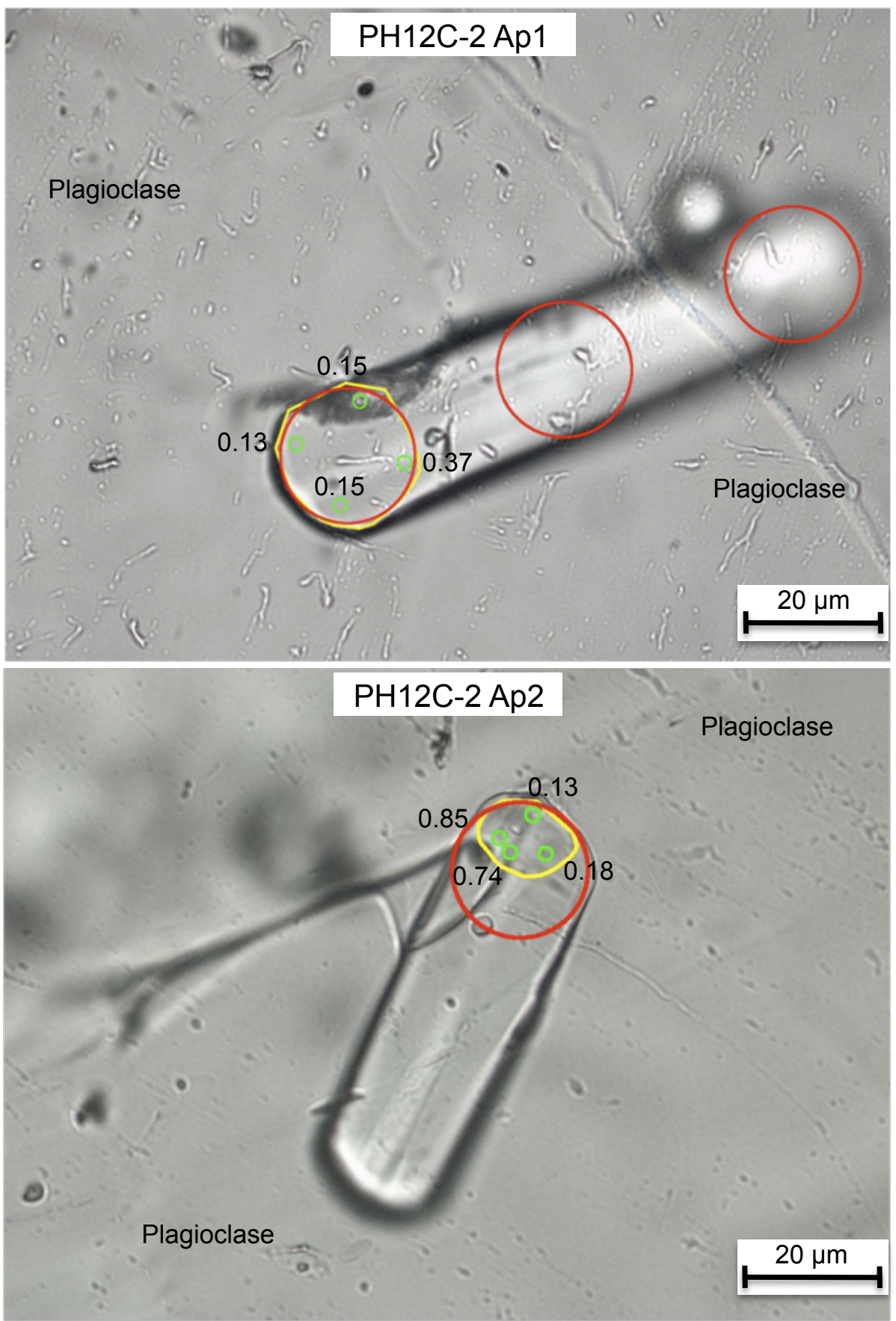

Figure D-1: Continued, EMP (green line and circles) and LA-ICP-MS (red circle) data correlation. EMP $\mathrm{SO}_{3}$ wt.\% values are shown beside the EMP spots. Laser spot size is represented by scale bar, EMP spot size is $2 \mu \mathrm{m}$. 

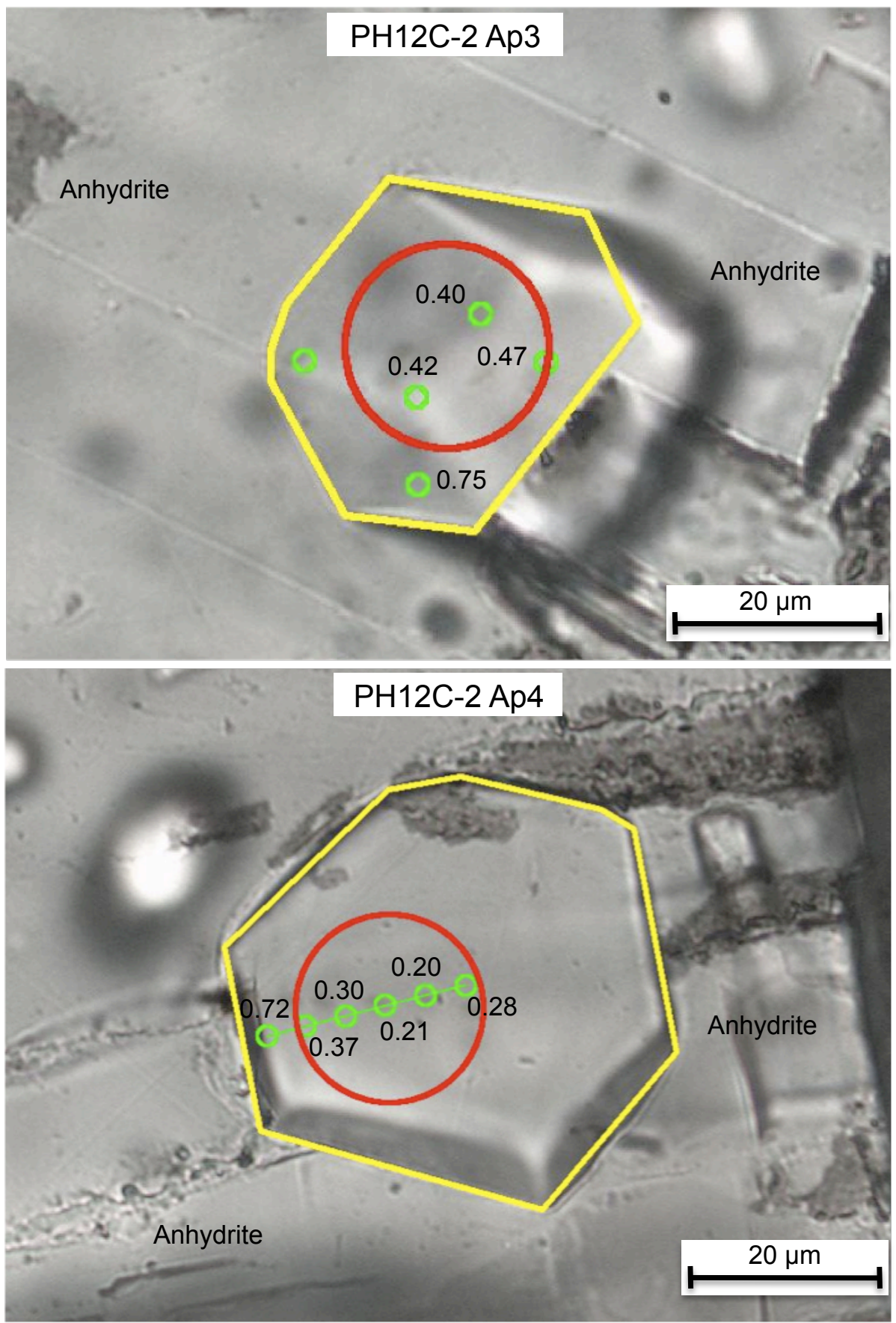

Figure D-1: Continued, EMP (green line and circles) and LA-ICP-MS (red circle) data correlation. EMP $\mathrm{SO}_{3}$ wt.\% values are shown beside the EMP spots. Laser spot size is represented by scale bar, EMP spot size is $2 \mu \mathrm{m}$. 

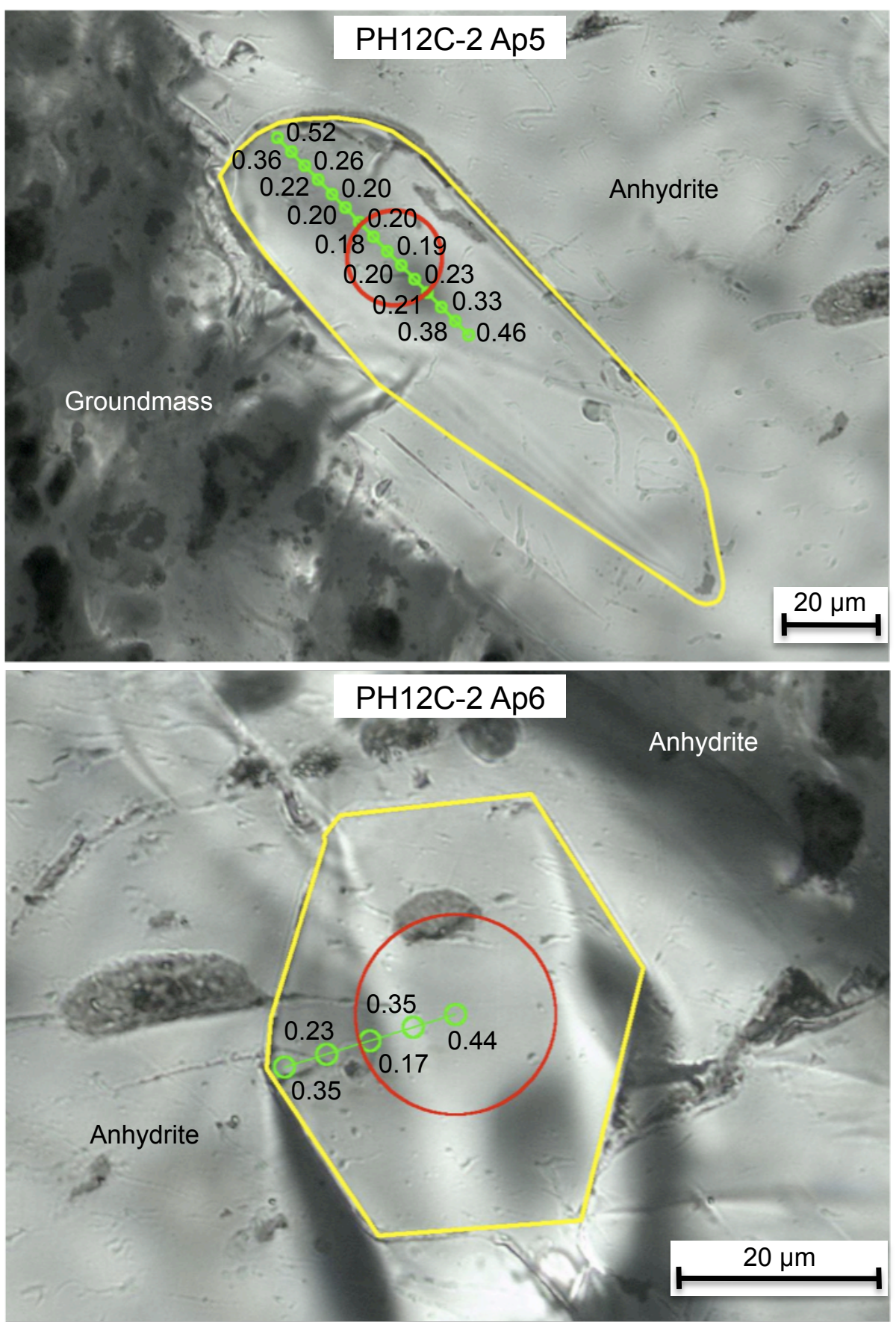

Figure D-1: Continued, EMP (green line and circles) and LA-ICP-MS (red circle) data correlation. EMP $\mathrm{SO}_{3}$ wt.\% values are shown beside the EMP spots. Laser spot size is represented by scale bar, EMP spot size is $2 \mu \mathrm{m}$. 

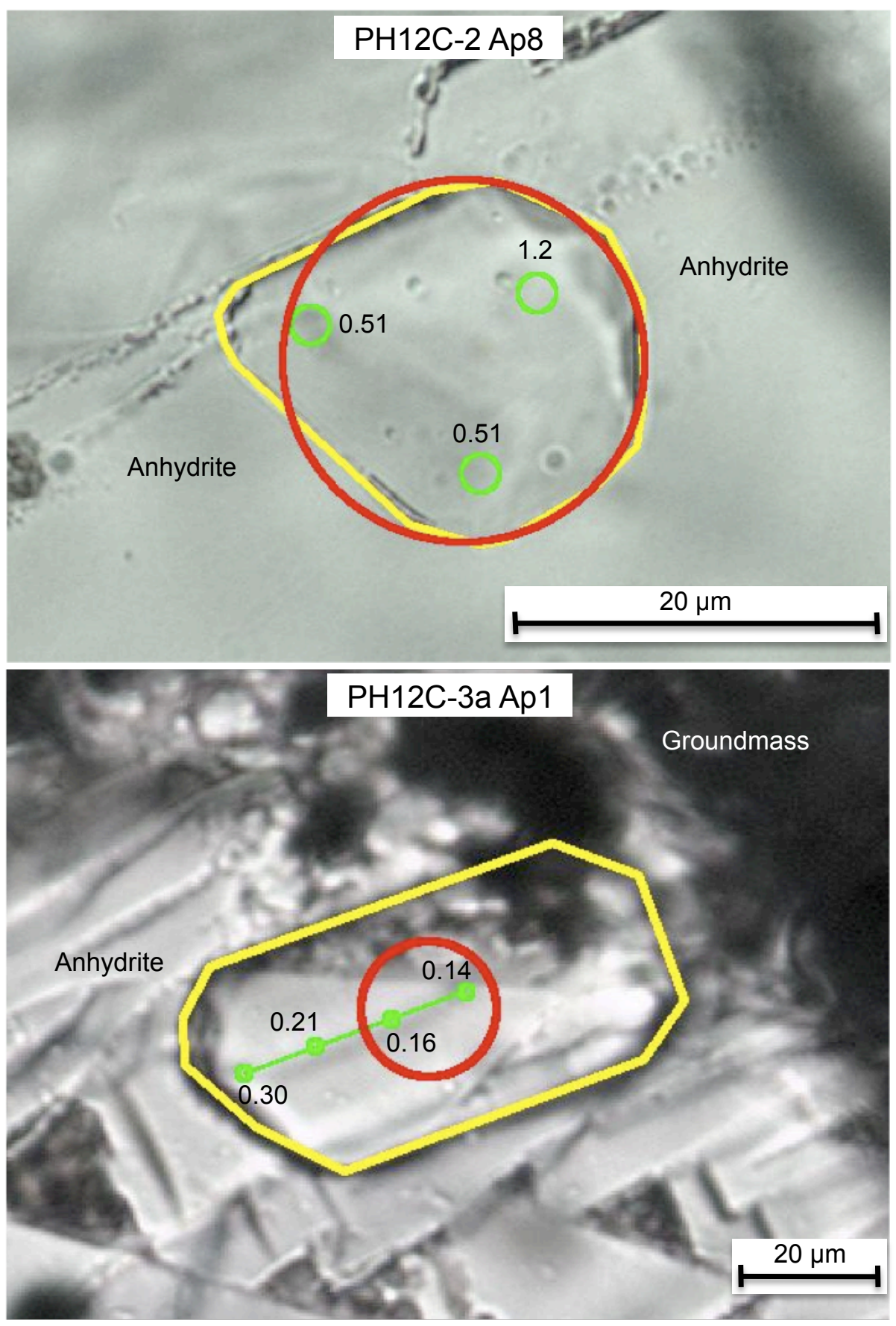

Figure D-1: Continued, EMP (green line and circles) and LA-ICP-MS (red circle) data correlation. EMP $\mathrm{SO}_{3}$ wt.\% values are shown beside the EMP spots. Laser spot size is represented by scale bar, EMP spot size is $2 \mu \mathrm{m}$. 

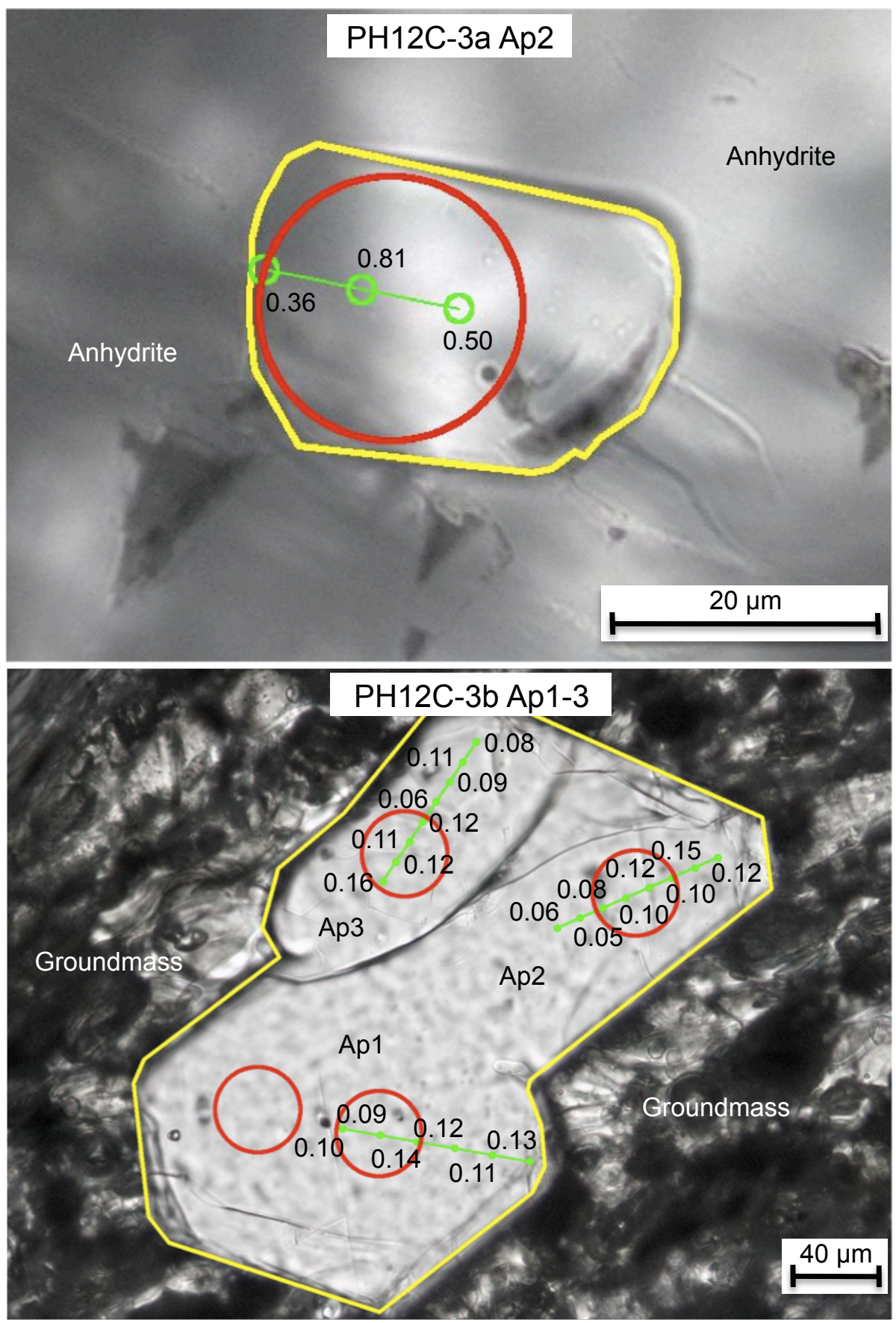

Figure D-1: Continued, EMP (green line and circles) and LA-ICP-MS (red circle) data correlation. EMP $\mathrm{SO}_{3}$ wt.\% values are shown beside the EMP spots. Laser spot size is represented by scale bar, EMP spot size is $2 \mu \mathrm{m}$. 

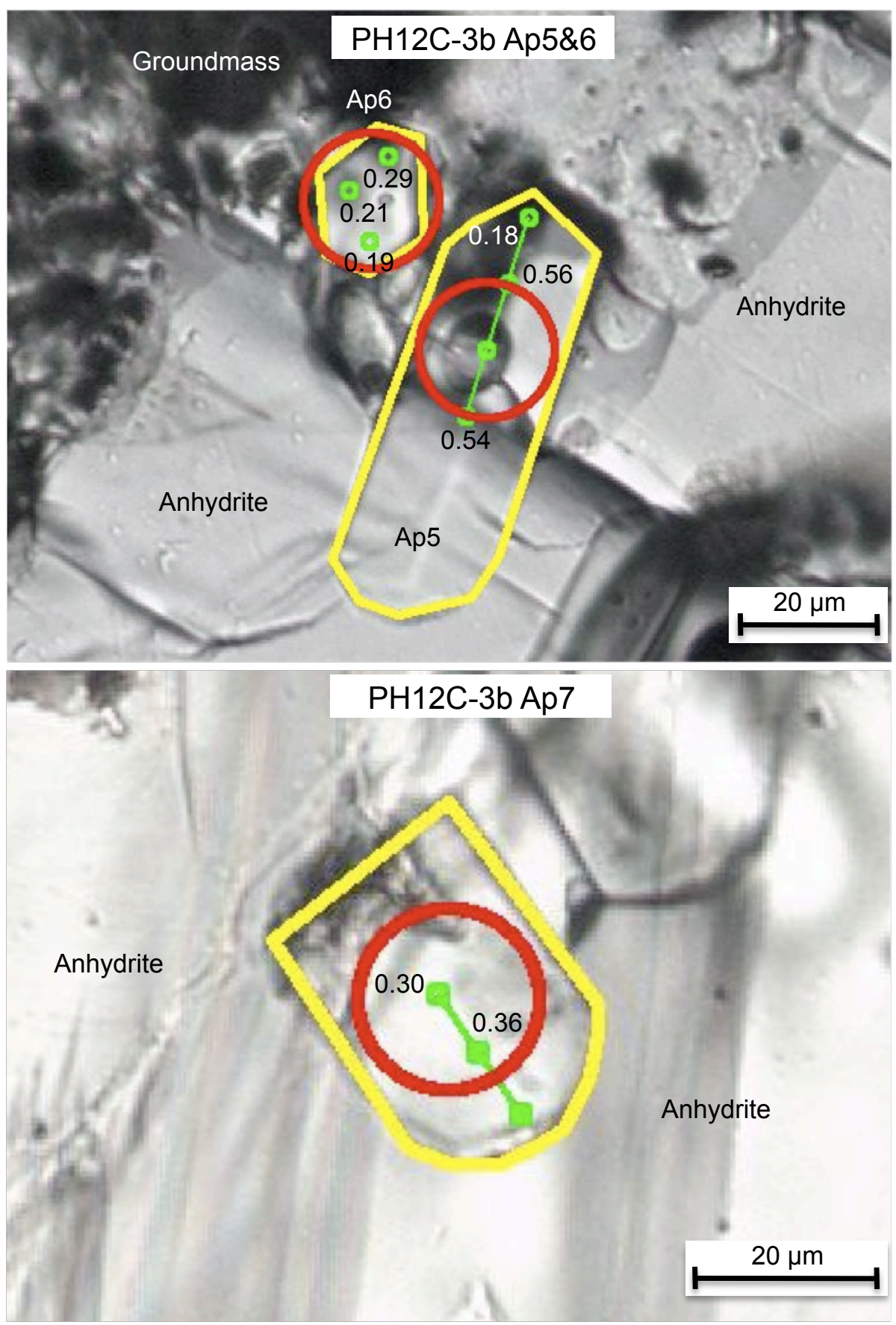

Figure D-1: Continued, EMP (green line and circles) and LA-ICP-MS (red circle) data correlation. EMP $\mathrm{SO}_{3}$ wt.\% values are shown beside the EMP spots. Laser spot size is represented by scale bar, EMP spot size is $2 \mu \mathrm{m}$. 

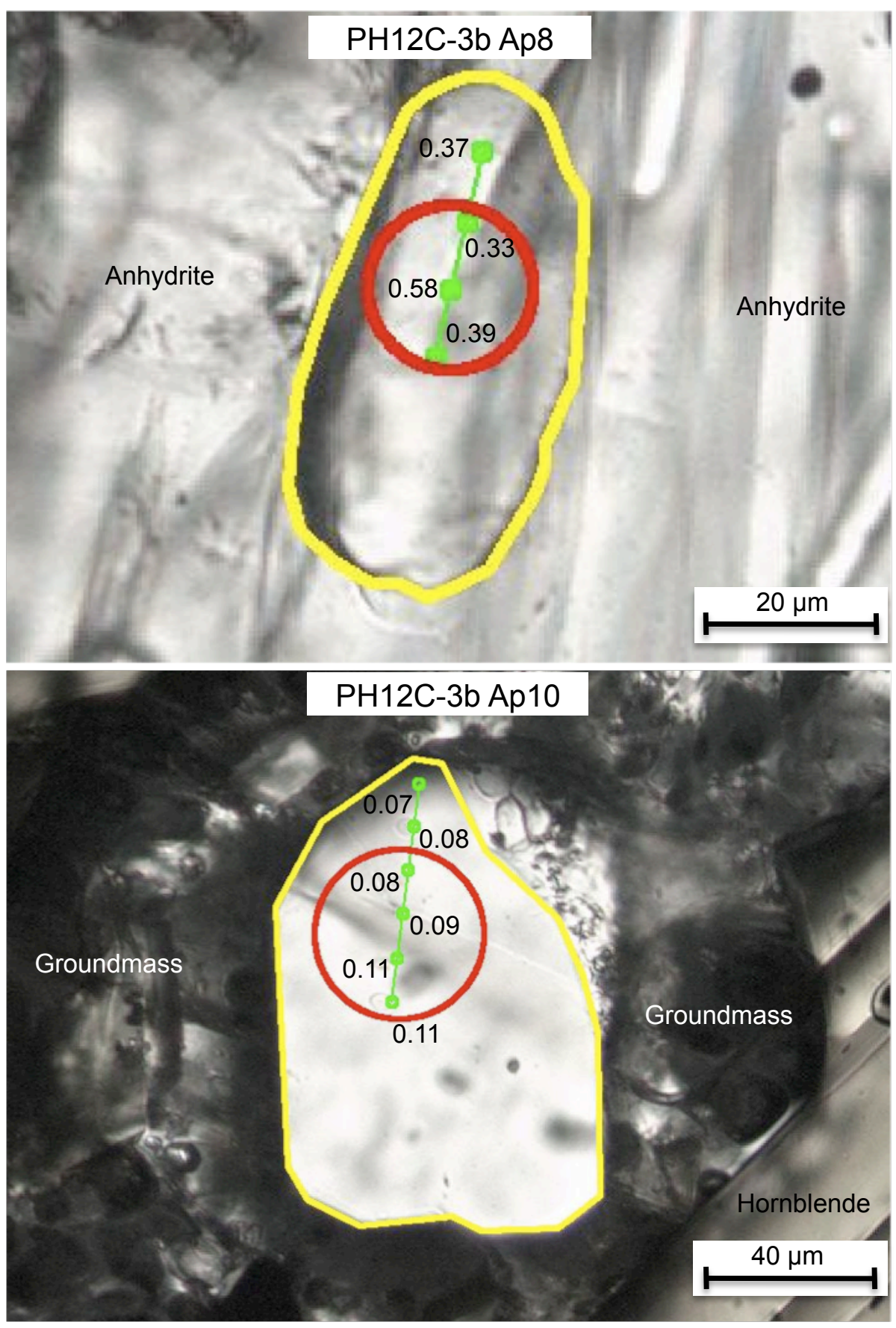

Figure D-1: Continued, EMP (green line and circles) and LA-ICP-MS (red circle) data correlation. EMP $\mathrm{SO}_{3}$ wt.\% values are shown beside the EMP spots. Laser spot size is represented by scale bar, EMP spot size is $2 \mu \mathrm{m}$. 

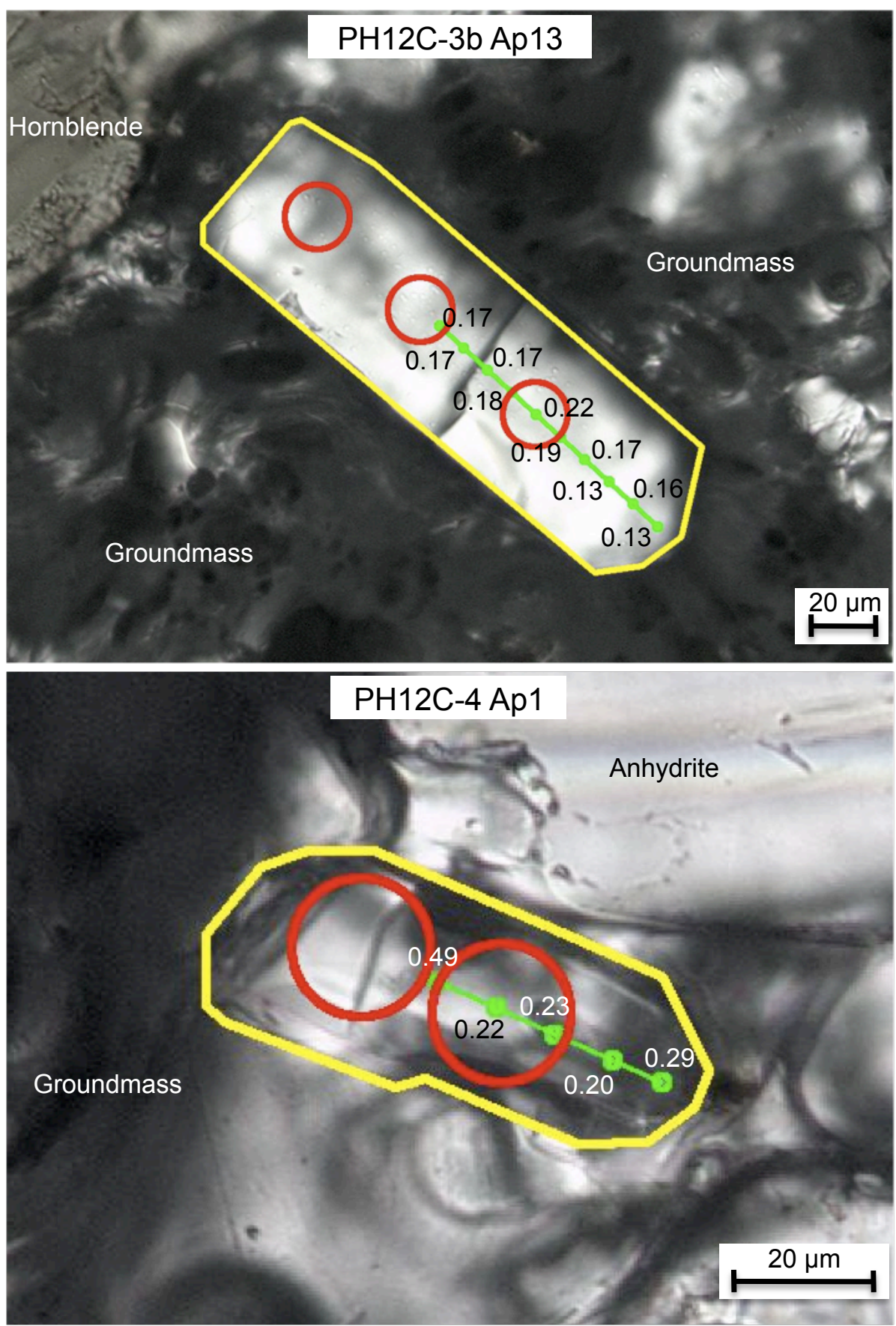

Figure D-1: Continued, EMP (green line and circles) and LA-ICP-MS (red circle) data correlation. EMP $\mathrm{SO}_{3}$ wt.\% values are shown beside the EMP spots. Laser spot size is represented by scale bar, EMP spot size is $2 \mu \mathrm{m}$. 


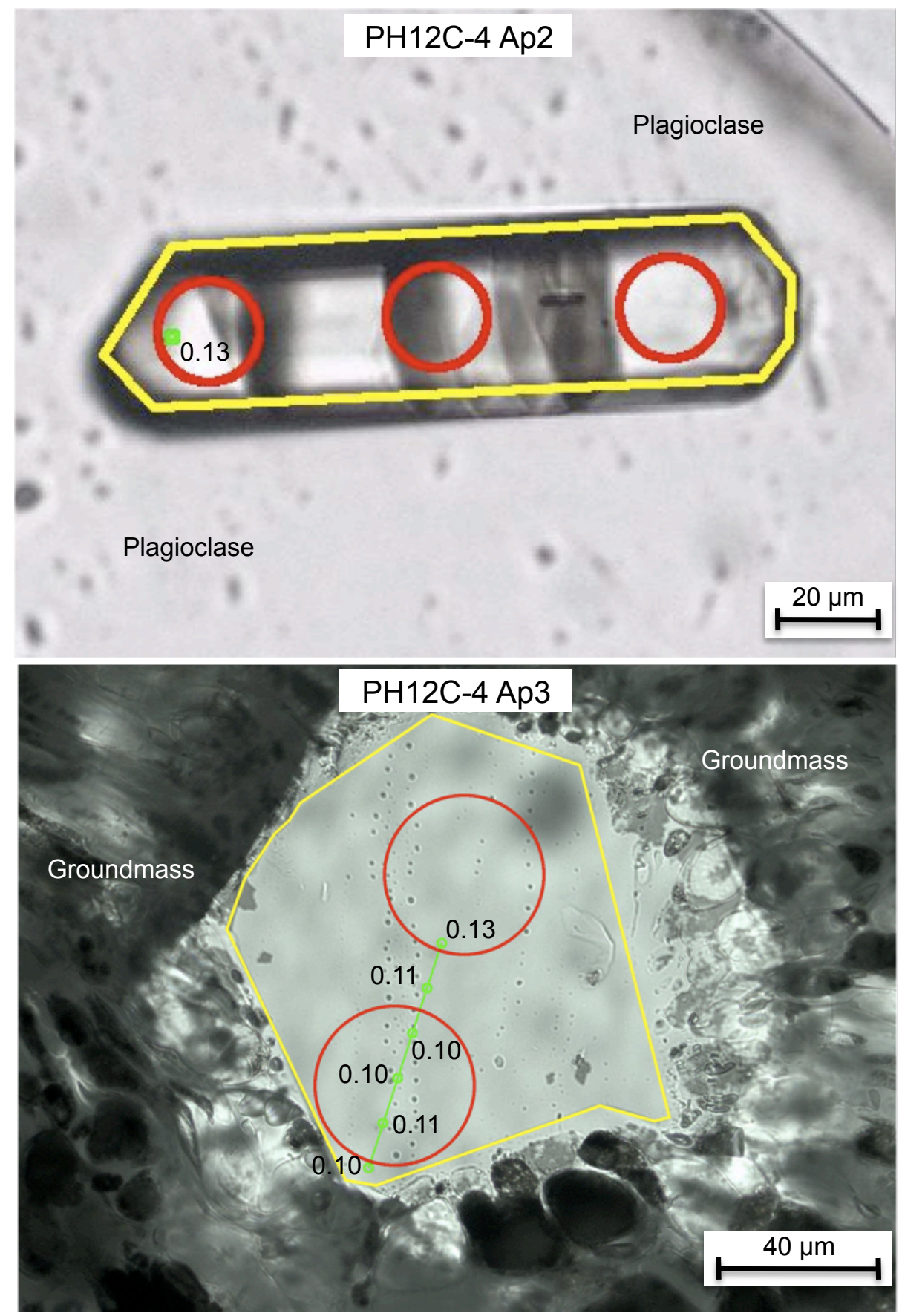

Figure D-1: Continued, EMP (green line and circles) and LA-ICP-MS (red circle) data correlation. EMP $\mathrm{SO}_{3}$ wt.\% values are shown beside the EMP spots. Laser spot size is represented by scale bar, EMP spot size is $2 \mu \mathrm{m}$. 


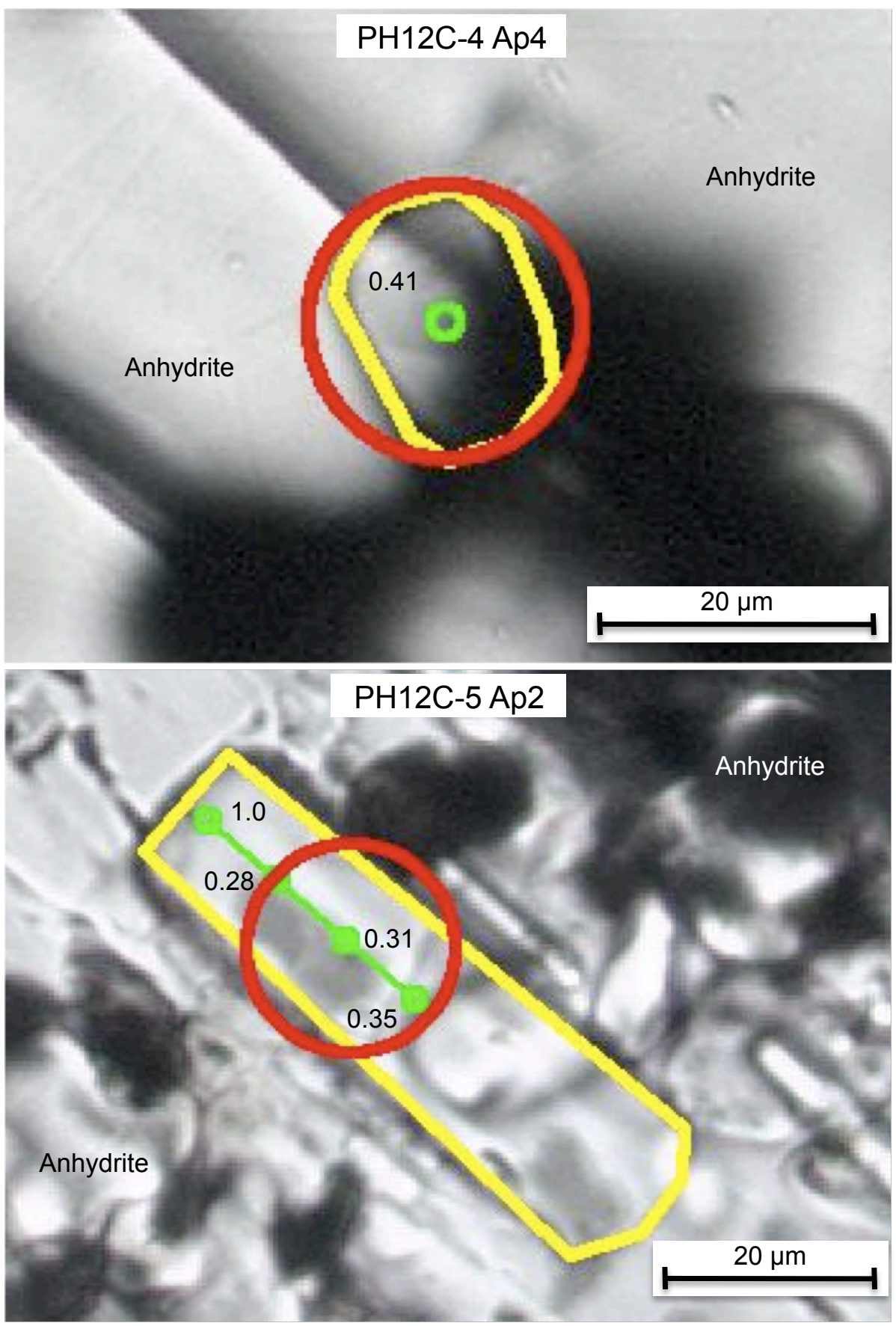

Figure D-1: Continued, EMP (green line and circles) and LA-ICP-MS (red circle) data correlation. EMP $\mathrm{SO}_{3}$ wt.\% values are shown beside the EMP spots. Laser spot size is represented by scale bar, EMP spot size is $2 \mu \mathrm{m}$. 


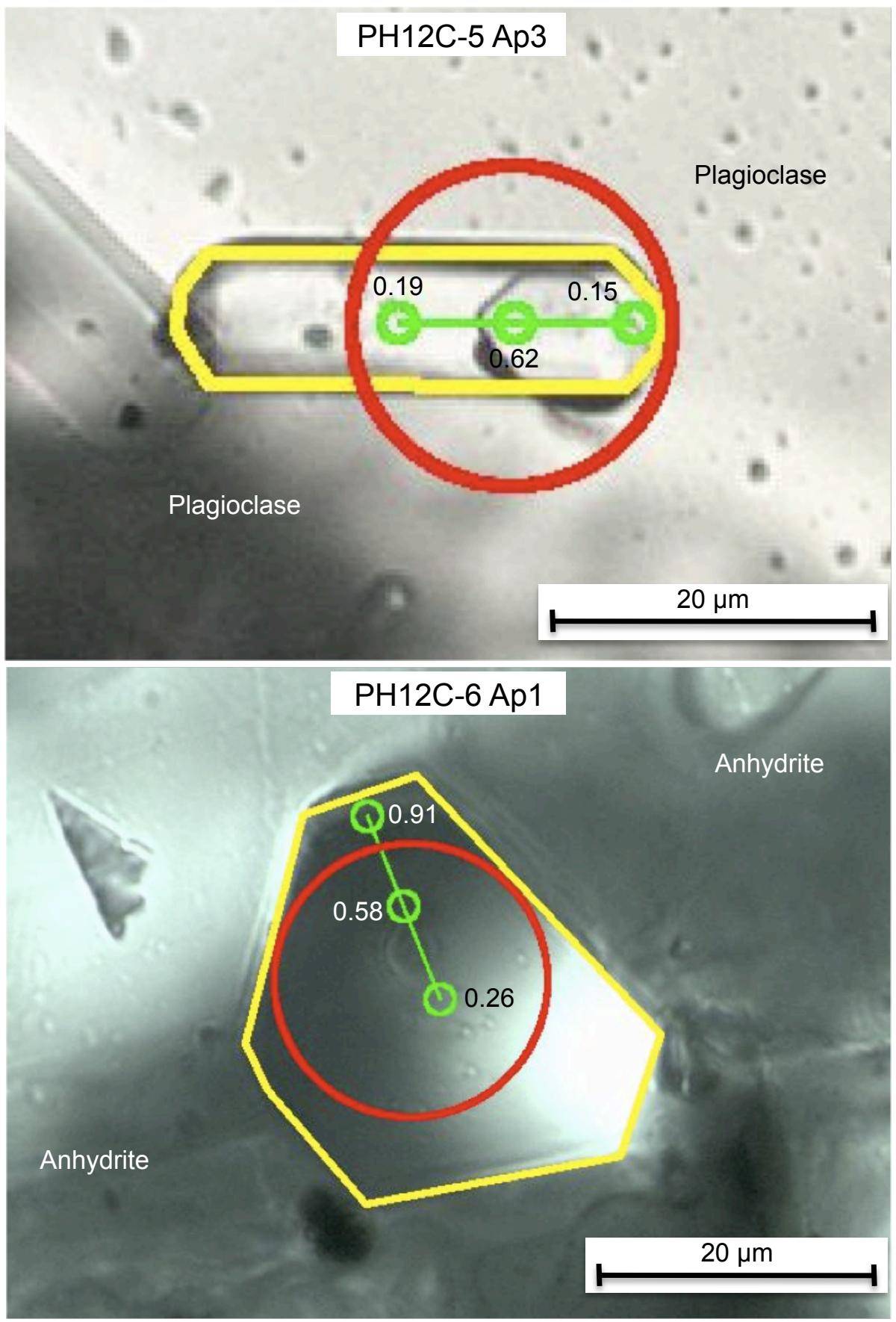

Figure D-1: Continued, EMP (green line and circles) and LA-ICP-MS (red circle) data correlation. EMP $\mathrm{SO}_{3}$ wt.\% values are shown beside the EMP spots. Laser spot size is represented by scale bar, EMP spot size is $2 \mu \mathrm{m}$. 

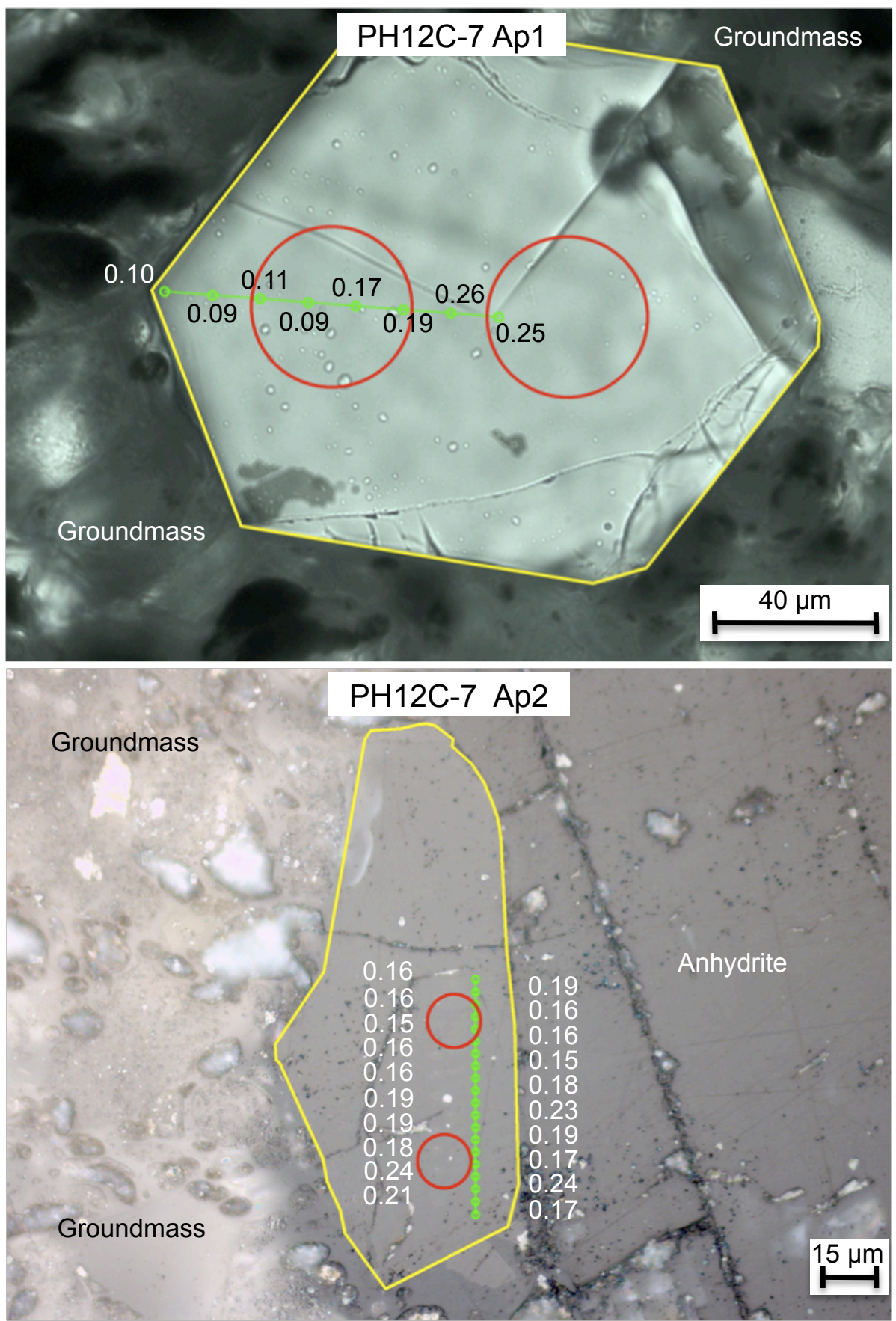

Figure D-1: Continued, EMP (green line and circles) and LA-ICP-MS (red circle) data correlation. EMP $\mathrm{SO}_{3}$ wt.\% values are shown beside the EMP spots. Laser spot size is represented by scale bar, EMP spot size is $2 \mu \mathrm{m}$. 

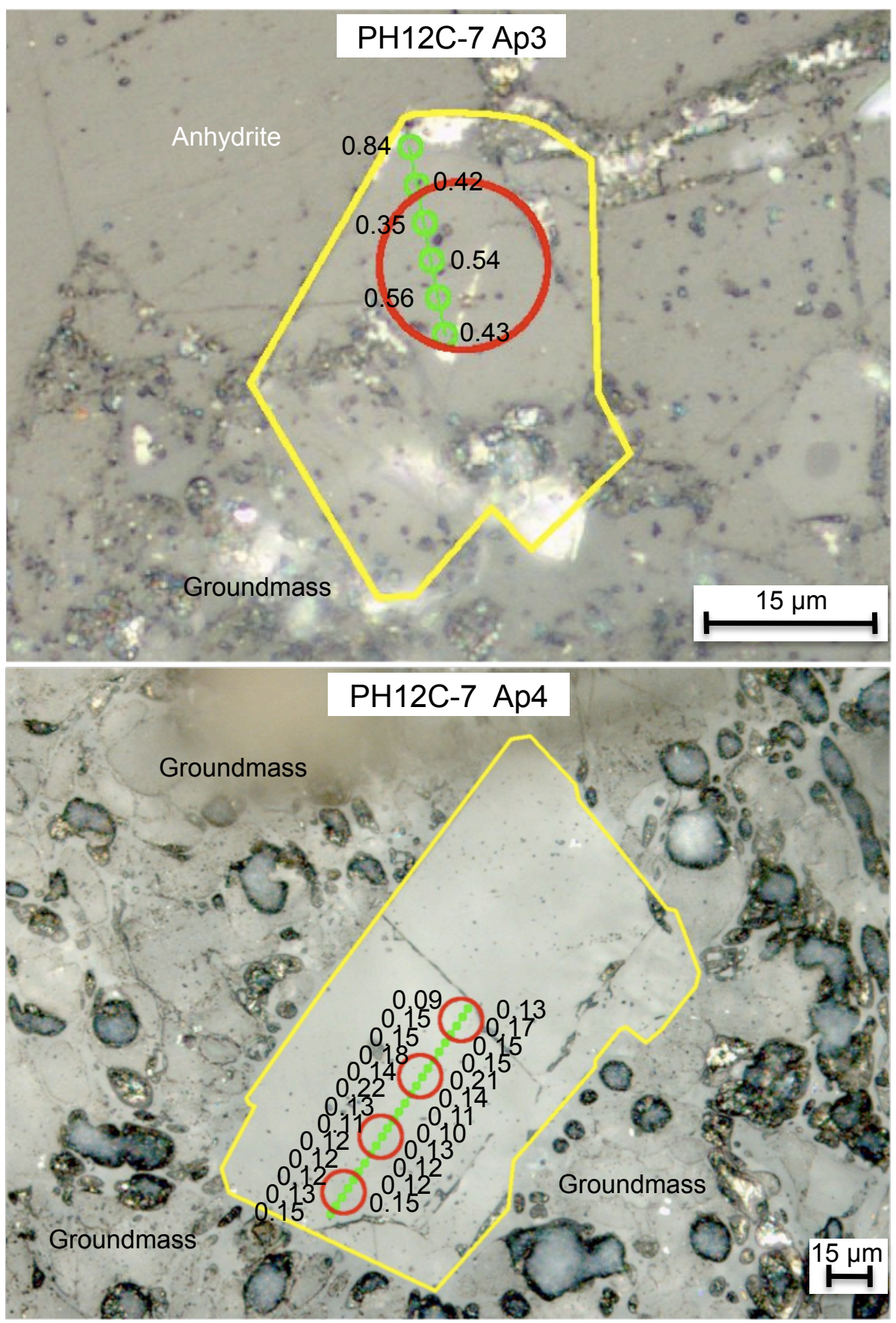

Figure D-1: Continued, EMP (green line and circles) and LA-ICP-MS (red circle) data correlation. EMP $\mathrm{SO}_{3}$ wt.\% values are shown beside the EMP spots. Laser spot size is represented by scale bar, EMP spot size is $2 \mu \mathrm{m}$. 

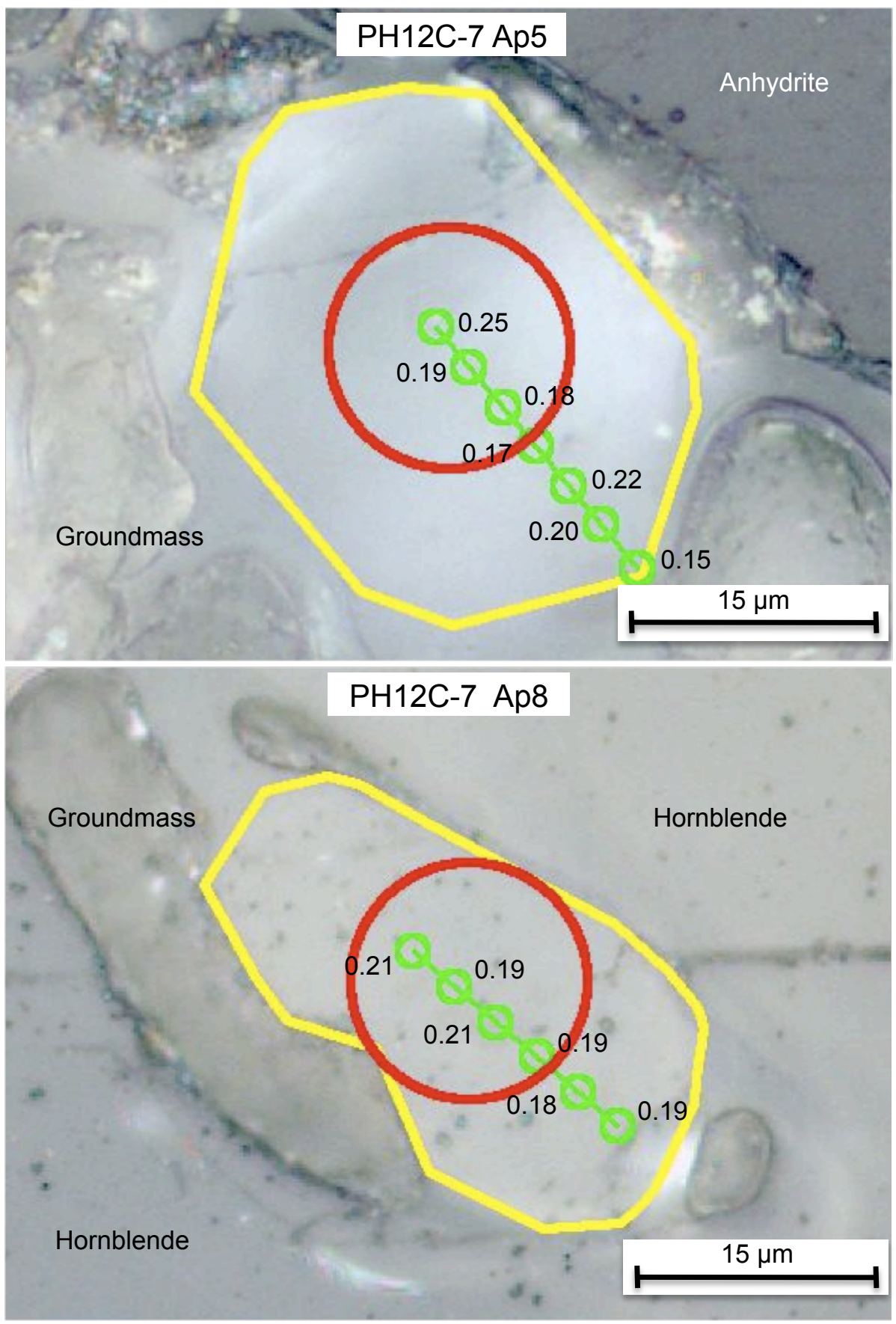

Figure D-1: Continued, EMP (green line and circles) and LA-ICP-MS (red circle) data correlation. EMP $\mathrm{SO}_{3}$ wt.\% values are shown beside the EMP spots. Laser spot size is represented by scale bar, EMP spot size is $2 \mu \mathrm{m}$. 

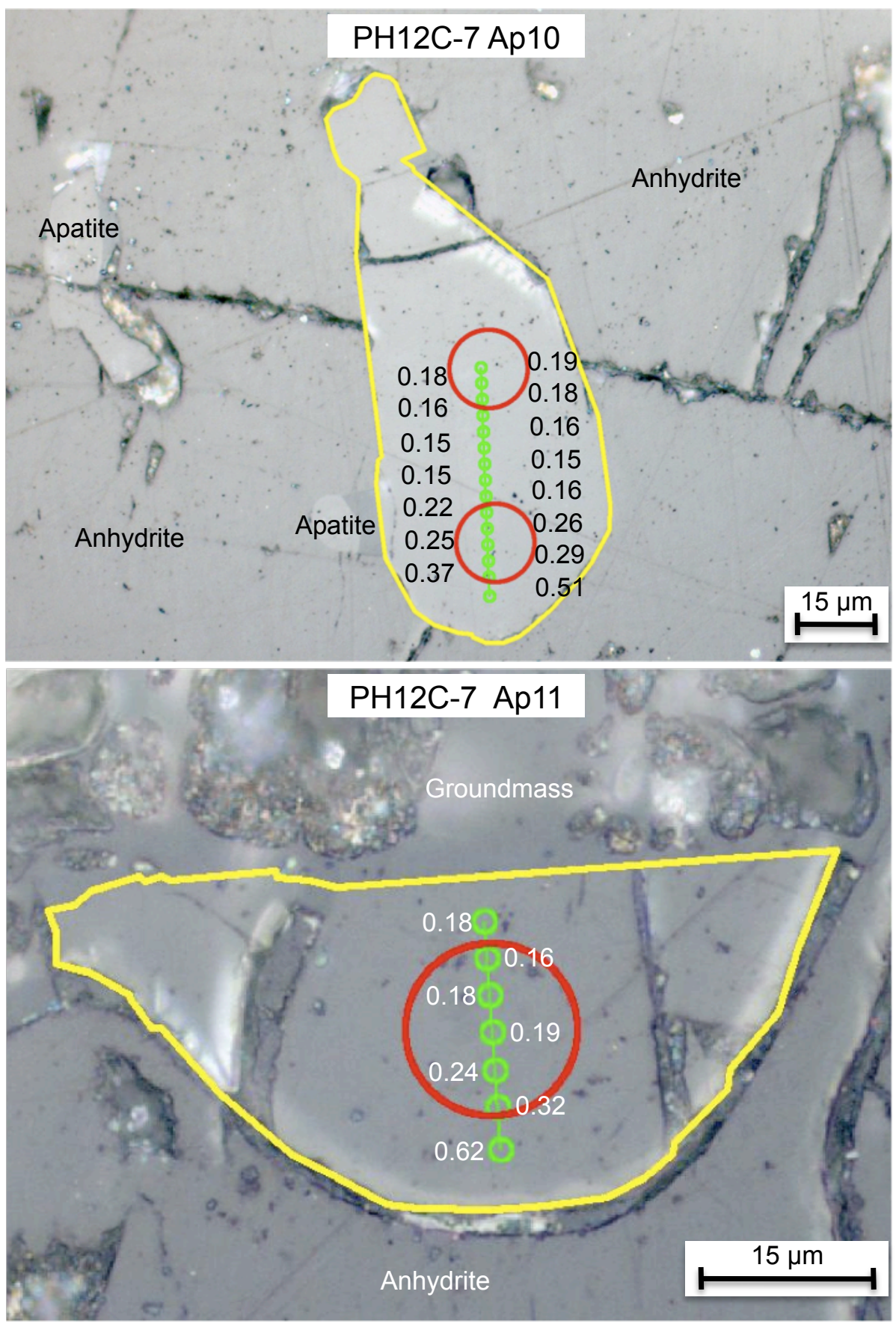

Figure D-1: Continued, EMP (green line and circles) and LA-ICP-MS (red circle) data correlation. EMP $\mathrm{SO}_{3}$ wt.\% values are shown beside the EMP spots. Laser spot size is represented by scale bar, EMP spot size is $2 \mu \mathrm{m}$. 

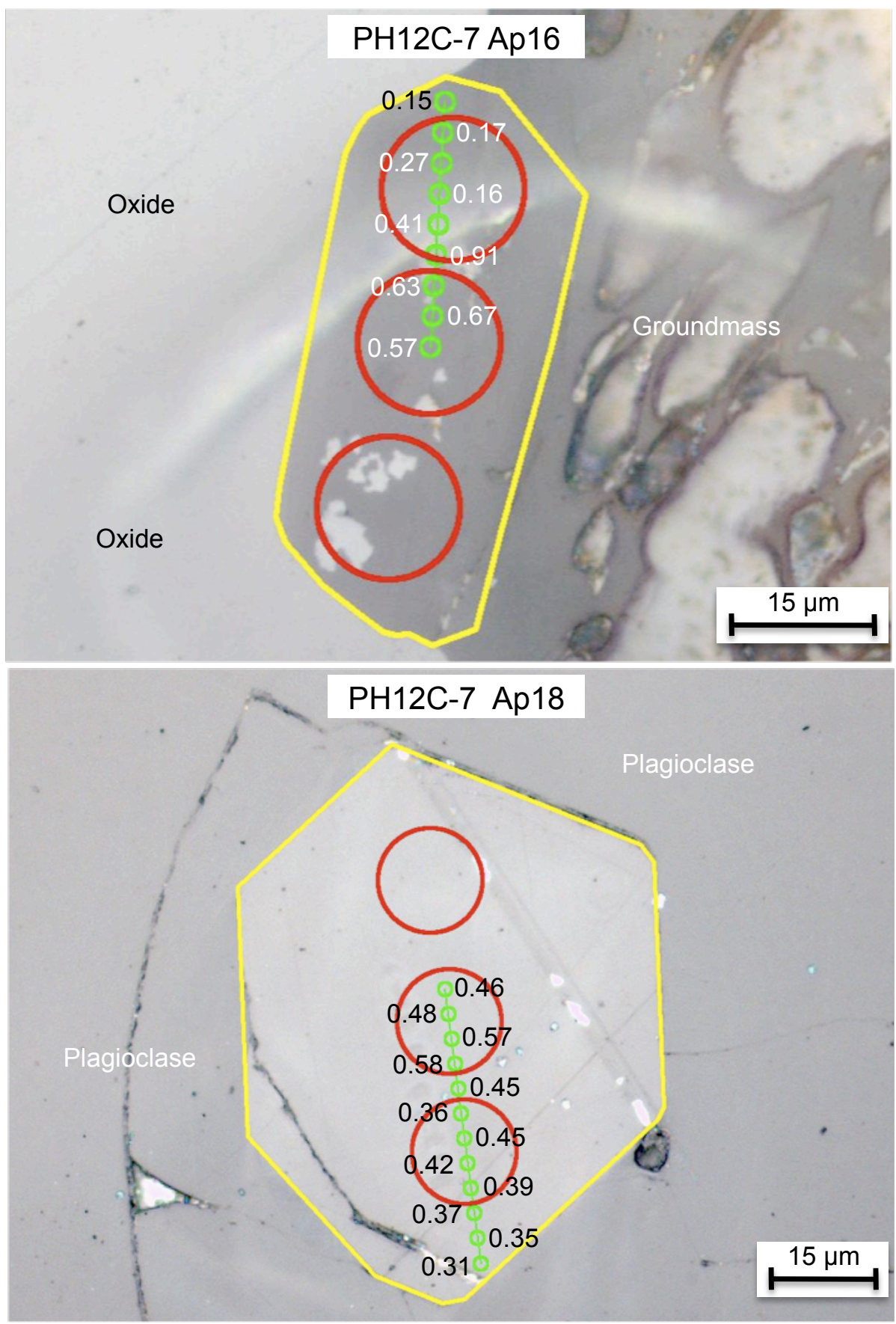

Figure D-1: Continued, EMP (green line and circles) and LA-ICP-MS (red circle) data correlation. EMP $\mathrm{SO}_{3}$ wt.\% values are shown beside the EMP spots. Laser spot size is represented by scale bar, EMP spot size is $2 \mu \mathrm{m}$. 

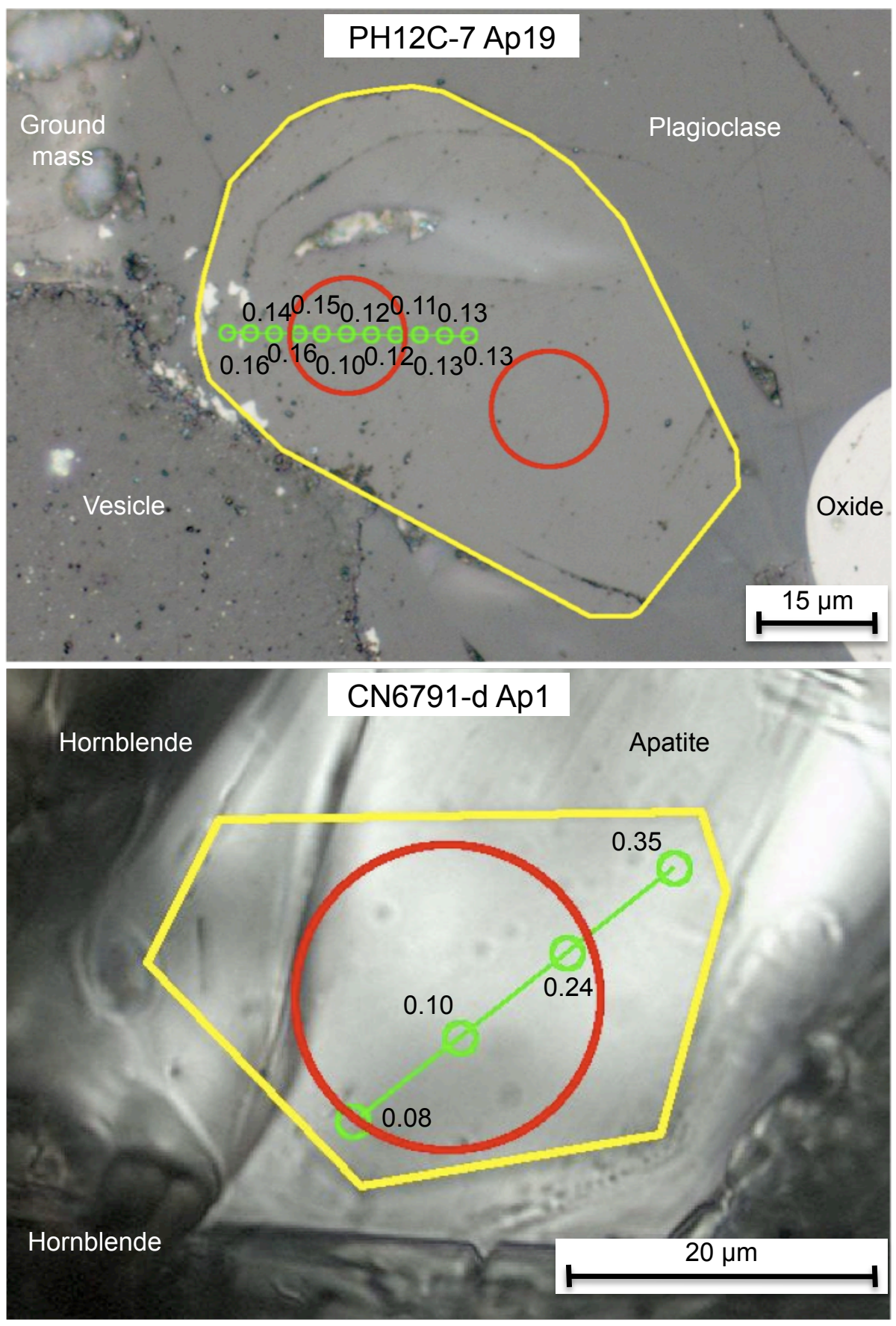

Figure D-1: Continued, EMP (green line and circles) and LA-ICP-MS (red circle) data correlation. EMP $\mathrm{SO}_{3}$ wt.\% values are shown beside the EMP spots. Laser spot size is represented by scale bar, EMP spot size is $2 \mu \mathrm{m}$. 

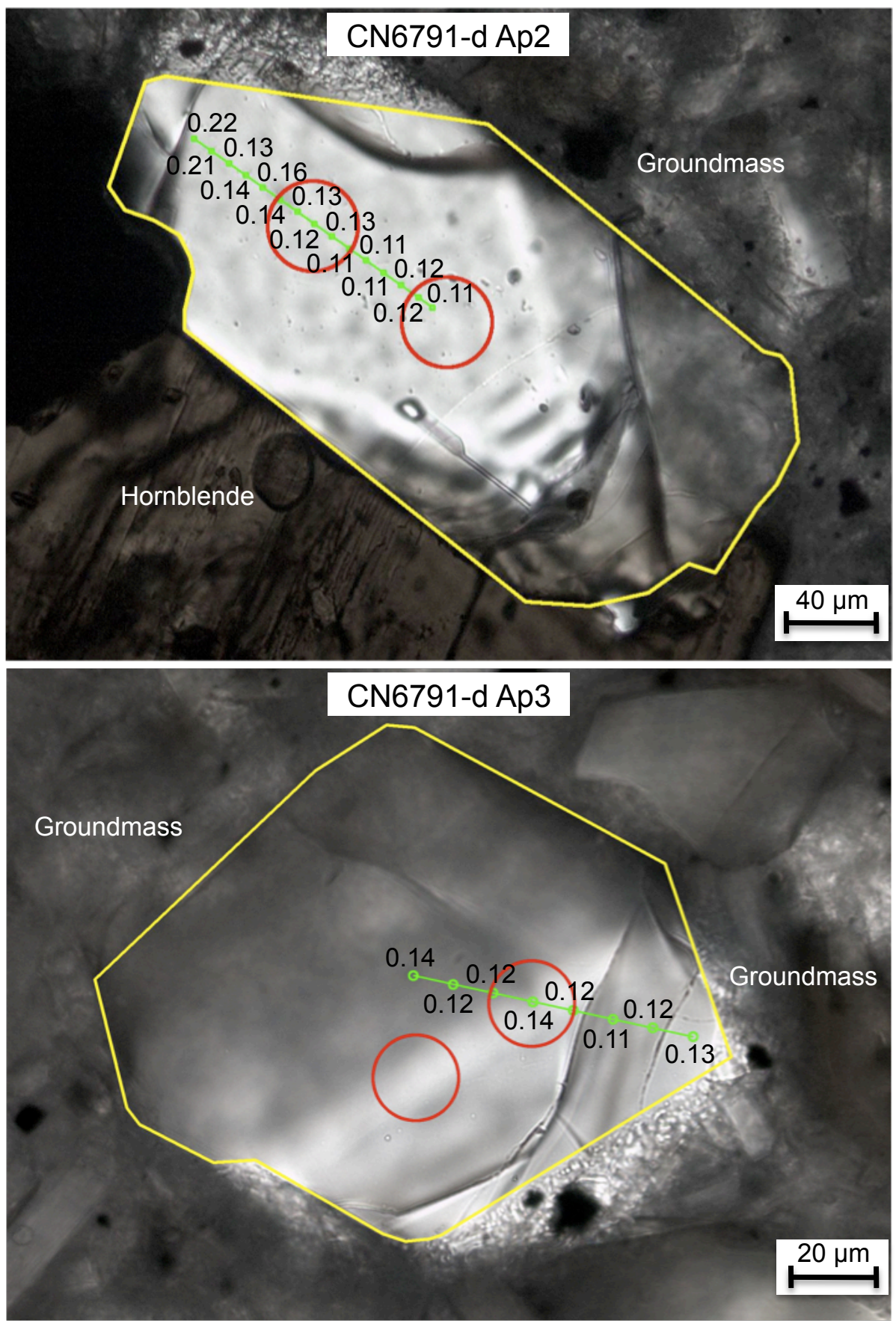

Figure D-1: Continued, EMP (green line and circles) and LA-ICP-MS (red circle) data correlation. EMP $\mathrm{SO}_{3}$ wt.\% values are shown beside the EMP spots. Laser spot size is represented by scale bar, EMP spot size is $2 \mu \mathrm{m}$. 

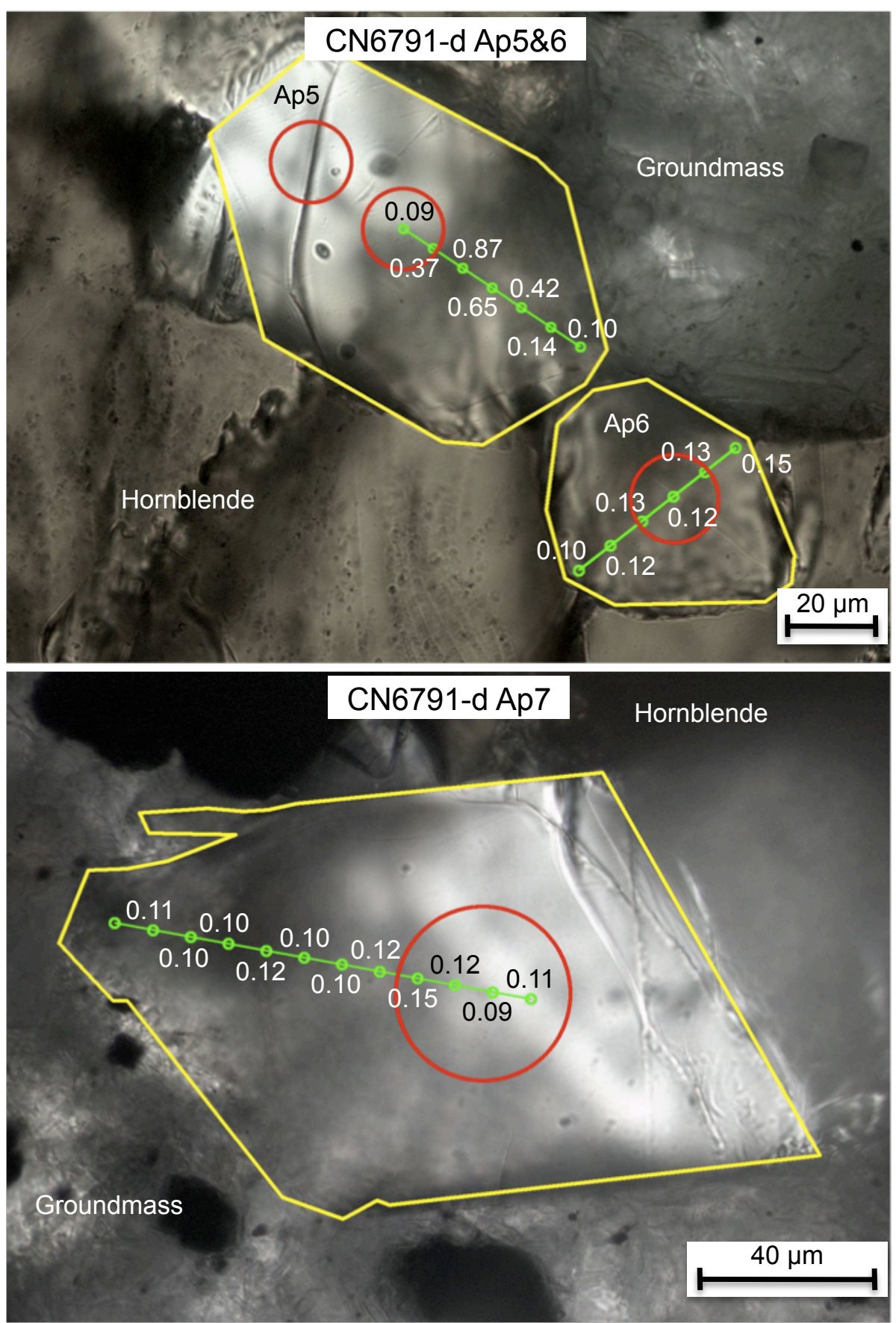

Figure D-1: Continued, EMP (green line and circles) and LA-ICP-MS (red circle) data correlation. EMP $\mathrm{SO}_{3}$ wt.\% values are shown beside the EMP spots. Laser spot size is represented by scale bar, EMP spot size is $2 \mu \mathrm{m}$. 

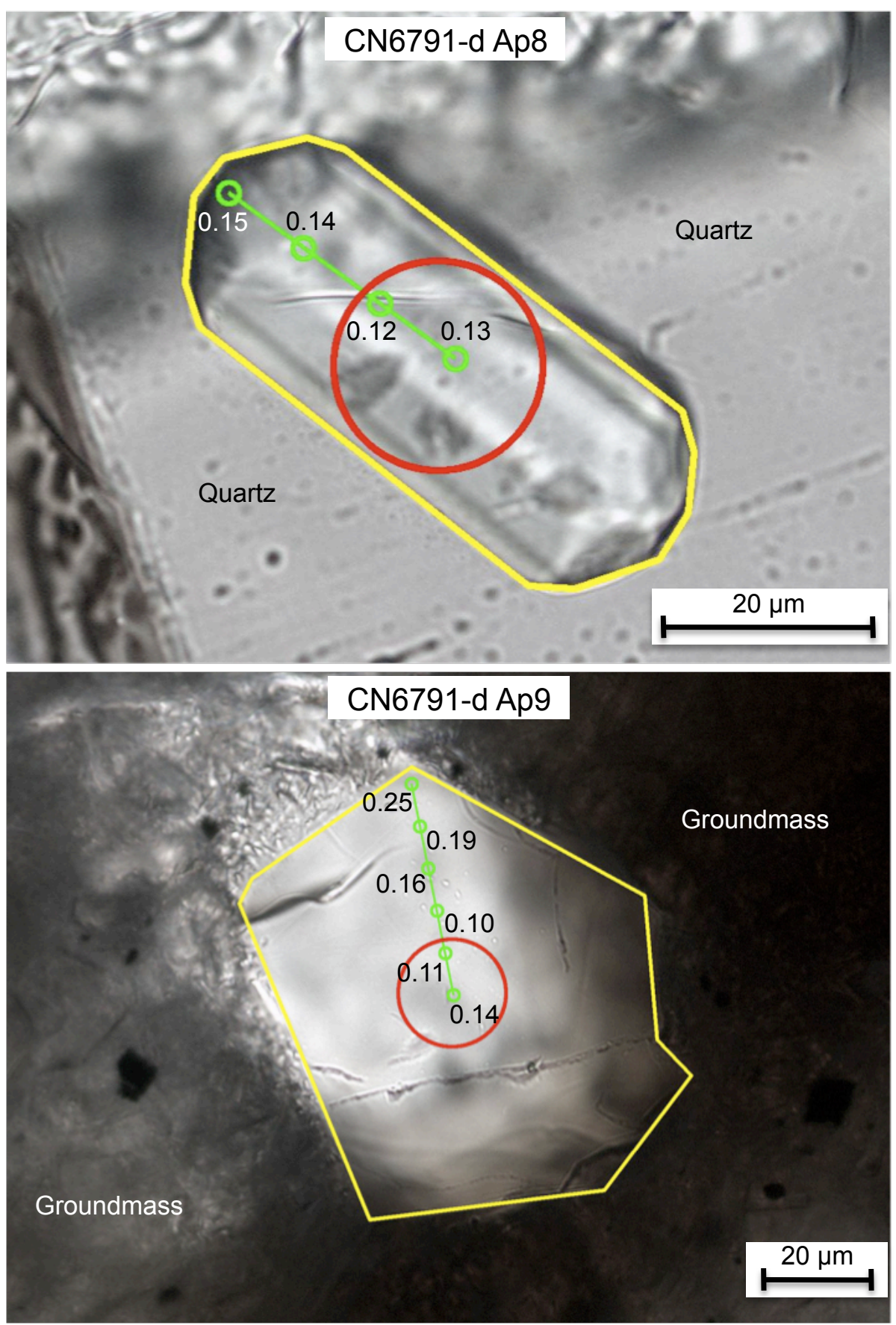

Figure D-1: Continued, EMP (green line and circles) and LA-ICP-MS (red circle) data correlation. EMP $\mathrm{SO}_{3}$ wt.\% values are shown beside the EMP spots. Laser spot size is represented by scale bar, EMP spot size is $2 \mu \mathrm{m}$. 

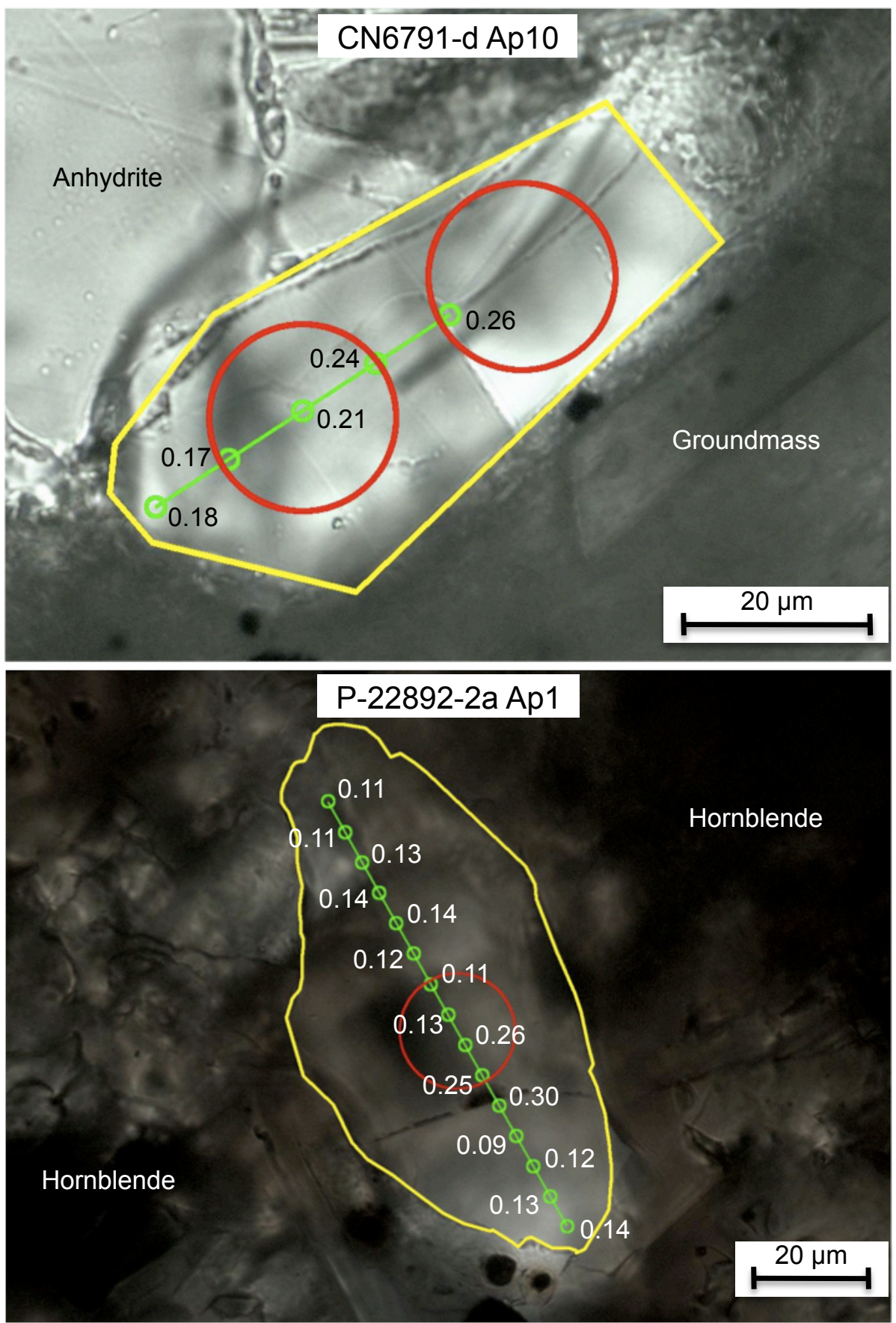

Figure D-1: Continued, EMP (green line and circles) and LA-ICP-MS (red circle) data correlation. EMP $\mathrm{SO}_{3}$ wt.\% values are shown beside the EMP spots. Laser spot size is represented by scale bar, EMP spot size is $2 \mu \mathrm{m}$. 

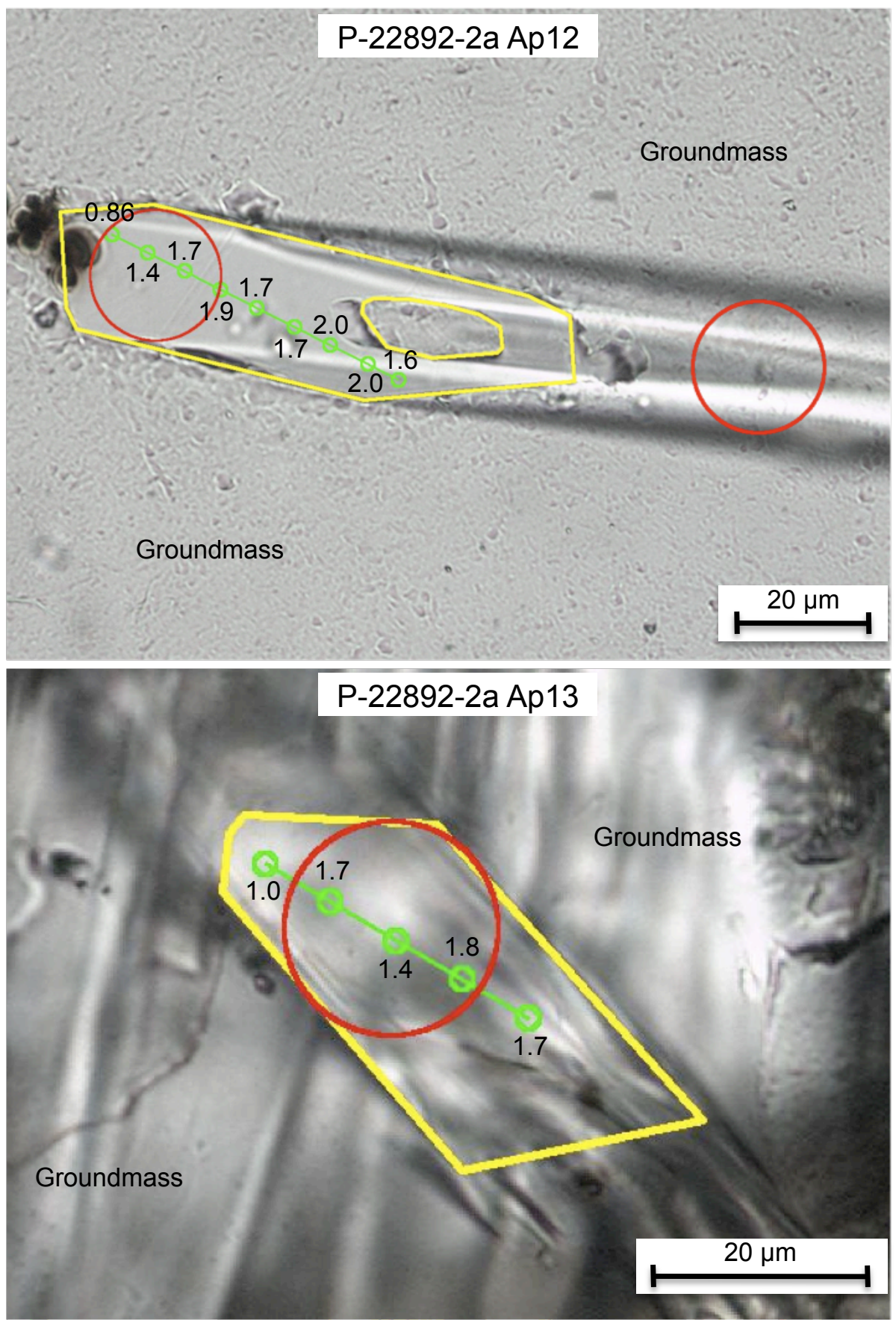

Figure D-1: Continued, EMP (green line and circles) and LA-ICP-MS (red circle) data correlation. EMP $\mathrm{SO}_{3}$ wt.\% values are shown beside the EMP spots. Laser spot size is represented by scale bar, EMP spot size is $2 \mu \mathrm{m}$. 

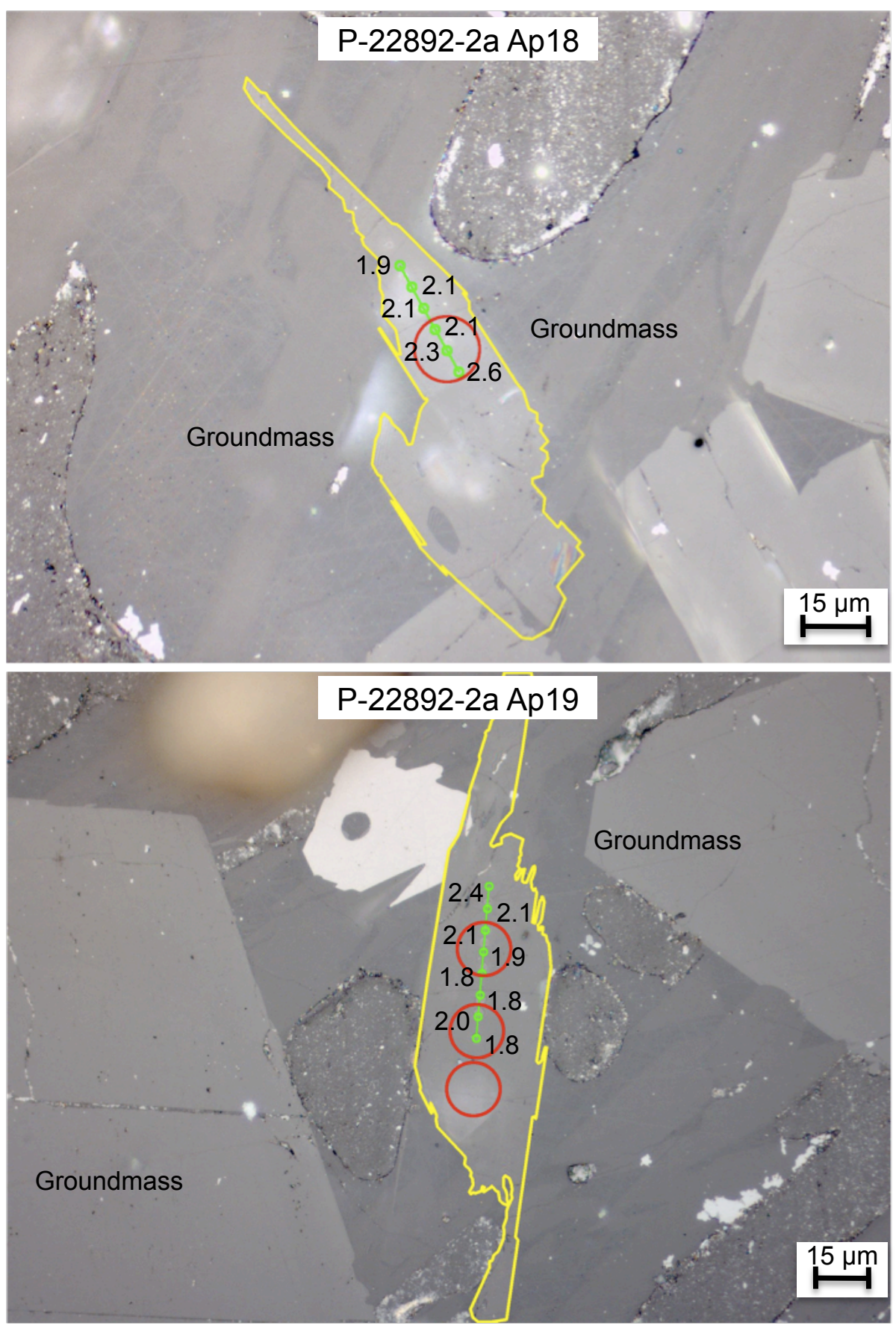

Figure D-1: Continued, EMP (green line and circles) and LA-ICP-MS (red circle) data correlation. EMP $\mathrm{SO}_{3}$ wt.\% values are shown beside the EMP spots. Laser spot size is represented by scale bar, EMP spot size is $2 \mu \mathrm{m}$. 

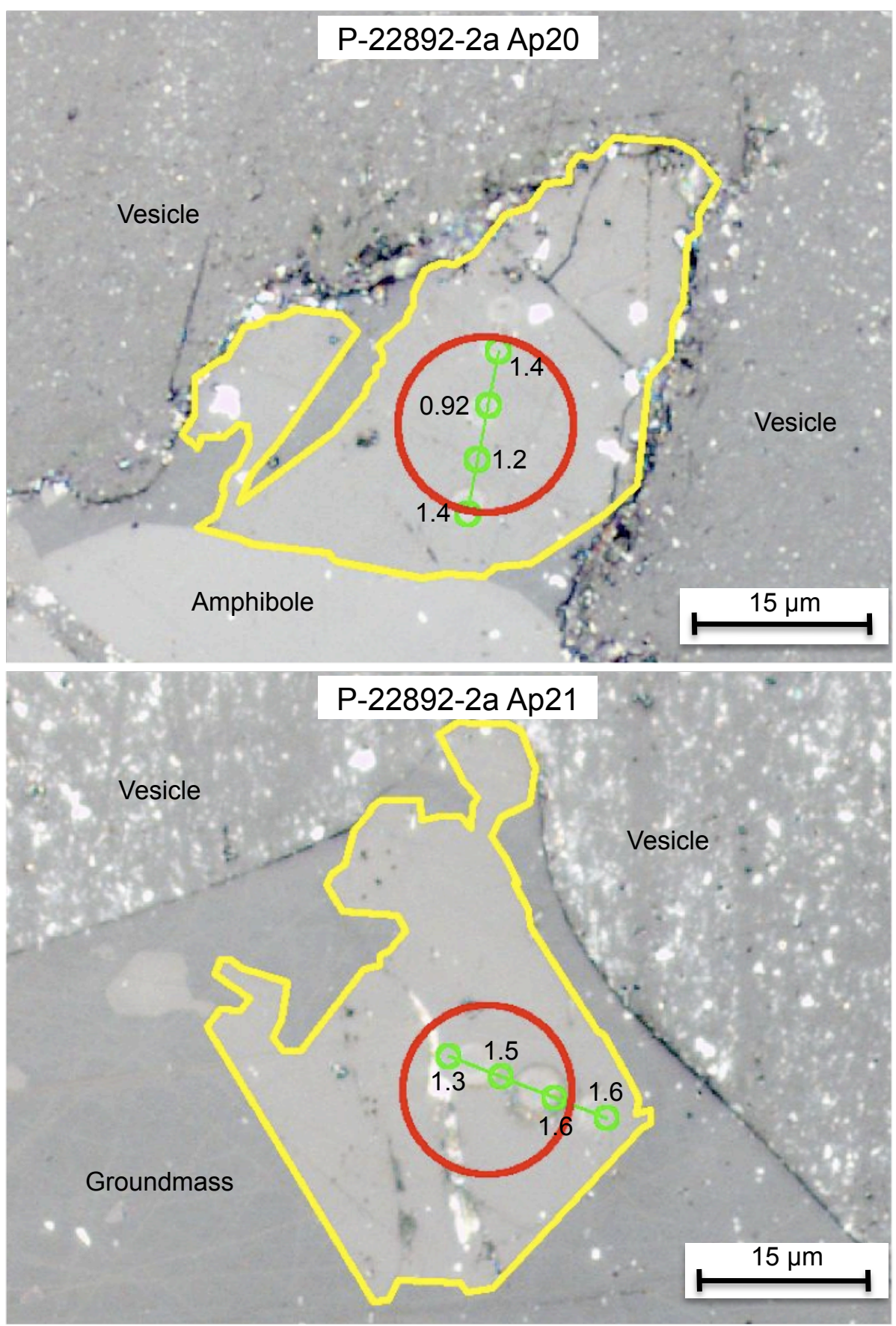

Figure D-1: Continued, EMP (green line and circles) and LA-ICP-MS (red circle) data correlation. EMP $\mathrm{SO}_{3}$ wt.\% values are shown beside the EMP spots. Laser spot size is represented by scale bar, EMP spot size is $2 \mu \mathrm{m}$. 

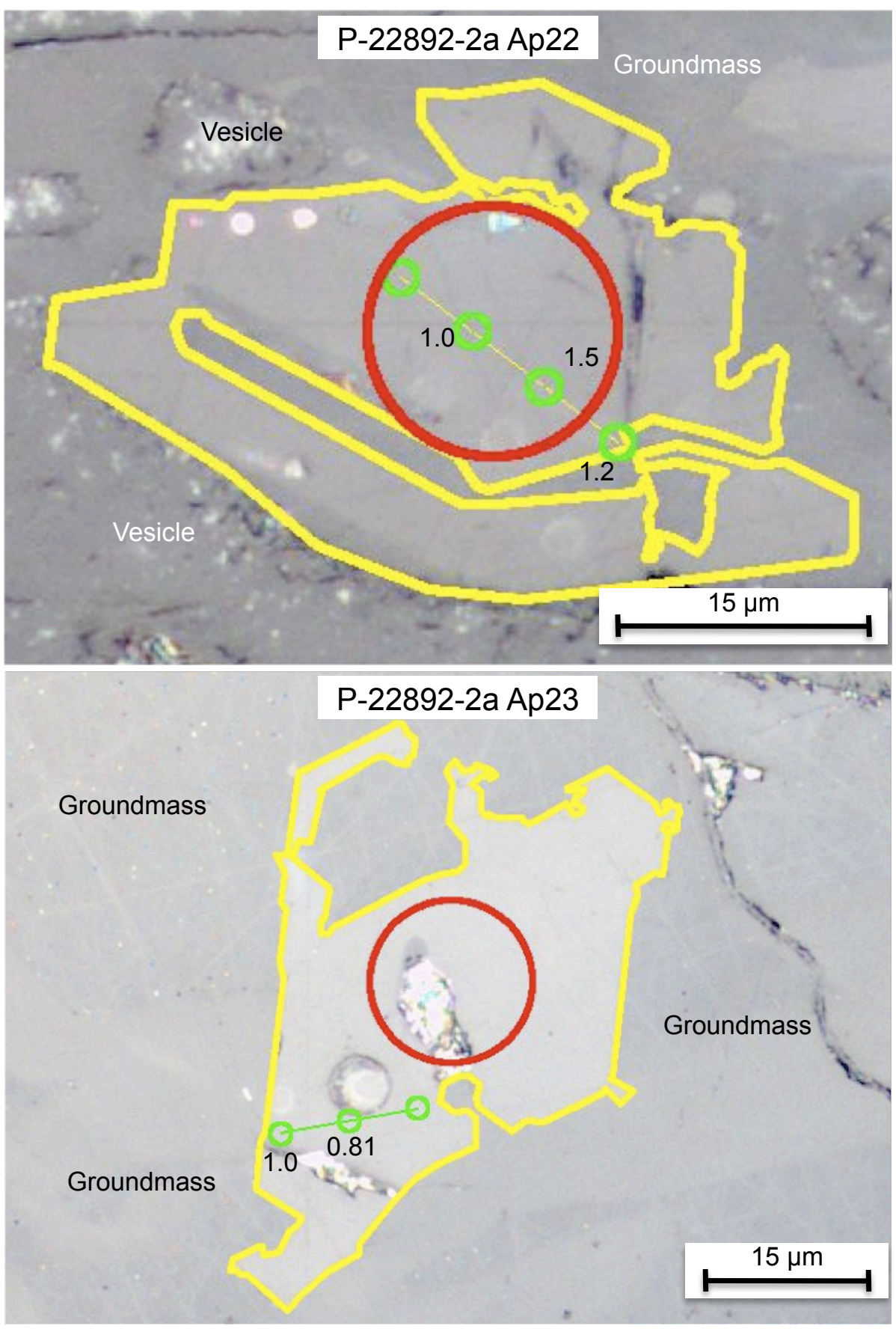

Figure D-1: Continued, EMP (green line and circles) and LA-ICP-MS (red circle) data correlation. EMP $\mathrm{SO}_{3}$ wt.\% values are shown beside the EMP spots. Laser spot size is represented by scale bar, EMP spot size is $2 \mu \mathrm{m}$. 

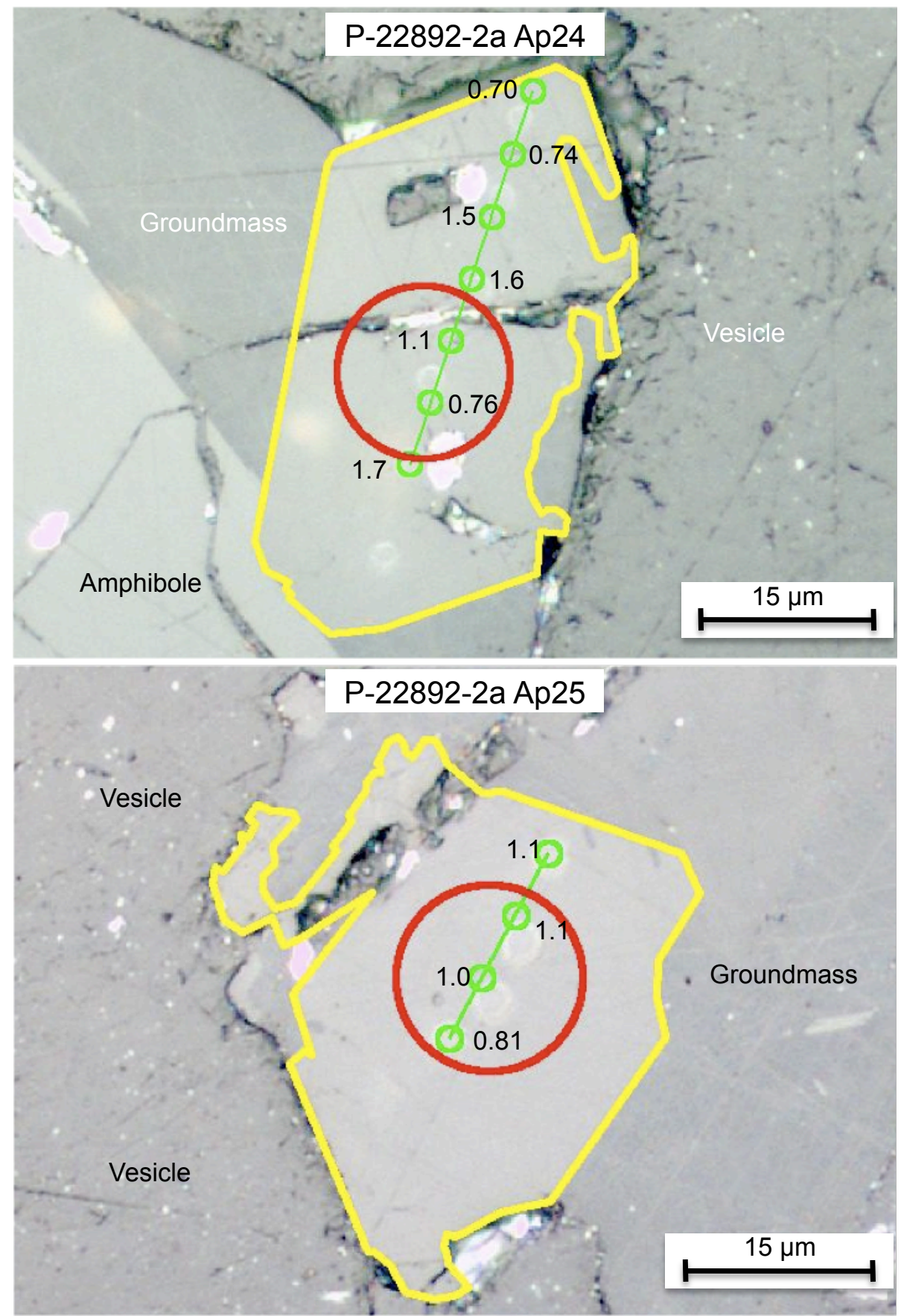

Figure D-1: Continued, EMP (green line and circles) and LA-ICP-MS (red circle) data correlation. EMP $\mathrm{SO}_{3}$ wt.\% values are shown beside the EMP spots. Laser spot size is represented by scale bar, EMP spot size is $2 \mu \mathrm{m}$. 

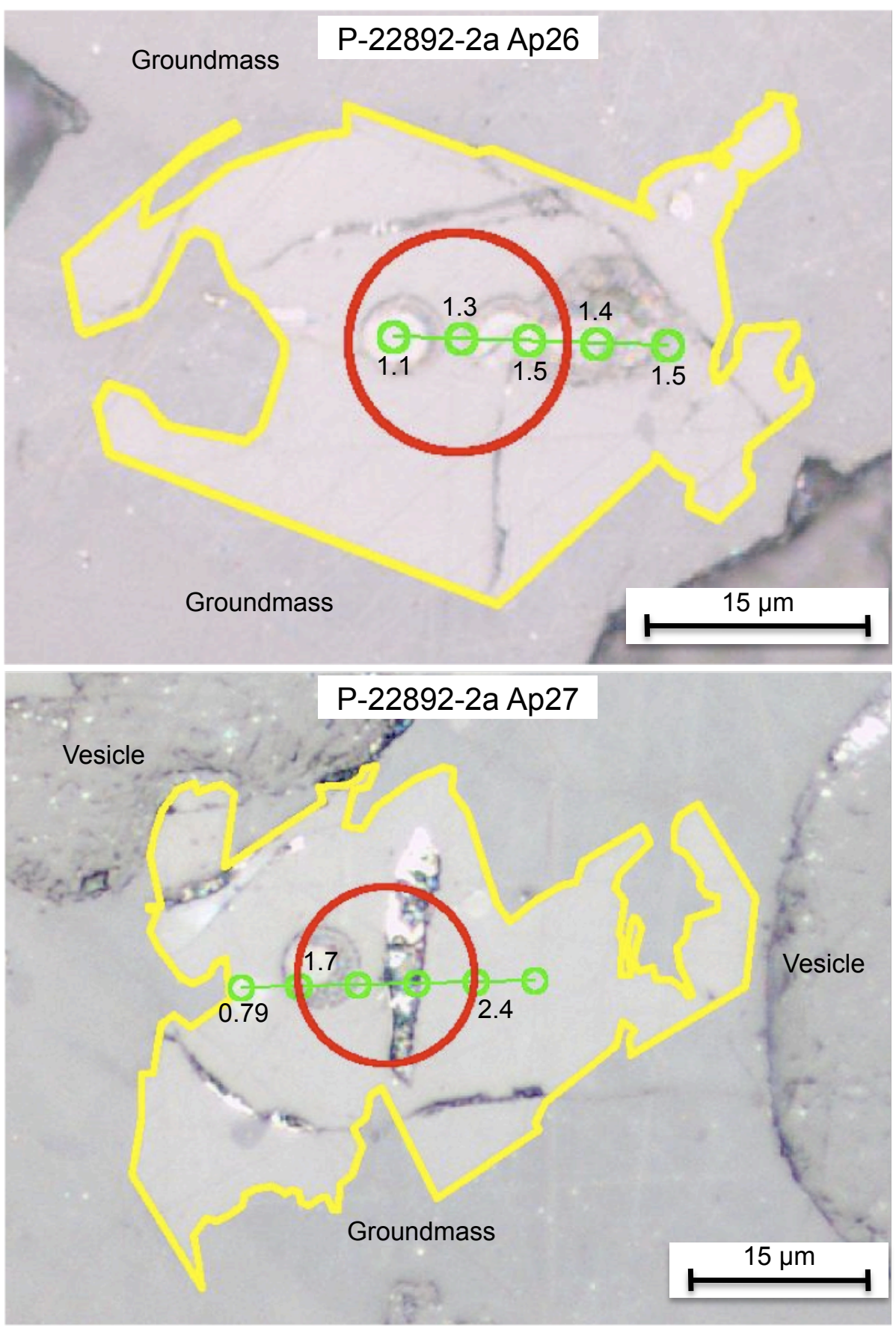

Figure D-1: Continued, EMP (green line and circles) and LA-ICP-MS (red circle) data correlation. $\mathrm{EMP} \mathrm{SO}_{3}$ wt.\% values are shown beside the EMP spots. Laser spot size is represented by scale bar, EMP spot size is $2 \mu \mathrm{m}$. 


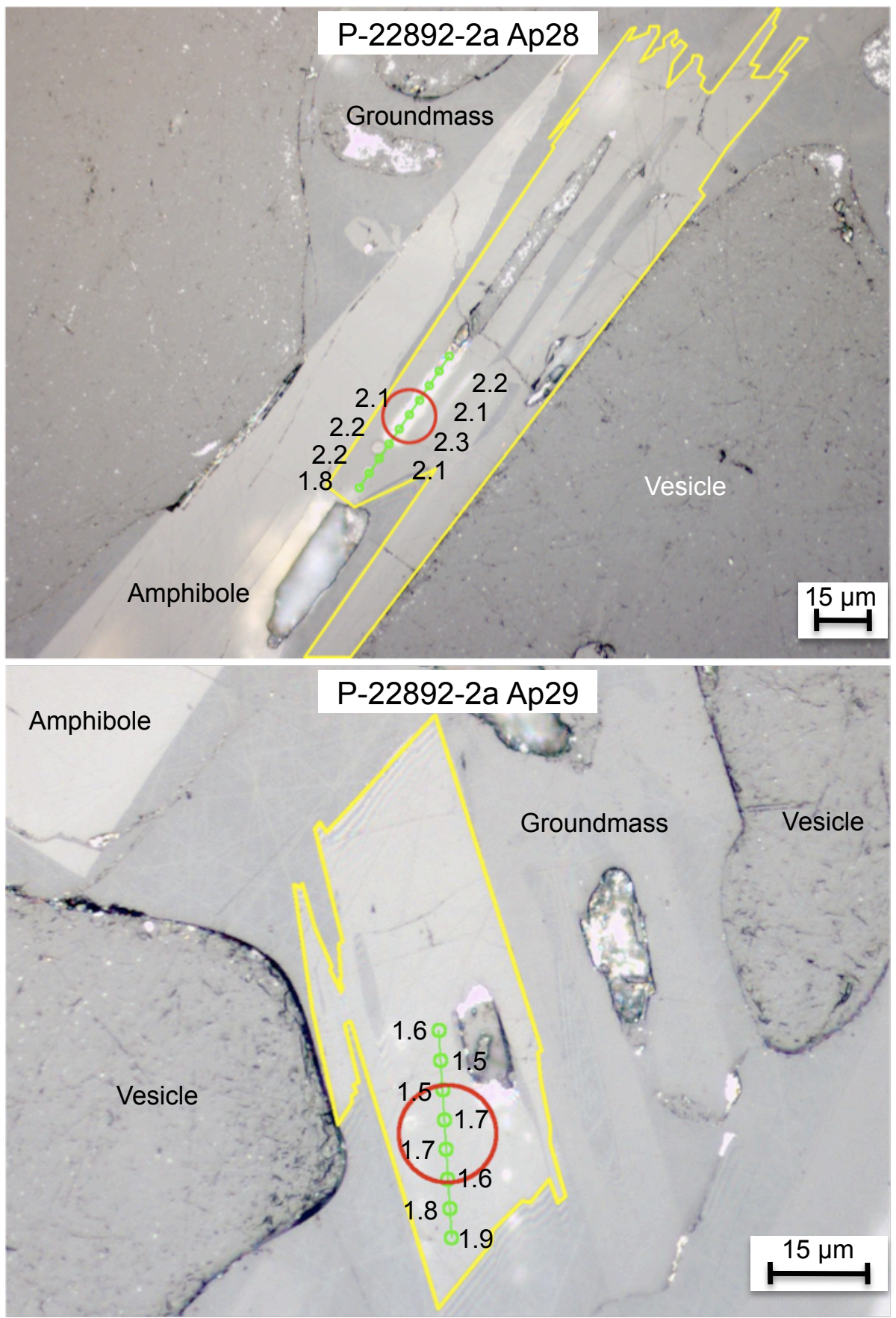

Figure D-1: Continued, EMP (green line and circles) and LA-ICP-MS (red circle) data correlation. EMP $\mathrm{SO}_{3}$ wt.\% values are shown beside the EMP spots. Laser spot size is represented by scale bar, EMP spot size is $2 \mu \mathrm{m}$. 

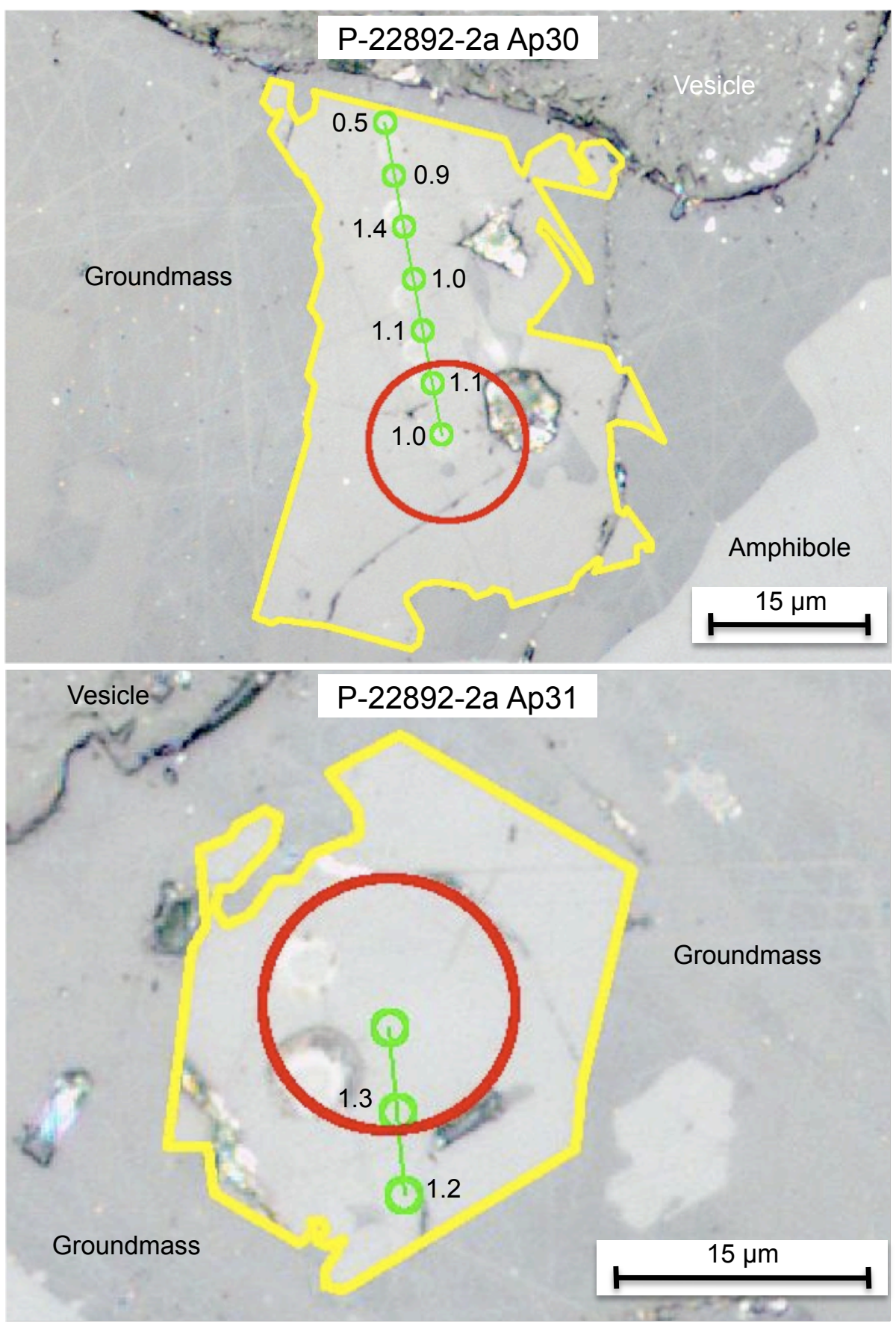

Figure D-1: Continued, EMP (green line and circles) and LA-ICP-MS (red circle) data correlation. EMP $\mathrm{SO}_{3}$ wt.\% values are shown beside the EMP spots. Laser spot size is represented by scale bar, EMP spot size is $2 \mu \mathrm{m}$. 

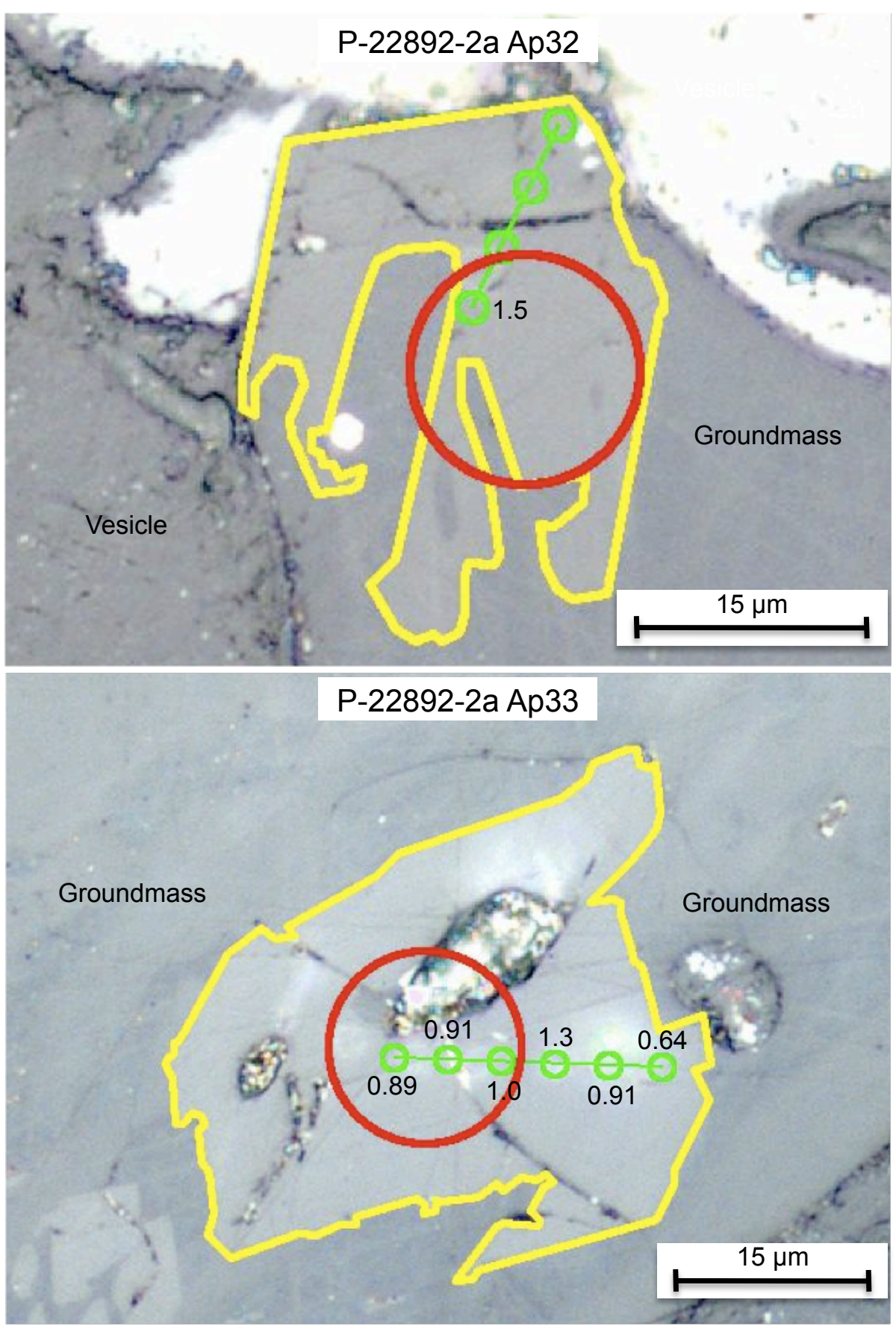

Figure D-1: Continued, EMP (green line and circles) and LA-ICP-MS (red circle) data correlation. EMP $\mathrm{SO}_{3}$ wt.\% values are shown beside the EMP spots. Laser spot size is represented by scale bar, EMP spot size is $2 \mu \mathrm{m}$. 


\section{APPENDIX E: HOST/MATRIX LA-ICP-MS}

Table E- 1. ETH LA-ICP-MS data of Durango Apatite reduced using SILLS (major elements in wt. $\%$, trace elements in ppm). $\mathrm{CaO}=55 \mathrm{wt} . \%$ was used as an internal standard.

\begin{tabular}{|c|c|c|c|c|c|c|c|}
\hline & $\begin{array}{c}\text { Durango } \\
1\end{array}$ & $\begin{array}{c}\text { Durango } \\
2\end{array}$ & $\begin{array}{c}\text { Durango } \\
3\end{array}$ & $\begin{array}{c}\text { Durango } \\
4\end{array}$ & $\begin{array}{c}\text { Durango } \\
5\end{array}$ & $\begin{array}{c}\text { Durango } \\
6\end{array}$ & $\begin{array}{c}\text { Durango } \\
7\end{array}$ \\
\hline $\mathrm{SiO}_{2}$ & 0.29 & 0.24 & 0.37 & 0.37 & 0.26 & 0.31 & 0.37 \\
\hline $\mathrm{TiO}_{2}$ & n.d. & n.d. & n.d. & n.d. & n.d. & n.d. & n.d. \\
\hline $\mathrm{Al}_{2} \mathrm{O}_{3}$ & n.d. & n.d. & 0.0001 & n.d. & n.d. & n.d. & n.d. \\
\hline $\mathrm{FeO}^{*}$ & 0.05 & 0.05 & 0.04 & 0.04 & 0.05 & 0.05 & 0.04 \\
\hline $\mathrm{MnO}$ & 0.01 & 0.01 & 0.01 & 0.01 & 0.01 & 0.01 & 0.01 \\
\hline $\mathrm{MgO}$ & 0.03 & 0.03 & 0.02 & 0.02 & 0.03 & 0.03 & 0.02 \\
\hline $\mathrm{CaO}$ & 55 & 55 & 55 & 55 & 55 & 55 & 55 \\
\hline $\mathrm{Na}_{2} \mathrm{O}$ & 0.24 & 0.25 & 0.19 & 0.20 & 0.23 & 0.24 & 0.20 \\
\hline $\mathrm{K}_{2} \mathrm{O}$ & 0.0003 & 0.0002 & 0.0003 & 0.0003 & 0.0002 & 0.0003 & n.d. \\
\hline $\mathrm{P}_{2} \mathrm{O}_{5}$ & 36.4 & 33.4 & 35.1 & 32.4 & 35.1 & 35.6 & 34.0 \\
\hline $\mathrm{S}$ & 1735 & 1200 & 1318 & 1099 & 1287 & 1346 & 1264 \\
\hline $\mathrm{Sc}$ & n.d. & 0.12 & 0.13 & 0.20 & 0.15 & 0.19 & n.d. \\
\hline $\mathrm{Cr}$ & n.d. & n.d. & n.d. & n.d. & n.d. & n.d. & n.d. \\
\hline $\mathrm{Ni}$ & n.d. & 1.56 & n.d. & n.d. & n.d. & n.d. & n.d. \\
\hline $\mathrm{Cu}$ & 0.39 & 0.37 & 0.49 & n.d. & 0.23 & 0.26 & 0.17 \\
\hline $\mathrm{Zn}$ & 0.34 & n.d. & 0.96 & n.d. & 0.32 & 0.61 & 0.39 \\
\hline $\mathrm{Rb}$ & 0.06 & 0.03 & 0.07 & n.d. & 0.04 & 0.03 & 0.06 \\
\hline $\mathrm{Sr}$ & 489 & 482 & 499 & 492 & 480 & 486 & 476 \\
\hline $\mathrm{Y}$ & 432 & 423 & 561 & 568 & 408 & 432 & 527 \\
\hline $\mathrm{Zr}$ & 0.55 & 0.49 & 0.66 & 0.70 & 0.51 & 0.64 & 0.63 \\
\hline $\mathrm{Nb}$ & 0.02 & n.d. & 0.02 & 0.02 & n.d. & n.d. & 0.01 \\
\hline $\mathrm{Ba}$ & 1.20 & 1.58 & 1.51 & 1.46 & 1.79 & 1.33 & 1.56 \\
\hline $\mathrm{Pb}$ & 0.64 & 0.54 & 1.01 & 0.88 & 0.62 & 0.78 & 0.96 \\
\hline Th & 197 & 169 & 267 & 272 & 168 & 193 & 272 \\
\hline $\mathrm{U}$ & 9.51 & 8.35 & 13.2 & 12.9 & 8.08 & 9.61 & 14.1 \\
\hline $\mathrm{La}$ & 3081 & 2904 & 3330 & 3401 & 2871 & 3175 & 3464 \\
\hline $\mathrm{Ce}$ & 4032 & 3878 & 4144 & 4142 & 3769 & 4051 & 4499 \\
\hline $\operatorname{Pr}$ & 325 & 318 & 329 & 329 & 308 & 326 & 323 \\
\hline n.d. & 1039 & 1020 & 1041 & 1044 & 978 & 1022 & 1019 \\
\hline $\mathrm{Sm}$ & 128 & 131 & 145 & 148 & 125 & 124 & 140 \\
\hline $\mathrm{Eu}$ & 16 & 16 & 16 & 17 & 16 & 16 & 15 \\
\hline $\mathrm{Gd}$ & 115 & 112 & 131 & 132 & 108 & 107 & 131 \\
\hline $\mathrm{Tb}$ & 13 & 13 & 16 & 17 & 13 & 13 & 16 \\
\hline Dy & 72 & 70 & 93 & 93 & 68 & 73 & 91 \\
\hline Но & 14 & 14 & 18 & 18 & 13 & 14 & 18 \\
\hline $\mathrm{Er}$ & 39 & 37 & 49 & 51 & 37 & 37 & 50 \\
\hline $\mathrm{Yb}$ & 27 & 26 & 36 & 35 & 26 & 27 & 34 \\
\hline
\end{tabular}


Table E- 1. Continued.

\begin{tabular}{|c|c|c|c|c|c|c|c|}
\hline & $\begin{array}{c}\text { Durango } \\
8 \\
\end{array}$ & $\begin{array}{c}\text { Durango } \\
9 \\
\end{array}$ & $\begin{array}{c}\text { Durango } \\
10 \\
\end{array}$ & $\begin{array}{c}\text { Durango } \\
11 \\
\end{array}$ & $\begin{array}{c}\text { Durango } \\
12 \\
\end{array}$ & $\begin{array}{c}\text { Durango } \\
13 \\
\end{array}$ & $\begin{array}{c}\text { Durango } \\
14 \\
\end{array}$ \\
\hline $\mathrm{SiO}_{2}$ & 0.38 & 0.35 & 0.38 & 0.39 & 0.42 & 0.380 & 0.364 \\
\hline $\mathrm{TiO}_{2}$ & n.d. & 0.0001 & n.d. & n.d. & n.d. & n.d. & 0.0001 \\
\hline $\mathrm{Al}_{2} \mathrm{O}_{3}$ & n.d. & n.d. & n.d. & n.d. & 0.00 & n.d. & n.d. \\
\hline $\mathrm{FeO}^{*}$ & 0.05 & 0.04 & 0.04 & 0.04 & 0.04 & 0.04 & 0.04 \\
\hline $\mathrm{MnO}$ & 0.01 & 0.01 & 0.01 & 0.01 & 0.01 & 0.01 & 0.01 \\
\hline $\mathrm{MgO}$ & 0.02 & 0.02 & 0.02 & 0.02 & 0.02 & 0.02 & 0.02 \\
\hline $\mathrm{CaO}$ & 55 & 55 & 55 & 55 & 55 & 55 & 55 \\
\hline $\mathrm{Na}_{2} \mathrm{O}$ & 0.20 & 0.19 & 0.19 & 0.20 & 0.20 & 0.20 & 0.20 \\
\hline $\mathrm{K}_{2} \mathrm{O}$ & 0.00 & 0.0002 & 0.0003 & 0.0002 & 0.00 & n.d. & 0.0006 \\
\hline $\mathrm{P}_{2} \mathrm{O}_{5}$ & 34.1 & 32.6 & 33.0 & 35.5 & 35.6 & 33.4 & 32.6 \\
\hline $\mathrm{S}$ & 1232 & 1303 & 1169 & 1209 & 1183 & 1264 & 1139 \\
\hline $\mathrm{Sc}$ & 0.10 & 0.08 & 0.15 & 0.12 & n.d. & 0.11 & 0.11 \\
\hline $\mathrm{Cr}$ & n.d. & n.d. & n.d. & n.d. & n.d. & n.d. & n.d. \\
\hline $\mathrm{Ni}$ & n.d. & n.d. & n.d. & 1.52 & n.d. & n.d. & n.d. \\
\hline $\mathrm{Cu}$ & 0.28 & n.d. & 1.36 & 1.47 & 0.87 & n.d. & 0.22 \\
\hline $\mathrm{Zn}$ & n.d. & n.d. & 0.92 & 0.66 & 0.77 & n.d. & 0.35 \\
\hline $\mathrm{Rb}$ & 0.04 & 0.06 & 0.05 & 0.04 & 0.06 & 0.03 & 0.07 \\
\hline $\mathrm{Sr}$ & 483 & 490 & 482 & 486 & 493 & 485 & 487 \\
\hline $\mathrm{Y}$ & 554 & 547 & 546 & 537 & 541 & 548 & 553 \\
\hline $\mathrm{Zr}$ & 0.72 & 0.52 & 0.52 & 0.52 & 0.55 & 0.57 & 0.61 \\
\hline $\mathrm{Nb}$ & n.d. & n.d. & n.d. & n.d. & 0.02 & n.d. & 0.02 \\
\hline $\mathrm{Ba}$ & 1.45 & 1.51 & 1.49 & 1.65 & 1.72 & 1.56 & 1.60 \\
\hline $\mathrm{Pb}$ & 1.00 & 0.74 & 1.20 & 1.20 & 1.14 & 0.85 & 0.82 \\
\hline $\mathrm{Th}$ & 290 & 265 & 281 & 269 & 281 & 286 & 271 \\
\hline $\mathrm{U}$ & 14.7 & 13.6 & 14.2 & 13.7 & 14.4 & 14.3 & 13.4 \\
\hline $\mathrm{La}$ & 3485 & 3667 & 3294 & 3322 & 3326 & 3317 & 3526 \\
\hline $\mathrm{Ce}$ & 4552 & 4560 & 4242 & 4137 & 4166 & 4075 & 4559 \\
\hline $\mathrm{Pr}$ & 330 & 321 & 323 & 329 & 333 & 323 & 327 \\
\hline n.d. & 1039 & 1024 & 1027 & 1053 & 1056 & 1024 & 1033 \\
\hline $\mathrm{Sm}$ & 143 & 139 & 142 & 146 & 144 & 139 & 143 \\
\hline $\mathrm{Eu}$ & 15 & 15 & 15 & 17 & 15 & 15 & 15 \\
\hline $\mathrm{Gd}$ & 132 & 132 & 128 & 132 & 132 & 128 & 126 \\
\hline $\mathrm{Tb}$ & 16 & 16 & 16 & 16 & 16 & 16 & 16 \\
\hline Dy & 93 & 90 & 90 & 91 & 89 & 94 & 92 \\
\hline Ho & 18 & 18 & 17 & 18 & 17 & 18 & 18 \\
\hline $\mathrm{Er}$ & 50 & 48 & 48 & 49 & 48 & 51 & 50 \\
\hline $\mathrm{Yb}$ & 35 & 33 & 33 & 34 & 33 & 35 & 34 \\
\hline
\end{tabular}


Table E- 1. Continued.

\begin{tabular}{|c|c|c|c|c|c|c|}
\hline & $\begin{array}{c}\text { Durango } \\
15\end{array}$ & $\begin{array}{c}\text { Durango } \\
16\end{array}$ & $\begin{array}{c}\text { Durango } \\
17\end{array}$ & $\begin{array}{c}\text { Durango } \\
18\end{array}$ & $\begin{array}{c}\text { Durango } \\
19\end{array}$ & $\begin{array}{c}\text { Durango } \\
20\end{array}$ \\
\hline $\mathrm{SiO}_{2}$ & 0.36 & 0.38 & 0.38 & 0.39 & 0.40 & 0.39 \\
\hline $\mathrm{TiO}_{2}$ & n.d. & 0.00 & 0.00 & n.d. & n.d. & n.d. \\
\hline $\mathrm{Al}_{2} \mathrm{O}_{3}$ & n.d. & n.d. & n.d. & 0.00003 & n.d. & n.d. \\
\hline $\mathrm{FeO}^{*}$ & 0.04 & 0.04 & 0.04 & 0.04 & 0.04 & 0.04 \\
\hline $\mathrm{MnO}$ & 0.01 & 0.01 & 0.01 & 0.01 & 0.01 & 0.01 \\
\hline $\mathrm{MgO}$ & 0.02 & 0.02 & 0.02 & 0.02 & 0.02 & 0.02 \\
\hline $\mathrm{CaO}$ & 55 & 55 & 55 & 55 & 55 & 55 \\
\hline $\mathrm{Na}_{2} \mathrm{O}$ & 0.18 & 0.19 & 0.20 & 0.19 & 0.20 & 0.21 \\
\hline $\mathrm{K}_{2} \mathrm{O}$ & 0.0002 & 0.0003 & 0.0003 & 0.0002 & 0.0003 & 0.0003 \\
\hline $\mathrm{P}_{2} \mathrm{O}_{5}$ & 33.8 & 33.6 & 33.6 & 32.9 & 33.3 & 32.6 \\
\hline $\mathrm{S}$ & 1209 & 1097 & 1190 & 1064 & 1475 & 1292 \\
\hline $\mathrm{Sc}$ & 0.09 & 0.09 & 0.10 & 0.11 & 0.17 & 0.12 \\
\hline $\mathrm{Cr}$ & n.d. & 2.01 & n.d. & 1.42 & n.d. & 2.30 \\
\hline $\mathrm{Ni}$ & n.d. & n.d. & n.d. & n.d. & n.d. & n.d. \\
\hline $\mathrm{Cu}$ & n.d. & 0.24 & 0.26 & 0.17 & 0.39 & 0.30 \\
\hline $\mathrm{Zn}$ & 0.20 & n.d. & 0.40 & n.d. & 0.42 & 0.34 \\
\hline $\mathrm{Rb}$ & 0.03 & 0.05 & 0.06 & 0.05 & 0.09 & 0.04 \\
\hline $\mathrm{Sr}$ & 485 & 488 & 492 & 485 & 491 & 492 \\
\hline $\mathrm{Y}$ & 541 & 548 & 555 & 559 & 553 & 551 \\
\hline $\mathrm{Zr}$ & 0.49 & 0.64 & 0.59 & 0.64 & 0.65 & 0.52 \\
\hline $\mathrm{Nb}$ & 0.01 & n.d. & n.d. & n.d. & 0.04 & 0.02 \\
\hline $\mathrm{Ba}$ & 1.57 & 1.56 & 1.49 & 1.71 & 1.69 & 1.24 \\
\hline $\mathrm{Pb}$ & 0.79 & 0.86 & 1.03 & 0.92 & 1.10 & 1.01 \\
\hline Th & 261 & 270 & 276 & 271 & 273 & 280 \\
\hline $\mathrm{U}$ & 13.3 & 13.5 & 14.2 & 13.9 & 14.2 & 14.3 \\
\hline $\mathrm{La}$ & 3668 & 3358 & 3309 & 3350 & 3319 & 3309 \\
\hline $\mathrm{Ce}$ & 4571 & 4456 & 4262 & 4396 & 4053 & 4025 \\
\hline $\operatorname{Pr}$ & 320 & 319 & 326 & 325 & 323 & 321 \\
\hline n.d. & 1012 & 1028 & 1030 & 1010 & 1034 & 1023 \\
\hline $\mathrm{Sm}$ & 138 & 141 & 140 & 144 & 143 & 140 \\
\hline $\mathrm{Eu}$ & 16 & 15 & 16 & 15 & 16 & 15 \\
\hline $\mathrm{Gd}$ & 129 & 129 & 132 & 130 & 130 & 128 \\
\hline $\mathrm{Tb}$ & 16 & 16 & 16 & 17 & 16 & 16 \\
\hline Dy & 90 & 91 & 90 & 90 & 90 & 89 \\
\hline Ho & 18 & 18 & 18 & 18 & 18 & 17 \\
\hline $\mathrm{Er}$ & 48 & 50 & 49 & 49 & 50 & 48 \\
\hline $\mathrm{Yb}$ & 33 & 33 & 34 & 34 & 34 & 34 \\
\hline
\end{tabular}


Table E- 2. ETH LA-ICP-MS data of anhydrite reduced using SILLS (major elements in wt.\%, trace elements in $\mathrm{ppm}) . \mathrm{CaO}=42 \mathrm{wt} . \%$ was used as an internal standard.

\begin{tabular}{|c|c|c|c|c|c|c|c|}
\hline & $\begin{array}{l}\text { CN6791-d } \\
\text { anhy of } \\
\text { ap10 }\end{array}$ & $\begin{array}{l}\text { CN6791-d } \\
\text { anh1 pt1 }\end{array}$ & $\begin{array}{l}\text { CN6791-d } \\
\text { anh1 pt2 }\end{array}$ & $\begin{array}{l}\text { PH12C-1 } \\
\text { anh of ap4 }\end{array}$ & $\begin{array}{l}\text { PH12C-2 } \\
\text { anh of ap3 }\end{array}$ & $\begin{array}{l}\text { PH12C-2 } \\
\text { anh of ap4 }\end{array}$ & $\begin{array}{c}\text { PH12C-2 } \\
\text { anh of } \\
\text { ap5\&6 }\end{array}$ \\
\hline $\mathrm{SiO}_{2}$ & n.d. & n.d. & 0.03 & 12.26 & n.d. & n.d. & n.d. \\
\hline $\mathrm{TiO}_{2}$ & 0.001 & 0.001 & 0.001 & 0.01 & 0.001 & 0.002 & n.d. \\
\hline $\mathrm{Al}_{2} \mathrm{O}_{3}$ & 0.000 & 0.002 & 0.003 & 0.23 & n.d. & 0.002 & n.d. \\
\hline $\mathrm{FeO}^{*}$ & 0.01 & 0.01 & 0.01 & 0.09 & 0.01 & 0.01 & 0.01 \\
\hline $\mathrm{MnO}$ & 0.0005 & 0.003 & 0.002 & 0.04 & 0.002 & 0.002 & 0.002 \\
\hline $\mathrm{MgO}$ & 0.002 & 0.003 & 0.003 & 0.71 & 0.002 & 0.003 & 0.001 \\
\hline $\mathrm{CaO}$ & 42 & 42 & 42 & 42 & 42 & 42 & 42 \\
\hline $\mathrm{Na}_{2} \mathrm{O}$ & 0.0004 & 0.0005 & 0.001 & 2.32 & 0.002 & 0.01 & 0.005 \\
\hline $\mathrm{K}_{2} \mathrm{O}$ & n.d. & n.d. & n.d. & 0.21 & n.d. & 0.002 & n.d. \\
\hline $\mathrm{P}_{2} \mathrm{O}_{5}$ & 0.08 & 0.02 & 0.03 & 7.70 & 0.07 & 0.07 & 0.09 \\
\hline $\mathrm{S}$ & 163744 & 140965 & 150168 & 126830 & 161162 & 167540 & 152031 \\
\hline $\mathrm{Sc}$ & n.d. & n.d. & n.d. & 0.26 & n.d. & n.d. & n.d. \\
\hline $\mathrm{Cr}$ & n.d. & n.d. & n.d. & n.d. & n.d. & n.d. & n.d. \\
\hline $\mathrm{Ni}$ & n.d. & n.d. & n.d. & 9.62 & n.d. & n.d. & n.d. \\
\hline $\mathrm{Cu}$ & 20.3 & n.d. & n.d. & 61.9 & n.d. & 1.25 & n.d. \\
\hline $\mathrm{Zn}$ & n.d. & 0.48 & 0.37 & 5.87 & n.d. & n.d. & n.d. \\
\hline $\mathrm{Rb}$ & n.d. & n.d. & n.d. & 6.03 & n.d. & n.d. & n.d. \\
\hline $\mathrm{Sr}$ & 2230 & 1482 & 989 & 1436 & 2029 & 1938 & 1903 \\
\hline $\mathrm{Y}$ & 23.1 & 8.08 & 9.88 & 74.8 & 26.7 & 25.9 & 29.8 \\
\hline $\mathrm{Zr}$ & n.d. & n.d. & n.d. & 18.91 & n.d. & n.d. & n.d. \\
\hline $\mathrm{Nb}$ & n.d. & n.d. & n.d. & 0.11 & n.d. & n.d. & n.d. \\
\hline $\mathrm{Ba}$ & 48.7 & 49.3 & 49.2 & 65.6 & 43.8 & 41.0 & 47.2 \\
\hline $\mathrm{Pb}$ & 16.7 & 4.40 & 27.5 & 262 & 11.3 & 591 & 3.92 \\
\hline Th & 0.51 & n.d. & n.d. & 3.65 & 0.47 & 0.44 & 0.34 \\
\hline $\mathrm{U}$ & n.d. & n.d. & n.d. & 1.24 & n.d. & n.d. & n.d. \\
\hline $\mathrm{La}$ & 204 & 3 & 6 & 306 & 241 & 227 & 248 \\
\hline $\mathrm{Ce}$ & 363 & 9 & 17 & 653 & 428 & 382 & 444 \\
\hline $\operatorname{Pr}$ & 37 & 1 & 3 & 73 & 45 & 41 & 45 \\
\hline n.d. & 128 & 7 & 14 & 270 & 162 & 149 & 166 \\
\hline $\mathrm{Sm}$ & 16 & 2 & 4 & 34 & 19 & 14 & 22 \\
\hline $\mathrm{Eu}$ & 4 & 0.5 & 1 & 8 & 3 & 3 & 4 \\
\hline $\mathrm{Gd}$ & 11 & 2 & 4 & 26 & 13 & 8 & 14 \\
\hline $\mathrm{Tb}$ & 1 & 0.3 & 0.4 & 3 & 1 & 1 & 1 \\
\hline Dy & 4 & 1 & 2 & 14 & 5 & 7 & 8 \\
\hline Но & 0.4 & 0.3 & 0.2 & 2 & 1 & 1 & 1 \\
\hline $\mathrm{Er}$ & 1 & 0.3 & 1 & 6 & 2 & 1 & 2 \\
\hline $\mathrm{Yb}$ & 1 & 1 & 0.3 & 5 & 1 & 0.3 & 1 \\
\hline
\end{tabular}

n.d. $=$ not detected 
Table E-2. Continued.

\begin{tabular}{|c|c|c|c|c|c|c|c|}
\hline & $\begin{array}{l}\text { PH12C-2 } \\
\text { anh of ap8 }\end{array}$ & $\begin{array}{l}\text { PH12C-3a } \\
\text { anh of ap1 }\end{array}$ & $\begin{array}{c}\text { PH12C-3b } \\
\text { anh of } \\
\text { ap5\&6 }\end{array}$ & $\begin{array}{c}\text { PH12C-3b } \\
\text { anh of } \\
\text { ap7-9 }\end{array}$ & $\begin{array}{l}\text { PH12C-4 } \\
\text { anh of ap4 }\end{array}$ & $\begin{array}{l}\text { PH12C-5 } \\
\text { anh of ap1 }\end{array}$ & $\begin{array}{l}\text { PH12C-5 } \\
\text { anh of ap2 }\end{array}$ \\
\hline $\mathrm{SiO}_{2}$ & n.d. & n.d. & n.d. & n.d. & 5.44 & n.d. & 0.13 \\
\hline $\mathrm{TiO}_{2}$ & 0.001 & 0.001 & 0.001 & 0.001 & 0.003 & 0.001 & 0.001 \\
\hline $\mathrm{Al}_{2} \mathrm{O}_{3}$ & 0.0001 & n.d. & n.d. & n.d. & 0.07 & 0.003 & 0.003 \\
\hline $\mathrm{FeO}^{*}$ & 0.01 & 0.01 & 0.01 & 0.01 & 0.04 & 0.01 & 0.01 \\
\hline $\mathrm{MnO}$ & 0.002 & 0.002 & 0.002 & 0.002 & 0.004 & 0.003 & 0.002 \\
\hline $\mathrm{MgO}$ & 0.002 & 0.002 & 0.001 & 0.001 & 0.13 & 0.002 & 0.003 \\
\hline $\mathrm{CaO}$ & 42 & 42 & 42 & 42 & 42 & 42 & 42 \\
\hline $\mathrm{Na}_{2} \mathrm{O}$ & 0.002 & 0.002 & 0.000 & 0.002 & 0.53 & 0.01 & 0.01 \\
\hline $\mathrm{K}_{2} \mathrm{O}$ & n.d. & n.d. & n.d. & 0.001 & 0.07 & n.d. & 0.004 \\
\hline $\mathrm{P}_{2} \mathrm{O}_{5}$ & 0.07 & 0.07 & 0.10 & 0.07 & 0.09 & 0.23 & 0.06 \\
\hline $\mathrm{S}$ & 155949 & 157176 & 144879 & 145250 & 200894 & 176417 & 158284 \\
\hline $\mathrm{Sc}$ & n.d. & n.d. & n.d. & n.d. & 0.33 & 0.76 & n.d. \\
\hline $\mathrm{Cr}$ & n.d. & n.d. & n.d. & n.d. & 9.12 & n.d. & n.d. \\
\hline $\mathrm{Ni}$ & n.d. & n.d. & n.d. & n.d. & 2.13 & n.d. & n.d. \\
\hline $\mathrm{Cu}$ & n.d. & 0.41 & n.d. & n.d. & 62.17 & 2.22 & n.d. \\
\hline $\mathrm{Zn}$ & n.d. & n.d. & n.d. & n.d. & 19.56 & 5.81 & 1.59 \\
\hline $\mathrm{Rb}$ & n.d. & n.d. & n.d. & n.d. & 2.01 & 0.46 & 0.83 \\
\hline $\mathrm{Sr}$ & 2095 & 2118 & 2273 & 2081 & 1968 & 1999 & 2145 \\
\hline $\mathrm{Y}$ & 33.1 & 32.2 & 7.4 & 27.6 & 32.1 & 32.0 & 27.1 \\
\hline $\mathrm{Zr}$ & n.d. & n.d. & n.d. & n.d. & 17.04 & 0.15 & 0.13 \\
\hline $\mathrm{Nb}$ & n.d. & n.d. & n.d. & n.d. & 0.59 & 0.09 & n.d. \\
\hline $\mathrm{Ba}$ & 44.7 & 43.3 & 15.5 & 36.1 & 50.4 & 41.7 & 39.1 \\
\hline $\mathrm{Pb}$ & 1.04 & 0.68 & 0.59 & 1.63 & 586 & 400 & 49.9 \\
\hline $\mathrm{Th}$ & 0.43 & 0.41 & n.d. & 0.46 & 0.64 & 0.71 & 0.13 \\
\hline $\mathrm{U}$ & n.d. & n.d. & n.d. & n.d. & 0.15 & 0.37 & n.d. \\
\hline $\mathrm{La}$ & 254 & 297 & 20 & 218 & 291 & 273 & 271 \\
\hline $\mathrm{Ce}$ & 465 & 502 & 39 & 393 & 561 & 465 & 446 \\
\hline $\operatorname{Pr}$ & 50 & 52 & 4 & 41 & 49 & 47 & 44 \\
\hline n.d. & 187 & 180 & 24 & 150 & 182 & 183 & 165 \\
\hline $\mathrm{Sm}$ & 20 & 19 & 4 & 19 & 22 & 20 & 18 \\
\hline $\mathrm{Eu}$ & 4 & 4 & 2 & 4 & 4 & 3 & 4 \\
\hline $\mathrm{Gd}$ & 15 & 12 & 2 & 10 & 16 & 11 & 14 \\
\hline $\mathrm{Tb}$ & 1 & 2 & 0.2 & 1 & 2 & 1 & 1 \\
\hline Dy & 7 & 7 & 1 & 5 & 7 & 5 & 4 \\
\hline Ho & 1 & 1 & 0.1 & 1 & 1 & 1 & 1 \\
\hline $\mathrm{Er}$ & 3 & 2 & 1 & 2 & 2 & 3 & 3 \\
\hline $\mathrm{Yb}$ & 1 & 1 & 0.2 & 1 & 1 & 1 & 0.3 \\
\hline
\end{tabular}


Table E-2. Continued.

\begin{tabular}{|c|c|c|c|}
\hline & $\begin{array}{l}\text { PH12C-6 } \\
\text { anh of ap1 }\end{array}$ & $\begin{array}{c}\text { PH12C-7 } \\
\text { anh of ap2 } \\
\text { ctr }\end{array}$ & $\begin{array}{c}\text { PH12C-7 } \\
\text { anh of ap2 } \\
\text { middle }\end{array}$ \\
\hline $\mathrm{SiO}_{2}$ & n.d. & n.d. & n.d. \\
\hline $\mathrm{TiO}_{2}$ & 0.001 & 0.002 & n.d. \\
\hline $\mathrm{Al}_{2} \mathrm{O}_{3}$ & 0.001 & 0.003 & n.d. \\
\hline $\mathrm{FeO}^{*}$ & 0.01 & n.d. & n.d. \\
\hline $\mathrm{MnO}$ & 0.002 & 0.002 & 0.002 \\
\hline $\mathrm{MgO}$ & 0.002 & 0.001 & n.d. \\
\hline $\mathrm{CaO}$ & 42 & 42 & 42 \\
\hline $\mathrm{Na}_{2} \mathrm{O}$ & 0.003 & 0.004 & 0.002 \\
\hline $\mathrm{K}_{2} \mathrm{O}$ & 0.001 & n.d. & n.d. \\
\hline $\mathrm{P}_{2} \mathrm{O}_{5}$ & 0.07 & 0.07 & 0.05 \\
\hline $\mathrm{S}$ & 144856 & 192470 & 194527 \\
\hline $\mathrm{Sc}$ & n.d. & n.d. & n.d. \\
\hline $\mathrm{Cr}$ & n.d. & n.d. & n.d. \\
\hline $\mathrm{Ni}$ & n.d. & n.d. & n.d. \\
\hline $\mathrm{Cu}$ & 0.74 & n.d. & n.d. \\
\hline $\mathrm{Zn}$ & n.d. & n.d. & n.d. \\
\hline $\mathrm{Rb}$ & n.d. & n.d. & n.d. \\
\hline $\mathrm{Sr}$ & 2177 & 2216 & 2196 \\
\hline $\mathrm{Y}$ & 29.5 & 36.1 & 32.0 \\
\hline $\mathrm{Zr}$ & n.d. & n.d. & n.d. \\
\hline $\mathrm{Nb}$ & n.d. & n.d. & n.d. \\
\hline $\mathrm{Ba}$ & 51.4 & 52.1 & 57.9 \\
\hline $\mathrm{Pb}$ & 1.33 & 4.08 & 3.12 \\
\hline $\mathrm{Th}$ & 0.37 & 0.30 & 0.37 \\
\hline $\mathrm{U}$ & n.d. & n.d. & n.d. \\
\hline $\mathrm{La}$ & 241 & 195 & 168 \\
\hline $\mathrm{Ce}$ & 422 & 376 & 306 \\
\hline $\operatorname{Pr}$ & 45 & 42 & 36 \\
\hline n.d. & 146 & 151 & 135 \\
\hline $\mathrm{Sm}$ & 21 & 22 & 18 \\
\hline $\mathrm{Eu}$ & 4 & 4 & 4 \\
\hline $\mathrm{Gd}$ & 13 & 14 & 10 \\
\hline $\mathrm{Tb}$ & 1 & 1 & 1 \\
\hline Dy & 7 & 7 & 7 \\
\hline Ho & 1 & 1 & 1 \\
\hline $\mathrm{Er}$ & 2 & 3 & 2 \\
\hline $\mathrm{Yb}$ & 1 & n.d. & 2 \\
\hline
\end{tabular}


Table E- 3. ETH LA-ICP-MS data of plagioclase reduced using SILLS (major elements in wt.\%, trace elements in ppm). $\mathrm{SiO}_{2}=58$ or $59 \mathrm{wt} . \%$, and total oxides $=100 \%$ were used as an internal standard dependent on material.

\begin{tabular}{|c|c|c|c|c|c|c|c|}
\hline & $\begin{array}{c}\text { CN6791-d } \\
\text { plag1 }\end{array}$ & $\begin{array}{c}\text { CN6791-d } \\
\text { plag2 }\end{array}$ & $\begin{array}{c}\text { CN6791-d } \\
\text { plag3 }\end{array}$ & $\begin{array}{c}\text { P-22892- } \\
2 \mathrm{a} \\
\text { plag xls1 }\end{array}$ & $\begin{array}{c}\text { P-22892- } \\
2 \mathrm{a} \\
\text { plag xls2 }\end{array}$ & $\begin{array}{l}\text { PH12C-1 } \\
\text { plag1 pt1 }\end{array}$ & $\begin{array}{l}\text { PH12C-1 } \\
\text { plag1 pt2 }\end{array}$ \\
\hline $\mathrm{SiO}_{2}$ & 58 & 58 & 58 & 61.19 & 63.72 & 59 & 59 \\
\hline $\mathrm{TiO}_{2}$ & 0.004 & 0.004 & 0.004 & 0.12 & 0.17 & 0.004 & 0.004 \\
\hline $\mathrm{Al}_{2} \mathrm{O}_{3}$ & 20.7 & 22.3 & 21.0 & 18.9 & 20.1 & 22.4 & 22.4 \\
\hline $\mathrm{FeO}^{*}$ & 0.13 & 0.13 & 0.13 & 1.20 & 1.42 & 0.12 & 0.14 \\
\hline $\mathrm{MnO}$ & 0.002 & 0.003 & 0.003 & 0.09 & 0.10 & 0.003 & 0.004 \\
\hline $\mathrm{MgO}$ & 0.01 & 0.01 & 0.01 & 0.28 & 0.34 & 0.01 & 0.01 \\
\hline $\mathrm{CaO}$ & 5.60 & 6.48 & 5.56 & 8.59 & 5.94 & 6.40 & 6.73 \\
\hline $\mathrm{Na}_{2} \mathrm{O}$ & 6.71 & 6.76 & 6.82 & 5.06 & 5.07 & 6.71 & 6.74 \\
\hline $\mathrm{K}_{2} \mathrm{O}$ & 0.31 & 0.30 & 0.35 & 2.51 & 2.84 & 0.31 & 0.31 \\
\hline $\mathrm{P}_{2} \mathrm{O}_{5}$ & 0.01 & 0.01 & 0.01 & 2.08 & 0.29 & 0.01 & 0.01 \\
\hline $\mathrm{S}$ & 578 & 382 & 421 & 946 & 492 & 439 & 357 \\
\hline $\mathrm{Sc}$ & 0.37 & 0.54 & 0.50 & 1.03 & 1.73 & 0.96 & 0.70 \\
\hline $\mathrm{Cr}$ & n.d. & n.d. & n.d. & 11.6 & n.d. & n.d. & n.d. \\
\hline $\mathrm{Ni}$ & n.d. & n.d. & n.d. & n.d. & n.d. & n.d. & n.d. \\
\hline $\mathrm{Cu}$ & 4.02 & 6.81 & 9.51 & 44.5 & 27.2 & 0.62 & 0.59 \\
\hline $\mathrm{Zn}$ & 3.48 & 5.06 & 3.50 & 46.2 & 57.5 & 3.41 & 3.19 \\
\hline $\mathrm{Rb}$ & 0.34 & 0.29 & 0.28 & 89.8 & 107 & 0.29 & 0.47 \\
\hline $\mathrm{Sr}$ & 884 & 983 & 927 & 1074 & 984 & 1046 & 1020 \\
\hline Y & 0.05 & 0.09 & 0.08 & 14.7 & 11.5 & 0.12 & 0.07 \\
\hline $\mathrm{Zr}$ & n.d. & n.d. & n.d. & 92.8 & 124 & n.d. & n.d. \\
\hline $\mathrm{Nb}$ & n.d. & n.d. & n.d. & 3.03 & 3.97 & n.d. & n.d. \\
\hline $\mathrm{Ba}$ & 200 & 182 & 197 & 575 & 678 & 190 & 204 \\
\hline $\mathrm{Pb}$ & 8.54 & 9.17 & 8.94 & 21.6 & 39.4 & 9.23 & 8.83 \\
\hline Th & n.d. & n.d. & n.d. & 10.7 & 13.2 & n.d. & n.d. \\
\hline $\mathrm{U}$ & n.d. & n.d. & n.d. & 3.70 & 3.48 & n.d. & n.d. \\
\hline $\mathrm{La}$ & 5 & 6 & 6 & 50 & 40 & 7 & 7 \\
\hline $\mathrm{Ce}$ & 6 & 7 & 8 & 103 & 75 & 8 & 9 \\
\hline $\operatorname{Pr}$ & 0.5 & 1 & 1 & 12 & 7 & 1 & 1 \\
\hline n.d. & 2 & 1 & 1 & 41 & 26 & 2 & 1 \\
\hline $\mathrm{Sm}$ & 0.2 & n.d. & n.d. & 7 & 5 & 0.2 & n.d. \\
\hline $\mathrm{Eu}$ & 1 & 1 & 1 & 2 & 1 & 1 & 1 \\
\hline $\mathrm{Gd}$ & n.d. & n.d. & n.d. & 5 & 3 & n.d. & n.d. \\
\hline $\mathrm{Tb}$ & n.d. & n.d. & n.d. & 0.4 & 1 & n.d. & n.d. \\
\hline Dy & n.d. & n.d. & n.d. & 2 & 2 & n.d. & n.d. \\
\hline Ho & n.d. & n.d. & n.d. & 0.5 & 0.4 & n.d. & n.d. \\
\hline Er & n.d. & n.d. & n.d. & 1 & 2 & n.d. & n.d. \\
\hline $\mathrm{Yb}$ & n.d. & n.d. & n.d. & 1 & 1 & n.d. & n.d. \\
\hline
\end{tabular}


Table E-3. Continued.

\begin{tabular}{|c|c|c|c|c|c|c|c|}
\hline & $\begin{array}{c}\text { PH12C-2 } \\
\text { plag of } \\
\text { ap1 }\end{array}$ & $\begin{array}{c}\text { PH12C-2 } \\
\text { plag of } \\
\text { ap1 }\end{array}$ & $\begin{array}{c}\text { PH12C-2 } \\
\text { plag of } \\
\text { ap2 }\end{array}$ & $\begin{array}{c}\text { PH12C-4 } \\
\text { plag of } \\
\text { ap2 }\end{array}$ & $\begin{array}{c}\text { PH12C-5 } \\
\text { plag of } \\
\text { ap3 }\end{array}$ & $\begin{array}{c}\text { PH12C-7 } \\
\text { plag1 }\end{array}$ & $\begin{array}{c}\text { PH12C-7 } \\
\text { plag2 }\end{array}$ \\
\hline $\mathrm{SiO}_{2}$ & 59 & 59 & 59 & 59 & 59 & 59 & 59 \\
\hline $\mathrm{TiO}_{2}$ & 0.005 & 0.003 & 0.01 & 0.004 & 0.01 & 0.01 & 0.005 \\
\hline $\mathrm{Al}_{2} \mathrm{O}_{3}$ & 22.8 & 23.5 & 25.1 & 22.2 & 23.0 & 23.1 & 22.3 \\
\hline $\mathrm{FeO}^{*}$ & 0.12 & 0.12 & 0.15 & 0.13 & 0.15 & 0.13 & 0.13 \\
\hline $\mathrm{MnO}$ & 0.003 & 0.003 & 0.003 & 0.003 & 0.003 & 0.003 & 0.003 \\
\hline $\mathrm{MgO}$ & 0.004 & 0.01 & 0.01 & 0.01 & 0.01 & 0.01 & 0.01 \\
\hline $\mathrm{CaO}$ & 5.86 & 6.28 & 7.10 & 6.21 & 6.82 & 6.45 & 5.95 \\
\hline $\mathrm{Na}_{2} \mathrm{O}$ & 8.15 & 7.69 & 7.63 & 6.87 & 6.89 & 6.89 & 7.08 \\
\hline $\mathrm{K}_{2} \mathrm{O}$ & 0.36 & 0.37 & 0.32 & 0.31 & 0.29 & 0.31 & 0.31 \\
\hline $\mathrm{P}_{2} \mathrm{O}_{5}$ & n.d. & 0.12 & 0.01 & 0.03 & 0.01 & 0.01 & 0.01 \\
\hline S & 462 & 305 & 440 & 236 & 294 & 444 & 340 \\
\hline $\mathrm{Sc}$ & n.d. & 0.97 & 1.04 & 0.29 & 0.69 & 0.47 & 0.55 \\
\hline $\mathrm{Cr}$ & n.d. & n.d. & n.d. & n.d. & n.d. & n.d. & n.d. \\
\hline $\mathrm{Ni}$ & n.d. & n.d. & n.d. & n.d. & n.d. & n.d. & n.d. \\
\hline $\mathrm{Cu}$ & 1.74 & 0.74 & 0.74 & 1.16 & 1.01 & 1.90 & 1.02 \\
\hline $\mathrm{Zn}$ & 4.27 & 3.10 & 2.37 & 3.17 & 3.46 & 4.02 & 2.74 \\
\hline $\mathrm{Rb}$ & 0.25 & 0.28 & 0.36 & 0.41 & 0.21 & 0.46 & 0.40 \\
\hline $\mathrm{Sr}$ & 872 & 858 & 1054 & 990 & 1052 & 1111 & 975 \\
\hline Y & n.d. & 0.11 & 0.05 & 0.08 & n.d. & 0.08 & 0.12 \\
\hline $\mathrm{Zr}$ & n.d. & n.d. & n.d. & n.d. & 0.13 & n.d. & n.d. \\
\hline $\mathrm{Nb}$ & n.d. & n.d. & n.d. & n.d. & n.d. & n.d. & n.d. \\
\hline $\mathrm{Ba}$ & 184 & 215 & 223 & 188 & 189 & 212 & 195 \\
\hline $\mathrm{Pb}$ & 8.51 & 10.9 & 8.08 & 9.13 & 6.84 & 8.38 & 8.73 \\
\hline Th & n.d. & n.d. & n.d. & n.d. & n.d. & n.d. & n.d. \\
\hline $\mathrm{U}$ & n.d. & n.d. & n.d. & n.d. & n.d. & n.d. & n.d. \\
\hline $\mathrm{La}$ & 6 & 7 & 7 & 7 & 5 & 7 & 6 \\
\hline $\mathrm{Ce}$ & 7 & 14 & 8 & 9 & 7 & 9 & 8 \\
\hline $\operatorname{Pr}$ & 1 & 1 & 1 & 1 & 0.5 & 1 & 1 \\
\hline n.d. & 1 & 2 & 1 & 2 & 1 & 2 & 1 \\
\hline $\mathrm{Sm}$ & n.d. & 0.2 & n.d. & n.d. & n.d. & 0.2 & n.d. \\
\hline $\mathrm{Eu}$ & 0.3 & 1 & 1 & 1 & 1 & 1 & 0.5 \\
\hline $\mathrm{Gd}$ & n.d. & n.d. & n.d. & n.d. & n.d. & n.d. & n.d. \\
\hline $\mathrm{Tb}$ & n.d. & n.d. & n.d. & n.d. & n.d. & n.d. & n.d. \\
\hline Dy & n.d. & n.d. & n.d. & n.d. & n.d. & n.d. & n.d. \\
\hline Ho & n.d. & n.d. & n.d. & n.d. & n.d. & n.d. & n.d. \\
\hline Er & n.d. & n.d. & n.d. & n.d. & n.d. & n.d. & n.d. \\
\hline $\mathrm{Yb}$ & n.d. & n.d. & n.d. & n.d. & n.d. & n.d. & n.d. \\
\hline
\end{tabular}


Table E-3. Continued.

\begin{tabular}{|c|c|c|c|c|c|}
\hline & $\begin{array}{c}\text { PH12C-7 } \\
\text { plag ctr }\end{array}$ & $\begin{array}{l}\text { PH12C-7 } \\
\text { plag rim }\end{array}$ & $\begin{array}{c}\text { PH12C-7 } \\
\text { host of } \\
\text { ap19 } \\
\end{array}$ & $\begin{array}{c}\text { PH12C-7 } \\
\text { F2 pt1 }\end{array}$ & $\begin{array}{c}\text { PH12C-7 } \\
\text { F2 pt2 }\end{array}$ \\
\hline $\mathrm{SiO}_{2}$ & 59 & 59 & 59 & 59 & 59 \\
\hline $\mathrm{TiO}_{2}$ & 0.004 & 0.01 & 0.01 & 0.01 & 0.004 \\
\hline $\mathrm{Al}_{2} \mathrm{O}_{3}$ & 23.1 & 22.8 & 23.8 & 24.3 & 22.7 \\
\hline $\mathrm{FeO}^{*}$ & 0.12 & 0.14 & 0.12 & 0.12 & 0.12 \\
\hline $\mathrm{MnO}$ & 0.003 & 0.003 & 0.004 & 0.003 & 0.003 \\
\hline $\mathrm{MgO}$ & 0.005 & 0.01 & 0.01 & 0.01 & 0.01 \\
\hline $\mathrm{CaO}$ & 5.95 & 5.91 & 5.81 & 5.92 & 5.48 \\
\hline $\mathrm{Na}_{2} \mathrm{O}$ & 6.78 & 6.84 & 7.08 & 7.08 & 7.11 \\
\hline $\mathrm{K}_{2} \mathrm{O}$ & 0.27 & 0.28 & 0.25 & 0.26 & 0.27 \\
\hline $\mathrm{P}_{2} \mathrm{O}_{5}$ & 0.01 & 0.01 & 0.01 & 0.01 & 0.01 \\
\hline $\mathrm{S}$ & 230 & 227 & 299 & 226 & 459 \\
\hline $\mathrm{Sc}$ & 0.82 & 0.88 & 0.44 & 0.43 & 0.46 \\
\hline $\mathrm{Cr}$ & n.d. & n.d. & n.d. & n.d. & n.d. \\
\hline $\mathrm{Ni}$ & n.d. & n.d. & n.d. & n.d. & n.d. \\
\hline $\mathrm{Cu}$ & n.d. & n.d. & 2.19 & 0.87 & 1.00 \\
\hline $\mathrm{Zn}$ & 3.49 & 3.32 & 2.98 & 2.54 & 2.97 \\
\hline $\mathrm{Rb}$ & 0.34 & 0.24 & 0.22 & 0.31 & 0.29 \\
\hline $\mathrm{Sr}$ & 876 & 967 & 1008 & 1093 & 1054 \\
\hline $\mathrm{Y}$ & 0.09 & 0.10 & 0.11 & 0.08 & 0.09 \\
\hline $\mathrm{Zr}$ & n.d. & n.d. & n.d. & n.d. & n.d. \\
\hline $\mathrm{Nb}$ & n.d. & n.d. & n.d. & n.d. & n.d. \\
\hline $\mathrm{Ba}$ & 158 & 205 & 183 & 233 & 213 \\
\hline $\mathrm{Pb}$ & 7.78 & 6.61 & 7.32 & 6.51 & 6.43 \\
\hline $\mathrm{Th}$ & n.d. & n.d. & n.d. & n.d. & n.d. \\
\hline $\mathrm{U}$ & n.d. & n.d. & n.d. & n.d. & n.d. \\
\hline $\mathrm{La}$ & 5 & 5 & 6 & 7 & 5 \\
\hline $\mathrm{Ce}$ & 7 & 7 & 8 & 9 & 7 \\
\hline $\operatorname{Pr}$ & 1 & 0.5 & 1 & 1 & 0.5 \\
\hline n.d. & 1 & 1 & 1 & 2 & 2 \\
\hline $\mathrm{Sm}$ & n.d. & n.d. & n.d. & n.d. & n.d. \\
\hline $\mathrm{Eu}$ & 0.5 & 1 & 1 & 1 & 0.5 \\
\hline $\mathrm{Gd}$ & n.d. & n.d. & n.d. & n.d. & n.d. \\
\hline $\mathrm{Tb}$ & n.d. & n.d. & n.d. & n.d. & n.d. \\
\hline Dy & n.d. & n.d. & n.d. & n.d. & n.d. \\
\hline Но & n.d. & n.d. & n.d. & n.d. & n.d. \\
\hline $\mathrm{Er}$ & n.d. & n.d. & n.d. & n.d. & n.d. \\
\hline $\mathrm{Yb}$ & n.d. & n.d. & n.d. & n.d. & n.d. \\
\hline
\end{tabular}


Table E- 4. ETH LA-ICP-MS data of hornblende reduced using SILLS (major elements in wt.\%, trace elements in ppm). $\mathrm{SiO}_{2}=41,42,44$, or $48 \mathrm{wt} . \%$ were used as an internal standard dependent on material.

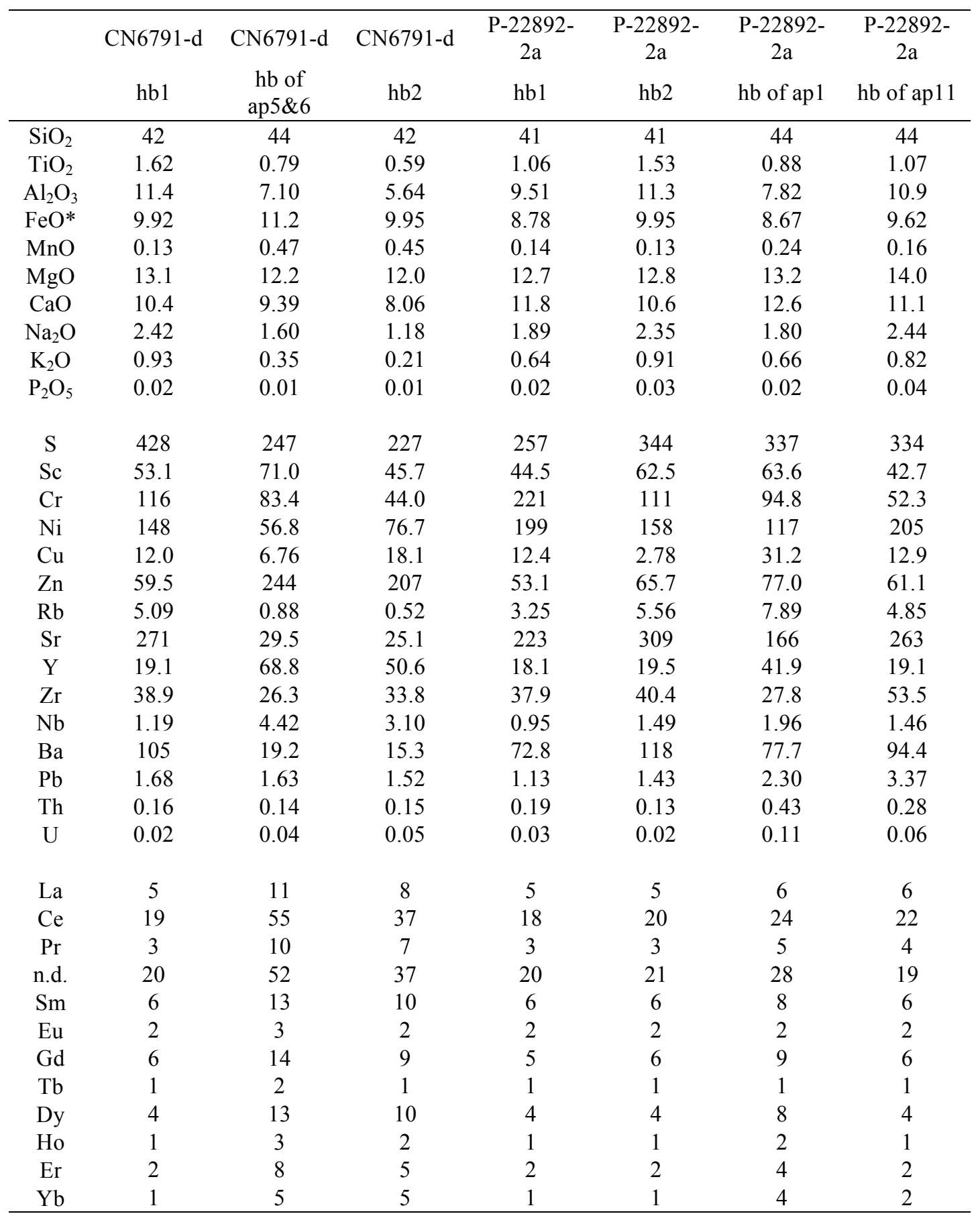


Table E-4. Continued.

\begin{tabular}{|c|c|c|c|c|c|}
\hline & $\begin{array}{c}\text { P-22892- } \\
\text { 2a } \\
\text { hb3 }\end{array}$ & PH12C-1 & PH12C-2 & $\begin{array}{c}\text { PH12C-7 } \\
\text { hb1 }\end{array}$ & $\begin{array}{c}\text { PH12C-7 } \\
\text { ap8 host } \\
\text { hb }\end{array}$ \\
\hline $\mathrm{SiO}_{2}$ & 41 & 48 & 48 & 48 & 48 \\
\hline $\mathrm{TiO}_{2}$ & 1.64 & 0.76 & 0.81 & 0.77 & 0.63 \\
\hline $\mathrm{Al}_{2} \mathrm{O}_{3}$ & 11.9 & 6.33 & 7.21 & 7.50 & 6.00 \\
\hline $\mathrm{FeO}^{*}$ & 10.5 & 11.1 & 12.0 & 12.4 & 10.5 \\
\hline $\mathrm{MnO}$ & 0.13 & 0.40 & 0.47 & 0.58 & 0.49 \\
\hline $\mathrm{MgO}$ & 12.2 & 14.1 & 14.1 & 12.9 & 13.2 \\
\hline $\mathrm{CaO}$ & 10.5 & 9.73 & 10.3 & 10.0 & 8.67 \\
\hline $\mathrm{Na}_{2} \mathrm{O}$ & 2.36 & 1.36 & 1.35 & 1.57 & 1.19 \\
\hline $\mathrm{K}_{2} \mathrm{O}$ & 0.95 & 0.23 & 0.29 & 0.38 & 0.20 \\
\hline $\mathrm{P}_{2} \mathrm{O}_{5}$ & 0.03 & 0.01 & 0.01 & 0.01 & 0.01 \\
\hline $\mathrm{S}$ & 260 & 182 & 287 & 231 & 261 \\
\hline $\mathrm{Sc}$ & 50.1 & 60.1 & 60.2 & 70.4 & 45.3 \\
\hline $\mathrm{Cr}$ & 11.1 & 66.0 & 101 & 116 & 118 \\
\hline $\mathrm{Ni}$ & 104 & 111 & 89.4 & 74.0 & 59.2 \\
\hline $\mathrm{Cu}$ & 2.27 & 1.57 & 0.90 & 1.19 & 6.08 \\
\hline $\mathrm{Zn}$ & 61.2 & 225 & 257 & 256 & 236 \\
\hline $\mathrm{Rb}$ & 4.98 & 0.52 & 1.10 & 0.94 & 0.44 \\
\hline $\mathrm{Sr}$ & 298 & 28.3 & 31.8 & 30.0 & 23.4 \\
\hline $\mathrm{Y}$ & 19.8 & 63.4 & 62.2 & 75.5 & 55.5 \\
\hline $\mathrm{Zr}$ & 44.5 & 31.0 & 35.4 & 28.6 & 24.5 \\
\hline $\mathrm{Nb}$ & 1.15 & 3.92 & 3.81 & 4.73 & 3.34 \\
\hline $\mathrm{Ba}$ & 122 & 19.6 & 25.5 & 24.2 & 14.4 \\
\hline $\mathrm{Pb}$ & 1.41 & 1.09 & 5.13 & 1.82 & 1.22 \\
\hline Th & 0.13 & 0.12 & 0.13 & 0.20 & n.d. \\
\hline U & n.d. & 0.04 & 0.04 & 0.03 & n.d. \\
\hline $\mathrm{La}$ & 5 & 9 & 10 & 14 & 9 \\
\hline $\mathrm{Ce}$ & 20 & 44 & 45 & 60 & 43 \\
\hline $\operatorname{Pr}$ & 4 & 8 & 9 & 11 & 8 \\
\hline n.d. & 21 & 45 & 44 & 57 & 41 \\
\hline $\mathrm{Sm}$ & 6 & 13 & 15 & 16 & 13 \\
\hline $\mathrm{Eu}$ & 2 & 3 & 3 & 3 & 2 \\
\hline $\mathrm{Gd}$ & 6 & 12 & 13 & 15 & 11 \\
\hline $\mathrm{Tb}$ & 1 & 2 & 2 & 2 & 2 \\
\hline Dy & 4 & 12 & 11 & 15 & 11 \\
\hline Но & 1 & 2 & 2 & 3 & 2 \\
\hline Er & 2 & 7 & 7 & 8 & 5 \\
\hline $\mathrm{Yb}$ & 2 & 6 & 7 & 8 & 6 \\
\hline
\end{tabular}


Table E- 5. ETH LA-ICP-MS data of matrix glass reduced using SILLS (major elements in wt.\%, trace elements in $\mathbf{p p m}$ ). Total oxides $=100 \mathrm{wt} . \%$ was used as an internal standard.

\begin{tabular}{|c|c|c|c|c|c|c|c|}
\hline & $\begin{array}{c}\text { CN6791-d } \\
\text { matrix } \\
\text { glass1 }\end{array}$ & $\begin{array}{c}\text { CN6791-d } \\
\text { matrix } \\
\text { glass2 }\end{array}$ & $\begin{array}{c}\text { CN6791-d } \\
\text { matrix } \\
\text { glass3 }\end{array}$ & $\begin{array}{c}\text { P-22892- } \\
2 \mathrm{a} \\
\text { matrix } \\
\text { glass } 1\end{array}$ & $\begin{array}{l}\text { PH12C-3b } \\
\text { glass near } \\
\text { ap13 }\end{array}$ & $\begin{array}{l}\text { PH12C-6 } \\
\text { glass near } \\
\text { ap1 }\end{array}$ & $\begin{array}{c}\text { PH12C-7 } \\
\text { matrix } \\
\text { glass1 }\end{array}$ \\
\hline $\mathrm{SiO}_{2}$ & 60.1 & 67.9 & 65.0 & 72.5 & 74.4 & 72.4 & 78.1 \\
\hline $\mathrm{TiO}_{2}$ & 0.96 & 0.33 & 0.27 & 0.17 & 0.04 & 0.06 & 0.10 \\
\hline $\mathrm{Al}_{2} \mathrm{O}_{3}$ & 14.4 & 15.6 & 18.7 & 14.3 & 5.76 & 2.85 & 12.4 \\
\hline $\mathrm{FeO}^{*}$ & 5.74 & 2.66 & 2.11 & 1.69 & 0.26 & 0.73 & 0.70 \\
\hline $\mathrm{MnO}$ & 0.11 & 0.09 & 0.07 & 0.16 & 0.01 & 0.04 & 0.03 \\
\hline $\mathrm{MgO}$ & 6.20 & 1.89 & 1.57 & 0.41 & 2.60 & 4.02 & 0.26 \\
\hline $\mathrm{CaO}$ & 6.69 & 4.54 & 5.34 & 0.83 & 4.45 & 6.47 & 1.22 \\
\hline $\mathrm{Na}_{2} \mathrm{O}$ & 3.69 & 4.29 & 4.54 & 4.25 & 10.7 & 12.20 & 4.13 \\
\hline $\mathrm{K}_{2} \mathrm{O}$ & 1.95 & 2.48 & 2.29 & 5.61 & 1.71 & 1.19 & 3.01 \\
\hline $\mathrm{P}_{2} \mathrm{O}_{5}$ & 0.17 & 0.19 & 0.14 & 0.09 & 0.03 & 0.02 & 0.03 \\
\hline S & 381 & 319 & 376 & n.d. & 1038 & 5150 & 439 \\
\hline $\mathrm{Sc}$ & 28.4 & 6.70 & 5.05 & 2.53 & n.d. & 3.86 & 1.30 \\
\hline $\mathrm{Cr}$ & 20.3 & 8.02 & 8.54 & n.d. & 39.5 & 5.50 & 7.59 \\
\hline $\mathrm{Ni}$ & 66.0 & 5.51 & 5.01 & n.d. & n.d. & 5.63 & n.d. \\
\hline $\mathrm{Cu}$ & 23.0 & 29.0 & 19.2 & 6.01 & 90.3 & 34.0 & 54.6 \\
\hline $\mathrm{Zn}$ & 64.9 & 58.9 & 42.5 & 96.4 & 7.55 & 14.4 & 39.6 \\
\hline $\mathrm{Rb}$ & 56.8 & 81.9 & 73.6 & 223 & 52.2 & 35.3 & 94.5 \\
\hline $\mathrm{Sr}$ & 437 & 507 & 728 & 63.0 & 108 & 76.9 & 178 \\
\hline $\mathrm{Y}$ & 16.7 & 11.5 & 9.70 & 9.55 & 2.13 & 5.30 & 4.30 \\
\hline $\mathrm{Zr}$ & 83.0 & 95.2 & 92.5 & 181 & 92.3 & 99.9 & 55.2 \\
\hline $\mathrm{Nb}$ & 3.29 & 3.85 & 3.54 & 6.43 & 1.54 & 0.81 & 3.89 \\
\hline $\mathrm{Ba}$ & 493 & 594 & 585 & 821 & 370 & 253 & 730 \\
\hline $\mathrm{Pb}$ & 11.8 & 15.8 & 13.8 & 24.6 & 134 & 94.4 & 4184 \\
\hline Th & 6.07 & 9.03 & 8.03 & 16.9 & 2.23 & 1.11 & 8.22 \\
\hline $\mathrm{U}$ & 1.81 & 2.73 & 2.30 & 7.49 & 1.13 & 0.55 & 2.62 \\
\hline $\mathrm{La}$ & 18 & 24 & 21 & 39 & 5 & 6 & 15 \\
\hline $\mathrm{Ce}$ & 39 & 47 & 41 & 80 & 10 & 13 & 24 \\
\hline $\operatorname{Pr}$ & 5 & 5 & 4 & 7 & 1 & 1 & 2 \\
\hline n.d. & 22 & 19 & 16 & 21 & 4 & 6 & 8 \\
\hline $\mathrm{Sm}$ & 5 & 4 & 4 & 3 & n.d. & 1 & 1 \\
\hline $\mathrm{Eu}$ & 1 & 1 & 1 & 1 & 1 & 0.3 & 0.2 \\
\hline $\mathrm{Gd}$ & 4 & 3 & 2 & 2 & n.d. & 1 & 1 \\
\hline $\mathrm{Tb}$ & 1 & 0.4 & 0.3 & n.d. & n.d. & 0.1 & 0.1 \\
\hline Dy & 3 & 2 & 2 & 1 & 1 & 1 & 1 \\
\hline Ho & 1 & 0.4 & 0.3 & 0.4 & n.d. & 0.2 & 0.1 \\
\hline Er & 2 & 1 & 1 & 1 & n.d. & 1 & 0.3 \\
\hline $\mathrm{Yb}$ & 2 & 1 & 1 & n.d. & n.d. & 1 & 1 \\
\hline
\end{tabular}

n.d. $=$ not detected 
Table E-5. Continued.

\begin{tabular}{cc}
\hline & $\begin{array}{c}\text { PH12C-7 } \\
\text { matrix } \\
\text { glass }\end{array}$ \\
\hline $\mathrm{SiO}_{2}$ & 77.1 \\
$\mathrm{TiO}_{2}$ & 0.10 \\
$\mathrm{Al}_{2} \mathrm{O}_{3}$ & 13.4 \\
$\mathrm{FeO}^{*}$ & 0.72 \\
$\mathrm{MnO}$ & 0.04 \\
$\mathrm{MgO}$ & 0.35 \\
$\mathrm{CaO}$ & 1.20 \\
$\mathrm{Na} 2$ & 4.33 \\
$\mathrm{~K}_{2} \mathrm{O}$ & 2.71 \\
$\mathrm{P}_{2} \mathrm{O}_{5}$ & 0.03 \\
& \\
$\mathrm{~S}$ & n.d. \\
$\mathrm{Sc}$ & n.d. \\
$\mathrm{Cr}$ & n.d. \\
$\mathrm{Ni}$ & n.d. \\
$\mathrm{Cu}$ & 44.4 \\
$\mathrm{Zn}$ & 37.4 \\
$\mathrm{Rb}$ & 93.6 \\
$\mathrm{Sr}$ & 185 \\
$\mathrm{Y}$ & 4.07 \\
$\mathrm{Zr}$ & 63.1 \\
$\mathrm{Nb}$ & 2.90 \\
$\mathrm{Ba}$ & 811 \\
$\mathrm{~Pb}$ & 9011 \\
$\mathrm{Th}$ & 5.53 \\
$\mathrm{U}$ & 2.82 \\
& \\
$\mathrm{La}$ & 17 \\
$\mathrm{Ce}$ & 24 \\
$\mathrm{Pr}$ & 3 \\
$\mathrm{n} . \mathrm{d}$. & 10 \\
$\mathrm{Sm}$ & 3 \\
$\mathrm{Eu}$ & n.d. \\
$\mathrm{Gd}$ & n.d. \\
$\mathrm{Tb}$ & 0.3 \\
$\mathrm{Dy}$ & n.d. \\
$\mathrm{Ho}$ & n.d. \\
$\mathrm{Er}$ & n.d. \\
$\mathrm{Yb}$ & n.d. \\
\hline $\mathrm{n} . \mathrm{d} .=\mathrm{not}$ & detected \\
& \\
$\mathrm{Mr}$ &
\end{tabular}


Table E-6. ETH LA-ICP-MS Durango Apatite error summary (1б) and detection limits (ppm).

\begin{tabular}{|c|c|c|c|c|c|c|}
\hline & \multicolumn{6}{|c|}{ ETH - August 3, 2010 - Durango } \\
\hline & \multicolumn{3}{|c|}{ Error Summary $(1 \sigma)$} & \multicolumn{3}{|c|}{ Detection Limits (ppm) } \\
\hline & high & low & average & high & low & average \\
\hline $\mathrm{SiO}_{2}$ & 0.01 & 0.01 & 0.01 & 131 & 80.9 & 106 \\
\hline $\mathrm{TiO}_{2}$ & 0.00003 & 0.00003 & 0.00003 & 0.83 & 0.23 & 0.53 \\
\hline $\mathrm{Al}_{2} \mathrm{O}_{3}$ & 0.00003 & 0.00003 & 0.00003 & 0.53 & 0.21 & 0.35 \\
\hline $\mathrm{FeO}^{*}$ & 0.002 & 0.001 & 0.001 & 6.68 & 4.27 & 5.56 \\
\hline $\mathrm{MnO}$ & 0.0001 & 0.0001 & 0.0001 & 0.32 & 0.19 & 0.28 \\
\hline $\mathrm{MgO}$ & 0.001 & 0.0004 & 0.001 & 0.52 & 0.26 & 0.37 \\
\hline $\mathrm{CaO}$ & 0.09 & 0.061 & 0.1 & 81.4 & 40.4 & 59.6 \\
\hline $\mathrm{Na}_{2} \mathrm{O}$ & 0.0005 & 0.0003 & 0.0004 & 0.60 & 0.36 & 0.46 \\
\hline $\mathrm{K}_{2} \mathrm{O}$ & 0.0001 & 0.00004 & 0.0001 & 2.04 & 0.84 & 1.52 \\
\hline $\mathrm{P}_{2} \mathrm{O}_{5}$ & 0.023 & 0.02 & 0.02 & 4.11 & 2.37 & 3.31 \\
\hline $\mathrm{S}$ & 13.5 & 7.04 & 10.8 & 40.2 & 18.0 & 29.4 \\
\hline $\mathrm{Sc}$ & 0.05 & 0.02 & 0.03 & 0.12 & 0.04 & 0.08 \\
\hline $\mathrm{Cr}$ & 0.76 & 0.76 & 0.76 & 2.95 & 1.43 & 2.13 \\
\hline $\mathrm{Ni}$ & 0.70 & 0.70 & 0.70 & 1.72 & 0.91 & 1.21 \\
\hline $\mathrm{Cu}$ & 0.12 & 0.09 & 0.11 & 0.29 & 0.12 & 0.17 \\
\hline $\mathrm{Zn}$ & 0.17 & 0.10 & 0.13 & 0.34 & 0.13 & 0.22 \\
\hline $\mathrm{Rb}$ & 0.02 & 0.01 & 0.02 & 0.03 & 0.01 & 0.02 \\
\hline $\mathrm{Sr}$ & 1.47 & 1.00 & 1.21 & 0.03 & 0.01 & 0.02 \\
\hline $\mathrm{Y}$ & 1.51 & 1.02 & 1.2 & 0.01 & 0.01 & 0.01 \\
\hline $\mathrm{Zr}$ & 0.07 & 0.05 & 0.06 & 0.06 & 0.02 & 0.03 \\
\hline $\mathrm{Nb}$ & 0.01 & 0.01 & 0.01 & 0.02 & 0.01 & 0.02 \\
\hline $\mathrm{Ba}$ & 0.21 & 0.15 & 0.17 & 0.10 & 0.06 & 0.09 \\
\hline $\mathrm{Pb}$ & 0.08 & 0.05 & 0.06 & 0.04 & 0.02 & 0.03 \\
\hline Th & 1.11 & 0.66 & 0.83 & 0.01 & 0.01 & 0.01 \\
\hline $\mathrm{U}$ & 0.24 & 0.14 & 0.18 & 0.02 & 0.01 & 0.01 \\
\hline $\mathrm{La}$ & 3.55 & 2.50 & 2.87 & 0.02 & 0.01 & 0.01 \\
\hline $\mathrm{Ce}$ & 3.95 & 2.88 & 3.25 & 0.01 & 0.01 & 0.01 \\
\hline $\operatorname{Pr}$ & 0.98 & 0.67 & 0.81 & 0.01 & 0.01 & 0.01 \\
\hline n.d. & 4.24 & 2.91 & 3.49 & 0.06 & 0.0 & 0.05 \\
\hline $\mathrm{Sm}$ & 1.69 & 1.17 & 1.38 & 0.12 & 0.05 & 0.07 \\
\hline $\mathrm{Eu}$ & 0.30 & 0.21 & 0.25 & 0.03 & 0.01 & 0.02 \\
\hline $\mathrm{Gd}$ & 1.67 & 1.14 & 1.34 & 0.08 & 0.05 & 0.07 \\
\hline $\mathrm{Tb}$ & 0.23 & 0.15 & 0.18 & 0.01 & 0.01 & 0.01 \\
\hline Dy & 1.11 & 0.75 & 0.86 & 0.04 & 0.03 & 0.04 \\
\hline Но & 0.24 & 0.17 & 0.19 & 0.01 & 0.01 & 0.01 \\
\hline $\mathrm{Er}$ & 0.87 & 0.59 & 0.67 & 0.05 & 0.03 & 0.05 \\
\hline $\mathrm{Yb}$ & 0.87 & 0.59 & 0.68 & 0.09 & 0.05 & 0.07 \\
\hline
\end{tabular}


Table E-6. Continued

\begin{tabular}{|c|c|c|c|c|c|c|}
\hline & \multicolumn{6}{|c|}{ ETH - August 4, 2010 - Durango } \\
\hline & \multicolumn{3}{|c|}{ Error Summary $(1 \sigma)$} & \multicolumn{3}{|c|}{ Detection Limits (ppm) } \\
\hline & high & low & average & high & low & average \\
\hline $\mathrm{SiO}_{2}$ & 0.01 & 0.01 & 0.01 & 95.9 & 66.1 & 79.1 \\
\hline $\mathrm{TiO}_{2}$ & 0.00003 & 0.00002 & 0.00003 & 0.69 & 0.19 & 0.44 \\
\hline $\mathrm{Al}_{2} \mathrm{O}_{3}$ & 0.00002 & 0.00001 & 0.00002 & 0.34 & 0.18 & 0.25 \\
\hline $\mathrm{FeO}^{*}$ & 0.001 & 0.001 & 0.001 & 6.91 & 3.51 & 4.73 \\
\hline $\mathrm{MnO}$ & 0.0001 & 0.0001 & 0.0001 & 0.32 & 0.16 & 0.24 \\
\hline $\mathrm{MgO}$ & 0.001 & 0.0004 & 0.0005 & 0.39 & 0.22 & 0.31 \\
\hline $\mathrm{CaO}$ & 0.08 & 0.06 & 0.07 & 69.0 & 36.0 & 50.4 \\
\hline $\mathrm{Na}_{2} \mathrm{O}$ & 0.0004 & 0.0003 & 0.0004 & 0.50 & 0.26 & 0.37 \\
\hline $\mathrm{K}_{2} \mathrm{O}$ & 0.0001 & 0.00004 & 0.0001 & 1.62 & 0.82 & 1.18 \\
\hline $\mathrm{P}_{2} \mathrm{O}_{5}$ & 0.02 & 0.01 & 0.02 & 3.42 & 1.73 & 2.64 \\
\hline $\mathrm{S}$ & 11.6 & 6.65 & 8.88 & 33.7 & 15.5 & 24.3 \\
\hline $\mathrm{Sc}$ & 0.04 & 0.02 & 0.03 & 0.14 & 0.04 & 0.07 \\
\hline $\mathrm{Cr}$ & 0.59 & 0.58 & 0.58 & 2.60 & 1.29 & 1.67 \\
\hline $\mathrm{Ni}$ & 0.67 & 0.67 & 0.67 & 1.98 & 0.65 & 1.13 \\
\hline $\mathrm{Cu}$ & 0.21 & 0.06 & 0.12 & 0.20 & 0.08 & 0.12 \\
\hline $\mathrm{Zn}$ & 0.19 & 0.08 & 0.14 & 0.35 & 0.15 & 0.24 \\
\hline $\mathrm{Rb}$ & 0.02 & 0.01 & 0.01 & 0.03 & 0.01 & 0.02 \\
\hline $\mathrm{Sr}$ & 1.29 & 0.95 & 1.09 & 0.03 & 0.01 & 0.02 \\
\hline Y & 1.29 & 0.98 & 1.12 & 0.02 & 0.01 & 0.01 \\
\hline $\mathrm{Zr}$ & 0.06 & 0.04 & 0.05 & 0.03 & 0.02 & 0.02 \\
\hline $\mathrm{Nb}$ & 0.01 & 0.01 & 0.01 & 0.02 & 0.01 & 0.01 \\
\hline $\mathrm{Ba}$ & 0.20 & 0.14 & 0.16 & 0.09 & 0.05 & 0.07 \\
\hline $\mathrm{Pb}$ & 0.08 & 0.05 & 0.06 & 0.03 & 0.01 & 0.02 \\
\hline Th & 0.9 & 0.69 & 0.81 & 0.01 & 0.01 & 0.01 \\
\hline $\mathrm{U}$ & 0.21 & 0.15 & 0.18 & 0.01 & 0.01 & 0.01 \\
\hline $\mathrm{La}$ & 3.06 & 2.41 & 2.68 & 0.01 & 0.01 & 0.01 \\
\hline $\mathrm{Ce}$ & 3.48 & 2.75 & 3.07 & 0.02 & 0.01 & 0.01 \\
\hline $\operatorname{Pr}$ & 0.87 & 0.64 & 0.74 & 0.01 & 0.01 & 0.01 \\
\hline n.d. & 3.76 & 2.75 & 3.19 & 0.08 & 0.03 & 0.05 \\
\hline $\mathrm{Sm}$ & 1.50 & 1.09 & 1.28 & 0.11 & 0.04 & 0.06 \\
\hline $\mathrm{Eu}$ & 0.26 & 0.20 & 0.23 & 0.02 & 0.01 & 0.02 \\
\hline $\mathrm{Gd}$ & 1.48 & 1.10 & 1.27 & 0.07 & 0.04 & 0.06 \\
\hline $\mathrm{Tb}$ & 0.19 & 0.15 & 0.17 & 0.02 & 0.01 & 0.01 \\
\hline Dy & 0.93 & 0.70 & 0.81 & 0.06 & 0.02 & 0.04 \\
\hline Ho & 0.21 & 0.16 & 0.18 & 0.01 & 0.01 & 0.01 \\
\hline Er & 0.74 & 0.55 & 0.65 & 0.05 & 0.03 & 0.04 \\
\hline $\mathrm{Yb}$ & 0.74 & 0.55 & 0.64 & 0.07 & 0.04 & 0.06 \\
\hline
\end{tabular}


Table E-7. ETH LA-ICP-MS anhydrite error summary (1б) and detection limits (ppm).

\begin{tabular}{|c|c|c|c|c|c|c|}
\hline & \multicolumn{6}{|c|}{ ETH - August 3, 2010 - Anhydrite } \\
\hline & \multicolumn{3}{|c|}{ Error Summary $(1 \sigma)$} & \multicolumn{3}{|c|}{ Detection Limits (ppm) } \\
\hline & high & low & average & high & low & average \\
\hline $\mathrm{SiO}_{2}$ & 0.11 & 0.01 & 0.07 & 350 & 148 & 212 \\
\hline $\mathrm{TiO}_{2}$ & 0.001 & 0.0002 & 0.0004 & 2.53 & 0.43 & 1.30 \\
\hline $\mathrm{Al}_{2} \mathrm{O}_{3}$ & 0.002 & 0.00011 & 0.001 & 0.88 & 0.34 & 0.60 \\
\hline $\mathrm{FeO}^{*}$ & 0.01 & 0.001 & 0.003 & 19.5 & 6.02 & 10.5 \\
\hline $\mathrm{MnO}$ & 0.0005 & 0.0001 & 0.0002 & 0.98 & 0.29 & 0.55 \\
\hline $\mathrm{MgO}$ & 0.01 & 0.0003 & 0.003 & 1.21 & 0.48 & 0.68 \\
\hline $\mathrm{CaO}$ & 0.23 & 0.10 & 0.16 & 192 & 66.2 & 123 \\
\hline $\mathrm{Na}_{2} \mathrm{O}$ & 0.004 & 0.00005 & 0.001 & 1.89 & 0.66 & 1.04 \\
\hline $\mathrm{K}_{2} \mathrm{O}$ & 0.001 & 0.0007 & 0.001 & 5.01 & 1.70 & 2.97 \\
\hline $\mathrm{P}_{2} \mathrm{O}_{5}$ & 0.03 & 0.001 & 0.01 & 9.92 & 4.37 & 6.22 \\
\hline $\mathrm{S}$ & 236 & 93.9 & 163 & 105 & 32.3 & 58.7 \\
\hline $\mathrm{Sc}$ & 0.12 & 0.11 & 0.11 & 0.24 & 0.09 & 0.16 \\
\hline $\mathrm{Cr}$ & 2.74 & 2.74 & 2.7 & 6.37 & 2.76 & 4.29 \\
\hline $\mathrm{Ni}$ & 4.50 & 2.27 & 3.39 & 3.88 & 1.55 & 2.60 \\
\hline $\mathrm{Cu}$ & 3.95 & 2.81 & 3.50 & 0.45 & 0.19 & 0.32 \\
\hline $\mathrm{Zn}$ & 2.17 & 0.20 & 0.93 & 0.74 & 0.26 & 0.38 \\
\hline $\mathrm{Rb}$ & 0.41 & 0.24 & 0.33 & 0.09 & 0.02 & 0.05 \\
\hline $\mathrm{Sr}$ & 9.5 & 3.13 & 5.79 & 0.05 & 0.02 & 0.04 \\
\hline Y & 1.31 & 0.24 & 0.73 & 0.07 & 0.02 & 0.03 \\
\hline $\mathrm{Zr}$ & 0.95 & 0.92 & 0.93 & 0.09 & 0.04 & 0.05 \\
\hline $\mathrm{Nb}$ & 0.13 & 0.06 & 0.10 & 0.06 & 0.02 & 0.03 \\
\hline $\mathrm{Ba}$ & 3.57 & 1.54 & 2.59 & 0.43 & 0.12 & 0.22 \\
\hline $\mathrm{Pb}$ & 4.90 & 0.23 & 2.01 & 0.08 & 0.03 & 0.05 \\
\hline Th & 0.29 & 0.12 & 0.19 & 0.05 & 0.02 & 0.03 \\
\hline U & 0.17 & 0.06 & 0.11 & 0.04 & 0.02 & 0.03 \\
\hline $\mathrm{La}$ & 2.62 & 0.13 & 1.59 & 0.05 & 0.02 & 0.03 \\
\hline $\mathrm{Ce}$ & 3.70 & 0.24 & 2.26 & 0.06 & 0.02 & 0.03 \\
\hline $\mathrm{Pr}$ & 1.09 & 0.08 & 0.65 & 0.05 & 0.01 & 0.02 \\
\hline n.d. & 5.12 & 0.46 & 3.02 & 0.19 & 0.07 & 0.10 \\
\hline $\mathrm{Sm}$ & 1.97 & 0.24 & 1.19 & 0.21 & 0.09 & 0.13 \\
\hline $\mathrm{Eu}$ & 0.50 & 0.07 & 0.29 & 0.06 & 0.02 & 0.03 \\
\hline $\mathrm{Gd}$ & 1.79 & 0.24 & 1.06 & 0.23 & 0.09 & 0.14 \\
\hline $\mathrm{Tb}$ & 0.24 & 0.04 & 0.13 & 0.03 & 0.01 & 0.02 \\
\hline Dy & 1.00 & 0.18 & 0.56 & 0.14 & 0.05 & 0.08 \\
\hline Ho & 0.20 & 0.04 & 0.10 & 0.03 & 0.01 & 0.02 \\
\hline Er & 0.73 & 0.09 & 0.37 & 0.16 & 0.06 & 0.09 \\
\hline $\mathrm{Yb}$ & 0.77 & 0.13 & 0.35 & 0.23 & 0.09 & 0.14 \\
\hline
\end{tabular}


Table E-7. Continued.

\begin{tabular}{|c|c|c|c|c|c|c|}
\hline & \multicolumn{6}{|c|}{ ETH - August 4, 2010 - Anhydrite } \\
\hline & \multicolumn{3}{|c|}{ Error Summary $(1 \sigma)$} & \multicolumn{3}{|c|}{ Detection Limits (ppm) } \\
\hline & high & low & average & high & low & average \\
\hline $\mathrm{SiO}_{2}$ & 0.04 & 0.04 & 0.04 & 598 & 235 & 371 \\
\hline $\mathrm{TiO}_{2}$ & 0.001 & 0.0002 & 0.0004 & 3.30 & 0.86 & 1.82 \\
\hline $\mathrm{Al}_{2} \mathrm{O}_{3}$ & 0.0005 & 0.0001 & 0.0003 & 1.44 & 0.61 & 1.00 \\
\hline $\mathrm{FeO}^{*}$ & 0.003 & 0.001 & 0.002 & 33.4 & 11.1 & 18.1 \\
\hline $\mathrm{MnO}$ & 0.0002 & 0.0001 & 0.0001 & 1.58 & 0.59 & 1.06 \\
\hline $\mathrm{MgO}$ & 0.001 & 0.0003 & 0.001 & 1.77 & 0.72 & 1.21 \\
\hline $\mathrm{CaO}$ & 0.33 & 0.11 & 0.22 & 383 & 149 & 216 \\
\hline $\mathrm{Na}_{2} \mathrm{O}$ & 0.001 & 0.0001 & 0.0002 & 2.56 & 0.89 & 1.61 \\
\hline $\mathrm{K}_{2} \mathrm{O}$ & 0.0004 & 0.0002 & 0.0003 & 7.56 & 3.59 & 5.18 \\
\hline $\mathrm{P}_{2} \mathrm{O}_{5}$ & 0.01 & 0.002 & 0.003 & 15.6 & 5.95 & 11.2 \\
\hline $\mathrm{S}$ & 345 & 114 & 217 & 157 & 65.6 & 103 \\
\hline $\mathrm{Sc}$ & 0.30 & 0.30 & 0.30 & 0.40 & 0.16 & 0.27 \\
\hline $\mathrm{Cr}$ & n.d & n.d & n.d. & 9.89 & 4.03 & 7.32 \\
\hline $\mathrm{Ni}$ & n.d & n.d & n.d. & 6.02 & 1.91 & 4.01 \\
\hline $\mathrm{Cu}$ & 1.35 & 0.29 & 0.72 & 1.14 & 0.31 & 0.59 \\
\hline $\mathrm{Zn}$ & 2.23 & 1.11 & 1.67 & 1.99 & 0.44 & 0.94 \\
\hline $\mathrm{Rb}$ & 0.25 & 0.21 & 0.23 & 0.11 & 0.05 & 0.08 \\
\hline $\mathrm{Sr}$ & 12.9 & 4.40 & 8.48 & 0.10 & 0.03 & 0.05 \\
\hline $\mathrm{Y}$ & 1.57 & 0.38 & 0.93 & 0.06 & 0.02 & 0.05 \\
\hline $\mathrm{Zr}$ & 0.16 & 0.13 & 0.15 & 0.20 & 0.05 & 0.10 \\
\hline $\mathrm{Nb}$ & 0.10 & 0.10 & 0.10 & 0.08 & 0.03 & 0.05 \\
\hline $\mathrm{Ba}$ & 4.70 & 1.46 & 3.03 & 0.62 & 0.18 & 0.35 \\
\hline $\mathrm{Pb}$ & 7.28 & 0.13 & 1.90 & 0.11 & 0.05 & 0.08 \\
\hline Th & 0.24 & 0.06 & 0.12 & 0.07 & 0.03 & 0.04 \\
\hline $\mathrm{U}$ & 0.16 & 0.16 & 0.16 & 0.06 & 0.02 & 0.04 \\
\hline $\mathrm{La}$ & 4.34 & 0.59 & 2.57 & 0.08 & 0.02 & 0.04 \\
\hline $\mathrm{Ce}$ & 5.73 & 0.84 & 3.44 & 0.06 & 0.02 & 0.04 \\
\hline $\mathrm{Pr}$ & 1.62 & 0.24 & 0.98 & 0.07 & 0.02 & 0.03 \\
\hline n.d. & 7.75 & 1.41 & 4.59 & 0.27 & 0.11 & 0.20 \\
\hline $\mathrm{Sm}$ & 2.75 & 0.62 & 1.70 & 0.32 & 0.13 & 0.22 \\
\hline $\mathrm{Eu}$ & 0.59 & 0.22 & 0.41 & 0.09 & 0.04 & 0.06 \\
\hline $\mathrm{Gd}$ & 2.14 & 0.49 & 1.38 & 0.34 & 0.14 & 0.24 \\
\hline $\mathrm{Tb}$ & 0.26 & 0.06 & 0.16 & 0.07 & 0.02 & 0.04 \\
\hline Dy & 1.23 & 0.26 & 0.76 & 0.20 & 0.09 & 0.14 \\
\hline Но & 0.23 & 0.04 & 0.15 & 0.06 & 0.02 & 0.04 \\
\hline $\mathrm{Er}$ & 0.97 & 0.23 & 0.49 & 0.23 & 0.10 & 0.16 \\
\hline $\mathrm{Yb}$ & 0.70 & 0.15 & 0.37 & 0.34 & 0.15 & 0.23 \\
\hline
\end{tabular}

$\mathrm{n}=10$

n.d. $=$ not detected 
Table E-7. Continued.

\begin{tabular}{|c|c|c|c|c|c|c|}
\hline & \multicolumn{6}{|c|}{ ETH - March 16, 2011 - Anhydrite } \\
\hline & \multicolumn{3}{|c|}{ Error Summary $(1 \sigma)$} & \multicolumn{3}{|c|}{ Detection Limits (ppm) } \\
\hline & high & low & average & high & low & average \\
\hline $\mathrm{SiO}_{2}$ & n.d. & n.d. & n.d. & 2519 & 1795 & 2157 \\
\hline $\mathrm{TiO}_{2}$ & 0.001 & 0.0008 & 0.0008 & 12.8 & 6.96 & 9.86 \\
\hline $\mathrm{Al}_{2} \mathrm{O}_{3}$ & 0.001 & 0.001 & 0.001 & 14.3 & 12.2 & 13.2 \\
\hline $\mathrm{FeO}^{*}$ & n.d. & n.d. & n.d. & 113 & 97.6 & 106 \\
\hline $\mathrm{MnO}$ & 0.0004 & 0.0003 & 0.0003 & 6.54 & 6.26 & 6.40 \\
\hline $\mathrm{MgO}$ & 0.001 & 0.0008 & 0.001 & 7.26 & 6.82 & 7.04 \\
\hline $\mathrm{CaO}$ & 0.32 & 0.31 & 0.31 & 986 & 655 & 820 \\
\hline $\mathrm{Na}_{2} \mathrm{O}$ & 0.0003 & 0.0003 & 0.0003 & 4.70 & 4.34 & 4.52 \\
\hline $\mathrm{K}_{2} \mathrm{O}$ & n.d. & n.d. & n.d. & 18.7 & 17.7 & 18.2 \\
\hline $\mathrm{P}_{2} \mathrm{O}_{5}$ & 0.01 & 0.006 & 0.006 & 67.5 & 59.79 & 63.6 \\
\hline $\mathrm{S}$ & 352 & 341 & 347 & 416 & 344.6 & 380 \\
\hline $\mathrm{Sc}$ & n.d. & n.d. & n.d. & 3.79 & 3.13 & 3.46 \\
\hline $\mathrm{Cr}$ & n.d. & n.d. & n.d. & 65.98 & 57.95 & 61.97 \\
\hline $\mathrm{Ni}$ & n.d. & n.d. & n.d. & 31.78 & 24.06 & 27.92 \\
\hline $\mathrm{Cu}$ & n.d. & n.d. & n.d. & 5.03 & 3.40 & 4.22 \\
\hline $\mathrm{Zn}$ & n.d. & n.d. & n.d. & 5.97 & 5.23 & 5.60 \\
\hline $\mathrm{Rb}$ & n.d. & n.d. & n.d. & 0.45 & 0.42 & 0.44 \\
\hline $\mathrm{Sr}$ & 14.4 & 13.9 & 14.1 & 0.48 & 0.37 & 0.43 \\
\hline $\mathrm{Y}$ & 1.77 & 1.74 & 1.75 & 0.28 & 0.27 & 0.27 \\
\hline $\mathrm{Zr}$ & n.d. & n.d. & n.d. & 0.60 & 0.56 & 0.58 \\
\hline $\mathrm{Nb}$ & n.d. & n.d. & n.d. & 0.46 & 0.35 & 0.40 \\
\hline $\mathrm{Ba}$ & 5.21 & 4.73 & 4.97 & 1.40 & 1.31 & 1.36 \\
\hline $\mathrm{Pb}$ & 0.73 & 0.67 & 0.70 & 0.65 & 0.62 & 0.63 \\
\hline Th & 0.19 & 0.16 & 0.17 & 0.25 & 0.23 & 0.24 \\
\hline $\mathrm{U}$ & n.d. & n.d. & n.d. & 0.22 & 0.21 & 0.21 \\
\hline $\mathrm{La}$ & 3.37 & 3.28 & 3.33 & 0.19 & 0.18 & 0.19 \\
\hline $\mathrm{Ce}$ & 4.61 & 4.35 & 4.48 & 0.26 & 0.17 & 0.22 \\
\hline $\operatorname{Pr}$ & 1.36 & 1.32 & 1.34 & 0.14 & 0.13 & 0.14 \\
\hline n.d. & 6.13 & 6.07 & 6.10 & 0.82 & 0.77 & 0.79 \\
\hline $\mathrm{Sm}$ & 2.53 & 2.40 & 2.46 & 0.95 & 0.89 & 0.92 \\
\hline $\mathrm{Eu}$ & 0.60 & 0.58 & 0.59 & 0.27 & 0.25 & 0.26 \\
\hline $\mathrm{Gd}$ & 2.11 & 1.89 & 2.00 & 1.03 & 0.97 & 1.00 \\
\hline $\mathrm{Tb}$ & 0.22 & 0.21 & 0.21 & 0.14 & 0.13 & 0.14 \\
\hline Dy & 1.17 & 1.14 & 1.15 & 0.60 & 0.56 & 0.58 \\
\hline Ho & 0.24 & 0.21 & 0.22 & 0.15 & 0.14 & 0.15 \\
\hline Er & 0.78 & 0.74 & 0.76 & 0.69 & 0.65 & 0.67 \\
\hline $\mathrm{Yb}$ & 0.80 & 0.80 & 0.80 & 1.03 & 0.97 & 1.00 \\
\hline
\end{tabular}


Table E-8. ETH LA-ICP-MS plagioclase error summary (1б) and detection limits (ppm).

\begin{tabular}{|c|c|c|c|c|c|c|}
\hline & \multicolumn{6}{|c|}{ ETH - August 3, 2010 - Plagioclase } \\
\hline & \multicolumn{3}{|c|}{ Error Summary $(1 \sigma)$} & \multicolumn{3}{|c|}{ Detection Limits (ppm) } \\
\hline & high & low & average & high & low & average \\
\hline $\mathrm{SiO}_{2}$ & 0.24 & 0.12 & 0.16 & 348 & 196 & 288 \\
\hline $\mathrm{TiO}_{2}$ & 0.004 & 0.0003 & 0.001 & 3.23 & 0.81 & 1.69 \\
\hline $\mathrm{Al}_{2} \mathrm{O}_{3}$ & 0.02 & 0.01 & 0.01 & 1.19 & 0.48 & 0.81 \\
\hline $\mathrm{FeO}^{*}$ & 0.02 & 0.003 & 0.006 & 19.6 & 10.9 & 14.6 \\
\hline $\mathrm{MnO}$ & 0.0007 & 0.0001 & 0.0002 & 1.11 & 0.49 & 0.75 \\
\hline $\mathrm{MgO}$ & 0.006 & 0.0004 & 0.001 & 1.25 & 0.75 & 0.92 \\
\hline $\mathrm{CaO}$ & 0.07 & 0.04 & 0.05 & 200 & 113 & 144 \\
\hline $\mathrm{Na}_{2} \mathrm{O}$ & 0.006 & 0.003 & 0.004 & 1.70 & 1.00 & 1.32 \\
\hline $\mathrm{K}_{2} \mathrm{O}$ & 0.004 & 0.0007 & 0.001 & 4.58 & 2.54 & 3.49 \\
\hline $\mathrm{P}_{2} \mathrm{O}_{5}$ & 0.01 & 0.001 & 0.002 & 11.7 & 6.48 & 8.29 \\
\hline $\mathrm{S}$ & 37.2 & 18.4 & 23.9 & 119 & 50.3 & 72.8 \\
\hline $\mathrm{Sc}$ & 0.23 & 0.08 & 0.12 & 0.27 & 0.13 & 0.19 \\
\hline $\mathrm{Cr}$ & 3.26 & 3.26 & 3.26 & 8.22 & 4.23 & 5.71 \\
\hline $\mathrm{Ni}$ & n.d. & n.d. & n.d. & 4.33 & 2.46 & 3.37 \\
\hline $\mathrm{Cu}$ & 2.70 & 0.24 & 0.90 & 0.68 & 0.28 & 0.46 \\
\hline $\mathrm{Zn}$ & 3.62 & 0.45 & 1.08 & 0.78 & 0.40 & 0.52 \\
\hline $\mathrm{Rb}$ & 1.69 & 0.05 & 0.35 & 0.09 & 0.03 & 0.06 \\
\hline $\mathrm{Sr}$ & 4.76 & 2.50 & 3.18 & 0.07 & 0.03 & 0.04 \\
\hline $\mathrm{Y}$ & 0.50 & 0.02 & 0.12 & 0.06 & 0.03 & 0.04 \\
\hline $\mathrm{Zr}$ & 2.37 & 1.75 & 2.06 & 0.10 & 0.06 & 0.07 \\
\hline $\mathrm{Nb}$ & 0.33 & 0.25 & 0.29 & 0.06 & 0.03 & 0.05 \\
\hline $\mathrm{Ba}$ & 9.92 & 2.71 & 4.35 & 0.32 & 0.19 & 0.23 \\
\hline $\mathrm{Pb}$ & 1.24 & 0.30 & 0.48 & 0.09 & 0.05 & 0.07 \\
\hline Th & 0.54 & 0.42 & 0.48 & 0.05 & 0.03 & 0.04 \\
\hline $\mathrm{U}$ & 0.27 & 0.24 & 0.25 & 0.04 & 0.03 & 0.03 \\
\hline $\mathrm{La}$ & 0.87 & 0.18 & 0.34 & 0.05 & 0.02 & 0.03 \\
\hline $\mathrm{Ce}$ & 1.20 & 0.20 & 0.43 & 0.05 & 0.02 & 0.03 \\
\hline $\operatorname{Pr}$ & 0.37 & 0.05 & 0.12 & 0.06 & 0.02 & 0.03 \\
\hline n.d. & 1.62 & 0.18 & 0.49 & 0.19 & 0.11 & 0.15 \\
\hline $\mathrm{Sm}$ & 0.75 & 0.08 & 0.34 & 0.23 & 0.13 & 0.16 \\
\hline Eu & 0.23 & 0.07 & 0.11 & 0.07 & 0.04 & 0.05 \\
\hline $\mathrm{Gd}$ & 0.65 & 0.53 & 0.59 & 0.24 & 0.14 & 0.17 \\
\hline $\mathrm{Tb}$ & 0.09 & 0.07 & 0.08 & 0.03 & 0.02 & 0.03 \\
\hline Dy & 0.38 & 0.32 & 0.35 & 0.19 & 0.08 & 0.12 \\
\hline Но & 0.08 & 0.08 & 0.08 & 0.04 & 0.02 & 0.03 \\
\hline Er & 0.35 & 0.27 & 0.31 & 0.16 & 0.10 & 0.12 \\
\hline $\mathrm{Yb}$ & 0.35 & 0.27 & 0.31 & 0.24 & 0.14 & 0.17 \\
\hline
\end{tabular}


Table E-8. Continued.

\begin{tabular}{|c|c|c|c|c|c|c|}
\hline & \multicolumn{6}{|c|}{ ETH - August 4, 2010 - Plagioclase } \\
\hline & \multicolumn{3}{|c|}{ Error Summary $(1 \sigma)$} & \multicolumn{3}{|c|}{ Detection Limits (ppm) } \\
\hline & high & low & average & high & low & average \\
\hline $\mathrm{SiO}_{2}$ & 0.28 & 0.20 & 0.24 & 892 & 315 & 481 \\
\hline $\mathrm{TiO}_{2}$ & 0.0008 & 0.001 & 0.001 & 4.36 & 1.67 & 2.47 \\
\hline $\mathrm{Al}_{2} \mathrm{O}_{3}$ & 0.02 & 0.02 & 0.02 & 3.41 & 0.86 & 1.61 \\
\hline $\mathrm{FeO}^{*}$ & 0.007 & 0.01 & 0.006 & 50.9 & 17.7 & 28.0 \\
\hline $\mathrm{MnO}$ & 0.0002 & 0.0001 & 0.0001 & 2.02 & 0.88 & 1.22 \\
\hline $\mathrm{MgO}$ & 0.0009 & 0.001 & 0.001 & 2.43 & 1.02 & 1.60 \\
\hline $\mathrm{CaO}$ & 0.09 & 0.06 & 0.07 & 638 & 199 & 330 \\
\hline $\mathrm{Na}_{2} \mathrm{O}$ & 0.009 & 0.006 & 0.007 & 2.42 & 1.28 & 1.74 \\
\hline $\mathrm{K}_{2} \mathrm{O}$ & 0.0020 & 0.001 & 0.002 & 14.5 & 4.82 & 8.12 \\
\hline $\mathrm{P}_{2} \mathrm{O}_{5}$ & 0.004 & 0.00 & 0.002 & 25.3 & 9.01 & 14.5 \\
\hline $\mathrm{S}$ & 91.1 & 29.1 & 48.7 & 284 & 84.3 & 153.0 \\
\hline $\mathrm{Sc}$ & 0.23 & 0.16 & 0.19 & 1.09 & 0.20 & 0.51 \\
\hline $\mathrm{Cr}$ & n.d. & n.d. & n.d. & 15.72 & 5.95 & 8.58 \\
\hline $\mathrm{Ni}$ & n.d. & n.d. & n.d. & 5.93 & 2.66 & 3.90 \\
\hline $\mathrm{Cu}$ & 0.67 & 0.38 & 0.50 & 0.80 & 0.50 & 0.65 \\
\hline $\mathrm{Zn}$ & 1.19 & 0.68 & 0.91 & 1.58 & 0.78 & 1.09 \\
\hline $\mathrm{Rb}$ & 0.11 & 0.07 & 0.09 & 0.16 & 0.04 & 0.09 \\
\hline $\mathrm{Sr}$ & 5.06 & 4.07 & 4.63 & 0.08 & 0.04 & 0.05 \\
\hline $\mathrm{Y}$ & 0.05 & 0.03 & 0.04 & 0.13 & 0.03 & 0.07 \\
\hline $\mathrm{Zr}$ & 0.08 & 0.08 & 0.08 & 0.16 & 0.07 & 0.10 \\
\hline $\mathrm{Nb}$ & n.d. & n.d. & n.d. & 0.09 & 0.04 & 0.06 \\
\hline $\mathrm{Ba}$ & 6.29 & 5.00 & 5.65 & 0.83 & 0.25 & 0.42 \\
\hline $\mathrm{Pb}$ & 0.72 & 0.49 & 0.60 & 0.16 & 0.08 & 0.10 \\
\hline Th & n.d. & n.d. & n.d. & 0.08 & 0.04 & 0.05 \\
\hline $\mathrm{U}$ & n.d. & n.d. & n.d. & 0.08 & 0.03 & 0.05 \\
\hline $\mathrm{La}$ & 0.39 & 0.30 & 0.35 & 0.07 & 0.03 & 0.05 \\
\hline $\mathrm{Ce}$ & 0.56 & 0.34 & 0.43 & 0.13 & 0.03 & 0.07 \\
\hline $\operatorname{Pr}$ & 0.14 & 0.08 & 0.11 & 0.06 & 0.03 & 0.04 \\
\hline n.d. & 0.51 & 0.28 & 0.39 & 0.54 & 0.16 & 0.27 \\
\hline $\mathrm{Sm}$ & 0.19 & 0.19 & 0.19 & 0.46 & 0.19 & 0.27 \\
\hline $\mathrm{Eu}$ & 0.19 & 0.12 & 0.15 & 0.14 & 0.06 & 0.08 \\
\hline $\mathrm{Gd}$ & n.d. & n.d. & n.d. & 0.49 & 0.20 & 0.29 \\
\hline $\mathrm{Tb}$ & n.d. & n.d. & n.d. & 0.07 & 0.03 & 0.04 \\
\hline Dy & n.d. & n.d. & n.d. & 0.31 & 0.13 & 0.18 \\
\hline Ho & n.d. & n.d. & n.d. & 0.08 & 0.03 & 0.05 \\
\hline Er & n.d. & n.d. & n.d. & 0.36 & 0.15 & 0.21 \\
\hline $\mathrm{Yb}$ & n.d. & n.d. & n.d. & 0.53 & 0.22 & 0.31 \\
\hline
\end{tabular}


Table E-8. Continued.

\begin{tabular}{|c|c|c|c|c|c|c|}
\hline & \multicolumn{6}{|c|}{ ETH - March 16, 2011 - Plagioclase } \\
\hline & \multicolumn{3}{|c|}{ Error Summary $(1 \sigma)$} & \multicolumn{3}{|c|}{ Detection Limits (ppm) } \\
\hline & high & low & average & high & low & average \\
\hline $\mathrm{SiO}_{2}$ & 0.20 & 0.12 & 0.15 & 379 & 182 & 292 \\
\hline $\mathrm{TiO}_{2}$ & 0.0007 & 0.0004 & 0.0005 & 2.33 & 0.82 & 1.80 \\
\hline $\mathrm{Al}_{2} \mathrm{O}_{3}$ & 0.02 & 0.01 & 0.01 & 2.91 & 0.89 & 2.07 \\
\hline $\mathrm{FeO}^{*}$ & 0.005 & 0.003 & 0.004 & 23.4 & 9.26 & 17.0 \\
\hline $\mathrm{MnO}$ & 0.0001 & 0.0001 & 0.0001 & 1.58 & 0.68 & 1.11 \\
\hline $\mathrm{MgO}$ & 0.0006 & 0.0004 & 0.001 & 1.91 & 0.86 & 1.45 \\
\hline $\mathrm{CaO}$ & 0.05 & 0.03 & 0.04 & 196 & 92.2 & 156 \\
\hline $\mathrm{Na}_{2} \mathrm{O}$ & 0.005 & 0.003 & 0.004 & 1.17 & 0.55 & 0.81 \\
\hline $\mathrm{K}_{2} \mathrm{O}$ & 0.0009 & 0.001 & 0.001 & 4.95 & 1.69 & 3.21 \\
\hline $\mathrm{P}_{2} \mathrm{O}_{5}$ & 0.002 & 0.001 & 0.001 & 15.2 & 7.33 & 11.5 \\
\hline $\mathrm{S}$ & 31.6 & 14.2 & 21.4 & 94.3 & 44.4 & 68.4 \\
\hline $\mathrm{Sc}$ & 0.25 & 0.10 & 0.18 & 0.71 & 0.22 & 0.45 \\
\hline $\mathrm{Cr}$ & n.d. & n.d. & n.d. & 19.0 & 7.14 & 12.4 \\
\hline $\mathrm{Ni}$ & n.d. & n.d. & n.d. & 6.26 & 2.81 & 4.49 \\
\hline $\mathrm{Cu}$ & 0.69 & 0.30 & 0.47 & 1.30 & 0.59 & 0.92 \\
\hline $\mathrm{Zn}$ & 0.79 & 0.49 & 0.63 & 1.35 & 0.97 & 1.10 \\
\hline $\mathrm{Rb}$ & 0.08 & 0.05 & 0.07 & 0.16 & 0.04 & 0.09 \\
\hline $\mathrm{Sr}$ & 4.10 & 2.63 & 3.22 & 0.08 & 0.03 & 0.06 \\
\hline $\mathrm{Y}$ & 0.05 & 0.02 & 0.03 & 0.08 & 0.03 & 0.05 \\
\hline $\mathrm{Zr}$ & n.d. & n.d. & n.d. & 0.16 & 0.07 & 0.11 \\
\hline $\mathrm{Nb}$ & n.d. & n.d. & n.d. & 0.09 & 0.04 & 0.06 \\
\hline $\mathrm{Ba}$ & 3.88 & 2.68 & 3.15 & 0.52 & 0.17 & 0.27 \\
\hline $\mathrm{Pb}$ & 0.40 & 0.23 & 0.31 & 0.17 & 0.07 & 0.10 \\
\hline Th & n.d. & n.d. & n.d. & 0.06 & 0.03 & 0.04 \\
\hline $\mathrm{U}$ & n.d. & n.d. & n.d. & 0.06 & 0.03 & 0.04 \\
\hline $\mathrm{La}$ & 0.26 & 0.17 & 0.20 & 0.05 & 0.02 & 0.04 \\
\hline $\mathrm{Ce}$ & 0.28 & 0.19 & 0.22 & 0.05 & 0.02 & 0.03 \\
\hline $\operatorname{Pr}$ & 0.07 & 0.04 & 0.05 & 0.04 & 0.02 & 0.03 \\
\hline n.d. & 0.22 & 0.18 & 0.20 & 0.21 & 0.10 & 0.14 \\
\hline $\mathrm{Sm}$ & n.d. & n.d. & n.d. & 0.25 & 0.11 & 0.17 \\
\hline $\mathrm{Eu}$ & 0.09 & 0.06 & 0.07 & 0.07 & 0.03 & 0.05 \\
\hline $\mathrm{Gd}$ & n.d. & n.d. & n.d. & 0.27 & 0.12 & 0.18 \\
\hline $\mathrm{Tb}$ & n.d. & n.d. & n.d. & 0.04 & 0.02 & 0.02 \\
\hline Dy & n.d. & n.d. & n.d. & 0.16 & 0.07 & 0.10 \\
\hline Ho & n.d. & n.d. & n.d. & 0.04 & 0.02 & 0.03 \\
\hline Er & n.d. & n.d. & n.d. & 0.18 & 0.08 & 0.12 \\
\hline $\mathrm{Yb}$ & n.d. & n.d. & n.d. & 0.27 & 0.12 & 0.18 \\
\hline
\end{tabular}


Table E-9. ETH LA-ICP-MS hornblende error summary (1б) and detection limits (ppm).

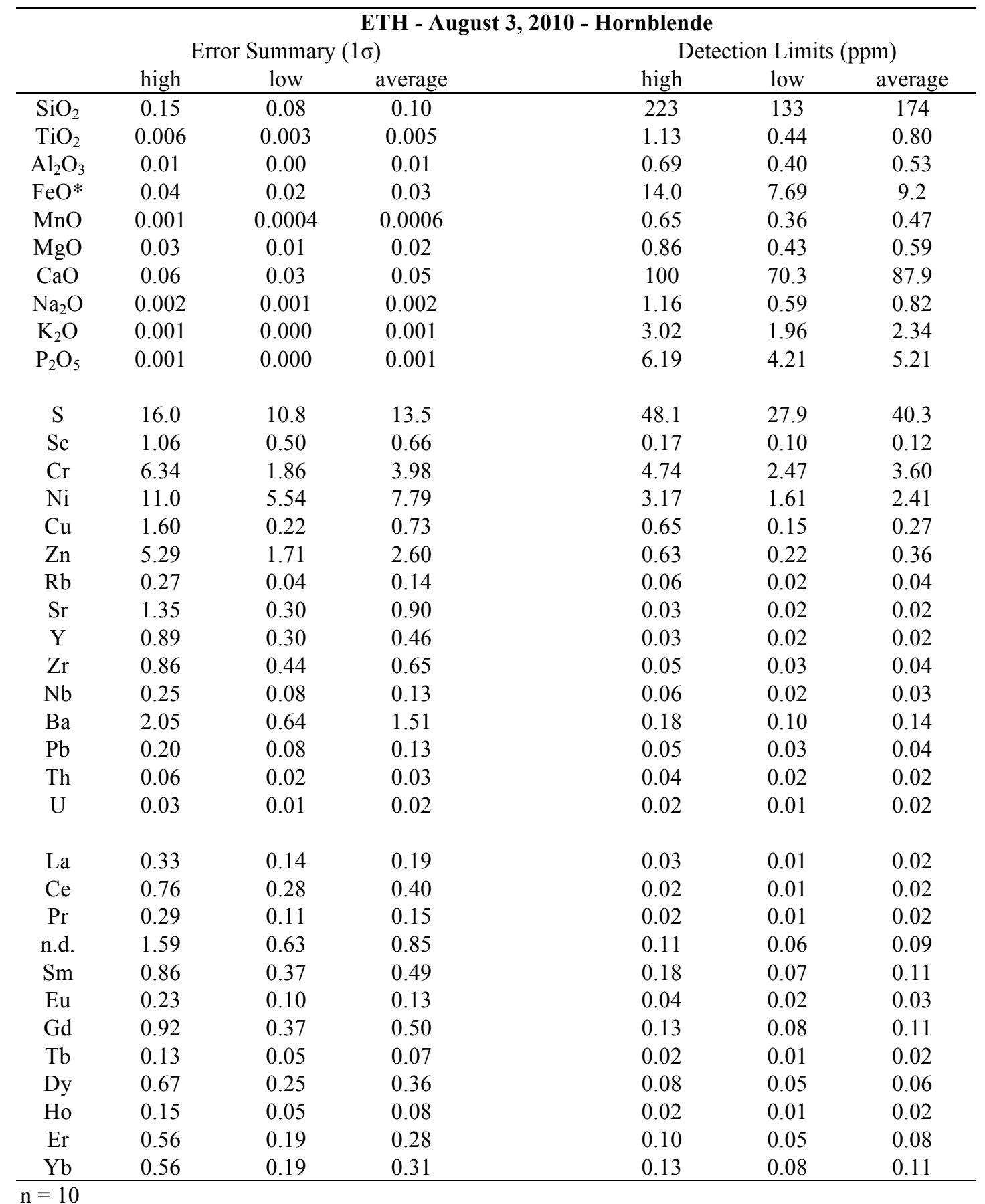


Table E-9. Continued.

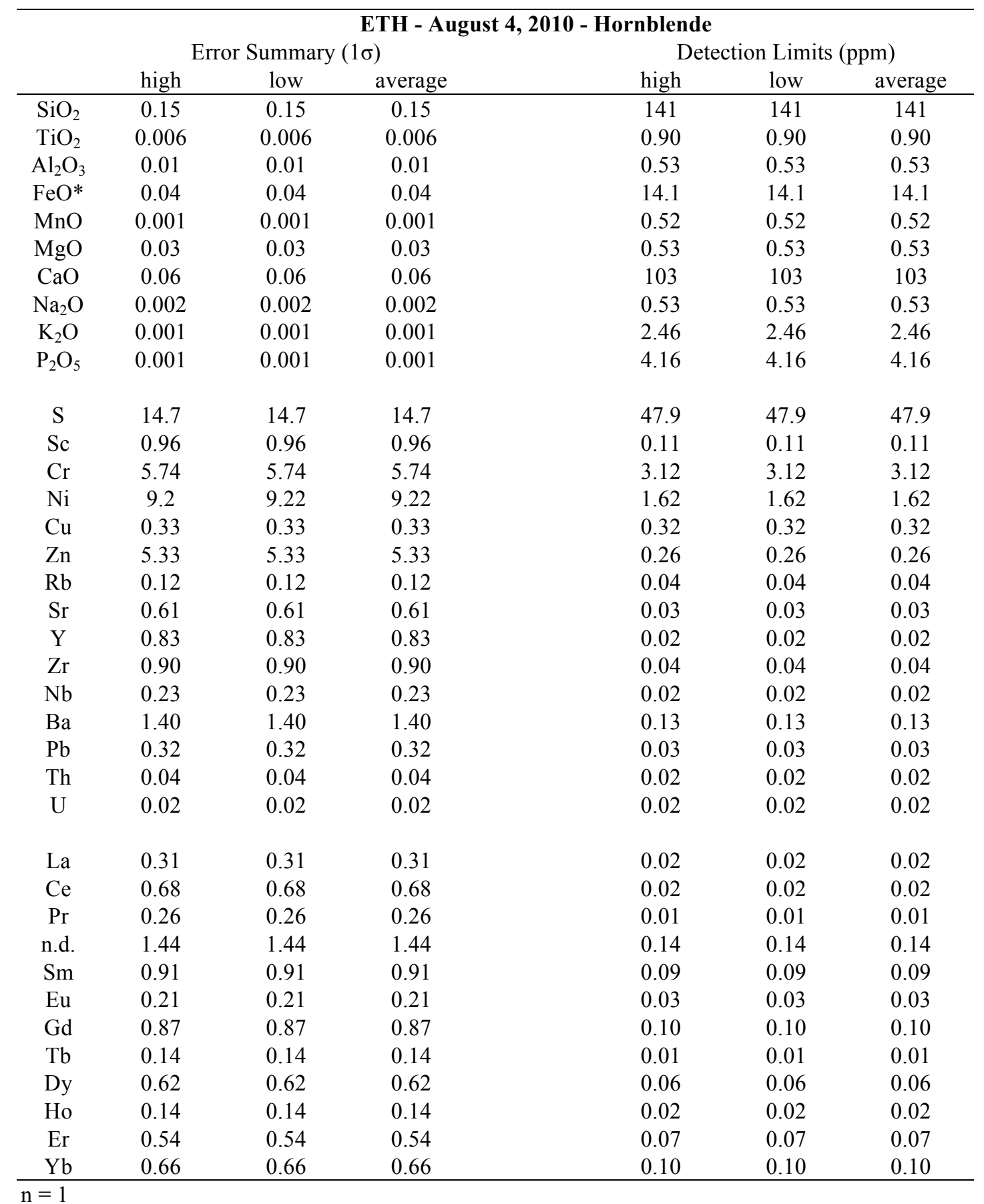


Table E-9. Continued.

\begin{tabular}{|c|c|c|c|c|c|c|}
\hline & \multicolumn{6}{|c|}{ ETH - March 16, 2011 - Hornblende } \\
\hline & \multicolumn{3}{|c|}{ Error Summary $(1 \sigma)$} & \multicolumn{3}{|c|}{ Detection Limits (ppm) } \\
\hline & high & low & average & high & low & average \\
\hline $\mathrm{SiO}_{2}$ & 0.22 & 0.22 & 0.22 & 744 & 744 & 744 \\
\hline $\mathrm{TiO}_{2}$ & 0.008 & 0.008 & 0.008 & 6.57 & 6.57 & 6.57 \\
\hline $\mathrm{Al}_{2} \mathrm{O}_{3}$ & 0.01 & 0.01 & 0.01 & 3.94 & 3.94 & 3.94 \\
\hline $\mathrm{FeO}^{*}$ & 0.05 & 0.05 & 0.05 & 32.2 & 32.2 & 32.2 \\
\hline $\mathrm{MnO}$ & 0.002 & 0.002 & 0.002 & 2.64 & 2.64 & 2.64 \\
\hline $\mathrm{MgO}$ & 0.04 & 0.04 & 0.04 & 2.86 & 2.86 & 2.86 \\
\hline $\mathrm{CaO}$ & 0.08 & 0.08 & 0.08 & 319 & 319 & 319 \\
\hline $\mathrm{Na}_{2} \mathrm{O}$ & 0.003 & 0.003 & 0.003 & 1.61 & 1.61 & 1.61 \\
\hline $\mathrm{K}_{2} \mathrm{O}$ & 0.001 & 0.001 & 0.001 & 9.37 & 9.37 & 9.37 \\
\hline $\mathrm{P}_{2} \mathrm{O}_{5}$ & 0.002 & 0.002 & 0.002 & 23.2 & 23.2 & 23.2 \\
\hline $\mathrm{S}$ & 40.3 & 40.3 & 40.3 & 107 & 107 & 107 \\
\hline $\mathrm{Sc}$ & 1.36 & 1.36 & 1.36 & 1.02 & 1.02 & 1.02 \\
\hline $\mathrm{Cr}$ & 13.2 & 13.2 & 13.2 & 27.4 & 27.4 & 27.4 \\
\hline $\mathrm{Ni}$ & 12.1 & 12.1 & 12.1 & 9.77 & 9.77 & 9.77 \\
\hline $\mathrm{Cu}$ & 1.53 & 1.53 & 1.53 & 2.65 & 2.65 & 2.65 \\
\hline $\mathrm{Zn}$ & 7.20 & 7.20 & 7.20 & 2.35 & 2.35 & 2.35 \\
\hline $\mathrm{Rb}$ & 0.12 & 0.12 & 0.12 & 0.13 & 0.13 & 0.13 \\
\hline $\mathrm{Sr}$ & 0.77 & 0.77 & 0.77 & 0.11 & 0.11 & 0.11 \\
\hline $\mathrm{Y}$ & 1.19 & 1.19 & 1.19 & 0.15 & 0.15 & 0.15 \\
\hline $\mathrm{Zr}$ & 1.15 & 1.15 & 1.15 & 0.23 & 0.23 & 0.23 \\
\hline $\mathrm{Nb}$ & 0.33 & 0.33 & 0.33 & 0.14 & 0.14 & 0.14 \\
\hline $\mathrm{Ba}$ & 1.36 & 1.36 & 1.36 & 0.54 & 0.54 & 0.54 \\
\hline $\mathrm{Pb}$ & 0.23 & 0.23 & 0.23 & 0.22 & 0.22 & 0.22 \\
\hline Th & n.d. & n.d. & n.d. & 0.10 & 0.10 & 0.10 \\
\hline $\mathrm{U}$ & n.d. & n.d. & n.d. & 0.09 & 0.09 & 0.09 \\
\hline $\mathrm{La}$ & 0.40 & 0.40 & 0.40 & 0.08 & 0.08 & 0.08 \\
\hline $\mathrm{Ce}$ & 0.85 & 0.85 & 0.85 & 0.07 & 0.07 & 0.07 \\
\hline $\operatorname{Pr}$ & 0.32 & 0.32 & 0.32 & 0.06 & 0.06 & 0.06 \\
\hline n.d. & 1.76 & 1.76 & 1.76 & 0.32 & 0.32 & 0.32 \\
\hline $\mathrm{Sm}$ & 1.06 & 1.06 & 1.06 & 0.37 & 0.37 & 0.37 \\
\hline $\mathrm{Eu}$ & 0.24 & 0.24 & 0.24 & 0.10 & 0.10 & 0.10 \\
\hline $\mathrm{Gd}$ & 1.02 & 1.02 & 1.02 & 0.41 & 0.41 & 0.41 \\
\hline $\mathrm{Tb}$ & 0.16 & 0.16 & 0.16 & 0.06 & 0.06 & 0.06 \\
\hline Dy & 0.76 & 0.76 & 0.76 & 0.23 & 0.23 & 0.23 \\
\hline Но & 0.18 & 0.18 & 0.18 & 0.06 & 0.06 & 0.06 \\
\hline $\mathrm{Er}$ & 0.55 & 0.55 & 0.55 & 0.27 & 0.27 & 0.27 \\
\hline $\mathrm{Yb}$ & 0.75 & 0.75 & 0.75 & 0.41 & 0.41 & 0.41 \\
\hline
\end{tabular}

$\mathrm{n}=1$
n.d. $=$ not detected 
Table E-10. ETH LA-ICP-MS matrix glass error summary (1б) and detection limits (ppm).

\begin{tabular}{|c|c|c|c|c|c|c|}
\hline & \multicolumn{6}{|c|}{ ETH - August 3, 2010 - Matrix Glass } \\
\hline & \multicolumn{3}{|c|}{ Error Summary $(1 \sigma)$} & \multicolumn{3}{|c|}{ Detection Limits (ppm) } \\
\hline & high & low & average & high & low & average \\
\hline $\mathrm{SiO}_{2}$ & 0.24 & 0.24 & 0.24 & 253 & 253 & 253 \\
\hline $\mathrm{TiO}_{2}$ & 0.003 & 0.003 & 0.003 & 1.16 & 1.16 & 1.16 \\
\hline $\mathrm{Al}_{2} \mathrm{O}_{3}$ & 0.01 & 0.01 & 0.01 & 0.83 & 0.83 & 0.83 \\
\hline $\mathrm{FeO}^{*}$ & 0.01 & 0.01 & 0.01 & 15.5 & 15.5 & 15.5 \\
\hline $\mathrm{MnO}$ & 0.0004 & 0.0004 & 0.0004 & 0.72 & 0.72 & 0.72 \\
\hline $\mathrm{MgO}$ & 0.004 & 0.004 & 0.004 & 0.94 & 0.94 & 0.94 \\
\hline $\mathrm{CaO}$ & 0.03 & 0.03 & 0.03 & 160 & 160 & 160 \\
\hline $\mathrm{Na}_{2} \mathrm{O}$ & 0.004 & 0.004 & 0.004 & 1.22 & 1.22 & 1.22 \\
\hline $\mathrm{K}_{2} \mathrm{O}$ & 0.004 & 0.004 & 0.004 & 3.70 & 3.70 & 3.70 \\
\hline $\mathrm{P}_{2} \mathrm{O}_{5}$ & 0.002 & 0.002 & 0.002 & 7.94 & 7.94 & 7.94 \\
\hline $\mathrm{S}$ & 22.5 & 22.5 & 22.5 & 62.0 & 62.0 & 62.0 \\
\hline $\mathrm{Sc}$ & 0.18 & 0.18 & 0.18 & 0.15 & 0.15 & 0.15 \\
\hline $\mathrm{Cr}$ & 2.6 & 2.6 & 2.6 & 5.17 & 5.17 & 5.17 \\
\hline $\mathrm{Ni}$ & n.d. & n.d. & n.d. & 4.35 & 4.35 & 4.35 \\
\hline $\mathrm{Cu}$ & 3.08 & 3.08 & 3.08 & 0.36 & 0.36 & 0.36 \\
\hline $\mathrm{Zn}$ & 2.57 & 2.57 & 2.57 & 0.35 & 0.35 & 0.35 \\
\hline $\mathrm{Rb}$ & 1.37 & 1.37 & 1.37 & 0.06 & 0.06 & 0.06 \\
\hline $\mathrm{Sr}$ & 1.76 & 1.76 & 1.76 & 0.04 & 0.04 & 0.04 \\
\hline $\mathrm{Y}$ & 0.27 & 0.27 & 0.27 & 0.03 & 0.03 & 0.03 \\
\hline $\mathrm{Zr}$ & 1.37 & 1.37 & 1.37 & 0.07 & 0.07 & 0.07 \\
\hline $\mathrm{Nb}$ & 0.28 & 0.28 & 0.28 & 0.04 & 0.04 & 0.04 \\
\hline $\mathrm{Ba}$ & 9.02 & 9.02 & 9.02 & 0.23 & 0.23 & 0.23 \\
\hline $\mathrm{Pb}$ & 11.0 & 11.0 & 11.0 & 0.06 & 0.06 & 0.06 \\
\hline Th & 0.37 & 0.37 & 0.37 & 0.04 & 0.04 & 0.04 \\
\hline $\mathrm{U}$ & 0.20 & 0.20 & 0.20 & 0.03 & 0.03 & 0.03 \\
\hline $\mathrm{La}$ & 0.46 & 0.46 & 0.46 & 0.03 & 0.03 & 0.03 \\
\hline $\mathrm{Ce}$ & 0.60 & 0.60 & 0.60 & 0.03 & 0.03 & 0.03 \\
\hline $\operatorname{Pr}$ & 0.17 & 0.17 & 0.17 & 0.02 & 0.02 & 0.02 \\
\hline n.d. & 0.72 & 0.72 & 0.72 & 0.14 & 0.14 & 0.14 \\
\hline $\mathrm{Sm}$ & 0.30 & 0.30 & 0.30 & 0.17 & 0.17 & 0.17 \\
\hline $\mathrm{Eu}$ & 0.07 & 0.07 & 0.07 & 0.07 & 0.07 & 0.07 \\
\hline $\mathrm{Gd}$ & 0.24 & 0.24 & 0.24 & 0.18 & 0.18 & 0.18 \\
\hline $\mathrm{Tb}$ & 0.04 & 0.04 & 0.04 & 0.03 & 0.03 & 0.03 \\
\hline Dy & 0.18 & 0.18 & 0.18 & 0.10 & 0.10 & 0.10 \\
\hline Ho & 0.03 & 0.03 & 0.03 & 0.03 & 0.03 & 0.03 \\
\hline Er & 0.13 & 0.13 & 0.13 & 0.12 & 0.12 & 0.12 \\
\hline $\mathrm{Yb}$ & 0.24 & 0.24 & 0.24 & 0.25 & 0.25 & 0.25 \\
\hline
\end{tabular}


Table E-10. Continued.

\begin{tabular}{|c|c|c|c|c|c|c|}
\hline & \multicolumn{6}{|c|}{ ETH - August 4, 2010 - Matrix Glass } \\
\hline & \multicolumn{3}{|c|}{ Error Summary $(1 \sigma)$} & \multicolumn{3}{|c|}{ Detection Limits (ppm) } \\
\hline & high & low & average & high & low & average \\
\hline $\mathrm{SiO}_{2}$ & 0.34 & 0.12 & 0.17 & 1075 & 115 & 349 \\
\hline $\mathrm{TiO}_{2}$ & 0.005 & 0.001 & 0.003 & 3.33 & 0.58 & 1.27 \\
\hline $\mathrm{Al}_{2} \mathrm{O}_{3}$ & 0.01 & 0.003 & 0.01 & 2.51 & 0.40 & 0.96 \\
\hline $\mathrm{FeO} *$ & 0.02 & 0.01 & 0.01 & 63.9 & 6.19 & 20.5 \\
\hline $\mathrm{MnO}$ & 0.0004 & 0.0002 & 0.0003 & 2.87 & 0.40 & 1.00 \\
\hline $\mathrm{MgO}$ & 0.021 & 0.006 & 0.011 & 4.04 & 0.49 & 1.33 \\
\hline $\mathrm{CaO}$ & 0.08 & 0.03 & 0.04 & 584 & 68.8 & 192 \\
\hline $\mathrm{Na}_{2} \mathrm{O}$ & 0.01 & 0.002 & 0.005 & 6.54 & 0.73 & 1.95 \\
\hline $\mathrm{K}_{2} \mathrm{O}$ & 0.004 & 0.001 & 0.002 & 18.5 & 2.09 & 5.63 \\
\hline $\mathrm{P}_{2} \mathrm{O}_{5}$ & 0.003 & 0.001 & 0.002 & 39.1 & 4.68 & 12.1 \\
\hline $\mathrm{S}$ & 85.4 & 15.3 & 29.7 & 252 & 35.3 & 86.6 \\
\hline $\mathrm{Sc}$ & 0.48 & 0.16 & 0.27 & 0.76 & 0.08 & 0.23 \\
\hline $\mathrm{Cr}$ & 8.71 & 1.38 & 3.18 & 18.6 & 3.26 & 6.69 \\
\hline $\mathrm{Ni}$ & 5.88 & 1.55 & 2.80 & 21.6 & 1.58 & 6.20 \\
\hline $\mathrm{Cu}$ & 5.79 & 1.08 & 2.14 & 1.46 & 0.18 & 0.49 \\
\hline $\mathrm{Zn}$ & 1.95 & 0.83 & 1.63 & 3.39 & 0.19 & 1.00 \\
\hline $\mathrm{Rb}$ & 1.50 & 0.44 & 0.82 & 0.29 & 0.02 & 0.09 \\
\hline $\mathrm{Sr}$ & 2.12 & 0.61 & 1.65 & 0.15 & 0.02 & 0.05 \\
\hline Y & 0.31 & 0.16 & 0.25 & 0.14 & 0.02 & 0.05 \\
\hline $\mathrm{Zr}$ & 2.57 & 0.97 & 1.34 & 0.28 & 0.05 & 0.10 \\
\hline $\mathrm{Nb}$ & 0.27 & 0.07 & 0.17 & 0.24 & 0.02 & 0.08 \\
\hline $\mathrm{Ba}$ & 9.46 & 2.81 & 5.32 & 0.96 & 0.17 & 0.33 \\
\hline $\mathrm{Pb}$ & 2.87 & 0.35 & 0.97 & 0.24 & 0.03 & 0.08 \\
\hline Th & 0.28 & 0.07 & 0.20 & 0.14 & 0.02 & 0.05 \\
\hline $\mathrm{U}$ & 0.20 & 0.05 & 0.12 & 0.13 & 0.02 & 0.04 \\
\hline $\mathrm{La}$ & 0.42 & 0.16 & 0.31 & 0.12 & 0.02 & 0.04 \\
\hline $\mathrm{Ce}$ & 0.58 & 0.23 & 0.45 & 0.13 & 0.02 & 0.05 \\
\hline $\operatorname{Pr}$ & 0.17 & 0.07 & 0.13 & 0.10 & 0.02 & 0.03 \\
\hline n.d. & 0.74 & 0.32 & 0.62 & 0.59 & 0.07 & 0.21 \\
\hline $\mathrm{Sm}$ & 0.39 & 0.17 & 0.31 & 0.68 & 0.09 & 0.23 \\
\hline $\mathrm{Eu}$ & 0.18 & 0.05 & 0.10 & 0.20 & 0.03 & 0.07 \\
\hline $\mathrm{Gd}$ & 0.37 & 0.16 & 0.28 & 0.73 & 0.09 & 0.25 \\
\hline $\mathrm{Tb}$ & 0.05 & 0.02 & 0.04 & 0.10 & 0.01 & 0.04 \\
\hline Dy & 0.28 & 0.12 & 0.20 & 0.43 & 0.06 & 0.15 \\
\hline Ho & 0.06 & 0.03 & 0.04 & 0.16 & 0.01 & 0.05 \\
\hline Er & 0.19 & 0.11 & 0.16 & 0.50 & 0.06 & 0.17 \\
\hline $\mathrm{Yb}$ & 0.22 & 0.12 & 0.18 & 0.72 & 0.09 & 0.24 \\
\hline
\end{tabular}


Table E-10. Continued.

\begin{tabular}{|c|c|c|c|c|c|c|}
\hline & \multicolumn{6}{|c|}{ ETH - March 16, 2011 - Matrix Glass } \\
\hline & \multicolumn{3}{|c|}{ Error Summary $(1 \sigma)$} & \multicolumn{3}{|c|}{ Detection Limits (ppm) } \\
\hline & high & low & average & high & low & average \\
\hline $\mathrm{SiO}_{2}$ & 0.78 & 0.56 & 0.67 & 1925 & 1377 & 1651 \\
\hline $\mathrm{TiO}_{2}$ & 0.009 & 0.009 & 0.009 & 10.5 & 8.23 & 9.36 \\
\hline $\mathrm{Al}_{2} \mathrm{O}_{3}$ & 0.05 & 0.037 & 0.04 & 8.61 & 6.69 & 7.65 \\
\hline $\mathrm{FeO}^{*}$ & 0.05 & 0.04 & 0.04 & 120 & 97.3 & 109 \\
\hline $\mathrm{MnO}$ & 0.002 & 0.001 & 0.002 & 8.48 & 7.79 & 8.13 \\
\hline $\mathrm{MgO}$ & 0.02 & 0.01 & 0.02 & 11.0 & 8.00 & 9.51 \\
\hline $\mathrm{CaO}$ & 0.09 & 0.07 & 0.08 & 950 & 897 & 924 \\
\hline $\mathrm{Na}_{2} \mathrm{O}$ & 0.01 & 0.01 & 0.01 & 7.76 & 5.72 & 6.74 \\
\hline $\mathrm{K}_{2} \mathrm{O}$ & 0.01 & 0.01 & 0.01 & 20.6 & 18.0 & 19.3 \\
\hline $\mathrm{P}_{2} \mathrm{O}_{5}$ & 0.008 & 0.007 & 0.008 & 82.4 & 59.5 & 71.0 \\
\hline $\mathrm{S}$ & n.d. & n.d. & n.d. & 430 & 352 & 391 \\
\hline $\mathrm{Sc}$ & 0.92 & 0.92 & 0.92 & 2.64 & 1.94 & 2.29 \\
\hline $\mathrm{Cr}$ & n.d. & n.d. & n.d. & 75.2 & 69.9 & 72.6 \\
\hline $\mathrm{Ni}$ & n.d. & n.d. & n.d. & 51.2 & 36.1 & 43.6 \\
\hline $\mathrm{Cu}$ & 9.03 & 3.12 & 6.07 & 5.41 & 4.61 & 5.01 \\
\hline $\mathrm{Zn}$ & 10.1 & 8.10 & 9.08 & 6.11 & 5.36 & 5.74 \\
\hline $\mathrm{Rb}$ & 5.38 & 4.58 & 4.98 & 0.49 & 0.35 & 0.42 \\
\hline $\mathrm{Sr}$ & 6.06 & 2.64 & 4.35 & 0.61 & 0.30 & 0.45 \\
\hline $\mathrm{Y}$ & 1.04 & 0.91 & 0.97 & 0.43 & 0.30 & 0.37 \\
\hline $\mathrm{Zr}$ & 6.59 & 5.13 & 5.86 & 0.92 & 0.65 & 0.78 \\
\hline $\mathrm{Nb}$ & 0.96 & 0.84 & 0.90 & 0.53 & 0.38 & 0.46 \\
\hline $\mathrm{Ba}$ & 28.1 & 21.7 & 24.9 & 2.13 & 1.55 & 1.84 \\
\hline $\mathrm{Pb}$ & 48.5 & 2.15 & 25.3 & 0.57 & 0.50 & 0.54 \\
\hline Th & 1.41 & 0.96 & 1.19 & 0.37 & 0.32 & 0.34 \\
\hline $\mathrm{U}$ & 0.88 & 0.65 & 0.76 & 0.33 & 0.28 & 0.30 \\
\hline $\mathrm{La}$ & 1.77 & 1.49 & 1.63 & 0.29 & 0.22 & 0.25 \\
\hline $\mathrm{Ce}$ & 2.51 & 1.76 & 2.13 & 0.28 & 0.21 & 0.25 \\
\hline $\mathrm{Pr}$ & 0.62 & 0.52 & 0.57 & 0.22 & 0.22 & 0.22 \\
\hline n.d. & 2.66 & 2.41 & 2.53 & 1.24 & 0.90 & 1.07 \\
\hline $\mathrm{Sm}$ & 1.35 & 1.03 & 1.19 & 1.46 & 1.03 & 1.24 \\
\hline $\mathrm{Eu}$ & 0.38 & 0.38 & 0.38 & 0.41 & 0.29 & 0.35 \\
\hline $\mathrm{Gd}$ & 1.01 & 1.01 & 1.01 & 1.55 & 1.19 & 1.37 \\
\hline $\mathrm{Tb}$ & 0.18 & 0.18 & 0.18 & 0.22 & 0.16 & 0.19 \\
\hline Dy & 0.57 & 0.57 & 0.57 & 0.90 & 0.67 & 0.79 \\
\hline Ho & 0.17 & 0.17 & 0.17 & 0.23 & 0.17 & 0.20 \\
\hline $\mathrm{Er}$ & 0.60 & 0.60 & 0.60 & 1.05 & 0.78 & 0.92 \\
\hline $\mathrm{Yb}$ & n.d. & n.d. & n.d. & 1.56 & 1.19 & 1.38 \\
\hline
\end{tabular}




\section{APPENDIX F: ELEMENT MAPS}

\section{Methods}

Element maps of selected apatites were generated with a CAMECA SX100 electron microprobe (EMP) housed at Oregon State University in Corvallis, OR via remote access at Portland State University in Portland, OR. The EMP operating conditions during apatite analyses were $15 \mathrm{kV}, 30 \mathrm{nA}$, and $0 \mu \mathrm{m}$ diameter electron beam. Elements selected for mapping and the analyzing crystals were: P (PET), F

(PCO), $\mathrm{Cl}$ (PET), S (LPET), and Na (LTAP). A backscattered electron (BSE) image was also collected for each apatite crystal mapped. 


\section{Apatite Analysis}

EMP element maps from this study (Fig. F-1) showed that high-sulfur areas within apatites are typically expressed as small globular clusters (1 to 3 spots) located near- to off-center of the apatite profile. In some cases, high-S rings or semi-rings are expressed in addition to or in lieu of the cluster shape. These shapes are nearly identical in the $\mathrm{Na}$ element map and further confirm that $\mathrm{Na}^{+}$is important in the coupled substitution with $\mathrm{S}^{6+}$. This physical distribution of high-S content was true regardless of the host mineral of the apatite, (e.g. anhydrite, magnetite, or hornblende). Based upon this and the fact that high-S concentrations are not expressed at the apatite/anhydrite interface as a complete rim, diffusion of $\mathrm{S}$ down a concentration gradient from anhydrite to apatite can be ruled-out as a mechanism for generating high-S concentrations in apatite. 

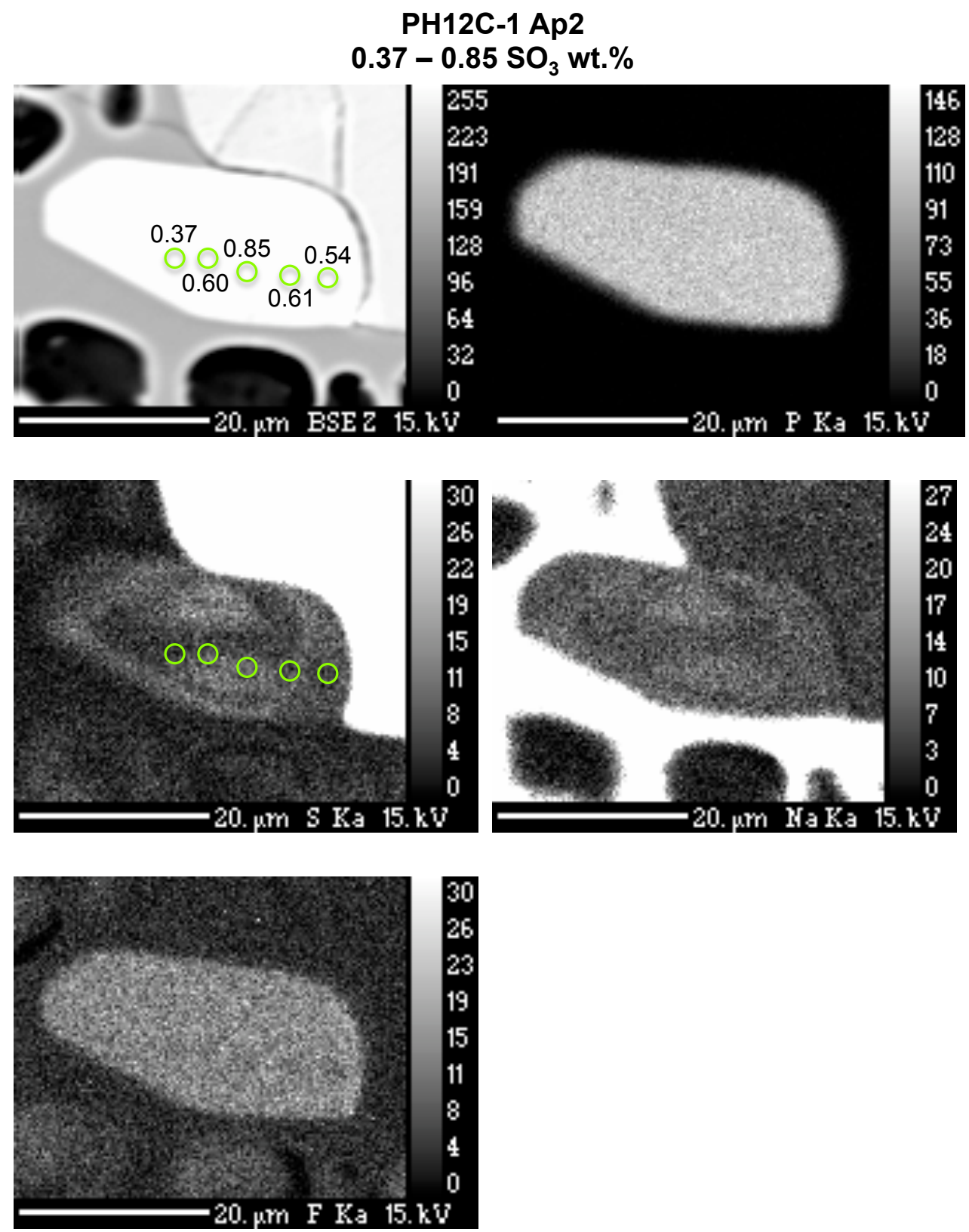

Figure F-1: BSE image and element maps (P, S, Na, and F) of apatite. Green circles represent EMP spot traverse analyses and the numbers indicated the $\mathrm{SO}_{3}$ wt.\% at each spot. High-S numbers correlated with the bright spots in the $\mathrm{S}$ map. Host is anhydrite. 

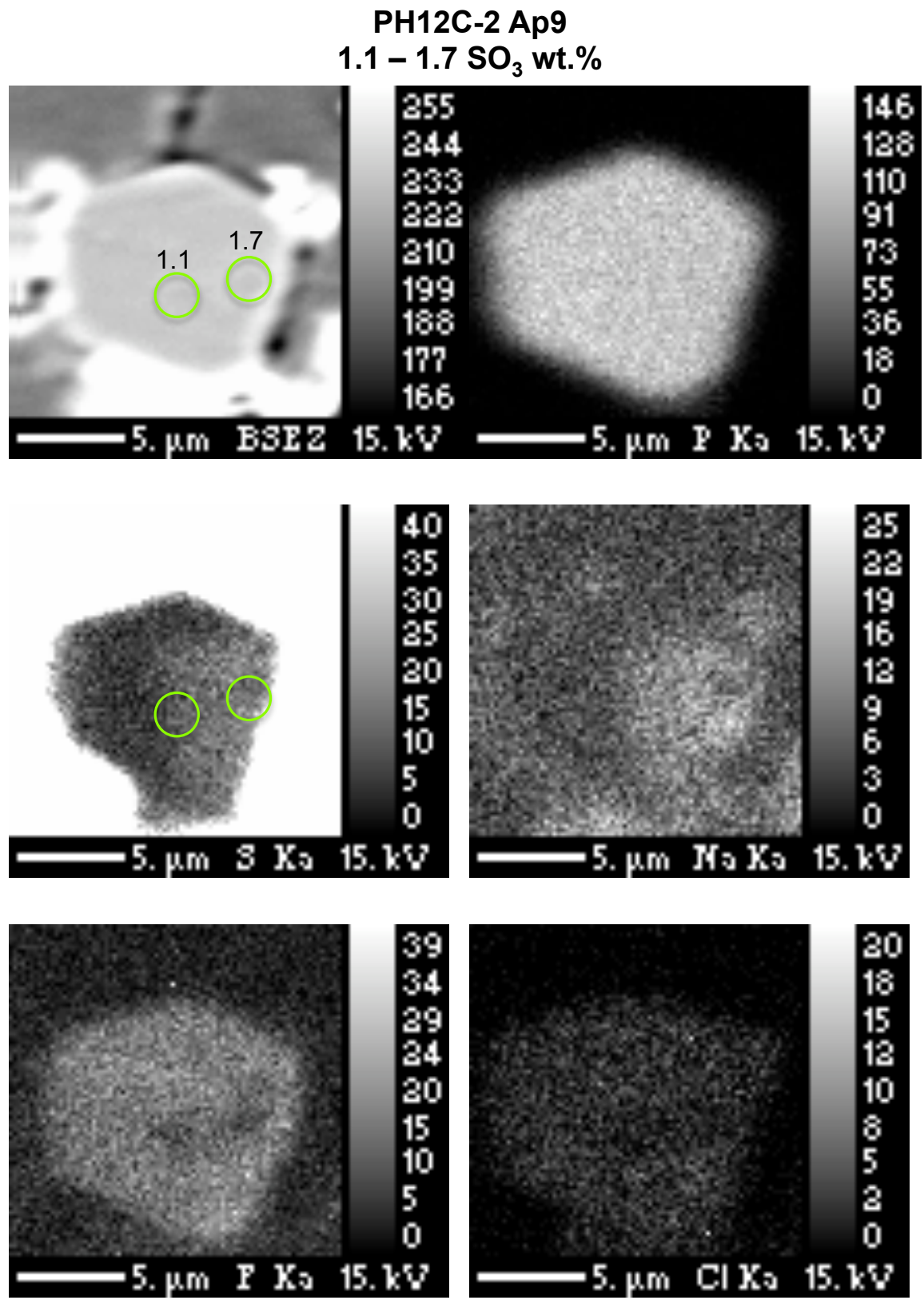

Figure F-1: Continued, BSE image and element maps (P, S, Na, F, and CI) of apatite. Green circles represent EMP spot traverse analyses and the numbers indicated the $\mathrm{SO}_{3} \mathrm{wt}$ \% at each spot. High-S numbers correlated with the bright spots in the $\mathrm{S}$ map. Host is anhydrite. 

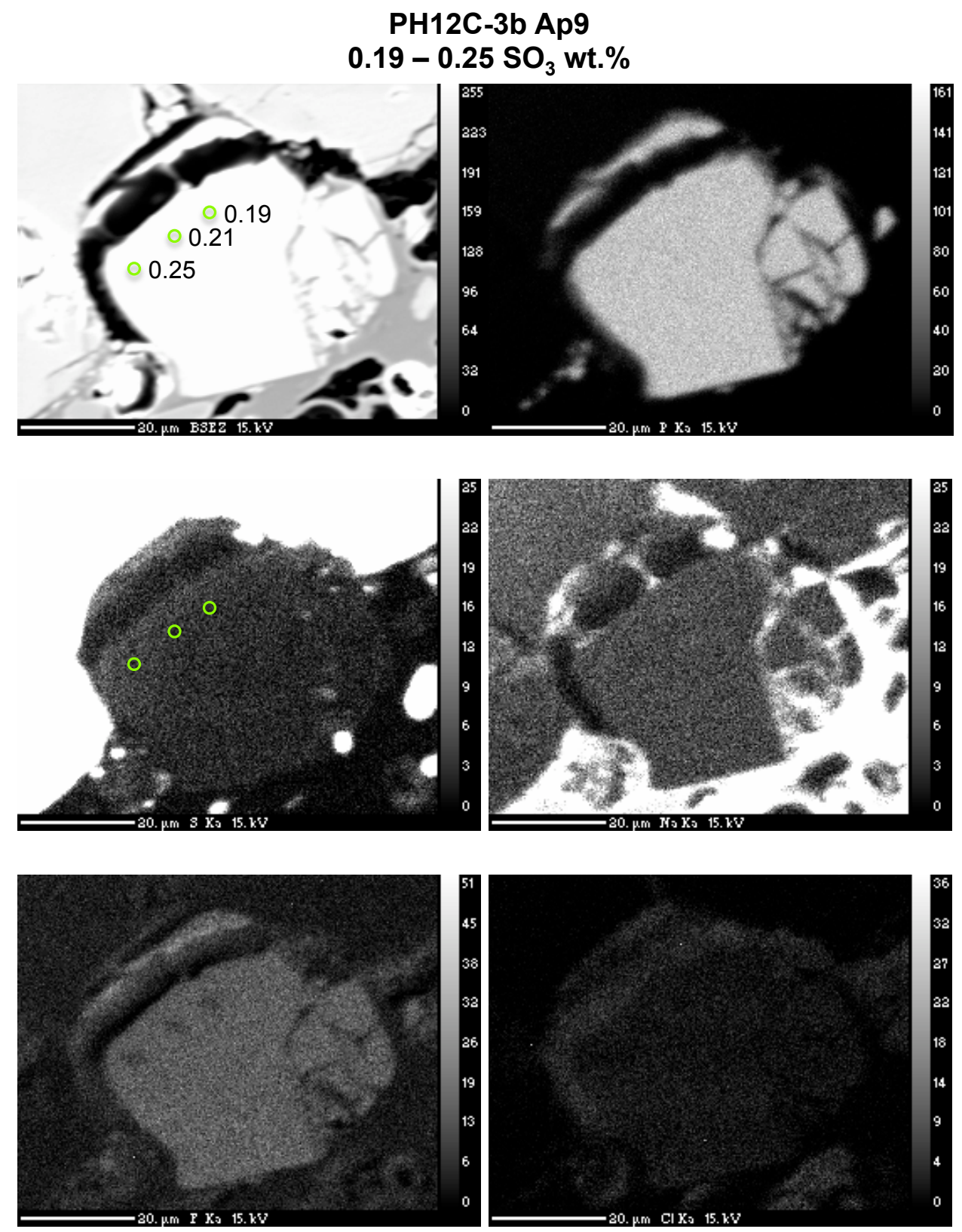

Figure F-1: Continued. Host is anhydrite. 

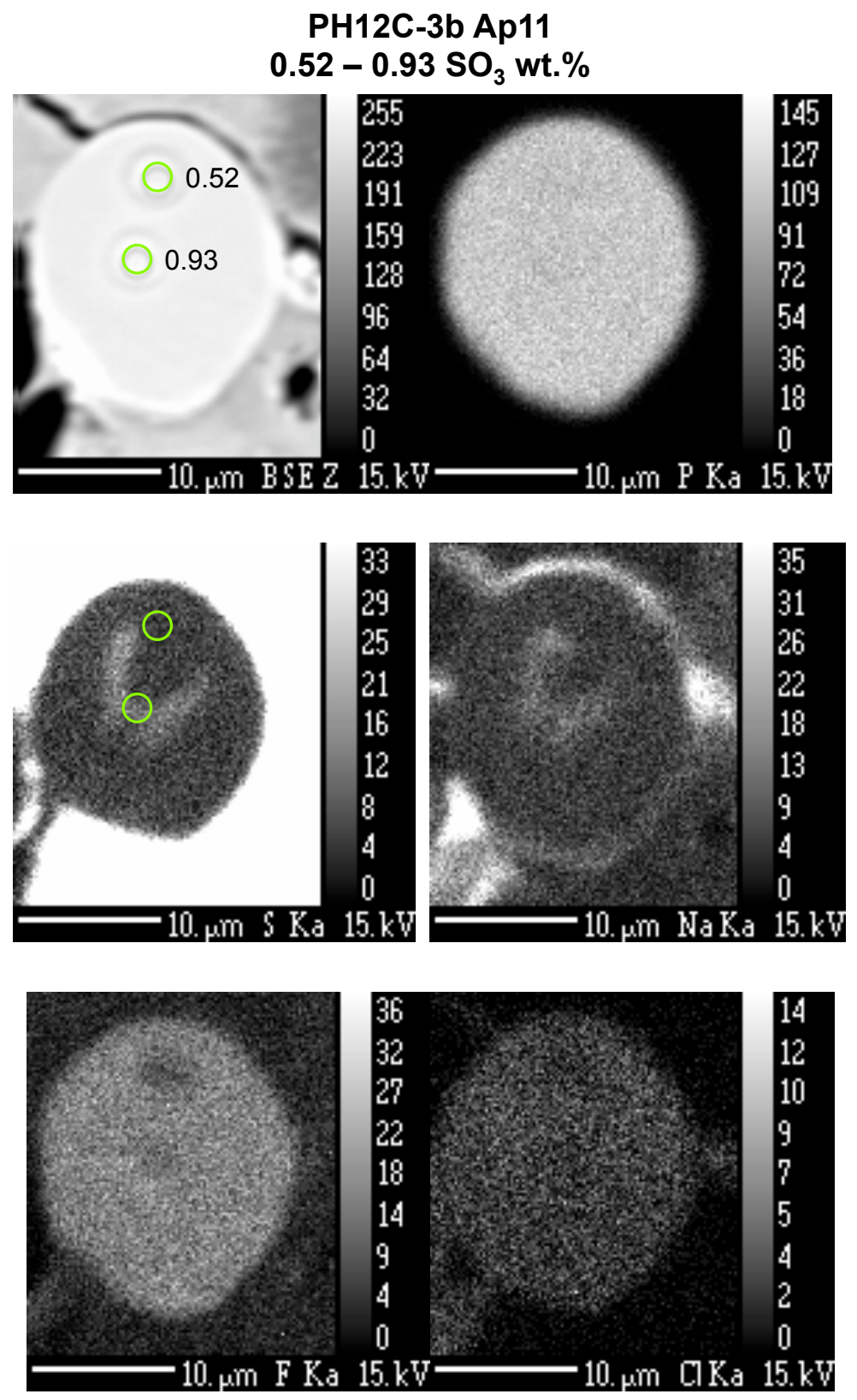

Figure F-1: Continued. Host is anhydrite. 

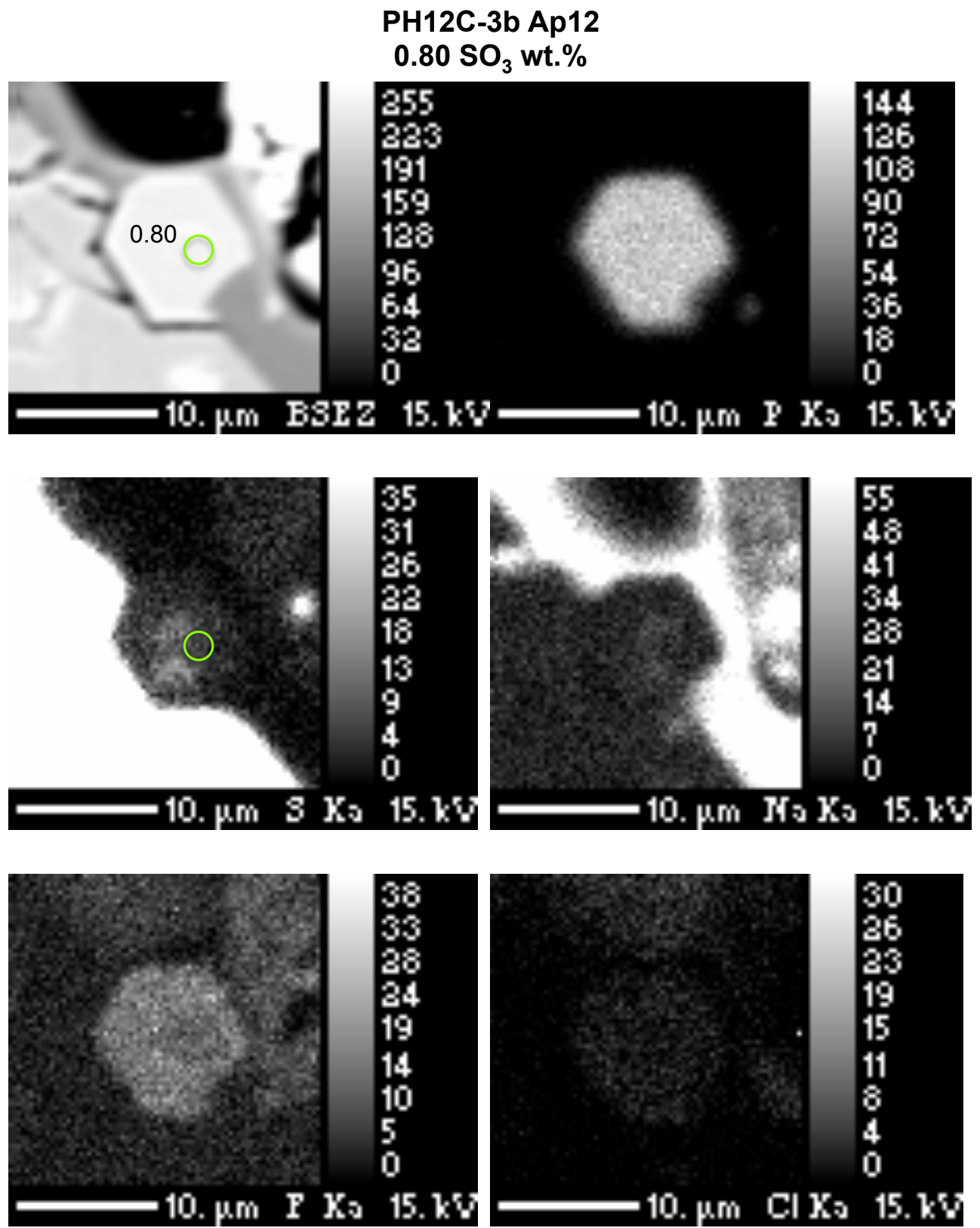

Figure F-1: Continued. Host is anhydrite. 

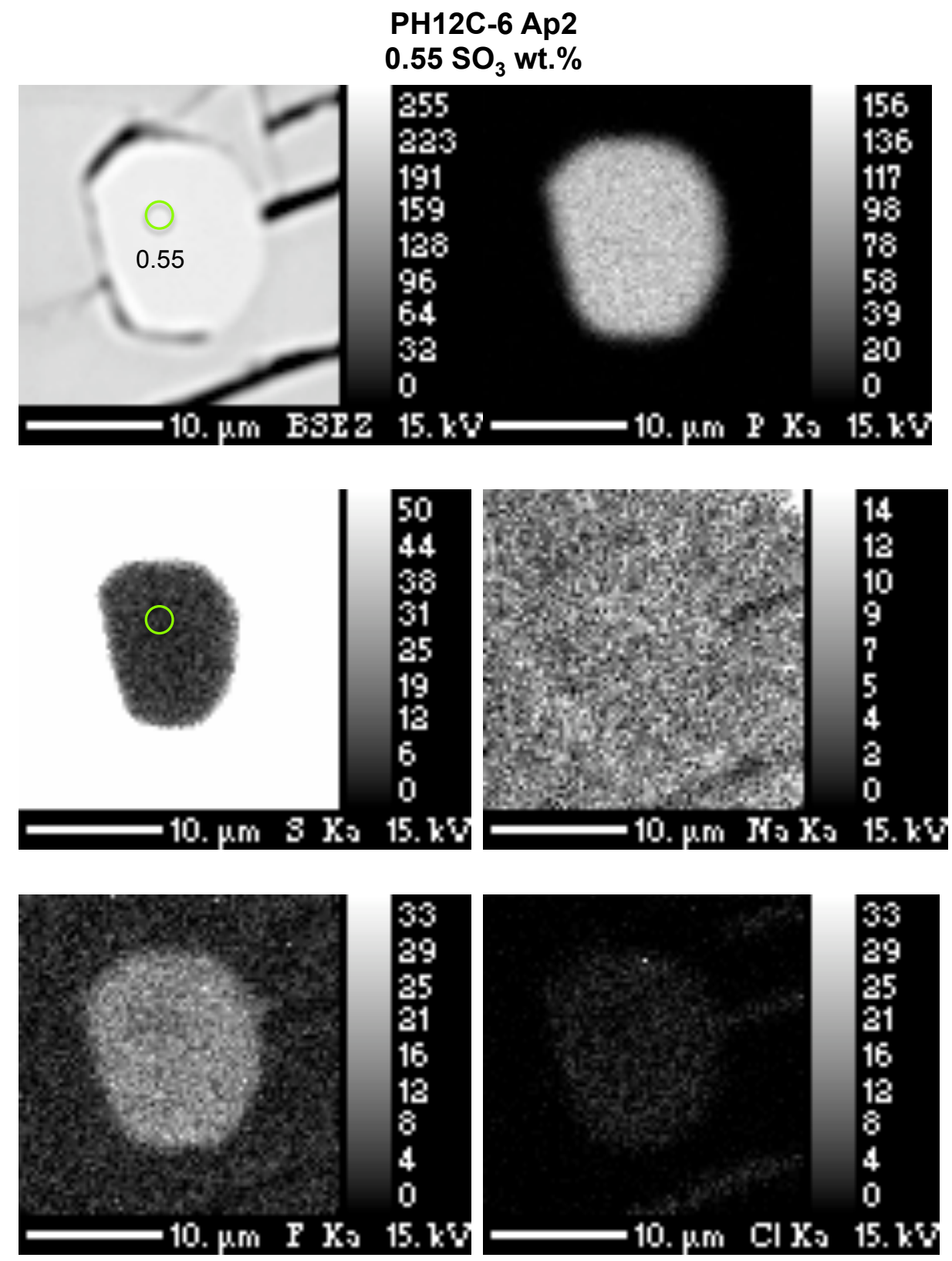

Figure F-1: Continued. Host is anhydrite. 

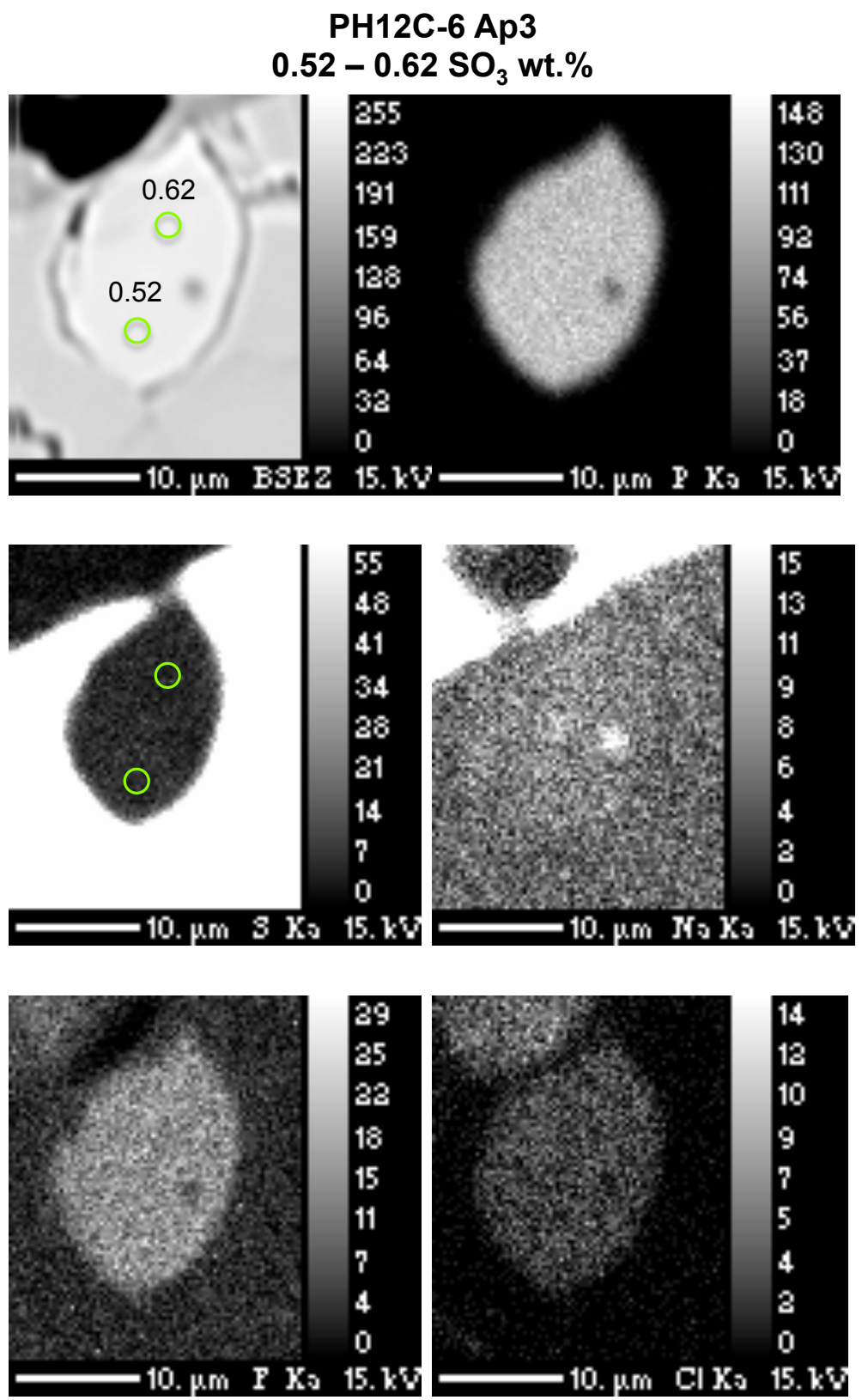

Figure F-1: Continued. Host is anhydrite. 

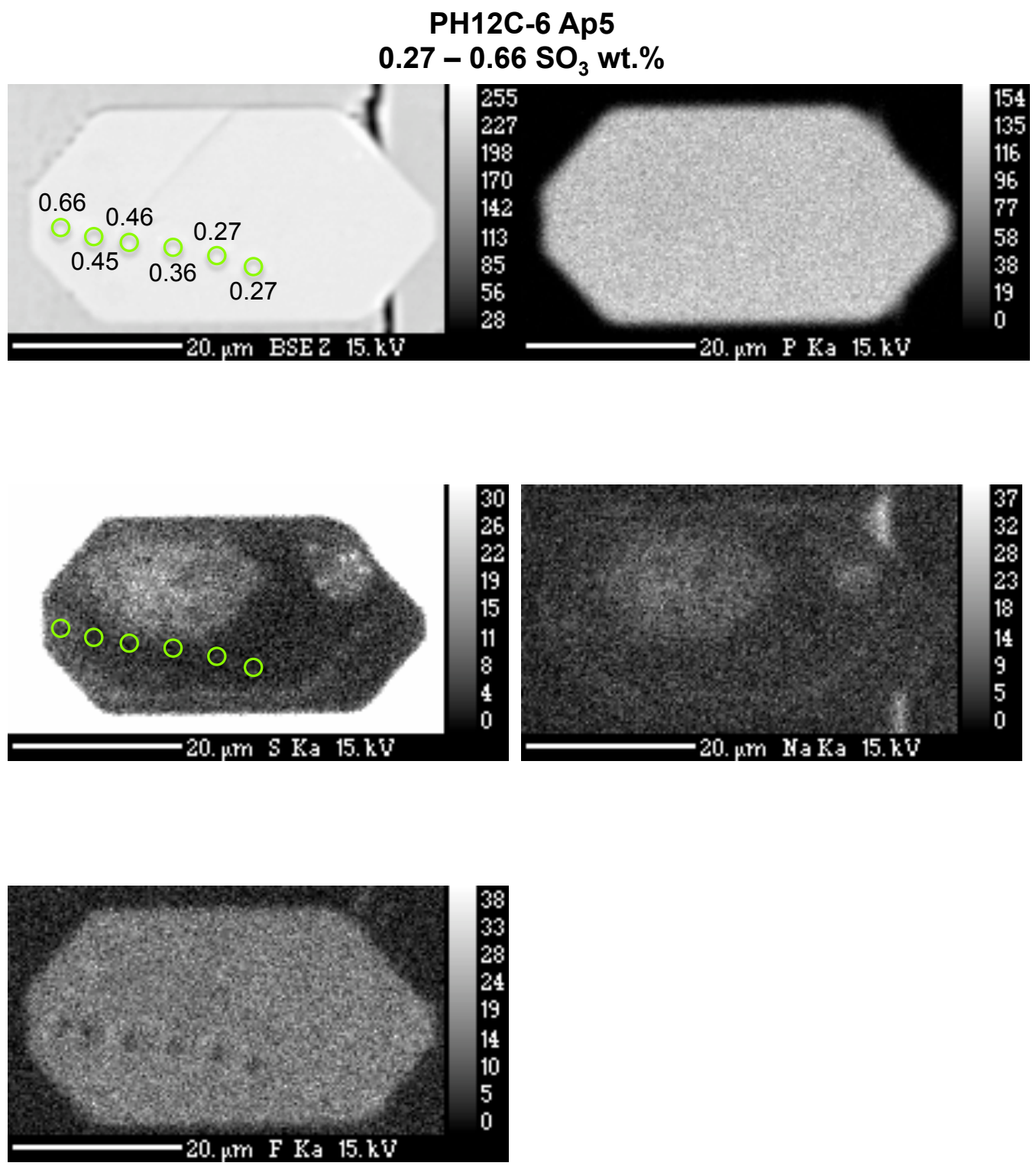

Figure F-1: Continued. Host is anhydrite. 

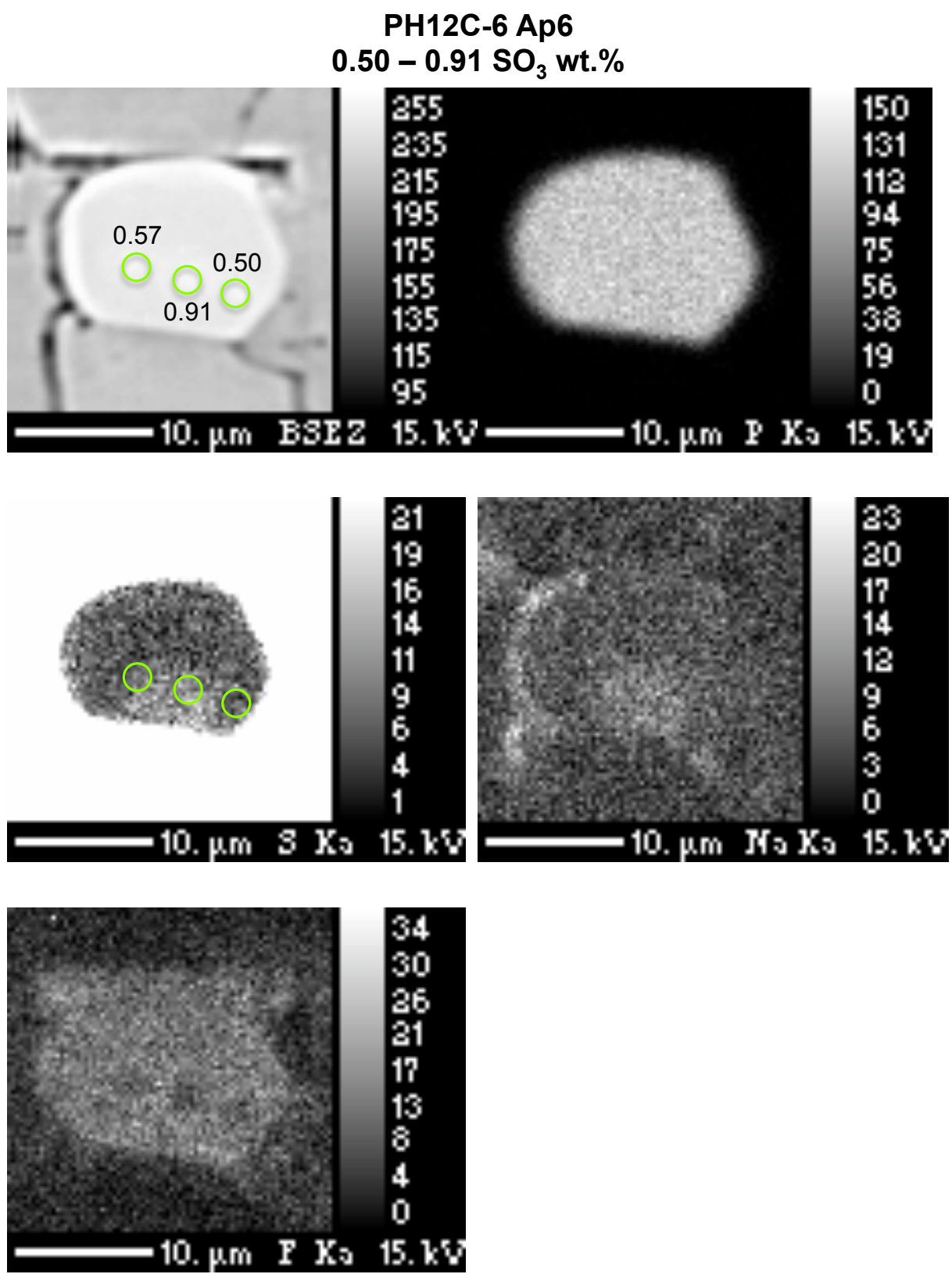

Figure F-1: Continued. Host is anhydrite. 

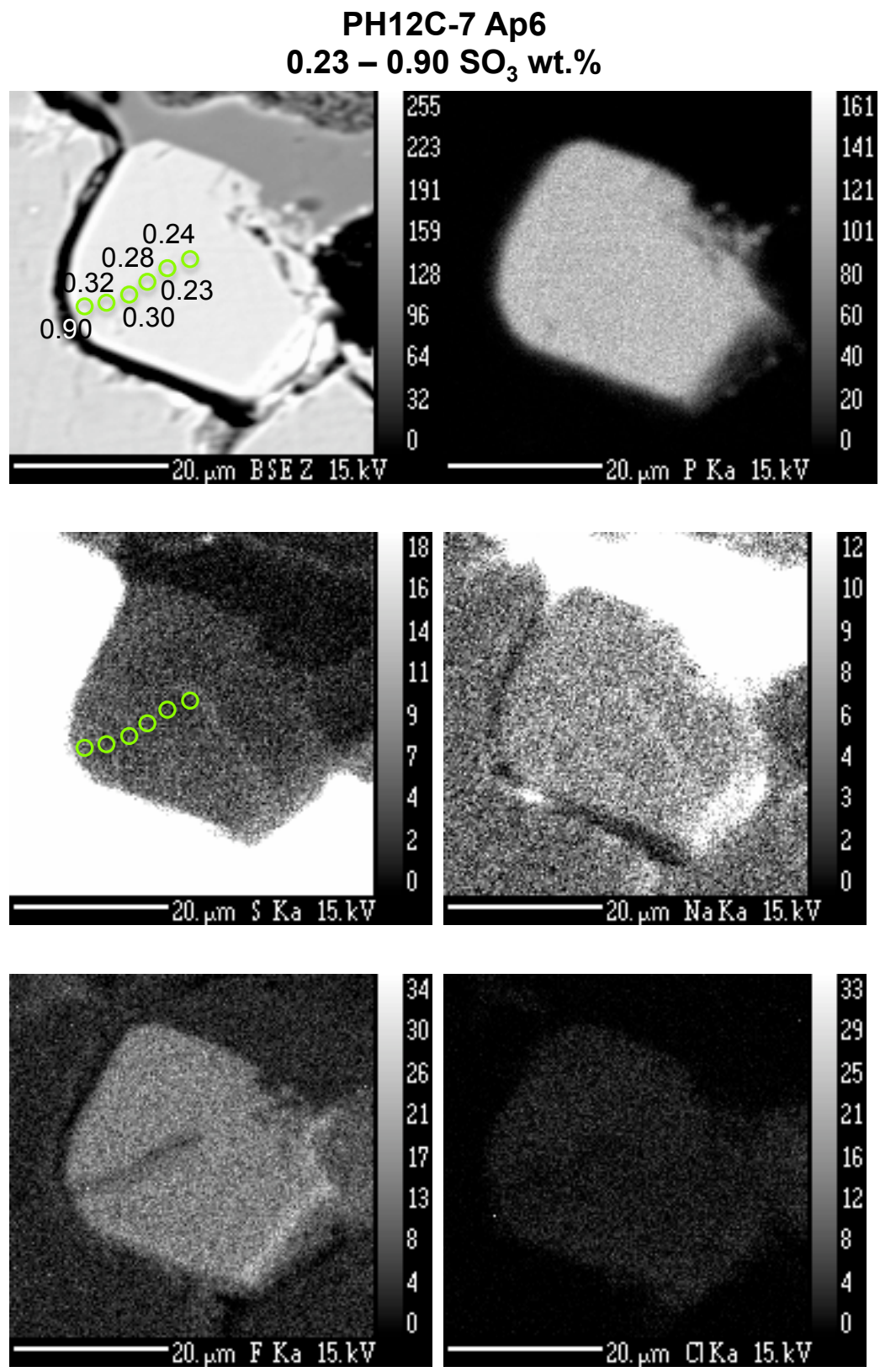

Figure F-1: Continued. Host is anhydrite. 

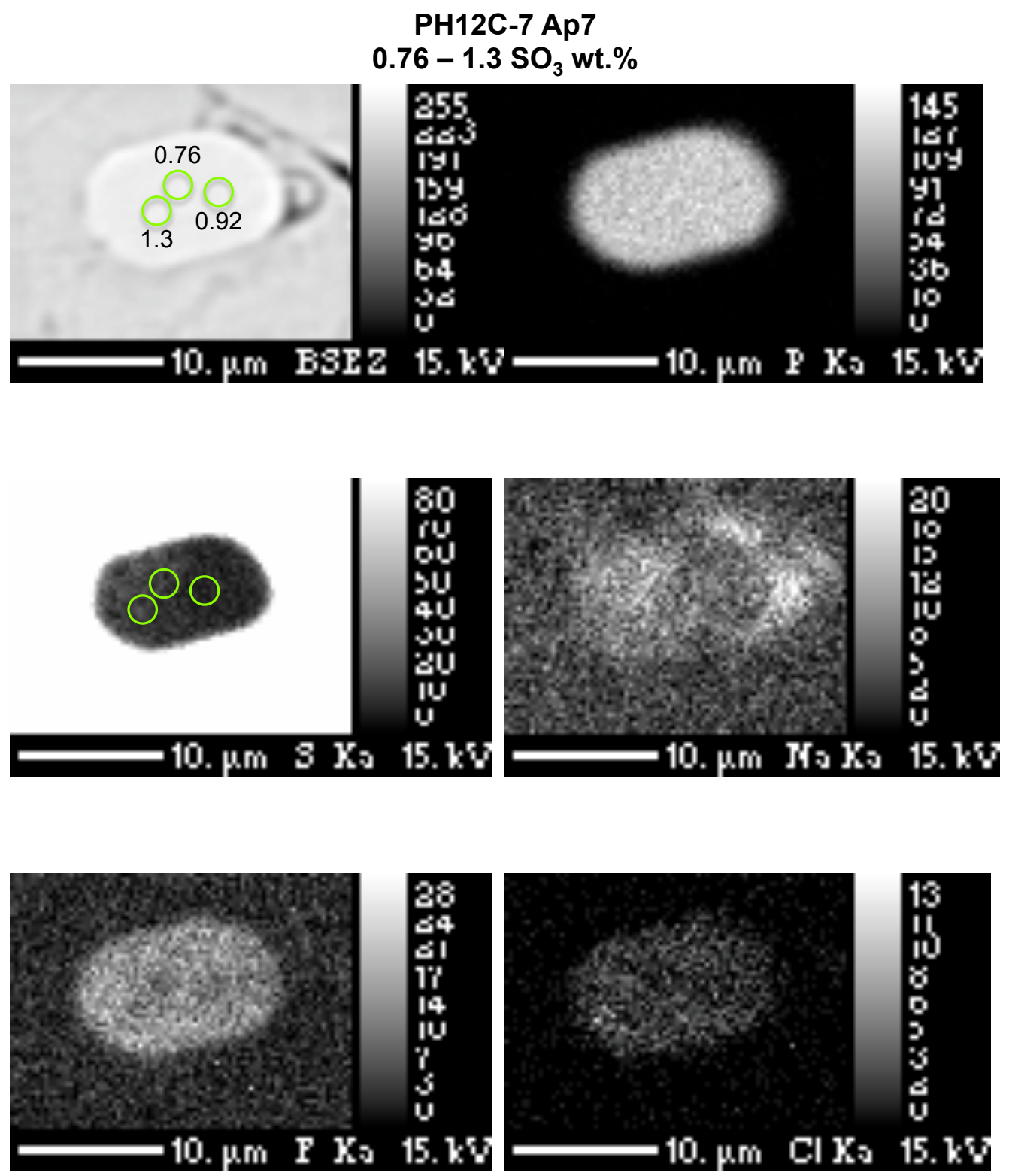

Figure F-1: Continued. Host is anhydrite. 

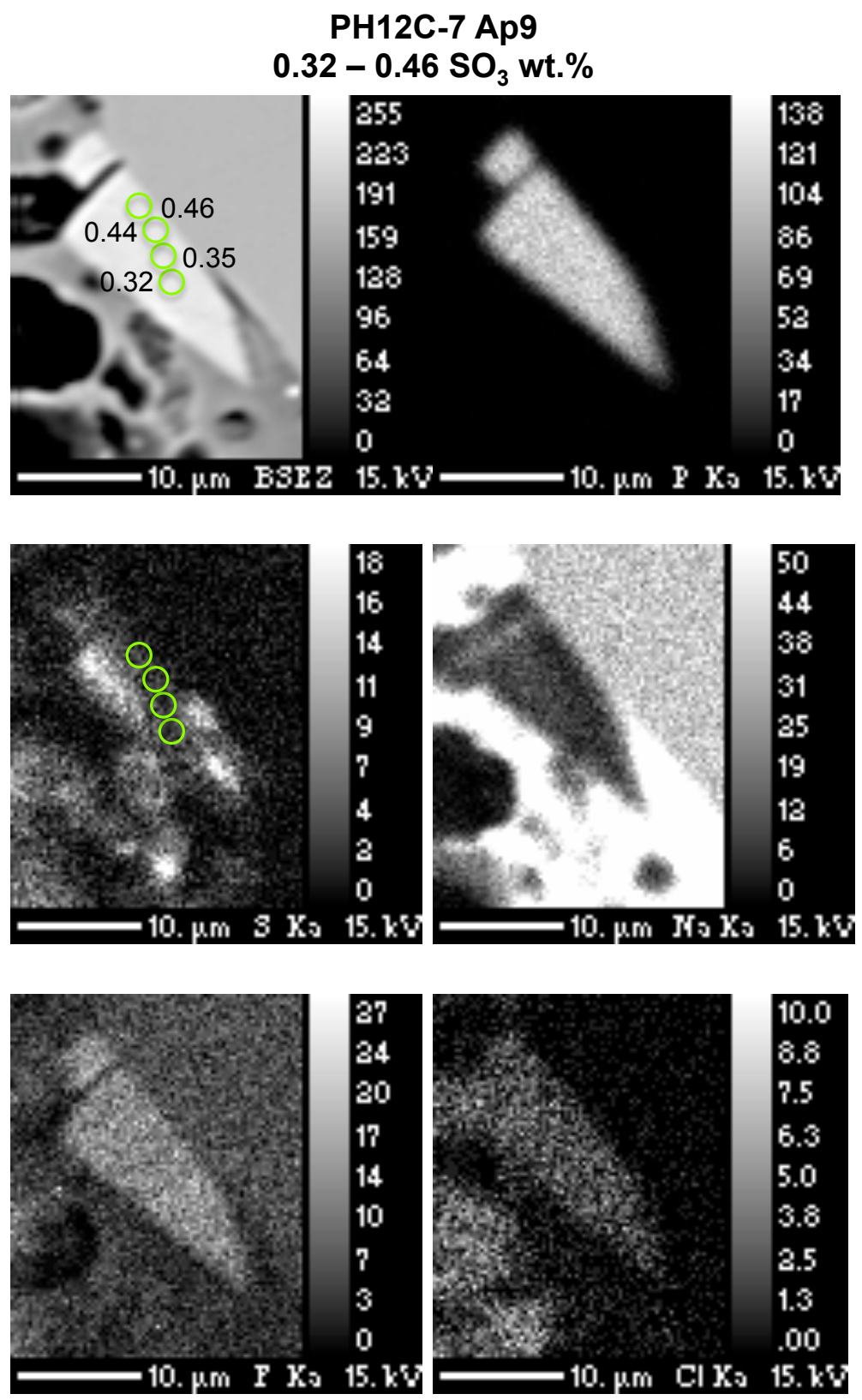

Figure F-1: Continued. Host is hornblende. 

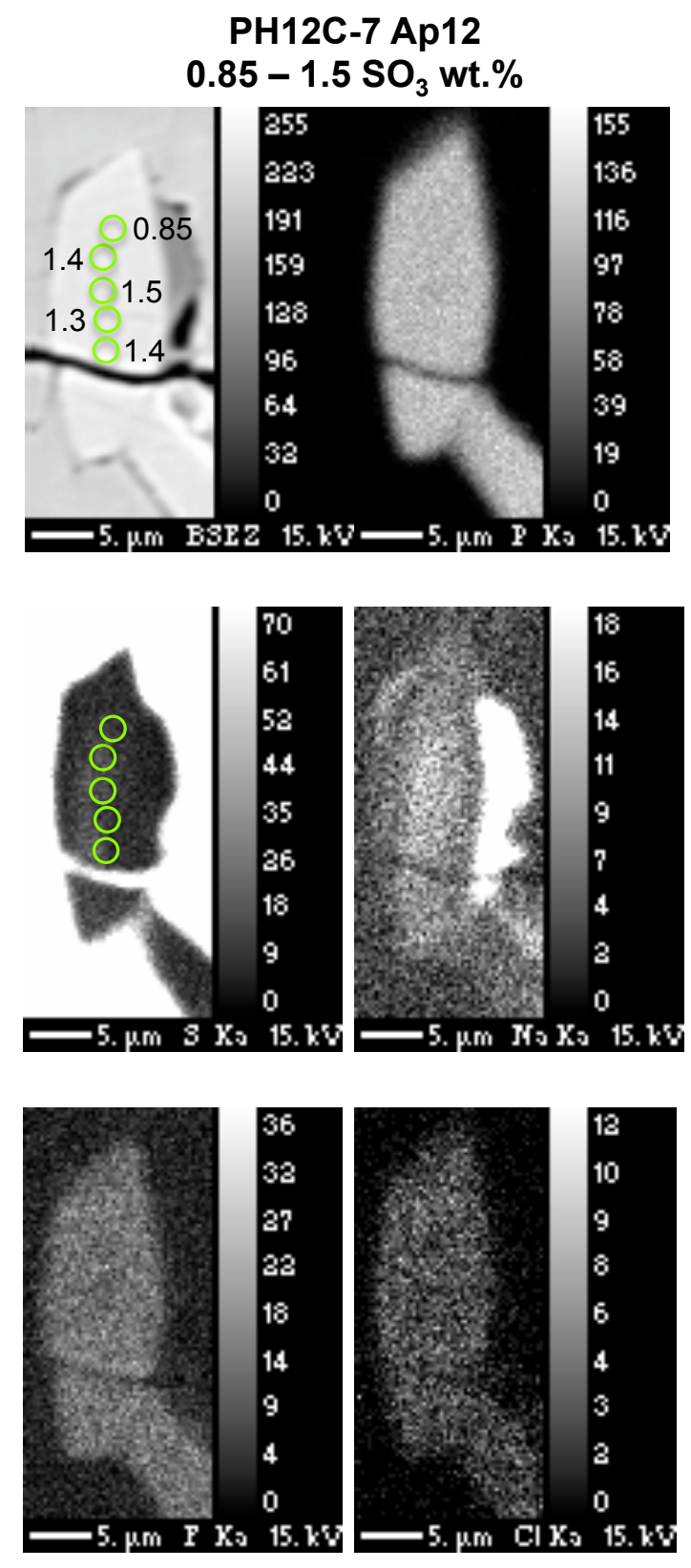

Figure F-1: Continued. Host is anhydrite. 


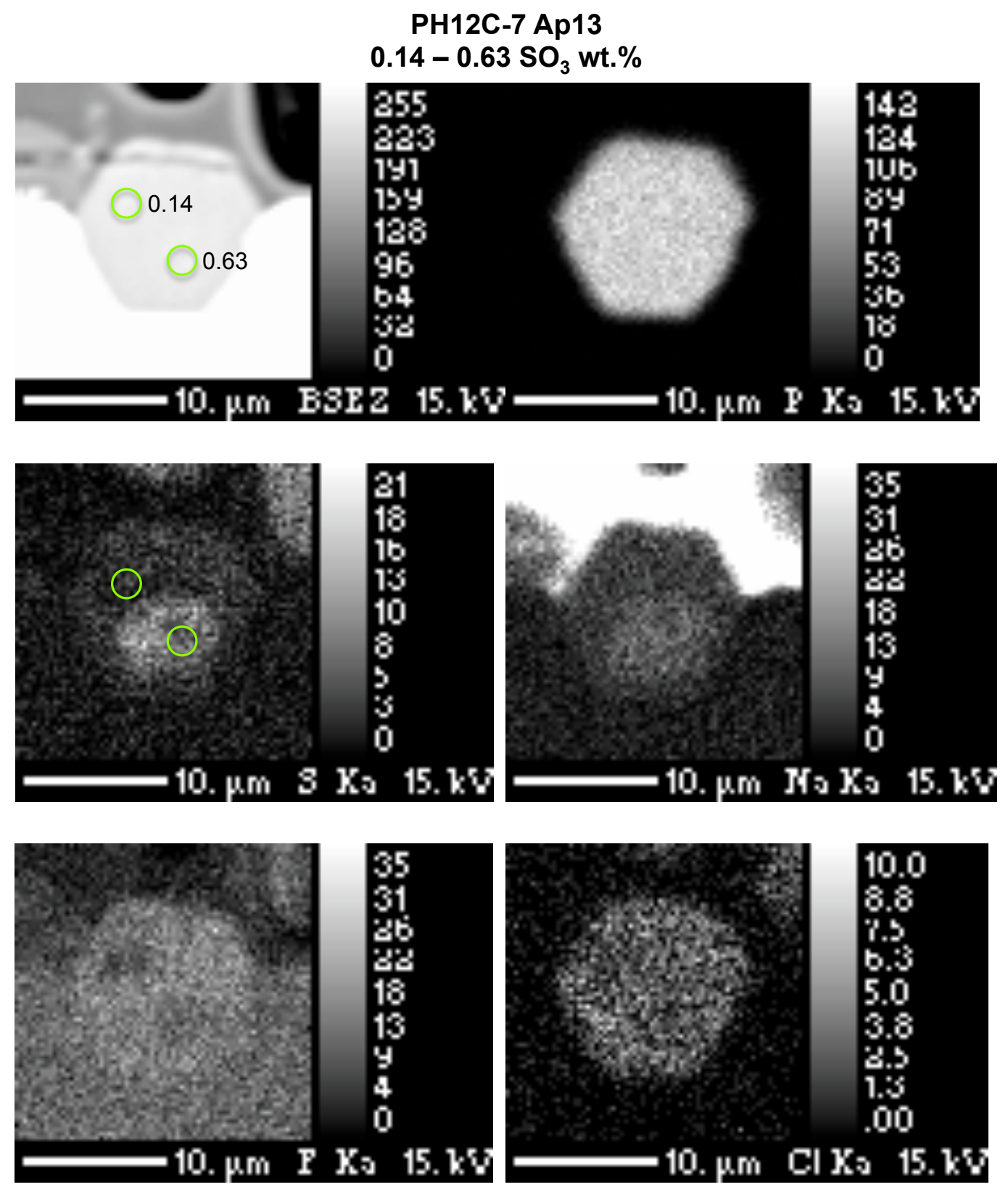

Figure F-1: Continued. Host is magnetite. 

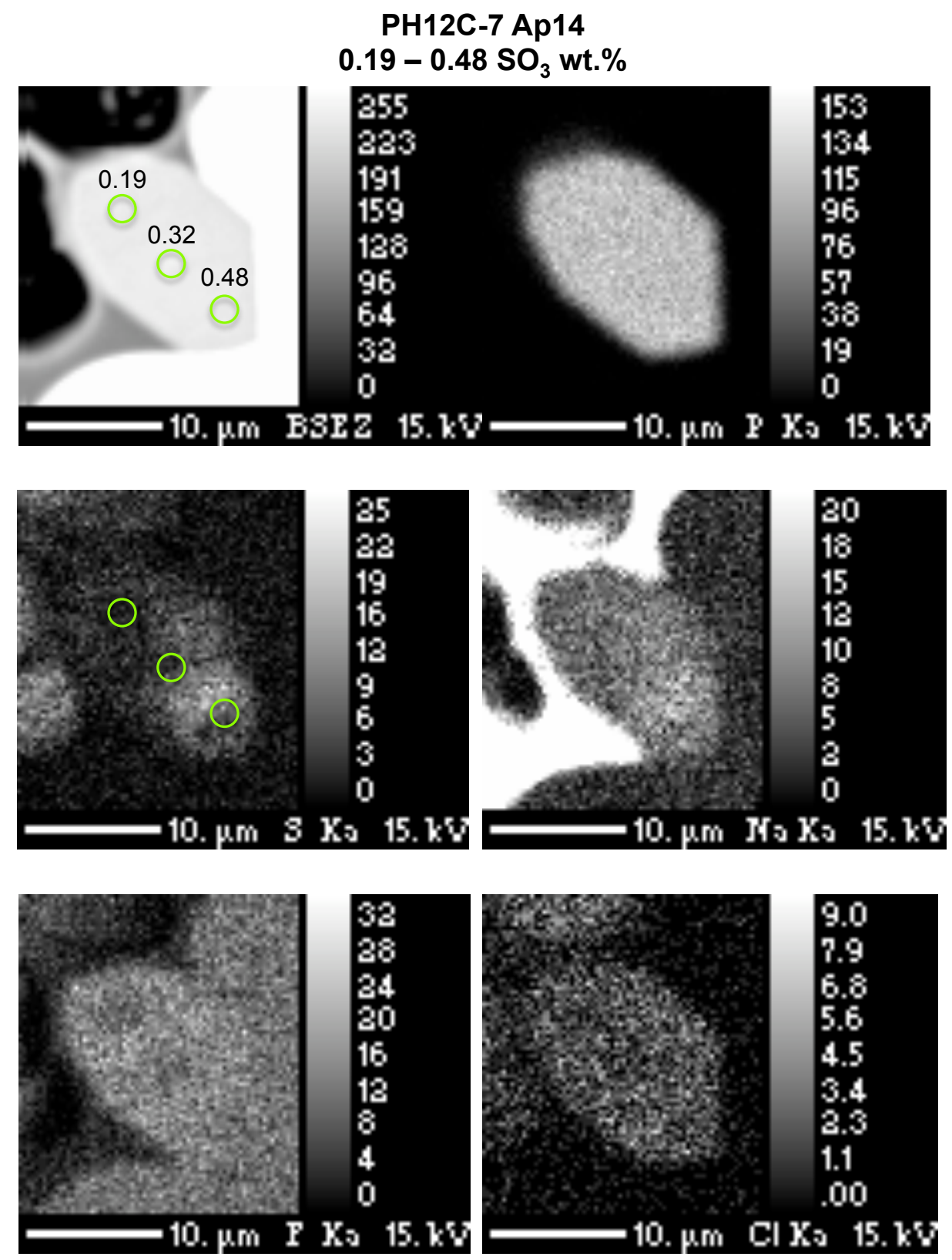

Figure F-1: Continued. Host is magnetite. 

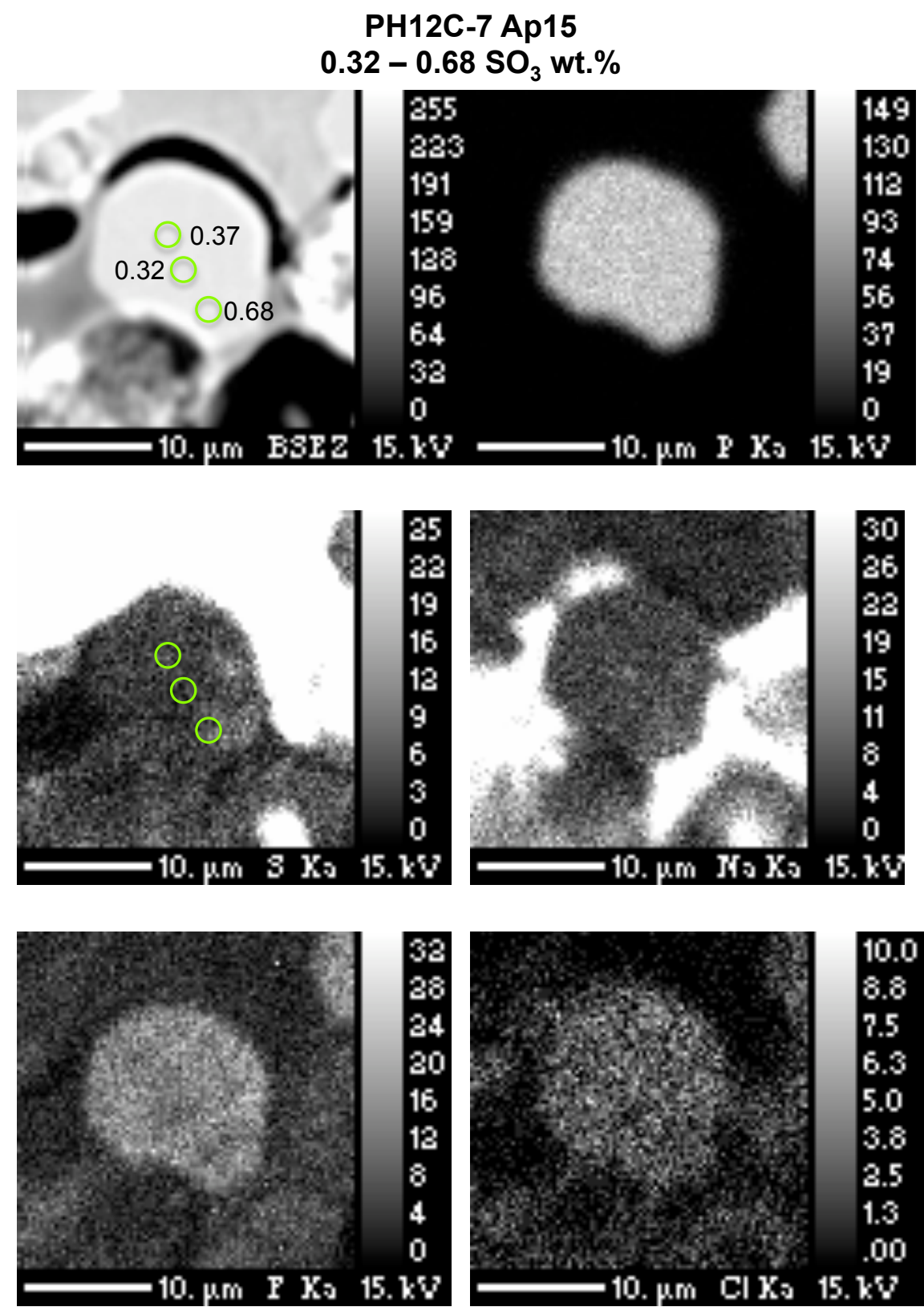

Figure F-1: Continued. Host is anhydrite. 

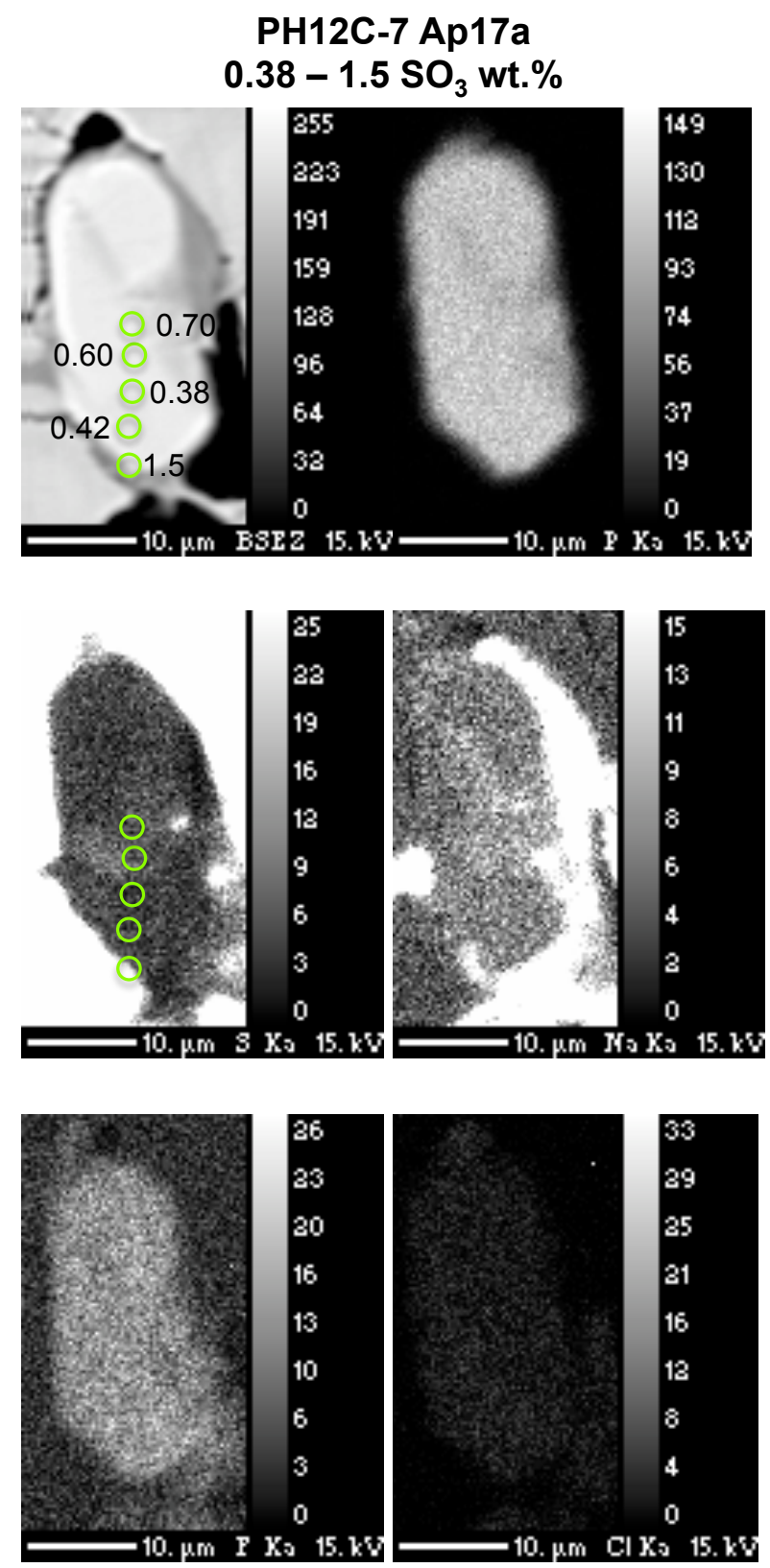

Figure F-1: Continued. Host is anhydrite. 